\title{
A személyiségi jog vagyoni értékminőségének elvi és dogmatikai alapjai, különös tekintettel a névjogra
}

\author{
PhD értekezés
}

Schultz Márton

Témavezető:

Prof. Dr. Görög Márta, egyetemi tanár 


\section{Tartalomjegyzék}

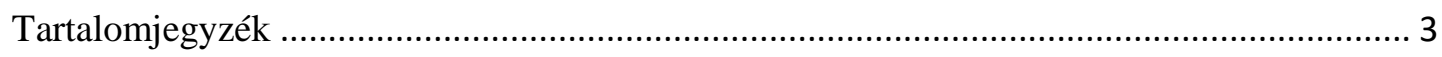

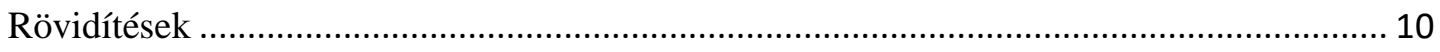

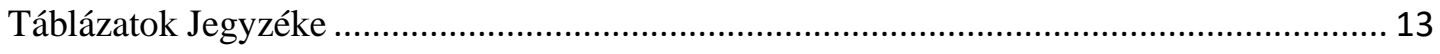

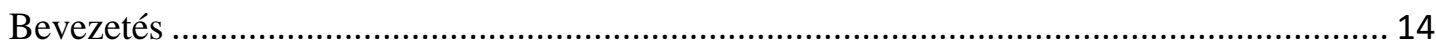

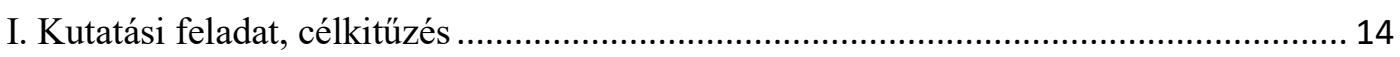

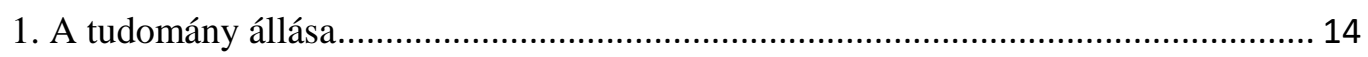

2. A dolgozat által vizsgált tárgykör .................................................................... 17

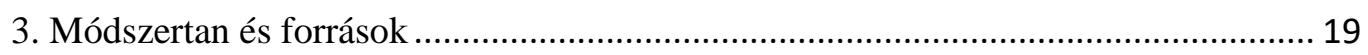

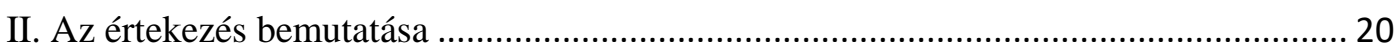

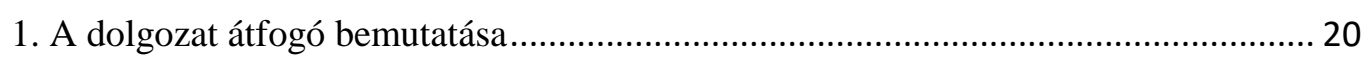

2. Az egyes részek bemutatása............................................................................... 21

A. Történeti fejlődés ...................................................................................... 21

B. A személyiségi jog vagyoni értékminőségének dogmatikai előfeltételei.............. 22

C. A vagyoni személyiségi jog mint alanyi jog .................................................... 24

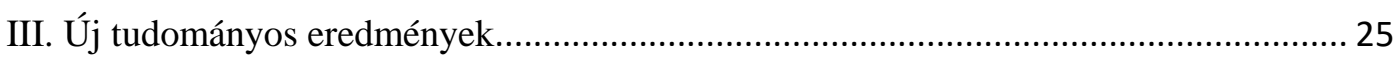

IV. A témában megjelent publikációk ……………................................................... 44

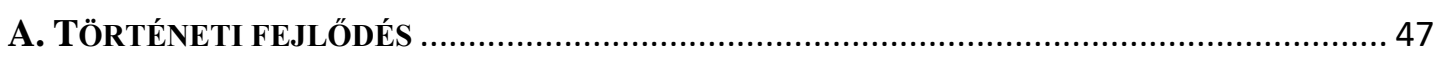

1. § A SZEMÉLYISÉGI JOG VAGYONI VONATKOZÁSAINAK FEJLŐDÉSE NÉMETORSZÁGBAN .. 48

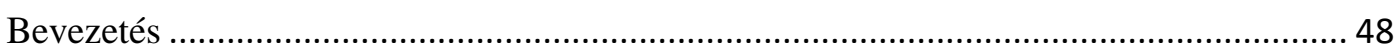

I. A személyiség védelme a II. világháború előtti német magánjogban ............................ 50

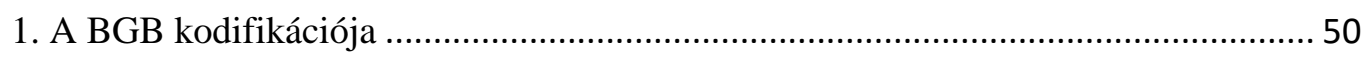

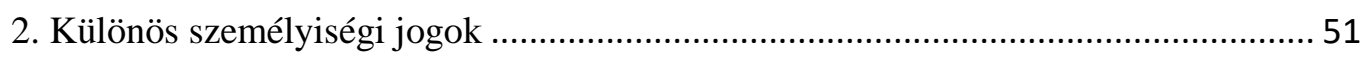

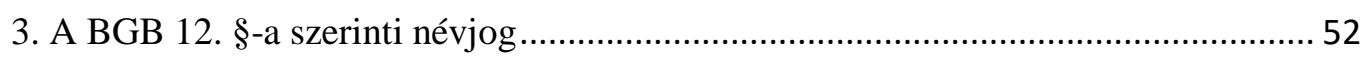

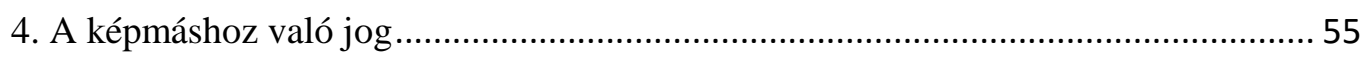

5. A védelem megtagadása a Reichsgericht gyakorlatában ........................................ 56

6. Az általános személyiségi jog bírói jogfejlesztés keretében történő elismerése ........ 57

III. Eszmei érdekek általános személyiségi jog általi védelme......................................... 58

1. Az általános személyiségi jog alkalmazási körének kiterjesztése a különös személyiségi jogok megsértésének eseteire

2. A különös személyiségi jogok törvényi hézagjainak meghódítása az általános személyiségi jog által

3. Az általános személyiségi jog vagyoni vonatkozásaira való utalás a joggyakorlatban

IV. A védelem monizmusa és dualizmusa 


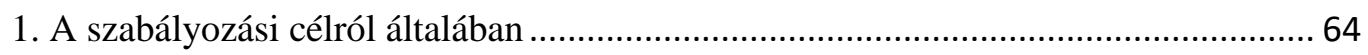

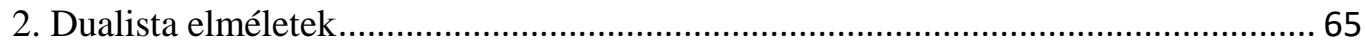

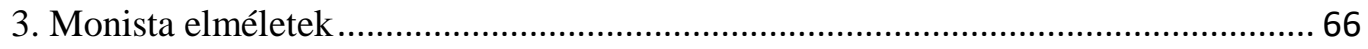

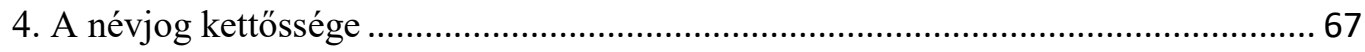

V. Az általános személyiségi jog vagyoni vonatkozásainak elismerése a BGH

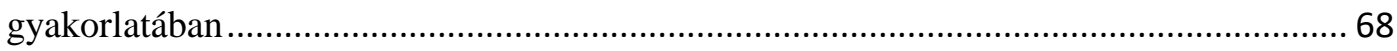

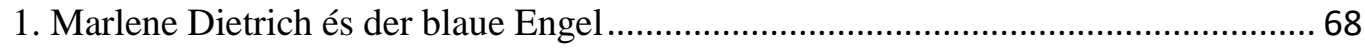

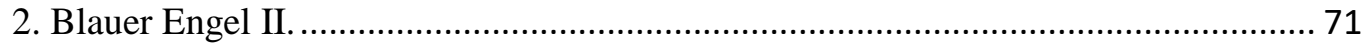

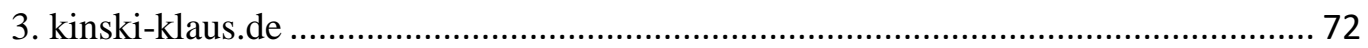

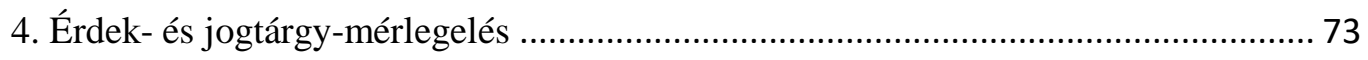

5. A névről és képmásról leválasztott vagyoni érték................................................... 74

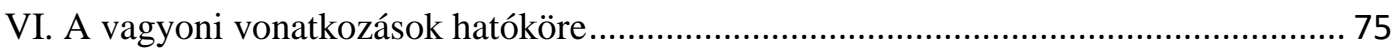

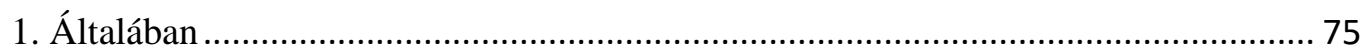

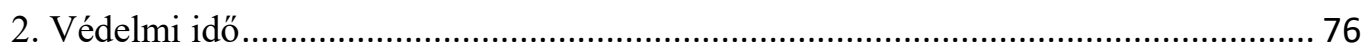

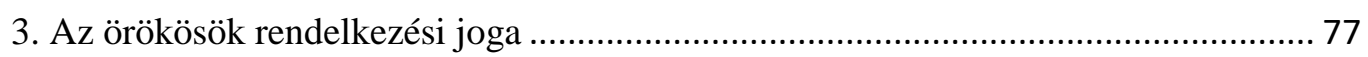

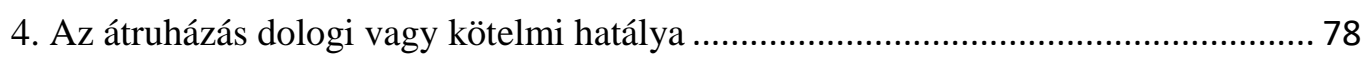

5. A szerzői jog analóg alkalmazása ....................................................................... 79

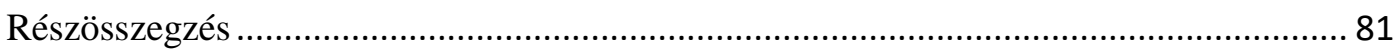

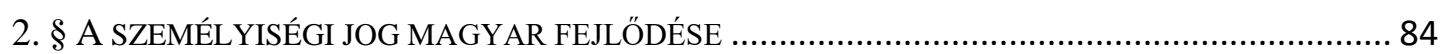

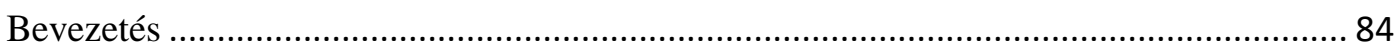

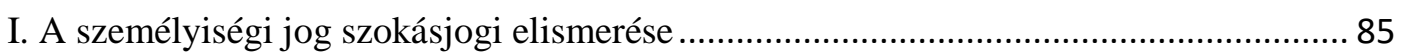

II. A személyiség védelme a jogrendszer meglévő szabályai által ................................... 86

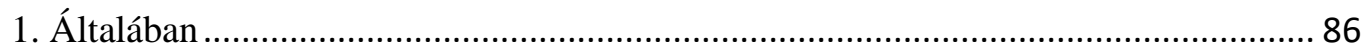

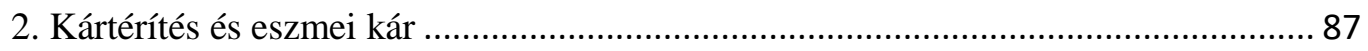

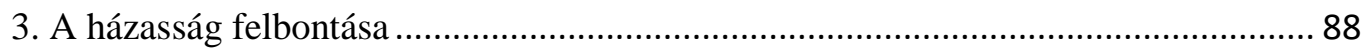

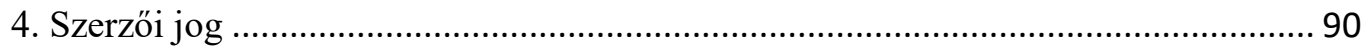

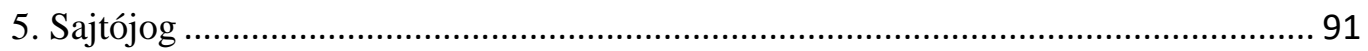

6. A jogrendszer más szabályai ............................................................................... 92

III. A személyiségi jog védelmének alakulása a joggyakorlatban ...................................... 93

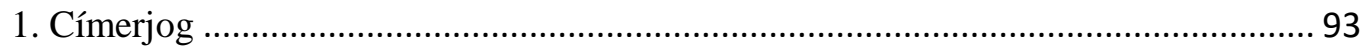

2. A névvédelemről általában.................................................................................... 93

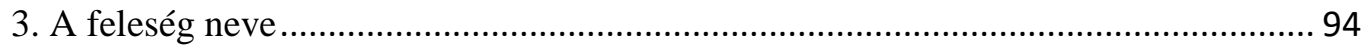

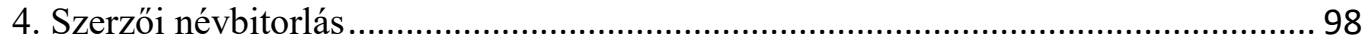

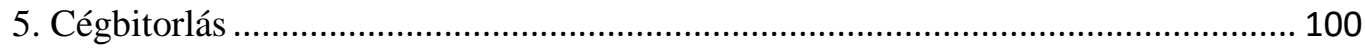

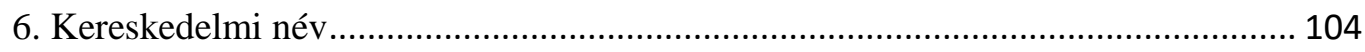

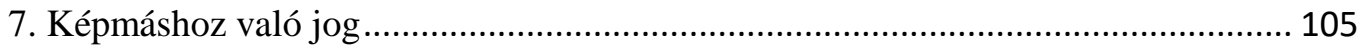


8. Jóhírnév és hitel

9. Kegyeleti jog.

10. A közszereplés és hozzájárulás megítélése ................................................. 113

IV. A szocialista polgári jog és vagyoni érték ................................................. 115

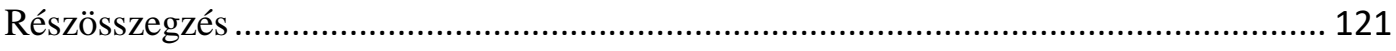

B. A VAGYONI ÉRTÉKMINŐSÉG DOGMATIKAI ELŐFELTÉTELEI............................... 124

3. § A SZEMÉLYISÉGVÉDELEM JOGALAPJA ....................................................... 125

Bevezetés ................................................................................................. 125

I. Az emberi méltóság .............................................................................. 126

1. Az emberi méltóság jelentéstartamai ...................................................... 126

2. Az emberi méltóság mint nevesített személyiségi jog ........................................ 126

3. Az emberi méltóság alkotmányjogi vonatkozásai.............................................. 128

4. Az emberi méltóság és az általános személyiségi jog összefüggései a német jogban 130

5. Az emberi méltóság mint a személyiségi jogok anyajoga ..................................... 132

6. Az emberi méltóság magánjogi felfogásának kritikája ....................................... 133

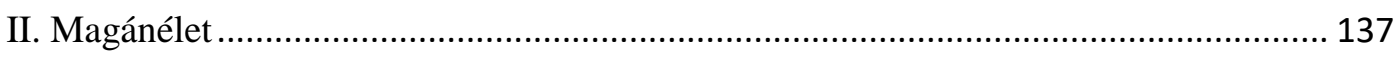

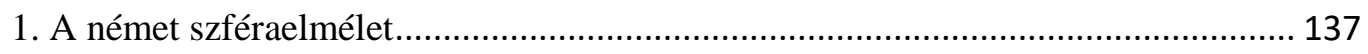

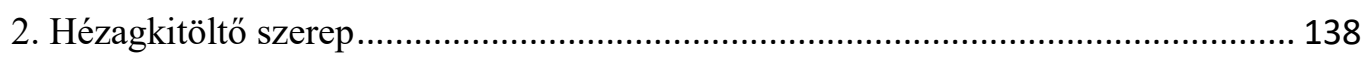

3. Magánélethez való jog és polgári jogi kodifikáció ............................................ 139

4. A magánélethez való jog tág felfogása ............................................................. 140

5. Külön törvény a magánélethez való jogról ...................................................... 142

6. A magánélethez való jog leszükítő értelmezése............................................. 143

III. Kibontakozás.............................................................................................. 144

1. A kibontakozás jelentéstartamai .............................................................. 144

2. A polgári jogi jogképesség mint genus proximum ........................................ 145

IV. A személyiségi jog .......................................................................... 146

1. Az általános személyiségi jog jogtechnikai funkciója ....................................... 146

2. A német modell: az általános személyiségi jog ............................................. 147

4. A svájci modell a magyar jogban ......................................................... 148

6. A félig zárt generálklauzula modellje ...................................................... 151

V. A személyiségi jog igényváza ................................................................ 155

1. Tényállás ....................................................................................... 155

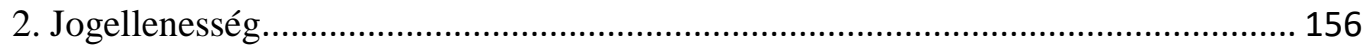

3. A személyiségi jog megsértésének megállapítása során vizsgálandó jogi tények ... 158

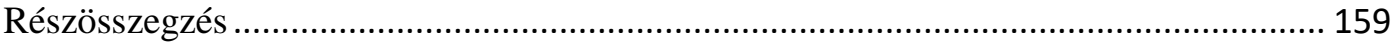




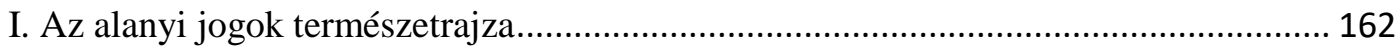

1. Az abszolút személyi jogok ............................................................................... 162

2. A személyi eszme teljes tagadása ……………...................................................... 164

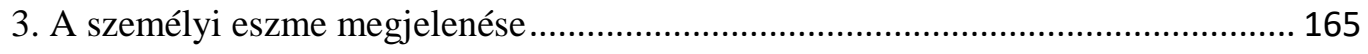

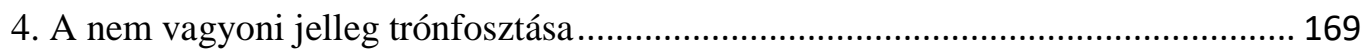

5. Az immateriális javak felosztása....................................................................... 172

6. A személyi és dologi viszonyok vegyülése....................................................... 175

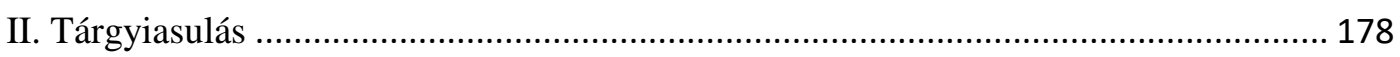

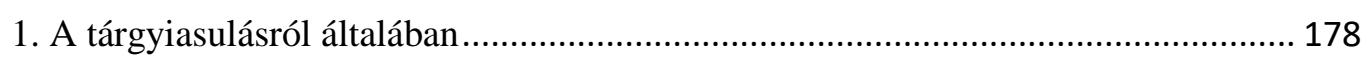

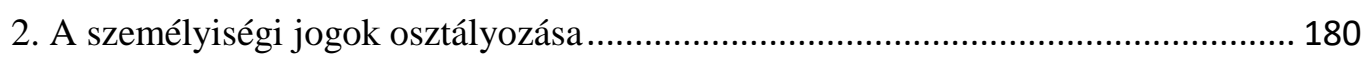

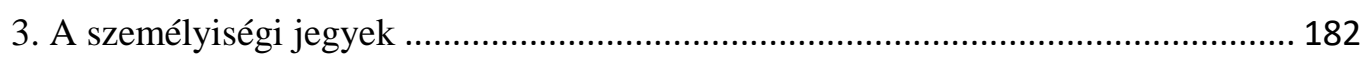

4. A személyiség külső megjelölése .................................................................... 183

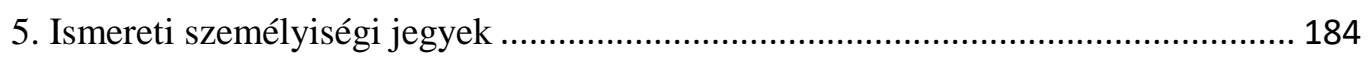

6. A név különutassága a személyiségi jogok között ................................................ 186

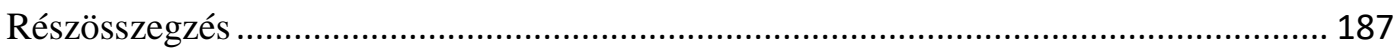

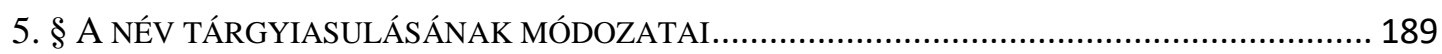

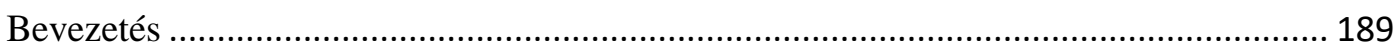

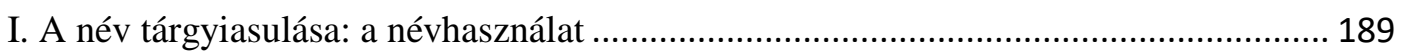

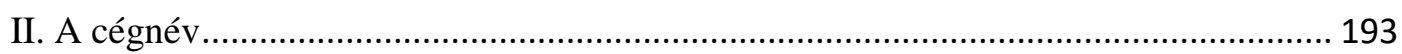

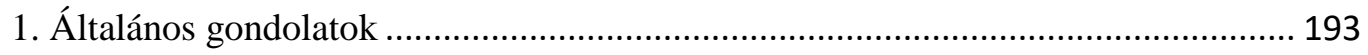

2. A cégnév mint alanyi jog elhelyezése a magánjog rendszerében ............................ 193

3. A védelem közös alapja: a jogképesség .................................................................. 197

4. Az elsőbbség követelménye .................................................................................. 198

5. A cégnév mint lajstromozást igénylő megjelölés....................................................... 199

6. A névjogban gyökerező váromány ........................................................................ 201

7. Névfoglalás mint megelöző eljárás ......................................................................... 202

8. A cégbitorlás névbitorlástól való megkülönböztetésének elvi indokai ...................... 202

9. Állásfoglalás a cégnév tárgyiasulását illetően....................................................... 203

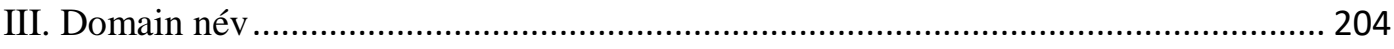

1. A domainnév fogalma ....................................................................................... 204

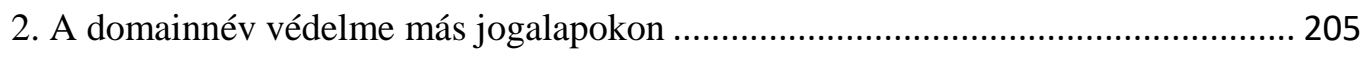

3. Megkülönböztető toldat és megkülönböztető képesség hiánya ................................. 205

4. Sui generis domainbitorlás mint névbitorlás ......................................................... 206

5. A domainbitorlás létjogosultsága ....................................................................... 209 
6. A név tárgyiasulása a domainnév vonatkozásában .................................................. 210

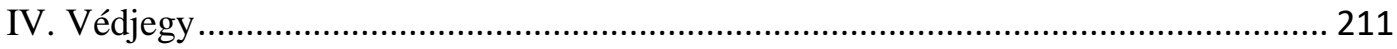

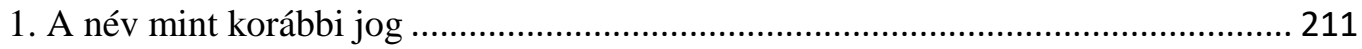

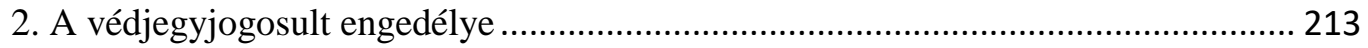

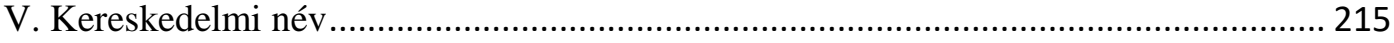

1. A vállalatjelzők osztályozása a háború előtti magánjogban...................................... 215

2. A kereskedelmi név fogalmára vonatkozó álláspontok ........................................... 216

3. A kereskedelmi név fogalma............................................................................ 218

4. A név tárgyiasulása kereskedelmi név esetén ....................................................... 219

VI. A megjelölések személyiségi jogba való behatásának értékelése............................... 219

VII. A név sui generis tárgyiasulása - a néven való vagyoni jog ................................... 223

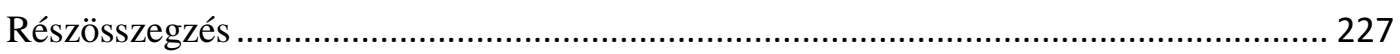

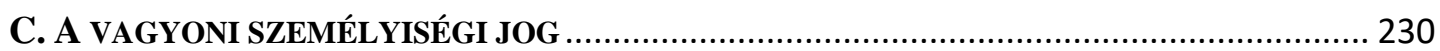

6. § VAGYONI ÉRTÉKMINŐSÉG ÉS TÉTELES JOG .............................................................. 231

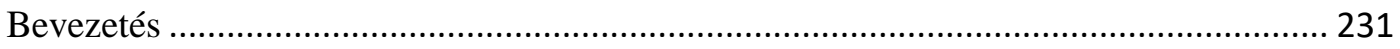

I. Elismeri-e a tételes magyar jog a személyiségi jog vagyoni értékét?............................ 231

II. Alkalmas-e az alanyi jog a vagyoni érdekek védelmére? ......................................... 234

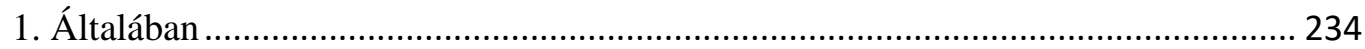

2. A kibontakozás joga [Ptk. 2:42. § (1) bek.] ….................................................... 235

3. Az emberi méltóság [2:42. § (2) bek. 1.m.] és a vagyoni érdek ............................ 236

4. Az eszmei és vagyoni érdekek védelméről való állásfoglalás .................................. 236

5. Jogkövetkezmények ……………................................................................. 237

III. A vagyoni értékminőség el nem ismerésének problémája ......................................... 238

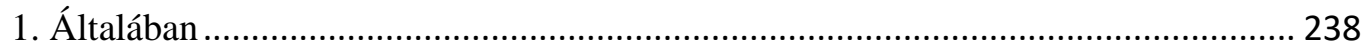

2. Megváltozott társadalmi viszonyok .................................................................... 239

3. A személyiségi jegyek jogellenes kereskedelmi felhasználása mint hamis látszat.. 241

4. A családi név kereskedelmi felhasználása ................................................................ 243

5. Személyiségi jegyek jogosult halála utáni felhasználása ......................................... 244

IV. A személyiségi jog vagyoni értékminőségének nevezéktana .................................... 245

V. Miért nem adaptálható a német megoldás? ............................................................... 247

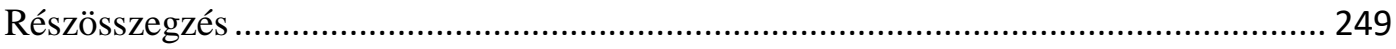

7. § A VAGYONI SZEMÉLYISÉGI JOG KÖRÜLHATÁROLÁSA ................................................... 251

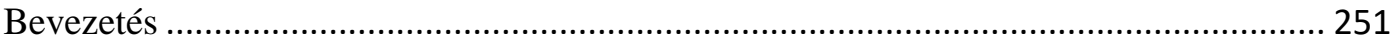

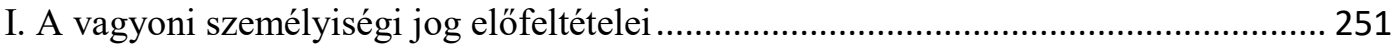

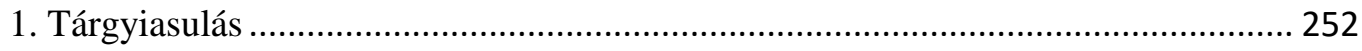

2. Ismertség avagy publicitás .................................................................................. 253 


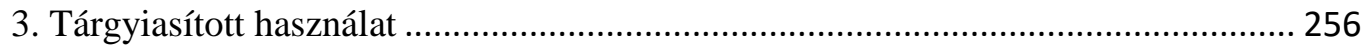

4. Jogi érdek a személyiségi jegy felett................................................................ 257

5. Vagyoni érdekkörben történő felhasználás …………………………………........ 259

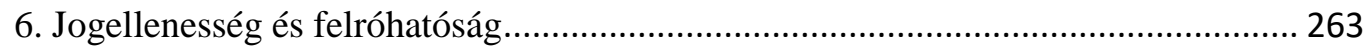

7. A vagyoni személyiségi jog igényváza .................................................................... 263

II. A vagyoni személyiség jogi jellegének egyes kérdései................................................ 265

1. Származékos jogszerzés...................................................................................... 265

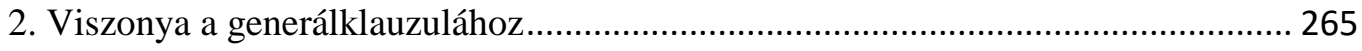

3. Az önállótlan vagyoni immateriális jogi kategorizálás ............................................. 268

4. A vagyoni személyiségi jogok átruházhatósága ................................................... 272

5. A vagyoni érdekek halál utáni védelme .................................................................. 277

6. A vagyoni személyiségi jog más módon történő megszünése .................................. 281

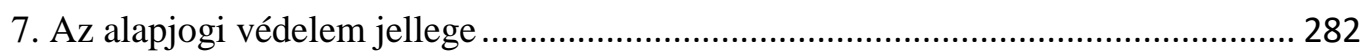

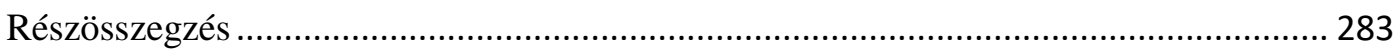

8. § A VAGYONI ÉRDEK MEGSÉRTÉSE ESETÉN ALKALMAZANDÓ JOGKÖVETKEZMÉNYEK ... 286

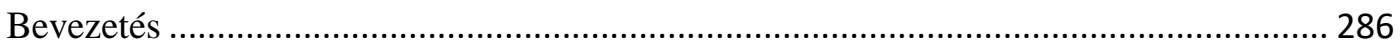

I. Az általános személyiségi jog megsértéséből eredő jogkövetkezmények .................... 286

1. Az alanyi jog elismerésével járó jogkövetkezmények ............................................. 286

2. A nem vagyoni kár megtérítése .......................................................................... 288

3. A vagyoni kár és a személyiségi jog kapcsolata ................................................... 289

4. A vagyoni jogkövetkezmények alkalmazhatóságának előfeltétele ........................... 290

5. A vagyoni szankciók funkciója és szükségessége ................................................ 291

6. A háromfokú kárelszámolás................................................................................... 293

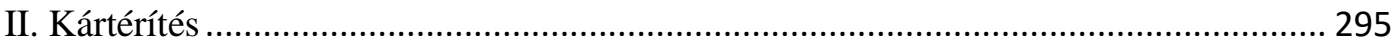

1. Kártérítés a BGB 823. §-a alapján ........................................................................... 295

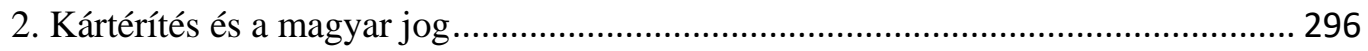

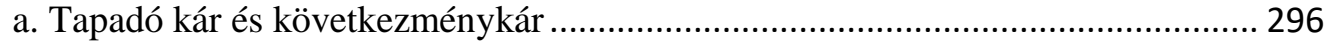

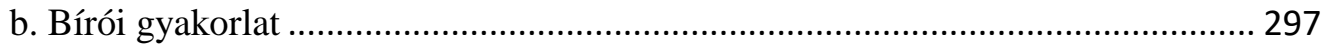

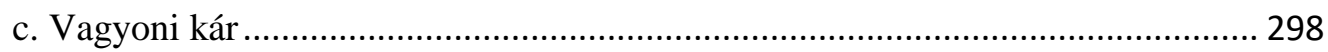

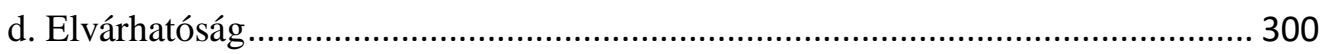

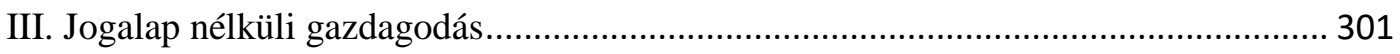

1. Alaptalan gazdagodás a BGB 812. § alapján .......................................................... 301

2. A jogalap nélküli gazdagodás vs. jogsértéssel elért előny átengedése...................... 303

3. Jogalap nélküli gazdagodás a jogosult halála után [Ptk. 2:50. § (2) bek.] ............... 307

IV. Jogkövetkezmények egymás mellett alkalmazhatósága ............................................ 309

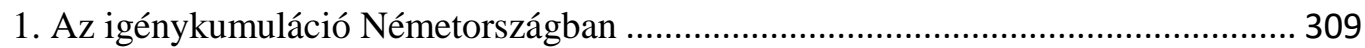


2. A vagyoni szankciók halmazatai a magyar jogban ................................................. 312

Részösszegzés ………....................................................................................... 314

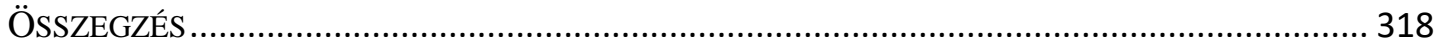

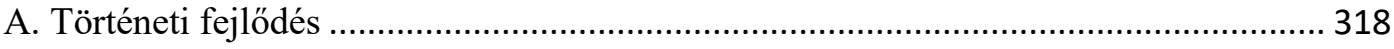

B. A vagyoni értékminőség dogmatikai előfeltételei ........................................................ 320

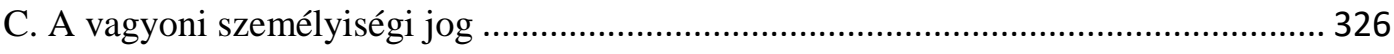

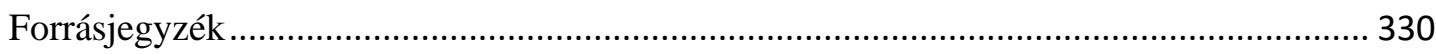

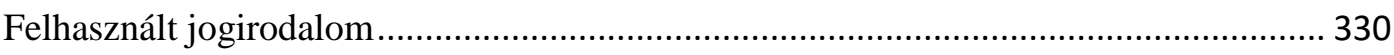

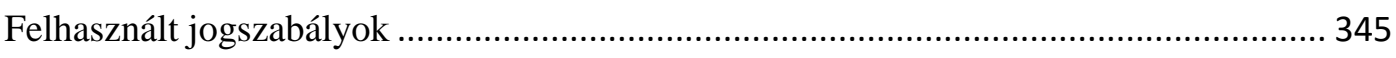

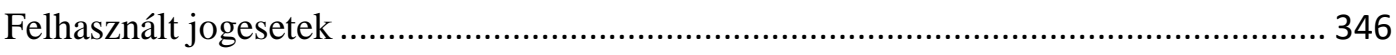

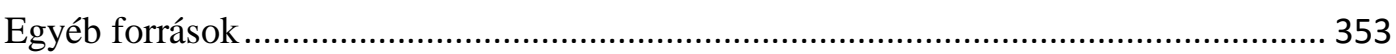




\section{Rövidítések}

2009-es Ptk.

$\mathrm{AB}$ hat.

ABGB

Aufl.

Bd.

BDT

Bek.

BGB

$\mathrm{BGH}$

BGHZ

BverfG

$\mathrm{BH}$

C.

Csjt.

Ctv.

D.

DÍT

DJZ

Dtár.

EJEB

EH

é.n.

FÍT

ff.

GG

GK

GRUR

Ht.

Inst.
2009. évi CXX. törvény a Polgári Törvénykönyvről

alkotmánybírósági határozat

Allgemeines Bürgerliches Gesetzbuch

Auflage, kiadás

Band, kötet

Bírósági Döntések Tára (folyóirat)

bekezdés

Bürgerliches Gesetzbuch

Bundesgerichtshof

Entscheidungen des Bundesgerichtshofs in Zivilsachen

Bundesverfassungsgericht, német alkotmánybíróság

Bírósági Határozatok (folyóirat)

Curia

1952. évi IV. törvény a házasságról, a családról és a

gyámságról

2006. évi V. törvény a cégnyilvánosságról, a bírósági

cégeljárásról és a végelszámolásról

Digeszta

Debreceni Ítélőtábla

Deutsche Juristenzeitung

Döntvénytár

Emberi Jogok Európai Bírósága

Elvi határozat

év nélkül

Fővárosi Ítélőtábla

sköv.; fortfolgende

Grundgesetz, német alaptörvény

Gazdasági Kolliégium(i állásfoglalás)

Gewerblicher Rechtsschutz und Urheberrecht

1894. évi XXXI. törvénycikk a házassági jogról

Institúciók 
ÍH

JURA

JuS

K.

Kir.

KJK

Kt.

KUG

Legf. Bír.

LG

Mtj.

NJW

NJW-RR

$\mathrm{OGH}$

OGH (Li)

OLG

Opt.

Optk.

ÖJZ

P.

PGR

PÍT

Ptk.

régi Ptk.

Rn.

RGZ

sköv.

St.

SZ

SZÍT
Ítélőtáblai Határozatok (folyóirat)

(1) Juristische Ausbildung (folyóirat); (2) JURA magyar

folyóirat

Juristische Schulung (folyóirat)

Kúria

királyi

Közigazgatási és Jogi Könyvkiadó

1875. évi XXXVII. törvénycikk a kereskedelmi jogról

Kunsturhebergesetz, Gesetz betreffend das Urheberrecht an

Werken der bildenden Künste und der Photographie; A képző-

és fényképészeti műveken fennálló szerzői jogot illető törvény

Legfelsőbb Bíróság

Landgericht, törvényszék (német)

1928. évi Magánjogi Törvényjavaslat

Neue Juristische Wochenschrift

Neue Juristische Wochenschrift Rechtsprechungs-Report

Oberste Gerichtshof (Ausztria)

Oberste Gerichtshof (Liechtenstein)

Oberlandesgericht, táblabíróság (német)

Osztrák Polgári Törvény, Optk.

Osztrák Polgári Törvénykönyv

Österreichische Juristen Zeitung

Polgári (ügyszak)

Törvény a személyi és társasági jogról (Liechtenstein)

Pécsi Ítélőtábla

2013. évi V. törvény a Polgári Törvénykönyvről

1959. évi IV. törvény a Polgári Törvénykönyvről

Randnummer, széljegy

Entscheidungen des Reichsgerichts in Zivilsachen (folyóirat)

és következő

1914. évi XIV. törvénycikk

Entscheidungen des österreichischen Obersten Gerichtshofs in

Zivilsachen (folyóirat)

Szegedi Ítélőtábla 


$\begin{array}{ll}\text { szj. } & \text { széljegy } \\ \text { tv. } & \text { törvény } \\ \text { tc. } & \text { törvénycikk (1949. évi XX. törvény hatálybalépéséig) } \\ \text { U. } & \text { Urteil } \\ \text { U.o. } & \text { ugyanott } \\ \text { UrhG } & \text { Urhebergesetz, a szerzői jogról és a szomszédos jogok } \\ & \text { oltalmáról szóló törvény (német) } \\ \text { V.ö. } & \text { vesd össze } \\ \text { ZeuP } & \text { Zeitschrift für europäisches Privatrecht } \\ \text { ZGB } & \text { Zivilgesetzbuch (svájc) } \\ \text { ZPO } & \text { Zivilprozeßordnung (polgári eljárásjogi törvény, német) } \\ \text { ZUM } & \text { Zeitschrift für Urheber und Medienrecht }\end{array}$

A törvényhely megjelölése nélküli szakaszhelyek a Ptk. szakaszhelyei. 


\section{Táblázatok Jegyzéke}

1. sz. táblázat A különös személyiségi jogok jogtárgyainak általános személyiségi jog általi védelme a joggyakorlatban

2. sz. táblázat A személyiségi jog eszmei és vagyoni vonatkozásainak védelme a német joggyakorlatban

3. sz. táblázat A Legfelsőbb Bíróság 1953-1989 között közzétett döntései

4. sz. táblázat A Királyi Kúria és a Legfelsőbb Bíróság személyiségi jogi tárgyú döntéseinek összehasonlítása

5. sz. táblázat $A z$ általános személyiségi jog megsértésének vizsgálati igényváza

6. sz. táblázat Az immateriális javak Meszlény-féle felosztása

7. sz. táblázat A tárgyiasítható személyiségi jegyek osztályozása

8. sz. táblázat A Ptk. vagyoni értékminőséget érintő szakaszhelyei

9. sz. táblázat A vagyoni személyiségi jog bitorlásának szempontjai

10. sz. táblázat A post mortem right to publicity védelmi ideje az USA egyes tagállamaiban 


\title{
Bevezetés
}

\author{
I. Kutatási feladat, célkitüzés
}

1. A tudomány állása

A személyiségi jogok vagyoni értékének, 1 forgalomképességének, átruházhatóságának kérdésköre a német nyelvü jogirodalomban már a második világháború után megjelenik, ${ }^{2}$ nagyobb visszhangot azonban Götting 1995-ben megjelent disszertációja után kapott. ${ }^{3}$ Erre hivatkozva ismerte el ugyanis 1999-ben a BGH egyes személyiségi jogi vonatkozások örökölhetőségét, átruházhatóságát. ${ }^{4} \mathrm{~A}$ jogintézmény német bírói gyakorlatban való megjelenésével és alkalmazásával egyidejüleg elindult a jogtudományban a jogintézményhez kapcsolódó jogi problémák mélyebb feltárása, temérdek disszertáció született a tárgykörben. ${ }^{5}$ A jogirodalmi viták eredményeképpen két jelentős álláspont rajzolódott ki a német jogirodalomban. Az uralkodó álláspont szerint a személyiségi jogon belüli vagyoni és személyi viszonyok egymástól elválaszthatatlanok, így a monizmus jellemzi őket, ${ }^{6}$ a másik, kisebbségi álláspont szerint a nem vagyoni személyi vonatkozásoktól függetlenül létezik egy vagyoni értékü személyiségi jog, amely örökölhető és átruházható. ${ }^{7}$ Az osztrák legfelsőbb bíróság $(\mathrm{OGH})$ szintén elismerte, hogy az Optk. 16. §-a szerinti általános személyiségi jognak vannak vagyoni vonatkozásai. ${ }^{8}$ A német jog eredményei alapján

\footnotetext{
${ }^{1}$ Vagyoni érték alatt a személyiségi jog csereértékre, pénzre válthatóságát, pénzben kifejezhető értékét értem, vagyoni érdek alatt pedig az alanyi jogon fennálló érdekkör vagyonjogi jellegét.

${ }^{2}$ Heitmann, Lutz: Der Schutz der materiellen Interessen an der eigenen Persönlichkeitssphäre durch subjektiv-private Rechte - zugleich ein Beitrag zur Abgrenzung des allgemeinen Persönlichkeitsrecht, Diss. Hamburg, 1963; KLIPPEL, DIETHELM: Der zivilrechtliche Schutz des Namens. Eine historische und dogmatische Untersuchung. Paderborn, 1985.

${ }^{3}$ GÖTTING, Horst-Peter: Persönlichkeitsrechte als Vermögensrechte. Paul Siebeck, Tübingen, 1995.

${ }^{4}$ NJW 2000, 2195 - Marlene Dietrich.

5 Többek közt például BEUTER, ClAUDIA: Die Kommerzialisierung des Persönlichkeitsrechts. Dissertation, Konstanz, 2004; HARTL, MiCHAEL: Persönlichkeitsrechte als verkehrsfähige Güter. Dissertation, Konstanz, 2004; SCHWEERS, CHRISTIAN: Die vermögenswerten und ideellen Bestandteile des Persönlichkeitsrechts nach dem Tod des Trägers. Dissertation, Köln, 2006; FRIEDRICH, KATRIN: Internationaler Persönlichkeitsrechtsschutz bei unerlaubter Vermarktung. München, CH Beck, 2003.

6 GÖTtING, HORST-PETER: Die Vererblichkeit der vermögenswerten Bestandteile des Persönlichkeitsrechts - ein Meilenstein in der Rechtsprechung des BGH, NJW 2001, 585.

${ }^{7}$ BEUTHIEN, VOLKER: Was ist vermögenswert, die Persönlichkeit oder ihr Image? NJW 2003. 1220.

${ }^{8}$ SZ 2010/70 - Maria Treben.
} 
a svájci jogtudomány is elkezdte vizsgálni, mennyiben lehetnek a személyiségi jogok forgalomképes, átruházható jogosultságok. ${ }^{9}$

A magyar jogirodalom ehhez hasonlatosan a kontinentális német jog megoldásait vizsgálja az amerikai jog mellett, és a témával foglalkozó jogtudósok többsége a személyiségi jogok vagyoni értékminősége mellett foglal állást. ${ }^{10} \mathrm{~A}$ német jog eredményeinek átvételét elöször Görög Márta veti fel egy 2010-es tanulmányában. ${ }^{11}$ A téma aktualitása ellenére nem született még olyan nagyobb jellegü, átfogó magyar munka, amely megválaszolja a személyiségi jogok vagyoni értékével, és ebből következő örökölhetőségével, átruházhatóságával kapcsolatos kérdéseket. A jogirodalom elsősorban a vagyoni értékminőség alátámasztását, igazolását célozza, ugyanakkor a forgalomképes, örökölhető személyiségi jogosultságokat nem tekinti a személyiségvédelem rendszerébe illeszkedőnek. ${ }^{12} \mathrm{~A}$ Ptk. - a német jogirodalom és joggyakorlat eredményeit alapul véve - a jogsértéssel elért vagyoni előny átengedésének lehetővé tételével a személyiségi jog vagyoni értékét már elismerte, ennek ellenére a személyiségi jogok vagyoni értékminősége koncepciálisan nem jelent még meg a magyar jogban.

Mindennek okán abból a feltevésből indulok ki, hogy a vagyoni értékminőség a kontinentális jogokban, így a magyar jogrendszerben is valóság, a Ptk. ugyanakkor számtalan ezzel kapcsolatos kérdést nem szabályoz, amely miatt ebben a tekintetben valóságos törvényi hézagról beszélhetünk. A dolgozat ezzel kapcsolatban a

\footnotetext{
${ }^{9}$ SeEmann, BRUno: Prominenz als Eigentum. Parallele Rechtsentwicklungen einer Vermarktung der Persönlichkeit im amerikanischen, deutschen und schweizerischen Persönlichkeitsschutz. Nomos, Baden-Baden, 1996.

${ }^{10}$ GÖRÖG MÁRTA: Néhány gondolat a Ptk. személyiségi jogi katalógusához. In: Görög Márta - Hegedüs Andrea (szerk.): Lege duce, comite familia. Ünnepi tanulmányok Tóthné Fábián Eszter tiszteletére jogászi pályafutásának 60. évfordulójára. Pólay Elemér Alapítvány, Szeged, 2017. 141. HARKAI ISTVÁN: A képmáshoz való jog és pénzben kifejezhető értéke a számitógépi programalkotásokban. In: Báró-Farkas Margit Chiara - Kemény Zsanett (szerk.) A pénzügyi világ kihívásai a 21. században. Szeged: Pro Talentis Universitatis Alapítvány, 2018.; MENYHÁRD ATTILA: Forgalomképes személyiség? In: Menyhárd Attila - Gárdos-Orosz Fruzsina (szerk.): Személy és személyiség a jogban. Wolters Kluwer, Budapest, 2016. NAVRATYIL ZOLTÁN: Gondolatok névjogról, szólásszabadságról. MTA Bölcsésztudományi Kutatóközpont, Budapest, 2015; STUMP KRISZTINA: A személyhez füzödö jogok vagyoni vonatkozásai - új fejlemények. Jogi Tanulmányok, 2014. 612.; SZEGHALMI VERONIKA: A személyiség ,értéke“ és annak post-mortem továbbélése. FORVM Szeged, Szeged, 2017.; SzTOJÁN KRISZTINA: Bismarcktól Tiger Woodsig: a személyiség kereskedelmi értéke. (https://arsboni.hu/bismarcktol-tiger-woodsig-szemelyiseg-kereskedelmierteke/); TAKÓ SÁNDOR: Az emberi képmás filmalkotási és filmterjesztési célú felhasználásának személyiségi jogi vonatkozásai. In: Görög Márta - Menyhárd Attila - Koltay András (szerk.): A személyiség és védelme. ELTE Eötvös, Budapest, 2017.

${ }^{11}$ GÖRÖG MÁRTA: A személyhez füződö jogok védelmét deklaráló generálklauzula. In: Csöndes Mónika - Nemessány Zoltán (szerk.): Merre tart a magyar civilisztikai jogalkotás a XXI. század elején? Kódex, Pécs, 2010. 125.

12 MENYHÁRD, 2016. 402. SZEGHALMI, 2017. 232.
} 
magánjogban releváns dogmatikai kérdésekre is hangsúlyt kíván helyezni, mint amilyen a személyiségi jog monista vagy dualista jellege tekintetében való állásfoglalás, a halál utáni jogosultak köre, az alkalmazandó jogkövetkezmények, a védelmi idő terjedelme stb. Ezzel összefüggésben nem egy publicitás alapú vagyoni személyiségvédelemből indulok ki, hanem az egyes személyiségi jogi jogosultságok tárgyiasulásán alapuló vagyoni értékminőségre építkezem, amely a civiljogi dogmatikai rendszerbe sokkal jobban belesimulhat.

Hangsúlyozandó, hogy a dolgozat nem a jogintézmény német jogi megoldásainak hü másolását és átvételét célozza, sokkal inkább a magyar jogrendszerbe illeszkedő megoldásokra törekszik, amelyet a magyar jog, a kir. Kúria hagyományaira és a magyar szerzők sajátos álláspontjaira építve törekszik kialakítani. Mivel a magyar jogirodalomban a téma mélyebb taglalása igen hiányos, így számos más magyar jellegzetességre támaszkodtam, amelyet a dolgozatba beépítettem, hogy egy dogmatikai rendszert kialakítsak. Ebből következik a kir. Kúria joggyakorlatának széles körü feltárása, a személyiségi jog immateriális jellegének felélesztése a két világháború közötti jogirodalomból, illetve a tárgyiasulás fogalmának felhasználása Balás P. Elemér és Törö Károly személyiségi jogi hagyatékából.

A jogirodalomban nem jelenik meg elhatárolási, osztályozási szempontként a publicitás, illetve a tárgyiasulás alapú vagyoni értékminőség kérdése. Az amerikai jogot alapvetően a publicitás, az adott személyiség széles körben való ismertségével kapcsolatos vagyoni jogosultság jellemzi. A kontinentális, civiljogi rendszerekben, amelyek közül a német jog az, amely a személyiségi jog vagyoni értékminőségének dogmatikai alapjait a leginkább tökélyre fejlesztette, nem található kifejezetten tárgyiasulásra épülő modellt. Maga Götting is elsősorban az átruházhatóság és örökölhetőség kimutatásához kapcsolja a vagyoni értéket, ${ }^{13}$ amelynél fogva a tárgyiasulás alapú vagyoni értékminőség absztrakt alkalmazása nem lelhető fel más szerzőknél. A tárgyiasulással a szellemi tulajdonjogokhoz való kapcsolódás, ${ }^{14}$ a dologi dinamika sokkal jobban alátámasztható, ezáltal tényállási, jogszabályi szinten jobban artikulálható az egyes személyiségi jegyek személyiségtől való elválása és ezzel egyidejü vagyoni értékminőség szerzése.

\footnotetext{
13 GÖTting, 1995. 9-10.

14 Beverly-Smith - OHLY - LuCAs-Schlotter: Privacy, Property and Personality, Cambridge University Press, 2005. 3.
} 
A személyiségi jogok egy része a magyar uralkodó álláspont szerint vagyoni értékkel bír. A kutatás nem annak vizsgálatára irányul tehát, hogy van-e vagyoni értékminősége a személyiségi jognak, hanem arra, hogy ez miként mérhető, hogyan írható le jogilag. Németországban a jogirodalomban számos tanulmány, disszertáció, szakkönyv és monográfia foglalkozik a témával és a joggyakorlat is az elismerése óta számos tekintetben konkretizálta a jogintézményt, az azonban törvényi szinten nem jelenik meg. A vizsgálat ebből fakadóan elsősorban arra irányul, hogy a személyiségi jogok vagyoni értékminőségét jogi tényekkel le tudjuk írni, annak tényállását meg tudjuk határozni, és ezáltal az általános személyiségi joghoz képest specifikálni tudjuk.

Abban az esetben ugyanis, ha a személyiségi jog rendelkezik vagyoni értékminőséggel, legalább is azt a német jogalkalmazás is úgy értékeli, illetve a magyar uralkodó álláspont is vagyoni értéket tulajdonit egyes személyiségi jogosultságoknak, úgy hogyan írható ez le a tényállás és a jogkövetkezmény szintjén mint alanyi jogi jogosultság.

A személyiségi jogok vagyoni értéke és forgalomképessége értékválasztás kérdése, jogpolitikai kérdés is. A jogalkotó értékelésén múlik az, hogy a személyiségi joghoz köthető vagyoni érték, vagyoni javak feletti rendelkezést elismeri-e, azt ki számára biztostja. Ebből eredően megkülönböztethető az is, hogy a jog kizárólag a vagyoni értéket ismeri el, de a személyiségi jegyeket nem tekinti forgalomképes jogosultságoknak, vagy a személyiségi jog vagyoni vonatkozásainak örökölhetőségét, átruházhatóságát elismeri.

Jelen kutatás nem vizsgálja, hogy az egyes nevesített személyiségi jogokba tartozó részjogosultságok hogyan rendelkeznek vagyoni értékkel, illetve hogy ezek esetén hogyan alakul az átengedés ellenértéke, illetve a fiktív licencia díj fizetési ${ }^{15}$ kötelezettség a joggyakorlatban. A kutatás tárgyát nem képezik továbbá azok a szerződéses konstellációk sem, amelyek a személyiségi jogok átruházására, használati engedély adására vonatkoznak, így sem a licencia, sem a merchandising szerződés. Nem tartozik a vizsgálat tárgykörébe a személyiségi jogok azon köre, amely az emberi

\footnotetext{
${ }^{15}$ A hipotetikus licenciadíj (elmaradt hasznosítási díj, licencia analógia): az a díjazás, amely a jogosultat megillette volna, ha a jogsértő engedélyt kért volna a vagyoni értékü személységi javak hasznosítására.
} 
test, az emberi testrészek forgalomképességével, átruházhatóságával foglalkozik, hanem kifejezetten az immateriális jogtárgyakra, a megjelölési jogokat ${ }^{16}$ vizsgálja.

A kutatás a személyiségi jogok közül elsősorban a névjogra koncentrál. Ennek oka alapvetően az, hogy a névjogon modellezhető legjobban a vagyoni értékminőség megjelenése, ugyanis a névjogon belül a vagyoni érték előfeltételének tekintett tárgyiasulásnak számtalan formája van jelen a hatályos jogunkban. A névjog tárgyiasulása tetten érhető a természetes személy nevének cégnévben való használatán, a kereskedelmi névként, domain névként való használaton, a védjegyként való bejegyzésen, de ugyanígy a reklámokban való felhasználáson is. A névjog esetén a tárgyiasulásnak azért van több módja, létezik több alfaja létezik, mert szóbeli megjelölési jellege révén számos más jogintézmény jogtárgyának tulajdonságát osztja, és ezáltal e jogtárgyak és a személyiségi jog névjogi vonatkozása között átjárás található. Ezáltal rendelkezik a név a többi személyiségi jognál sokkal szélesebb körben vagyoni értékkel.

A névjog mint személyiségi jog másrészről nem egységes jog, több jogtárgyat véd. Védi a természetes személy nevét, védi a cégnevet mint önálló jogtárgyat, a kereskedelmi nevet, a domain nevet mint szintén önálló jogtárgyakat. Így a névjog mint személyiségi jog sok esetben akkor is védi az adott szóbeli megjelölést, ha a természetes személy nevéhez, a személyiség megjelöléséhez ennek semmi köze. Ezzel tulajdonképpen az előbbi tárgyiasulási folyamaton túl a névjogon belül, illetve amellett további, más tárgyiasult, vagyoni értékkel bíró, átruházható jogosultságokat is oltalmaz a magyar jog és bírói gyakorlat a személyiségi jogon mint legszemélyesebb jogon belül. Ez szintén olyan körülmény, amely miatt a névjog kiemelését szükségesnek tartottam.

\footnotetext{
${ }^{16}$ A néven- és megjelöléseken való jogok elnevezést a svájci jogelméletben August Egger (EGGER, August: Einleitung. Das Personen. Zürich, Schultheß \& Co, 1930. 246-248.), a német jogelméletben Otto von Gierke használja. Ez utóbbitól vette át az elnevezést Bozóky Alajos is (BOZÓKY AlAJOS: A személyjogokról. In: Fodor Ármin (szerk.): Magyar Magánjog I. Singer és Wolfner, Budapest, 1905. 464.), de azt Almási Antal (AlMÁsI ANTAL: A személyiségi jog elhatárolása és tartalma. Jogtudományi Közlöny 1927. 133. 135.) is előszeretettel használta. A megjelölések joga lényegében a szóbeli megjelölések jogi védelmének gyüjtőfogalma, amelybe ugyanúgy beletartozik a vagyoni értékminőséget egyértelmüen felmutató vállalat- és árujelzők joga, mint a személyesebb jellegü, a személyiségi jogon belül elhelyezkedő névjog, illetve névjogok is.
} 
A téma feldolgozását elsősorban dogmatikai irányból közelítem meg, ez jelentősen keveredik a jogtörténeti irányú vizsgálattal, amely a dolgozat első A részében tisztábban, a dolgozat B és C részeiben pedig kifejezetten összehasonlító jelleggel jelenik meg. Elsősorban a jogtörténeti és a hatályos német és magyar jog összehasonlításából, illetve a bírósági határozatokból kinyert esetnormákból jut el a dolgozat a dogmatikai rendszerezéshez.

A téma vizsgálata szempontjából kiemelkedő volt a személyiségi jog kialakulásának jogirodalma. Ekkor került kialakításra a jogintézmény, az alanyi jog, ekkor vált a személyiségi jog legszemélyesebb jellegü joggá, amely alapján a személyiségi jog a személytől elválaszthatatlan, amelyről nem lehet lemondani, másra nem lehet átruházni, és amely a jogosult halálával megszünik. A második világháború utáni magyar jogirodalom vonatkozásában elsősorban a hatályos jogirodalmon és kommentárirodalmon túl az 1959-es Ptk. vonatkozó értelmezését, és az 1977-es Ptk. novella szabályait vizsgáltam. A német nyelvü irodalomban elsősorban a kommentárirodalom, néhány fontosabb jelentőségü tanulmány, illetve a témában megjelent, legjelentősebb irodalom került feldolgozásra.

A magyar joggyakorlat feldolgozása tekintetében a teljességre törekedve az ÍH, BDT és a BH összes releváns személyiségi jogi döntését feldolgoztam, és éptettem be a dolgozatba. A királyi Kúriai joggyakorlatát elsősorban a történeti rész bemutatása szempontjából használom fel, hiszen e részben kiemelt szerepet fordítok a vagyoni érték és gazdasági felhasználás bírósági gyakorlatban való megjelenésének. A német joggyakorlat vonatkozásában elsősorban azokból a döntvényekből indultam ki, amelyek valamely elvi kérdést fogalmaztak meg a személyiségi jogi védelmen belül. Emellett néhány általam jogi szempontból érdekesnek ítélt döntést is bevontam a vizsgálódásba, különösen, ha egy alsóbíróság egy vitás kérdésben foglalt el egy sajátos álláspontot. A német joggyakorlatot sokszor összehasonlítom a magyarral, illetve a kir. Kúriáéval. A joggyakorlat feldolgozása során a dinamizmusra törekedtem, így nem csak bemutatom a jogi indokolást, hanem azt kritikai szemponttal összevetem a dogmatikával, és ez alapján kritizálom, illetve értek egyet az adott jogi indokolással.

A magyar bírósági döntéseket és döntvényeket a német jogirodalomban is alkalmazott megoldással rövid névvel láttam el, amely az ítélet hivatkozási számát követi a lábjegyzetekben. Ezen elnevezéseket a törzsszövegben is segítségül hívom. 
Célom ezzel az volt, hogy az egyes ítéletek könnyebben felismerhetőek legyenek, az azokban tett megállapítások könnyebben megjegyezhetőek legyenek.

A dolgozat alapvetően a dogmatikai rendszerezésre építkezik, a jog szövegrétegéből kiindulni azért is lenne nehéz, mert az mind a német jogban, mind a magyar jogban szinte teljesen hiányzik, így a dogmatika irányából teszek ennek kialakítására kísérletet. A joggyakorlat szempontjából nemcsak bemutatom, hanem állást is foglalok abban, hogy a saját osztályozásom alapján az adott jogi probléma szubszumciója miként valósul meg. Az ítéletek és a bírói gyakorlat kritikai vizsgálatánál nagymértékben felhasználtam az ún. Anspruchsmethodét,${ }^{17}$ illetve a Fürst László által jogszabályi redukciónak nevezett módszert, amely a jogi érvelés megfelelő elsajátításában segített, ${ }^{18} \mathrm{~s}$ így nem vontam be előkérdések és előfeltételek vizsgálatát ott, ahol azok megvalósulásában joggal lehetett bízni. Nagy hatással volt rám Szladits Károlynak a magánjogi igényhalmazatokról és törvényhalmazatokról vallott felfogása, amelyet a dolgozatban sok helyen megjelenítek. ${ }^{19}$ A magánjog általános rendszerének megértése körében elsösorban Szladits Károly, Személyi Kálmán ${ }^{20}$ és Peter Bydlinksi ${ }^{21}$ felfogására támaszkodtam.

\section{Az értekezés bemutatása}

\section{A dolgozat átfogó bemutatása}

A dolgozat három részből áll: (A) a történeti fejlődés, (B) a vagyoni értékminőség dogmatikai előfeltételei, illetve (C) a vagyoni személyiségi jog mint alanyi jog.

A történeti rész a német és a magyar jog fejlődését mutatja be (A). Elsőként a vagyoni értékminőség, érdekkör jelenlétét vizsgálja a német és a magyar joggyakorlat történeti fejlődésében, ezen túl bemutatja azon dogmatikai rendszert, amely alapján a személyiségi jog vagyoni vonatkozásai a német jogban oltalmat nyernek (1-2. §§). A vagyoni érdek meglétét követően a dolgozat a magyar személyiségvédelmi rendszerben kívánja absztrakt jelleggel elhelyezni a személyiségen fennálló vagyoni

\footnotetext{
${ }^{17}$ FRITZSCHE, JÖRG: Fälle zum BGB Allgemeiner Teil. CH Beck, München, 5. Auflage, 2014.

${ }^{18}$ FÜRST LÁSZLÓ: A magánjog szerkezete. Grill, Budapest, 1934.

${ }^{19}$ SzLADITS KÁROLY: A magyar magánjog vázlata I. Grill, Budapest, 1933.

${ }^{20}$ SZEMÉLYi KÁlMÁN: A névjog. Franklin, Budapest, 1915.

${ }^{21}$ BYDLINSKI, PETER: Grundzüge der juristischen Methodenlehre. Facultas wuv, Wien, 2012.
} 
jogosultságokat. Az elhelyezés dogmatikai előfeleltelei szempontjából két nagy kérdéskör vizsgálandó (B). Az, hogy a személyiségi jog jogalapja mennyiben alkalmas a vagyoni minőség elhelyezésére (3. §), illetve hogy a személyiségi joggal összefüggésben hogyan válhatnak el a személyiségi jogi részjogosultságok a személyiség belső magjától (4. §). A személyiségi jogtól való elválást a névjog példáján mutatom be (5. §). Az elvi alapok után kialakításra kerülnek egy esetleges vagyoni személyiségi jog dogmatikai alapjai (C). Ennek során először azt vizsgálom, a Ptk. személyiségi jogi szabályai mennyire engedik a vagyoni értékminőség jelenlétét (6. §). Ezt követően a vagyoni értéket védő, dogmatikailag értékelt alanyi jog jogi tényeit, tényálláselemeit határozom meg (7. §), amelyek együttes beállása esetén alkalmazhatóak a személyiségi jogon fennálló vagyoni érdek megsértéséből származó jogkövetkezmények (8. §).

\section{Az egyes részek bemutatása}

\section{A. Történeti fejlödés}

A német jog vizsgálata azért került a dolgozat elejére, mert ez lesz az a jogrendszer, amelyet a magyarhoz a későbbiekben hasonlítani fogok, így logikusnak tünt a dolgozat elején tisztázni a rendszerét, s a későbbiekben csak annyiban hivatkozni rá és vizsgálni, amennyiben az az adott jogintézmény, kérdéskör magyar vonatkozása tekintetében szükséges és releváns. A téma feldolgozása során próbáltam hangsúlyozni a magyar és a német személyiségvédelem eltérő jellegét, a német jogban a bírói esetjog kiemelkedő jelentőségét és az ún. különös személyiségi jogok intézményét, amely nálunk ilyen formájában nem létezik. A német jog vizsgálata egyrészröl rámutat arra, hogy melyek a jogintézmény vitás kérdései az adott témában, hol térnek el az álláspontok, másrészröl hogyan és milyen összefüggésekben jelenik meg a vagyoni értékminőség, és mikor marad a személyiségi jog a legszemélyesebb jog. Ezek meghatározzák a dolgozat dogmatikai alapjait, mintegy mederként szolgálnak a vizsgálat során.

A magyar jogtörténetre koncentárló kutatás (2. §) több kérdés vizsgálatára irányul. Vizsgáltam elsősorban azt, hogy mikor és hogyan jelentkezett a jogirodalomban és a joggyakorlatban a személyiségi jog védelme nem vagyoni jogosultságként, ezzel összefüggésben azt, hogy mennyiben tekintette a háború előtti 
jogirodalom a személyiségi jogokat nem vagyoni jellegü jognak, vagy volt-e olyan álláspont, amely bizonyos személytől való függetlenedést lehetővé tett. Az egyes személyiségi jogi részjogosultságokat külön-külön vizsgáltam ebböl a szempontból. Ide sorolható számos névjogi vonatkozású jogintézmény: a cégnév, a feleség neve, az általános névbitorlás, amelyek esetén a személyiségi jog mint névjog egyes részei különböző jogalapokból nőtt ki. A bírói gyakorlat ismerte el továbbá a kegyeleti jogot, a képmáshoz való jogot és a hitelt is személyiségi részjogosultságként. Ebben a részben foglalkozok a közszereplői minőséggel is. A joggyakorlat tekintetében összehasonlítottam a háború előtti piacgazdasági, illetve az az utáni, tervgazdasági viszonyok között hozott ítéletek jellegét, hogy az esetleges vagyoni értékminőségre ezzel is rámutassak, az eltérő társadalmi-gazdasági viszonyok ugyanis alapvetően más jellegű személyiségvédelmet indukáltak sok tekintetben.

A jogtörténeti irányú kutatás célja elsősorban arra irányult, hogy igazolam azt, hogy a személyiségi jogok vagyoni értéke nem újkeletü, nem a XXI. század eredménye, hanem az már a XX. század elején is jelen volt, s az nagymértékben összefüggött a személyiség magánjogi védelmének igényével, s ezzel a jogintézmény létjogosultsága a magyar jogrendszerben legitimálható legyen.

\section{B. A személyiségi jog vagyoni értékminöségének dogmatikai elöfeltételei}

A vagyoni érték elismeréséhez szükséges, hogy a személyiségvédelmi rendszer ne úgy legyen törvényi szinten kialakítva, hogy az csupán a személyiséghez kapcsolódó eszmei és erkölcsi érdekek védelmezésére alkalmas. Vizsgálandó volt ezért, hogy a hatályba lépett új Ptk. ezt a lehetőséget mennyiben támogatja. Ezzel kapcsolatban a törvényben biztosított alanyi jogi, illetve alanyi jog-szerü diszpozíciókat vizsgáltam, az emberi méltóságot, a magánélethez való jogot és a kibontakozást mint a személyiségi jog generálklauzuláját. Mivel a vagyoni értékminöség egyes személyiségi jogi vonatkozásokhoz egyértelmüen kapcsolódik, ezért a vizsgált kérdés az volt, hogyan lehet elérni a magyar személyiségvédelemben azt, hogy az emberi méltóság joga és az egyes személyiségi jegyek örökölhetösége s átruházhatósága ne kerüljön elvi szinten kizárásra. A kutatás e része vizsgálja, hogy mi a személyiségi jog jogalapja, milyen értelmezési lehetőségei vannak az emberi méltóságnak a magánjogi személyiségvédelemben, illetve hogy miért nem alkalmazható a magánjogra az Alkotmánybíróság által az alkotmányjogban használt, szélesen értelmezett méltóság- 
fogalom. Ezután a magánélethez való jog helyét vizsgálom a személyiségi jogok között. Különösen a generálklauzulához és más személyiségi jogokhoz való viszonyát. Ezt követően állást foglalok abban a kérdésben, hogy az egyes nevesített személyiségi jogok egyfajta önálló alanyi jogként funkcionálnak vagy egy általános, egyetlen alanyi jog részjogosultságát képezik-e, s ennek alapján meghatározom azon szempontokat, amelyekből a(z általános) személyiségi jog felépül. A személyiségi jog megsértési feltételeinek meghatározása után lehetséges elhelyezni, pozícionálni a vagyoni érdekhez kapcsolódó jogi tényeket.

Ahhoz, hogy a vagyoni értékminőséget a tényállás szintjén értékelni tudjuk, meg kell törni azon dogmát, hogy a személyiségi jog legszemélyesebb jog, amely a személytől elválaszthatatlan. Az elválaszthatatlanság ellen szól, hogy egyes személyiségi jogi jogosultságok képesek a tárgyiasulásra, a személyiségtől való részleges elválásra. Azzal tehát, hogy egy személyiségi részjogosultság, személyiségi jegy vagyoni értékminöséget szerez, tulajdonképpen eltávolodik a legszemélyesebb jellegtöl, ezzel az eltávolodással a jogtárgy kilép a személyiségi jog mint alanyi jog keretei közül, és egyfajta vagyoni jogként, vagyoni immateriális jogként funkcionál tárgyiasul.

A dolgozat a személyiségi jog tárgyiasulását a névjog példáján mutatja be. Kutatásaim során egyértelművé vált, hogy egy jogosultság személyi érdekszférába való tartozása nem állandó, hanem azt a dinamika jellemzi. Balás P. Elemér hagyatékára építve, az általa kidolgozott rendszerre alapozva vizsgáltam azt, hogy a név mikor válik a személyiség részévé, illetve mikor kerül ki onnan. A tárgyiasulás tekintetében a névjogra koncentrálva kerül bemutatásra az, hogyan és milyen formában képes a név, illetve más szóbeli megjelölés tárgyiasulni a személyiségvédelmen belül. A vagyoni értékminőség igazolása szempontjából ugyanis a tárgyiasulás tölt be jelentős szerepet. A név tárgyiasulása számtalan módon végbemehet. Történhet más jogintézmény keretében, mint amilyen a védjegy, történhet a személyiségi jogon belül más jogtárgy által, mint amilyen a kereskedelmi név vagy a domain név, illetve történhet a kisebb személyes jelleget felmutató cégnév által. A név ezen túl önmagában is tárgyiasulhat, amely elsősorban annak felhasználási módjához kötődik. A névjog tekintetében tehát a tárgyiasulásnak számtalan módja azonosítható. 


\section{A vagyoni személyiségi jog mint alanyi jog}

A vagyoni érdekek védelme tekintetében a Ptk. kodifikációját és a törvényszöveget vizsgálom. A magyar Ptk. ugyanis részben a német jog eredményeire épül. Ebből kifolyólag a vagyoni érdekek védelmét részben tartalmazza. Megvizsgálom, hogy az egyes, a vagyoni érdeket érintő szakaszhelyek mennyiben támogatják azt, hogy a személyiségi jog eszmei és vagyoni érdeket is védjen, illetve, hogy a törvény által nem szabályozott kérdéskörök bírói jogértelmezéssel feloldhatóak-e, vagy a jogalkotónak kell beavatkoznia a kérdésben.

Az egyes személyiségi jegyek tárgyiasulása nem csak az elválaszthatatlanság dogmájára ad választ, hanem meg is határozza azt, hogy az így létrejövő új jogosultságnak mi a formája. A tárgyiasulásnak azonban számtalan formája létezik. Ehhez kapcsolódik a vagyoni értékminőség másik fontos jellemzője, a jogosult vagyoni érdekkörébe tartozó felhasználás. A tárgyiasulás ugyanis önmagában nem jelent vagyoni értéket, ezzel a személyiségi jegy nem válik vagyoni joggá. A személyiségi jogokat, a személyiségi jegyeket tárgyiasult formájukban kizárólag eszmei, erkölcsi érdekkörben is fel lehet használni, anélkül, hogy a vagyoni viszonyokkal bármilyen kapcsolat kialakulna. Ebből kiindulva meghatározhatóak azok az elemek, amelyekkel a vagyoni érdekkörben felhasznált tárgyiasult személyiségi jegyeket egy jól lehatárolt halmazba sorolhatjuk. Ha a halmaz minden eleme megvan, azaz ha a vagyoni értékü személyiségi jegyekhez kapcsolódó jogi tényeket meg tudjuk határozni, úgy meg tudjuk fogalmazni az alanyi jogot s ehhez kapcsolódóan az alanyi jog megsértését is.

A német bírói gyakorlat a személyiségi jog vagyoni vonatkozásainak megsértése esetén alkalmazott esetkörök és jogkövetkezmények tekintetében viszonylag kiforrott. Ezzel kapcsolatban kitérek a jogalkalmazásban problémás esetkörökre, illetve a jogirodalom által vitatott megoldásokra. A német jog bemutatása után a magyar polgári jogi kodifikáció megoldását és azok helytállóságát vizsgálom részletesebben. A Ptk. a jogkövetkezmény szintjén bizonyos vonatkozásokban a vagyoni értékű személyiségi jogot elismeri és oltalmazza is, így ezzel kapcsolatban a kérdés az volt, hogy alkalmas-e arra a magyar személyiségvédelmi szankciórendszer, hogy a személyiségi joghoz kapcsolódó vagyoni érdekkört átfogóan és effektíven védje? 


\section{III. Új tudományos eredmények}

A tárgyiasítható személyiségi jegyek alkalmasak arra, hogy a vagyoni forgalomban részt vegyenek, ha a vagyoni személyiség mint speciális személyiségi szféra részévé válnak. A vagyoni személyiség egy, a szerzői joghoz hasonló személyiségi szféra, amely vagyoni és személyiségi viszonyokat is ötvöz. Míg az általános személyiségi jog személyi immateriális jogosultság, addig a vagyoni személyiségi jog önállótlan vagyoni immateriális jog. A vagyoni személyiségi jog az általános személyiségi jogból jön létre az ahhoz kapcsolódó többletelemek megvalósulásával, és a személyiség egy speciális értékminőségét képezi. Ez a speciális értékminőség, a vagyoni viszonyokkal való vegyülés, teszi lehetővé, hogy e személyiségi jegyek átruházhatóak, örökölhetőek legyenek, illetve megsértésük esetén vagyoni szankciók legyenek alkalmazhatók valamint, hogy a személyiségi jogi szankciók alkalmazási köre konkretizálásra kerüljön. A vagyoni viszonyokkal való vegyülés alapvetően a személyiségi jegy személyiségtől való elválásával, tárgyiasulásával ragadható meg, illetve annak felhasználási módján, amely a jogosult vagyoni érdekkörébe kell, hogy tartozzon.

A vagyoni személyiségi jog tényállásának meghatározása nem teszi feltétlenül önálló alanyi joggá ezt a jogosultságot, azonban az általános személyiségi jogtól való elválása a jogkövetkezmények tekintetében is manifesztálódik. Míg az általános személyiségi jog csupán eszmei, erkölcsi érdekeket véd, addig a vagyoni személyiségi jog a jogosult vagyoni érdekkörét is védi, s ennek okán csak e második jog esetén keletkezik a jogtárgy megsértéséből vagyoni kár, illetve csak ekkor igényelhető a jogsértéssel elért vagyoni előny átengedése.

Az egyes témakörök legjelentősebb megállapításai, eredményei a következők.

ad 1. $\S$

Melyek a személyiségi jog vagyoni vonatkozásaihoz kapcsolódó vitás kérdések, illetve melyek azok a kérdések, amelyekben a biróságoknak az alanyi jog elismerésével összefüggésben állást kellett foglalniuk?

A német bírói gyakorlat az általános személyiségi jogra vonatkozó felfogását jelentősen megváltoztatta 1999-ben. A BGH szerint ugyanis az általános személyiségi 
jog a hagyományos eszmei, erkölcsi érdekeken túl vagyoni érdekeket is véd. Ezt nem csak a személyiségi jog jogosultjának életében, hanem halála után is értékelni kell jogilag. A vagyoni érdekek a halál után nem válnak a kegyeleti jog részévé, hanem egyfajta vagyoni jog módjára öröklődnek. A vagyoni összetevők védelmi ideje 10 év poszt mortem a kodifikált képmáshoz való jog mintájára. A személyiségi jog vagyoni vonatkozásainak átruházhatósága kérdését a német bírói gyakorlat még egyértelműen nem válaszolta meg, így nem egyértelmü. hogy dologi hatályú átruházásra lehetőség van-e.

A német jogrendszerben törvényileg elismert és tényállásilag meghatározott névhez és képmáshoz való személyiségi jogokat ez az analógia nem érintette. A különös személyiségi jogok helyett a bíróságok az általános személyiségi jog felé fordultak, azt fejlesztették tovább, jóllehet a vagyoni értékkel kapcsolatos életviszonyok a két kodifikált személyiségi jog: a név és a képmás vonatkozásában jelentkeznek. Ez a megoldás szemben áll azon gierkei gondolattal, miszerint „a személyiség általános jogához kell visszanyúlni mindaddig, míg belöle a különös személyiségi jogok ki nem vétetnek“، ${ }^{22} \mathrm{~A}$ BGH azonban nem csak ekkor nyúlt az általános személyiségi joghoz, hanem akkor is, amikor az értelmezés a különös személyiségi jogok javára is eldönthető lett volna, illetve akkor is, amikor a vagyoni érték egyértelműen a nevesített személyiségi jogoknak szólt. A bíróság tehát nem a néven és képmáson való vagyoni jogként konkretizálta az újonnan elismert jogosultságot, hanem az általános személyiségi jog különös esetének tekintette ezt. Más szavakkal azt is mondhatjuk, hogy a német személyiségvédelemben a lex specialis derogat legi generali szabálya fordítottan érvényesül ebben a tekintetben, az általános személyiségi jog javára. A két különös személyiségi jogon fennálló vagyoni értékminőség a jogirodalom s még a joggyakorlat részéről is részletesen kiforrott és meghatározott volt, ami a generálklauzulára támaszkodást ilyen formában nem követelte volna meg. Ennek a különbségtételnek ugyanakkor inkább jogtechnikai jelentősége van, amely e jogok dogmatikai kikristályosodását jobban elősegítette volna.

Kiemelendő továbbá, hogy a német uralkodó álláspont a vagyoni érdeket az általános személyiségi jognak tulajdonítja, így az általános személyiségi jognak vannak vagyoni vonatkozásai, illetve ennek mintájára a poszt-mortem személyiségi jognak is vannak vagyoni vonatkozásai. A német jog nem választja le az eszmei

${ }^{22}$ GIERKE, 1895. 704-705. 
érdekeket védő általános személyiségi jogról a vagyoni vonatkozásokat, s ezzel továbbra is benne marad abban a csapdában, amit a kodifikáció elmaradása eredményezett. Az eszmei érdekekről való leválasztás, illetve leválasztódás ugyanis hozzájárult volna a jogi dogmatika csiszolódásához. Nem kerül tehát, legalábbis egyértelmű módon, értékelésre ebben a rendszerben az, hogy az általános személyiségi jog mint olyan alapvetően eszmei, erkölcsi érdekeket véd és csak bizonyos többletelem esetén vagyoni érdekeket is.

A német bírói gyakorlat tehát a személyiségi jog vagyoni értékminőségét az általános személyiségi jogon belül ismerte el. Az általános személyiségi jog ezzel eszmei és vagyoni vonatkozásokkal rendelkezik. Ez a két vonatkozás, érdekkör egymástól elválaszthatatlan, egységes jogot alkot, így az általános személyiségi jogot a monizmus jellemzi. Az általános személyiségi jog vagyoni vonatkozásainak 1999-es joggyakorlatbeli elismerésével értékelésre került az, hogy bizonyos személyiségi jogi vonatkozások átruházhatóak és örökölhetőek. Az általános személyiségi jog vagyoni vonatkozásai dologi hatállyal is átruházhatóak, ami azt jelenti, hogy az e jogot megszerző személy nem a személyiségi jog jogosultjával szemben bír kötelmi igénnyel, hanem harmadik személyek viszonylatában kizárólagos jogot szerez az átruházott vagyoni vonatkozás felett. Annak megsértése esetén saját jogon érvényesíthet igényt. Az általános személyiségi jog vagyoni vonatkozásai a halál után is védelemben részesülnek, ez a védelem azonban eltér az eszmei érdekek halál utáni védelmétől. Az eltérés abban jelentkezik, hogy a vagyoni vonatkozások a hagyaték részét képezik, azt az örökösök öröklik meg. A vagyoni vonatkozások a jogosult halálától számított 10 éves időtartamon belül biztosítanak rendelkezési jogot az örökösök számára, akik e jogot az örökhagyó kifejezett vagy feltehető érdekeinek figyelembevételével gyakorolhatják. A jogirodalom a szabályozás hézagait elsősorban a szerzői jog alkalmazásával töltené ki a joggyakorlatban.

A német személyiségvédelem a magyar jogtól eltérő alanyi jogi konstrukcióban oltalmazza a személyiségi érdekszférát. A német jog az eszmei érdekek védelmére több alanyi jogot ismer, míg a magyar jog csak egyet. A német jog a különös személyiségi jogok között nevesíti a névhez és képmáshoz való jogokat, amely jogok vagyoni értékminősége a személyiségi jog más vonatkozásaival összevetve a nemzetközi összehasonlításban is kiemelkedő szerepet töltenek be. A német bírói gyakorlat azonban mégsem ezen alanyi jogok vagyoni értékminőségének elismerése mellett foglalt állást, hanem az amúgy is vízfej, kétséges legitimációs alapokon nyugvó 
általános személyiségi jog absztrakt vagyoni értékminősége mellett állt ki.

A személyiség vagyoni értékminőségének általános személyiségi jog keretében való elhelyezése tekintetében a német jog kiindulópontot nyújt ugyan, de eltérő kulturális és jogi környezetben kellett azt a német bíróságoknak elhelyeznie. A magyar jog szempontjából e kérdéskörök ugyan nem jelentenek problémát, hiszen a magyar jog az általános-különös személyiségi jogok közötti különbségtételt nem ismeri.

ad 2. $\S$

Igazolható-e az, hogy a személyiségi jogok vagyoni értéke nem újkeletü, nem a XXI. század eredménye, hanem az már a XX. század elején is jelen volt, és az nagymértékben összefüggött a személyiség magánjogi védelmének igényével?

A személyiségi jog tételes jogi kodifikációja Magyarországon korábban azért maradt el, mert a magánjog egészének sem sikerült írott kódexet alkotni. Németországban ezzel szemben tudatosan lemondtak a személyiségi jog általános kodifikációjáról és BGB-be építéséről.

A személyiség bizonyos megnyilvánulásait már meglévő jogintézmények is védték (házassági jog, kártérítés), más részét a jogalkotó rendelte oltalmazni külön törvényekben (pl.: a becsület védelme tekintetében a St. és a Bv.). A vagyoni viszonyok szempontjából legjelentősebb két jogot, a nevet és a képmást, a német megoldástól eltérően nem szabályozta a jogalkotó, és ezzel óriási szabályozási hézagot hagyott a személyiségi jog testén.

A német megoldásban a név és a képmás ún. különös személyiségi jogok, amelyek törvényben rögzítettek, és a Reichsgericht gyakorlata csak ezeket a törvényben szabályozott jogokat ismerte el, és a személyiséget csak e vonatkozásaiban óvta. A korabeli német gyakorlat ezzel tökéletlen és elavult volt, a német jogalkotó azonban nem avatkozott be, a BGB-t nem módosította. A magyar joggyakorlat a jogalkotó által hagyott hézagokat feltöltötte, s kb. 1930-ra már általános védelmet biztosított a személyiségi jog megsértésének eseteire. A Kúria elsősorban a névjog, a képmáshoz való jog és a kegyeleti jog tekintetében emelte élő joggá az Mtj. 108. és 109. §§-ait. A magyar jog ezzel a német jogot megelőzte, s ennek oka valószínűleg abban rejlik, hogy a Kúria sokkal fogékonyabb volt a személyi eszme keresztülvitelére, amely a nem vagyoni kár megtérítése körében kialakult törvényértelmezés tekintetében is tetten érhető. 
A név jogi védelmének a kialakításakor a jogalkotó kezdetben egyes speciális jogintézmények vonatkozásában adott kereshetőségi jogot a névjog megsértése esetére. E jogintézmények közül egyesek kifejezetten személyi érdekeket védtek. Ilyen volt a feleség házassági névviselése, amely a családi jogban mint relatív személyjogban került szabályozásra, másrészről ilyen volt a szerzői név bitorlása mint névbitorlás.

A név ettől függetlenül, pusztán megjelölési funkciójánál fogva alkalmas volt arra is, hogy árukat, szolgáltatásokat, illetve kereskedelmi cégeket jelöljön meg. Ezeket az eseteket a jogalkotó külön, speciális védelemben részesítette a kereskedelmi, illetve a védjegytörvényben. Ezek sajátossága, hogy a név ilyen irányú használata nem pusztán viselőjét jeleníti meg, hanem az előbb említett árukat, szolgáltatásokat, illetve magát a kereskedelmi tevékenységet. E funkciójánál fogva a név használata a személyiségtől különválik. Külön érdekes, hogy a név itt nem a hagyományos vagyoni jogi (kötelmek, dolgok) keretében jelenik meg, hanem elsősorban az iparjogvédelem, illetve tágabb értelemben a szellemi alkotások, szellemi tulajdon oldaláról. A név ezen elválása, a névhasználat ilyen jogi konstrukciója okán nyílik lehetőség a név forgalomban való részvételére, öröklésére, átruházásra, amely által egyértelműen eltávolodik a legszemélyesebb, átruházhatatlan jogosultsági jellegétől. Balás, aki a személyiségi jog kizárólagos eszmei oltalmát képviselte, ezt azzal oldotta meg, hogy szerinte az erre vonatkozó jogi rendelkezéseket kizárólag a kereskedelmi jog, versenyjog alapján lehet értékelni, mert ezekben nem a személyi szemlélet, hanem a dologi dinamika ölt testet. ${ }^{23}$

A névjog elismerésével az egykori királyi Kúria nem csupán egy személyes jogosultságot, hanem egy sokkal árnyaltabb, összetettebb jogosultságot ismert el. A névjog egyrészről ugyan a névviseléshez, a személyes jelleghez kapcsolódik, ugyanakkor funkciójánál fogva a megjelölésekkel is kapcsolatba kerül, amelyet a személyes jellege árnyal és korlátoz is. A termékek, áruk, szolgáltatások piacra jutása, kereskedelmi forgalomban való részvétele, illetve a kelendőség fokozásának egyik eszköze a név, amely önmagában ellentétben áll az általános jogi megközelítésével. Ezen ellentéttel szemben ugyanakkor már a korabeli jogi dogmatikai, illetve a bírói gyakorlat is teret engedett e szellemi tulajdon-szerü hasznosításnak, használatnak,

${ }^{23}$ BALÁs, 1941. 646, 648. 652, 655, 656. 
amely a személyiségi jogok vagyoni értéküségének problematikájához, illetve annak megoldásához is segítséget nyújt.

A képmás védelme a szerzői jogi szabályozásról lett leválasztva, s az ábrázolt személy hozzájárulását az Mtj.-ben szereplő személyiségi jog keretei közé illeszkedőnek tekintette a bírói gyakorlat. A képmás jogosulatlan felhasználása esetén a jogosultat nemcsak eszmei kár, illetve abbahagyási kereset illette meg, hanem az 1921-es Szjt. alapján vagyoni kárának megtérítését is követelhette.

Míg a szocializmusban a védelem kifejezetten a nem vagyoni, eszmei érdekek oltalmazására szükült, addig a királyi Kúria joggyakorlatában a személyiségi jogok esetén (különösen a képmás és a név védelménél) ezen eszmei oltalom csupán egy iránya volt a védelemnek, emellett jelentkezett a gazdasági versennyel, árutermeléssel összefüggően a személyiségi jogok gazdaságban betöltött funkciójával összefüggő bitorlásuk elleni védelem. Ez nemcsak arra mutat rá, hogy a személyiségi jogok vagyoni értékkel bírnak azáltal, hogy bizonyos irányú átengedésük vagyoni ellenérték fejében a gyakorlatban szokásos ügyletnek minösül, hanem arra is, hogy ezek a tendenciák Magyarországon a bírói gyakorlatban már a '20-as, '30-as években, a személyiségi jog szokásjogi elismerésével egyidejüleg, párhuzamosan és egyben organikusan jelentkeztek. Ezt a fejlődési tendenciát törte meg a szocialista jogrend, amely objektíve kizárta e fejlődési irány dogmatikai kikristályosodását.

ad 3. $\S$

Hogyan lehet elérni a magyar személyiségvédelemben azt, hogy az emberi méltóság joga miatt az egyes személyiségi jegyek örökölhetösége, és átruházhatósága ne kerüljön elvi szinten kizárásra?

Az emberi méltóság és a személyiségi jogi generálklauzula közötti értelmezési ellentmondás tekintetében arra az álláspontra helyezkedtem, hogy a Ptk. 2:42. § (1) bek. az, ami legtágabb körben, általánossággal védi a személyes viszonyokat, és ez tekintendő alanyi jognak, jogalapnak. A 2:42. § (2) bek. 2. m. nem ad tartalmi meghatározást, s ennél fogva kevesebbet nyújt, ez a törvényből elhagyható, hiszen ugyanezen funkciót az előbbi szakasz sokkal jobban el tudja látni. A kibontakozás és a méltóság viszonyában az emelendő ki, hogy a Ptk. 2:42. § (2) bek. 1. m. szerinti emberi méltóság egyfajta értelmező szabály, amely az ember személyiségi jogainak egyfajta mögöttes értékminősége. Az emberi méltóság az ember személyiségi jogainak 
minimum mércéje, olyan érték, amellyel szemben mások jogainak és érdekeinek minden esetben meg kell hajolnia, amely esetén nincsen érdekmérlegelés. Ha ezt elfogadjuk, úgy a Ptk. 2:44. §-ával összhangban értelmezhető a Ptk. 2:42. § (2) bek. 1. mondata is, amely az emberi méltóságot egy korlátozhatatlan jogként írja le.

A magánélethez való jog védelmi köre nem terjedhet ki arra, hogy minden eddig nem nevesített személyiségi jogsértést alávonjanak, hiszen akkor az általános személyiségi jog funkciójába lépne. Meglátásom szerint elsősorban olyan tényállások tartoznak a magánélethez való jog megsértése körébe, amelyek a személyiségi szférát átfogóan, több tényezőre kiterjedően érintik és sértik. A Ptk.-beli magánélethez való jog lényegében tehát azokat az adatokat, információkat fogja át, amelyek az általános élettapasztalat szerint a jogosult érdekkörébe tartoznak, és amelyeket magának megtarthat, rendelkezhet arról, hogy kivel ossza meg öket. Abban az esetben, ha az adat, információ más személyiségi jog formájában jelenik meg (pl.: képmás formájában), úgy az elsőbbséget élvez többlettényállási elem hiányában. A magánélet védelméről szóló 2018. évi LIII. törvény e többlettényállási elemet a nevesített személyiségi jogok „magánélettel kapcsolatban” való megsértéseként szabályozza, ${ }^{24}$ ez kellő lehatárolást biztosíthat.

A személyiségi jog egységes alanyi jog, amely a kibontakozásból kiindulva biztosítja a személy önmegvalósítását. Ez az önmegvalósítás a dologi, vagyoni viszonyokkal szembeállítva elsősorban a személyes, nem vagyoni viszonyokra koncentrál, azonban amennyiben az önmegvalósítás módja vagyoni érdekekkel kerül kapcsoltba, úgy ennek oltalmazása is lehetséges a Ptk. 2:42. § (1) bekezdésével összefüggésben. A személyiségi jog egységes védelme melletti állásfoglalás azt is jelenti, hogy a vagyoni értékminőség elismerése nem az egyes, nevesített személyiségi jogok vonatkozásában, külön-külön alakítandó ki, hanem absztraktan. A magyar jogi hagyományok töretlen módon egy absztrakt magánjogi generálklauzula mellett foglalnak állást, ebből kifolyólag a vagyoni érdekek védelmét is absztrakt módon kell megvalósítani, különben külön néven és képmáson való alanyi jogok kerülnének megkonstruálásra, amely a magyar személyiségvédelmi rendszertől idegen.

${ }^{24}$ 2018. évi LIII. tv. 2. § (1) bek. 
ad 4. $\S$

Hogyan írható le az, hogy egy személyiségi részjogosultság, személyiségi jegy vagyoni értékminöséget szerez, eltávolodik a legszemélyesebb jellegtöl?

A személyiségi jognak a magánjogi dogmatikai rendszerben való elhelyezése szempontjából olyan alanyi jogról beszélünk, amely egyrészről abszolút szerkezetű védelmet nyújt a jogosult számára, másrészről személyi jog, azaz védelmének alapvető funkciója az ember személyes viszonyainak védelme körébe esik. Ezt összegezve megállapíthatjuk, hogy a személyiségi jog abszolút személyi jog. A személyi jelleggel összefüggésben mind a háború előtti magánjog, mind a szocialista polgári jog annak nem vagyoni jellegéből indul ki, amely rendezőelv hatályos jogunkban is tovább él. Sem a jogirodalom, sem a joggyakorlat nem ismeri el egyértelmüen azt, hogy a személyiségi jog bizonyos felhasználási módok esetén a vagyoni jogokhoz közelít, a személyiségtől azonban nem válik el.

A nem vagyoni jelleg kizárólagosságának történeti fejlődése tekintetében másik irányban is vizsgáltuk a történeti fejlődést, amely az ún. eszmei vagy immateriális javak magánjogi megjelenése volt. A századforduló környékén a magánjog nem kizárólag az egyének egymás közötti vagyoni érdekeit védte, hanem megjelentek új magánjogi jogtárgyak, az eszmei javak, amelyek megjelenése a dogmatikában ahhoz volt köthető, hogy a jog ismerje el egyrészről azt, hogy vannak testetlen jogtárgyak, másrészről, hogy más személy nem vagyoni érdekeit is meg lehet sérteni. Ez volt a személyi eszme megjelenése. A személyi eszme először a szerzői jogi és iparjogvédelmi jogintézmények törvényi szabályozása által jelent meg, ezt követte a személyiségi jogok szabályozásának az igénye a kódextervezetekben. A testetlen, immateriális javak szerinti csoportosítás alapján a személyiségi jogok személyi immateriális javak, amelyek jellemzője, hogy a jogosult személyéhez tapadnak, azok nem átruházhatóak, nem örökölhetőek.

Ha a jogtárgy eltávolodik a személyiség belső magjától, úgy kilép a személyiségi jog mint alanyi jog keretei közül, és egyfajta vagyoni jogként, vagyoni immateriális jogként funkcionál, azaz örökölhetö és átruházható jogosultsággá válik.

Ezen személyi immateriális javak közé tartozó jogtárgyak egy része képes lehet arra, hogy önállótlan vagyoni immateriális joggá váljon, azaz olyan joggá, amelyek esetén 
a jogtárgy az átruházást és öröklést azzal a feltétellel türi, hogy az továbbra is a személyhez tapad. E tárgyiasulás útján való transzformációval tulajdonképpen megteremtődik annak a dogmatikai alapja, hogy a személyiségi jogok a személytől elválhatnak. Ennek az elméleti lehetősége tehát ezzel adott.

A kutatás ezután azt vizsgálta, hogy ezen, a vagyoni értékminőségre vonatkozó elméleti lehetőségen túl ténylegesen mely személyiségi jogok azok, amelyek testetlen jellegük folytán alkalmasak arra, hogy tárgyiasuljanak, és ezzel önállótlan vagyoni immateriális joggá váljanak. Ezeket tárgyiasítható személyiségi jegyeknek neveztem, és két nagy csoportra osztottam őket. Az egyik ezek közül a személyiségi külső megjelölését szolgálják, mint a név, képmás, a másik pedig a személyiséggel kapcsolatos tulajdonságokat információ formájában hordozzák, mint amilyen az életkép, magántitok vagy a magánélethez való jog egyéb vonatkozásai. A tárgyiasítható személyiségi jegyek közül a névjogot emeltem a vizsgálat középpontjába annak szóbeli megjelölési jellege révén, amely által a tárgyiasulás számtalan módjára képessé válhat.

ad $5 . \S$

Hogyan és milyen formában képes a név, illetve más szóbeli megjelölés tárgyiasulni a személyiségvédelmen belül?

A névjog tárgyiasulása többféleképpen végbemehet. Ide sorolható egyrészről a más jogintézmény keretében történő tárgyiasulás. Ilyen a szellemi tulajdonjog körébe tartozó védjegyjog, és ilyen a személyiségi jogi védelmen belüli, más jogtárgy formájában történő tárgyiasulás. A személyiségi jogon belüli tárgyiasulásra példa a cégnév, a kereskedelmi név és a domainnév formájában történő tárgyiasulás, amelynek vizsgálata során különbséget kell tenni aközött, hogy a megjelölés alapja egy fantáziaszó vagy a személyiségi jog mint korábbi jog. A névjog tárgyiasulása, a képmáshoz való joghoz hasonlóan, sui generis módon is végbemehet. A névjog ily módon történő tárgyiasulásával jön létre a néven való vagyoni jog, amelybe a név reklámcélú felhasználása tartozik. A név termékek és szolgáltatások megjelölése tekintetében tulajdonképpen üzletjelzőként funkcionál és ennél fogva elsősorban mint kereskedelmi név részesülhet védelemben. Ez az oka annak, hogy a név sui generis tárgyiasulásának az alkalmazási köre sokkal szükebb, mint a képmásé, amely esetén 
az üzletjelzőként való használat a szóbeli megjelölési jelleg hiányában nem értékelhető a kereskedelmi név megsértéseként.

A név cégnévként való tárgyiasulása által cégnévhez füződő személyiségi joggá válik. Amennyiben a cégnév fantáziaszó, úgy a személyiségi jog értelemszerüen a jog gyakorlása során nem jelent korlátot. Abban az esetben, ha a cégnév természetes személy nevét tartalmazza, úgy a céghasználat korlátja a névjog jogosultjának személyiségi joga. Ilyen korlát lehet az, ha a gazdasági társaság a cégnevet más jogi személy alapítása során fel kívánja használni.

Ugyanígy tárgyiasul a név, ha az domainnévvé válik. Ebben az esetben szintén új, a névjog mint személyiségi jogtól független alanyi jog jön létre, amely szintén abszolút, kizáró jelleget biztosít a jogosultnak. A domainnév nem a jogalany neve, nem cégnév, de nem is védjegy. A domainnév ugyanígy nem üzletjelző, nem kereskedelmi név automatikusan, noha szerezhet ilyen minőséget huzamos használattal, mint ahogy bejegyzéssel az adott megjelölés védjeggyé vagy cégnévvé is válhat. Ekkor azonban új jogosultság keletkezik. A domainnév tehát, mivel nem minden esetben rendelkezik kereskedelmi névi minőséggel, nem kizárólagosan a jogosult gazdasági, üzleti, kereskedelmi érdekét védi, ugyanúgy kiterjed az ettől független, nem vagyoni, erkölcsi jellegü sérelmek orvoslására, és ennek keretében is kizáró jogot biztosít a jogosult számára.

A névjog alkalmazásának a személyiségvédelmen belüli előbb felleltározott dogmatikai rendszere ugyanakkor egy másik következtetésre is vezet. A személyiséghez kapcsolódó érdekek köre tág, nem pusztán az ember érzületére, nem vagyoni érdekeire terjed ki kizárólagosan, hiszen nem csak az emberrel szoros összefüggésben álló jogtárgyak védelmét látja el a magánjogi személyiségvédelem. Ebből is látszik egyrészről azon állításom helyessége, hogy az alkotmányos emberi méltóság joga csupán a személyiségvédelem egy részét fedi le, és hogy a személyiségi jog magánjogi alapja a 2:42. § szerinti kibontakozás joga. Másrészről a magyar személyiségi jog, a svájcihoz és a liechtensteini joghoz hasonlatosan elsősorban az egyén személyes viszonyait védi. A személyes viszonyok körébe tartozik minden olyan, elsősorban eszmei érdek, jogtárgy, amely a közfelfogás által egy személy kizárólagos rendelkezési jogába utalt. E személyes viszonyoknak a vagyoni viszonyokkal való keveredése, de el nem enyészése érhető tetten a névjogok tárgyiasulásán. Itt rajzolódik ki leginkább az a feszültség is, amely e jogtárgyak forgalomképessége okán azok osztályozásában is jelentkezik. Az eszmei, immateriális 
javak summa divisiója alapján személyiségi jog a forgalomképtelen, nem örökölhető immateriális jog, míg a társadalmi, ipari felhasználhatósága okán forgalomképes immateriális javak a szellemi tulajdonjog területére esnek. A személyi és vagyoni viszonyoknak a tárgyiasulás általi keveredése, különösen az így létrejött új alanyi jogban a személyiségi jog erkölcsi vonatkozásainak további fellelhetősége jelentős klasszifikációs problémákat vet fel, különösen az individuum és a személy kiemelt fokú védelme okán. Ha ugyanis a tárgyiasulással ezek a jogtárgyak teljesen vagyoni joggá válnak, az a személyiségi jog jogosultjának érdekét kizárja, míg ha a tárgyiasul, értékestett jogtárgy esetében a felhasználáshoz a személyiségi jog jogosultjának átruházás utáni beleegyezését követeljük meg, úgy a piaci viszonyokat korlátozzuk.

A magyar magánjogi személyiségi jogba betoluló jogtárgyak és érdekek védelme a németnél jóval tágabb, azt is mondhatjuk: más jellegü. A német jogban látható volt, hogy az általános személyiségi jog magánjogi elismerése előtt a képmás és a név védelme kiterjeszthetö lett volna a vagyoni érdekekre, azt maga a jogalkotó is előrevetítette már a kodifikáció során is. A nagy váltást az emberi méltóságból és a kibontakozáshoz való jogból eredeztetett általános személyiségi jog elismerése jelentette egyrészröl. Ez ugyanis jelentős eszmei, nem vagyoni védelmi áramlatot adott a személyiségi jog joggyakorlatának alkotmányos jogalapja és szankciói által. Erre erősített rá a Markengesetz, a védjegytörvény 1995-ös módosítása, amely a kereskedelmi név védelmét a védjegybitorlással összekapcsolván egy általános vállalatjelző-bitorlást hozott létre. Ez kivette a talajt a BGB 12. §-a szerinti névjog kiterjesztő és analóg alkalmazása alól. Ez azt jelentette, hogy a BGB 12. §-ának alkalmazási köre a jelentős vagyoni érdeket magában foglaló vállalat- és árujelzők tekintetében nem volt alkalmazható, tárgyi hatálya a fennmaradó eszmei érdekekre szükült. E jogváltozás után kerültek elismerésre a személyiségi jog vagyoni vonatkozásai, amelyek már szintén ebben a személyiségvédelmi keretrendszerben kerültek értelmezésre és alkalmazásra. Ennek okán sem a BGH a jog elismerésekor, sem a bírói gyakorlat nem tud hivatkozni arra, hogy a BGB 12. §-a szerinti névjog védelme tágabb kört fog át, a vagyoni érdekek sokkal szerteágazóbbak a személyiség védelmén belül.

A magyar jogban más a helyzet, ott az előbb említett megjelölések, névjogok a személyiségvédelemben jelen vannak. Hasonló helyzetben a svájci jog van, amely viszont a személyiségi jog vagyoni értékét nem ismeri. A jogtárgyak sokasága okán ugyanakkor megnő a tárgyiasulási módok száma, és ezzel a vagyoni érdekek, a 
vagyoni, kereskedelmi felhasználhatóság módjainak száma is. Ez azt is eredményezi, hogy a vagyoni és eszmei érdekek a személyiségvédelmen belül sokkal több területen ütköznek, és hogy egy esetleges vagyoni személyiségvédelmi rendszer kialakításának német útja nem alkalmazható, azt más úton kell biztosítani. Erre a tárgyiasulás alapú vagyoni személyiségvédelem eddig alkalmasnak bizonyul.

ad 6. $\S$

Lehetséges a Ptk. szabályait akként értelmezni, hogy a személyiségi jog vagyoni értéke értékelésre kerüljön, vagy mindenképpen szükséges jogalkotói beavatkozás?

Milyen következménnyel jár az, ha a Ptk. és a joggyakorlat a vagyoni érdekeket a személyi érdekekkel azonosan kezeli?

A személyiségi jog vagyoni értékét a jogalkotó elismerte azzal, hogy lehetővé tette a jogsértéssel elért vagyoni előny átengedését, hiszen egy vagyonjogi jogkövetkezmény alkalmazása csak oylan abszolút jog megsértéséhez kapcsolódhat, amely (legalább részben) vagyoni jog. Ez az elismerés azonban egy hézagos rendszerben történt, a jogalkotó a szankciók oldaláról, különösen a jogsértéssel elért vagyoni előny átengedésével. A jogalkotó célja egyértelműen az volt, hogy a személyiségi jogon fennálló vagyoni érdekek védelemben részesüljenek. A részleges elismerés azonban több problémát eredményezett, hiszen a jogalkotó az alanyi jog oldalán a vagyoni érdeket nem értékelte, nem rendelkezett az emberi méltóság és a vagyoni érdekek viszonyáról, nem rendelkezett a vagyoni jogok jogutódlásáról és átruházásáról, azok védelmi idejéről. Ez nem jelenti feltétlenül azt, hogy ezek létére igenlő választ kellene adnunk. A probléma inkább az, hogy ebben a tekintetben a jogalkotó akaratrát egyáltalán nem ismerjük, mert a német jog figyelembevétele is csak a jogkövetkezményekre koncentrált. E szabályozási hézagok és hiányosságok ellenére a vagyoni érdek, a személyiségen fennálló vagyoni jog léte a jogszabály szintjén megjelenik, így azt a jogalkalmazónak is rendszerszinten értékelnie kell, nem moshatja azt össze az eszmei érdekek védelmével.

A jogalkalmazónak teleologikusan redukálnia kell az eszmei jogok védelmét, amelyben nehézséget jelent, hogy azok a vagyoni jogokkal egy alanyi jogon belül helyezkednek el, és a törvény explicite nem is említi azokat. A vagyoni érdekbe tartozó személyiségi jogi részjogosultságok alapvetően forgalomképes javak. Azaz 
átruházhatóak, használatukra engedély adható, örökölhetőek. Ha a bírói gyakorlat ezt a vagyoni érdekkört nem értékeli, és azokat az eszmei vonatkozásokkal azonosan kezeli, úgy „félreszubszumál”. Az eszmei érdekek nem örökölhetőek, a halállal megszünnek, és nem választhatóak el a személytől. Számos probléma keletkezik azonban abból, ha a vagyoni érdekkörbe tartozó részjogosultságokat is e szabályok alá vonjuk. A probléma ezzel kapcsolatban az, hogy mind az eszmei, mind a vagyoni érdekek ugyanazon törvényhely keretében [Ptk. 2:42. § (1) bek.] részesülnek védelemben, így ez jogalkotói beavatkozás hiányában kizárólag a bírói jog szintjén értékelhető. Erre alkalmas lehet az, ha a vagyoni értékminőséget egy tárgyiasulási teszthez köti a bíróság.

A vagyoni érdek nem csupán a törvény szintjén, hanem a jogalkotó akarata, a törvény célja keretében is megjelenik, noha igen rejtetten. A bírói esetjog a személyiséghez kapcsolódó materiális érdekeket ugyanakkor számos vonatkozásában értékeli, kezeli, kártérítés alapján licencia díj fizetését látja megengedhetőnek. Ez azonban nem a vagyoni érdek rendszerszintü elismerésén nyugszik és nem is a jogalkotó szándékán, hanem kizárólag az észszerüség és igazságosság mentén, önállóan munkálódik.

Lényegében a magánjog-bölcseleti probléma alapját az képezi tehát, hogy a bírói esetjog és a jogirodalom ugyanabba az irányba halad, mint amerre a Ptk., de ezt az irányt sem az egyik, sem a másik fél nem ismeri fel kétséget kizáróan, s mégis egy eredmény, cél felé közelednek. A Ptk. rendszerezése azonban a vagyoni érdekek védelme tekintetében tökéletlen, és statikája okán a bíróságok feladata az, hogy a szöveg és a cél szerinti értelmezést segítségül hívják, és szintetizálják azokat a jogirodalmi eredményekkel, ennek során foglaljanak állást, és vizsgálják a jog tartalmát, keletkezését és megszűnését. Határozzák meg a kegyeleti jog és a post mortem vagyoni jogok viszonyát, a védelmi időt, vizsgálják a jog átszállásának dologi hatályú lehetőségeit stb. Ennek a módszere alapvetően a jogfejlesztő értelmezés: az analógia alkalmazása, a jog általános elveinek felhasználása és a teleologikus redukció. Talán túl nagy elvárás ez azonban a bíróságoktól, hiszen egyrészről a jogterületnek nincsen kellő irodalma, és teljesen új területként tünik az fel, másrészről a Ptk. nem is következetes a vagyoni érdek elismerését illetően. A jog értelmezése tekintetében azonban a vagyoni érdek észrevétele és értékelése követelmény, így a bíró a jogalkotói beavatkozásra nem várhat, neki kell megtalálni az igazságos megoldást, de az eszmei érdekekre vonatkozó szabályokat nem alkalmazhatja a más jelleget 
felmutató forgalomképes, tárgyiasult személyiségi jegyekre. Számos részletkérdés megválaszolása elsősorban a jogalkotó feladata lenne, így elsősorban az alanyi jog keletkezése, tartalma és megszünése tekintetében kell kialakítania az ahhoz kapcsolódó dogmatikai rendszert. Mivel a Ptk. az alanyi jogot mint eszmei, erkölcsi érdekeket védő jogként fogja fel, így a személyiségi jogok öröklése a törvényben ki van zárva általánosságban. Az eszmei érdekek halál utáni védelmére a kegyeleti jog alkalmas. Ugyan a jogsértéssel elért vagyoni előny átengedését poszt mortem is védi a törvény, nem tudható meg azonban, hogy ebben a tekintetben a védelmi idő meddig terjed, meddig érvényesthető ez a jog. Ez egyértelmüen abból következik, hogy a jogalkotó akarata részleges, csak a jogkövetkezményeket fogta át. Ennek okán a jogalkotói beavatkozás mindenképpen szükségesnek bizonyul.

ad 7. $\S$

Ha a vagyoni érdekkörben felhasznált tárgyiasult személyiségi jegyeket egy jól lehatárolt halmazba sorolhatjuk, azaz ha a személyiségi jog vagyoni értékminöségéhez kapcsolódó jogi tényeket meg tudjuk határozni, úgy meg tudjuk fogalmazni az alanyi jogot, és ehhez kapcsolódóan az alanyi jog megsértését is.

A korábbiakban részletesen vizsgált tárgyiasulás mint a személyiségi jog eszmei szférájának a fizikai vagy más eszmei világokkal való kapcsolatba jutásának leírására szolgáló jogi tény, ebben a formájában önállóan nem alkalmas a személyiségi jog vagyoni minőségének egyedüli mérésére. A személyiségi jogi részjogosultságok tárgyiasulásuk által nem kerülnek ki minden esetben az eszmei, erkölcsi érdekkörből, így ez inkább csak a vagyoni értékminőség vizsgálatának előfeltételeként értelmezhetőek. A tárgyiasulás által a személyiségi jogok, a személyiségi jegyek a személyiségtől részlegesen elválnak, és meglátásom szerint ez a részleges elválás az meglátásom szerint, amely a forgalomképes, és ezáltal örökölhető és dologi hatállyal átruházható személyiségi jogi vonatkozások létjogosultságát meg tudja alapozni.

Az egyes tárgyiasítható személyiségi jogi jogosultságok személyiségi jogtól való elválásának lehetősége miatt nem egyértelmü, hogy a jogosultnak van-e afelett jogi érdeke, azaz megilleti-e a jogtárgyra vonatkozó alanyi jog. Ez mind a személyiség külső megjelölésének eszközei, mind az ismereti személyiségi jegyek vonatkozásában releváns. Míg a személyiségi jog vonatkozásában, annak elválaszthatatlansága okán, egyértelmü volt a jogosult érdeke, addig e jogok tekintetében ez nem mindig 
megállapítható. Ebben a tekintetben abból kell kiindulni, hogy a jogosultnak van-e joga rendelkezni a személyiségi jegy felett, illetve, hogy a jogellenes tárgyiasítás az ő érdekkörét, jogi érdekét sérti-e.

A vagyoni értékminőség elismerése szempontjából a jogosult személyének széles körü ismertsége, esetleges közszereplői minősége csekély szerepet játszik. Ennek oka az, hogy a személyiségi jog tárgyiasulása és vagyoni értékminősége akkor is kimutatható, ha publicitás, ismertség korábban az adott személyiséggel kapcsolatban nem merült fel. A jogellenes tárgyiasítással a személyiségi jog ennek hiányában is vagyoni értékkel bír. Ez különösen jelentős a más jogintézmények formájában történő tárgyiasítás tekintetében (védjegy, kereskedelemi név, cégnév, domainnév), de ugyanígy fellelhető a név, képmás sui generis tárgyiasítása tekintetében is. Ennél fogva a személyiség ismertségének, egy esetlegesen kialakult arculatnak (a vagyoni személyiségi jognak mint függő jogi helyzetnek) ebből kifolyólag kizárólag a jogkövetkezmények vonatkozásában van jelentősége. A publicitás így az elmaradt díjazás, illetve a jogsértéssel elért vagyoni előny bírói megállapítása során az érték meghatározása tekintetében vehető figyelembe.

A vagyoni értékminőség megállapítására akkor kerülhet sor, ha a személyiségi jegyet vagyoni érdekkörben használják fel, tárgyiasítják. Ebben a tekintetben a jogosult rendelkezési joga előfeltétel, a vagyoni érdekkörben történő felhasználás kvalifikált jogi érdeket feltételez. Ez a jogi érdek vagyoni érdek, ezzel válik a személyiségi jegyen fennálló jog vagyoni joggá. A vagyoni érdekkörben történő felhasználás alapvetően a személyiségi jegyek tárgyiasulása által a kereskedelmi fogalomban, az áruforgalomban való részvételéhez köthető. Ennél fogva a jogosult vagyoni érdekkörébe tartozik a személyiségi jegy felhasználása reklámcélra, termékekkel, szolgáltatásokkal való kapcsolatba hozása, üzletjelzőként való használata, hírértékének kihasználása.

Egy vagyoni személyiségi jog elismeréséhez az szükséges tehát, hogy a személyiségi jog egyes vonatkozásainak tárgyiasulását elismerjük. E tárgyiasulás nem teljes, ennél fogva a személy eszme továbbra is áthatja a vagyoni érdekek védelmét is, a személyiségi jegy eredeti jogosulttal való kapcsolata fennmarad. Ennek oka, hogy a személyiségi jegy tárgyiasulása után továbbra is e személyre vonatkozik, e személynek továbbra is állhat fenn jogos érdeke e személyiségi jegyen.

A vagyoni személyiségi jog körülhatárolásával és elismerésével számos kérdés megválaszolatlan marad. A vagyoni személyiségi jog a személyiségi jogból jön létre 
annak kvalifikált felhasználásával, többlet-tényálláselemek megvalósulásával. A vagyoni személyiségi jog megszerzése ennél fogva származékos jogszerzés. A jogszerzésnek ez a származékos jellege az, amely a személyiségi jogtól való részleges elválás értékelése. A tárgyiasulással ugyanis a személyiségi jegy a személyiségi jogtól elválik, ez az elválás ugyanakkor részleges, amely megteremti annak a lehetőségét, hogy a személyiségi jog jogosultja fellépjen akkor, ha a személyiségi jegyét jogellenesen használják fel. A vagyoni személyiségi joghoz képest, annak specialitásánál fogva, az általános személyiségi jog szubszidiárius. A vagyoni személyiségi jog kielégíti azokat a feltételeket, amelyek a szellemi alkotási, önállótlan vagyoni immateriális jogi kvalifikációhoz szükségesek. Ez rámutat arra is, hogy a személyiségi jegyek, a tárgyiasítható személyiségi jogi szféra a személyiség legbelső magjától távolabb kerül és átruházható, örökölhető jogosultságként funkcionálhat.

A tételes magyar jog nem ismeri el a személyiségen fennálló vagyoni érdekek örökölhetőségét. A német jog példáján láthat lesz, hogy ez a bírói gyakorlatban 10 év, az USA tagállamaiban pedig igen eltérő védelmi idők kerültek meghatározásra 10 évtől 100 évig. Álláspontom szerint egy 20 éves védelmi idő lenne ideális, azonban elsősorban a jogalkotónak kellene mérlegelnie abban a kérdésben, hogy az örökösök számára biztosít monopóliumot a személyiségi jegyek vagyoni felhasználása felett, vagy ennek kisebb teret biztosítva rövid idő után bárki számára lehetővé teszi a kereskedelmi felhasználást is.

ad $8 . \S$

Alkalmas-e arra a magyar személyiségvédelmi szankciórendszer, hogy a személyiségi joghoz kapcsolódó vagyoni érdekkört átfogóan és hatékonyan védje?

A személyiségi jog vagyoni értékminőségének megjelenése a jogkövetkezmények körében a vagyonjogi szankciók alkalmazásának lehetővé tételéhez köthető. Ilyen vagyonjogi szankció a kár megtérítése és a gazdagodás visszatérítése, vagyoni jogkövetkezmény ugyan, de nem tartozik ide az eszmei érdekek kompenzálása okán a sérelemdíj, illetve a nem vagyoni sérelem bármilyen formájú megtérítése. A Ptk. szövegszinten lehetővé teszi a kártérítés és a jogsértéssel elért vagyoni előny átengedését a személyiségi jogok megsértése esetére. Amennyiben a személyiségi jogok között külön szabályt ezek tekintetében nem tartalmazna a törvény, úgy a kódex absztrakt jellegéből adódóan a Ptk. 6:519. és a 6:579. §-a szerinti igények ekkor is 
megvalósulhatnak. A vagyonjogi szankciók alkalmazása a pozitív értelmezés alapján mindenképpen lehetséges. Problémát képez ugyanakkor, hogy a személyiségi jog általában eszmei érdekeket oltalmaz, amelyek esetén a vagyonjogi igények objektíve nem merülhetnek fel. A Ptk. nem határolja le a személyiségi jog megsértéséről azokat az eseteket, amikor ezek a jogkövetkezmények igénybe vehetőek, és ezzel összemossa a személyiségi jog eszmei és vagyoni érdekeinek védelmét.

A kártérítés alkalmazása tekintetében uralkodó az az álláspont, hogy a személyiségi jogok megsértése esetén a károk vonatkozásában csupán a következménykárok megtérítésére van lehetőség. Ennek oka, hogy a személyiségi jogok alapvetően mint nem vagyoni jogosultságok jelennek meg a Ptk. rendszerében. A tapadó károk elismerésének feltétele az lenne, hogy elismerjük, hogy a személyiségi jog megsértésével vagyoni kár keletkezik, amely vagyoni kár elsősorban a személyiségi jog kereskedelmi felhasználásához köthető licenciadíj megfizetésének elmaradásában áll. A Ptk. kodifikációja során nem merült fel olyan álláspont, amely a kártérítési jog ilyen irányú alkalmazását is előirányozta volna. Ez azt jelenti, hogy a kártérítési jog vonatkozásában a vagyoni értékminőségét a Ptk. nem értékelte - jóllehet nem is zárta ki. A jogalkalmazási gyakorlat korábban több döntésében hajlott az elmaradt hozzájárulás esetén fizetendő díjazás mint kár megállapítására. A probléma elsősorban abban jelentkezik, hogy a kereseti kérelmekben a vagyoni kár megtérítését egyáltalán nem kérik a személyiségi jog jogosulatlan kereskedelmi felhasználása esetén.

A jogalap nélküli gazdagodás az objektív teleologikus értelmezés alapján egyértelműen a személyiségi jogon fennálló vagyoni érdekkör megsértésének értékelésére szolgál. A Ptk. ezt élők között következetesen végigviszi. A személyiségi jog jogosultjának halála után az örökösöknek biztosít jogot arra, hogy a kegyeleti jogsértéssel elért vagyoni előnyt a jogsértő számukra térítse meg. Helyes a Ptk. álláspontja abban a vonatkozásban, hogy az igényérvényesítésre jogosultak körét az örökösökben határozza meg, hiszen az igény vagyonjogi igény. A jogsértő cselekmény vonatkozásában a törvény az eszmei és vagyoni érdekek védelmét mossa össze azzal, hogy a kegyeleti jogsértést az igény megvalósulásának feltételéül támasztja. A kegyeleti jogsértés mindig kizárólagosan az eszmei érdekek halál utáni védelmére szolgál, így a vagyoni jogkövetkezmény értékelésében nem játszhatna szerepet. Másik hibája ennek a szabálynak az, hogy a személyiségi jogi részjogosultságok dologi hatályú átruházása esetén a személyiségi jog jogosultjának halála után a jogszerző nem 
érvényesítheti ezzel kapcsolatos igényét. Az igény elvesztése által a dologi hatállyal megszerzett jog tulajdonképpen kötelmi igénnyé válik. Helyesebb lett volna ezért az erről rendelkező Ptk. 2:50. § (2) bekezdést a törvényből kihagyni, a vagyoni előny átengedése esetén, lévén kötelmi, vagyonjogi jogintézmény, így dogmatikailag az örökösök szerzik azt meg a hagyaték részeként.

A Ptk. által alkalmazott jogkövetkezményi rendszer ebből eredően nem következetes. A vagyoni értékminőséget, a vagyoni szankciók alkalmazását kizárólag a jogsértéssel elért vagyoni előny esetén, a személyiségi jog jogosultjának életében biztosítja. Dogmatikailag helytelenül építi ezt be az öröklés általi jogutódlás tekintetében azáltal, hogy a kegyeleti jog keretében helyezi el az erre irányuló igényt. A kártérítést ugyan a törvényszöveg lehetővé teszi, a kodifikáció azonban nem foglalkozott a személyiségi jog megsértéséből eredő vagyoni károk megtérítésével, és nem határolta le azt az eszmei érdekek esetén is alkalmazandó következménykárokról.

Az alanyi jogok biztosítása a tárgyi jogban önálló jogi normával történik. Az önálló jogi norma tényállásból és jogkövetkezményből áll. A Ptk. rendszere együtt védi a vagyoni és személyi viszonyokat, nem különíti el az azok esetén alkalmazandó jogkövetkezményeket. Ha a személyiségi jogon fennálló egységes alanyi jogon belül megkülönböztetjük az eszmei és vagyoni érdekeket, úgy védhető a Ptk. rendszere, hiszen ezzel lehatárolható a vagyoni szankciók alkalmazási köre. Ezzel a törvényt nem kell módosítani. Mivel egy írott kódexről beszélünk, ezért meglátásom szerint helyesebb az, ha a törvény meghatározza azokat az esetköröket, amelyek esetén ezek a jogkövetkezmények alkalmazandóak. Ezzel a jogalkotó maga értékelné, mikor sérül a vagyoni érdekkör, és mikor alkalmazható a kártérítés, illetve a jogsértéssel elért vagyoni előny átengedése. Én ezt egy vagyoni személyiségi jog elismerésében látom a tényállási oldalon, amelyhez ez a két jogkövetkezmény hozzákapcsolandó. Ezzel jönne létre egy önálló alanyi jog, amely a személyiségi joghoz képest speciális. Ez a vagyoni személyiségi jogi szféra nem szükül kizárólag a vagyoni érdekkörre, annak megsértése esetén a személyiségi jog további szankciói is alkalmazhatóak. A joggyakorlat ugyanis azt mutatja, hogy az esetek többségében a jogosult eszmei érdekköre is sérül a vagyoni mellett. Annak sem lenne egyébként akadálya, hogy a két érdek sérülése esetén a személyiségi jog és a vagyoni személyiségi jog megsértését külön-külön állapítsa meg a bíróság, és ezek jogkövetkezményét külön alkalmazza (a személyiségi jog dualizmusa). Így az sem okozna zavart a jogalkalmazásban, ha a 
jogalkotó az eszmei érdekeket védő személyiségi jog mellett egy kizárólagosan vagyoni érdeket védő vagyoni jogot hozna létre.

A kártérítési jog külön, a vagyoni személyiségi jog szankciójaként való elhelyezése körében konkretizálásra szorul, hiszen az a következménykárok tekintetében az eszmei érdekek sérelme esetén is alkalmazható. Ebben a tekintetben a jogalkotónak elsősorban a lucrum cessans körében kellene értékelnie az elmaradt licencia díj megtéritését, amely által egyértelmüvé válna, hogy a személyiségi jog vagyoni érdekkörének sérelme vagyoni kárt eredményezhet. 
SCHULTZ MÁRTON: Gondolatok a személyiségi jogok generálklauzulájáról és az emberi méltóságról. Magyar Jog 2016, 685.

SCHULTZ MÁRTON: A férj joga felesége nevén. Gondolatok a névhasználati engedély szabályaihoz. Családi Jog 2017/4. 14.

SCHULTZ MÁRTON: A nemesi névelemeket tartalmazó nevek engedélyezése az osztrák jogalkalmazási gyakorlatban. Gondolatok a névhasználati engedély szabályaihoz. In: Bragyova András (szerk.): Miskolci Doktorandusz Konferencia tanulmánykötet. Bíbor kiadó, Miskolc, 2017.

SCHULtZ MÁRTON: A névbitorlás egyes kérdései, különös tekintettel a szerzöi név bitorlására. Doktori Mühelytanulmányok, Győr, 2017.

SCHULTZ MÁRTON: Valós alakok megjelenitése szerzői müvekben: névoltalom, életképoltalom vagy a magánszféra oltalma? Jogösszehasonlítás a magánszféra védelmének elméleti és gyakorlati kérdéseiröl. In: Görög Márta, Menyhárd Attila, Koltay András (szerk.) A személyiség és védelme: Az Alaptörvény VI. cikkelyének érvényesülése a magyar jogrendszeren belül. Budapest, ELTE ÁJK, 2017.

SChULtZ Márton: A cégnév szellemi tulajdon jellege és viszonya a személyiségi joghoz. In: Görög Márta, Mezei Péter (szerk.): A szellemi tulajdonvédelem és a szabadkereskedelem aktuális kérdései. Szeged, Iurisperitus Bt., 2018.

SCHULTZ, MARTIN: Vermögenswerte Bestandteile des Persönlichkeitsrechts. FORVM, 2018.

SCHULTZ MÁrTON: Azonosnevüség és domain nevek. A névjogi igény szubszidiaritása a német és osztrák joggyakorlatban. In Medias Res 2018/2. 
SCHULTZ MÁRTON: A szocializmussal összefüggö névjogi jogsértések és az ipari tulajdon kapcsolata. In: Erdős Csaba (szerk.): Doktori Mühelytanulmányok 2018 Doctoral Working Papers. Gondolat, Budapest, 2018.

SCHUltz MÁRTON: Az általános személyiségi jog vagyoni szankcióktól független elismerése, tekintettel a kir. Kúria névjogi joggyakorlatára. In: Fejes Zsuzsa (szerk.): Jog határok nélkül. SZTE Állam- és Jogtudományi Doktori Iskola, Szeged, 2018.

SCHULTZ MÁRTON: A Debreceni Ítélötábla döntése a név jogosulatlan kereskedelmi felhasználása tárgyában. A névjog megsértésének lehetséges tényállásai és a kereskedelmi felhasználás mint vagyoni sérelem. Jogesetek Magyarázata 2019/1.

SCHULtz MÁRTON: New tendencies in the Hungarian case law regarding the manifestation and pecuniary value of personality rights. Studii si Cercetari Juridice Europene / European Legal Studies and Research, Temesvár, 2019.

SChUltz MáRTON: A vagyoni személyiségi jog. A személyiségi jog vagyoni és személyi viszonyainak monizmusa a tárgyiasítható személyiségi jegyek vonatkozásában. Jogelméleti Szemle 2019/1.

SCHULTZ MÁRTON: A személyiségi jog vagyoni vonatkozásainak fejlödése Németországban. A joggyakorlat kritikája. Jogelméleti Szemle 2019/3.

SCHULTZ MÁRTON: A név vállalat- és árujelzőként történö tárgyiasulása és a szóbeli megjelölések névként történő védelme. Iparjogvédelmi és Szerzői Jogi Szemle 2019/5.

\section{Megjelenés alatt}

GÖRÖG MÁRTA - SCHULTZ MÁRTON: A névtárgyiasulása a kereskedelmi megjelölések vonatkozásában.

SCHULTZ MÁRTON: A használati jellegü vállalat- és árujelzök kodifikációja Németországban. Mi ebböl a tanulság a magyar jog szempontjából? 
SCHULTZ MÁRTON: Elismeri-e a Ptk. a személyiségi jogok vagyoni értékét?

SCHUltz MÁRTOn: Dologi dinamika a személyi szemlélet metszetében: személyi és vagyoni érdekek különválása a néven és képmáson való jogok elismerésének hajnalán.

SCHULTZ MÁRTON: Reklámötletekben és médiaközleményekben jogosulatlanul felhasznált személyiségi jegyekhez kapcsolt vagyoni jogkövetkezmények. 
A. TöRTÉNETI FEJLŐDÉS 


\section{1. § A SZEMÉLYISÉGI JOG VAGYONI VONATKOZÁSAINAK FEJLŐDÉSE NÉMETORSZÁGBAN ${ }^{25}$}

\section{Bevezetés}

A német jogban mind a jogelmélet, mind a joggyakorlat elismeri a személyiségi jogok vagyoni vonatkozásait, ${ }^{26}$ e vonatkozások ebből következő átruházhatóságát, örökölhetőségét, és az ezek esetén a vagyoneltolódásban bekövetkező jogkövetkezmények alkalmazhatóságát. A személyiségi jog eszmei érdekek melletti vagyoni értékminősége ugyanakkor hosszú jogfejlődés eredménye, amely a BGB kodifikációjának időszakáig nyúlik vissza.

Jelen fejezet célja annak bemutatása, hogyan alakult a német személyiségvédelem a BGB hatálybalépésétől kezdődően. A joganyag bemutatása során a személyiségi jegyek kereskedelmi felhasználására koncentrálok a különös és az általános személyiségi jog közötti viszony kiemelésével. A dolgozat e része tehát nem terjed ki a német személyiségvédelmi rendszer átfogó bemutatására, csupán a személyiségi jog vagyoni vonatkozásai elismerésének jogfejlődésére. A fejezet először körüljárja a II. világháború előtti személyiségi jogi védelmet, az azzal kapcsolatos joggyakorlatot, az általános személyiségi jog bírói jogfejlesztés általi elismerését és szabályait, a személyiségi jogi jogalkotásra vonatkozó jogirodalmi álláspontokat, illetve a személyiségi jog vagyoni vonatkozásaira vonatkozó esetcsoportokat. Ezeket az ismereteket később a magyar személyiségvédelem rendszerének mélyebb feltárása során felhasználom, azokra visszautalok.

Az 21. században folyamatosan nő az ún. személyiség-merchandising és az ismert személyek személyiségi jegyei értékesítésének jelentősége. Termékeket látnak el ismert vagy kevéssé ismert személyek személyiségi jegyeivel, a nevüket, képmásukat reklámcélra jogosulatlanul használják fel. Hírességek életének történetei a bulvársajtó szalagcímeivé válnak. A jogosultak kereskedelmi kizsákmányolása elleni védelem sokáig az eltiltásra, az abbahagyásra koncentrált anélkül, hogy bárminemü

\footnotetext{
25 Jelen fejezet szövegének német nyelvü változata a Szegedi Tudományegyetem és az Universität Potsdam által a „Deutsches Recht mit Ausbildung zum Fachübersetzer LL.M.“ képzés keretében szakdolgozatként került leadásra, azon csak kisebb mértékü változtatásokat eszközöltem.

${ }^{26}$ A ,die vermögenswerte Bestandteile des allgemeinen Persönlichkeitsrecht“ kifejezést az alábbiakban az általános személyiségi jog vagyoni vonatkozásainak fordítom. Az ideelle Interessen kifejezést pedig eszmei/ideális/nem vagyoni érdekként.
} 
vagyonkiegyenlítést elismert volna. Ez változott meg lényegesen az utóbbi évtizedekben, amikor is a német felsőbírói gyakorlatban az általános személyiségi jog vagyoni vonatkozásai elismerésre kerültek.

A személyiség védelmét a jogalkotó nem szabályozta részleteiben, így a bírói jog oldaláról került kialakításra egy kielégítő jogvédelem, amely az ún. különös személyiségi jogok hézagos szabályozását egészítette ki, és fejlesztette tovább. A különös személyiségi jogok közé tartozik a névjog, a képmáshoz való jog és az alkotószemélyiség.

A BGH által elismert általános személyiségi jog legitimációját kellőképpen meg kellett alapozni, mert a Grundgesetzben szabályozott alapjogok alkalmazhatóságát (az emberi méltóság és a cselekvési szabadság jogai) azok közvetett hatálya miatt meg nem engedett bírói jogfejlesztésnek tekintették. A legitimációt azzal érték el, hogy a bírói jogban elismert általános személyiségi jog előtt létező különös személyiségi jogok alkalmazási körét nem fejlesztették tovább, mert a bírói gyakorlat úgy találta, hogy a törvényben pontosan meg nem határozott és nem szabályozott esetekben szintén az általános személyiségi jog alkalmazandó. Ennek az lett a következménye, hogy a különös személyiségi jogok mint a magánjogi személyiségvédelem különös megjelenési formái és részszabályozásai, nem voltak képesek továbbfejlődni. Ez a folyamat éppen az ellentéte az Otto von Gierke által elképzelt személyiségvédelemnek. Gierke azon a véleményen volt, hogy a személyiség általános joga csak addig nyújthat védelmet, míg különös személyiségi jogok belöle ki nem kristályosulnak: „A határ a különös személyiségi jogok és a személyiség általános joga között ezért részben ingoványos s bizonytalan. A szilárd törvényi alakba öntött személyiségi jogok mindenesetre nem merülnek ki az önmagukra vonatkozó szabályozásban. Sokkal inkább érzékeny hézagokat hagynak. E hézagok kitöltése ott szükséges, ahol a kortárs jogérzet azt megköveteli. Ekkor a személyiség általános jogához kell visszanyúlni mindaddig, míg belöle a különös személyiségi jogok ki nem vétetnek“. 27

A BGH gyakorlata ezzel szemben, mint látni fogjuk, a generálklauzula kiszélesítéséről szól. Ez a fejlődés analogikus módon (bár nem a hagyományos értelemben vett analógia mint jogtechnikai eszköz útján) történt, amelynek okán sok, egyébként szabályozást igénylő kérdés megválaszolatlan vagy szándékosan nyitott

${ }^{27}$ GIERKe, OtTo von: Deutsches Privatrecht Band I. Leipzig, Verlag Duncker \& Humblot, 1895. 704705. 
maradt. Ide tartozik többek között az örökölhető személyiségi jegyek halál utáni védelmi ideje, az e jogok élök közötti rendelkezési joga, azok átruházása, átruházhatósága, illetve az örökösök (vagy más jogutódok) rendelkezési jogának mértéke.

Egyes személyiségi jegyek örökölhetőségének és átruházhatóságának elismerésével részben kikerülnek a személyiségvédelem hagyományos dogmatikai rendszeréből és a szerzői joggal és más eszmei javakkal kerülnek kapcsolatba. A személyiségi jogok vagyoni jogokkal való kapcsolata nem új keletü, már a 20. század elején rendelkeztek ilyen vonatkozásokkal, ahogy Sólyom László is utal rá: „a történelmi összefüggések az általános személyiségi jog példáján figyelhetök meg a legjobban. Ennek közvetlen gazdasági vonatkozásait nem szokás említeni; sőt, ezt a jogot sokszor teljesen elfedi a materiális értékekkel szembeállitott "személyiség" ideológiája.“ ${ }^{28}$ Ezt a gondolatot a kontinentális jogrendszerek közül leginkább Németország fejlesztette tökélyre, csiszolta ki annak dogmatikai záróköveit.

I. A személyiség védelme a II. világháború előtti német magánjogban

\section{A BGB kodifikációja}

A BGB kodifikációja során vitatott volt, vajon kell-e a magánjogon belül általános védelmet biztosítani a személyiségnek. A római jogi alapok ${ }^{29}$ és a pandektizmus ezt nem irányozták elő, mert a személyt és a vele azonos személyiséget pusztán mint jogalanyt ismerték el, ${ }^{30}$ és nem mint jogtárgyat. Így például Savigny azon az állásponton volt, hogy az ember a teste és élete felett semmiféle rendelkezési joggal nem bírhat. Otto von Gierke ezzel szemben elismert egy jogot a személyiség felett, amely „alanyának a saját személyiségszférájának egy része felett uralmi jogot biztosit. “31 A 19. század végén a magánjogra mint pusztán vagyonjogra tekintettek, ${ }^{32}$

${ }^{28}$ SóLYOM LÁSZLÓ: A személyiségi jogok elmélete. Közgazdasági és Jogi Könyvkiadó, Budapest, 1983. 21.

29 Lásd PÓLAY ElEMÉR: Die römischrechtlichen Wurzeln des zivilrechtlichen Schutzes der Persönlichkeit. Acta Universitatis Szegediensis: Acta Juridica et Politica, (37) 1-22. (1987) 257280.

${ }^{30}$ Svájcban nincs különbségtétel a személy és személyiség között, ott a személyiség védelméröl beszélnek 1. Art 28 ZGB.

${ }^{31}$ GIERKE, 1895. 207.

${ }^{32}$ KANNOWSKI/Staudinger Vorbem zu § 1 Rn 22. 
ami azt is jelentette, hogy az ideális, nem vagyoni jellegü személyi javak ebben a rendszerben nem voltak elhelyezhetőek, és más jogterületek szabályozására (elsősorban a büntetőjogra és a közigazgatási jogra) voltak bízva. A személyiségi jog átfogó kodifikációjára tehát Németországban nem került sor.

Kizárólag a névjog került elismerésre, amelyet az általános részben önálló alanyi jogként a BGB 12. §-ában helyeztek el. A névjog kodifikációjának alapjául szolgált az, hogy e jogot már a Reichsgericht gyakorlata is elismerte, és hogy már ekkor védett eszmei (családi jogi), ${ }^{33}$ illetve vagyoni érdekeket is (cégnév, védjegyjog). Az ideális (eszmei) oldal nagymértékben támaszkodott a családi jog névszerzési és elvesztési tényállásaira.

Hogy mennyire helytelen volt a személyiségi jog szabályozását elutasító álláspont, arra mutat rá Joseph Kohler a BGB hatálybalépése után 3 évvel: „és mivel a rómaiak azon esetekben, mikor a személyiség joga megsérült, kizárólag vétkes cselekményböl eredö kötelességszegést láttak, úgy azt gondoltuk, itt nem kell mélyebbre ásnunk; és a további magyarázatát annak, miben áll itt a jogtalanság, félretettük, pont úgy, ahogyan azt a rómaiak is tették“ ${ }^{34}$ A svájci polgári törvénykönyv a „személyes viszonyok” védelmére generálklauzulát hozott létre ${ }^{35}$ amely pár évvel később Liechtensteinben is átültetésre került. ${ }^{36}$ Ezzel Németország tulajdonképpen hátrányba került, a személyiség bírói jogvédelme más országokban indult meg hamarabb.

\section{Különös személyiségi jogok}

A különös személyiségi jogok olyan alanyi jogok, amelyek a személyiséget már az általános személyiségi jog 1954-es elismerése előtt is védték. A különös személyiségi jogok lex specialisnak minősülnek az általános személyiségi joghoz képest, ezért a szubszumció során azt megelőzően vizsgálandóak. ${ }^{37}$ A különös személyiségi jogok törvényi védelemben részesülnek, amely az általános személyiségi jogtól teljesen független, ide tartozik a névjog, a saját képmáshoz való jog és az alkotószemélyiség.

\footnotetext{
${ }^{33}$ Lásd KLIPPEL, 1985. 152.

${ }^{34}$ KoHLER, JosepH: Das Eigenbild im Recht. Berlin, J. Guttentag, 1903.

${ }^{35}$ Art 28 ZGB.

${ }^{36}$ Art 39 PGR.

${ }^{37}$ A joggyakorlatban lásd különösen NJW 1990, 1986 - Emil Nolde.
} 
Egy kisebbségi álláspont ide sorolja a védjegyjogot is. ${ }^{38}$ A névjog a BGB 823 . § (1) bek. ${ }^{39}$ értelmében „egyéb jognak“ minősül, a képmáshoz való jog a BGB 823. § (2) bek. ${ }^{40}$ értelmében. A különös személyiségi jogok kifejezett célja a személyiség védelme, ezért azok a jogok, amelyek esetén ez a személyiségvédelmi cél csupán mellékesen jelenik meg, nem tartoznak ide. További sajátjuk, hogy pontosan körülhatárolt tényállással rendelkeznek, amelyek megvalósítása által a cselekmény jogellenessé válik, szemben az általános személyiségi joggal, amely egy nyitott törvényi tényállás, ennél fogva tartalma nem meghatározott. ${ }^{41}$ Míg az általános személyiségi jog esetén egy jogalkalmazói jogtárgy- és érdekmérlegelés szükséges az jogsértés megvalósulásához, addig a különös személyiségi jogoknál a mérlegelést a jogalkotó már elvégezte. ${ }^{42}$ A BGB 12. §-ában szabályozott névbitorlás tényálláseleme ugyanakkor a ,jogos érdek” sérelme, amely jogos érdek törvényileg nem került meghatározásra, és így ez ugyanúgy jogalkalmazói értelmezés és mérlegelés tárgyát képezi. A különös személyiségi jogok Götting szerint olyan személyiségi jogok, amelyek már az általános személyiségi jog előtt elismerést nyertek, és törvényi szabályozásban részesültek. ${ }^{43}$ A névjog Svájcban ezzel szemben nem számít különös személyiségi jognak, az a személyiségvédelmi generálklauzula (ZGB 28. cikk) ${ }^{44}$ egy különös megnyilvánulása, értelmezése, tehát csupán e norma konkretizálását célozza.

\section{A BGB 12. §-a szerinti névjog}

A BGB kizárólag a névjogot szabályozza, és a névvitatás, valamint a névbitorlás ellen véd. A névjog csak akkor sérül, „ha valaki a jogosult nevének használatára való jogát

\footnotetext{
${ }^{38}$ Götting/Schertz/Seitz (Hrsg.): Handbuch des Persönlichkeitsrechts, CH Beck, 2008.

${ }^{39}$ BGB 823. § (1) bek. Aki szándékosan vagy gondatlanul más életét, testi épségét, egészségét, szabadságát, tulajdonát vagy egyéb jogát jogellenesen megsérti, köteles a másiknak az ebből származó kárát megtérítenie; § 823 Abs. 1 BGB Wer vorsätzlich oder fahrlässig das Leben, den Körper, die Gesundheit, die Freiheit, das Eigentum oder ein sonstiges Recht eines anderen widerrechtlich verletzt, ist dem anderen zum Ersatz des daraus entstehenden Schadens verpflichtet.

${ }^{40}$ BGB 823. § (1) bek. Ezt a szabályt kell alkalmazni akkor is, ha valaki egy másik személy védelmére szolgáló törvényt sért meg; BGB 823. § Abs 2. Die gleiche Verpflichtung trifft denjenigen, welcher gegen ein den Schutz eines anderen bezweckendes Gesetz verstößt.

${ }^{41}$ GöTTING in Götting/Schertz/Seitz (szerk.): Handbuch des Persönlichkeitsrechts, CH Beck, 2008. § $11 \mathrm{Rn} 4$.

42 U.o.

${ }^{43}$ GÖTTING in: Götting/Schertz/Seitz (szerk.), Handbuch des Persönlichkeitsrechts, § 11 Rn. 1.

44 ZGB 28. cikk Akit személyiségében jogellenesen megsértenek, saját maga védelmére bírói jogvédelmet kérhet mindenkivel szemben, aki a jogsértésben közrehatott; Art 28. ZGB Wer in seiner Persönlichkeit widerrechtlich verletzt wird, kann zu seinem Schutz gegen jeden, der an der Verletzung mitwirkt, das Gericht anrufen.
} 
vitatja, vagy ha valaki a jogosult érdekét azzal sérti, hogy az ö nevével megegyezö nevet használ jogellenesen, úgy a jogosult a jogsértés megszüntetését kérheti. Ha további jogsértéstől kell tartani, a jogosult a jogsértés abbahagyását kérheti." A Reichsgericht joggyakorlatában ennek ellenére a névjog megsértése nemcsak akkor valósult meg, ha valaki másnak a nevét saját személyisége megjelölésére használta, hanem akkor is, ha azt reklámozási célra használta, vagy azt védjegyként bejegyeztette. ${ }^{45} \mathrm{Az}$ ezzel kapcsolatos leghíresebb ügy a Graf Zeppelin-ügy. ${ }^{46} \mathrm{~A}$ tényállás szerint egy dohánygyár Zeppelin gróf nevét és arcképét, beleértve felsőtestét dohánytermékek vonatkozásában védjegyként lajstromoztatta, illetve azt árukon és áruk csomagolásán felhasználta. A Reichsgericht abból indult ki, hogy egy név jogosulatlan használata nemcsak akkor valósul meg, ha valaki egy idegen nevet saját személyisége megjelölésére használ, hanem akkor is, ha valaki egy idegen névvel reklámcélokra, árujelzőként vagy cégérként él vissza. A bíróság hangsúlyozta, hogy a név használata nem azonos a név viselésével, vagy ahogy a Reichsgericht fogalmazott: „sokkal inkább akként kell felfogni a dolgot, hogy a névjogosult a neve használatát amely a név viselésétöl megkülönböztetendö - egy másik személynek szerzödéssel átengedi, azaz vele szemben lemond azon jogáról, hogy a név használatát számára megtiltsa.“ A BGB 12. §-a eredetileg nemcsak az összetéveszthetőség ellen, hanem minden más a névvel összefüggő érdek védelmére szolgált. ${ }^{47}$

Mivel a jogalkotó a személyiség általános védelmétől eltekintett, voltak olyan esetek, amikor a szubszumció a különös személyiségi jogok tekintetében nem vezetett eredményre. Ilyenek voltak a szerzői jogi védelmet nem élvező levelekkel kapcsolatos ügyek. Ehhez hasonlatosan, a névjog érdekes alkalmazási lehetőségét vetették fel olyan ügyek, amelyekben egy személy nevét vagy magát a személyt „írásban és képben“ (Schrift und Bild) mutatták be, vagy ha a nevét egy kitalált figura megnevezésére használták. A Reichsgericht foglalkozott ezzel a kérdéskörrel, ugyanakkor minden esetben, jóllehet más okokból, megválaszolatlanul hagyta a BGB 12. §-ának alkalmazhatóságát. Ez a Biedermann-döntésben azzal az indokolással történt meg, hogy „a 12. § még a lehetö legméltányosabb értelmezése esetén sem vonatkozik azon esetekre, amikor a név használatát egy tipikus alak megjelölésére használják azzal, hogy egy meghatározott személyhez bármilyen kapcsolata állna fenn.

\footnotetext{
${ }^{45}$ RGZ 86, 308, 310.

${ }^{46}$ RGZ 74, 308 - Graf Zeppelin.

${ }^{47}$ KLIPPEL, 1985. 421.
} 
Még becsületsértés [Beleidigung] sem lehetséges akkor, ha egy ilyen kapcsolat a felperessel összefüggésben hiányzik. Nincsen másról szó a perbeli ügyben, mint egy ártalmatlan élcröl, amelyet lehetetlen a felperes személyével kapcsolatba hozni. “48

A kérdés az 1917-es Weberlied-döntésben is nyitott maradt. A Reichsgericht abból indult ki, hogy a név a személy külső megjelölésére szolgál, hogy más személyektől őt megkülönböztesse, és a BGB 12. §-ának alkalmazása kizárt, ha egyáltalán nem is a névről, hanem a személyröl van szó. Sosem lehet a névjog megsértéséről beszélni akkor - mondta ki a Reichsgericht -, ha a név jogosult viselöje magával a nevével kerül megnevezésre, róla azonban valami valótlant állítanak. A bíróságnak meg kellett állapítania, hogy a perbeli versben egy olyan férfiről volt szó, aki a felperessel azonos nevet viselt, amely körülmény a BGB 12. §-ának alkalmazását kizárta. ${ }^{49}$

A BGB 12. §-a alapvetően az ember nevét védi. Ez a védelem a jogképességhez kapcsolódik, és mivel az ember jogképessége a halálával megszünik, úgy a névjogi igény is kizárólag élete idejére szükül. ${ }^{50} \mathrm{~A}$ névnek az ember jogképességéhez való kapcsolódása kizárja tehát azt, hogy a névjog a jogosult halála után is elismerésre kerüljön. A probléma nagyon hasonló a később bemutatásra kerülő általános személyiségi joghoz, amely esetén a poszt mortem személyiségi jog (postmortales Persönlichkeitsrecht) az elhunyt személyre való emlékezetéhez kapcsolódik mint egyfajta továbbható védelem. A névjog esetében azonban egy sokkal egyszerübb érvet lehet találni a BGB 12. §-a alkalmazási körének a jogosult halála utáni időre való kiterjesztésre. A név ugyanis nem azonos a személlyel, hanem sokkal inkább egy, a jogalanyról leválasztható megjelölés (a BGB 12. §-a eredeti értelmében az emberé). E védelem tehát nem a jogalanyra magára vonatkozik, hanem a jogtárgyra, amely jelen esetben a név, egy szóbeli megjelölés. Ezzel pedig a jogképességhez való kötődés is feloldódik. A név mint jogtárgy túléli a személyt. Götting korábban azon az állásponton volt, hogy egy post mortem névvédelem a képmáshoz való jog analógiájára a halál után elismerhető lehet. ${ }^{51}$

\footnotetext{
${ }^{48}$ DJZ 1906, 543 - Biedermann.

${ }^{49}$ RGZ 91, 350 - Weberlied. Hasonló: NJW 2004, 605 - Derrick.

${ }^{50} \mathrm{BGHZ} 8,318,324$.

${ }^{51}$ GÖTTING, 1995. 107.
} 
A képmás már a 19. században szerzői jogilag védett volt. Az erre vonatkozó szabályozási igényt a fényképkészítés feltalálása, és az ún. pillanatkép (Momentfotografie) hívta életre. Ez a védelem a megrendelt fényképhez kapcsolódóan alakult ki, és a szerző jogainak korlátját képezte. A képmáshoz való jog szabályozása viszont még a megrendelés tekintetében is tökéletlen és elégtelen volt, és a lefényképezett személy érdekei pontosan abban az esetben nem kaptak kellő védelmet, ha a megrendelő és a leképzett személy nem voltak azonosak. ${ }^{53}$

Az abbahagyásra és az eltiltásra vonatkozó igények szükségességét a képmáshoz való joggal összefüggésben a Bismarck-eset hívta életre, amikor is a halott birodalmi kancellárt két újságíró azon céllal fényképezte le, hogy a felvételeket később napilapoknak adják el. Kiemelendő ugyanakkor, hogy a Reichsgericht az esettel büntetöügy keretében foglalkozott, illetve hogy akkoriban az elkövetés helyén, Friedrichsruhban a szász tükör volt hatályban, ami természetszerüleg semmilyen rendelkezést nem tartalmazott a személyiség védelme vonatkozásában. A bíróság a birodalmi kancellár halálos ágyához való jogosulatlan behatolást mint magánlaksértést értékelte, és a condictio ad iustam causam ${ }^{54}$ (jogellenes jogcímből származó gazdagodás) alapján rendelte el a felvételek kiadását. A BGB egy évvel később lépett hatályba, bárminemű utalással a képmáshoz való jogra, jóllehet a jogirodalom egy része annak magánjogi szabályozását kifejezetten támogatta. ${ }^{55} \mathrm{~A}$ személy külső megjelenését védő személyiségi jog az 1907-es Kunsturhebergesetz ${ }^{56} 22$. sköv. §§aiban $^{57}$ került „elrejtésre“. A képmásvédelem ennek ellenére nem a szerzői jog része, hanem egy személyiségi jog, és a KUG 22. § 1. mondata ennél fogva a BGB deliktuális felelősségének [BGB 823. § (2) bek.] „más jogot védö törvény“ rendelkezésébe

52 „Das Recht am eigenen Bilde“ szó szerinti fordításban a saját képhez való jog, a továbbiakban képmáshoz való jog.

${ }^{53}$ GÖTTING, 1995. 16-17.

${ }^{54}$ D. 12.5.

${ }^{55}$ KOHLER, 1903.; COHN: Neue Rechtsgüter. Liebmann, Berlin, 1902.

${ }^{56}$ A szerzői jog egyes részeiről rendelkező törvény, a továbbiakban KUG.

57 KUG 22. § Képmások csak a lefényképezett személy beleegyezésével terjeszthetőek, illetve hozhatóak nyilvánosságra. A beleegyezés kétség esetén akkor is megadottnak tekintendő, ha a lefényképezett személy díjazásban részesül a lefényképezésért cserében. A lefényképezett személy halála után 10 évig a hozzátartozóinak hozzájárulása szükséges. § 22 KUG Bildnisse dürfen nur mit Einwilligung des Abgebildeten verbreitet oder öffentlich zur Schau gestellt werden. Die Einwilligung gilt im Zweifel als erteilt, wenn der Abgebildete dafür, daß er sich abbilden ließ, eine Entlohnung erhielt. Nach dem Tode des Abgebildeten bedarf es bis zum Ablaufe von 10 Jahren der Einwilligung der Angehörigen des Abgebildeten. 
tartozik. ${ }^{58}$ E jognak a képzőművészetről és a fotográfiáról szóló szerzői jogi törvénybe való betagozódása abból adódik, hogy a képmáson fennálló szerzői joghoz hasonlóan annak nyilvánosságra hozatala a szabályozás tárgya, és a kép létrehozójának szerzői joga nagymértékben átfedésben van vele annyiban, hogy a kép felhasználásához a leképezett személy hozzájárulása szükséges. ${ }^{59}$ Másrészről az akkor uralkodó jogelméleti felfogás, a jogrendszer zártságának az elve, a windscheidi Begriffsjurisprudenz per se nem engedte a magánjogi viszonyok körének kitoldását a BGB-ben, hiszen az egyben a német kodifikáció kudarcaként is értelmezhető lett volna.

5. A védelem megtagadása a Reichsgericht gyakorlatában

Az átfogó személyiségvédelem fontossága már a két világháború közötti időben is egyre jobban érződött. Ez egyrészről megmutatkozott a különös személyiségi jogok alkalmazási körének a tágításán, másrészről azon esetekben, amikor jogvédelmet kellett volna adni a félnek, a BGB azonban nem tartalmazott erre vonatkozóan jogalapot. Ahogy a Reichsgericht fogalmazott, „egy általános alanyi személyiségi jog a hatályos polgári jogtól idegen. Csak és kizárólag különös, törvényileg szabályozott személyiségi jogok léteznek. “60 Az analógia útján történő elismerés pontosan azért nem volt lehetséges, mert a BGB kodifikátorai az általános személyiségi jog törvénybe iktatásáról szándékosan mondtak le, ez pedig kizárta, hogy az analógia vonatkozásában törvényi hézagról lehessen beszélni. A Reichsgericht e pozitivista törvényértelmezése mellett a Rundfunk-döntésben ${ }^{61}$ is kitartott: „egy általános személyiségi jog, amelynek köszönhetöen a szerzö a jogairól kimeritöen rendelkezni tudna, csak egy, a jogrendszerben egyenként elismert jogosultságoknak gyüjtöfogalma, amely nem biztositja az igényérvényesitést, és amely sem eltiltási, sem kártéritési igényt nem alapoz meg mindaddig, míg nem egy, törvényben külön szabályozott jogosultságról van szó. “62 Az átfogó, generálklauzula jellegü védelemmel szemben állt az is, hogy ez a jog egészen bizonytalan, tényállása teljesen üres, és emellett tartalmilag is a korszellemmel együtt változik, módosul és fejlődik. ${ }^{63}$ A személyiségi

\footnotetext{
58 LeTTL, TOBIAS: Urheberrecht. CH Beck, München, 2. Auflage, 2013. § 12 Rn. 2.; médiajogi szemszögből: PeTERSEN, Jens: Medienrecht. CH Beck, München, 2010. 54.

${ }^{59}$ BGHZ 20, 345 - Paul Dahlke.

${ }^{60}$ RGZ 92, 401, 403. - Nietzsche Briefe

${ }^{61}$ RGZ 71, 413, 414 - Der Tor und der Tod / Rundfunk.

${ }^{62}$ RGZ 71, 413.

${ }^{63}$ Lásd HuBMANN, HeINRICH: Das Persönlichkeitsrecht. Böhlau Verlag, Münster / Köln, 1953. 109.; az
} 
jogi javak a névjog és a képmás által nyújtott eszmei védelmen túl más jogintézmények keretében részesültek kizárólag védelemben, mint amilyen a cégnév, illetve a védjegyjog is volt.

6. Az általános személyiségi jog bírói jogfejlesztés keretében történő elismerése

A személyiségi jog felfogásának és szabályozásának több lehetséges útja létezik, az osztályozás történhet egyrészröl a versenyjog, a szellemi alkotások (eszmei javak) oldaláról, ${ }^{64}$ másrészről a privacy (magánélet) által, vagy akár az emberi méltóság oldaláról. ${ }^{65}$ Németország azt az utat választotta, hogy az általános személyiségi jogot a német Alaptörvényben biztosított emberi méltósággal hozta kapcsolatba. Az ember méltósága a személyiségvédelemben politikailag is szerepet játszott annyiban, hogy a Reichsgericht vonatkozó joggyakorlatával való szembenállást is hivatott (volt) kifejezni. Az elismerés azért volt sajátos, mert nem analógia útján történt, hanem inkább absztrakt módon deklarálta a jogot a bíróság e jog meglétét. ${ }^{66} \mathrm{Az}$ általános személyiségi jog ezzel egy teljesen más helyzetbe került, mint amilyen Svájcban található, a politizálódása által ugyanis e jog „mint az emberi méltóság érintetlensége, vagy pozitív fogalmazásban, mint a személyiség szabad kibontakozásához való jog, az alkotmányos alapjogok közé emelkedik“، ${ }^{67}$

A személyiségi jog elismerése tehát nem a BGB módosításával történt, hanem bírói jogfejlesztés útján. A Grundgesetz 1949-es hatálybalépése után védelemben részesült az 1. cikk (1) bekezdésben az emberi méltóság, a 2. cikk (1) bekezdésben a személyiség szabad kibontakozásához való jog. A BGH ezt a megváltozott jogi környezetet úgy tekintette, hogy az alkotmánykonform jogértelmezés csak abban az esetben adott, ha egy polgári jogi általános személyiségi jog elismerésre kerül: ${ }^{68}$ „,mivel

Egyesült Államokban különösen Solove, DANIEL J.: Conceptualizing Privacy, California Law Review 2002. 1087. sköv.

${ }^{64}$ A német jog az Immaterialgüterrecht elnevezést használja a szellemi alkotások védelme tekintetében, amely immateriális javak jogaként adható vissza, ez a korabeli magyar terminológiában eszmei javakként szerepel.

${ }^{65}$ Beverly-Smith - OHLY - LuCAS-Schlotter: Privacy, Property and Personality. Cambridge University Press, 2005. 4.

${ }^{66}$ Lásd HamBaCh, HeINRICH: Das bürgerliche Gesetzbuch aus Sicht der anglo-amerikanischen Literatur unter besonderer Beachtung des Richterleitbildes und des allgemeinen Persönlichkeitsrechts. Dissertation, Hamburg, 2004. 127.

${ }^{67}$ SólYOM, 1983, 34.; HAMBACH, 2004. 118.; ehhez még POKOL BÉLA: The Concept of Law. The multilayered legal system. Rejtjel Kiadó, Budapest, 2001.

${ }^{68}$ KANNOWSKI/Staudinger Vorm zu § 1 Rn. 24. 
most már az Alaptörvény tartalmazza az ember jogát a méltóságának megóvására (GG 1. cikk) és a személyiség szabad kibontakozásához való jogot is magán-, mindenki által tisztelendö jogként ismeri el mindaddig, míg e jog mások jogait vagy az alkotmányos rendet vagy a jó erkölcsöket nem sérti (GG 2. cikk), úgy az általános személyiségi jogot, mint egy alkotmányosan garantált alapjogot, el kell ismerni. “69

A BGH azon az állásponton volt a Leserbrief-döntésben, ${ }^{70}$ hogy a német Alaptörvény előbb említett 1 . és 2 . cikkei egy általános személyiségi jogot implikálnak a magánjogban, amely a BGB 823. § (1) bekezdése szerint „egyéb jognak“ minősül. A jog elismerése tehát erre az 1954-es bírósági döntésre vezethető vissza, nem a későbbi ún. Herrenreiter-döntésre. ${ }^{71} \mathrm{~A}$ bíróság hangsúlyozta, hogy a személyiség átfogó védelme a Reichsgericht joggyakorlatában azért került elutasításra, mert az akkor érvényben levő német jogrend nem tartalmazott pozitív törvényi szabályt egy általános személyiségi jogra vonatkozóan. A Reichsgericht szöveghű értelmezésével ellentétben a kártérítési jogból kiindulva hozták létre e jogot. Ettől eltérően Svájcban különálló jogalap, alanyi jog található a német BGB-ből hiányzó személyekről szóló részben. A teljes joggyakorlat és minden a személyiségvédelemhez kapcsolódó döntés az ekkor elkezdett bírói jogfejlesztés továbbvitelén alapul, ahogy Opoku fogalmaz: „the general right of personality is undoubtedly one of the most remarkable contributions the German judges have ever made ". ${ }^{72}$

III. Eszmei érdekek általános személyiségi jog általi védelme

1. Az általános személyiségi jog alkalmazási körének kiterjesztése a különös személyiségi jogok megsértésének eseteire

Az általános személyiségi jog elismerése után a BGH megkísérelte kibővíteni annak alkalmazási körét. Egy ilyen bővítés volt az, amikor a BGB 253. § (1) bekezdést akkor hatályos formájában contra legem alkalmazta becsületsértés esetén a nem vagyoni károk pénzbeli megtérítésére. ${ }^{73} \mathrm{~A}$ joggyakorlat hasonló konstrukciót hozott létre a

\footnotetext{
${ }^{69} \mathrm{BGHZ} 13,334$.

${ }^{70} \mathrm{BGHZ} 13,334$.

${ }^{71}$ MEDICUS, DIETER - PETERSEN, JENS: Bürgerliches Recht. Eine nach Anspruchsgrundlagen geordnete Darstellung zur Examensvorbereitung. 23. Auflage, Vahlen, München, 2011. Rn 615.

${ }^{72}$ K. OPOKU, Delictual Liability in Germany. International and Comparative Law Quarterly 21, 1972. 269.

${ }^{73}$ HonSELl, HeINRICH: Einleitung zum Bürgerlichen Gesetzbuch. In: Roth, Herbert (szerk.): J. von
} 
különös személyiségi jogok vonatkozásában is. Néhány esetben a szubszumció mindkét jog (azaz a különös személyiségi jogok és az általános személyiségi jog) vonatkozásában sikeres lett volna, ezt bizonyos esetekben a tényállás jellege (pl. jogellenes megnevezés), máskor a jogkövetkezmény alkalmazhatósága (pl. kártérítés és jogalap nélküli gazdagodás) támogatta.

Egy ilyen döntés a híres Caterina Valente-eset, ${ }^{74}$ amelyben a BGH a reklámozás célját szolgáló jogellenes megnevezést az általános személyiségi jog megsértésének tekintette. A tényállás szerint az alperes protézis tisztítására és rögzítésére szolgáló preparátumokat forgalmazott. A „C“ magazin 1957.07.10.-i különszámában, 648.197 példányban egész oldalas hirdetést tett közé, amelyben egy meg nem nevezett énekesnő valószínűsíthető élményeit és az alperes termékeit dicsérték fel. A leírásban a felperes (Caterina Valente), egy ismert müvésznő, neve is szerepelt. Felperest nem kérdezte meg az alperes arról, hogy vajon személyének megemlítéséhez a reklám szövegében hozzájárulását adja-e.

A bíróság abból indult ki, hogy a BGB 12. §-a szerinti igény akkor valósul meg, ha a jogosult nevét egy másik személy, akimelyet ez nem illet meg megjelölésként, illetve megkülönböztetési eszközként, használja. A joggyakorlat e tényállás alkalmazási körét olyan esetekre is kiterjesztette, amikor a név viselöjét a neve használata által olyan helyiségekkel, termékekkel vagy készítményekkel hozzák kapcsolatba, amelyekhez semmi köze nincs. Túl messzire menne azonban azon indokolás - mondta a BGH - hogy egy személyre történö bármely önhatalmú, reklámozással összefüggő névbeli utalás kivétel nélkül névbitorlást eredményezzen. Azt a kérdést azonban, hogy a BGB 12. §-ának alkalmazása ezen esetek közül néhányra vonatkozik-e, a bíróság szándékosan nyitva hagyta azzal az indokolással, hogy „a jogrendszer ezen esetek vonatkozásában már kielégitö jogvédelemmel rendelkezik“. Ez pedig az újonnan elismert általános személyiségi jog volt.

A BGH általi szubszumció akkor válik érthetőbbé, ha a felperes kereseti kérelmét megvizsgáljuk. Valente asszony abbahagyásra és egy meghatározott pénzösszeg fizetésére perelt a jogcím megjelölése nélkül. A kereseti kérelemben nem került részletezésre az, hogy a konkrét esetben a pénzfizetésre irányuló kereset melyik jogalapra támaszkodik. Az abbahagyásra és a kártérítésre irányuló keresetet a BGB 12.

Staudingers Kommentar zum Bürgerlichen Gesetzbuch mit Einführungsgesetz und Nebengesetzen.

Sellier - de Gruyter, Berlin, 2013. Rn 128.; BGHZ 26, 394 - Herrenreiter.

${ }^{74}$ NJW 1959. 1269 - Caterina Valente. 
§-ának alkalmazásával meg lehetett volna oldani, mert az abbahagyást ez a norma tartalmazza jogkövetkezményként, a kártérítésről rendelkező BGB 823. § (1) bekezdés értelmében a BGB 12. §-a „egyéb jognak minősül”, így ez alapján is megállapítható lett volna a névjog sérelme a vonatkozó jogkövetkezmények alkalmazásával. Abban az esetben azonban, ha a fizetésre irányuló (marasztalási) kereset, ahogyan azt a BGH is megállapította, nem vagyoni (eszmei) kártérítésre irányul, úgy a helyzet lényegesen megváltozik, mert ezt a BGB 12. §-a nem tette lehetővé. Az elégtételről rendelkező BGB 847. §-át a BGH a képmáshoz való jog megsértésére analóg módon alkalmazta. Ehhez hasonló konstrukcióval ítélt meg „méltányos kártalanítást” pénzben (billige Entschädigung in Geld) az általános személyiségi jog megsértésére hivatkozással. ${ }^{75}$

Ezt a névjog esetén is megtehette volna a BGH, ekkor szintén analógiát kellett volna alkalmaznia. Meglátásom szerint nem az általános személyiségi jog megsértésére való igény valósul meg akkor, ha a nyilvánosság számára ismert eladóművészek nevét a hozzájárulásuk nélkül reklámhirdetésekben említik meg. A BGB 12. §-ának kiterjesztő értelmezése éppen azért volt adott, mert magának a jogalkotónak is az volt az akarata, hogy a nevet átfogóan, az üzleti élet körén kívül is védje; ${ }^{76}$ a bírói jogfejlesztés ennek az alanyi jognak a vonatkozásában is megtörténhetett volna. Itt azonban már megjelenik a magánjogi általános személyiségi jogi aktivizmus, a bírói jogfejlesztés által elismert jog legitimálása, a magánjogi személyiség védelmének általános személyiségi jog keretében történő egyfajta egységesítése, alkalmazásának és szabályainak kiterjesztése. A Graf Zeppelin-ügyben, hasonló esetben már megállapította a bíróság a névjog megsértését, itt ez egyártelmüen azért maradt el, hogy a frissen elismert általános személyiségi jog által védett érdekek köre bővítésre kerülhessen.

Idegen név reklámcélú jogosulatlan használatát a $\mathrm{BGH}$ a Carrera-ügyben ${ }^{77}$ szintén az általános személyiségi jog megsértésének tekintette, és a jogalap nélkül szerzett előny visszatérítését a BGB 812. $§-a^{78}$ alapján ítélte meg a felperesnek. Az ügy tényállása szerint alperes a cégnevének vezérszavát képező „Carrera”

\footnotetext{
${ }^{75}$ BGHZ 26, 349 - Herrenreiter.

${ }^{76}$ Protokolle der Kommission für die Zweite Lesung, Bd. 6. 113. (A BGB második szövegét tárgyaló bizottsági jegyzőkönyvek).

77 NJW 1981, 2402 - Carrera.

${ }^{78}$ BGB 812. § Aki más teljesítése által vagy egyéb módon a másik személy rovására valamit jogalap nélkül megszerez, az e másik személynek ezt kiadni köteles; § 812 BGB Wer durch die Leistung eines anderen oder in sonstiger Weise auf dessen Kosten etwas ohne rechtlichen Grund erlangt, ist ihm zur Herausgabe verpflichtet.
} 
árumegjelöléssel játékautókat gyártott és forgalmazott. Az 1967-77. évi programja egyik részének csomagolásán a felperes jármüvét is megjelenítette egy fénykép felhasználásával, mégpedig olyan módon, hogy egy leretusált hirdetés helyett a versenyautó elején a „Carrera” vezérszó harmadik személyek számára is olvasható maradt. A felperes azon a véleményen volt, hogy alperes ezzel a megjelenítéssel a vásárlói érdekkörében olyan látszatot keltett, mintha ő - a felperes - a valóságban is az alperes által reklámozná termékeit.

$\mathrm{Az}$ eset jogi értékelésébe a bíróság a Caterina Valente-ügyben tett megállapításait is belevonta, és (ismét) megállapította, hogy idegen név reklámcélú használata nem mindig a BGB 12 . §-a szerinti névjog megsértését eredményezi. ${ }^{79} \mathrm{~A}$ Caterina Valente-ügyhöz képest a névhasználat jelen ügyben nem volt összekötve a személyiségi jog jogosultja hírnevének és megítélésének csökkenésével, így a fizetésre irányuló marasztalási kereset nem a BGB 847. §-a szerinti elégtétellel, hanem a 812. $\S$ szerinti jogalap nélküli gazdagodás alapján került megítélésre. A BGB 812. §-a szerinti igény a Caterina Valente-üggyel ellentétben a névjog megsértéséből is származhatott volna. A jogalap azonban nem a névjog volt, hanem a korábbi ítélkezési irányvonalat fenntartva az általános személyiségi jog.

A személyiségi jog halál utáni érvényesülésének kérdésében a BGH a Noldeügyben tett alapvető kijelentéseket, jóllehet azt a Mephisto-ügyben ismerte el. A Reichsgericht joggyakorlatában a név védelme a halállal megszünt, mert a jogképessége is végetért a jogosult halálával. A jogváltozáshoz itt is az általános személyiségi jog elismerése vezetett. A jogvita tárgya két akvarell volt, amelyet az 1956-ban elhunyt Emil Nolde expresszionista festő stílusában festettek, és amelyet az ő kézjegyével láttak el, a képek azonban nem Noldétól származtak. A BGH az igény értékelése szempontjából a következőkre jutott: „Az, hogy vajon azon joggyakorlat, amely szerint a névjog a halállal megszünik, továbbra is fenntartható-e, vagy hogymint ahogy a felülvizsgálati bíróság is látja [...] a BGB 12. §-ának névjoga az általános személyiségi jog egy szeleteként a személyiségi jogi védelmi hatásával a névviselö halála után is továbbhatni képes, itt most nem jelentös. Ennek az oka az, hogy a fellebbezési bíróság által tett megállapitások alapján nem állapitható meg, hogy felperes a festö nevét használta-e. ${ }^{\text {(80 }} \mathrm{A}$ BGH az alsóbírósági érvelést elfogadta, amely az igényt az általános személyiségi jogra alapította, és ez egyben azt is jelentette,

\footnotetext{
${ }^{79}$ NJW 1959, 1269 - Caterina Valente.

${ }^{80}$ NJW 1990, 1986 - Emil Nolde.
} 
hogy a poszt mortem névvédelem elismerését ismét megtagadták. A személyiség jogi védelme a német Alaptörvény 1. cikk (1) bekezdése értelmében nem szünik meg a halállal, „sokkal inkább arról van szó, hogy egy általános érték- és tartózkodási igény hat tovább, amely az elhunyt személyek továbbható életképét továbbra is védi a súlyos behatásokkal szemben." 81

2. A különös személyiségi jogok törvényi hézagjainak meghódítása az általános személyiségi jog által

A nem szabályozott személyiségi jogi területek mellett a BGH által elismert általános személyiségi jog a korábban jogalkotás útján elismerésre került személyiségi jogokat is hátráltatta a továbbfejlödésben. Ez történt különösen akkor, ha egy különös személyiségi jog valamely alkalmazási köre tekintetében a jogalkotó nem helyezett el rendelkezést a törvényben. Néhány esetben a törvényhozó szándékával ellentétben került megváltoztatásra a szubszumció menete, mint ahogyan azt a Caterina Valente és a Carrera esetek mutatják.

A legfontosabb és legjelentősebb tényállásokat az alábbi táblázatban foglaltam össze annak megjelölésével, hogy mely törvényhelyen vagy bírósági ítéleten nyugszik a jog elismerése. A félkövérrel jelölt ítéletek azok, amelyek esetén az igényt az általános személyiségi jogra alapozva ismerte el a bíróság.

\section{1. sz. táblázat}

A különös személyiségi jogok jogtárgyainak általános személyiségi jog általi védelme a birói gyakorlatban

\begin{tabular}{|c|c|c|c|}
\hline \multirow{8}{*}{$\S 12 \mathrm{BGB}$} & \multirow{2}{*}{\multicolumn{2}{|c|}{$\begin{array}{l}\text { Névvitatás } \\
\text { Névbitorlás }\end{array}$}} & $\S 12 \mathrm{BGB}$ \\
\hline & & & $\S 12 \mathrm{BGB}$ \\
\hline & & BGHZ 1959, 1269. \\
\hline & \multirow{2}{*}{\multicolumn{2}{|c|}{$\begin{array}{l}\text { Vállalatjelzők } \\
\text { Post mortem védelem }\end{array}$}} & $\S \S 5,15$ MarkenG \\
\hline & & & BGHZ 107, 384. \\
\hline & \multicolumn{2}{|c|}{ Vagyoni érték } & NJW 2000, 2195. \\
\hline & \multirow{2}{*}{$\begin{array}{l}\text { Domain név } \\
\text { (bitorlás) }\end{array}$} & Eszmei & $\begin{array}{l}\S 12 \text { BGB, } \\
\text { NJW 2002, } 2031 .\end{array}$ \\
\hline & & Vagyoni & BGHZ 169, 193. \\
\hline
\end{tabular}

${ }^{81}$ NJW 1990, 1986 - Emil Nolde. 


\begin{tabular}{|c|c|c|}
\hline \multirow{3}{*}{$\S 22 \mathrm{KUG}$} & Általános védelem & $\S 22 \mathrm{KUG}$ \\
\hline & Post mortem védelem & $\S 22 \mathrm{~S} .3 \mathrm{KUG}$ \\
\hline & Vagyoni érték & NJW 2000, 2201. \\
\hline$\overline{(U r h G)}$ & $\begin{array}{llll}\begin{array}{l}\text { Levelek } \\
\text { nélkül }\end{array} & \text { szerzői jogi oltalom } \\
\end{array}$ & BGHZ 13, 334. \\
\hline - & Hang & NJW 1990, 1996. \\
\hline
\end{tabular}

(saját szerkesztés)

3. Az általános személyiségi jog vagyoni vonatkozásaira való utalás a joggyakorlatban

Már a polgári jogi személyiségvédelem kikristályosodásának korában sem állt messze az irodalomtól az, hogy bizonyos személyiségi jogoknak vagyonjogi karaktert tulajdontson. ${ }^{82}$ Már említésre került, hogy mivel a BGB-t nem módostották, a bírói gyakorlatban a Leserbrief-döntés ${ }^{83}$ útján kezdték el megadni a jogvédelmet. A BGH akkor úgy érvelt, hogy a személyiség általános védelmének alapja az alkotmányos emberi méltóság és szabad kibontakozás alapjogain nyugszik. Ez azonban azt feltételezte, hogy a védelem eszmei, nem vagyoni jellegü; ennek ellenére a BGH már 1968-ban sem vonakodott megemlíteni azt, hogy az általános személyiségi jog nem minden tekintetben minősül átruházhatatlan és örökölhetetlen jognak, hanem rendelkezik vagyoni vonatkozásokkal is. ${ }^{84}$ Arról azonban, hogy mely jogok, illetve jogosultságok tartoznak ebbe a körbe, és milyen mértékben lehetséges ez, a BGH hallgatott. Az ,általános személyiségi jog vagyoni vonatkozásai” mint fogalom ezen ítélet előtt nem lelhető fel az irodalomban. A védjegy-, (árujelző-) és cégjogban ${ }^{85}$ már megtalálhatóak voltak olyan személyiségi jegyek (elsősorban a név és a képmás), amelyek messzemenően tárgyiasultak, és ezzel vagyoni értékkel rendelkeztek, valamint forgalomképesek is voltak. ${ }^{86}$ Ezen kívül a képmáshoz való jogot a bírói gyakorlat egy kizárólagos értékesítési jogként (ausschließliches Verwertungsrecht) kvalifikálta azért, hogy a használat és hasznosítás átengedésének ellenértékeként el tudja ismerni a díjfizetési kötelezettség jogszerüségét és lehetőségét. ${ }^{87}$

\footnotetext{
${ }^{82}$ GIERKE, 1895. 704-705.

${ }^{83}$ BGHZ 13, 334 - Leserbrief.

${ }^{84}$ BGHZ 50, 133 - Mephisto.

${ }^{85}$ A kialakuláshoz és dogmatikához 1. KLIPPEL, 1985.

${ }^{86}$ Lásd GötTing, 1995.

${ }^{87}$ BGHZ 20, 345 - Paul Dahlke.
} 
A kép és a név védelmét a hamburgi táblabíróság a Heinz Erhardt-döntésben ${ }^{88}$ a hangra is kiterjesztette, ahogy a bíróság fogalmaz, „[a KUG 22. §-ának] védelme $<E>$ jellegzetes hangjára és szavajárására tekintettel a jelen ügyre alkalmazást nyer. A személyiségi jogi sérelem intenzitása nem kisebb mértékü, mint a képmás és a név védelme esetén. A rádió reklámjának minden hallgatója számára-teljesen mindegy, hogy az utánzást felismerte-e - a müvészi személyiség emlékezete idézödik fel teljes valójában. De ennek fel is kell idézödnie, mert a reklám éppen ebböl a hatásából nyeri ki az elérni kívánt figyelmet és megnyerést." ${ }^{89}$ A döntés időpontjában, 1989-ben a személyiségi jog vagyoni vonatkozásai még nem nyertek elismerést, a bíróság ugyanakkor hangsúlyozta, hogy a személyiségi jogok mindenelőtt akkor részesülnek védelemben, ha reklámban anyagi előnyszerzés céljából kerülnek kihasználásra. ${ }^{90}$

\section{A védelem monizmusa és dualizmusa}

\section{A szabályozási célról általában}

Különböző álláspont található a jogirodalomban arra nézve, hogy miért és hogyan szabályozzák az egyes jogrendszerek a személyiségi jogok kommercializálódását, vagyoni értékét. E teóriák rendelkezhetnek gazdasági tartalommal, ${ }^{91}$ az egyén védelmére is koncentrálhatnak, vagy éppen a fogyasztó jogaira. ${ }^{92} \mathrm{Az}$ örökölhető és átruházható személyiségi jegyek elismerésének német útja a személyiség védelmét, pontosabban az általános személyiségi jogot állítja ennek középpontjába. A kérdés ezzel kapcsolatban inkább az, milyen mélységig hatja át a szabályozást (vagyis inkább szabályrendszert) a ,personality theorie“, azaz a személyi eszme. Tulajdonképpen a kérdés tehát az, hogy mekkora mértékü rendelkezési joga marad a személyiségi jog jogosultjának e tárgyiasult alkotórészek felett. A dualista elméletek szerint a kommercializálódott személyiségi részek vagyonjoggá válnak, és ezzel uralmi joggá

${ }^{88}$ NJW 1990, 1995 - Heinz Erhardt.

${ }^{89}$ U.o.

${ }^{90}$ U.o.

${ }^{91}$ L. SEEMANN, BRUNO: Prominenz als Eigentum. Parallele Rechtsentwicklungen einer Vermarktung der Persönlichkeit im amerikanischen, deutschen und schweizerischen Persönlichkeitsschutz. Nomos, Baden-Baden, 1996.

92 Rendszerezve bemutatja CORBETT, VAL: The right of publicity and the search for principle, In: Koltay, András (szerk): Media Freedom and Regulation in the new Media World, Budapest, Wolters Kluwer, 2014. 
is, amely az általános személyiségi jogtól és annak jogosultjától függetlenül létezik. A monista teória képviselői szerint ezzel szemben a személyiségi jog jogosultjának eszmei érdekei e vagyoni, tárgyiasult vonatkozások felett mind élők között, mind halál esetére figyelembe veendőek. Az alábbiakban ezek a teóriák kerülnek bemutatása.

\section{Dualista elméletek}

A személyiségi jogok dualizmusa élesen elválasztja egymástól az eszmei és a vagyoni, materiális érdekeket. ${ }^{93} \mathrm{Ez}$ azt jelenti, hogy két, eltérő törvényi alap is védi a személyiségi jogokat. Az egyik ilyen az eszmei érdekeket védő, alapvetően tartózkodásra irányuló kizáró igény, a másik pedig a vagyoni érdekeket az értékesítés, használat ellen védő forgalomképes vagyoni jog. Ehhez az elmélethez hasonlít leginkább az Egyesült Államokban kialakított Right of Privacy és Righty of Publicity.

A személyiség és az image (személyiségkép) közötti különbségtételen alapuló dualista védelmet ismer el Beuthien. ${ }^{94} \mathrm{Az}$ ő felfogásában a személyiségkép egy, a személyiségről leválasztható örökölhető és átruházható vagyoni jog. Beuthien abból indul ki, hogy a személyiség és az arculata (személyiségkép) között azért kell éles határvonalat vonni, mert a személyiség mint olyan nem fokozható le egyszerü tárggyá. ${ }^{95}$ Szerinte van egyrészről a személyiség, amely az élő személy lényeges alkotóeleme, ${ }^{96}$ és vannak uralmi jogok, amelyek egyfajta értékesíthető jogok, és amelyeket ő személyiségi javakon fennálló jogoknak nevez (Persönlichkeitsgüterrechte). ${ }^{97}$ A személyiség ugyanis - véleménye szerint - nem lehet jogtárgy, de egy, a személyiségen fennálló jog már igen, akkor is ha az alapvetően átruházhatatlan. Az ideális és materiális érdekek közötti ezen éles különbségtétel okán könnyen meghatározható véleménye szerint, hogy melyek a személyiségi jogba tartozó örökölhető jogosultságok, ez pedig végső soron a jogbiztonságot szolgálja. Azokat a szerződéseket, amelyek tárgya maga a személyiség, nem lehet érvényesen megkötni, és ez nem amiatt van, mert a személyiségi jog nem jogtárgy, hanem mert az elismert személyiségi jog nem átruházható. A személyiségi jogok a polgári jog

\footnotetext{
93 GÖTtING in: Götting/Schertz/Seitz, Handbuch des Persönlichkeitsrecht, § 10 Rn 4.

94 BEUTHIEN, 2003, 1220 sköv.

${ }^{95}$ U.o. 1221.

${ }^{96}$ BEUTHIEN VOLKeR - SCHMÖLZ, ANTON S.: Persönlichkeitsschutz durch Persönlichkeitsgüterrechte. Erlösherausgabe statt nur billige Entschädigung in Geld, CH Beck, 1999. 24.

${ }^{97}$ BEUTHIEN - SCHMÖLZ, 1999. 37. sköv.
} 
szempontjából jogtárgynak minősülnek, ${ }^{98}$ és annyiban, amennyiben eszmei érdekek védelmére irányulnak, alapvetően nem átruházhatóak és nem örökölhetőek.

Hasonló állásponton van Heitmann, aki az eszmei és vagyoni érdekek közötti dualista elválasztást egy személyiségi hasznosítási jog (Persönlichkeitsnutzungsrecht) konstruálásában látja. Az ő nézete szerint ez a személyiségi hasznosítási jog egy átruházható, örökölhető vagyoni jog. ${ }^{99}$

3. Monista elméletek

A személyiségi jogok monizmusa nem jelent mást, mint a szerzői jogban: a személyiségi és a vagyoni jogok és jogosultságok egységét. ${ }^{100}$ Más szavakkal kifejezve: „akkor is, ha ezen rendelkezési lehetőség következtében a személyiségi jog bizonyos vonatkozásai önállósodnak, a személyiséggel való kapcsolatuk továbbra is fennáll.“101 A személyiségi jogon belül fogalmilag az eszmei és a vagyoni érdekek közt tesznek különbséget, ${ }^{102}$ Götting személyiségi jogok, vagyoni jogok és eszmei javak (Immaterialgüterrechte; tulajdonképpen szellemi alkotások) között differenciál. ${ }^{103}$ Egy álláspont szerint a szerzői jog szabályai a személyiségi jogi védelem szabályrendszerének kiépítése során példaként használhatóak a monista rendszerben, mert a védelem módjának hasonlósága miatt az analóg alkalmazás nem kizárt. ${ }^{104}$

A monista elmélet nagyban arra koncentrál, hogy a dualista elméletben egy önálló vagyoni jog jön létre a személyiségi jogok vagyoni érdekei tekintetében, amely teljesen korlátlan a személyiségi jogtól. Ez meglátásom szerint a dualizmus esetében sem lenne így, hiszen ettől függetlenül lehetőség van arra, hogy a jog korlátozottan legyen átruházható, a forgalomképessége is korlátozott lehet. Erre példa lehet a

\footnotetext{
98 ALMÁSI, ANTON: Ungarisches Privatrecht. Band I. Walter de Gruyter \& Co. Leipzig, 1922. 101. sköv. Más állásponton: BroX, HANS - WALKER, Wolf-DIETRICH: Allgemeiner Teil des BGB. 40., neu bearbeitete Auflage, Vahlen, München, 2016. Rn. 778. a személyiség megóvására vonatkozó jogot ismer el. A személyiségi jog jogtárgyként való kizárása azt feltételezi, hogy a magánjog lényegében vagyoni jogként kerül értelmezésre.

${ }^{99}$ HeITMANN LUTZ: Der Schutz der materiellen Interessen an der eigenen Persönlichkeitssphäre durch subjektiv-private Rechte - zugleich ein Beitrag zur Abgrenzung des allgemeinen Persönlichkeitsrecht. Diss. Hamburg, 1963.

100 Ehhez LETTL, § 1 Rn 51; § 5 Rn 3.

${ }^{101}$ GöTTING in: Götting/Schertz/Seitz, Handbuch des Persönlichkeitsrechts, § 10 Rn 16.

102 KLASS, Nadine: Anhang zu § 12. Das Allgemeine Persönlichkeitsrecht. In: Westermann, Harm Peter, Grunewald, Barbara, Maier-Reimer, Georg (szerk.): Erman. Bürgerliches Gesetzbuch. Dr. Otto Schmidt Verlag, Köln, 2011. Rn 16. [Erman/KLASs, BGB, 14. Aufl., Anh § 12]; BGHZ 50, 133 Mephisto; NJW 2000, 2195 - Marlene Dietrich.

103 GÖTTING, 2001, 585.

${ }^{104}$ GötTING, 1995. 279. sköv.
} 
haszonélvezet, amely vagyoni jog, de az átruházás tekintetében korlátozott. A monizmus és a dualizmus közötti elméleti különbségtétel ugyanakkor segít megérteni a személyiségi jogi érdekek kettősségének egymásra hatását. Látható ugyanakkor az is, hogy a német jog mint bírói jog a pozitív jog rétegét nélkülözi. Ez részben az értékelésben is torzulást okoz. Egy kodifikált személyiségi jogi rendszerben, mint amiylen a magyar is, az eszmei és vagyoni érdekek különválasztása sokkal élesebb kell hogy legyen, feltéve, ha elismerjük a vagyoni érdek létét. Ez abból fakad, hogy az átruházhatóság csak a vagyoni vonatkozások tekintetében lesz lehetséges. Ehhez hasonlóan a poszt mortem védelem tekintetében a vagyoni érdekeket le kell választani az erkölcsi érdekeket védő kegyeleti jogtól. Szintén problémát jelent a vagyonjogi jogkövetkezméynek alkalmazása, ezt is le kell választani a puszta eszmei, erkölcsi érdekek védelméről. Ezt a Ptk. nem teszi meg, jóllehet iylen jogkövetkezményeket alkalmaz. Ha ezeket együtt szemléljük, úgy könnyen az az érzés keletkezhet a jogalkalmazóban, hogy ez két külön jogosultság. Ez elkerülendő, hiszen az eszmei és vagyoni érdekek sokszor egy életviszonyban, egy magatartással sérülnek. Célszerü lehet ezért meglátásom szerint a személyiségi jog generálklauzulájához képest egy speciális kerettényállást konstruálni.

\section{A névjog kettőssége}

Kizárólagosan a névjogra vonatkozó dualista elméletet képvisel Diethelm Klippel, aki a névjogi személyiségi jog mellett egy névjogi vagyoni jogot is elismer (a névjog kettős karakterének elmélete). Klippel azon az állásponton van, hogy mindaddig, míg a névjogi érdek az összetéveszthetőség elkerülésére irányul, úgy nem egy a személyiségi jogtól elválasztható jogról beszélünk, hanem egy eszmei jogról (magyar terminológiával szellemi alkotásról). ${ }^{105} \mathrm{~A}$ névjog örökölhetősége és átruházhatósága tekintetében megoldja a problémát szerinte az, hogy a névjogot mint személyiségi jogot átruházhatatlannak és örökölhetetlennek tekinthetjük a továbbiakban is, azonban, elsősorban a kereskedelmi jogi és védjegyjogi összefüggésekben a név bizonyos tekintetben forgalomképes. Ebben a tekintetben a név ugyanis néven való vagyoni joggá (Namensimmaterialgüterrecht) válik. ${ }^{106}$ Ide sorolható a névjog gazdasági,

${ }^{105}$ KLIPPEL, 1985. 521.

106 U.o. 561. 
kereskedelmi megjelölésként való felhasználása ${ }^{107}$ mellett az is, hogy a név reklámértékkel bír és a filmsztárok gazdaságilag értékesíthetik nevüket. ${ }^{108}$ Ezzel nem az általános személyiségi jog, hanem a BGB 12. §-a szerinti névjog bír eszmei és vagyoni vonatkozásokkal. Így a vagyoni vonatkozások, a vagyoni értékminőség és az ehhez kapcsolódó járulékos kérdések nem kerülnek összetüzésbe az általános személyiségi jog Németországban kialakított modelljével, és a védendő eszmei, erkölcsi érdekekkel sem.

V. Az általános személyiségi jog vagyoni vonatkozásainak elismerése a BGH gyakorlatában

1. Marlene Dietrich és der blaue Engel

Jóllehet a BGH már egész korán, 1968-ban utalt rá, hogy a személyiségi jog jellege nem kizárólagosan eszmei, azt a kérdést akkoriban nyitva hagyta, hogy mikor és milyen terjedelemben lehetnek a személyiségi jogok vagyonjogok. ${ }^{109}$ A döntvény erejével bíró ügyben Marlene Dietrich lánya perelte be a Lighthouse Musical GmbHt, mert a perbeli cég a „Marlene“ szóvédjegy jogosultja volt, és emellett allicenciát biztosított musicallel és különböző merchandise termékkel összefüggésben a Marlene védjegy használatára két további cégnek. ${ }^{110}$ Marlene Dietrich lánya a jogsértés abbahagyása mellett kártérítésre perelt, mert a védjegy bejegyzésére és használatára az alperesnek meglátása szerint nem volt joga. ${ }^{111} \mathrm{~A}$ jogi probléma lényegében abban állt, hogy kártérítési igény nem származhatott az általános személyiségi jog megsértéséből, mert ez a jog kizárólag eszmei érdekeket védett, azaz a konkrét jogsértések esetén csak azok kizárásra irányuló igényeket (Abwehranspüche) enged meg.

A személyiségi jegyek (Persönlichkeitsmerkmale) jogellenes értékesítése és kommercializációja azonban sokkal kevésbé eszmei, mint anyagi (vagyoni) érdekeket sért. Ezzel összefüggésben a $\mathrm{BGH}$ a következő megállapítást tette. „Az általános

\footnotetext{
107 U.o. 503.

108 U.o. 501.

${ }^{109}$ BGHZ 50, 133 - Mephisto.

${ }^{110}$ L. még PETERSEN, Jens: Postmortaler Persönlichkeitsschutz. JURA 2008, 271, 272.

111 NJW 2000, 2195 - Marlene Dietrich.
} 
személyiségi jog és annak különös megjelenési formái, a képmáshoz való jog és a névjog a személyiség nemcsak eszmei, hanem vagyoni érdekeit is védik. Ha a személyiségi jog vagyoni vonatkozásait a kép, név vagy más egyéniesítő személyiségi jegy jogellenes felhasználásával vétkesen megsértik, úgy a személyiségi jog jogosultja a jogsérelem súlyosságától függetlenül kártérítésre jogosult. A személyiségi jog vagyoni vonatkozásai a személyiségi jog jogosultjának halála után továbbra is fennállnak mindaddig, amíg az eszmei érdekek is védelemben részesülnek. Az ebből eredő jogosultságok így a személyiségi jog jogosultjának örököseire szállnak át, és ők tudnak az örökhagyó kifejezett vagy valószínűsíthető akaratának érvényt szerezni."

Ezt a kommerciális, gazdasági érdeket értékelte a BGH, amikor megállapította, hogy a személyiségi jogok gazdaságilag értékesíthetőek, és ennél fogva a személyiségi jog jogosultja ezek felett vagyoni joggal is rendelkezik. A személyiségi jognak ezt a vagyonjogi oldalát a BGH kevésbé tekinti egy új jelenségnek, sokkal inkább egy olyan körülménynek, amely korábban nem került a bíróság által értékelésre. Ezt az általános személyiségi jog vagyoni vonatkozásainak nevezi (vermögenswerte Bestandteile des allgemeinen Persönlichkeitsrechts). A személyiségi jog jogosultjának minden esetben, a jogsértés súlyától függetlenül rendelkezésére áll a kártérítési igény, ha a képmás, név vagy más megjelölésre alkalmas személyiségi jegy jogosulatlan felhasználásával vétkesen ${ }^{112}$ megsérti a személyiségi jog vagyoni vonatkozásait. ${ }^{113}$

Az általános személyiségi jog vagyoni vonatkozásainak elismerésére még ugyanazon a napon egy párhuzamos döntésben szintén sor került a BGH részéről. Az ún. Blauer Engel-ügyben szintén Marlene Dietrich személyégi jegyei voltak a jogvita tárgyai, konkrétan Marlene Dietrich lánya édesanyjától rá átszállott képmáshoz való joga megsértése címén perelte az alperest, aki a „Der blaue Engel“ (A kék angyal) című filmből egy utánképzett jelenetéből felhasznált fényképpel sértette meg ezt a jogot azzal, hogy egy Marlene Dietrich filmbeli testtartását utánzó hölgyről készült fényképet Marlene lánya engedélye nélkül használt fel reklámozási célokra. ${ }^{114}$ A BGH ebben az ügyben a vagyoni vonatkozások halál után terjedelme kérdésében lényeges megállapítást tett: a képmáshoz való jog kereskedelmi hasznosítása a halál után 10 évig lehetséges a jogosult örökösei számára a KUG 22. § 2. és 3. mondata analóg

\footnotetext{
${ }^{112}$ Az eredeti szövegben „,schuldhaft“, azaz szándékosan vagy gondatlanul.

${ }^{113}$ NJW 2000, 2195 - Marlene Dietrich.

${ }^{114}$ NJW 2000, 2201 - Der Blaue Engel.
} 
alkalmazása alapján. ${ }^{115}$

Egyes személyiségi jegyek örökölhetőségének elismerése a személyiség teljesebb és jobb védelmét szolgálja olyan jogsértések ellen, amelyek ezen a módon kerülhetőek el kielégítő mértékben. Ahogy Schulze Wesel fogalmaz „a személyiségi jogok részleges öröklése sem az elhunyt elkereskedelmiesitéséhez [Kommerzialisierung], sem az örököseinek érdekütközéseihez nem vezet. Sokkal inkább éppen fordítva történik ez, és az elhunyt személyiségének jobb védelmét érjük el." 116 Götting a két döntést akként méltatta, hogy a személyiségi jogok örökölhetetlenségének dogmáját végre áttörte a bírói gyakorlat, amikor a személyiségi jogoknak vagyoni, illetve eszmei tulajdoni [immaterialgüterrechtliche] jelleget tulajdonított. ${ }^{117} \mathrm{E}$ dogmatikai fordulat azért fontos és szükséges, mert „,az elhalt híres személyiségek reklámértékének szabad és korlátlan kizsákmányolása, amelynek a következménye a személyiségi jog vagyoni vonatkozásainak el nem ismerése volt, szembemegy az egyre növekvö kommercializációval, megsérti a logika egyszerü szabályait, akkor is, ha abszolút jogoknak meghatározott személyhez köthetöségének gazdasági irányitó funkciójára vonatkozó egyszerüen érthetö következtetéseket figyelmen kívül hagyjuk. “118

Az ingó dolgoknál a birtoklás joga, ingatlannál az ingatlan-nyilvántartás jelzi egy dolog valamely személy érdekkörébe tartozását, és rámutat arra, ki az a jogalany, aki e jogok élvezetéből másokat kizárhat. A személyiségi jegyeknél maga a személyiségi jog jogosultja az, akinek az érdekkörébe az adott jog tartozik. Ezt a jog minden további jogi tény, feltétel nélkül elsimeri, szemben a materiális jogtárgyakkal, ahol ezt a birtoklással, nyilvántartással kifejezetten jelezni kell. A személyiségi jegyek egy személyhez kötése, érdekszférájába tartozónak vélése értelemszerüen azt illeti, akire a személyiségi jegy utal. Ezzel összefüggésben mutat rá tulajdonképpen Götting arra, hogy az átruházhatósággal, örökölhetőséggel tulajdonképpen ez kerül áttörésre, és ezt ő nem tekinti ördögtől valónak, pontosan azért, mert erre akkor is sor kerülne, ha ezt a jog nem ismerné el. Erre lényegében a személyiségi jog és személyiségi jegy eszmei (nem anyagi) jellege ad lehetőséget. Míg egy dolog, egy ingatlan a fizikai valóságban létező, egyszeri jelenség, addig a név, képmás stb. sokszorosítása,

\footnotetext{
115 PETERSEN, 2008. 273.

116 SCHULZE WeSSEL, LAMBERT: Die Vermarktung Verstorbener. Persönlichkeitsrechtliche Abwehr- und Ersatzansprüche. Arno Spitz, Berlin, 2001. 131.

117 GÖTTING, 2001. 585.

118 U.o. 586.
} 
felhasználása nem egy megfogható dologhoz köthető, a szellemi tulajdonjogokhoz hasonlóan bármikor, bárhol megsérthető jog. Pontosan erre az érzékeny, könnyü jogsértési metódusra ad hathatós választ az átruházhatóság, örökölhetőség bizonyos fokú elismerése, hiszen így e bitorlásokkal szemben fel lehet lépni a vagyoni érdekkör megsértésére alapozottan is. E jogok elismerése lényegében a jogellenes felhasználására adott reakció, amely épp ennek el nem ismeréséből táplálkozott, és ezen jogi hézagot volt képes kihasználni.

\section{Blauer Engel II.}

A polgári bíróság határozatát megtámadták azon okból, mert az indítványozó szerint kártértési igény a képmáshoz való jog mint a személyiségi jog vagyoni vonatkozásának halál utáni megsértése alkotmányellenes, hiszen ez az igény nem öröklődhetne. Az ellenérdekü fél ebben az ügyben is Marlene Dietrich lánya, Maria Riva volt. ${ }^{119}$ A panaszos azon a véleményen volt, hogy ennek bíróság általi elismerése meg nem engedett bírói jogfejlesztés. A Szövetségi Alkotmánybíróság hangsúlyozta, hogy az egyszerü jog bíróság általi továbbfejlesztése önmagában nem ütközik a német Alaptörvénybe pusztán azért, mert az egy örökölhető vagyoni értékkel bíró személyiségi jog elismeréséhez vezet. Rámutatott arra, hogy az alkotmányjogi, illetve a polgári jogi értelemben vett személyiségvédelem egymással nem azonos, és az alkotmányjog részéről kifejtett ellenőrzés az egyszerű jog értelmezése során az alkotmányjogi mércék figyelembevételére szükül. Arra azonban nem terjed ki az ellenőrzési jog, hogy felülvizsgálásra kerüljön a polgári jogi normák helyes alkalmazása. Ebből kifolyólag a Szövetségi Alkotmánybíróság arra jutott, hogy az örökölhető vagyoni értékű személyiségi jog elismerése a megengedett bírói jogfejlesztés határait nem lépi túl. ${ }^{120}$

Abban a kérdésben, hogy vajon ezek a vagyoni vonatkozások, az eszmei érdekekhez hasonlóan a német Alaptörvény 1. és 2. cikkének védelmét élvezik-e, vagy hogy azok inkább a tulajdonjog védelme alapján ítélendőek-e meg, ahogy ezt Götting is javasolja, ${ }^{121}$ a Szövetségi Alkotmánybíróság nem foglalt egyértelmüen állást.

\footnotetext{
${ }^{119}$ NJW 2000, 2201 - Der blaue Engel.

${ }^{120}$ NJW 2006, 3409 - Blauer Engel II.

${ }^{121}$ GÖTTING, 1995. 139. sköv.
} 
Az általános személyiségi jog vagyoni vonatkozásainak elismerése, az örökölhetőség deklarálása, illetve a német Alaptörvénnyel való konformitásának megállapítása után is sok kérdés maradt nyitva a jog tartalma és megszünése tekintetében. A BGH foglalkozott többek között a BGB 12. §-a szerinti névjoghoz való viszonyával, az örökösök rendelkezési jogával, és a poszt mortem személyiségi jog vagyoni vonatkozásainak védelmi idejével is. A perbeli ügy tárgya a „kinski-klaus.de“ domain néven fennálló jogosultság volt. ${ }^{122}$ A felperesek az 1991. november 23-án elhunyt Klaus Nakszynski örökösei voltak, aki Klaus Kinski müvésznéven vált széles körben ismertté. 2002 március 21-ei felszólításukban utaltak arra, hogy az alperesek a ,kinksiklaus.de“ domain nevet bejelentették, és használták azt abból a célból, hogy egy általuk szervezett, Klaus Kinskiről szóló kiállítást reklámozzanak, és azt követelték a felperesek, hogy az alperesek e tevékenységükkel hagyjanak fel. Az alperesek ugyanis a felperesek szerint az örökhagyó hírességének hasznosításához (Vermarktung) való abszolút jogukba avatkoztak be, és a felszólási költségek megtérítésén túl kártérítést követeltek.

Az általános személyiségi jog örökölhető részeinek elismerése után a BGH kitartott amellett, hogy a BGB 12. §-a szerinti névjog a jogosult halálával megszünik. Ha a név a halál után valamely módon felhasználásra kerül - állapította meg a BGH amely a poszt mortem általános személyiségi jogot sérti, úgy továbbra is fennáll a védelem. ${ }^{123}$ A Marlene Dietrich-döntésben nyitva maradt az a kérdés, mennyi ideig élik túl a jogosultat a vagyoni vonatkozások, a Blauer Engel-döntésben a KUG-t alkalmazta analóg módon, azonban nem annak a védelmi időre vonatkozó rendelkezéseit. ${ }^{124}$ Egy 2002-es, szintén Marlene Dietrich egy fotója ügyében a Müncheni Táblabíróság (Oberlandesgericht München) nem tekintette mérvadónak a KUG 22. § szerinti 10 éves, képmáshoz való jog védelmi idejét, hanem egy ennél hosszabb védelmet sem zárt ki. A BGH ezzel szemben a jogkérdést akként válaszolta meg, hogy a jogalkotó döntése a képmáson fennálló poszt mortem joggal összefüggésben a poszt mortem személyiségi jog vagyoni vonatkozásaira is átültetendőek. Az ugyanakkor megválaszolatlan maradt, és nem is teljesen

\footnotetext{
122 BGHZ 169, 193 - kinksi-klaus.de.

123 U.o.

${ }^{124}$ A Schutzdauer és Schutzfrist terminusok elhatárolásához LETTL, 2013. § 7 Rn 3.
} 
következetes, hogy ez a védelmi idő a BGB 12. §-ából származó igények tekintetében miért nem érvényesül. Úgy tűnik, a személyiség egységes védelmének követelménye ezt az értelmezést kizárólag az általános személyiségi jog oldaláról támogatja, a különös személyiségi jogok oldaláról pedig nem. Kiemelendő ezen túl, hogy a bíróság másként nevezi a védelmi időt a vagyoni vonatkozások tekintetében (Schutzdauer), mint a törvény által szabályozott képmáshoz való jog vonatkozásában (Schutzfrist). ${ }^{125}$

A fenti joggyakorlat következtében az általános személyiségi jog rétegekre bomlott, e rétegek az alábbi táblázatban kerültek összefoglalásra azon elnevezéssel, amelyen a BGH is jelöli őket. A táblázatban feltüntetésre került az is, hogy a BGH jogfelfogásában ezek mennyiben hatnak a különös személyiségi jogokra - azaz mennyiben veszik át azok helyét. Ezek a rétegek és ez az osztályozás a német jogirodalomban ilyen módon nem jelennek meg.

\section{2. sz. táblázat}

A személyiségi jog eszmei és vagyoni vonatkozásainak védelme a német joggyakorlatban

\begin{tabular}{|c|c|c|c|}
\hline & \multirow[t]{2}{*}{ ÁLTALÁNOS SZEMÉLYISÉGI JOG } & \multicolumn{2}{|c|}{ KÜLÖNÖS SZEMÉLYISÉGI JOG } \\
\hline Élő́k között & & NÉV & KÉPMÁS \\
\hline $\begin{array}{l}\text { eszmei } \\
\text { védelem }\end{array}$ & „,általános személyiségi jog” & BGB 12. $\S$ & KUG 22. § \\
\hline $\begin{array}{l}\text { vagyoni } \\
\text { védelem }\end{array}$ & \multicolumn{3}{|c|}{ „,az általános személyiségi jog vagyoni vonatkozásai” } \\
\hline $\begin{array}{c}\text { halál utáni } \\
\text { eszmei } \\
\text { védelem }\end{array}$ & \multicolumn{2}{|c|}{ „poszt mortem személyiségi jog” } & KUG 22. $\S$ \\
\hline $\begin{array}{c}\text { halál utáni } \\
\text { vagyoni } \\
\text { védelem }\end{array}$ & \multicolumn{3}{|c|}{ „a poszt mortem személyiségi jog vagyoni vonatkozásai” } \\
\hline
\end{tabular}

(saját szerkesztés)

4. Érdek- és jogtárgy-mérlegelés

A különös személyiségi jogok tekintetében a jogalkotó a kodifikálással már elvégezte

\footnotetext{
125 BGHZ 169, 193 - kinki-klaus.de.
} 
az érdekmérlegelést, így például a BGB 12. §-a egy ,jogos érdeket” követel meg a tényállásában. Az általános személyiségi jog tekintetében nincsen olyan törvényileg lefektetett zsinórmérték, amely a jog gyakorlásnak módját és kereteit meghatározná. Már a Leserbrief-döntésben utalt arra a BGH, hogy egy jogtárgy-mérlegelést kell elvégezni az igény vizsgálata során. ${ }^{126}$ Kivételt képeznek ez alól azok az esetek, amelyekben az emberi méltóság sérül, itt ugyanis minden érdek- és jogtárgymérlegelés felesleges a jogsérelem súlyossága okán. ${ }^{127}$ A mérlegelésbe bevonható jogtárgyak és érdekek különbözőek lehetnek, ilyen például az a körülmény, ha valaki relatív vagy abszolút kortörténeti szereplö, vagy ha a véleménynyilvánítás szabadsága vagy a művészeti élet szabadsága sérül, vagy a társadalom információs érdeke az adatok nyilvánosságra hozatalát követeli meg. A személyiségi jog vagyoni vonatkozásainak elismerését követően azonban nem volt egyértelmü, hogy mikor és milyen mértékben kell vagy lehet érdekmérlegelést végezni. A kérdés azonban egyszerủen megválaszolható: az eszmei és vagyoni érdekek keveredése ahhoz vezet, hogy a vagyoni érdekek, az eszmei érdek beszivárgása okán, és azért, mert a két érdek nem válik el élesen egymástól, így érdekmérlegelés szükséges a jogsértés megállaptásához. Az OLG München által tárgyalt ügyben nem volt szó arról, hogy a vagyoni jogkövetkezmények Marlene Dietrich poszt mortem személyiségi jogának sérelme okán alkalmazhatóak-e, mert a bíróság a tényállást pusztán eszmei oldalról közelítette meg a jogsértés megalázó volta miatt, így a vagyoni jogkövetkezmények e tényállás mellett eleve nem voltak alkalmazhatóak. A byróság csak az eszmei oldalra koncenctrált, arra, hogy a meztelen képek a halott életképének megsértésre alkalmasak, azt nem értékelte, hogy a felhasználás módja vagyoni érdesérelemhez vezet. Ezt tudatosan tette a Müncheni Táblabíróság, ki is emelte, hogy a vagyoni érdekek védelme nem vezethet a személyiség túlkommercializálásához.

\section{A névről és képmásról leválasztott vagyoni érték}

A vagyoni vonatkozások közé elsősorban a név, a képmás és más személyiségi jegyekhez kapcsolódó jogosultságok sorolhatóak, mint amilyen a hang is. A két legfontosabb ezek közül azonban a képmás és a név, mert ezek különös személyiségi jognak minősülnek, amelyek ennél fogva már az általános személyiségi jog előtt

${ }^{126}$ BGHZ 13, 334 - Leserbrief.

${ }^{127}$ BGHZ 50, 133 - Mephisto. 
törvényileg szabályozásra kerültek. Mint a fenti ítéletek is rámutatnak, az általános személyiségi jog vagyoni vonatkozásai által átfogott életviszonyok éppen e két jog megsértéséhez kapcsolódnak.

A név és a képmás személyről leválasztható jogtárgyak, nem úgy mint például a becsület. Ez az „eltárgyiasítás” ${ }^{128}$ e jogok öröklését és átruházhatóságát sokkal inkább megindokolhatóvá tették volna, ez azonban jobban a dualista teória támogatását jelenthetné. A vagyoni érték jogirodalomban fellelhető, jól kimunkált szabályozási- és alkalmazási köre ${ }^{129}$ azonban ezzel a név és a képmás ideális körére szükült (magyarul a BGH nem értett egyet az irodalommal). Jelen esetben ugyanis nem új jogtárgyak elismeréséről volt szó, hanem a már elismert jogtárgyakhoz kapcsolódó új, védendő jogi érdekek jogalkalmazás általi bevonásáról.

A vagyoni érték vagyoni jog vagy eszmei tulajdoni (szellemi alkotási) formában történő elismerése a BGB 12. § és a KUG 22. § alá szubszumálással is megtörténhetett volna. Ez a megoldás a már törvényileg egyébként is elismert jogok egyébként e vonatkozásban kialakult alkalmazási köre által biztonságot nyújtott volna, másrészről azok a jogok, amelyeket e két szakasz nem fog át, a mögöttes vagyoni személyiség vagy más néven az általános személyiségi jog vagyoni vonatkozásai által átfogó védelemben részesülhettek volna. Nem teljesen érthető, hogy a BGH miért a nyitott „„örvényi” tényállás alkalmazási körét bővítette ezzel is, ráadásul a jogalkotó által kodifikált jogokkal szemben.

\section{A vagyoni vonatkozások hatóköre}

\section{1. Általában}

Az, hogy a személyiségi jog örökölhető és átruházható vonatkozásokkal rendelkezik, már bemutatásra került, sokkal inkább e jog kontúrjaira kell rámutatni azért, hogy világossá váljék, milyen tulajdonságokkal bír e jog. Ennek keretében elsősorban a védelmi idő, az örökösök rendelkezési jogának terjedelme, illetve a szerzői jog analóg alkalmazása kerül bemutatásra.

A BGH monista jellegü védelmet választott, amelyben az anyagi és az eszmei

128 GÖTTING, 1995.

${ }^{129}$ Vö. GÖTtinG, 1995; KLIPPEL, 1985. 
érdekek egymással elválaszthatatlanul össze vannak kötve, a védelemnek ez a formája lehetővé teszi a bíró számára, hogy nagyobb mozgástérrel rendelkezzen a tényállás pontos megállapítása során. A dualista védelemben az eszmei (tehát az általános személyiségi jogi), és a vagyoni (a gazdasági személyiség, az image, arculat, a vagyoni személyiség) érdekek szigorúan el vannak egymástól határolva. E két érdek ilyen egyértelmü kettéválasztása nagyon durva értelmezési hibákhoz is vezethetett volna a későbbi joggyakorlatban abból az okból, hogy a jogsértés megállapítása sokkal egyértelmübb irányvonalak mentén kellett volna, hogy történjen, amely egy méltányos mérlegelést a szükséges esetekben nem tett volna lehetővé. Ezt elkerülendő a BGH a monista védelem mellett döntött. A dualista jellegű védelem nem a monista ellentéte, sokkal inkább minőségibb különbség van a kettő között. A dualista modell ugyanis egy már sokkal kifinomultabb dogmatikát követel meg, amelyet csak az esetjog tud kiformálni. A két jog közötti viszony problematikája etekintetben nagyban hasonlít az általános és a különös személyiségi jogéhoz.

\section{Védelmi idő}

A személyiségi jogok vagyoni vonatkozásait az ideálisokkal azonosan kell értékelni, a poszt mortem személyiségi jog ideális érdekei a német Alaptörvény 1. cikk (1) bekezdése szerinti emberi méltóságon nyugszanak, és a bírói gyakorlat ezeket mint az elhunyt továbbható életképét fogja fel. ${ }^{130} \mathrm{Ez}$ a védelem nem lehet rövidebb, mint a jogosult halála után számított 30 év. ${ }^{131}$

Különböző álláspontok vannak arra nézvést, hogy a vagyoni vonatkozások meddig részesülnek védelemben, a $\mathrm{BGH}$ a kinski-klaus.de-döntésben a 10 éves időt kielégítőnek találta. Ez tehát rövidebb, mint az eszmei érdekek védelme, ahogy a BGH is hangsúlyozta: ,az általános személyiségi jog poszt mortem védelme nem szünik meg teljes mértékben a 10 év letelte után, az eszmei érdekek poszt mortem védelme annak feltételei és terjedelme szerint ennél tovább is tart."132

Az egyik álláspont szerint a poszt mortem személyiségi jog vagyoni vonatkozásai addig részesülnek védelemben, amíg az eszmei érdekek. ${ }^{133}$ Az uralkodó

\footnotetext{
${ }^{130}$ BGHZ 50, 133 - Mephisto.

${ }^{131}$ BGHZ 107, 384 - Emil Nolde.

132 BGHZ 169, 193 - kinski-klaus.de.

133 STAUDINGER, ANSGAR - SCHMIDT, RÜDIGER: Marlene Dietrich und der (postmortale) Schutz vermögenswerter Persönlichkeitsrechte. Jura 2001, 241, 246; FROMMEYER, INGO:
} 
álláspont, amely a korábban bemutatott bírói gyakorlatot követi, egy 10 éves védelmi időt fogad el. Egy másik álláspont szerint a védelmi időt a halált követő hetven évben kellene megállapítani, tehát a szerzői joghoz hasonló módon. ${ }^{134}$

A másik oldalról ugyanakkor ott található a közérdek és a piac érdeke arra vonatkozólag, hogy e jegyek felett szabadon lehessen rendelkezni a kereskedelmi életben, vagy ahogy a BGH fogalmaz, egy, még életében híressé vált személy személyiségképe a halála után a közös történelmünk részévé válik. ${ }^{135} \mathrm{Ha}$ a vagyoni jog védelmi ideje eltelik, úgy bárkinek lehetősége van rá, hogy e személyiségi jegyeket használja, illetve felhasználja. ${ }^{136}$

\section{Az örökösök rendelkezési joga}

A személyiségi jog nemcsak, hogy örökölhetö, hanem át is ruházható, amiből az következik, hogy ez a lehetőség az örökösök számára is nyitva áll, rendelkezési jogukba tartozik e jog átruházása, használatának átengedése. A poszt mortem személyiségi jog vagyoni vonatkozásai az eszmeiektől eltérően nem az elhunyt személy hozzátartozóit, hanem örököseit illetik meg. Azokban a korábban bemutatott esetekben, amikor Marlene Dietrich személyiségi jogainak adott jogvédelmet a bíróság, ez a személy Marlene egyetlen lánya, Maria Riva volt. Esetében a hozzátartozó és az örökös egybeesett. ${ }^{137}$

A poszt mortem személyégi jog vagyoni vonatkozásai nem egy egyszerü vagyoni jogot alkotnak, amely az örökösöket minden korlát nélkül jogosítja, hanem egy behatárolt rendelkezési jogot, ami a személyiségvédelem monizmusából következik. Az ideális érdekek az anyagi érdekekkel elválaszthatatlanul össze vannak kapcsolódva, ami azt eredményezi, hogy nem egy levált vagyoni jog, egy személyiségi eszmei tulajdonjog jön létre. ${ }^{138}$ A BGH már a Marlene Dietrich-döntésben lefektette a vagyoni vonatkozásokhoz kapcsolódó rendelkezési jog mércéjének alapjait. Az örökösöket megillető jogosultságok, azaz a megörökölt vagyoni vonatkozásokkal való

Persönlichkeitsschutz nach dem Tode und Schadensersatz - BGHZ 143, 214 ff. (,,Marlene Dietrich”) und BGH, NJW 2000, 2201 f. (,,Der blaue Engel”). JuS 2002, 13. 18.

${ }^{134}$ GÖTtiNG, 2001. 586. Schricker/Gerstenberg/Götting, UrheberR, 2. Auflage, 1999, § 60/§22 KUG, $\mathrm{Rn} 24$.

135 BGHZ 169, 193 - kinski-klaus.de.

${ }^{136}$ Dazu NJW 2001, 615 - Johann Sebastian Bach.

${ }^{137}$ NJW 2000, 2195 - Marlene Dietrich; NJW 2000, 2201 - Der blaue Engel; OLG München GRURRR 2002, 341 - Nackbilder.

${ }^{138}$ Másként: BEUTHIEN, 2001. 1220 
rendelkezésre nem kerülhet sor az örökhagyó valószínűsíthető akarata ellenére, mert nem egy korlátlan használati jogot örökölnek. E jogosultságok gyakorlásának meg kell felelnie az örökhagyó kifejezett vagy valószínűsíthető érdekeinek. Marlene Dietrich arra vonatkozó akarata és szándéka, hogy a halála után az aktfotóit ne tegyék közé, abból is adódik, hogy élete végén kifejezetten kerülte a nyilvánosságot, ahogy Götting fogalmaz, nagyon 'publicityscheu' (félte a publicitást) volt. ${ }^{139}$

\section{Az átruházás dologi vagy kötelmi hatálya}

Járulékos kérdésként merül még fel az élők közötti rendelkezési jog esetében a vagyoni értékü személyiségi jogi vonatkozás átengedésének kötelmi vagy dologi hatálya. Kötelmi hatály esetén csupán inter partes, a szerződő felek között keletkezik jogviszony, míg dologi vagy kvázi dologi hatályú átruházás esetén a jogszerző abszolút, in rem jogot szerez, amely alapján a jogsértéstől másokat is eltilthat, akár az eredeti jogosultat is, illetve a saját jogon való perlését is lehetővé teszi. Mint látható volt a jogirodalom bemutatása során, a jogirodalom a vagyoni értékminőség elismerésével a dologi hatályú átengedést tartaná logikusnak, ettől a bírói gyakorlat azonban kifejezetten ódzkodott eddig. Ennek leghíresebb példája a NENA-ügy.

A perbeli tényállás szerint az énekesnő Nena egy jogkezelő szervezettel egy ún. „Merchandising-Sponsor-Promotion-szerződést” kötött, amelyben minden kereskedelmileg értékesíthető jogát (így a képmáshoz való jogát is) e szervezetre átruházta. ${ }^{140} \mathrm{~A}$ jogkérdés az volt, hogy a jogkezelő szervezet harmadik személyekkel szemben felléphet-e, ha azok Nena képét gazdaságilag hasznosítják, illetve használják. A BGH abból indult ki, hogy a szerződés értelmezése arra vezet, hogy az ezekre az esetekre egy általános meghatalmazást tartalmaz, amely a perlést a szervezet számára lehetővé teszi. A jogalap nélküli gazdagodás lényege abban állt, hogy a jogsértő a jogkezelő szervezet beleegyezésének ki nem kérésével kísérelte meg a gazdasági hasznosításhoz való hozzájárulás költségeit elkerülni. Arról, hogy a jogkezelő szervezet perlési joga a törvényen alapul, vagy az akaratlagos félképesség (gesetzliche, gewillkürte Prozeßstandschaft) alapján ítélendő meg, a bíróság nem nyilatkozott. A képmáshoz való jog átruházását a BGH nemlegesen válaszolta meg, és kizárólagosan a kereskedelmi hasznosításhoz való hozzájárulásról beszélt. A felperes azon az

\footnotetext{
${ }^{139}$ GöttiNG in: Götting/Schertz/Seitz, Handbuch des Persönlichkeitsrechts, § 10 Rn 15.

${ }^{140}$ BGH 14.10.1986 VI ZR 10/86 „NENA““
} 
állásponton volt, hogy Nena képének kereskedelmi hasznosításához való hozzájárulását 5500 DM díjfizetés ellenében engedte volna át alperesnek, amely összeg a szokásosan követelt licencia díj alsó határát képezi. A BGH a fizetendő díj megállapításánál nem azt vette figyelembe, hogy mekkora összeg fizetésére lenne a jogsértő hajlandó, hanem egyedül azt, hogy Nena képmásának kereskedelmi célú hasznosítása estére kötött megállapodás során mekkora díj fizetésére kerülne sor.

Götting abból indul ki, hogy egy egyszerü, kötelmi hatályú átruházás dogmatikailag jelen esetben kizárt. ${ }^{141} \mathrm{Ez}$ ahhoz vezet, hogy a döntést akként kell értelmezni, hogy Nena a képmáshoz való jogait (kvázi) dologi hatállyal, tehát abszolút hatállyal átruházta. ${ }^{142}$ Ennek okán a képmáshoz való jog szigorú átruházhatatlansága nem tartható álláspont, amely ezen jogosultság vagyoni tartalmára is rámutat.

\section{A szerzői jog analóg alkalmazása}

Az irodalomban a szerzői jog szabályainak analóg alkalmazására azzal az indokolással utalnak, hogy a szerzői jogot „a személyiségi jog további fejlődése szempontjából modellként elö kell venni“ ${ }^{143}$ Götting azon az állásponton van, hogy ,e jog jogosultja számára lényeges jelentőséggel bír az, hogy identitása ki által kerül kereskedelmi hasznositásra, amely miatt az erre vonatkozó használati jog továbbruházását a szerzői jogi szabályozásnak megfelelöen (UrhG 34. § (1) bek. 1. m.) a hozzájárulásától kellene függővé tenni. Etekintetben is kifejeződik a személyiségi jog elidegenithetetlen, átruházhatatlan legszemélyesebb magjának továbbható kapcsolata, amely harmadik személyhez való viszonyában is figyelembe veendö, és amely a szerzői joghoz hasonló módon csökkenti a hasznositási jogosultságok forgalomképességét". ${ }^{144}$

A szerzői jog analóg alkalmazása a személyiségi jog nem minden területén követhető következetesen. A névjoggal összefüggő érdekek a hasonló szabályozási tárgy, illetve az összetéveszthetőség tényállási eleme okán a védjegyjoghoz hasonít inkább. A névjog, a vállalatjelzők (geschäftliche Bezeichnungen), a cégnév és a védjegyjog közös dogmatikai alapokon nyugszanak, amelynek alapja a megjelölési jelleg, a kizárólagosság és ezzel összefüggésben az összetéveszthetőség kizárása. A

\footnotetext{
${ }^{141}$ GÖTTING, 1995. 62.

142 GÖTTING, 1995. 63.

143 GÖTTING, 2001. 856.

${ }^{144}$ GötTING in: Götting/Schertz/Seitz, Handbuch des Persönlichkeitsrechts, § 10 Rn 17.
} 
névjog korábban a megjelölési jogok generálklauzulája volt, sőt a „német megjelölési jogoknak alapnormája”. ${ }^{145}$ A névvel összefüggő vagyoni érdekek, az átruházás, a névjog mint vagyonjog, mint szellemi tulajdon megszűnése inkább azt feltételezi, hogy a névjog - legalábbis mint megjelölés - a vállalatjelzőkhöz hasonló módon kerüljön megítélésre. Így például a domain nevek védjegyjogi védelemben részesülnek a bitorlás ellen, ha azonban ennek tényállás elemei nem valósulnak meg, és így ezen igény nem érvényesíthető, szubszidiáriusan a BGB 12. §-ának feltételei még vizsgálandóak. ${ }^{146} \mathrm{~A}$ domain neveken fennálló jog az általános személyiségi jog vagyoni vonatkozásainak egy megnyilvánulása, amelynek okán ennek megfelelően is részesülnek védelemben. ${ }^{147} \mathrm{~A}$ fogalmi átfedések, illetve az igénykollíziók és halmazatok ${ }^{148}$ a név, védjegy, más kereskedelmi név között arra mutatnak rá, hogy a védjegyjog analóg szabályainak alkalmazása releváns lehet. Így például a név tárgyiasulása tekintetében a védjegyjogi belenyugvás intézménye, illetve a korábbi erősebb jog, valamint a kizáró okok szempontjából a védjegyjogi dogmatika megalapozottabbnak tünik.

A szerzői jog analóg alkalmazása mellett hozható fel érvként, hogy a szerzői jog kifejlett dogmatikával rendelkezik. A szerző személyiségi jogai (Urheberpersönlichkeit) és a szerzői vagyoni jogok meghatátozottak, tartalmuk kiforrott. E jogok tartalmi determináltsága elhatárolásuk egyszerübb. A személyiségi jogok esetén ilyenröl nem beszélhetünk, és erre eddig a BGH sem törekedett. Lényegében a konkrét esettől függ annak meghatározása, hogy egy jog valóban bír-e vagyoni vonatkozással, erre jó példa a Marlene Nacktbilder-eset. A szerzői jog ilyen jellegü, átfogó alkalmazása ugyanis meglátásom szerint előfeltételként támasztaná az egyes részjogosultságok körvonalazását. Nem állítható tehát, hogy a szerzői jog modellként való felhasználása minden tekintetben elönyös, figyelembe kell venni ugyanis az egyes jogok sajátosságait is. Az általános személyiségi jog, így annak vagyoni vonatkozásainak is alanyi jogi jellege képlékeny, nem törvényi jogon alapul, így azt nagymértékben áthatja a bírói jogfejlesztés elve, az analogikus gondolkodás, amely esetén az argumentum a simili elve alapján elismerendő joghoz legközelebb esö, leghasonlóbb jogintézmény szabályait kell alkalmazni a hasonszerüség alapján. Ez a

\footnotetext{
145 Staudinger/HABERMANN (2013) § 12 Rn 4.

146 NJW 2002, 2031 - shell.de.; PETERSEN, JENS: Namensrecht und Domain-Namen. JURA 2007, 175, 177.

${ }^{147}$ BGHZ 169, 193 - kinski-klaus.de.

${ }^{148}$ Ehhez FEZER § 15 MarkenG Rn 29.
} 
német jogban inkább csak egy kényszerútnak tünik, hogy a jogalkalmazás némiképp a jogszerüség talaján maradhasson, ettől függetlenül az átruházhatóság, reklámcélú felhasználás, a védelmi idő és a jogok egymáshoz való viszonya tekintetében példaként szolgálhat a szerzői jog.

\section{Részösszegzés}

A német bírói jog egy örökölhető és átruházható jogot fejlesztett ki a személyiségi jogból, amely a korábbi eszmei érdekekkel továbbra is kapcsolatban áll. E jog elismerésére a bírói jog továbbfejlesztésével, a szintén csak bíróilag elismert általános személyiségi jog keretében került sor. A német jogrendszerben törvényileg elismert és alanyi jogként meghatározott névhez és képmáshoz való személyiségi jogokat ez az analógia nem érintette. Ez azonban szemben áll azon gierkei gondolattal, miszerint,$a$ személyiség általános jogához kell visszanyúlni mindaddig, míg belöle a különös személyiségi jogok ki nem vétetnek”. ${ }^{149}$ A BGH azonban nemcsak ekkor nyúlt az általános személyiségi joghoz, hanem akkor is, amikor az értelmezés a különös személyiségi jogok javára is eldönthető lett volna, illetve akkor is, amikor a vagyoni érték egyértelműen a nevesített személyiségi jogokhoz kapcsolódik. A bíróság tehát nem a néven és képmáson való vagyoni jogként konkretizálta az újonnan elismert jogosultságot, hanem az általános személyiségi jog különös esetének tekintette ezt. Más szavakkal azt is mondhatjuk, hogy a német személyiségvédelemben a lex specialis derogat legi generali szabálya fordítottan érvényesül, tehát lex generali derogat legi speciali érvényesült az általános személyiségi jog javára. A két különös személyiségi jogon fennálló vagyoni értékminőség a jogirodalom és még a joggyakorlat részéről is részletesen kiforrott és meghatározott volt, ami a generálklauzulára támaszkodást ilyen formában nem követelte volna meg. Ennek a különbségtételnek ugyanakkor inkább jogtechnikai jelentősége van, amely e jogok dogmatikai kikristályosodását jobban elősegítette volna.

Kiemelendő továbbá, hogy a német uralkodó álláspont a vagyoni érdeket az általános személyiségi jognak szentel, így az általános személyiségi jognak vannak vagyoni vonatkozásai, illetve ennek mintájára a poszt-mortem személyiségi jognak is

\footnotetext{
${ }^{149}$ GIERKE, 1895. 704-705.
} 
vannak vagyoni vonatkozásai. A német jog nem választja le az eszmei érdekeket védő általános személyiségi jogról a vagyoni vonatkozásokat, $\mathrm{s}$ ezzel továbbra is benne marad abban a csapdában, amit a kodifikáció elmaradása eredményezett. Az eszmei érdekekről való leválasztás, illetve leválasztódás ugyanis hozzájárult volna a jogi dogmatika csiszolódásához. Nem kerül tehát, legalábbis egyértelmü módon, értékelésre ebben a rendszerben az, hogy az általános személyiségi jog mint olyan alapvetően eszmei, erkölcsi érdekeket véd, s csak bizonyos többletelem esetén vagyoni érdekeket is.

A német bírói gyakorlat tehát a személyiségi jog vagyoni értékminőségét az általános személyiségi jogon belül ismerte el. Az általános személyiségi jog ezzel eszmei és vagyoni vonatkozásokkal rendelkezik. Ez a két vonatkozás, érdekkör egymástól elválaszthatatlan, egységes jogot alkot, így az általános személyiségi jogot a monizmus jellemzi. Az általános személyiségi jog vagyoni vonatkozásainak 1999-es elismerésével a joggyakorlatban értékelésre került az, hogy bizonyos személyiségi jogi vonatkozások átruházhatóak és örökölhetőek. Az általános személyiségi jog vagyoni vonatkozásai dologi hatállyal átruházhatóak, ami azt jelenti, hogy az e jogot megszerző személy nem a személyiségi jog jogosultjával szemben bír kötelmi igénnyel, hanem harmadik személyek viszonylatában kizárólagos jogot szerez az átruházott vagyoni vonatkozás felett. Annak megsértése esetén saját jogon érvényesíthet igényt. Az általános személyiségi jog vagyoni vonatkozásai a halál után is védelemben részesülnek, ez a védelem azonban eltér az eszmei érdekek halál utáni védelmétől. Az eltérés abban jelentkezik, hogy a vagyoni vonatkozások a hagyaték részét képezik, azt az örökösök öröklik meg. A vagyoni vonatkozások a jogosult halálától számított 10 éves időtartamon belül biztosítanak rendelkezési jogot az örökösök számára, akik e jogot az örökhagyó kifejezett vagy feltehető érdekeinek figyelembevételével gyakorolhatják. A jogalkalmazás tekintetében a jogirodalom a szabályozás hézagait a szerzői jog alkalmazásával töltené ki.

A magyar jogtól a német személyiségvédelem eltérő alanyi jogi konstrukcióban oltalmazza a személyiségi érdekszférát. A német jog az eszmei érdekek védelmére több alanyi jogot ismer, míg a magyar jog csak egyet. A német jog a különös személyiségi jogok között nevesíti a névhez és képmáshoz való jogokat, amely jogok vagyoni értékminősége a személyiségi jog más vonatkozásaival összevetve a nemzetközi összehasonlításban is kiemelkedő szerepet töltenek be. A német bírói gyakorlat azonban mégsem ezen alanyi jogok vagyoni értékminőségének elismerése 
mellett foglalt állást, hanem az amúgy is vízfej, kétséges legitimációs alapokon nyugvó általános személyiségi jog absztrakt vagyoni értékminősége mellett állt ki. Ezzel e két nevesített jog további cizellálása nem tud megvalósulni, hiszen az ezekhez a javakhoz tartozó jogos érdekeket az általános személyiségi jog ernyőtényállása körében értékeli a joggyakorlat.

A személyiség vagyoni értékminőségének elhelyezése tekintetében tehát a német jog kiindulópontot nyújt ugyan, de eltérő kulturális és jogi környezetben kellett azt a német bíróságoknak elhelyeznie. A magyar jog szempontjából e kérdéskörök ugyan nem jelentenek problémát, hiszen a magyar jog az általános-különös személyiségi jogok közötti ilyen különbségtételt nem ismeri. Más kérdés az, hogy a magyar jogban mint kodifikált jogban hogyan helyezhető el, hogyan változtatható meg az alanyi jogi tényállás úgy, hogy írott jogi szinten alkalmas legyen arra, hogy az egyes, a személyiségi jogot érintő érdekek védelmét kielégítően biztosítsa. Mielőtt e kérdéskörre rátérnénk, célszerü megvizsgálni, hogyan jelent meg a vagyoni értékminőség hazánkban az egyes személyiségi jogokkal összefüggésben. 


\title{
2. § A SZEMÉLYISÉGI JOG MAGYAR FEJLÖDÉSE
}

\author{
Bevezetés
}

Jelen fejezet a személyiségi jog magyarországi kialakulását és elismerését vizsgálja abból a szempontból, hogy a személyiség védelmének kialakulásakor az eszmei érdekek mellett mennyiben jelenik meg a vagyoni érdekkör, felhasználás. A személyiségi jog kodifikációját, a személyiségi jog elismerése szempontjából releváns jogi szempontokat, mint amilyen az Optk., illetve a római jog, bírságos bántalmak rendszere, illetve a magánjogi kodifikáció eredményei más tanulmányomban már vizsgáltam. ${ }^{150}$ Jelen dolgozat kifejezetten a vagyoni érdekkör kimutatására és vizsgálatára koncentrál. Fontos hangsúlyozni ugyanis, hogy a vagyoni érdek megléte a személyiségi jog nem egy új tulajdonsága, hanem annak elismerésével és fejlődésével szervesen összefügg. A német jog ebből a szempontból elsősorban a védjegyjog, illetve a cégnév szabályait vizsgálja. Hazánkban hasonló irányban jelentkezett a személyiségi jog, különösen a névjog oltalma, lényeges eltérést jelent azonban az, hogy polgári törvénykönyv hiányában Németországgal és Ausztriával ellentétben nálunk a névjog nem került oltalmazásra, így az ebből a szempontból jelentkező társadalmi igényt a joggyakorlatnak kellett feloldania, ezért erre nagyobb mértékben koncentrálunk. ${ }^{151}$

A személyiségi jog nem a maga teljességében jelentkezett jogrendszerünkben, hanem - a hézagos törvényi szabályozáson túl elsősorban - először a névjog mint a személyiségi jog egy megnyilvánulása került elismerésre a kártérítéstől függetlenül, önálló jogalapon. Ennek oka elsősorban a többirányú szabályozás: a kereskedelmi törvény cégre vonatkozó szabályai és a bitorlási tényállása volt az, amelyből e jog elsőként kinőhetett, de emellett a védjegyre vonatkozó szabályozásban is a név oltalma volt a hangsúlyos a jogirodalomban; ezt mutatja az is, hogy a századeleji irodalom a névoltalom vonatkozásában rendelkezett ezekről az általános magánjogon belül. A

\footnotetext{
${ }^{150}$ A személyiségi jog magyarországi elismerését egy tanulmányomban részletesebben bemutattam, ennek egyes részeit e fejezet ben is átvettem. SCHULTz MÁRTON: Az általános személyiségi jog vagyoni szankcióktól független elismerése, tekintettel a kir. Kúria névjogi joggyakorlatára. Megjelenés alatt.

${ }^{151}$ A névjog személyi és vagyoni viszonyaival egy tanulmányomban már korábban foglalkoztam, amelyet jelen fejezetbe be is építettem. SCHULtz MÁRTON: Személyi és vagyoni érdekek különválása a névjog elismerésének hajnalán. Megjelenés alatt.
} 
személyiségi jog néven keresztül megvalósult védelme elsősorban tehát a kereskedelemi, vagyoni hasznosítással szembeni védelemben vívta ki magának a jogi elismerést. Csak ezután került oltalmazásra a képmás, a kegyelet és bizonyos tekintetben a becsület is az általános magánjogban a személyiségi jogi generálklauzula alapján.

A dolgozat jelen fejezete elsősorban a kir. Kúria joggyakorlatát vizsgálja, hiszen a magánjogi kodifikáció eredményeképpen 1959-ig nem fogadtak el a bíróságok számára alkalmazható, normatív erővel bíró törvénykönyvet. Ebböl a szempontból a szokásjog kútföjéhez kell fordulnunk, amely esetén a jog megismerési forrása a bírói ítéleteket jelenti. Ebből vonhatóak le következtetések arra vonatkozóan, mennyiben emelte a jogi közmeggyőződés az Mtj. személyiségi jogra vonatkozó szakaszait élő joggá, írott szokásjoggá, és ebben a tekintetben a személyiségi jog felhasználása mennyiben kapcsolódott a kereskedelemhez, az iparhoz, az áruk, szolgáltatások kelendőségének fokozásához. A kir. Kúria gyakorlatán túl megkísérlem szembe állítani a második világháború előtti, kapitalista bírói jogalkalmazást a szocialista tervgazdaság személyiségi jogi joggyakorlatával, hogy az esetlegesen jelen levő vagyoni érdeket és értékminőséget ebből az irányból is alátámasszam.

\section{A személyiségi jog szokásjogi elismerése}

A magánjogi kodifikáció folyamatosan elhúzódott, ${ }^{152}$ majd az ország területvesztése miatt a civiljogászok a korábbi területek magánjogi egységének megtartásában bíztak. Erre az idő múlásával, és az utódállami jogalkotások megélénkülésével azonban egyre kisebb volt az esély. Ebből kifolyólag az általános személyiségi jog törvényi szinten való megjelenésére 1960-ig várni kellett, ekkor lépett hatályba ugyanis az első magánjogi (polgári jogi) kódex. Ugyan az Mtj. javaslat maradt, de azt az akkori jogfelfogásban a bírói gyakorlat mint a jogi közmeggyőződéssel egyezőt tételes joggá emelte. Jóllehet elvétve már voltak olyan ítéletek korábban is, amelyek a tervezetek személyiségvédelmet előirányzó rendelkezéseit az ügy eldöntése során értékelték, 1928 után lett azonban bátrabb a bírói gyakorlat a személyiségi jogi ügyek elbírálása tekintetében. Beck Salamon 1927-ben például még így nyilatkozott egy ítélet

${ }^{152}$ Ehhez VÉKÁs LAJOS: Történeti visszapillantás a magyar magánjog kodifikációjára. Jogtudományi Közlöny 2011. 261. 
megbeszélése során: „Ismételten örömmel szögezzük le azt a szemmellátható jogfejlesztést, hogy a Kuria tudatosan ülteti át a javaslat rendelkezéseit az élö jogba. Javaslatunk különféle szövegei - az elsö Tervezettöl kezdve - teljes határozottsággal a személyiségi jog magánjogi oltalmának megóvása mellett foglaltak állást. Legszivesebben beiktatnók az I. Tervezet vonatkozó indokolásának egész fejezetét, amelyre felhívjuk a figyelmet. A Kuria ezuttal, sajnos, tartotta magát a régi gyakorlathoz, noha az alsófokú biróságok érdemben akadálytalanul belebocsátkoztak az ügy tárgyalásába." ${ }^{153}$ Schuster Rudolf még 1938-ban is hasonlóan nyilatkozik egy ítélet megbeszélése során, jóllehet ekkor a Kúria már több tekintetben megállapítja a személyiségi jog önálló sérelmét: „Az itélet ugyanis sérti, nézetem szerint, a személyiségi jogot. Ezzel a joggal, sajnos, bíróságaink nagyon ritkán foglalkoznak és az erre vonatkozó jogszabályokat gyakran figyelmen kívül hagyják, amint az a jelen esetben is történt." 154

Az akkor hatályos jogrend által elismert jogforrási formában a személyiség általános védelme a tételes jog részét képezte, hiszen a bírói gyakorlat az Mtj.-nek a személyiség védelmére irányuló rendelkezéseit jogszabálynak tekintette. A vizsgálat szempontjából ennek és nem a tervezetek szövegének van jelentősége, a hatályos jogot ugyanis ez alapján lehet meghatározni.

II. A személyiség védelme a jogrendszer meglévő szabályai által

\section{1. Általában}

A személyiségi jog önálló, illetve általános magánjogi védelme előtt is rendelkezett olyan alanyi jogi rendelkezésekkel, amelyek a személyiséget közvetve vagy akár közvetlenül is védték. Ezek közül a jogirodalom a kártérítési jogot, a jegyszegést, a házasság felbontását, illetve egyéb magánjogi szabályokat (pl.: cselédtörvény egyes rendelkezései) emeli ki. A szerzői jogi személyiségi jogi vonatkozásokra már kifejezetten mint a személyiségi jog részére tekintettek. Nem sorolták ide a cég védelmét, illetve a védjegyjogot, amelyet a német jogirodalom már a személyiségre

\footnotetext{
${ }^{153}$ B.S. [Beck Salamon]: A személyiségi jog magánjogi oltalma. Polgári Jog 1927. 238.

${ }^{154}$ SCHUSTER RUDOLF: Bírói gyakorlat a tiltott utánzás és mintaoltalom kérdéseiben tekintettel a Tvt.re. Polgári Jog 1938. 183.
} 
vonatkozó szabályozásnak tekint. Kivételt képez etekintetben Bozóky Alajos, ő azonban nem emiatt, hanem az általa követett személyiségi jogi elmélet miatt a teljes szellemi alkotások jogát személyiségi jognak tekinti. ${ }^{155}$

A magánjogi kodifikáció sikertelenségei ellenére számos szabály volt, amely a személyiséget védte, ilyen íratlan szabály volt a magánjogi vétkes cselekményből származó kártérítés, és az ebből kifejlődő, a személy eszmei érdekeit védő eszmei kártérítés, továbbá a becsületsértés, rágalmazás körében kialakult sajtójogi védelem, ${ }^{156}$ illetve említhetjük még a szerzői jogon belül kialakult személyiségvédelmet.

2. Kártérítés és eszmei kár

Dezső Gyula az általános személyiségi jog első megfogalmazásának a Szegedi Ítélőtábla 1911. G. 156. sz. ítéletét tekinti, amely a személyiséget egy deflorációs perben a női becsület vonatkozásában vizsgálta. ${ }^{157} \mathrm{~A}$ határozat kimondja, hogy a személyiséghez tartozó bármely erkölcsi javunk megsértése az abból eredő kárnak, és pedig pusztán erkölcsi kárnak megtérítésére is kötelez. ${ }^{158}$ A bírósági ítéletek ugyanakkor jogalapnak (alanyi jognak) nem a személyiségi jogot, hanem a jogellenes kártérítés szabályát tekintették. Ez tehát csak a személyiségi jog magánjogi megjelenését, de nem általános alanyi jogi elismerését jelzi.

A személyiségi jogi sérelem magánjogi tilos cselekményként való értelmezése a vagyoni kárról leváló eszmei kártérítéssel vívta ki első, önálló jogkövetkezményét. Ez azonban csak egy jogkövetkezménye volt a személyiségi jognak a sok közül, jóllehet gyakorlati relevanciája ennek volt az egyik legnagyobb. A személyiségi jogok megsértésének magánjogi tiltott cselekményként való értelmezése tehát a személyi eszme létét mutatja, nem pedig annak önálló alanyi jogként való elismerését. A személyi szemlélet tehát ebben a vonatkozásban a jogkövetkezmény tekintetében kerül értékelésre. $^{159}$

\footnotetext{
155 BOZÓKY, 1905. 464.

${ }^{156}$ A sajtójog vonatkozásában 1. GELLÉN KLÁRA: Balás P. Elemér a sajtóhelyreigazítási jog tárgyáról. In: Koltay András (szerk.): Balás P. Elemér emlékkönyv. Wolters Kluwer, Budapest, 2018.; KOLTAY ANDRÁs: Mit üzen Balás P. Elemér a 21. század médiaszabályozásának? In: Koltay András (szerk.): Balás P. Elemér emlékkönyv. Wolters Kluwer, Budapest, 2018.; VALlASEK MAGDOLNA: $A$ sajtószabadság eszméje és jogi fogalma Balás P. Elemér és kortársai sajtójogi írásaiban. In: Koltay András (szerk.): Balás P. Elemér emlékkönyv. Wolters Kluwer, Budapest, 2018.

${ }^{157}$ DEZSÖ GYULA: Az objectiv kártérités tana. Grill, Budapest, 1917. 339.; hasonló állásponton GÖRÖG MÁRTA: A kegyeleti jog és nem vagyoni kártérités. Pólay Elemér Alapítvány, Szeged, 2008. 97.

158 DEZSÖ, 1917. 339.

${ }^{159}$ A nem vagyoni kártérítés korabeli gyakorlatát és fejlődését részletesen feldolgozza GöRÖG MÁRTA:
} 
A jogalkalmazás azonban az eszmei kár megtérítése tekintetében kifejezetten a vagyoni szemlélettől szenvedett, amely ahhoz vezetett, hogy „a bírói gyakorlat a nem vagyoni kárt csak arra az esetre [találta] megítélhetőnek, ha a sérelmet szenvedett erkölcsi érdek vagyoni kár okozására is alkalmas."160

A csábtás intézménye mint olyan kifejezetten jellemző a két világháború közötti korszellemre, a még meglévő feudális csökevények modern. Magánjogi csábítás alatt a kir. Kúria állandó gyakorlata azt érti, midőn a férfi a tapasztalatlan és tisztességes nőt házassági ígérettel, függő, szorult helyzetének vagy a nála elfoglalt bizalmi (hivatali) állásának kihasználásával reábírja arra, hogy vele házasságon kívüli nemi viszonyt kezdjen. ${ }^{161}$ A kár megtérítése szempontjából még jelentősek azok az ügyek, amelyek esetén a jegyesség felbontásra került, és a fél ezzel okozott kárt. Itt tulajdonképpen a házasság mint relatív személyi viszony leendő létrejötte mint függő jogi helyzet megsértése az, amely kárt indukál. ${ }^{162}$

\section{A házasság felbontása}

Az 1894-es Ht. a vétkességi elvre épült. ${ }^{163}$ A vétkesség a házasság felbontására alapot adó jogi tény körében került értékelésre. A házasság felbontására ugyanis csak akkor kerülhetett sor, ha valamely házasfél törvényben tételesen felsorolt vétkes magatartások valamelyikét (Ht. 76-80. §§) elkövette. Almási e bontó okok alapját „családjogi tiltott cselekménynek” ${ }^{164}$ nevezi. A bontó okok közt voltak olyanok, amelyek feltétlen bontó okok, illetve olyanok, amelyek viszonylagos bontó okok. Ez utóbbiak esetén a bíró az eset körülményei alapján mérlegelhette, felbontja-e ítélettel a házasságot. ${ }^{165}$ A bontó okok között voltak kifejezetten olyanok, amelyek büntetőjogi

A nem vagyoni kártérités kiterjesztése az általános személyiségi jog megsértésének eseteire. Acta Universitatis Szegediensis. Acta Juridica et Politica, Tomus LXVI. Fasc. 7. Szeged, 2004.

${ }^{160}$ C. $1435 / 1918$.

161 Többek között: C. 8668/1928; C. 4771/1929; C. 764/1929; C. 1056/1929; C. III. 6755/1929; C. III. 7720/1929; C. III. 8074/1929; C. III. 831/1931; C. III. 3304/1931; C. III. 3884/1931; C. III. 910/1932.

${ }^{162}$ A témát részletesen feldolgozza UnGÁR MARGIT - TÓTH GYÖRGY - HAJNAL HENRIK: Csábítás jegyszegés és jog. Pécsi Egyetemi Könyvtár, Pécs, 1939; Jogesetmegbeszélésre lásd különösen Ifj. SzIGETI LÁSZló: Magánjogi csábitás. Polgári Jog 1926. 289.; Ifj. SziGETi LÁszló: Csábítás. Polgári Jog 1928. 47.

${ }^{163}$ A vétkességi elv csökevényes továbbélésére a névjog tekintetében lásd SCHULTZ MÁRTON: $A$ férj joga felesége nevén. Gondolatok a névhasználati engedély szabályaihoz. Családi Jog 2017. 4. sz. 14.

${ }^{164}$ ALMÁSI ANTAL: Házassági jog. In: Szladits Károly (szerk.): Magyar Magánjog II. Családi Jog. Grill, Budapest, 1940. 141.

165 JANCSÓ GYÖRGY: Házassági jog. In: Fodor Ármin (szerk.): Magyar Magánjog IV. Családjog. Singer 
szempontból is relevánsak lehettek pl. kettős házasság (Ht. 76. §), természet elleni fajtalanság (Ht. 76. §), házastárs élete ellen törés, testi épség, egészséget veszélyeztető szándékos, súlyos bántalmazás (Ht. 78. §). Voltak ellenben olyanok, amelyek kifejezetten a személyiségi szférába tartozó magatartással voltak elkövethetőek, tehát amelyek a házasfelek közötti relatív személyi viszonyhoz kapcsolódó erkölcsi jellegü kötelezettségek megsértéseként voltak értelmezendőek. Balás a becsület jogi védelme körébe beleérti a házassági jog ezirányú tényállásait is, ${ }^{166}$ ide sorolható a férj fenyítési joga, a szóbeli becsületsértés formái, a feleség gondnokság alá helyezésének megkísérlése joggal való visszaéléssel. A fenyítési jog tekintetében a Kúria kiemelte, hogy „a férjnek a feleség testi fenyítéshez való jogát egyetlen társadalmi osztály felfogása sem ismeri el, még kevésbé egyeztethetö össze a házasság erkölcsi tartalma által megkövetelt kölcsönös tisztelettel és megbecsüléssel."167

Különös, a házasság felbontásával és a levéltitokkal összefüggő jogesetet tartalmaz a Jogi Hírlap Döntvénytára a személyiségi jogi résznél elhelyezve. „A nőnek személyi önállóságából folyó az a joga, hogy naplót vezessen, a házasság megkötésével nem szenved csorbulást, s a napló tartalma és az abban foglalt gondolatok a házasság alatt is a nö kizárólagos tulajdona marad, afelett tehát írójának felhatalmazása nélkül a férj sem rendelkezhetik és önhatalmúlag nem helyezheti magát annak birtokába. A nönek ez a joga csak annyiban van korlátozva, amennyiben azt a házassági jogok és kötelességek, a házastársak társadalmi, vagy más lényeges viszonyai megkövetelik. A férj tehát a család anyagi és erkölcsi javainak védelmére vonatkozó hivatásán alapuló családföi minöségénél fogva, a körülmények által indokolt esetekben eltilthatja ugyan nejét a napló vezetésétöl, söt a házastársak közötti benső viszony megzavarására vezetett súlyos gyanuokok birtokában, a saját és felügyelete alá tartozó család fontos érdekeinek védelmében a naplót birtokába ejtheti és tartalmát megismerni is jogosult ugyan, jogcím nélkül azonban a nönek közlésre nem szánt, kizárólag a maga részére megtartani kívánt és e célból lezárva tartott naplóban kifejezett gondolatait, érzelmeit és érzéseit a férj nincs jogositva ellenörizni."168

és Wolfner, Budapest, 1899. 141.

166 BaLÁs P. ElEMÉR: Személyiségi jog. In: Szladits Károly (szerk.): Magyar Magánjog I., Grill, Budapest, 1941. 637.

${ }^{167}$ Kúria 1940. június 6. K. P. III. 1068/1940.

${ }^{168}$ BODA GYULA: A jogi hírlap döntvénytára. A Jogi Hírlap Kiadása, Budapest, 1930. 48-49. 


\section{Szerzői jog}

A szerzői jog kezdetben kifejezetten vagyoni jog volt, személyiségi jogokat sem az 1884-es, sem az 1921-es Szjt. nem tartalmazott, így ebben a joggyakorlat kezdte el kimunkálni az erre vonatkozó szabályrendszert. A szerző személyiségi jogai a vagyoni jogokkal szemben álltak, amelyekkel szemben ez előbbiek sem átruházhatóak, sem örökölhetőek nem voltak. A személyiségi jogok létének elvi alapja az volt, hogy amennyiben a szerzői mü átruházásra kerül, és arról a szerző jogszerüen a későbbiekben nem rendelkezhet, úgy azon oknál fogva, hogy az ő alkotótevékenysége eredményeként létrejött alkotással való kapcsolata biztosításra kerüljön, megilletik bizonyos jogok. E személyiségi jogok a szerző ötletét, alkotótevékenységét, gondolatainak megtestesülését védik, többek között azzal, hogy biztosítják a mü integritását, egységét, illetve azt, hogy a közönség a művet a szerzőtől származtassa (névfeltüntetés joga).

Annak ellenére, hogy a személyiségi jogokat nem tartalmazták a törvények, már az 1884-es Szjt. hatálya alatt elismerte a Kúria a szerző személyiségi jogait, a konkrét ügyben a mű integritásához való jogot. A festőmüvésznek mint szerzőnek a személyiségi jogát sérti a Kúria szerint az, ha műalkotását annak tulajdonosa a művész beleegyezése nélkül átfesti és nyilvános helyiségben kifüggesztve tartja. ${ }^{169}$ Ezt a szabályt a Kúria is kimondta. „A Szjt.-nek a szerzői jog átruházásáról és átszállásáról rendelkezö 3. §-át helyesen akként kell értelmezni, hogy a szerzői jog átruházása esetén is a szerzőnél maradnak meg továbbra is mindenkor az ö személyiségéhez tartozó jogok, nevezetesen az a jog, amelynél fogva annak elismerését és feltüntetését követelheti, hogy ö a mü szerzője, - és az a jog, melynél fogva a münek reá sérelmes megváltoztatása ellen tiltakozhatik; s e jogok a szerzö halálával is fenmaradnak arra az időre, amelyre a halála után a mü még védelem alatt áll." ${ }^{170}$ A szerző személyiségi jogának léte, illetve a művön fennálló tulajdonjog és a szerző személyiségi joga között fennálló konkurencia már az 1884-es törvény hatálya alatt foglalkoztatta a jogirodalmat. ${ }^{171} \mathrm{~A}$ vizsgálat szempontjából csak azok az esetek lesznek relevánsak, amelyek a személyiségi jog szubszidiárius, mögöttes védelmét támogatják, jóllehet a személyi szemlélet az alkotószemélyiség elismerésében is tetten érhető.

\footnotetext{
${ }^{169}$ C. $3880 / 1915$.

${ }^{170}$ K. P. I. 348/1932.

${ }^{171}$ HoKKES ZOLTÁN: A festő müvészi személyiségének oltalma. Jogtudományi Közlöny 1916. 334-335.
} 


\section{Sajtójog}

„A hazai joggyakorlat ugyan már az 1914:XIV. t.-cikk életbelépte elött is bizonyos esetben megállapitotta az immateriális károkért való felelösséget, a sajtó közlemények által okozott nem vagyonjogi károkért megfelelö pénzbeli elégtétel iránti követelést azonban csak az 1914:XIV. t.-cikk 39. §-a állapítván meg, tekintettel ennek a törvénynek a 62. § második bekezdésében foglalt rendelkezésére, amely szerint a törvénynek a vagyonjogi felelösségre vonatkozó idézett szabálya az annak életbelépte elött elkövetett cselekményekre nem alkalmazható."172 Annak ellenére, hogy 1911-től kezdődően a bírói gyakorlat ilyen esetekben már megítélte a nem vagyoni kár megfizetését. ${ }^{173}$

Az 1914-es sajtótörvény ${ }^{174}$ külön rendelkezett a rágalmazásról és a becsületsértésről, azzal, hogy ezek megvalósítása magánjogi jogkövetkezményeket is kivált, így különösen a kár megtérítését. A Kúria 1914-es elvi jelentőségü határozatában kifejtette, hogy bírói gyakorlaton alapuló jogszabály az, hogy a testi sérülést szenvedő fél erkölcsi kára megtérítéséül vagyoni elégtételt követelhet, amennyiben ez az eset körülményei szerint méltányosnak mutatkozik. A polgári jogi felelősség érvényesítése független a büntetőjogi felelősségre vonástól, az önállóan is érvényesíthető, ${ }^{175}$ mégpedig mind a vagyoni, mind az eszmei kár (elégtétel) tekintetében. ${ }^{176} \mathrm{Ez}$ akkor is alkalmazandó, ha a becsületsértés, illetve rágalmazás nem a sajtó útján kerül elkövetésre, ${ }^{177}$ ekkor azonban a becsület védelméről szóló törvény rendelkezéseit kell alkalmazni. ${ }^{178}$ Ilyen lehet az, ha egy földbizottsági tagot azon váddal illetnek, hogy Szerbiával érintkezésben volt és hazaáruló, mert a népet a magyarság ellen bujtogatta. ${ }^{179} \mathrm{~A}$ vagyoni és a személyi érdek elválása a becsület sérelménél, a hitelrontásnál is felmerült. A Nagyváradi Tábla vagyoni kárnak tekintette azt, hogy a perbeli cikk által a jogosult hírnevét oly módon tették tönkre,

\footnotetext{
172 C. $4811 / 1914$.

173 DEZSÖ, 1917. 343.

174 1914. évi XIV. tc. (rövidítve: St.).

175 St. 39. §; K. I. 1983/1937.; K. IV. 1802/1931. A kérdést részletesen feldolgozza WELTNER ANDOR: Érvényesithetö-e a sajtótörvény alapján a kártéritési igény polgári úton, megelözö bünvádi eljárás nélkül? Polgári Jog 1935. 246.

${ }^{176}$ C. P. 977/1914.; A pénzbeli elégtétel megítélésének szempontjai tekintetében K. IV. 2376/1930.

177 St. 28. §; K. IV. 8069/1927.

178 1914. évi XLI. tc. (rövidítve: Bv.); BALÁs, 1941. 636.

${ }^{179}$ K. IV. 8069/1927.
} 
hogy a cikk a hitelképességébe vetett bizalmat megrendítette, a hitelezők őt megrohanták, és a már megrendelt árukat visszatartották. ${ }^{180} \mathrm{Az}$ a tény, hogy az elszenvedett kár pontosan nem határozható meg, a kártérítés akadálya nem lehet. ${ }^{181}$

A jogkövetkezmény tekintetében a kártérítés esetén a jogi tárgy a személyiségnek a becsület irányában való oltalmára vonatkozott. Balás szerint a Bv. 2. §-a a becsület magánjogi oltalmát csaknem teljes egészében lefedte, ugyanakkor a Mtj. 108. §-ának alkalmazását 1928-tól mögöttes jelleggel elismerte, ${ }^{182}$ így a hírnév jogellenes megsértése esetén, annak ellenére, hogy az Mtj. külön nem nevesíti, az általános magánjog alapján is kérhető volt az abbahagyás. ${ }^{183}$ A joggyakorlat nemcsak a személy megbecsülésének eszmei oldalát vonta ide, hanem a gazdasági személyiségnek a védelmét is. A személyiségi jogot sérti a Kúria szerint az olyan hitelrontás (illetve más, a tisztességtelen verseny tilalma alá eső cselekmény), amelyet nem versenytárs követ el, és ezzel kapcsolatban a jogosult vagyoni kára megtérítését is követelheti. ${ }^{184}$

\section{A jogrendszer más szabályai}

Személyi Kálmán, a személyiségi jogok tárgya vonatkozásában hivatkozik a cselédtörvény ${ }^{185}$ egy szakaszára, és árnyalja a személyiségi jogok védelmét korábbi törvényeinkben. A cselédtörvény akként rendelkezik, hogy a cseléd saját személye felett szabadon kell, hogy rendelkezhessen. ${ }^{186}$ Személyi szerint a törvény e rendelkezése mutat rá arra, hogy a magyar törvényhozás már a korábbiakban is védte a személyiséget. ${ }^{187}$ Ugyanígy a cselédtörvényt idézi Kolosváry is. ${ }^{188}$ Ő azt a szabályt emeli ki, amikor a gazda vagy a családtagja a cseléddel szemben, annak testi épségét, egészségét veszélyeztető magatartást tanúsít, a cseléd ilyenkor a jogviszonyt egyoldalúlag azonnali hatállyal felbonthatta. ${ }^{189}$

\footnotetext{
${ }^{180}$ Nagyváradi Kir. Törvényszék 1913. évi P. 37.870. sz. döntés.

${ }^{181}$ DEZSÖ, 1917. 342.

182 BALÁs, 1941. 636.

${ }^{183}$ K. P. I. 5152/1939. Grill Dtár XXXIII. 537.

${ }^{184}$ K. P. I. 8640/1930. („Chanel nyolc“). Grill Dtár XXVII. 457.

185 1876. évi XIII. tc.

186 1876. évi XIII. tc. 6 . §.

${ }^{187}$ SZEMÉLYI, 1915. 51.

${ }^{188}$ KOLOSVÁRY BÁLINT: Magánjog. Vezérfonal a magyar magánjogból tartott egyetemi elöadásokhoz. Studium, Budapest, 1944. 72.

189 1876. évi XIII. tc. 52. §
} 
III. A személyiségi jog védelmének alakulása a joggyakorlatban

\section{Címerjog}

A személyiségi jogi védelem körébe vonja a Curia 1902-ben a nemesi címerre való jogot, és ezzel mint legelső személyiségi jegyet ismeri el, amikor kimondja, hogy „a nemesi czímer jogosulatlan használatának kimondása és ennek használatának eltiltása a bíróságok hatáskörébe tartozik." ${ }^{190}$ Raffay ezt kifejezetten az 1900-as Ptk. tervezetének (Máptk.) hatására vezeti vissza annak ellenére, hogy ez a tervezet nem tartalmazott sem kifejezetten ilyen jogot, sem generálklauzulát. Ezt a döntést 4 évvel később a Curia egy másik ítélete meg is erősíti, mikor elvi éllel leszögezi azt, hogy „senki sem köteles türni, hogy czimerét más jogosulatlanul használja. E sérelem ellen magánjogi oltalmul a használattól való eltiltás szolgál." ${ }^{191}$ Ezt a döntést emeli ki a Mtj. indokolása is, amely e címerhez való jogot kifejezetten a régi magyar magánjogból származtatja. ${ }^{192}$ A háború előtti magánjogban az uralkodó álláspont szerint a címer védelme a személyiség védelme körében került oltalmazásra, azon belül pedig a névvel összefüggésben. ${ }^{193}$

\section{A névvédelemről általában}

A név jogi védelme nem az eszmei károk megtérítése által került a jog hatókörébe, mint más személyiségi jogok megsértése estén (pl.: testi sértés, élet elvétele, defloratio, csábítás stb.). A név egyrészről a cégre vonatkozó szabályok, másrészről pedig a feleség névviselése útján került oltalmazásra actio confessoria (megállapítás) és actio negatoria (abbanhagyás) által. Ennek oka elsősorban abban keresendő, hogy a jogában megsértett személy érdeke nem a kár megtérítésére, hanem elsősorban az abbahagyásra és az eltiltásra koncentrálódott, amely okán az igény nem volt a deliktuális felelősség alanyi joga alá szubszumálható. A személyiségi jog statuálása, mint egy a szokásjog alapján a jogban lévő szabály elismerése elsősorban éppen ezért kapcsolható a névjoghoz, illetve a jogrendszerben fellelhetö, a nevet valamilyen

\footnotetext{
${ }^{190}$ C. $1902 / 2516$.

${ }^{191}$ C. $1906 / 3916$.

${ }^{192}$ Indokolás Magyarország Magánjogi Törvénykönyvének Törvényjavaslatához I, 1932.

193 BOZÓKY, 1905. 481.; SZLADITS, 1933. 362.
} 
viszonyrendszerben védő szabályhoz, mert itt jelentkezhetett az a jogalkotói hézag, amely esetén a bíró hiányt érzett, érezhetett. A német jogban a jogfejlesztés ebben a tekintetben nem volt szükséges a BGB 12. §-a miatt.

\section{A feleség neve}

Az 1894. évi XXXI. törvénycikk, a házassági jogról szóló törvény (Ht.) alapján a feleség a férje nevét házasságra utaló toldással viselte, amihez ugyan hozzákapcsolhatta leánykori nevét, de arra joga nem volt, hogy egyedül leánykori nevét használja, a férje neve nélkül. ${ }^{194} \mathrm{~A} \mathrm{Ht}$. az ún. vétkességi elvre épült, amely alapján a házasság felbontására valamely fél vétkes magatartása következtében kerülhetett sor. Ha e fél a feleség volt, nem viselhette tovább férje nevét. Ha nem ő volt a vétkes, akkor sem automatikusan volt jogosult férje nevének viselésére, hanem eziránti akaratát a bíróságon a bontás során ki kellett fejeznie. ${ }^{195}$ A névviselés a házasság felbontása iránti mellékigény volt, és ennek okán a házassági jogviszonnyal együtt szünt meg. Jóllehet az, hogy az elvált, nem vétkes, illetve az özvegy nő férje nevét tovább viselhette, ennek a logikáját megbontja, de ezt Jancsó tkp. a méltányosságra vezeti vissza, mert szerinte ,a névviselés feltétlen tagadása túl szigorú lenne". 196

A jogirodalom egy része a feleség házassági nevének viselését, illetve az attól való eltiltást, annak megszünését a személyiségi joghoz kapcsolta abból az okból, hogy annak legitimációja ebből az irányból is megalapozásra kerüljön. A kir. Curia 1901. 01.09.-i ítéletében akként foglalt állást, hogy „a név viselésére vonatkozó oly vitás kérdés, mely házassági kötelékre van alapítva, ennek megszünte után is mint családi állással kapcsolatos, magánjogi jellegü, a családi név viselhetése felőli vitás kérdések eldöntése tehát, akár a családi név bitorlásának eltiltása, akár az annak viselhetésére vonatkozó jogosultság megállapítása forog szóban, a bíróságok hatásköréhez tartozik“ ${ }^{197}$ A Curia egy másik ügyben kifejezetten kiemelte erre vonatkozólag azt, hogy „a személyállapotra vonatkozó kérdés bírói útra csak annyiban tartozik, amennyiben valamely családi állásból folyó jognak vagy kötelességnek lehet alapja;

\footnotetext{
${ }^{194}$ ReINER JÁnOS: Jogi Dolgozatok. Pfeiffer Ferdinánd, Budapest, 1898. 20.

${ }^{195}$ Ht. 94. §

196 JANCSÓ, 1899. 455. 21. lj.

197 C. 5336/1990.
} 
pusztán máséval hasonló név viseléséhez való jogosultság azonban bírói útra nem tartozik." ${ }^{198}$ A Curia ezt a gyakorlatát meg is erősíti abban az ügyben, amelynek tárgya az Araczki névtől való eltiltás volt. ${ }^{199}$ Ezt a döntést a jogirodalom egy része ${ }^{200}$ a személyiségi jog megnyilvánulásának tekinti. Egy másik álláspont szerint ez a felfogás nem különbözteti meg a név megszerzését, annak alanyi jogi jellegétől, tulajdonképpen a jog védelmétől. ${ }^{201}$ A névjog szabályanyaga alapvetően annak megszerzésre, módosítására és elvesztésére, illetve annak jogi védelmére oszlik ketté. A második álláspont tünik helyesnek, hiszen a Curia kifejezetten kiemeli, hogy a bitorlás esetén kereshetőségi jog nem áll fenn, és a név csak mint a személyállapottal kapcsolatos járulékos kérdés jelenhet meg a törvénykezésben. Így ebben a tekintetben a bíróság a névjog szabályainak csupán az első, a közigazgatási joggal és a családi joggal összefüggő vonatkozásait ismerte el, de nem tekintette olyan alanyi jognak, amelyből követelési jog származna.

A névjog személyiségi jogi jellegét hangsúlyozza ki egy 1924-es kúriai döntés, amely szerint a házasság felbontása során a feleség a férj nevét tovább viselhette, ugyanakkor a házasság felbontása után érdemtelensége esetén a férje nevének viselésétől mégis eltiltható volt. ${ }^{202}$ Az ítélőtábla a keresetet azért utasította el, mert egyrészről nem volt olyan anyagi jogszabály, amely szerint a Ht. 94. §-a alapján a férje nevének viselésére feljogosított nő e jogának gyakorlásától érdemtelenség okán megfosztható lenne; másrészről azért, mert a nő névviselésétől való eltiltásnak akadálya a házasságot felbontó korábbi ítélet (jogereje), amely e jogát statuálja, megállapítja.

A Kúria az indoklásában rámutatott arra, hogy a feleségnek csak az ún. „leánykori”, születési neve az, amely neki mint legszemélyesebb joga jelentkezik, és ő csak ettől nem fosztható meg semmi módon. Illetve érdekes módon a Kúria kivételes esetként említi meg azt, ha a nő nem vétkes a házasság felbontása során, és ezzel e döntésében a feleség vétkességét, érdemtelenségét teszi főszabállyá mint a házasság felbontására vezető okot.

A jogalap tekintetében a Kúriai indoklásból nem a Ht. 94. § e szakaszának kiterjesztő értelmezésére lehet következtetni, hanem egy másik anyagi jogi szabály

\footnotetext{
198 C. $4662 / 1900$.

${ }^{199}$ C. $1140 / 1912$.

${ }^{200}$ MesZléNY, ARTUR: Magánjog I. Személyi és Családi Jog. Grill, Budapest, 1931. 224-261.

${ }^{201}$ SZEMÉLYI, 1915. 138, 175.

202 C. $6417 / 1924$.
} 
létére. Mivel ez a jogszabály az indokolásban nem kerül megjelölésre, ezért ez valószínűleg nem törvényjogon, hanem szokásjogon alapuló szabály. Ez pedig ahogy azt az ítéletet közlő Magánjogi Döntvénytár szerkesztője, Szladits Károly is felismerte, a ptk. tervezetének a személyiségi jogi vonatkozású szakasza, aminek alapján az ítélet mint a „névhez füződő személyiségi jog nagyon érdekes kiterjesztése [jelentkezik]. Az egészen új tétel szerint a nö névviselési jogának ez az elvesztése nem valami specifikus érdemtelenségi következmény, hanem a férj névjogának folyománya." 203 Szladits ennek okán javasolja azt, hogy a személyiségi jog kodifikációja során erre legyenek figyelemmel. ${ }^{204}$

A feleségnek ez a neve ugyan is, amelyröl a bíró a bontó ítéletben is rendelkezik, nemcsak mint magánjog van jelen, hanem a volt feleség ezen a néven a hatóságok előtt is eljárhat, és így ennek nem csak magánjogi, hanem közigazgatási jogi következményei is vannak, szemben a magánjogi névtől való eltiltással. Ezzel a névvel a feleség nem csak a magánosok közötti viszonyaiban szerepel, ezért ez a névviselés nem is tekinthető kizárólag magánjogi jellegünek. Ennél fogva az ítélet teljesen helytelenül tekinti ezt a rendelkezést a személyiségi jogban gyökerezőnek, amely ellen actio negatoriaval fel lehet lépni. Más, teljes egészében magánjogi jellegủ esetet képez az, ha a feleség a házasság felbontásakor érdemtelenség okán férje nevének viselésétől kerül eltiltásra, és ennek ellenére ezt a nevet ő személyes viszonyaiban tovább használja. Itt ugyanis olyan nevet használ, amelyre való jogosultságát bírói ítélet vonta el, és ennél fogva a férj személyiségi jogának a név vonatkozásában való megsértését eredményezi ez.

A Kúria továbbra is fenntartotta a gyakorlatát a férj nevének érdemtelenség okán való eltiltása vonatkozásában, és azt még olyan esetben is megítélte, amikor például a nő már a házasságkötés előtt is prostituáltként (,igazolványos kéjnőként”) dolgozott úgy, hogy erről férje tudott és abba beleegyezett, és ezt a tevékenységét a házasság fennállásakor is folytatta férje neve alatt. A Kúria szerint az ilyen erkölcstelen állapot megszüntetését a neve tisztességének védelmében még az olyan férj, vagy volt férj, is bármikor kérheti, aki az erkölcsi törvény ellen a maga részéről is súlyosan vétett. Közömbös az is, hogy a férj a házasság megszünése óta milyen életmódot folytat. ${ }^{205}$ Érdekesmód a Kúria nem tér ki arra, hogy a férjnek a teljes

\footnotetext{
203 Magánjogi Dtár XIX. 8. o.

${ }^{204}$ U.o.

205 Boda Gyula, Vincenti GuszTÁv: Magánjog: 1933. IX. 1.-1936. IX. 1. Jogi Hírlap kiadása.
} 
beleegyezése a jogsérelmet, és így az érdemtelenségi okot miért nem zárja ki. Hasonló módon érdemtelenség alapja lehet az, ha a feleség a közös házasságból származó gyermekekből az apa iránti tiszteletet és megbecsülést kiölni törekszik. ${ }^{206}$ Érdemtelenségi ok a névviselés szempontjából az is, ha a feleség a házasság felbontása után egy másik férfival közös lakásban él úgy, hogy a külvilág felé férjnek és feleségnek állítják be magukat. ${ }^{207}$ A Kúria a névviselésre való érdemtelenséget még akkor is megállapította, amikor a volt feleség a volt férjét alaptalanul illette a vérfertőzés vádjával. ${ }^{208} \mathrm{Ez}$ azonban igen tág értelmezése annak a Kúria 729. sz. EHában foglalt szabálynak, hogy a névviseléstől való eltiltásra csak a megbotránkoztató erkölcsi élet megátalkodott folytatása szolgálhat alapul. Így a feleség bármely, későbbi magatartása, amely a legkisebb társadalmi rosszallást kiválthatta, ahhoz vezetett, hogy a férje bírói ítélettel házassági nevének viselésétől eltilthatta. Ez a fenti esetekből is láthatóan túl tág, még a korabeli társadalmi viszonyokra tekintettel is. ${ }^{209}$

Abban az esetben, ha a házasság felbontására a feleség vétkes cselekménye adott alapot, úgy a feleséget férje nevének viselésétöl a bontó ítéletben el lehetett tiltani. ${ }^{210}$ Wagner Lilla utal rá, hogy ,igenis megbélyegző a nö számára, ha a házasság felbontásánál ö́t tartották vétkesnek, ha ebböl mindenki tudja rögtön: ez a nö nem viseli a férje nevét, mert vétkes volt, mert ha nem lett volna, viselné már csak azért is, hogy ezt ne gondolják róla." 211 A vétkességnek ilyen, a név szempontjából való további értékelése még a magyar magánjog feudális maradványainak egyike, amely az elkövetett vétkes cselekmény közvetlen szankcionálásán túl a név által más számára is egyértelmüvé teszi a családjogi vétkes cselekmény elkövetését. Ezzel a névnek nem személyiségi jogi, hanem státuszjogi jellege domborodik még ki.

Mint látható, a feleség házassági névviselési szabályai vonatkozásban a joggyakorlat szubszidiárusan, mögöttesen elismerte a névjog mint a személyiség joga egy megnyilvánulásának alanyi jogi jellegét, alkalmazhatóságát. Ebben a vonatkozásban a név pusztán eszmei, a családi jogi relatív személyes viszonyhoz kapcsolódó jogosultságként jelentkezik, amely önmagában nem kerül kapcsolatba (szemben pl. a feleség mint kereskedő cége esetével) vagyoni, kereskedelmi, ipari

Budapest, 1936. 76.

\footnotetext{
${ }^{206}$ K. III. 2680/1940. Jogi Hírlap Dtár. 1941. 34.

${ }^{207}$ K. III. 1938/1940. Jogi Hírlap Dtár. 1940. 630.

${ }^{208}$ K. III. 301/1934. Jogi Hírlap Dtár. 1934. 607.

${ }^{209}$ Wagner LILlA: Az elvált nö nevéröl. Polgári Jog 1926. 232.

${ }^{210}$ Kritikus ezzel kapcsolatban WAGNER, 1926. 233.

${ }^{211}$ WAGNER, 1926. 234.
} 
tevékenységgel, amelynek okán a név a személytől bizonyos fokban el tudna válni. Itt tehát kizárólag mint névviselés jelenik meg a névjog.

4. Szerzői névbitorlás

A szerzői nevet a szerzői jogi törvény rendelkezései részesítették védelemben, azok a szerző személyiségi jogának, az alkotószemélyiségnek a részét képezik. A szerző személyiségi jogát képezi az, hogy a müvén őt mint szerzőt feltüntessék, megilleti őt a névfeltüntetés joga. A szerzői jog ebben a tekintetben a szerző nevének feltüntetésére irányul művén, legyen ez a név az anyakönyvi neve vagy választott, felvett név, álnév. Nem ilyen azonban az, amikor olyan személyt tüntetnek fel szerzőként a müvön, amely annak nem szerzője. ${ }^{212}$ A névbitorlásnak e szerzői müre konkretizált válfaját a bírói gyakorlat 1928-tól kezdődően tekinti a névjog megsértésének:

„,valakinek az a ténye, hogy mást tüntet fel ennek beleegyezése nélkül az ö szerzeményét nem tartalmazó müvön szerzöként, nem esik az Szjt.-ben meghatározott vétség fogalma alá, mert e törvény 23. \$-a értelmében valamely müvön nevének akarata ellenére történt megjelölését csak az panaszolhatja, aki a münek szerzője vagy akinek alkotását a mü tartalmazza; az ellenben, akinek nevét beleegyezése nélkül oly müvön tüntették fel szerzöként, amely nem foglalja magában az ő szerzeményét, csak az általános magánjog alapján személyiségi jogának jogellenes megsértése címén léphet fel kártérítés iránt az ellen, akit nevének feltüntetése tekintetében szándékosság vagy gondatlanság terhel. A követelés ily esetben az abbanhagyásra (a jogellenes névhasználat eltiltására) és erkölcsi kár megtérítésére irányulhat."213

Ebben az esetben a szerzői jogi törvény alanyi joga nem ad védelmet, hanem az általános magánjog (a személyiségi jog) alkalmazható. Ugyanígy az a szerző, aki a saját szerzeményének szerzőjéül más élő vagy elhalt személyt tüntet fel, annak beleegyezése nélkül, sérti az utóbbinak személyiségi jogát, s az ezzel okozott erkölcsi

${ }^{212}$ Boda GyUla - Meszlény ARTUR: Magánjog: 1930. IX. 1.-1933. IX. 1. Jogi Hírlap kiadása, Budapest, 1933. 64.

${ }^{213}$ K.P. I. 5201/1928; ALFÖLDY DEZsö: A magyar szerzöi jog. Különös tekintettel a m. kir. Kúria gyakorlatára. Grill, Budapest, 1936. 38-39. 
kárért pénzbeli elégtétellel tartozik azonfelül, hogy a jogsértő névhasználattól eltiltható. $^{214}$

A szerzői név bitorlásával a kir. Kúria is foglakozott, bár a legtöbb jogeset a szerzőség elismerését, a szerző neve feltüntetésével kapcsolatos visszásságokat vizsgálja, ${ }^{215}$ egy döntésben a Kúriának egy elhalt író nevének (Huszár Imre) ${ }^{216}$ felvett névként történő felhasználása jogszerüségének kérdéséről kellett állást foglalnia, ${ }^{217}$ amely jogot a szerzöi jogi törvény által nyújtott védelem már nem képes lefedni, és így ezzel összefüggésben az általános magánjogi névbitorlás tényállásának alkalmazása merült fel.

A történeti tényállás szerint az alperes színháznál (1. r. alperes) 1927-től kezdődően egy angol színdarabot játszottak, amely színdarab magyar szövegének fordítását a 2. rendủ alperes készítette el. A fordító a fordítás szerzőjeként az 1916-ban meghalt H.I. (Huszár Imre) nevét tüntette fel, aki a felperes szülője volt.

A Kúria az ítélet indokolásában kifejtette, hogy a személyiségi jogot sérti az, ha egy szerző felvett névként (korabeli terminológiával: álnév) olyan szerző nevét használja, aki hasonló téren fejtett ki szerzői tevékenységet, mert ezáltal olyan benyomás keletkezik, hogy az adott mü annak a személynek a szellemi alkotása, akinek a nevét felvett névként használják. A történeti tényállás rámutat arra, hogy nem a névviselési jogában megsértett személy, hanem annak leszármazója érvényesített igényt a jogsértő alperessel szemben, így a bíróságnak e vonatkozásban is vizsgálnia kellett a jogsértést. A Kúria arra jutott, hogy meghalt személy neve sem tüntethető fel szerzői mű szerzőjeként más által, és kiemeli emellett a bíróság azt is, hogy az ezzel ellentétes szokás törvényrontó erővel nem rendelkezhet. ${ }^{218} \mathrm{Az}$ ítélet azonban e konkrétumokon túl sokkal absztraktabban fogalmazta meg a jogalkalmazás során alkalmazandó felsőtételt; eszerint az a szerző, aki a saját szerzeményének szerzőjeként más személyt tüntet fel, ennek beleegyezése nélkül, az a másik fél személyiségi jogát (a névviselés vonatkozásában) sérti.

${ }^{214}$ BODA - VINCENTI, 1936. 76.

215 Így például: szerzői jogbitorlás a név elhagyásával (C. I. 1573/1943.); Szerzői jogbitorlás. Cikkíró nevének önkényes elhagyása (C. I. 1401/1943.); társszerzők személyiségi jogainak védelme (C. I. 1302/1935.)

${ }^{216}$ A döntést feldolgozza még LEGEZA DÉNES: A kiadói szerzödés története. A reformkortól 1952-ig. Pólay Elemér Alapítvány, Szeged, 2018. 123.

${ }^{217}$ K. I. 2193/1934. („Huszár Imre”).

218 „S ha kialakul is olyan szokás, hogy az írók elhalt írók neveit álnévül használják, az ily szokás, amennyiben az a közönség megtévesztésére alkalmas, figyelembe nem vehető.” (K. I. 2193/1934.). 
Összességében ez alapján az mondható el, hogy egy személynek más szerzői mủvén szerzőként való feltüntetése ugyan nem valósítja meg a szerzői jog bitorlását, azonban a személyiségi jogi, általános magánjogi védelem igénybe vehető. A személyiségi jog névjogi vonatkozása a szerzői jog tekintetében nem a szerző személyiségi jogainak kiterjesztő értelmezésével került megoldásra, hanem sokkal inkább az attól való lehatárolással került megkonstruálásra az erre vonatkozó magánjogi jogosítvány.

\section{Cégbitorlás}

A kereskedelemre, annak jog szabályaira vonatkozó tételes szabályokat kódex jelleggel a kereskedelmi törvény ${ }^{219}$ szabályozta, amely az Allgemeines Deutsches Handelsgesetzbuch alapulvételével készült. ${ }^{220}$ A kereskedelmi jog a magánjog egy speciális leágazása, amely az általános magánjogtól eltérő kereskedelmi ügyleteket szabályozza, központi „figurája” a kereskedő (Kaufmann), aki a kereskedelmi jogban a jogok és kötelezettségek mintaalanya. ${ }^{221}$

A törvény szerint kereskedő az, aki saját nevében kereskedelmi ügyletekkel iparszerüleg foglalkozik. ${ }^{222}$ A kereskedő a kereskedelmi jogi jogviszonyokban a cég által jelenik meg. A cég az a név, amely alatt a kereskedő üzletét folytatja, s melyet aláírásul használ ${ }^{223}$ abban az esetben, ha a kereskedők üzletüket egyedül folytatják, úgy cégül saját polgári nevüket (legalább a vezetéknevüket) kötelesek használni. ${ }^{224}$

A cég egyrészről kapcsolódik magához a kereskedőhöz, aki főszabály szerint a polgári nevét köteles cégként bejegyeztetni, másrészt kapcsolódik a kereskedelmi tevékenységhez, a vállalathoz is. Azért, hogy a kereskedő jogai ne szenvedjenek sérelmet, a jog lehetőséget biztosít számára, hogy a céggel rendelkezzen, amely által az a kereskedő hatalmi körébe kerül.

De mikortól illeti meg a kereskedőt ez a védelem? Mondhatjuk, hogy a kereskedelmi cég létrejöttének a pillanatától, hiszen innentől kezdve vesz részt a

\footnotetext{
219 1875. évi XXXVII. törvénycikk, Kt.

${ }^{220}$ FEHÉRVÁRY JENÖ: Magyar kereskedelmi jog rendszere. Grill, Budapest, 1941. 3.

${ }^{221}$ Mintaalany a kereskedő azért, mert a Kt. elsősorban rá szabva határozza meg a kereskedelmi jogból származó jogokat és kötelezettségeket, és ezt a szabályozást terjeszti ki utaló normával a kereskedelmi társaságokra a 4. § (1) bekezdésben.

${ }^{222}$ Kt. 3. $\S$

${ }^{223}$ Kt. 10. $\S$

${ }^{224}$ Kt. 11. § (2) bek.
} 
kereskedelmi forgalomban, innen használhatja cégét aláírásra stb., és ez van összhangban a személyiségi jogok keletkezésével is. A kereskedő akkor válik teljes jogúvá, és csak akkor ömlik rá a Kt. teljes szabályrendszere, ha a cégbejegyzés megtörtént, ${ }^{225}$ jóllehet a Kt. kifejezetten megemlíti, hogy míg a cégbejegyzés meg nem történt, a kereskedő azokban a jogokban, melyeket a jelen törvény a kereskedők részére megállapít, nem részesülhet; ellenben elvállalt kereskedelmi kötelezettségeiért harmadik személyek irányában felelős. ${ }^{226}$ Ebböl pedig az következik, hogy a kereskedő az üzletét a cég alatt akkor folytathatja, ha a cégbejegyzés megtörtént, illetve aláírásul is csak akkor használhatja ezt. ${ }^{227}$ Ezt mondta ki a Curia is: akinek cége bejegyezve nincsen, a Kt. 24. §-a alapján cégbitorlás miatt fel nem léphet. ${ }^{228}$ Fehérváry említi meg, hogy a be nem jegyzett cég egyrészről névoltalomra tarthat igényt, másrészről felléphet a tisztességtelen versenyről szóló törvény szabályai szerint. ${ }^{229}$ Ezeket az intézményeket Fehérváry 1941-ben említi, ${ }^{230}$ s ezek valószínűleg a későbbi jogfejlődés eredményei, mert Nagy Ferencnél 1913-ban ezek még nem jelentkeznek.

Nagy mutat rá, hogy a cégbitorlás ellen kétféle eljárás vehető igénybe; egyrészről a peren kívüli eljárás: a cégbejegyzésre illetékes törvényszék a bitorlót a jogosulatlanul használt cég abbahagyására hívja fel. Ez a szabály a Kt. 21. §-án alapul. Ilyen másrészről a cégbitorlási kereset, amely a Kt. 24. §-ában került szabályozásra. Cégbitorlási keresetet az indíthat, aki valamely cég bitorlása által jogaiban sérelmet szenved, és követelheti azt, hogy a bitorló a használattól eltiltassék. Hasonlóan kétirányú védelem van a német jogban a HGB alapján még most is. ${ }^{231}$

A kereskedő köteles a cég változását, megszünését $\mathrm{s}$ a cégtulajdonos személyében beállott változást bejelenteni. ${ }^{232}$ Nem tekinthető ilyennek az az eset, amikor a kereskedő a nevét megváltoztatja. ${ }^{233}$ Amennyiben az a tag lép ki a kereskedelmi társaságból, akinek a neve a cégben szerepel, úgy a cég további

\footnotetext{
${ }^{225}$ NAGY FERENC: A magyar kereskedelmi jog kézikönyve. Atheneum, Budapest, 1913. 114.

${ }^{226}$ Kt. $16 . \S$

${ }^{227}$ Kt. $10 . \S$

${ }^{228}$ C. $753 / 1878$.

${ }^{229}$ FEHÉRVÁRY, 1941. 40; Kt. 24. §; 1923. évi V. tc. 8. §

${ }^{230}$ FEHÉRVÁRY, 1941. 40.

${ }^{231}$ ENSTHALER, JÜRGEN: Gewerblicher Rechtsschutz und Urheberrecht. Springer, Berlin, 2003. 271.

232 Kt. 19. $\S$

233 FEHÉRVÁRY, 1941. 43.
} 
használatához a kilépő tag beleegyező nyilatkozata szükséges [Kt. 15. § (2) bek.]. ${ }^{234}$ Ezek által tehát a cégvalódiság elve valamiként eltorzul.

Nem vonatkozik ez a szabály arra a nőre sem, aki házasságkötése előtt kezdte meg egy cég használatát leánykori nevén, ezt a házasság után is folytathatja ezen a néven. ${ }^{235}$ A férjezett nő cégül a férje vezetéknevét csak akkor használhatja, ha ahhoz olyan toldatot csatol (pl.: keresztnevét), ami által a cég a saját férje nevétől is megkülönböztethető. ${ }^{236}$ Míg egy nő a házasságkötés után is jogosult a leánykori nevén bejegyzett céget ezen a néven tovább folytatni, addig vitás, hogy a házasságkötés után jogosult-e ilyen céget bejegyeztetni. ${ }^{237}$ Míg a C. 266/1904. sz. ítélet szerint az egyéni cég szövegéből a nemnek nem kell kitünnie, addig a Budapesti Tábla 2780/1904 és 2995/1904 sz. döntései értelmében egy házas nő vonatkozásában annak a körülménynek, hogy a cég tulajdonosa nő, egyértelmüen kifejezésre kell jutnia.

Az a személy tehát, aki valamely cég bitorlása által jogaiban sérelmet szenved, követelheti, hogy a bitorló a cég további használatától a Kt. 21. §-ban érintett pénzbirság mellett eltiltassék, és kártérítésben marasztaltassék. ${ }^{238}$ Személyi kiemeli, hogy a cég és a név ugyanazt a célt szolgálja: a személyiség megjelölését, egyediesítését. $^{239}$

Fehérváry megkülönbözteti a cégbitorlást és a jogosulatlan céghasználatot. Nála a cégbitorlás szük értelmű, és csak az olyan céghasználatot jelenti, amely másnak a cégjogát sérti, míg a jogosulatlan céghasználat alatt minden olyan céghasználatot ért, amely a törvény rendelkezéseibe ütközik, akár sérti más alanyi jogát, akár nem. ${ }^{240}$

A Kúria régebbi gyakorlatában a be nem jegyzett cég nem léphetett fel cégbitorlás miatt ${ }^{241}$ Erre azért nem volt lehetőség, mert a Kúria a Kt. 24. §-ában foglalt cégbitorlást úgy értelmezte, hogy az akkor alkalmazható, ha bejegyzett cég tulajdonosának a joga sérül. ${ }^{242}$ Személyi mutat rá arra, hogy a Kúria a gyakorlatán változtatott, és a cégbitorlást olyan elkövetési módnak tekinti, „amely sérelmes lehet valakire akkor is, ha nem bejegyzett céget használ, vagy ha egyáltalán nem is céget

\footnotetext{
${ }^{234}$ Kt. 15. § (2) bek.

${ }^{235}$ FEHÉRVÁRY, 1941. 41.

${ }^{236}$ Kúria 316. EH, C. 676/1908.

${ }^{237}$ FEHÉRVÁRY, 1941. 42.

${ }^{238}$ Kt. 24. § (1) bek.

${ }^{239}$ SZEMÉLYI, 1915. 97.

${ }^{240}$ FEHÉRVÁRY, 1941. 46.

${ }^{241}$ C. $753 / 1878$.

${ }^{242}$ C. $1328 / 1892$.
} 
használ“. ${ }^{243}$ A Curia 1908-ban mondta ki azt, hogy Kt. 24. §-ában szabályozott cégbitorlási keresettel mindenki élhet, aki valamely cég bitorlása által jogaiban sérelmet szenved, legyen akár bejegyzett, akár be nem jegyzett kereskedő, akár nem is kereskedő, és ennél fogva senki sem köteles türni nevének idegen cégben való használatát. ${ }^{244}$ Míg a be nem jegyzett cég esetén a jogvédelem elsősorban a Kt. 24. §ának kiterjesztő értelmezésén nyugszik, addig a névjog ilyen irányú beolvasása a kereskedelmi törvénybe meglátásom szerint analógia, hiszen egy, eredetileg a tényállás alá nem tartozó jogviszonyra terjeszti ki a védelmet. Tulajdonképpen Személyi is ennek tekinti ezt, bár ő úgy fogja fel a Curia gyakorlatát, mint egy új szokásjog kialakulását, ${ }^{245}$ és kijelenti: „ez a védelem [...] kétségtelenül a névre való jognak szól, s voltaképpen névbitorlási keresetet konstruálnak itt <<cégbitorlás〉> címe alatt“. ${ }^{246}$ Nagy Ferenc is hasonló állásponton van. ${ }^{247}$ Fehérváry a jogosulatlan céghasználatot is akként fogja fel, hogy az nemcsak a cégjogot, hanem a névjogot is sértheti. $^{248}$

A jogalkotó a Kereskedelmi Törvénnyel a nevet egy speciális irányban részesítette védelemben, a kereskedő nevének irányából. Ehhez a speciális részvédelemhez, amely a teljes névjogot nem fogta át, biztosított a jog védelmet a cégbitorlási kereset által. Ez a cégbitorlási kereset azon oknál fogva, hogy a céget védte, nem volt sok tekintetben alkalmas arra, hogy a névjogot teljes körüen védje. Kezdetben a Kúria a névvel kapcsolatos, de a cégbitorlási igényre alapított jogvitákat elutasította, majd elismerte ezeket. Ezzel az általános magánjogon (a személyiségi jogon) alapuló névvédelmet a céghez kapcsolódó vonatkozásaiban is elismerte a cébitorlás. Ez azonban nem volt teljes védelem, ugyanakkor rámutatott arra a jogirodalom által is hangoztatott nézetre, hogy a név átfogó, általános védelmére lenne szükség.

A cégbitorlás tág értelmezése, a névjog ilyen irányú elismerése rámutat arra is, hogy a nemvagyoni vonatkozások mellett a nevet a kereskedelmi, vagyoni viszonyok vonatkozásában is védelmezni kell. Ez a védelem nem merülhet ki az egyes, iparjogvédelmi és más szellemi tulajdonhoz kapcsolódó védelmi, bitorlási

243 SZEMÉLYI, 1915.175.

${ }^{244}$ C. $310 / 1908$.

245 SZEMÉLYI, 1915. 175.

${ }^{246}$ U.o.

${ }^{247}$ NAGY, 1913. 137.

248 FEHÉRVÁRY, 1941. 46. 
szabályokban, hanem mögöttesen is érvényesülnie kell. Ennek a védelemnek az alapja a személyiségi jogi névbitorlás elismerése, mégpedig általános elismerése. A név ugyanakkor ezen anyagi javakkal való kapcsolatba jutása esetén is az egyént, a személyt, s így a személyiséget védi a jogellenes magatartásokkal szemben, s így a személyiségi jog mint jogintézmény céljának teljes mértékben eleget tud tenni.

\section{Kereskedelmi név}

Szemben a cégnévvel és a védjeggyel, amelyeket az állam lajstromoz, és a névkizárólagosság követelménye által a megkülönböztető-képességet állami vizsgálat tárgyává teszi, amely által a védelem alapját nyújtó névfunkció is biztosított, a be nem jegyzett kereskedelmi neveken, az üzletjelzőkön fennálló jog használabavétellel keletkezett. A be nem jegyzett kereskedelmi név mindig valamely megjelöléshez kapcsolódik: jelölhet árut, magát az üzletet, az üzlethelyiséget, a vállalatot stb. A Kúria kimondta, hogy az Mtj. névjogi védelme kiterjed a kereskedelmi nevekre (a cégekre) is. $^{249}$

A joggyakorlatból kiemelendő az ún. Ritz-eset, amely esetén a Ritz név, amely családi név jellegét elvesztette, azonban olyan nemzetközi üzletjelzővé vált, amely által annak tulajdonosa felléphet azzal a személlyel szemben, aki a „Ritz” szót a Dunapalota megnevezés mellett üzletének megjelölésére használja, mert a szálloda megjelölése és a vállalat (Ritz Hotel limited) közötti kapcsolt látszatát kelti. ${ }^{250} \mathrm{Az}$ átruházott üzlet korábbi tulajdonosa nemcsak azon cég (Csángó Cipőüzlet) használatához járul hozzá az üzlet átruházásával, amely neki családi neve („Csángó”), hanem az e névelemet tartalmazó védjegy bejegyzése ellen sem tiltakozhat, azon túl, hogy az új tulajdonost az üzleti név használata megilleti. ${ }^{251}$ Érdekesebb ennél az az ügy, amely szerint a fellépő felperes jogelődje, egy herceg, megengedte a hercegi családi nevének a szappangyár ,piperecikkein” reklám gyanánt való feltüntetését. ${ }^{252}$ A perbeli esetben herceg Esterházy Miklós adott engedélyt neve használatára, amelyet a gyár a halála (1920) után tovább használt. A Kúria a névhasználat átengedését az egyén élettartamára szükítette, és sajátos megoldást alkalmazott, ugyanis akként

\footnotetext{
${ }^{249}$ K. 1936. VI. 30. - P. IV. 2146/1936.; Grill Dtár XXX. 685.

${ }^{250}$ K. 1753/1939. („Ritz”). Ritz név bitorlása cégnévben: K. IV. 3967/1937. és K. IV. 3968/1937. sz. döntések.

${ }^{251}$ K. 1758/1938. („Csángó”).

${ }^{252}$ K. 2571/1936. (,herceg E.M.”).
} 
fogalmazott, hogy a családtagok a családi nevet (a perbeli esetben az Esterházy nevet) visszakövetelhetik, ha a gyár nem az átruházó teljes nevét használja. 253

„A név használata az egyén legszemélyesebb joga; arról az egyén szabadon rendelkezhetik és a nevének mint kizárólagos tulajdonának a használatát másnak megengedheti, - azonban csakis a saját nevének a használatát ruházhatja át jogérvényesen és a névhasználat átengedése csak az átengedő egyén életére, illetőleg haláláig szólhat. Minthogy azonban a név családi névből és utónévből áll, ebből folyólag az egyén engedélye csak annyiban érvényes, amennyiben a teljes névnek a használatát engedi át másnak; amennyiben pedig csak a családi nevét engedi át, az csupán olyan értelemben joghatályos, hogy az átruházó egyén teljes nevének a használatba vétele tekinthető átengedettnek.

A felperes jogelődje, herceg A. ugyan a „herceg A .” név használatát engedte meg az alperesnek, de ezzel - a kifejtettek szerint — csak a herceg teljes nevének az átengedése tekinthető jogszerünek, vagyis a „herceg A.” név haszánálatának az átengedése, s az is csak az átengedő hercegnek az élettartamára. Ebből következik, hogy a felperesnek mint a hercegi család tagjának jogában áll tiltakozni az ellen, hogy az alperes a hercegi család családi nevét az áruin használja. Igaz, hogy herceg A. már 1920. május havában meghalt $\mathrm{s}$ az alperes azóta is használja áruin az „A” névmegjelölést. Azonban a névhez való jog sohasem enyészik el, a nevet a család bármely tagja bármikor visszakövetelheti s így mégha az „A” család tagjai és a felperes is tudtak volna az „A” név használatáról, erre irányuló külön akaratkijelentés nélkül a használathoz való hozzájárulásra, avagy arra, hogy felperes a családi névnek az alperes által való használatába örök időkre beleegyezett, okszerű következtetést vonni nem lehet." - mondta ki a Kúria. Ellentétes állásponton van Balás, aki a családtagok visszakövetelési jogát azon az alapon utasítja el, mert ez a névnek mint jogtárgynak dologi jogi alapú szemléletét mutatja. ${ }^{254}$

\section{Képmáshoz való jog}

A képmás kiterjedtebb oltalmának szükségessége a XX. század elején jelentkezett, ehhez az időszakhoz köthető a pillanatfénykép feltalálása, amely a fénykép rögzítésének könnyebb, mindenki által hozzáférhető módját adta meg. Ezzel a korábbi

253 U.o.

${ }^{254}$ BALÁS, 1941. 652. 
megrendelésre készült festmények, szoborképmásokon túl, illetve az emlékezetből való arckép-utánképzés egyszerü és megszokott technikáihoz képest más jellegü fényképrögzítés jogi szabályozást igényelt. Kolosváry Bálint a problémát a következőképpen foglalja össze: „Napjainkban a helyzet az, hogy hirtelen, pillanatnyi gyorsasággal elpattan valahol egy Kodak, - és az érzékeny lemezen ott van, amit a gép lencséje lopva rögzített; ott van valaki, tudta és akarata nélkül, a maga szolgai hüséggel lemásolt valóságában és a negatívról tetszés szerinti számban készithetö levonatok a fényképész zsákmányát képezik.",255

A képmás jogi védelmét kezdetben a szerzői jog oldaláról védte a jogalkotó. ${ }^{256}$ A kir. Kúria még az első szerzői jogi törvény ${ }^{257}$ hatálya idejében több határozatában ${ }^{258}$ kimondta, hogy a törvény 72 . §-ának az a rendelkezése, amely szerint „,a megrendelt fényképészeti arckép utánképzési joga kizárólag a megrendelőt illetik, az egyén személyiségi jogának folyománya, amelynél fogva senki sem tartozik türni, hogy a róla készült fényképet más az ő engedélye nélkül sokszorosítsa s forgalomba helyezze, amiből következik, hogy aki valamely fényképpel a lefényképezett egyén engedélye nélkül, vagy az engedély korlátainak túllépésével rendelkezik, ugyancsak megsérti a 72. §-t. ${ }^{259}$ Lényegében már az 1900-as javaslat is ezen okból irányozza elő a képmás külön tényállásban megfogalmazott védelmét, ${ }^{260}$ a magánjogi kodifikáció azonban elmaradt, így a német megoldáshoz hasonlatosan a magyar jog kezdetben kizárólag a szerzői jog oldaláról, a megrendelő felől közelítve oltalmazta a képmást. Az 1921-es Szjt. ${ }^{261} 64$. §-a értelmében a megrendelt arcképek és szoborképmások tekintetében a (60. §-ban meghatározott) jogok gyakorlásához a megrendelö beleegyezése is szükséges, de a műnek nem üzletszerü célra hü többszörözésére a megrendelő a szerző beleegyezése nélkül is jogosítva van.

\footnotetext{
${ }^{255}$ Kolosváry BÁLint: Az arckép és a jog. Széphalom Könyvtár, Szeged, 1927. 3-4.

256 NÓTÁRI TAMÁS: Megjegyzések a kép védelméhez a magyar szerzői jog történetében. Acta Universitatis Sapientiae, Legal Studies, 6, 2 (2017) 323.; KOKOLY ZsOLT: A képmáshoz való jog Balás P. Elemér és kortársai szemléletében. In: Koltay András (szerk.): Balás P. Elemér emlékkönyv. Wolters Kluwer, Budapest, 2018. 23.

257 1884. évi XVI. tc.

${ }^{258}$ C. $3555 / 1908$. C. P. $2650 / 1909$. C. P. $38 / 1910$.

${ }^{259}$ K. 1930. X. 14. P. I. 3647/1928. („olajügynök”).

260 „A ki jogos érdekében sérelmet szenved az által, hogy más az ő képmásával visszaél, a visszaélés megszüntetését követelheti és kérheti az újabb jogsértéstől való eltiltást." A Magyar Általános Polgári Törvénykönyv tervezete, 1900, 90. §. Indokolás a Magyar Általános Polgári Törvénykönyv tervezetéhez. Első kötet: Bevezetés, Személyjog, Családjog. Budapest, Grill, 1901. 155, 156.

261 1921. évi LIV. törvénycikk.
} 
A magyar viszonylatban a képmásokkal való visszaélés tekintetében Kolosváry a következő, az áruk kelendőségének fokozásával is összefüggő esetet szolgáltatja a szabályozás szükségességének alátámasztására: „egy füszerkereskedőnek új csomagoló papirosra, papirzsákocskákra volt szüksége s hogy azokat minél tetszetősebben állíttassa ki, valamelyik divatos fényképésznél egy costümös felvételt vásárolt, mely a helyi társadalom egyik közismert nőtagjáról készült. A kép ezer és ezer sokszorosításban, a füszerüzletek szokásos jelvényeivel felcicomázva odakerül a csomagoló papirokra. Pakkoltak bele mindenfélét, amit ilyen üzletekben árusítani szoktak és az elhasznált, elrongyolódott és összegyürődött papirok szétszórva, széltől kergetve az ünnepelt szépség arcképének hüséges másával osztották a többi papirhulladékok közös sorsát."262

A törvényi szabályozás, ahogy Kolosváry rámutat, odáig nem terjed ki, hogy azokat az eseteket szabályozza, amikor a megrendelő és az ábrázolt személy nem azonos. ${ }^{263}$ A Kúria az 1921-es Szjt. 64. §-ának megrendelőre vonatkozó szabályait 1928-ban kiterjesztette az ábrázolt személyre, és így annak hozzájárulását is megkövetelte az őt ábrázoló képnek a 60. §-ban meghatározott felhasználási eseteihez. Ezzel lényegében már a királyi Kúria elismerte a licencia analógiát. „A Szjt. 64. §-ának s a 65. § második bekezdésének helyes értelmezése szerint valamely arckép vagy szoborképmás többszörösítéséhez, közzétételéhez, forgalombahelyezéséhez és üzletszerü bemutatásához abban az esetben is, ha a megrendelö nem azonos az ábrázolt személlyel, az ábrázolt személy beleegyezése is szükséges, s hogy az, aki az említett cselekményeket az ábrázolt személy beleegyezése nélkül akár szándékosan, akár gondatlanságból véghez viszi, a 18. § értelmében büntetés alá esik és kártérítéssel tartozik." ${ }^{264}$ A személyiségi jogból eredően Alföldy ezt úgy válaszolja meg, hogy az ilyen fényképek közléséhez az ábrázolt személy hozzájárulása is szükséges. ${ }^{265} \mathrm{~A}$ Kúriának a fenti döntése az első, amely a képmáshoz való jogot elismeri és oltalmazza, nem szól ugyanakkor arról, vajon annak szabályait a szerzői jog alapján kell-e megítélni. Egy másik ügyben ehhez hasonlóan egy közszereplő mint ábrázolt személy beleegyezését vizsgálta a Kúria, amikor a fényképét egy róla szóló cikkben tették közé. 266

\footnotetext{
${ }^{262}$ KOLOSVÁRY, 1927. 4.

${ }^{263}$ KOLOSVÁRY, 1927. 10.

${ }^{264}$ K. P. I. 3647/1928. („olajügynök”).

265 ALFÖLDY, 1936. 155.

266 K. P. I. $3647 / 1928$.
} 
A képmás szerzői jogi törvényben való szabályozása hazánkban is oda vezetett, hogy a Kúria azt kezdetben a szerzői jog bitorlásából kiindulva értelmezte. Az állandó bírói gyakorlat ${ }^{267}$ a Szjt. szabályait akként értelmezte, hogy valamely arckép vagy képmás közzétételéhez az ábrázolt személy beleegyezése is szükséges s az, aki a bárki által készített fényképet az ábrázolt személy beleegyezése nélkül akár szándékosan, akár gondatlanságból közzéteszi, vagy közzététeti, a Szjt. 18. §-a szerint kártérítéssel tartozik. $^{268}$ 1941-ban a Kúria azonban már úgy határoz, hogy valamely személyről készült felvétel hírlapban való olyan közlése, amely valamely termék, szolgáltatás reklámjával hozza összefüggésbe az ábrázolt személy, a személyiségi jogot sérti. ${ }^{269}$

A vagyoni vonatkozások igen könnyen leválaszthatóak voltak a tisztán nem vagyoni viszonyokról. Ennek oka, hogy a szerzői mű esetén irányadó szabályozásból fejlődött ki a képmás védelme, s így ennek szabályait alkalmazták a képmásra is. Az 1921-es Szjt pedig külön rendelkezett az üzletszerü többszörözésről mint a hozzájárulás megadása alóli kivételről. Az üzletszerűség körében értékelt a bírói gyakorlat több körülményt is. Ilyen volt az az eset, amikor fürdőruhában, a főváros föútvonalain hirdetőoszlopon tették közé a felperesekről készült fényképeket. ${ }^{270}$ Ilyen egy bünöző viaszfigurájának plasztikonban való mutogatása belépési díj fizetése ellenében, ${ }^{271}$ ilyen továbbá fényképnek hírlapban napi eseménnyel kapcsolatos közzététele is. ${ }^{272}$

A vagyoni vonatkozások azonban a tényálláson túl a szankció tekintetében is megjelentek, amely a nem vagyoni kár mellett a vagyoni kárigényt is megalapozza. Ezzel került felszínre az, hogy a képmáson való jog az ábrázolt személy vagyoni érdekkörébe tartozó jogosultság. A vagyoni szankciók megítélését könnyítette az, hogy a képmáshoz való jogot a szerzői joghoz hasonlóan kezelte a bírói gyakorlat. Jóllehet a Kúria állandó bírói gyakorlata az ábrázolt személy hozzájárulását személyiségi joga gyakorlása folyományának tekintette, mögöttes szabályanyagként azonban a bitorlás tekintetében a szerző joghoz nyúlt vissza, amely megengedte a kártérítésre kötelezést is.

\footnotetext{
${ }^{267}$ K. 940. EH.

${ }^{268}$ K. P. I. 5820/1939;; Grill Dtár XXXIII. 539. („spiccelés”). K. P. I. 4102/1938. („,meztelenül Dunaparton“). K. P I. 3463/1938. („lemetszett lábak”).

${ }^{269}$ K. P. I. 860/1941. (,ez a biztos tipp”).

${ }^{270}$ K. P. I. 3618/1930. („hirdetőoszlop”)

${ }^{271}$ K. P. I. 623/1939. (,viaszképmás”).

${ }^{272}$ K. P. I. 5332/1932. (,,igazolványkép“).
} 
A vagyoni kár megtérítése körében a Budapesti Kir. Ítélőtábla a fénykép hírlapban való megjelenésével kapcsolatosan a következő megállapításokat tette: „a kir. itélötábla már más hasonló perekből tudja, hogy hasonló egyszerü fényképek leközlésének átengedéséért a hírlapok a fényképészeknek 3-5 pengö körüli összeget szoktak fizetni" ${ }^{273}$ A hirdetőoszlop-ügyben nem értékelte a Kúria azt a körülményt, hogy a jogsértő képek hirdetőoszlopon, reklám céljára kerültek elhelyezésre, és a vagyoni kárigénynek nem adott helyt. ${ }^{274}$

A viaszképmás-ügyben a törvényszék a nem vagyoni kárigényt méltányossági okokra hivatkozva utasította el, tekintve, hogy a jogát érvényesítő felperes büntetőeljárása miatt lett híres, s a napi események egy központi figurája. ${ }^{275} \mathrm{Az}$ ítélőtábla ugyanakkor rámutatott arra, hogy a méltányossági ok értékelése jelen esetben nem lett volna alkalmazható, tekintettel arra, hogy jelen esetre nem az általános magánjog, hanem a szerzői jog szabályai irányadónak a kártérítés tekintetében is. ${ }^{276}$ Egy másik ügyben, amikor a lefényképezett személyek képét hirdetőoszlopokon, reklám céljára többszörözték, s amellyel összefüggésben a Kúria a közlés jogellenességét arra hivatkozva látta megalapozottnak, hogy „az ily személyek maguk vannak hívatva elbírálni azt, hogy a róluk készült felvételeknek ily módon való közzétételét a jóízléssel összeegyeztethetőnek tartják-e."277

A képmáshoz való jog személyiségi jogi jellegét a Kúria az ábrázolt személy halála utáni jogérvényesítés tekintetében is leválasztotta a szerzői jogról, ${ }^{278}$ és az Mtj.-t alkalmazta szokásjogi úton. Ez azt jelenti, hogy az ábrázolt személy hozzátartozói nem a szerzői jogi rendelkezések alapján, hanem az általános magánjog alapján, a kegyeleti jog megsértésére hivatkozva léphettek fel a halál után történt többszörözés, közlés, terjesztés miatt. ${ }^{279}$ Alföldy lényegében a Kúria szerzői jogi névbitorlási ügyében hozott törvényértelmezését terjeszti ki analóg módon a képmásra. ${ }^{280} \mathrm{Ez}$ a védelem ugyanakkor tartalmában csökkent, hiszen a hozzátartozók az elhalt személy jogai érdekében csak annyiban léphetnek fel, amennyiben azt a kegyelet megkívánja.

\footnotetext{
${ }^{273}$ Budapesti Kir. Ítélőtábla 1932. IX. 19. P. XIV. 2755.

${ }^{274}$ K. P. I. 3618/1930. (,hirdetőoszlop“)

${ }^{275}$ Budapesti Kir. Törvényszék 1938. V. 5. - 9. P. 33.875/1938.

${ }^{276}$ Budapesti Kir. Ítélőtábla 1938. XII. 12. P. XIV. 8372.

${ }^{277}$ K. P. I. 3618/1930. (,hirdetőoszlop”)

278 ALFÖLDY, 1936. 156.

${ }^{279}$ K. P. I. 2193/1934. („Huszár Imre”).

${ }^{280}$ ALFÖLDY, 1936. 156.
} 
A svájci doktrína szerint a ZGB 28. cikkének személyiségi jogi generálklauzulája minden személyes viszonyra kiterjedt, s így jóval tágabb kört fogott át, mint a német jogirodalom által kidolgozott általános személyiségi jogi modell. A hazai jogirodalom azonban kezdetben igen óvatosan nyúlt a személyiségi jogokhoz, mert nem volt egyértelmü, hogy a jogi biztosításuk esetén a perek milyen tömegével kellene megbirkózni, másrészről a hazai jogirodalom nagyobb részt a német jogirodalom hatása alatt állt, s annak megoldásait méltatta, illetve vitatta.

A svájci jog e tágan értelmezett személyes viszonyai közé tartozik a vagyoni becsület, vagy más néven a hitel mint személyiségi jog. A svájci doktrína a személyiség tágabb védelmét ebből a szempontból az ún. gazdasági személyiség konstrukciója által védi, ${ }^{281}$ amely elsősorban a gazdasági cselekvési szabadságot védi, azt a jogot, hogy a személy szabadon bocsátkozhat jogügyletekbe. ${ }^{282} \mathrm{~A}$ hitel személyiségi jogi védelmének konstrukciója elsősorban azoknál a jogtudósoknál jelentkezik, akik a személyiség védelmének kialakítása szempontjából a svájci doktrína hatása alatt állnak. ${ }^{283} \mathrm{~A}$ hitel nem más, mint a harmadik személyek azon bizalma, hogy a jogalany vagyona által helyt tud állni tartozásaiért. ${ }^{284}$ Dezső szerint a hitel az egyén gazdasági erejébe vetett bizalom. ${ }^{285}$ A hitel általános magánjogi, azaz személyiségi jogi védelméhez kapcsolható az ún. hitelrontás is. ${ }^{286}$

A hitel, az üzleti tisztesség védelme a személyiségi jogba ott hatolt be elsősorban, ahol a tisztességtelen verseny szabályai valamely oknál fogva nem nyertek alkalmazást. Ennek legjobb példája a Chanel nyolc-ügy.

Az alperesnek „Egy, kettő, három” címü vígjátékában, amely a budapesti Vígszínházban több alkalommal elöadásra került, s a Franklin Társulat kiadásában könyvalakban is megjelent, a következö párbeszéd folyik le:

„Norisson”: (diktálás közben Brasch kisasszony fejéhez hajolt) Milyen parfüm ez, Brasch kisasszony?

\footnotetext{
281 EGGER, 1933. 259.

${ }^{282}$ EGGER, 1933. 230.

${ }^{283}$ MESZLÉNY ARTUR: A svájci polgári törvénykönyvröl. Atheneum, Budapest, 1909. 161.; DEZSÖ, 1917. 315.

${ }^{284}$ MESZLÉNY 1909. 161.

285 DEZSÖ, 1917. 315.

${ }^{286}$ MESZLÉNY, 1931. 250.
} 
„Brasch”: Chanel nyolc.

„Norisson": Vegyen Molyneux huszonkettöt, az tizennyolc százalékkal olcsóbb és harminchét százalékkal jobbszagú.

A felperes „Les parfumes Chanel S. A. ” párizsi cég és a „Les parfums de Molyneux” ugyancsak párizsi cég versenytársak. Az alperes a per során nem is állította, hogy a két illatszerre vonatkozó fenti beállitás - úgy értelmezve azt, hogy a Molyneux cég gyártmánya olcsóbb s mégis jobb minőségü, mint a Chanel cégé - a valóságnak megfelelne. ${ }^{287}$

A kir. Kúria megítélése szerint tehát a kifogásolt szövegrész nem a versenytársi viszony hiányából, hanem azért nem minősül az id. törvénycikkbe ütközőnek, mert a panaszolt párbeszéd, nyilván tréfásjellegü, és nemcsak nem irányult arra, de nem is volt arra alkalmas, hogy a közönségnek a két versenyvállalatról alkotott nézetét komolyan befolyásolja s a Molyneux cég áruinak kelendőségét fokozza, avagy a felperes üzleti hírnevét rontsa. Nem lehet azonban kétséges, hogy a panaszolt szövegrész a felperesnek mint hírnévre féltékeny kereskedőnek (gyárosnak) személyiségi jogát mégis sérti, amikor a felperes gyártmányát egy vígjáték keretében a közönség mulattatására a felperesre bántó tréfa tárgyává teszi. Ennek okán a Kúria az alperest marasztalta.

A hitel személyiségi jogi védelme a nem vagyoni kár konstellációjában is megjelent. A Kúria Meszlény és Dezső álláspontjával azonosan jogi személyek számára is megengedhetőnek tartotta a nem vagyoni kár iránti igényt a hitel megsértése esetén. A Kúria annak a valótlan kijelentésnek a tekintetében, hogy „, a felperes üzlete zsidó üzlet, a felperes zsidóbb a zsidónál”, az erkölcsi sérelemmel arányban álló nem vagyoni kártérítést ítélt meg. ${ }^{288}$

\section{Kegyeleti jog}

A kegyelet magánjogi védelme azt is mondhatjuk, hogy sajátos magyar találmány, ugyanis a svájci jog, amely a személyiségi jog kodifikációjának alapjául szolgált, mind a mai napig nem ismeri el a halál utáni személyiségvédelmet; ${ }^{289}$ a német jog pedig,

\footnotetext{
${ }^{287}$ K. P. I. 8640/1930. („Chanel nyolc“). Grill Dtár XXVII. 457.

${ }^{288}$ Kúria 1938. máj. 3. - P. IV. 1284/1938.; Grill Dtár XXXI. 939.

${ }^{289}$ Egger, 1933. 254. BrÜCKNER, Christian: Das Personenrecht des ZGB. Zweiter Teil. Der Schutz
} 
amelyet a jogirodalom követett, csupán a '70-es években ismerte el azt. ${ }^{290}$ A kegyeleti jog ennél fogva egyrészről valószínüleg a büntetőjogi szabályozásból, másrészről a sírhellyel és temetkezéssel kapcsolatos közigazgatási szabályozásból nőhette ki magát, a miniszteri indokolás erre nézve nem tartalmaz utalást. ${ }^{291}$

A kegyeleti jog védelmét az Mtj. 109. §-a biztosította. A személyiség a halál után annyiban részesült védelemben, amennyiben azt a kegyelet megkívánta. A szerző személyiségi jogai a halála utáni 50 éves védelmi időn belül érvényesíthetők voltak, a Kúria a konkrét ügyben azonban az Mtj. 109. §-át alkalmazva állapította meg a halál utáni védelmi idő hosszát. ${ }^{292}$ A kegyeleti jog érvényesítésére a hozzátartozók voltak jogosultak. Érdekes mód Balás a kegyeletet nem a hozzátartozó jogainak, s így nem az ő joguk sérelmének tekintette, hanem az elhalt személy joga más általi érvényesítésének, hiszen szerinte a halállal a személyiség nem szünik meg. ${ }^{293}$ A kegyeleti jog joggyakorlata alapvetően két nagy területre osztható. Az egyikbe tartoznak a más személyi vonatkozások poszt mortem megsértésének esetkörei, így a képmás halál utáni felhasználása, a névjog megsértése. A másik esetkörbe sorolhatóak a kegyeleti jog sírállítással, a sír feletti rendelkezéssel kapcsolatos jogi problémák. Ekörében tipikus életviszonynak minősül az elhalt közös szülők eltemetésének módja, helye, sírfeliratuk meghatározása, ${ }^{294}$ az elhalt nyugvóhelyének megválasztása. ${ }^{295}$

A Kúria a herceg Esterházy Miklós-ügyben nem a herceg kegyeleti jogának megsértéseként értékelte a cselekményt, az alapján nem is értékelhette volna, hiszen a magatartás nem volt jogsértő, hanem a családtagok névjoga felől. Így, a címerjoghoz hasonlóan egy bármely, azonos nevü személy által visszakövetelhető személyiségi jogtárgyat konstruált. Ezzel már a Kúriánál felmerült a kegyeleti jogot nem sértő, poszt mortem személyiségi jogi jogsértésekkel kapcsolatos értelmezési ellentmondás a bírói gyakorlatban. Az általános jogérzet ugyanis azt súgja, hogy helyesen döntött a Kúria akkor, amikor a gyárat a név további (kizárólagos, bár meghatározott tevékenységi körre vonatkozó) használatától eltiltotta. Talán még meglepőbb, hogy Balás a név

der Persönlichkeit. Basel, 2000. Rn. 261-262. A joggyakorlatból: BGE 104 II 225 E. 5 b S. 234 ff.; 129 I 302 E. 1.2.1 S. $306 \mathrm{f}$.

${ }^{290}$ BGHZ 50, 133 - Mephisto; BVerfGE 30, 173 - Mephisto.

${ }^{291}$ Indokolás Magyarország Magánjogi Törvénykönyvének a m. kir. Igazságügyi Minisztérium által 1928 márc. 1-én az Országgyülés elé terjesztett törvényjavaslatához. M. Kir. Igazságügyi Minisztérium, Budapest, 1929. 53.

${ }^{292}$ K. I. 2193/1934. („Huszár Imre”).

${ }^{293}$ BALÁs, 1941. 632.

${ }^{294}$ K. P. I. 4614/1940. Grill Dtár XXXIV. 420

${ }^{295}$ K. P. I. 2110/1941. Grill Dtár XXXV. 457. 
dologi szemléletű értékelésére hívja fel a figyelmet e döntéssel kapcsolatban. ${ }^{296}$ A személyiségi jog itt azonban még érthetően nem tudta levetkőzni tisztán személyi szemléletét, hiszen a joggyakorlatban is csak az 1928-as Mtj. alkalmazásával kezdte el nem vagyoni pályafutását a magánjogban.

10. A közszereplés és hozzájárulás megítélése

A közszereplés kérdésköre és a személyiségi jog kizáró jellegének erőteljes érvényesülése a rejtvemaradhatás jogával összefüggésben merült fel, amely jog az egyén magánéletét védi, azt a jogát, hogy az egyén magánéletének megnyilvánulásai ne váljanak nyilvánossá, ne legyenek köztudomásúak. ${ }^{297}$ A közéleti szerepléssel összefüggésben a vizsgálat szempontjából annak van jelentősége, hogy a közéleti szereplő személyiségének megnyilvánulásai feletti rendelkezési joga meddig terjed. Az egyik álláspont szerint a közszereplők személyiségvédelme általában alacsonyabb mértékű, Goldberger szerint a közéleti szereplők személyiségi joga közérdekü korlátozás alá esik abból az okból, hogy a társadalom a közélet, a napi politika eseményeiről kellő mértékben tudomást tudjon szerezni. ${ }^{298}$ Ö kivételnek a magánélethez való jogot és a becsületet (,tógája bemocskolását azonban türnie nem kell”) tekinti. ${ }^{299}$ Kolosváry szerint nem tartható az az álláspont, amely szerint a közszereplök (,,akik közszereplésük okán a történelemhez tartoznak, vagy oda fognak tartozni, s hivatásuknál fogva állandóan a nyilvánosság szinpadán mozognak.") $)^{300}$ csökkent védelmet élveznek, mert a közszereplök köre nincsen meghatározva, másrészről számukra is azonos szintủ védelmét kell biztosítani. ${ }^{301}$ Kivételnek tekinti ugyanakkor:

- a tömegfelvételeket,

- a karikatúrát, kivéve ha az nem az élcre, illetve a közélet eseményeire vonatkozik, hanem a személyt becsmérli,

\footnotetext{
296 BALÁS, 1941. 652.

${ }^{297}$ MESZLÉNY ARTUR: A személyiség védelme a polgári törvénykönyv tervezetében. Jogászegyleti értekezések. XXVI kötet. 1901. 217.; GOLDBERGER JÓZSEF: Közszereplés és személyiségi jog. Polgári Jog 1931. 134.; BEREND BÉLA: A nyilvánossághoz való jog. In: Emlékkönyv Meszlény Artur születésének 60. évfordulójára. Politzer Zsigmond, Budapest, 1936. 91.

298 GoldBERGER, 1931. 134.

${ }^{299}$ U.o.

${ }^{300}$ KOLOSVÁRY, 1927. 8.

${ }^{301}$ U.o. 9.
} 
- a bünelkövetőket és büntetőeljárás alatt állókat. ${ }^{302}$

A közéleti szereplők képmásának közzététele tekintetében a Kúria hasonló álláspontot foglalt el már 1928-ban. „Az élet felfogása szerint a közéletben szereplő személyekröl feltehetö, hogy nincs kifogásuk fényképüknek a lapokban való közlése ellen és pedig nemcsak akkor, ha a fényképük közlését kísérö cikk róluk kedvezöen nyilatkozik, hanem akkor sem, ha a vonatkozó cikk közéleti müködésüket tárgyilagos bírálat alá veszi. Kizártnak kell azonban az ábrázolt személy hozzájárulását tekinteni, ha arcképe oly beállítást tartalmazó cikk keretében tétetik közé, amely az ábrázolt személyre nyilván bántó és lekicsinylö", 303

Hozzájárulást követelt meg a Kúria abban az esetben, amikor egy hírhedté vált bűnelkövető viaszképmását plasztikonban közzétették. ${ }^{304}$ A Kúria ezt azzal indokolja meg, hogy az a körülmény, hogy a felperes büncselekménye folytán esetleg hírhedté lett, nem fosztja meg őt a személyiségi jognak mindenkit illető védelmétől abban az esetben, ha a személyiségi jognak korlátozását a közérdek nem követeli, a felperes képmásának üzleti célból csupán a kíváncsiság kielégítésére szolgáló mutogatása azonban a közérdekkel nem igazolható. ${ }^{305}$ Ebben a döntésben már a jogszabály szétterítésének több szintjét különbözteti meg a bíróság, s lényegében alkivételként határozza meg az üzletszerű felhasználást, bár ez az esetkör nem esik az 1921.-es Szjt. 64. § szerinti üzletszerü többszörözés hatálya alá.

Ennél sokkal érdekesebb ugyanakkor a Kálnoki Bedő Sándor országgyülési képviselőről a Pesti Hírlapban egy napi eseménnyel összefüggően igazolványképének közzététele. A Kúria ugyanis az 1921-es Szjt. 64. §-a szerinti üzletszerü többszörözésnek tekintette fényképének a hírlapban egy napi eseménnyel kapcsolatban való közzétételét. A jelen esetben mérlegelte azt, hogy egy igazolványképről volt szó, azon a fénykép szerzőjének neve nem szerepel, az ábrázolt személy „közéleti férfiú”, és ami a legfontosabb „az élet felfogása szerint a hírlap nem kötelezhetö arra, hogy a fénykép szerzőjét felkutassa a közzétételhez való hozzájárulás kieszközlése végett". ${ }^{306}$ Ezen üzletszerüség ellenére a közéleti szereplők arcképének közlését napilapban e személyek hozzájárulása nélkül is megengedhetőnek találta a

\footnotetext{
302 U.o. 9-10.

${ }^{303}$ K. P. I. 3647/1928. („olajügynök”).

${ }^{304}$ K. P. I. 623/1939. (,viaszképmás”).

${ }^{305}$ U.o.

${ }^{306}$ K. 1930. XII. 2. — 9 P. 41.902. (,,igazolványkép“)
} 
Kúria. „Az alperesek felülvizsgálati kérelmükben felhozták, hogy újabban nálunk is mindinkább meghonosodott az a szokás, hogy a lapok különösen a közéletben szerepet játszó egyének arcképeit közzéteszik s hogy e nélkül a közönségnek az újsághoz füzödő igénye ma már ki sem elégithető. Igaz ugyan, hogy újabb időben a napilapok is a közéletben szereplö személyek arcképét közölni szokták a müködésükröl, valamely szereplésükről, avagy ténykedésükről szóló cikk kiséretében; de az élet mai felfogása szerint feltehetö, hogy ily esetben a fénykép közlése ellen az illetö közéleti egyéniségnek nincs kifogása éspedig nemcsak akkor, ha a kísérö cikk róla kedvezöen nyilatkozik, hanem akkor sem, ha a vonatkozó cikk közéleti müködését tárgyilagos bírálat alá veszi." 307

Az a német joggyakorlatban elúőforduló esetkör, amely során közéleti szereplők, híres személyiségek képmását, személyiségi jegyeit használják áruk kelendőségének fokozására, ${ }^{308}$ a magyar bírói gyakorlatban nem ismert. Az azonban egyértelmüen kirajzolódik, hogy a képmáshoz való jogot, a mai magyar joggyakorlathoz és a német joggyakorlathoz hasonlóan vagyoni értékü kizárólagos jognak tekintette a Kúria.

\section{A szocialista polgári jog és vagyoni érték}

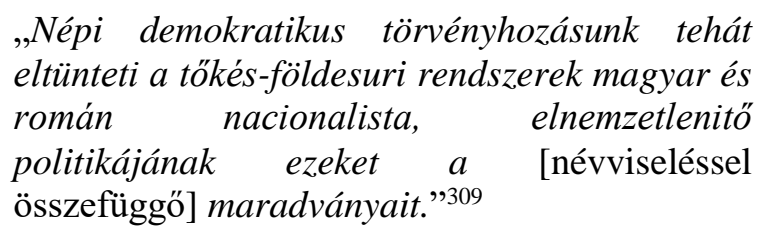

Több szerző azon az állásponton van, hogy a személyiség védelmének kezdete a szocializmus időszakára tehető, ${ }^{310}$ illetve számos bírói ítélet is ebből a tényből indul ki. ${ }^{311}$ Az igazság azonban az, mint láthattuk, hogy a személyiség védelme már korábban igen hathatós módon megvalósult. Felmerült azonban olyan álláspont is a

${ }^{307}$ K. 1930. X. 14. P. I. 3647/1928. (,olajügynök“).

${ }^{308}$ Részben kivétel ez alól a herceg Eszterházy Miklós-ügy (K. 2571/1936.), amelyben ugyanakkor a herceg közismertsége nem játszik szerepet.

${ }^{309}$ FeKeTE GYÖRGY: Polgári Jog (Általános rész, személyek és dologi jogok). Tanügyi sokszorosító, Kolozsvár, 1958. 206.

${ }^{310}$ BARzó TímEA: A személyiségi jogok. In: Bíró György (szerk.): Általános Tanok és Személyek Joga. Novotni, Miskolc, 2014. 235.

311 BH 1994. 21. („Rácz”); Legf. Bír. Pf. IV. 21007/1992. („Láng”). 
kodifikáció során, amely nemcsak a szerzői és újítói jogot hagyta volna ki a törvényből kodifikáltsága okán, hanem a személyiség más irányú védelmét (név, becsület stb.). ${ }^{312}$ Az 1959. évi Ptk. volt az, amely a pozitív jogban először biztosította a jogvédelmet a korábbi bíró döntvényjoggal szemben, ugyanakkor igen óvatos volt, és lényegében a korábbi bírói gyakorlat által kimunkált, legrelevánsabb jogokat vette fel a kódexbe: névjogot, ${ }^{313}$ a képmást, ${ }^{314}$ a hangfelvételt és a levéltitkot. ${ }^{315}$ Ezen túl pedig biztosította a megkülönböztetés tilalmát, a jóhírnév és a becsület védelmét, a magánlakás védelmét a generálklauzula keretein belül. A kódex, az Mtj.-hez hasonlóan, biztosította a személyiség védelmét a kegyeletsértő magatartásokkal szemben is. ${ }^{316}$ Természetszerü volt, hogy a kodifikációnak nekilátó jogtudósok, illetve a tágabb értelemben vett, a jogalkotásnál felszólalt jogászság korábbi tapasztalataiból merített, és így alkotta meg a személyek jogi védelmének szabályait. A korábban bemutatott, kiforrott személyiségi jogok védelmével szemben a Ptk. - egyébként a ZGB-hez hasonlatosan - az általános védelmen túl csak a névjogot kívánta nevesíteni, a szerzői és találmányi jog, illetve a kegyeleti jog mellett. ${ }^{317} \mathrm{Az}$, hogy mennyire nem volt egyértelmü, a személyi (eszmei) javak oltalma mely jogokra terjed ki, mutatja jól, hogy a Közgazdaságtudományi Egyetem javasolta a védjegyjog felvételét a törvény e részébe, a Győri Megyei Bíróság pedig a szellemi alkotások általános felvételét. ${ }^{318} \mathrm{Az}$ ELTE I. és II. számú Polgári Jogi Tanszéke azon az állásponton volt, hogy „a névjog szabályozása a személyjog körébe logikusabban illeszkedik be [...], mint ahogy beilleszkedett a német ptk. megfelelő helyére. [Az általános részbe.] Csakhogy a névjog - amint ezt a svájci ptk. megoldása érzékelteti - szorosan kapcsolódik a többi személyiségi jogokhoz. Névjog van és védelmet érdemel a jogi személyek esetében is és ez amellett szól, hogy a névjogról az ember és a jogi személyek szabályozása után a személyiségi jogokról szóló külön fejezetben rendelkezzék a törvénykönyv".319

\footnotetext{
312 Világhy MiKLós: A kereskedelmi név (cég) problémája. Polgári Jog 1968. 595.

313 1959. évi IV. tv. 82. § (1) bek.

314 1959. évi IV. tv. 83. § (2) bek.

315 1959. évi IV. tv. 83. § (1) bek.

316 1959. évi IV. tv. 86. § (3) bek.

317 [Függelék a személyi jog tematikájához] Az Igazságügyminisztérium iratanyaga az 1959-es Polgári Törvénykönyv elökészitésével és hatályba léptetésével kapcsolatban, I. kötet. Magyar Közlöny Lapés Könyvkiadó Kft., Budapest, 2017. 202.

${ }^{318}$ Az Igazságügyminisztérium iratanyaga az 1959-es Polgári Törvénykönyv elökészitésével és hatályba léptetésével kapcsolatban, I. kötet. Magyar Közlöny Lap- és Könyvkiadó Kft., Budapest, 2017. 218.

319 (Nizsalovszky Endre) Az Igazságügyminisztérium iratanyaga az 1959-es Polgári Törvénykönyv elökészitésével és hatályba léptetésével kapcsolatban, I. kötet. Magyar Közlöny Lap- és Könyvkiadó Kft., Budapest, 2017. 190.
} 
Petrik Ferenc szerint a személyiségi jogoknak azért nem alakult ki terjedelmesebb joggyakorlata, mert (1) a szabályozás túl általános volt, (2) a témának nem volt szocialista irodalma, illetve (3) a társadalom érzéketlen volt a személyiség védelmével szemben. ${ }^{320}$ A Legfelsőbb Bíróság közzétett eseti döntéseit egy táblázatba gyüjtöttem össze azzal a céllal, hogy azok tartalmi, mennyiségi tulajdonságait megvizsgáljam, illetve a személyiségi jegyek vagyoni, reklámcélú, médiajogi és más kereskedelmi vonatkozású jogellenes felhasználásának jelenlétét kimutathassam.

\section{3. sz. táblázat}

A Legfelsőbb Bíróság 1953-1989 között közzétett döntései.

A személyhez füzödö jogokkal kapcsolatos jogviták ${ }^{321}$

\begin{tabular}{|c|c|c|}
\hline ÉVSZÁM & SZEMÉLYISÉGI JOG & DÖNTÉS \\
\hline $1953-1963$ & - & - \\
\hline $1963-1965$ & - & - \\
\hline 1966-1967 & Névviselési jog & BH 1967. 327. feleség névbitorlása \\
\hline $1968-1970$ & - & - \\
\hline $1971-1972$ & - & - \\
\hline $1973-1975$ & jóhírnév & $\begin{array}{l}\text { BH 1973. 60. dolgozóról valótlan adatokat } \\
\text { tartalmazó tájékoztatás }\end{array}$ \\
\hline $1976-1977$ & kegyeleti jog & BH 1976. 311. BH 1976310. \\
\hline \multirow[t]{2}{*}{$1978-1979$} & jóhírnév & $\begin{array}{l}\text { munkával kapcsolatos értékelés mint a jó } \\
\text { hírnév sérelme BH 1979. } 204 . \\
\text { BH 1979. } 411 .\end{array}$ \\
\hline & névviselési jog & $\begin{array}{l}\text { múvészegyüttes névviselése BH } 1979 . \\
411 .\end{array}$ \\
\hline \multirow[t]{6}{*}{$1980-1981$} & jóhírnév & BH 1980.377. („Kányák”). \\
\hline & névviselés & $\begin{array}{l}\text { BH 1980. 467. („,Dankó Pista } \\
\text { Nótaegyüttes”). }\end{array}$ \\
\hline & kegyeleti jog & $\begin{array}{l}\text { BH 1981. 356. („Itt nyugszik F.J. és két } \\
\text { felesége”) }\end{array}$ \\
\hline & $\begin{array}{l}\text { Személyiségi jog } \\
\text { szubszidiaritása }\end{array}$ & BH 1980.332 \\
\hline & általános védelem & BH 1981. 57. \\
\hline & sajtóhelyreigazítás & BH 1981. 402.; BH 1980.83. \\
\hline \multirow[t]{5}{*}{$1982-1985$} & hangfelvétel & BH 1985. 57. \\
\hline & képmás & BH 1985. 17. \\
\hline & kegyeleti jog & BH 1984.352. \\
\hline & általános védelem & BH 1982. 507. \\
\hline & sajtóhelyreigazítás & $\begin{array}{l}\text { BH 1984. 5. BH 1983. 15. ВH 1984. } 5 . \\
\text { BH 1982. 89. BH 1983. 354. BH } 1984 . \\
\text { 353. BH 1983. 114, 152, 276, } 275,151 . \\
\text { BH 1985. 423. BH 1985. 98. BH } 1985 .\end{array}$ \\
\hline
\end{tabular}

${ }^{320}$ PetriK FerenC: A törvényszerkesztő dilemmái 2. Polgári Jog 1978. 150. 156.

${ }^{321}$ A táblázat a $<<$ Polgári Jogi Döntvénytár. Bírósági Határozatok. Közgazdasági és Jogi Könyvkiadó, Budapest. $>>$ köteteiben közzétett döntések felhasználásával készült. Az egyes idősávok az egyes köteteket jelentik. 


\begin{tabular}{|l|l|l|}
\hline & & 183. BH 1985.184. BH 1985. 185. BH \\
& & 1982.236. \\
\hline \multirow{3}{*}{$1986-1989$} & névviselés & BH 1987. 11. („System”). \\
\cline { 2 - 3 } & kegyeleti jog & BH 1986. 183. \\
\cline { 2 - 3 } & sajtóhelyreigazítás & BH 1989. 480. BH 1989. 479. BH \\
& & 1986.142. BH 1988. 98. BH 1988. 97. BH \\
& & 1989.352. BH 1989. 316. BH 1986. 23. \\
& & BH 1986. 22. BH 1986. 272. BH 1988.96. \\
\hline
\end{tabular}

(saját szerkesztés)

A táblázat vizsgálatából több megállapításra is juthatunk. A táblázatot az 1977. évi Ptk. novella hatálybalépése osztja két részre. Az 1959. évi IV. törvény hatálybalépése után viszonylag kevés üggyel találkozhatunk. Ide sorolható egyrészről a feleség névviseléstől való eltiltása, amely a korábbi jog szerint a Ht. 94. §-ából és az ahhoz kapcsolódó joggyakorlatból következett. Más döntések az ún. hamis kádervélemény 322 körében, illetve a sírhellyel való rendelkezés tárgyában születtek. Ezek közül a hamis kádervélemény, azaz a munkavállalóról készült valótlan adatokat tartalmazó tájékoztatás mint személyiségi jogi sérelem az új elem. A névjog, illetve a kegyeleti jog sérelme a háború előtt magánjogban is jelentkezett. Az 1977-es Ptk. novella hatálybalépést követően az ügyszám jelentősen megemelkedett, azonban számottevő változás nem érzékelhetô, új problémák nem merültek fel. A tendencia hasonló az 1928-as Mtj.-hez, amely után pár évvel szintén jelentős módosulás következett be a joggyakorlatban. A személyiségi jog általános védelmével, a szerzői joghoz viszonyított szubszidiaritásával kapcsolatos jogesetek ugyanis jogszabályértelmezéssel és dogmatikai alátámasztással korábban is megindokolhatóak lettek volna. Figyelemre méltó ugyanakkor az 1977-ben bevezetett sajtó-helyreigazítási igények számának megugrása, az államszocializmus enyhülésével való egyenes arányú növekedése. A helyreigazítás 1982 és 1985 közötti feltünően nagy arányának oka a jogszabály értelmezéséhez kapcsolódó pontosító, elvi ítéleteknek köszönhető.

A Legfelsőbb Bíróság személyiségi jogi gyakorlatának eltérő jellege sejlik ki abból, ha az a királyi Kúria joggyakorlatával kerül szembe szembeállításra. Ez rámutathat arra, mennyiben más tárgyköröket védett a két bírói fórum. Az alábbi táblázatban néhány tipikus személyiségi jogi jogsérelmet sorakoztattam fel a teljesség igénye nélkül, a királyi Kúria tekintetében elsősorban a Jogi Hírlap Döntvénytárát ${ }^{323}$ alapul véve:

322 TÖRŐ KÁROLY: Személyiségvédelem a polgári jogban. KJK, Budapest, 1979. 406.

${ }^{323}$ Boda GyUla - MeszlénY ARTUR: A Jogi Hirlap Döntvénytára I-V kötet. A Jogi Hírlap Kiadása, 


\section{4. sz. táblázat}

A Királyi Kúria és a Legfelsőbb Bíróság személyiségi jogi tárgyú döntéseinek összehasonlitása

\begin{tabular}{|c|c|c|c|}
\hline $\begin{array}{l}\text { SZEMÉLYISÉGI } \\
\text { JOG }\end{array}$ & KONKRÉT JOGOSULTSÁG & KIRÁLYI KÚRIA & $\begin{array}{l}\text { LEGFELSÖBB } \\
\text { BÍRÓSÁG }\end{array}$ \\
\hline \multirow[t]{8}{*}{ névjog } & $\begin{array}{l}\text { feleség névviseléstől } \\
\text { eltiltása }\end{array}$ & $\begin{array}{l}\text { K. IV. 5101/1938. } \\
\text { K. III. 5226/1938. } \\
\text { K. P. III. } \\
\text { 5838/1926. }\end{array}$ & BH 1967. 327. \\
\hline & polgári jogi társaság neve & - & BH 1987. 11. \\
\hline & felvett név & - & BH 1980. 467. \\
\hline & név cégnévbe való felvétele & K. P. IV. 27/1938. & - \\
\hline & személynév mint üzletjelző & $\begin{array}{l}\text { K. P. IV. } \\
1753 / 1939 . \\
\text { K. P. IV. } \\
3967 / 1937 \\
\end{array}$ & - \\
\hline & a névhasználat átruházása & $\begin{array}{l}\text { K. P. II. } \\
2571 / 1936 .\end{array}$ & - \\
\hline & $\begin{array}{l}\text { név felhasználása } \\
\text { reklámhoz }\end{array}$ & $\begin{array}{l}\text { K. P. II. } \\
5006 / 1936 .\end{array}$ & - \\
\hline & név elszemélytelenedése & $\begin{array}{l}\text { K. P. IV. } \\
824 / 1941 .\end{array}$ & - \\
\hline \multirow[t]{5}{*}{ képmás } & $\begin{array}{l}\text { hirdetőoszlopon való } \\
\text { közzététel }\end{array}$ & K. P. I. 3618/1930. & - \\
\hline & $\begin{array}{l}\text { személy külső } \\
\text { megjelenésének } \\
\text { utánképzése, ennek } \\
\text { belépődj ellenében történő } \\
\text { mutogatása }\end{array}$ & K. P. I . 623/1939. & - \\
\hline & $\begin{array}{l}\text { lóversenyen készüilt } \\
\text { fénykép reklám célú } \\
\text { felhasználása }\end{array}$ & K. P. I . 860/1941. & - \\
\hline & $\begin{array}{l}\text { sajtóreklám céljára } \\
\text { felhasznált fénykép } \\
\text { engedély nélküli } \\
\text { többszörösítése }\end{array}$ & K. P. I. 1323/1938. & - \\
\hline & sajtóban közlés & K. P I 3463/1938. & - \\
\hline kegyeleti jog & temetés & K. P. I. 4614/1940. & BH 1981. 356. \\
\hline \multirow[t]{2}{*}{ hírnév, hitel } & $\begin{array}{l}\text { áru tréfa tárgyává tétele } \\
\text { vígjátékban }\end{array}$ & K. P. I. 8640/1930. & - \\
\hline & becsület, jó hírnév sérelme & K. IV. 8069/1927. & BH 1979. 411. \\
\hline
\end{tabular}

A táblázatból egyértelműen kitűnik az, hogy az eszmei érdekek oltalmazására szolgáló jogsértések - pl.: a feleség érdemtelenné válik férje nevének viselésére, a kegyeleti jog sérelme - mindkét jogrend alapján védelemben részesült. A kir. Kúria gyakorlatában 
ugyanakkor számos olyan esetkör található, amely a szocializmusban nem jelentkezett. Ezek az esetkörök mindegyike a piacgazdasághoz kapcsolódik, azaz olyan jogi kérdés eldöntésére irányulnak, amelyek a szocialista tervgazdálkodásban objektíve nem tudtak jelentkezni, ilyen a képmás, a név reklám célú felhasználása, a név kereskedelmi felhasználáshoz kapcsolódóan annak cégnévbe vétele, üzletjelzőként való használata, elszemélytelenedése, illetve a hírnévnek, hitelnek megsértése azáltal, hogy valamely kereskedő áruját tréfa tárgyává teszik (a táblázatban szürkével jelzett esetkörök).

A szocialista polgári jog alapvetően az állami tulajdon primátusából kiindulva nem tette lehetővé azt, hogy kereskedők cége és üzleti neve, vállalatjelzője között viták alakuljanak ki, és hogy a magánosok termékeik kelendősége érdekében reklámtevékenységet végezzenek, amely a tőkés magánjog alapján számtalan személyiségi jogi jogsértés alapját képezte, ahogy az a táblázatból is kirajzolódik. Erre mutatnak rá legerőteljesebben a vállalatok államosítása ${ }^{324}$ és az ezzel kapcsolatos, már a rendszerváltozást követően jelentkező névjogi jogviták is. ${ }^{325}$

Ez a megállapítás egy teljesen más oldalról támasztja alá korábbi vizsgálódásainkat, miszerint a személyiségi jogok nem pusztán eszmei, erkölcsi védelmét nyújtják az egyénnek, hanem sokszor kifejezetten materiális előnyt jelentenek számára, amely harmadik személyek jogellenes magatartásával el is vonható. Ebből egyértelműen kirajzolódik az, hogy a kir. Kúria gyakorlatában és az akkori társadalmi életben, korunkhoz hasonlóan, a személyiségi jogok a jogosult vagyoni érdekkörébe tartoztak.

Bár elsősorban a nem vagyoni kártérítés kiiktatásával összefüggésben szokták emlegetni, ugyanakkor a fenti összefüggéseiben még inkább értelmet nyer az a tétel, miszerint „a személyiségi jogok szocialista polgári jogi védelme a kapitalista védelemtől mindenekelött elvi alapjaira nézve különbözik. A szocialista jogrendszer nem tekinti többé árunak az ember legszemélyesebb, nem vagyoni jellegü jogait, hanem azokat mint az ember legföbb értékeit s mint éppen nem vagyoni értékeket részesiti következetes védelemben." 326 A vagyoni viszonyokkal való összefüggés piacgazdasági determináltsága rámutat a személyiségi jogok versenyben betöltött

\footnotetext{
324 1948. évi XXV. tc. az egyes ipari vállalatok állami tulajdonba vételéről.

325 SCHULTZ MÁRTON: A szocializmussal összefüggö névjogi jogsértések és az ipari tulajdon kapcsolata. Gondolat, Budapest, 2019.

${ }^{326}$ VILÁGHY MiKLÓS - EÖRSI GYUlA: Magyar Polgári Jog I. Tankönyvkiadó, Budapest, 1965. 163.; hasonló állásponton a román jog tekintetében Fekete, 1958. 201.
} 
szerepére, és egyben arra, hogy a személyiségi jogok esetén a nem vagyoni jellegből kiindulva a versenyjogi pillanat a legtöbb esetben az, amely a vagyoni értékminőséget ezen eszmei javaknak kölcsönözni tudja.

\section{Részösszegzés}

A személyiségi jog tételes jogi kodifikációja Magyarországon azért maradt el, mert a magánjog egészének sem sikerült írott kódexet alkotni. Németországban ezzel szemben tudatosan lemondtak a személyiségi jog általános kodifikációjáról és BGBbe építéséről.

A személyiség bizonyos megnyilvánulásait már meglévő jogintézmények is védték (házassági jog, kártérítés), más részét a jogalkotó rendelte oltalmazni külön törvényekben (pl.: becsület védelme tekintetében a St. és a Bv.). A vagyoni viszonyok szempontjából legjelentősebb két jogot, a nevet és a képmást, a német megoldástól eltérően nem szabályozta a jogalkotó, s ezzel óriási szabályozási hézagot hagyott a személyiségi jog testén.

A német megoldásban a név és a képmás ún. különös személyiségi jogok, amelyek törvényben rögzítettek, s a Reichsgericht gyakorlata csak e törvényben szabályozott jogokat ismerte el, és a személyiséget csak e vonatkozásaiban óvta. A korabeli német gyakorlat ezzel tökéletlen és elavult volt, a német jogalkotó azonban nem avatkozott be, a BGB-t nem módosította. A magyar joggyakorlat a jogalkotó által hagyott hézagokat feltöltötte, s kb. 1930-ra már általános védelmet biztosított a személyiségi jog megsértésének eseteire, s elsősorban a névjog, a képmás és a kegyeleti jog tekintetében emelte élö joggá az Mtj. 108. és 109. §§-át. A magyar jog ezzel a német jogot megelőzte, s ennek oka valószínüleg abban rejlik, hogy a Kúria sokkal fogékonyabb volt a személyi eszme keresztülvitelére, amely a nem vagyoni kár megtérítése körében kialakult törvényértelmezés tekintetében is tetten érhető. Ha arra a kérdésre keressük a választ, mikortól beszélhetünk a személyiségi jog létezéséről jogforrási szinten, úgy azt kell mondani, 1924 óta. Az elvált nő nevénél tárgyalt $C$. 6417/1924. sz. döntés volt ugyanis az, amely egyértelmüen nem más jogrendszerbeli, hanem szokásjogi szabályra utalt. Ezzel került egyértelmüen elismerésre az abszolút védelmet biztosító személyiségi jog. Ekkorra a jogi közmeggyőződés olyan mértékben igényelte a személyiségi jog elsimerését, hogy annak szokásjogon alapuló egy döntése 
egy döntéssel. Ekkora a jogi közmeggyőződés mellett az általános magánjogi tervezetek is védik a személyiséget, és számos más jogalapon nyugvó korábbi döntés is hivatkozik rá. Nem vesz el az 1924-es határozat érdeméből el az sem, hogy az 1928as javaslat közzétéelét követően a bírói gyakorlat jogszokásként alkalmazza azt.

A név jogi védelmének a kialakításakor a jogalkotó kezdetben egyes speciális jogintézmények vonatkozásában adott kereshetőségi jogot a névjog megsértése esetére. E jogintézmények közül egyesek kifejezetten személyi érdekeket védtek, s a személyi jog területén helyezkedtek el. Ilyen volt a feleség házassági névviselése, amely a családi jogban mint relatív személyjogban került szabályozásra, másrészről ilyen volt a jog a szerzőségre, a szerzői névjog, amely a szerző személyiségi jogába mint speciális személyi szférába tartozó jog volt.

A névjog ettől függetlenül, pusztán megjelölési funkciójánál fogva alkalmas volt arra is, hogy árukat, szolgáltatásokat, illetve kereskedelmi cégeket jelöljön meg. Ezeket az eseteket a jogalkotó külön, speciális védelemben részesítette a kereskedelmi, illetve a védjegytörvényben. Ezen esetkörök sajátosságát az képezi, hogy a név nem pusztán viselőjét jeleníti meg, hanem az előbb említett árukat, szolgáltatásokat, illetve magát a kereskedelmi tevékenységet. E funkciójánál fogva a név használata a személyiségtől különválik. Külön érdekes, hogy a név itt nem a hagyományos vagyoni jogi (kötelmek, dolgok) keretében jelenik meg, hanem elsősorban az iparjogvédelem, illetve tágabb értelemben a szellemi alkotások, szellemi tulajdon oldaláról. A név ezen elválása, a névhasználat ilyen jogi konstrukciója okán nyílik lehetőség a név forgalomban való részvételére, öröklésére, átruházásra, amely által egyértelműen eltávolodik a legszemélyesebb, átruházhatatlan jogosultsági jellegétől. Balás, aki a személyiségi jog kizárólagos eszmei oltalmát képviselte, ezt azzal oldotta meg, hogy szerinte az erre vonatkozó jogi rendelkezéseket kizárólag a kereskedelmi jog, versenyjog alapján lehet értékelni, mert ezekben nem a személyi szemlélet, hanem a dologi dinamika ölt testet. ${ }^{327}$

A névjog elismerésével az egykori királyi Kúria nem csupán egy személyes jogosultságot, hanem egy árnyaltabb, összetettebb jogosultságot ismert el. A névjog egyrészről ugyan a névviseléshez, a személyes jelleghez kapcsolódik, ugyanakkor funkciójánál fogva a megjelölésekkel is kapcsolatba kerül, amelyet a személyes jellege árnyal és korlátoz is. A termékek, áruk, szolgáltatások piacra jutása, kereskedelmi

${ }^{327}$ BALÁs, 1941. 646, 648. 652, 655, 656. 
forgalomban való részvétele, illetve a kelendőség fokozásának egyik eszköze a név, amely önmagában ellentétben áll név az általános jogi megközelítésével. Ezen ellentéttel szemben ugyanakkor már a korabeli jogi dogmatika, illetve a bírói gyakorlat is teret engedett e szellemi tulajdon-szerü hasznosításnak, használatnak, amely a személyiségi jogok vagyoni értéküségének problematikájához, illetve annak megoldásához is segítséget nyújt.

A képmás védelmét a bírói gyakorlat a szerzői jogi szabályozásról leválasztotta, és az ábrázolt személy hozzájárulását az Mtj.-ben szereplő személyiségi jog részének tekintette. A képmás jogosulatlan felhasználása esetén a jogosultat nemcsak eszmei kár, illetve abbahagyás iránti kereset illette meg, hanem az 1921-es Szjt. alapján vagyoni kárának megtérítését is követelhette, amely kifejezetten a vagyoni érdekkör megjelenésének mutatója.

Azt láthatjuk, hogy míg a szocializmusban a védelem kifejezetten a nem vagyoni, eszmei érdekek oltalmazására szükült, addig a királyi Kúria joggyakorlatában a személyiségi jogok esetén (különösen a képmás és a név védelménél) ezen eszmei oltalom csupán egy iránya volt a védelemnek, emellett jelentkezett a gazdasági versennyel, árutermeléssel összefüggően a személyiségi jogok gazdaságban betöltött funkciójának jogellenes bitorlása. Ez nemcsak arra mutat rá, hogy a személyiségi jogok vagyoni értékkel bírnak abban a tekintetben, hogy bizonyos irányú átengedésük vagyoni ellenérték fejében a gyakorlatban szokásos ügyletnek minősül, hanem arra is, hogy ezek a tendenciák Magyarországon a bírói gyakorlatban már a '20-as, '30-as években, a személyiségi jog szokásjogi elismerésével egyidejüleg, párhuzamosan és egyben organikusan fejlődtek. E fejlődési tendenciát törte meg a szocialista jogrend, amely objektíve kizárta e fejlődési irány dogmatikai kikristályosodását. 
B. A VAGYONI ÉRTÉKMINŐSÉG DOGMATIKAI ELŐFELTÉTELEI 


\section{3. § A SZEMÉLYISÉGVÉDELEM JOGALAPJA}

\section{Bevezetés}

Jelen fejezetben a személyiségi jog mint alanyi jog jogalapja kerül megvizsgálásra abból a szempontból, hogy a tárgyi jog mennyiben alkalmas arra jelenlegi állapotában, hogy a személyiségi jogon fennálló vagyoni érdeket is védje. Van olyan álláspont, amely szerint a vagyoni érdekek védelme a magyar jogi dogmatika alapján nem lehetséges. Én azon az állásponton vagyok, hogy a törvényi szabályozás ennek gátat nem szab, nem került ugyanis törvénybe foglalásra sem az, hogy a személyiségi jog legszemélyesebb jellegű jogosultság, sem hogy e jog átruházhatatlan, nem örökölhető, erre csak a dogmatikából következtethetünk. ${ }^{328}$ A dogmatika pedig lehetőséget ad e jog örökölhetőségére, átruházhatóságára, ezt a német jog példáján is látható volt. Pozitív jogi kötöttség ebből a szempontból tulajdonképpen nincs, egyedül az emberi méltóság fogalma lehet az, amely ennek esetleg gátat szab. Ebből kifolyólag a fejezet az emberi méltóság és az általános személyiségi jog magánjogi viszonyrendszerét vizsgálja, ugyanis mind a magánélet alapú, mind a méltóság alapú védelem is küzd a személyiségi jog vagyoni értéküségének elismerésével kapcsolatos dogmatikai defektusoktól, és felszínre hozza a szabályozási alappal kapcsolatos problémákat. ${ }^{329}$

Az emberi méltóság mellett a magánélethez való jog mint személyiségi jog elés lehatárolására is kísérletet teszek, különösen a hatályba lépett magánélet védelméről szóló törvényre tekintettel. A magánélethez való jog vizsgálatára ebben a tekintetben azért van szükség, mert egyfajta generálklauzulaként jelenik meg a generálklauzulában, és egyes személyiségi jegyek megsértésének idevonásával jogalapot képezhet a személyiségi jog vagyoni vonatkozásainak megsértése tekintetében is.

A magánjogi értelemben vett személyiségi jog hagyományos alapja, a kibontakozás tekintetében azt vizsgálom, hogy a jogalkalmazás szempontjából

\footnotetext{
${ }^{328} \mathrm{Pl}$. „Fontos jellemzője a személyhez füződő jogoknak: a jog személyessége. [...] A személyesség egyben azt is jelenti, hogy ezek a jogok a jogosult személyességétől elválaszthatatlanok, más személyre csak meghatározott feltételek mellett szállhatnak át." PETRIK FERENC: A személyiség jogi védelme. A sajtó-helyreigazitás. HVG-ORAC, Budapest, 2001. 28.

${ }^{329}$ Az emberi méltóság és a személyiségi jog kapcsolatával a következő tanulmányomban foglalkoztam: Gondolatok a személyiségi jogok generálklauzulájáról és az emberi méltóságról. Magyar jog 2016. 685. A fejezet egyes részei ebből a tanulmányból származnak.
} 
elsősorban a svájcihoz hasonló egy és oszthatatlan jogként kezeli-e a jogalkalmazás a személyiségi jogot vagy inkább az egyes nevesített személyiségi jogokra mint önálló alanyi jogokra hivatkozik a jogalkalmazás. Ez a kérdés a vagyoni alkotóelemek szempontjából kifejezetten fontos, hiszen ennek mentén határozható meg, hogy elsősorban egy-egy személyiségi jog bír-e vagyoni értékkel vagy a személyiségi jog mint egész.

A személyiségi jog jogalapja körüli kérdések vizsgálata után bemutatom a személyiségi jog megsértése esetén vizsgálandó tényállási elemeket (a személyiségi jog igényvázát). A személyiségi jog vagyoni vonatkozásait, a vagyoni személyiségi jogot, csak úgy határozható meg, és a személyiségvédelem rendszerében elhelyezni, ha kellő rálátással rendelkezünk a személyiségi jog működésére.

\section{Az emberi méltóság}

\section{Az emberi méltóság jelentéstartamai}

Az emberi méltóság fogalmát a magánjogi személyiségvédelemben az 1977-es Ptk. novella vezette be a jóhírnév és a becsület védelmével összefüggésben. Az emberi méltóság e felfogása tekintetében egy nevesített személyiségi jogról beszélhetünk. Az emberi méltóság rendszerváltozás utáni Alkotmányban való szerepeltetésével az általános személyiségi jog egyfajta megfogalmazásaként tekintett az Alkotmánybíróság, amely által a magánjogban ez mint a személyiségi jogok anyajoga került felfogásra. Egy harmadik értelmezését képezi az emberi méltóságnak a megaláztatás tilalmaként, egyfajta emberi minőségként és minimumaként való értelmezése, amely az első, nevesített személyiségi jogi felfogással részben átfedésben van.

2. Az emberi méltóság mint nevesített személyiségi jog

A régi Ptk. az emberi méltóságot a jóhírnévre és a becsületre vonatkozó szabályok körében oltalmazta, mely szabályozás a minden embert megillető emberi rangot 
jelentette, míg a becsület a személyiség társadalmi értékelését. ${ }^{330}$ Törő Károly a három jog viszonyát úgy határozta meg, hogy az emberi méltóság és a becsület a jóhírnévhez képest szubszidiárius jellegü: akkor kell sérelmüket vizsgálni, ha a jóhírnév sérelme nem állapítható meg, ${ }^{331}$ tehát egyfajta fokozatbeliség jellemzi a három fogalom viszonyát. ${ }^{332}$ Jóllehet mind a becsület, mind az emberi méltóság külön nevesített részjogosultságok, a bíróságok gyakran összemossák e két kategóriát. ${ }^{333}$ Maga Törő is azon a véleményen van, hogy a fogalmak nehezen elhatárolhatóak, mert mindhárom célja a személy társadalmi értékelésének és megítélésének biztosítása és egyben védelme. ${ }^{334}$

Az emberi méltóság a jogalanyi léthez kapcsolódik, azonban annál szükebb, kizárólag az embert megillető jog, amely a sajátos emberi mivoltot jelenti. ${ }^{335}$ Lényegében az értékelésnek ez a foka az, amely által az emberi méltóság és a kibontakozás joga elhatárolható. Míg a kibontakozás a személy jogalanyiságának legnagyobb mértékü kiteljesedésére és kiteljesítésére koncentrál, addig az emberi méltóság az ember jogalanyiságának legalapvetőbb magjára, az emberi minőségre, az emberként kezelésre szükül le. Ez az emberi értékminőség, jogi minimum, nem olyan érték, amely sérelme esetén az igény megvalósul, hanem helye van érdekmérlegelésnek, a becsülethez hasonlóan. ${ }^{336}$ A Legfelsőbb Bíróság is osztja ezt az álláspontot, az emberi méltóság sérelmét ugyanis akkor állapítja meg, ha „,a személyt emberi mivoltában megalázzák, méltatlan és hátrányos helyzetbe sodorják." ${ }^{337} \mathrm{~A}$ polgári bíróságok gyakorlatában az emberi méltóság sérül akkor, amikor egy iskolai tanárnő arcképét egy meztelen női testhez montírozták, aminek következtében az a látszat keletkezett, hogy a képen a tanárnő jelenik meg teljes egészében. ${ }^{338}$ Ugyanígy sérti e jogot, ha a büntetés-végrehajtási intézet nem biztosítja a minimális mozgásteret a fogvatartás során. ${ }^{339}$

\footnotetext{
330 TÖRÖ, 1979. 352.

331 TÖRÖ, 1979. 421.

332 TÖRÖ KÁROLY: A személyiség és a szellemi alkotások védelme a módosított Polgári Törvénykönyvben. Magyar Jog 1978, 982, 987.

${ }^{333}$ GÖRÖG MÁRTA: A személyiség védelme a becsület és a jóhírnév vonatkozásában. In: CSEHI ZOLTÁN - KOLTAY ANDRÁS - NAVRATYIL ZOLTÁN (szerk.): A személyiség és a média a polgári és a büntetöjogban. Complex, Budapest, 2014. 157.

334 TÖRÖ, 1979. 352.

335 TÖRÖ, 1978. 987, 420.

336 TÖRÖ, 1979. 430.

${ }^{337}$ Legfelsőbb Bíróság Pfv. (III. 22.) 084/1996.

338 BDT 2011. 2549.

${ }^{339}$ BH 2016. 240.
} 
A Ptk. 1977-es novellájában az emberi méltóságnak a szocialista polgári jogban egy további szerepe is volt. A burzsoá osztályokkal és joggal szemben minden embernek egyaránt kívánta biztosítani az emberi méltósághoz való jogot, és ezzel részben magában foglalta a jogalanyisággal is kapcsolatba hozható megkülönböztetés tilalmát. ${ }^{340}$

\section{Az emberi méltóság alkotmányjogi vonatkozásai}

A rendszerváltozással az Alkotmány módosításának eredményeképpen az újonnan bekerülő alapjogok között helyet kapott az emberi méltóság joga is. A müködését a rendszerváltozás után megkezdő Alkotmánybíróságra hárult a feladat, hogy az alapvető jogok jogrendszerben elfoglalt helyét meghatározza, így a magánjogbeli szerepüket és érvényesülésüket is.

Az emberi méltósághoz való jogot az Alkotmánybíróság úgy értelmezte, hogy az az egyén autonómiájának, önrendelkezésének egy olyan, mindenki más rendelkezése alól kivont magja, amelynél fogva az alany ember marad, s nem válhat eszközzé vagy tárggyá. A méltósághoz való jognak ez a felfogása különbözteti meg az embert a jogi személyektöl, amelyek teljesen szabályozás alá vonthatók, nincs „,érinthetetlen “ lényegük. E jog ún. ,anyajog”, olyan szubszidiárius alapjog, amelyet mind az Alkotmánybíróság, mind a bíróságok minden esetben felhívhatnak az egyén autonómiájának védelmére, ha az adott tényállásra a nevesített alapjogok egyike sem alkalmazható. $^{341}$

Ezzel lényegében az Alkotmánybíróság a polgári jogi, és a német alapjogi emberi méltóság fogalomhoz hasonlóan az emberi minőségként, érinthetetlen lényegként definiálja ezt az alapjogot. Ehhez hasonlóan az emberi méltóság fogalmának e szűk értelmezését Pokol Béla a megaláztatás tilalmának nevezi, amely lényegében az emberi jellegben való megalázásra fókuszál.

Az Alkotmánybíróság az emberi méltóság alapjogának jelentését és tartalmát tovább cizellálta. Az Alkotmány ekkor nem tartalmazta az emberi méltóságon túl sem a magánélethez való jogot, sem a személyiség szabad kibontakozásához való jogot, ezért e jogok a pozitív jogban alkotmányjogi szinten nem jelentek meg, ami azt is kizárta, hogy jogsértést jogszabályhely megjelölésével e jogok tekintetében el lehessen

\footnotetext{
340 TÖRÖ, 1979. 420.

341 8/1990. (IV. 23.) AB hat.
} 
ismerni. A jogvédelem megadása érdekében az Alkotmánybíróság ezt a következő értelmezéssel küszöbölte ki, lévén Alkotmányt nem módosíthatott:

„Az Alkotmánybíróság az emberi méltósághoz való jogot az ún. általános személyiségi jog egyik megfogalmazásának tekinti. A modern alkotmányok, illetve alkotmánybírósági gyakorlat az általános személyiségi jogot különféle aspektusaival nevezik meg: pl. a személyiség szabad kibontakozásához való jogként, az önrendelkezés szabadságához való jogként, általános cselekvési szabadságként, avagy a magánszférához való jogként." 342

Az Alkotmánybíróság ezzel egy általános személyiségi jogot ismert el, és nem is kendőzte azt, hogy az emberi méltóság, amelyet az Alkotmány tartalmaz, ennek csupán egy részét képezi. Egy másik lehetséges értelmezés, hogy a fenti fogalmak szinonimák, ezzel lényegében a jogalap problémája megoldódik, azonban arra nem kapunk választ, hogy ugyanazt a jogot miért kell több elnevezéssel illetni, ha nincsen közöttük különbség. Az emberi méltósághoz való jog lényegesen szükebb tartalommal való felfogásának legjelentősebb képviselője Pokol Béla, aki a két fogalom azonosításának elvi helytelenségére világít rá. ${ }^{343}$ Pokol szerint az emberi méltóság általános cselekvési szabadságként értelmezése a hazai alkotmánybírósági gyakorlatban az emberi méltóság eredeti tartalmának, a megaláztatás tilalmának teljes háttérbe szorulását eredményezte. ${ }^{344}$

Az általános személyiségi jog fogalmának magyar jogrendszerbe való bevezetése és az emberi méltósághoz közelítése az emberi méltóság fogalmának tulajdonképpen még egy, az emberi értékminőségtől független tartalmat és definíciót adott. Így lényegében az emberi méltóság, mint olyan, egyszerre jelent több dolgot. Ez pedig végső soron dogmatikailag ahhoz a helytelen állapothoz vezet, hogy egy fogalom többféle normatív tartalommal bír. Ehhez a horizontális hasadáshoz járul a fogalom magánjogra való kivetülése, amely vertikálisan is új értelmet hoz az emberi méltóságnak. A jelen vizsgálat szempontjából az bír jelentőséggel, hogy az „általános személyiségi jog” fogalmának alapjogi megjelenése és a polgári jogi

\footnotetext{
342 8/1990. (IV. 23.) AB hat.

${ }^{343}$ Erről részletesen: POKOL BÉLA: Alkotmánybirráskodás. Szociológiai, politológiai és jogelméleti megközelítésekben. Kairosz Kiadó, Budapest, 2014.

344 998/B/2009. Ab. hat. párhuzamos indokolása.
} 
személyiségvédelem generálklauzulája között összefüggés keletkezett, ami nem lett volna baj akkor, ha az általános személyiségi jog nincs a fent említett módon kapcsolatban az emberi méltósággal. Ez a kapcsolat ugyanakkor az Alkotmánybíróság értelmezésének az eredménye, amely a német jog eltérő pozitív jogi alapja miatt annak érvelését és indokolását olyan módon, azokkal az alapjogokkal nem tudta átvenni, mert a magyar Alkotmányból a jogalap hiányzott.

4. Az emberi méltóság és az általános személyiségi jog összefüggései a német jogban

Korábban már bemutatásra került, hogy a német magánjogi személyiségvédelemben fordulatot jelentett a német Alaptörvény hatálybalépése. A Grundgesetz ugyanis védte az emberi méltóságot (GG 1. cikk), illetve a személyiség szabad kibontakozásához való jogot (általános cselekvési szabadság, GG 2. cikk). A német jogalkotó továbbra sem módosította a BGB-t, így a személyiségi jog kodifikációja elmaradt. Az általános személyiségi jog bírói elismerésére 1954-ben került sor. Egyesek azon az állásponton vannak, hogy az általános személyiségi jog elismerése nem is analógia útján történt, hanem a BGH csupán deklarálta ezt a jogot, az analógia feltételeinek vizsgálata nélkül. ${ }^{345}$ A BGH nagyon érdekesen fogalmazott:

"A Reichsgericht azt gondolta, hogy egy, a levelek nyilvánosságrahozatalára vonatkozó és a szerzői jogtól független személyiségvédelmet azért kell megtagadnia, mert az akkor érvényes német jogrend nem tartalmazott egy általános személyiségi jogra vonatkozó pozitív törvényi elöírást sem. [...] A Reichsgericht jóllehet számtalan döntésében ítélt meg a BGB 828. §-a alapján védelmet a személyiségi jogoknak [...], ugyanakkor csak egyes meghatározott személyiségi javakat ismert el abszolút hatályú, kizáró jellegü személyiségi jogként. [...] Mivel most már az Alaptörvény tartalmazza az ember jogát a méltóságának megóvására (GG 1 . cikk) és a személyiség szabad kibontakozásához való jogot is magán-, mindenki által tisztelendö jogként ismeri el mindaddig, míg e jog mások jogait vagy az alkotmányos rendet vagy a jó erkölcsöket nem sérti (GG 2. cikk), úgy az általános személyiségi jogot, mint egy alkotmányosan garantált alapjogot el kell ismerni. ${ }^{346}$

\footnotetext{
345 OPOKU, 1972. 269.

${ }^{346}$ BGHZ 13, 334 - Leserbrief.
} 
Az általános személyiségi jog ezzel indult lényegében útjára a magánjogban, ez a bírói jogfejlesztés eredményeként, két alapjog együttes alkalmazásával elismert magánjogként. Az emberi méltóság tehát nem önállóan, hanem az általános cselekvési szabadsággal együtt, e jogszabályhelyek együttes alkalmazásával képezi az általános személyiségi jog magánjogi alapját. Az általános cselekvési szabadság sokkal tágabb értelmü jog, amelynél fogva az emberi méltósághoz való jog alkalmazási és megállapítási köre az emberi életminőség legközelebbi magját jelentő szférára szükül.

A post mortem személyiségi jog elismerésével összefüggésben ugyanakkor felmerült az a kérdés, hogy mennyiben alkalmas e két alapjog a jogalanyiság megszünése után is a személyiségvédelmi funkciót betölteni, és lehet az igény alapja. Ez leginkább az emberi méltóság jogával összefüggésben merült fel. A Bundesverfassungsgericht akként foglalt állást, hogy az emberi méltóság sérthetetlenségének követelményével összeegyeztethetetlen lenne az, ha egy embernek, akinek a méltósága pusztán emberi mivoltából fakad, a halála után méltánytalan, lealacsonyító helyzetbe kerülne. Ennél az oknál fogva a BVerfG úgy találta, hogy az emberi méltóság joga által nyújtott védelem a halál után nem szünik meg. 347

Hasonló problémához vezet a jogi személyek és más személyegyesülések személyiségvédelmének alapja azon okból, hogy mennyiben alkalmazható ezekre az emberi méltóság, illetve a cselekvési szabadság által biztosított személyes élettér, ${ }^{348}$ ez a bizonytalanság leginkább a jogi személyek mögöttes, alkotmányjogi védelme esetén kérdéses. ${ }^{349}$ A német Alaptörvény 19. cikke ugyanis elöírja azt, hogy a jogi személyek egy alapjog megsértésére csak annyiban hivatkozhatnak, amennyiben jogi természetük alapján rájuk az alkalmazható. ${ }^{350}$ A jogi személyek alapvetően nem lehetnek hordozói az emberi méltósághoz való jognak azon okból, mert az az emberi minőséget feltételezi, kifejezetten az embernek mint jogalanynak van fenntartva, és emiatt a jogirodalom oldalán magának az egész általános személyiségi jognak az automatikus alkalmazása is kérdéses. ${ }^{351}$ Van olyan álláspont is, amely az általános személyiségi jog alkalmazhatóságát az emberi méltóság hiánya okán teljes mértékben

\footnotetext{
${ }^{347}$ BVerfG NJW 1971, 1645 - Mephisto.

${ }^{348}$ Erman/KLASS, BGB 14. Aufl., Anh $\S 12$, Rn 59.

${ }^{349}$ BverfG NJW 2010, 3501, 3502 - Gen-Milch.

${ }^{350}$ GG 19. cikk (3) bek.

${ }^{351}$ Erman/KLASS, BGB 14. Aufl., Anh § 12, Rn 59.
} 
kizárja. ${ }^{352} \mathrm{Az}$ általános személyiségi jogról leválasztott, a BGB 12. §-ában szabályozott névjog esetén a jogi személyekre, a személyegyesülésekre és vállalatokra történő alkalmazás megindokolása azzal történik, hogy míg természetes személy esetén a védendő érdek egy személyes érdek, addig a másodlagos jogalanyok tekintetében egy, a személytől elvált és a gazdasági tevékenységgel összekapcsolódott, önállósult gazdasági, üzleti érdeket véd. ${ }^{353}$

Götting a személyiségi jogok kommercializálódásával, vagyoni értéküségével kapcsolatban vetette fel a polgári jogi személyiségvédelem emberi méltóság alapjogi behatását a polgári jogi személyiségvédelmen belül. Az örökölhető és átruházható személyiségi jegyek elismerése ugyanis minden további magyarázat nélkül szemben áll az emberi méltósággal, értékminőséggel, és ő e jogosultságok felett azok vagyoni, illetve immateriális jogi karakterénél fogva a tulajdon alkotmányos védelmét tekinti mögöttesnek. ${ }^{354}$

\section{Az emberi méltóság mint a személyiségi jogok anyajoga}

2008-ban a Kodifikációs Főbizottság azon az állásponton volt, hogy az általános személyiségi jogot nem szabad az emberi méltósággal azonosítani, mert a jogalkalmazás szűkebb értelemben használja azt a polgári jogban. ${ }^{355}$ Eszerint az álláspont szerint egyrészről a személyiségi jogok a jogi személyek esetén nem értelmezhetőek, másrészről a polgári jogi judikatúrában az emberi méltóságnak már van egy jelentése, harmadrészről pedig felveti annak a veszélyét, hogy a polgári jogi és az alapjogok hivatkozása, védelme közötti határvonal elmosódik. ${ }^{356}$ A 2009. évi Ptk. sem emelte jogszabályi szintre azt, hogy a személyiségi jogok forrása az emberi méltóság, ugyanakkor mögöttesen ez a szerkesztési mód is kifejezetten akként értelmezi a személyiségi jog generálklauzuláját, hogy az az emberi méltóságból táplálkozik. ${ }^{357}$

\footnotetext{
352 Staudinger/KANNOWSKI (2013) Vorbem zu $§ 1$ bgb Rn 30.

${ }^{353}$ Staudinger/HABERMANN (2013) § 12 BGB Rn 18.

354 GÖTTING, 1995. 139. sköv.

${ }^{355}$ Az új Polgári Törvénykönyv koncepciója. A Kodifikációs Főbizottság 2001. november 8.-i ülésén elfogadott formában.

356 A Kodifikációs Főbizottság koncepcióját ismerteti KECSKÉS LÁsZLÓ: Polgári Jog. Személyek Joga. Dialóg-Campus, Budapest-Pécs, 2005. 324.

${ }^{357}$ GÁRDOS PÉTER (szerk.): Kézikönyv az új Polgári Törvénykönyvhöz. Complex, Budapest, 2009. 149.
} 
Az Alkotmányba foglalt emberi méltóság alapvető joga és a köré rakódott alkotmánybírósági judikatúra azt eredményezte, hogy a polgári jogi személyiségi jogokat az emberi méltósággal mint általános személyiségi joggal teljes mértékben azonosították. A Polgári Törvénykönyv ezzel nemcsak egy generálklauzulával, hanem egy „anyajoggal” is rendelkezik a személyiség védelmének szabályai között. Az, hogy ez az anyajog miben más mint egy generálklauzula, miért ez az ún. ,anyajog” kerül a szabályozás középpontjába a generálklauzula helyett, illetve, hogy az emberi méltóság mint ,anyajog” milyen funkciót tölt be a jogalkalmazásban, teljesen megválaszolatlan marad ezáltal.

A jogalkotó célja alapvetően az volt, hogy feloldja az alkotmányjogi értelemben vett emberi méltóság, és a személyiségi jogok között korábban szerepeltetett emberi méltóság fogalmai közötti feszültséget. Kiemelendő ugyanakkor, hogy e generálklauzula címzettje elsősorban az Alkotmánybíróság. Ez az álláspont az emberi méltóság sérelmét valamennyi személyiségi jog sérelme esetén megállapítja. 358 Az emberi méltóságra nem úgy tekint mint egy minden érdekmérlegelést kizáró jogra, és ezért nem tudja feloldani a Ptk. 2:42. § (2) bek. 1.m. és a 2:44. § szerinti emberi méltóság fogalom közötti ellentétet. ${ }^{359}$

\section{Az emberi méltóság magánjogi felfogásának kritikája}

Az emberi méltóság Ptk.-ban szerepeltetése véleményem szerint csupán zavart okoz, és nem oldja meg az alapvető jogok és a polgári jog védelmének megfelelő elhatárolását. Ilyen többek között az, hogy ezzel a magánjog átveszi az alkotmánybírósági érvelést, egyfajta generálklauzulaként állítja be törvény az emberi méltóságot, és így megduplázza az alanyi jogot. Az alkotmányjogban az általános személyiségi jog, illetve az általános cselekvési szabadság jogainak elismerése nem választható le az emberi méltóság fogalmáról, hiszen csak így oldható meg e jogok Alaptörvénybe való beleértése, enélkül ezeknek nem lenne pozitív jogi alapja. Ezzel szemben a magánjogban ilyen meggondolásra egyáltalán nem lenne szükség, hiszen a személyiségi jog generálklauzulája mint alanyi jogi tényállás ilyen alátámasztást, emberi méltósággal vagy más alapjoggal való, magánjog szintjén megjelenő

\footnotetext{
358 VÉKÁs LAJOS: Bírálat és jobbitó észrevételek az új Ptk. Törvényjavaslatához (a zárószavazás előtt). ${ }^{359}$ U.o. Magyar Jog 2013, 1, 4.
} 
kapcsolatbahozást nem igényel. ${ }^{360}$ Azzal azonban, hogy ezt a Ptk. mégis megteszi, a személyiségvédelem egészének jogértelmezése szempontjából zavart okoz.

E tág, mögöttes, generálklauzuláris és egyben alanyi jogi jelleget tulajdonít a Kúria az emberi méltósághoz való jognak, és egyfajta alkotmányjogi szürőként, az alkotmányjogi értelmezéssel összhangban építi azt be a polgári jogba. A Kúria szerint ugyanis „a rendőri intézkedésről készült képfelvétel nyilvánosságra hozható, az emberi méltóságból fakadó személyiségi jogi sérelem csak ritkán alapozza meg a sajtószabadság korlátozását. [...] a demonstrációt biztosító rendőrök képmásának nyilvánosságra hozatal[a] nem volt öncélú, mert az nem volt az emberi méltóság benső lényegét érintő, vagy a sajtószabadsággal való visszaélést megvalósító tudósítás."361 Itt látható, hogy a Kúria egyrészről az emberi méltóságot pozitív jogilag, a személyiségi jog megsértése szempontjából szűken értelmezi, ugyanakkor az idézet első felében kifejezetten más értelmet is tulajdonít neki. Ez az értelem nem igazán mérhető, nem igazán vizsgálható, s nem is vizsgálja azt a Kúria sem. Megfogalmazása, az „emberi méltóságból fakadó jog” is inkább ünnepélyes, preambulumba illö, semmint egy magánjogi alanyi jog keretei közé. Ez inkább egy hidat képez a polgári jogban, amely összeköti azt az alkotmányjoggal. Erre azonban nem lenne a jogalkalmazás szempontjából szükség.

A kodifikáció eredményeként azért került sor a Ptk.-ban az emberi méltóság „anyajoggá” emelésére, hogy a két jelentés (anyajog és megaláztatás) között törvényi szinten állapítsa meg a jogalkotó által helyesnek tekintett értelmet. ${ }^{362}$ Ennél fogva az emberi méltóság fogalmának a régi Ptk. 76. §-ában foglalt tartalma, illetve a jóhírnévvel, becsülettel fennálló korábbi kapcsolta tulajdonképpen megszünt. A Ptk. megszünteti ezt a korábbi, szükebb értelmü méltóság fogalmat, nem is nevesíti külön a személyiségi jog megsértése esetének a méltóságot, ennek ellenére rendezi e nevétől megfosztott részjog sorsát. Abban az esetben, ha az emberi méltóság egyszerre jelenti valamennyi személyiségi jog alapját, illetve emellett az előbb említett külön nevesített személyiségi jogot is, nem lehet tudni, mikor mit értünk az emberi méltóság fogalma alatt. A méltóság másik fontos jellemzője az embert megillető érinthetetlen lényeg,

\footnotetext{
${ }^{360}$ Ellentétes állásponton TöKEY BALÁZS: Az élethez és az emberi méltósághoz való jog mint személyiségi jog. In: In: Grad-Gyenge, Anikó - Kabai, Eszter - Menyhárd, Attila (szerk.): Liber Amicorum - Studia G. Faludi Dedicata. ELTE Eötvös, Budapest, 2018. 461.

${ }^{361}$ BH 2018. 248. [32] („Rendvédelmi szakszervezetek tüntetése”).

${ }^{362}$ SZÉKELY - VÉKÁS, 2013. 56.
} 
ami által az ember nem válhat tárggyá a jogban. Ez már a jog tartalmáról rendelkezik, ezért a bíróságok a jogértelmezés során ezt fogják mérceként, zsinórmértékként használni. Az emberi méltóság ilyen megfogalmazása azonban erősen leszükített értelmü.

Az emberi méltóságnak tág értelmezése az Alkotmánybíróság részéről az alapjogi szinten egyfajta szükségmegoldásként jelentkezett, és már az alkotmányjogban is megduplázta annak értelmét. Ezt célszerű a polgári jogba nem átvinni, hanem az addig felépített magánjogi személyiségvédelmi rendszert tovább fejleszteni. Ez nem jelentené logikailag azt, hogy az emberi méltóság alapjogi behatását ki kellene zárni, csupán hogy jogtechnikai értelemben nem tekintendő alanyi jognak. Ehhez a gondolathoz kapcsolódik lényegében az is, hogy a Ptk. az emberi méltóság nélkül is ismeri a generálklauzula működési mechanizmusát, és alkalmazza az alanyi jog intézményét is, ez volt korábban az ún. általános személyiségvédelmi szabály, más néven az általános személyhez füződő jog.

Az emberi méltóság és a személyiség szabad érvényesítésének párhuzamos törvényi szerepeltetésének az a felfogása, amely az emberi méltóságot tekinti alanyi jognak, azaz olyan jognak, amely önállóan is alkalmazható, nem ad választ arra, hogy a kibontakozásról rendelkező 2:42. § (1) bekezdésnek mi a funkciója. Azon értelmezés, amely mindkettőt alanyi jognak tekinti, szintén helytelen azon okból, hogy a két alanyi jog igényhalmazatot indukál. Ezen értelmezés alapján ugyanis az a helyzet állna elö, hasonlóan a kontraktuális és deliktuális felelősségből származó igényekhez, hogy két párhuzamos jogalap létezik, amelyek átfedésben vannak egymással, és amelyek esetén az egyik specialitása miatt a szubszumció során elsőbbséget élvez. Az emberi méltóságnak tág felfogása nem csupán a generálklauzula viszonylatában értelmezhetetlen, hanem az egyes személyiségi jogi részjogosultságok viszonylatában is. Ha valamely nevesített vagy nem nevesített személyiségi jog megsérül, úgy az maga után vonja az emberi méltóság sérelmét is, hiszen minden személyiségi jog az emberi méltóságból fakad, így az is szükségszerüen megsérül. Ezzel lényegében két jog megsértéseként értékeli ugyanazt a körülményt. Hasonló eredményre vezet az, ha a 2:42. § (1) bek. és (2) bek. 1. m. együttes alkalmazásával kerül megállapításra a jogsértés.

A harmadik lehetséges megoldás szerint, amely a legkielégítőbb módon tud működni, a Ptk. emberi méltósággal foglalkozó 2:42. § (2) bekezdése úgy 
értelmezendő, mint ami a Ptk. 2:42. § (1) bekezdésének generálklauzuláját magyarázza, és rámutat az emberi méltósággal való összefüggésre, anélkül azonban, hogy e normára önállóan hivatkozni lehetne. ${ }^{363}$ E magyarázattal van összhangban a (2) bekezdés második mondata is, ami figyelmeztet, hogy a személyiségi jogokat a polgári jog szürőjén keresztül kell megközelíteni. Ezzel elkerülhető a generálklauzula megduplázása, választ adunk a 2:42. § (1) bekezdésének funkciójára, és az emberi méltóságot is kielégítően el lehessen helyezni a dogmatikai rendszerben. E kibontakozás-alapú személyiségvédelmi rendszerben az emberi méltóság nem csupán a magánjogi személyiségi jog mögöttes, alkotmányjogi alapját képezi, hanem egyfajta emberi minimumot is jelent. Az Alaptörvény II. cikk (1) bekezdése szerint az emberi méltóság sérthetetlen, amely sérthetetlenség hagyományosan korlátozhatatlanságot jelent. Ezt az értelmezést támogatja a 2:44. § is, amely az emberi méltóság sérthetetlenségének deklarálásával egy szükebb értelmü méltóság fogalommal operál. ${ }^{364}$ Ebben a rendszerben tehát az emberi méltóság egy belső szűk mag a személyiségvédelmen belül, és a kibontakozás joga ernyő módjára magában foglalja e jogot, a magánélet szféráját, és minden más, e rendszerbe foglalt nevesített és nem nevesített személyiségi jogot is. A téma vizsgálata szempontjából a legfontosabb ugyanakkor az, hogy az emberi méltóság ilyen értelmezésével nyitva áll a lehetősége annak, hogy a személyiséggel kapcsolatos vagyoni érdekek meglétére anélkül is logikai lehetöség van, hogy a kódexet tulajdonképpen nem módositjuk, legalább is ebben a tekintetben. Ha az emberi méltóság nem (vagy nem kizárólagosan) jogalapja a magánjogi személyiségvédelemnek, úgy nyitva áll az út a személyiségi jog egy részének, a vagyoni értékü személyiségi javaknak a legszemélyesebb jellegtöl való elválására, a forgalomképesség megszerzésére. Ez persze nem jelenti azt, hogy ezek forgalomképesek is lesznek, csupán ennek objektv lehetőségét.

${ }^{363}$ Ezt az értelmezést látszik támogatni NAVRATYIL ZOLTÁN: Az emberi méltóság magánjogi szerepe és a véleménynyilvánitás szabadsága. In: Koltay András - Török Bernát (szerk.): Sajtószabadság és médiajog a 21. század elején 3. Wolters Kluwer, Budapest, 2016. SCHULTZ MÁRTON: Gondolatok a személyiségi jogok generálklauzulájáról és az emberi méltóságról. Magyar Jog 2016, 685. KOLTAY ANDRÁS: Az „,általános személyiségi jog” nyomában - kísérlet a méltóság, becsület, jó hírnév fogalmi elhatárolására. Magyar Jog 2017, 602.; KOLTAY ANDRÁS: Az „általános személyiségi jog “ azonositása felé. In: Koltay András - Török Bernát (szerk.): Sajtószabadság és médiajog a 21. század elején 4. Wolters Kluwer, Budapest, 2017. 295. BARzó TímEA: Személyiségvédelem. In: Barzó Tímea - Papp Tekla (szerk.): Civilisztika I. Dialóg Campus, Budapest, 2018. 178-179.

${ }^{364}$ NAVRATYIL ZOLTÁN: Az emberi méltóság magánjogi szerepe és a véleménynyilvánitás szabadsága. In: Koltay András - Török Bernát (szerk.): Sajtószabadság és médiajog a 21. század elején 3. Wolters Kluwer, Budapest, 2016. 230. 


\section{Magánélet}

\section{A német szféraelmélet}

A privátszféra védelme a német jogrendszerben elsősorban az ún. szféra-elmélethez (Sphärentheorie) kapcsolódik, amely differenciálás lényegét a személyiségi jogba való behatások jogszerüségének eltérő mércéje képezi. ${ }^{365}$ Ennek alapján míg a privát- és szociális szférába való behatások esetén enyhébb a mérce, amely az egyedi ügyben elvégzendő érdekmérlegeléstől függ, addig az intimszféra esetén egy abszolút, sérthetetlen védelmet nyújt a német jog. ${ }^{366}$ Ezen abszolút védelem okán az intimszférába való behatás esetén, a másik két szférával ellentétben nincsen érdekmérlegelés, a behatás minden további érdekmérlegelés nélkül jogellenesnek minősül. A BGH a Mephisto-döntésben rámutatott, hogy abban az esetben, ha az intimszféra sérül, úgy az érdekmérlegelés vizsgálata teljesen szükségtelenné válik. ${ }^{367}$ Amíg a privátszférába való behatások türésére nagyobb mértékben lehet kötelezni a magánszemélyeket, így a közszereplőket is, ${ }^{368}$ addig az intimszféra mint a személyiség legbelső magja esetén az abszolút kortörténeti szereplők is védelmet élveznek.

Amennyiben a magánélet, magánszféra sérül, úgy az általános személyiségi jog megsértését állapítja meg a bíróság. A magánélet területe magában foglalja egyrészről a családi viszonyokat és a személyes kapcsolatokat, másrészről a lakóház körüli életet is védi. ${ }^{369}$ Tartalmi szempontból azok az információk tartoznak a magánélet körébe, amelyek tipikusan magán jellegünek tekintendőek azon oknál fogva, hogy az arról való nyilvános beszéd vagy közszemlére tétel illetlennek minősül. ${ }^{370}$

E szféra-védelem nem önmagában áll, hanem mindig valamely személyiségi jogi tényálláshoz, esetcsoporthoz kapcsolódik elsősorban. A szféra szerinti személyiségi jogi ítélkezési gyakorlat a német személyiségvédelem kezdeti szakaszára

\footnotetext{
${ }^{365}$ Ehhez GÖRÖG MÁRTA: A magánélethez való jog mint a személyiségi jog újabb, magánjogi kódexben nevesitett vonatkozása. In: Balogh Elemér (szerk.): Számadás az Alaptörvényröl. Magyar Közlönyés Lapkiadó, Budapest, 2016. 51.

${ }^{366}$ Erman/KLASS, BGB 14. Aufl., Anh § 12, Rn 17.

${ }^{367}$ BGHZ 50, 133 [III. 2.] - Mephisto.

${ }^{368}$ A magánszférába való behatások jogellenességének kizárása növekvő tendencia, Sulyok a deprivacy elnevezést használja erre. SULYOK MÁRTON: Magánszféravédelem a tisztességes eljárásban - Az alapjogsértő bizonyitás összehasonlitó alkotmányjogi vizsgálata. Disszertáció, Szeged, 2017. 70.

${ }^{369}$ Erman/KLASS, BGB 14. Aufl., Anh § 12, Rn 20.

${ }^{370}$ Erman/KLASS, BGB 14. Aufl., Anh $\S 12$, Rn 126.
} 
volt jellemző kizárólagos rendező elvként, amelynek huzamosabb fenntartása azért nem volt lehetséges, mert az egyes szférák a konkrét esetben gyakran egybemosódtak, így a bíróságok a jogi értékelés során ezt félretették, és egyből átcsaptak a konkrét eset érdekeinek mérlegelésébe. ${ }^{371}$

\section{Hézagkitöltő szerep}

A magánélethez való jog hézagkitöltő szerepet foglal el az angol-amerikai jogban, illetve az Emberi Jogok Európai Egyezményében és ehhez kapcsolódóan az Európai Unió Alapjogi Chartájában is. A hézagkitöltő szerep oka hasonló a magyar alkotmányjognak az emberi méltóság fogalmát bővítő megoldásához. A fentebb említett rendszerekben ugyanis a személyiség védelmének egyedüli központi normája, amely ugyan megfogalmazásából adódóan tág kört fog át, noha védelme nem a személyiség teljes körü védelmét célozza.

Az Emberi Jogok Európai Egyezményének 8. cikkével összefüggésben Grád András és Weller Mónika úgy fogalmaznak, hogy az „magában foglalja a személy mind erkölcsi, mind fizikai integritását, amibe az a jog is beletartozik, hogy a saját életét élje, bárminemü külső megfigyelés vagy más beavatkozás nélkül, továbbá személyiségét szabadon kiteljesíthesse." 372 Az angol irodalom ugyanakkor felhívja a figyelmet rá, hogy az Egyezmény 8. cikke szerinti magánélet (private life) és a privacy fogalmai egymással nem azonosak, és mindaz, ami a magánélet fogalmi körébe vonható az angol jog privacy fogalmának megsértését is jelenti, ez azonban fordítva nem igaz, mert az Egyezmény 8. cikke szerinti magánélet tágabb. ${ }^{373}$ Az Európa Tanács ezt a következőképpen fogalmazta meg az X v Iceland ügyben. „Számos angolszász és francia szerzö szerint a "magánélet" tiszteletben tartása maga a privacy, az élethez való jog, amely a nyilvánosságtól véd [...] ugyanakkor a magánélet tiszteletbentartásához való jog ezzel nem ér véget. Magában foglalja, jóllehet csak bizonyos fokig, a jogot, hogy az egyén más személyekkel kapcsolatokat létesítsen és

\footnotetext{
${ }^{371}$ Erman/KLASS, BGB 14. Aufl., Anh $\S 12$, Rn 17.

372 GRÁD ANDRÁS - WELLER MÓNIKA: A strasbourgi emberi jogi bíráskodás kézikönyve. HVG-ORAC, Budapest, 2011. 449-450.

${ }^{373}$ WARBY, MARK - MOREHAM, NiCOLE - Christie, IAIN (szerk): The Law of Privacy and the Media. Oxford University Press, Second edition. [2.04.]
} 
ápoljon, különösen a saját személyiségének fejlesztésével és megvalósításával összefüggő területen." 374

3. Magánélethez való jog és polgári jogi kodifikáció

A magánélethez való jog új jogként került be a személyiségi jogok katalógusába, és annak védelmét már a 2009-es Ptk. is előirányozta, elsősorban azon indokból, mert e jog nemzetközi jogi védelmét több szerződés is védelemben részesíti. ${ }^{375}$ Ilyen a Polgári és Politikai Jogok Nemzetközi Egyezségokmányának 17. cikke, az Emberi Jogok Európai Egyezményének 8. cikke, erre tekintettel az Európai Unió Alapjogi Chartájának 7. cikke, illetve a gyermekek jogairól szóló New York-i Egyezmény 16. cikke is. A magánélethez való jogot a bírói gyakorlat annak pozitív jogban való megjelenése előtt helyesen a generálklauzulába ágyazott jognak tekintette. ${ }^{376} \mathrm{~A}$ régi Ptk. nem tartalmazta az erre vonatkozó tényállást a magánélethez való jog sérelme esetén sem, így azt a bírói érdekmérlegelés során kellett megállapítani. A Legfelsőbb Bíróság a magánéletbe való beavatkozás mércéjének az abba való önkényes beavatkozást tekintette. ${ }^{377}$ Ezt vette át a 2008-as Szakértői Javaslat is, amely szerint a magánéletbe való beavatkozás akkor sérti a személyiségi jogot, ha önkényes, indokolatlan és szükségtelen, ${ }^{378}$ amely megoldást a Ptk. is átvette. ${ }^{379} \mathrm{~A}$ Ptk. a magánélethez való jog tartalmi meghatározása szempontjából továbbra sem tartalmaz fogódzót, így a kérdés a konkrét jogvitában továbbra is a bíróságok érdekmérlegelésébe utalt. Bár a Ptk. azt a megoldást követte, hogy a polgári jogi személyiségi jogok nem azonosak az alkotmányokban és a nemzetközi szerződésekben szereplő alapvető jogokkal, a magánélethez való jognál ugyanakkor nyíltan ennek okán építi azt be a személyiségi jogok közé. Annak ellenére, hogy bármi tartalmi fogódzót adna arra nézvést, miként határolható el annak tartalma más

\footnotetext{
${ }^{374}$ X v Iceland Application 6825/74, (1976) 5 DR 86, 87.

375 SzÉKELY LÁSZLÓ - VÉKÁs LAJOS: Személyiségi jogok. In: Vékás Lajos (szerk.): A Polgári Törvénykönyv magyarázatokkal. Complex, Budapest, 2013. 57.

${ }^{376}$ Abban az esetben, ha a személyiségi jogtól független alanyi jogot kontruálna a jogalkalmazási gyakorlat, megduplikálná a magánosok abszolút személyes viszonyait, amely által a két igény közötti halmazat a személyiségvédelem rendszerét borítaná fel.

${ }^{377}$ BH 2001. 61.

378 SzÉKELY LÁSZLÓ: Harmadik Rész. Személyhez füződő jogok. In: Vékás Lajos (szerk.): Szakértői Javaslat az új Polgári Törvénykönyv tervezetéhez. Complex, Budapest, 2008. 165.

${ }^{379}$ SZÉKELY - VÉKÁs, 2013. 57.
} 
jogoktól, mikor állapítható meg e jog megsértése, s a legfontosabb, miben különbözik ez a személyiség szabad érvényesítését biztosító (általános) személyiségi jogtól.

4. A magánélethez való jog tág felfogása

A jogirodalom a külföldi jogrendszerek magánélet védelmét biztosító rendelkezéseit, ítélkezési gyakorlatát vette górcső alá, hogy a magánélet tartalmi meghatározása szempontjából a joggyakorlatnak segítséget nyújtson. ${ }^{380}$ Megjegyzendő, hogy az amerikai jog a privacyt a személyiségvédelem alapjának tekinti, ${ }^{381}$ ahogyan a kontinentális jogok az általános személyiségi jogot. Ebből fejlődött ki és vált le a right to publicity is. ${ }^{382}$ Magyarországon és a kontinentális Európában általában, ezt a szerepet nem a privacy, hanem a személyiségi jog töltötte be. Menyhárd Attila mutat rá a magánélethez való jog tartalmának meghatározása tekintetében, hogy annak egyes tartalmi elemeit nevesített személyiségi jogok (szabadság, magánlakás, jóhírnév, magántitok, képmás és hangfelvételhez való jog) is védik. ${ }^{383}$ A magánélethez való jog személyiségi jogi jellege, tartalmi meghatározása, besorolása szoros összefüggésben van több személyiségi joggal. Ezen összefüggés a jogtárgy védelmének azonossága, hasonlósága okán halmazatot implikál e jogi kategóriák között. A jogütközés ugyanakkor csupán a dogmatika szempontjából bír jelentőséggel, hiszen a megsértett jog a személyiségi jog [Ptk. 2:42. § (1) bek.] marad. A jogirodalom általánosságban ezt az eszmei halmazatot a magánélethez való jog javára dönti el, vagyis az egyes nevesített személyiségi jogokat a magánélethez való jog megnyilvánulásának tekinti. ${ }^{384}$ A bírói gyakorlat ehhez hasonlóan kapcsolatot von le a magánélethez való jog és más nevesített személyiségi jogok között, ugyanakkor az eddig már „bevált”, elismert és nevesített személyiségi jogok megsértése és a magánélethez való jog megsértése egymástól elkülönül - az egyes jogoknak, személyiségi vonatkozásoknak ugyanakkor van közös metszete a magánélettel. Ha a történeti tényállás az egyes

\footnotetext{
${ }^{380}$ MENYHÁRD ATTILA: A magánélethez való jog elméleti alapjai. In Medias Res 2014/2. 384-406.

${ }^{381}$ WARREN, SAMUEL - BRANDEIS, LUIS: The Right to Privacy. Harvard Law Review (1890) 4, 193.

382 Götting, 1995. 267. JOHnSON, ERIC E.: Disentangling the right of publicity. Northwestern University Law Review Vol 111. No. 4. 896. A joggyakorlatban először elismeri Haelan Laboratories Inc. v. Topps Chewing Gum Inc. 202 F 2d 866 (2nd Cir 1953). A Supreme Court: a Zacchini v. Scripps-Howard Broadcasting Co. 433 US 562 (1977).

${ }^{383}$ MENYHÁRD, 2014. 385.

${ }^{384}$ MENYHÁRD AtTILA: Forgalomképes személyiség? In: Menyhárd Attila, Gárdos-Orosz Fruzsina (szerk.): Személy és személyiség a jogban. Wolters Kluwer, Budapest, 2016. 76.; GÖRÖG MÁRTA: A kereskedelmi név védelme. In: Faludi Gábor, Lukácsi Péter (szerk.): A védjegytörvény magyarázata. HVG-ORAC. Budapest. 2014. 589. [Görög 2014b] SZEGHALMI, 2017. 224.
} 
nevesített jogokon túli személyiségi jogsértést eredményez, a bírói gyakorlat akkor állapítja meg a magánélethez való jog megsértését. A magánélethez való jog e hézagkitöltő szerepét támogatja Görög Márta is. ${ }^{385}$ Rámutatott az ítélkezési gyakorlat arra, hogy a magántitok és a magánélethez való jog megsértése nem azonosítható egymással, a magántitok a magánéleti adatokhoz képest szükebb, melynek körébe olyan nem nyilvános, kevesek által ismert tény, adat vagy körülmény tartozik, melyek megőrzéséhez az adott személynek méltányolható érdeke füződik. ${ }^{386}$ Ugyanígy a képmáshoz való jog sérelme állapítandó meg akkor, ha a jogosult hozzájárulása nélkül készül róla fénykép. Ez a magánélet sérelmét nem is valósítja meg minden esetben. ${ }^{387}$ E megállapítással a bíróság kifejezetten arra az álláspontra helyezkedett, hogy a képmáshoz való jog nem a magánélethez való jog egy megnyilvánulása, hiszen akkor a képmáshoz való jog sérelme esetén a magánélethez való jog sérelme is megvalósulna.

Ezt az álláspontot támogatja Navratyil Zoltán is, aki a névjog és a szólásszabadság viszonyrendszerében a névjog tágabb felfogását képviseli. Szerinte a névjog sérelme valósul meg mint mögöttes sérelem akkor, ha (1) balesetek, büncselekmények áldozatainak nevét hozzák nyilvánosságra, (2) egy személyt név szerint megjelölnek egy korábbi büncselekményével kapcsolatban, (3) egy személy téves beazonosítása esetén, (4) más módon kerül valaki beazonosításra nyilvánosan, (5) egy személy életképe bemutatása, megsértése esetén, (6) a név kereskedelmi célú jogellenes felhasználása esetén. ${ }^{388} \mathrm{Ez}$ a rendszerezés Koltay Andrásnak a személyazonosság felfedésének mint a magánszféra megsértésének rendszerezését követi, amelyet Navratyil a névre vonatkoztatva egészít ki. ${ }^{389}$ A névjog tág felfogása arra vonatkozik, hogy a névjog azáltal is megsérthető, ha valakit jogosulatlanul megneveznek, vagy a nevét jogosulatlanul felfedik. ${ }^{390}$ Az ezzel összefüggő esetkörök, életviszonyok azonban más személyiségi jog sérelmével is kapcsolatba hozhatóak, és kifejezetten alkalmasak arra, hogy a névjogot, legalább bizonyos vonatkozásban, a magánélethez való jog ernyője alá vonják. Ebben a tekintetben fel kell hívni a figyelmet arra, hogy ezzel tulajdonképpen mind a névjog, mind a magánélet sérelme

\footnotetext{
385 GÖRÖG, 2016. 63.

${ }^{386}$ Fővárosi Ítélőtábla 1. Pf. 20. 780/2015/6/II.

${ }^{387}$ Győri Ítélőtábla Pf. I. 20.081/2015/3/I.

388 NAVRATYIL, 2015. 19-20.

389 NAVRATYIL, 2015. 19; KOLTAY ANDRÁs: A szólásszabadság alapvonalai. Századvég, Budapest, 2009. 468.

390 TÖRÖ, 1979. 336; NAVRATYIL, 2015. 44.
} 
megállapítható a személyiségi jogon belül ugyanazon jogsértő magatartás vonatkozásában, annak ellenére, hogy nem különíthetőek el az egyes jogtárgyakat sértő cselekményeket.

Én korábban arra az álláspontra helyezkedtem a fent említett (5) esetkör, az életkép tekintetében, hogy a névjog kizárólag az összetéveszthetőség ellen véd, a jogosulatlan megnevezés ellen nem. ${ }^{391}$ Ezt az álláspontot látszik támogatni egyébként a névjog történeti fejlödése és bírói gyakorlata is. A névjog annak célja szerint a személyiség megkülönböztető képességét védi a név - és általában a szóbeli megjelölések - tekintetében, amelyet az összetéveszthetőség kiküszöbölésével ér el. A fent említett esetkörök közül e szükebb értelmezéshez kizárólag a név jogosulatlan kereskedelmi felhasználása kapcsolódik (6), amely a névbitorlás tényállása alapján bírálandó el. Ez az esetkör a később tárgyalandó jogellenes tárgyiasítás tipikus esete. A többi esetkör tekintetében a magánélethez való jog megsértése lehet releváns, illetve ha a tényállásban a magánéleti elem csökevényes vagy hiányos, úgy a személyiségi jog más irányú megsértése. ${ }^{392}$

5. Külön törvény a magánélethez való jogról

A magánéletről szóló törvény a kibontakozáshoz való jog részének tekinti a magánélethez való jogot ${ }^{393}$ azzal, hogy e jog céljának különösen a névviseléshez való jog, a személyes adatok, a magántitok, a képmás és hangfelvétel, a becsület és a jó hírnév védelmét tekinti. ${ }^{394}$ Ezzel a törvény elég érdekes álláspontra helyezkedik, különösen, ha a Ptk.-val együtt értelmezzük azt. Eszerint a személyiségi jogok az emberi méltóságból fakadnak, innen fakad a magánélethez való jog is. A magánélethez való jog ugyanakkor a kibontakozáshoz való jog része. A kibontakozáshoz való jog része minden más személyiségi jog is. Az emberi méltóság és a kibontakozás jogába tartozó egyes, egymást átfedő személyiségi jogosultságok ugyanakkor a magánélethez

\footnotetext{
391 SCHULTZ MÁRTON: Valós alakok megjelenitése szerzői müvekben: névoltalom, életképoltalom vagy a magánszféra oltalma? Jogösszehasonlitás a magánszféra védelmének elméleti és gyakorlati kérdéseiről. In: Görög Márta - Menyhárd Attila - Koltay András (szerk.) A személyiség és védelme: Az Alaptörvény VI. cikkelyének érvényesülése a magyar jogrendszeren belül. Budapest: ELTE ÁJK, 2017. 65-82.

392 A szerzői név tekintetében a névbitorlás megsértésének kizárására 1. SCHULTZ MÁRTON: $A$ névbitorlás egyes kérdései, különös tekintettel a szerzői név bitorlására. Doktori Mühelytanulmányok, 2017. 320.

393 2018. évi LIII. tv. 2. § (1) bek.

394 2018. évi LIII. tv. 8. § (1) bek.
} 
való jog által (is) védelemben részesülnek. Ez alapján úgy tünik a magánélet, a kibontakozás és az emberi méltóság triászát az alkotmánybírósági gyakorlatnak megfelelően egyfajta szinonimaként kezeli a törvény. ${ }^{395}$ A magánélethez való jogot ennek ellenére a Ptk. az emberi méltósághoz viszonyítva, ${ }^{396}$ a törvény a kibontakozás jogához viszonyítva tekinti szükebb jogosultságnak. ${ }^{397} \mathrm{Az}$, hogy a magánélet specialitása e másik két joggal szemben miben jelentkezik, a törvény nem válaszolja meg, a magánélet fogalmával adós marad. A törvény szerint a magánélethez való jog lényege, hogy azt az egyén akarata ellenére mások ne sérthessék meg, ${ }^{398}$ ez azonban nem ad választ a jog tartalmára, csak arra mutat rá, hogy a magánélethez való jog magánjogi alanyi jog, hiszen minden abszolút jognak ez a lényege.

\section{A magánélethez való jog leszükítő értelmezése}

A magánélethez való jognak ez, az ember, a magánosok személyes viszonyait tágabb körben átölelő védelmi köre nem vezethet oda, hogy minden eddig nem nevesített személyiségi jogsértést alávonjanak, hiszen akkor a genus proximum, az általános személyiségi jog szerepét venné át, amely által az ki is üresedne. ${ }^{399}$ Egyes, bizonyos, a Ptk.-ban is nevesített személyiségi jegyek, amelyek a joggyakorlatban is hosszú múltra tekintenek vissza, a magánélethez való joggal kisebb-nagyobb mértékü átfedésbe kerülhetnek a védett jogtárgyuknál, személyiségi vonatkozásuknál fogva. Ez az átfedés tulajdonképpen mind a magánélet, mind a más nevesített jogok felé elhajlíthatja a jogértelmezést. Meglátásom szerint elsősorban olyan tényállások vonandóak a magánélethez való jog megsértése körébe, amelyek a személyiségi szférát átfogóan, több tényezőre kiterjedően érintik és sértik, hiszen azok a személyiségi vonatkozások, amelyek esetlegesen a magánélet egy részét jelenthetnék, már kikristályosodtak az ítélkezési gyakorlatban. A magánélethez való jog mint magánjog lényegében tehát azokat az adatokat, információkat fogja át, amelyek közzététele és nyilvánosságra hozatala az általános élettapasztalat szerint a jogosult érdekkörébe tartozik. Abban az esetben, ha az adat, információ más személyiségi jog

\footnotetext{
395 8/1990. (IV. 23.) AB határozat.

${ }^{396}$ Ezt a Ptk. párhuzamosan, két helyen is megteszi: $2: 42$. $\S$ (1) bek. és $2: 43$. $\S$ b) pont.

397 2018. évi LIII. tv. 2. § (1) bek.

398 2018. évi LIII. tv. 8. § (2) bek.

${ }^{399}$ Hasonlóan GÖRÖG MÁRTA: A know-how jogi védelmének alapvető kérdései. HVG-ORAC, Budapest, 2012. 48.
} 
formájában jelenik meg (pl.: képmás formájában), úgy az elsőbbséget élvez többlettényállási elem hiányában. A magánélet védelméröl szóló törvény ezt a többlettényállási elemet a nevesített személyiségi jogok „magánélettel kapcsolatban” való megsértéseként szabályozza. ${ }^{400}$

\section{Kibontakozás}

\section{A kibontakozás jelentéstartamai}

A kibontakozásnak számos megfogalmazása van, a Ptk. mint a személyiség érvényesítését említi, a svájci ZGB személyes viszonyokról beszél, a német Alaptörvény a személyiség szabad kibontakozásáról, az Alkotmánybíróság általános cselekvési szabadságról rendelkezik. A kibontakozás joga profán megfogalmazásban annyit tesz: mindenki azt csinál, amit akar. Kant úgy fogalmaz, hogy „,cselekedj úgy, hogy önkényed szabad használata bárki szabadságával általános törvény szerint férhessen össze, kötelezettséget támaszt ugyan velem szemben, de a legcsekélyebb mértékben sem várja el, még kevésbé követeli meg, hogy teljességgel e kötelezettség kedvéért magam korlátozzam szabadságomat a fenti feltételek szerint." ${ }^{401}$ Lényegében ez a gondolat ölt testet a személyiségi jog szabályozásában, mintegy a tulajdonjog analógiájára egyfajta „személyi jogi szomszédjogi klauzulaként”. A ZGB 28. cikkének eredeti szövege a következőképpen fogalmazta meg az alanyi jogot: ,,akit személyes viszonyaiban jogellenesen megsértenek, a zavarás abbahagyását kérheti." ${ }^{402} \mathrm{~A}$ személyes viszony tulajdonképpen a nem vagyoni javakat, érdeket jelenti. ${ }^{403} \mathrm{~A}$ személyes viszonyok ennél fogva, különösen a vagyoni javakkal szembeállítva, jelentik a testi-lelki és szociális egyéniség védelmét, azaz az önmeghatározást. ${ }^{404} \mathrm{~A}$ méltóság joga a német személyiségvédelemben is a személyiség belső magvára szükül. A jogirodalom is kiemeli, hogy a személyiségi védelem alapja az általános cselekvési szabadság, azaz a személyiség szabad kibontakozásához való jog. ${ }^{405}$ A kibontakozást

\footnotetext{
400 2018. évi LIII. tv. 2. $\S$ (1) bek.

${ }^{401}$ KANT, IMMANUEL: Az erkölcsök metafizikája. Gondolat, Budapest, 1991. 326.

402 ZGB 28. cikk

403 MESZLÉNY, 1909. 143-144.

${ }^{404}$ EGGER, 1930. 242.

405 GöttING in: Götting/Schertz/Seitz, Handbuch des Persönlichkeitsrechts, § 1 Rn. 3.; BGHZ 26, 349. - Herrenreiter; BVerfGE 49, 286, 298
} 
mint a személyiségi jog alapját több magyar szerző is magáénak vallja. Törö Károly a személyiség megvalósítását, érvényesítését és kibontakozását emeli a védelem középpontjába. ${ }^{406}$ Petrik Ferenc a személyiséget egyfajta értékminőségnek tekinti, amely az önmegvalósításának feltételeit tartalmazza. ${ }^{407}$

A kibontakozás tehát jelenti mindazon érdekeket, viszonyokat és helyzeteket, amelyek nem részesei a vagyoni forgalomnak, és nem egy más személyhez való viszony szabályozására irányulnak. Ennél fogva a kibontakozás joga magában foglalja a jogalany minden egyéni és társadalmi valóságában foglalt érdekét és jogosultságát. A kibontakozás joga tehát nem szükül az ember méltóságára, az „emberi minimumra”, sem a magánéletére, azaz azon viszonyaira, amelyekből az egyén a nyilvánosságot kizárni törekszik. A kibontakozás jogának, azaz az általános cselekvési szabadságnak ez a definiálása alkalmas arra, hogy ne szükítse le a személyiség védelmét tartalmilag, hanem minden nem vagyoni, személyi alanyi jog szabályozási köre alá tartozzon. Sőt a nem vagyoni vonatkozások védelme nem kizárólagos. Ha a személyiség kibontakozása vagyoni érdekekkel fonódik össze, úgy ezek védelmére is alkalmas a kibontakozás. Dezső is felhívja a figyelmet arra, hogy a személyi és vagyoni viszonyok közötti elhatárolás inkább elméleti, dogmatikai jelentőségü, a gyakorlatban ezek azonban keverednek. ${ }^{408}$ Ezt az elvet viszi keresztül a Ptk. a 2:42. § (1) bekezdésben, amikor a személyiség szabad érvényesítéséről beszél. A kibontakozás jogának magánjogi személyiségvédelmi jogalappá emelése számos olyan problémát felold, amelyre az emberi méltóság alapú védelem hosszú távon nem képes: a jogi személy személyiségvédelme elvi alapjának ellentmondásait, a vagyoni értékü személyiségi jegyek dogmatikai alapját, a kellő érdekmérlegelést az emberi méltósággal rendelkező természetes személyek és az ezzel nem rendelkező jogi személyek közötti jogvitákban. 409

2. A polgári jogi jogképesség mint genus proximum

A polgári jogi jogviszonyok, így a személyiségi jogi jogviszony alanya is csak az lehet, aki polgári jogi értelemben jogképességgel rendelkezik. Ez így mind a jogi,

\footnotetext{
406 TÖRÖ, 1979. 35, 50.

${ }^{407}$ Petrik Ferenc: I. Fejezet. A személyiségi jogok vázlata. In: Petrik Ferenc (szerk.): A személyiség jogi védelme. KJK 1992. 18.

408 DEZSÖ, 1917.

${ }^{409}$ Erről részletesen SCHULTZ, 2016. 685, 693.; KOLTAY, 2017. 267, 295.
} 
mind a természetes személyeket megilleti. A jogképesség a jogi személyek esetében csökkent mértékben érvényesül, tekintve hogy másodlagos jogalanyok, „célszemélyek”. Ezzel van összhangban a Ptk. 3:1. § (3) bekezdése is, ami a személyiségi jogok vonatkozásában konkretizálja a jogképességet. A Ptk. a személyhez füződő jogok helyett az 1928-as Mtj.-vel ${ }^{410}$ azonos módon a személyiségi jogok kifejezést használja az embert megillető személyiségi jogra, a jogi személyek esetén pedig, az 1959-es Ptk. fogalomhasználatát megtartva, személyhez füződő jogokként nevesíti az e körbe tartozó jogokat. ${ }^{411}$ Görög Márta szerint a jogi személyek jellegüknél fogva nem lehetnek egyes személyhez füződő jogok hordozói, mert nem rendelkeznek emberi méltósággal. A jogi személynél, álláspontja szerint a személyiség hiányzik, ezért személyiségi jogi jogalanyiságuk ,jogi nonszenszhez vezetne”: csak személyhez füződő jogaik lehetnek. ${ }^{412}$ Egy másik álláspont szerint a jogi személyek is bírnak személyiségi jogokkal, s ebben a viszonylatban a két fogalom szinonimaként jelentkezik. ${ }^{413}$ Egy harmadik álláspont nem a jogalanyok, hanem a jog tartalma szerint különbözteti meg a két jogot: személyiségi jognak nevezi azon jogokat, amelyek mind természetes, mind jogi személyeket is megilletnek. ${ }^{414}$

\section{A személyiségi jog}

1. Az általános személyiségi jog jogtechnikai funkciója

A személyiségi jog magánjogi védelme jogtechnikai megoldásának több lehetősége van. A szabályozás kezdetleges jellegéhez kapcsolódóan kiemelhető az a megoldás, amely a személyiséget egyáltalán nem vagy csupán más szabályozások által közvetve védi. Az angol jogban a privacy híján különböző tortok által biztosítottak védelmet a személyi érdekeknek, mint amilyen a trespass, nuisance. ${ }^{415} \mathrm{~A}$ kontinentális jogrendszerekben viszonylag hamar egyértelművé vált, hogy a személyiség védelme tekintetében - függetlenül attól, hogy mit tekintünk az alapjának -, az egyes nevesített

\footnotetext{
${ }^{410}$ Mtj. 107. $\S$

${ }^{411}$ Ptk. 3:1. § (3) bek.

${ }^{412}$ GÖRÖG, 2011. 570.

${ }^{413}$ SZÉKELY LÁSZLÓ: Személyiségi Jogok, in: Vékás Lajos - Gárdos Péter (szerk.): Kommentár a Polgári Törvénykönyvhöz, Wolters Kluwer, Budapest, 2014.

${ }^{414}$ LEKOVICS BARNABÁS - KESERÜ BARNA ARNOLD: Általános rész. In: Lenkovics Barnabás - Keserü Barna Arnold - Köhidi Ákos: Polgári jogi alapok. ELTE Eötvös, Budapest, 2018. 40.

415 BEVERLEY-SMITH - OHLY - LUCAS-SCHLOETTER, 2005. 80.
} 
jogokon túl szükséges egy bizonyos általános védelmet adó jogosultság, amely a személyiségbe történő bármely jogellenes behatás ellen véd. A személyiségi jogok teljes körü felsorolására való törekvés elenyészően jelenik meg a jogirodalomban, ${ }^{416}$ ehelyett egy nyitott törvényi tényállás formájában kerül megkonstruálásra a védelem. A személyiség védelmének szabályozási modelljei így ennél fogva ezen általános kerettényállás jogtechnikai müködési mechanizmusa tekintetében mutatnak fel eltérő jelleget. Ebből a szempontból a svájci modell és a német modell az, amelyek a fő csapásokat kijelölik. A magyar alapvetően a svájci modifikált változata, míg az osztrák személyiségvédelmi rendszer lényegileg német alapú. Ettől eltérő a lengyel modell, amely nem ismer generálklauzulát, csupán különös személyiségi jogokat. ${ }^{417}$

A svájci modellben az egyes személyiségi jogi tényállások közötti kollíziók pusztán törvényi (eszmei) halmazatot képeznek, addig a német modellben - abból eredően, hogy a személyiségi jogi kodifikáció fejlődése megakadt - a különös személyiségi jogok és az általános személyiségi jog között igényhalmazat keletkezik. Ezt a generálklauzulát hívja a svájci jog és a régebbi magyar jogirodalom személyiségi jognak, a német jog pedig a korábbi, részleges védelmet nyújtó különös személyiségi jogokkal szembeállítva általános személyiségi jognak. A svájci jogban az „általános” jelzőre pontosan azért nem volt szükség, mert azt más személyiségi vonatkozástól nem kellett elhatárolni, annak általánosságát külön nem kellett hangsúlyozni, az a tényállásból egyértelműen következett. Az általános személyiségi jog fogalma csak a rendszerváltozás környékén jelenik meg a magyar jogban a német alkotmánybírósági joggyakorlat hatására. A dolgozat a személyiségi jog elnevezést használja a magyar jog tekintetében, az általános személyiségi jogot akkor, ha az más személyiségi réteghez való viszonyában jelentkezik (pl.: szerző személyhez füződő jogai, a vagyoni személyiségi jog), ha a német védelemről esik szó, illetve az alapjogi védelem esetén.

2. A német modell: az általános személyiségi jog

A német pozitív jogban nem lelhető fel egy általános személyiségi jogi generálklauzula. A BGB a névjogot, a KUG a képmáshoz való jogot nevesíti. E két jog esetében a német jogalkotó az érdekmérlegelést a törvényi szabályozás által a

\footnotetext{
${ }^{416}$ LADÁNYI BÉLA: A személyiség védelme. Jogállam 1904. 372.

417 TARGOSZ, TOMASZ: $§ 66$. Polen. In: Götting, Horst-Peter - Schertz, Christian - Seitz, Walter (szerk.): Handbuch des Persönlichkeitsrechts. C.H.Beck, München, 2008. 1118.
} 
tényállásban már elvégezte, így a bíró mozgástere kisebb, szemben az 1954-ben elismert általános személyiségi joggal, ahol az érdekek közti mérlegelés a blankettaszabály ${ }^{418}$ okán nagyobb. ${ }^{419}$ Az általános személyiségi jog önálló alanyi jogként való elismerése eredményeként ezek a speciális, törvényi személyiségi jegyek (illetve a szerző személyiségi jogai, az Urheberpersönlichkeit vonatkozásában személyiségi réteg) elsőbbséget élveznek az általános személyiségi joggal szemben. A személyiségvédelem e megosztottságának az az eredménye, hogy - mivel a névjog a halállal megszünik, ${ }^{420}$ és ezért post mortem védelemben nem részesülhet -, erre csak az általános személyiségi jog sérelmének megvalósulásával van lehetőség. ${ }^{421} \mathrm{E}$ korábbi, nevesített személyiségi jogok tehát a német jog védelmét bizonyos irányban megbontják. A BGH az általános személyiségi jog alanyi jogán belül esetcsoportokat ismert el, és a jogirodalom is ezek alapján az csoportok alapján kezeli ezt az egységes jogot. ${ }^{422}$ Mint arra rámutattam, a BGH az általános személyiségi jog elismerése óta számtalan döntésében hajlott arra, hogy mind a tényállási oldalon, mind a jogkövetkezményi oldalon, ha valamely különös személyiségi jog értelmezése is lehetséges lett volna, úgy az általános személyiségi jog alkalmazási eseteinek körét bővítette, illetve inkább analógiát alkalmazott, hogy az általános személyiségi jog alkalmazása és legitimációja kellő mértékben meg tudjon valósulni.

4. A svájci modell a magyar jogban

A magyar magánjogi kodifikáció szempontjából a jogirodalom általánosságban véve egy átfogó védelem mellett tett javaslatot. A jogalkotás nem egyes kiforrott személyiségi jogok védelmére koncentrált, ${ }^{423}$ hanem az átfogó és egységes védelemre, az álláspontok ugyanakkor eltértek. Míg Bozóky elmélete alapvetően a német jogirodalom által kimunkált általános személyiségi jog müködési mechanizmusát

\footnotetext{
${ }^{418}$ Mivel a német magánjogban az általános személyiségi jog mint alanyi jog a BGB-ben nem szerepel, hanem annak létét a BGH ismerte el, így nincsen a jogalkotó által meghatározott konkrét tartalma sem. A bírói gyakorlat az általános személyiségi jogot a személyiség szabad kibontakoztatásához való alkotmányos alapjogból (GG 2. cikk) és az emberi méltósághoz való jogból (GG 1. cikk) vezette le. A személyiség szabad kibontakoztatásának magánjogi tartalma minden esetben a bíróságok jogértelmezési tevékenységével kerül az egyedi esetben megállapításra, ök töltik ki tartalommal e blanketta-szabályt.

${ }^{419}$ BGHZ 13, 334 - Leserbrief.

${ }^{420}$ BGH NJW 2007, 648.

${ }^{421}$ BGHZ 107, 384 - Emil Nolde.

${ }^{422}$ Erman/ KLASS, BGB, 13. Aufl., Anh $\S 12$ Rn. 24.

${ }^{423}$ A Máptk. még ezt az álláspontot foglalta el, majd az 1914-es Tervezet már a svájci eredményeket alapul véve általános védelmet sürgetett, azóta ez az álláspont állandó és töretlen a mai napig.
} 
követte, ${ }^{424}$ addig Balás egy egységes, általános generálklauzulaként fogta fel minden jog védelmét a svájci modellhez hasonlatosan. ${ }^{425}$

A személyiségi jog bizonyos tényállások tekintetében történő bírói elismerésének megjelenésekor alanyi jognak a kir. Kúria egyértelmüen a személyiségi jogot tekintette, amely az ítéletek megfogalmazásából egyértelműen kitűnik. A személyiségi jogból következik a névhez való jog, más megfogalmazásban a névviselésben gyökerező személyiségi jog. ${ }^{426}$ Elvi éllel mondta ki azt is a Kúria, hogy a személyiség jogához tartozik az adományosnak az az igénye, hogy az ő részére adományozott érmeket és kitüntetéseket más ne használja. ${ }^{427} \mathrm{Az}$ egységes svájci modell magyar jogirodalomból történő bírói átvételét mutatja a szerző személyiségi jogával való kollízió értelmezése: ,akinek nevét beleegyezése nélkül oly művön tüntetik fel szerzőként, mely nem az ő szerzeménye, az általános magánjog alapján személyiségi jogának jogellenes megsértése címén léphet fel" ${ }^{428}$ Hasonlóan fogalmaz a Kúria a jogkövetkezményi nézőpontból is: „ez az elégtétel annak kimondásában is állhat, hogy a panaszolt szövegrész a kereskedőnek (gyárosnak) személyiségi jogát sérti”. ${ }^{429}$ Görög Márta szerint az egyes személyiségi vonatkozások személyiségi jogokként való nevesítése elsősorban jogtechnikai szemszögből bír jelentőséggel, ${ }^{430}$ amely által a személyiségi jog egységes jellege nem kerül megbontásra.

Az 1959-es Ptk. vizsgálata alapján arra juthatunk, hogy ez szintén egységes jognak tekintette az ún. „személyhez füződő jogokat”. Ugyan a törvény többes számban beszél erről a jogosultságról, ugyanakkor a jogi norma megfogalmazásából arra következtehetünk, hogy a Ptk. kodifikátorai az egységes alanyi jogi modell (azaz a svájci modell) alapulvételével alakították ki a személyiség polgári jogi védelmének szabályait.

\section{1. § (1) A személyhez füzödö jogok a törvény védelme alatt állnak.}

${ }^{424}$ BOZÓKY, 1905. 455.

${ }^{425}$ BALÁs, 1941. 631.

${ }^{426}$ BODA, 1930. 48.

427 U.o.

428 BODA - MESZLÉNY, 1934. 64.

${ }^{429}$ K. I. 8640/1930. (,Chanel nyolc“)

${ }^{430}$ GÖRÖG MÁRTA: A személyiség védelme a jó hírnév és a becsület vonatkozásában. In: Csehi Zoltán, Koltay András, Navratyil Zoltán (szerk.): A személyiség és a média a polgári és a büntetőjogban. Wolters Kluwer, Budapest, 2014. 146. [GöRÖG, 2014a] 
Az 1959-es Ptk. e megfogalmazása egyértelműen alanyi jogi jellegü, önálló jogi norma, amely kifejezésre juttatja azt a gondolatot, hogy a személyiségi jogokat a (polgári) jog elismeri, és azok megsértése esetére védelmet nyújt, jóllehet azt máshol mondja meg, hogyan. A norma ugyanakkor nagyon szükszavú, nem definiál, azt is mondhatjuk, hogy az alanyi jog biztosításának egyik legfrappánsabban semmitmondó kodifikációs technikájával élt a jogalkotó. Erre nyilvánvalóan azért volt szükség, mert a személyiség tejes körü, átfogó jellegü tartalmi definiálása szinte majdhogynem lehetetlen. E normából azonban nem állapítható meg, milyen modell szerint müködik az alanyi jogi rendszer, ehhez más normákat kell segítségül hívnunk:

82. § (1) A személyhez füzödő jogok körében védelem alatt áll az állampolgárok és a jogi személy joga a névviseléshez; e jog sérelmét jelenti különösen, ha valaki jogosulatlanul más nevét vagy máséhoz hasonló nevet használ.

(2) A személyhez füzödö jogok védelme kiterjed a jó hírnév védelmére is.

Érdekes megfigyelni a Ptk. megfogalmazását. Nem azt mondja ki, hogy a névviseléshez való jog is személyhez füződő jog, hanem, hogy e ,jogok körében” áll védelem alatt. Hasonló a helyzet a jó hírnév esetén is. Egyértelművé teszi azonban az osztályozást a képmáshoz való jog:

83. § (2) A más képmásával vagy hangfelvételével való visszaélés [...] a személyhez füzödö jogok megsértését jelenti.

Itt a törvény nem a képmáshoz való jog megsértéséről beszél, hanem az ún. „személyhez füződő jogok” megsértéséről, azaz nem konstruál önálló alanyi jogi létet a képmáshoz való jognak, nem tekinti azt különös személyiségi jognak. A törvényhely megfogalmazása egyértelműen arra utal, hogy itt egy önállótlan magyarázó normával állunk szemben. Ez pedig azt igazolja, hogy a személyhez füződő jogok védelmét egy alanyi jog keretében rendezte a jogalkotó, azzal ugyanakkor zavart okozott, hogy a törvényszöveg szintjén ezen egy alanyi jogot személyhez füződő jogok elnevezéssel illette. Ehhez valószínűleg köze volt annak, hogy el kívánták kerülni a kodifikáció során a burzsoá személyiségi jog terminus használatát. 
6. A félig zárt generálklauzula modellje

Az 1977-es Ptk. novella volt az, amely a hagyományos, egységes alanyi jogi jellegtől elmozdult. A változás nem is elsősorban a törvényi megfogalmazásban jelentkezett, hanem az ahhoz kapcsolódó jogirodalomban. Törö Károly ugyanis félreértelmezi a generálklauzula és a nevesített jogok viszonyát, és fordított logikát alkalmaz, a konkrétra fókuszál az absztrakt helyett. Törö szerint „a Ptk. 75. §-ának az (1) bekezdésében foglalt általános személyiségvédelmi szabály [...] az egyes személyhez füződő jogokra vonatkozó különös rendelkezések kiegészítését jelenti." ${ }^{431} \mathrm{Az}$ általános szabály logikailag ugyanakkor nehezen egészíthetne ki egy különös szabályt, annál fogva, hogy a különös szabály - tehát az egyes nevesített jogok - differentia specificája többletelemet tartalmaz, és az általánost magában kell foglalnia. Az 1959es Ptk. eredeti szövege által elöirányzott védelemhez akkor juthatunk vissza, ha a szabályt megfordítjuk, és azt mondjuk, az egyes személyhez füződő jogokra vonatkozó különös rendelkezések az általános személyiségvédelmi szabály kiegészítését jelentik. Ezzel a megfogalmazással nyer ugyanis értelmet az a norma, hogy „,a személyhez füződő jogok védelme kiterjed a jóhírnév védelmére is.”432 Ez a norma támogatja ugyanis az általános szabályt, és nem fordítva.

Ez azonban azt is jelenti, hogy Törő az egyes személyiségi jogokat emeli a védelem középpontjába, azok megsértését látja - Bozókyhoz hasonlóan megállapítani. Ez ki is tünik személyiségvédelmi felfogásából, hiszen a személyiségi jog keretszabályának alkalmazási körét nem tárgyalja kimerítően, csupán az egyes nevesített jogok megsértését. Kiemeli emellett azt is, hogy a régi Ptk. nemcsak, hogy külön szabályozza a nevestett személyiségi jogokat (ezt teheti önállótlan jogi norma keretében is), hanem külön védi az általános személyiségi jog mellett. ${ }^{433}$ Ezzel lényegében egy, a német jog szabályozása során bemutatott modellben képzeli el a személyiségi jog védelmének müködését, amelyben az általános és a különös személyiségi jogok eltérő alanyi jog keretében, eltérő tényállással, és (elméletileg) eltérö jogkövetkezményekkel bírnak.

Jóllehet az 1959-es kodifikáció a svájci modell szerinti megoldást irányozta elő, mint ahogy az a törvényszerkesztésböl kitünik, ennek ellenére ez nem tisztán

\footnotetext{
431 TÖRÖ, 1978.984.

432 1959. évi IV. tv. 78. § (1) bek.

${ }^{433}$ TÖRÖ, 1979. 59.
} 
érvényesül, hanem a joggyakorlat - és azt követően a jogelmélet is - a sokkal konkrétabb nevesített személyiségi jogok felé fordult. Ez a fordulat ugyanakkor mégsem úgy történt, mint Németországban, tehát nem arról volt szó, hogy a nevesített személyiségi jogok után mögöttesen kialakult egy joggyakorlat a személyiségvédelem általános szabálya vonatkozásában is. Ennek oka lényegében abban keresendő, hogy a jogalkotó 1977-ben beavatkozott a pár személyiségi jogot taglaló törvénybe, és újakat épített bele, amelyek alkalmazásának esetkörét ezek specifikációjával a generálklauzula alól kivonta. A Novella miniszteri indokolása is kiemeli, hogy a névjog kiterjesztésére a gyakorlati tapasztalatok miatt került sor, az adatnyilvántartással kapcsolatos személyiségi jogi rendelkezéseket pedig azért nem szabályozták korábban, mert a számítógép használata még nem terjedt el. ${ }^{434}$ Ezzel a megoldással ugyanakkor azt érte el a jogalkotó, hogy az egyes törvényhelyek értelmezése helyett a jogalkalmazó a speciális rendelkezések felé forduljon a sérelem megállapításakor. Ezzel lényegében de facto azt érte el, hogy a régi Ptk. 75. §-a nem került alkalmazásra, lévén túl általános és semmitmondó volt, és mintegy alanyi jogként a részletesebb, nevesített személyiségi jogi rendelkezések kerültek alkalmazásra. A nevesített személyiségi jogok lényegében valamennyi, gyakorlati életben felmerülő jogsértést lefedtek, és nem volt akkora hiátus, mint Németországban, ahol majd' az egész személyiségvédelmi joggyakorlat az általános személyiségi jogra épül fel. Ezzel a megoldással ugyanakkor a magyar magánjogi személyiségvédelem megragadt a svájci és a német modell között félúton. Ez a félig lezárt generálklauzula szerinti modell tehát elsősorban a nevesített jogokra koncentrál, mintegy külön alanyi jogként, jóllehet a törvény szövege ezeket a normahelyeket egyértelmüen önállótlan jogi normaként szabályozza. Ez azt jelenti, hogy a nevesített személyiségi jogok alkalmazási és szabályozási köre a személyiségi jogi generálklauzulára való hivatkozást szinte lehetetlené teszi. Erre csak akkor kerül sor, ha az adott történeti tényállás a jogérzet szerint bírói jogvédelmet igényel, amely azonban nem oldható fel a törvényi katalógussal, és így szubszidiárus jelleggel a generálklauzulához nyúl a bíró. Ez akkor valósul meg, ha valóban meg is állapítja a személyiségi jog sérelmét; abban az esetben, ha sem a nevesített személyiségi jogok, sem a generálklauzula nem adhat védelmet, csak a nevesített személyiségi jogokig jut el a szubszumcióban a bíró. Ebben az esetben tehát nem tekinti azt szubszidiáriusnak, jóllehet jogtechnikailag a

434 1977. évi IV. tv. miniszteri indokolása I. cím. 2.,3.,4. 
szubszumció szempontjából ezt a logikai kört is le kellene zárni, hiszen az alanyi jogi tényállás a személyiségi jog szabad érvényesülésére vonatkozik, nem az egyes személyiségi jogi tényállásokra. Ez lényegében azt jelenti, ha az életviszony a nevesített személyiségi jogok levizsgálása után nem vezet jogsértéshez, úgy nem vizsgálja külön a generálklauzula sérelmét, jóllehet az a generálklauzuláris védelemből nem csak akkor következne, ha erre alapozottan a jogsértés megállaptható lenne. Ez azonban hiányzik.

A német mintájú általános személyiségi jogi védelem tehát lényegében azért nem valósul meg, mert a generálklauzula alkalmazása esetleges, a svájci személyiségi jogi modell pedig azért nem, mert a jogalkalmazás a nevesített személyiségi jogokra koncentrál. A generálklauzula azért lesz félig lezárt, mert alkalmazására csak akkor kerül sor, ha a jogérzet a bírói jogvédelem egyértelmü megadását indukálja, ez azonban nem illeszthető a nevesített személyiségi jogok keretébe. ${ }^{435}$ Olyan fajta „általános személyiségi jogi aktivizmus”, amellyel Németországban találkozunk, nem jelent meg a magyar jogalkalmazásban. A törvényi védelem jellege éppen azon oknál fogva nem sorolható be egyik kategóriába sem, mert elméletileg egy jogot véd egy többesszámú elnevezés alatt, és ezzel a jogalkalmazást megzavarja, ezáltal ugyanis érthető ez egy jogként (svájci modell, nevesített személyiségi jogok), ${ }^{436}$ illetőleg több jogként is (általános személyiségi jogi modell, különös személyiségi jogok). ${ }^{437}$

A Ptk. a generálklauzula funkciójának erősítését célozta. ${ }^{438}$ Ezt tette egyrészről azzal, hogy valamennyi, a törvényben részletesen szabályozott személyiségi jogot a személyiségi jog megsértésének tekint, és ezzel kiemeli, hogy egy jog sérül: a személyiségi jog. 439 Másrészről az egyes nevesített személyiségi jogok

435 Pl.: „A gyógykezelő, gondozó tevékenység megválasztásánál és foganatosításánál megfelelő körültekintéssel és alapossággal kell eljárni. Ennek elmulasztása nemcsak a vonatkozó szakmai szabályoknak, hanem egyszersmind a személyhez füződő - a törvényben biztosított - jogoknak a megsértését is jelentheti.” BH 1982. 507.; „személyhez füződő jogokat sért a gyógyintézet, ha a beteg gyógykezelésével, mütétjével kapcsolatos okiratok kiadását megtagadja.” Legf. Bír. Pfv. IV. 20.895/1994.

436 Pl.: „A személyhez fúződő jogok megsértése megvalósulhat a képmás vagy hangfelvétel visszaéléssel történő elkészítésével is.” BH 1985. 57.; BH 1982. 507.; „Személyhez füződő jogokat sért a gyógyintézet, ha a beteg gyógykezelésével, mütétjével kapcsolatos okiratok kiadását megtagadja.” Legf. Bír. Pfv. IV. 20.895/1994.

${ }^{437} \mathrm{Pl}$.: „A felperes kifogásainak ez a része ezért nem lehet a személyiségvédelem alapja, mert a Ptk. 76. §-a nema büntetőeljárásra vonatkozó jogorvoslati eszköz.” Legf. Bír. Pf. IV. 21.274/1992.; „Nem jelenti a névviselési jog sérelmét az a magatartás, amihez a jogosult hozzájárult. A névhasználat átengedése más jogi személy részére ilyen esetben is megvalósítja a névviseléshez való jog sérelmét.” Pf. IV. 21007/1992. („Láng”).

438 SZÉKELY-VÉKÁS, 2013. 56.

${ }^{439}$ SCHULTZ, 2016. 690-691. 
megfogalmazását sem alanyi jogi formában tette meg. Ebben a tekintetben a Ptk. 2:42. $\S$ (1) bek. és a 2:42. § (2) bek. 1. mondatának viszonya okozhat zavart. A Ptk. ennek ellenére az egységes, svájci védelem mellett tett javaslatot. Erre utal az is, hogy a Ptk. 2:42. § (1) bekezdése közlönyállapot szerinti szövege megegyezik az 1914-es Javaslat generálklauzulájával, ami pedig a ZGB mintáját követte. Ezzel a jogalkotó lényegében Balás álláspontjával ért egyet, aki szerint „,nem beszélhetünk becsületjogról, hanem a személyiség oltalmáról a becsület vonatkozásában. ${ }^{440}$,

Ez már a korábbi bírói gyakorlaton tettenérhető. Példaként hozható a Pécsi Ítélőtábla egy döntése. „A bíróságnak gondosan, körültekintően és szabatosan, a kereseti kérelemmel és a tényállással összhangban kell megfogalmaznia érdemi döntését. Amennyiben a kereset személyhez füződő jog megsértésének megállapítására irányul, pontosan meg kell jelölnie, hogy mely magatartással melyik személyhez füződő jog megsértését állapította meg. A felperes keresetében a képmáshoz füződő személyiségi joga megsértését állította, az elsőfokú bíróság az indokolásban foglaltak szerint ezzel a tartalommal állapította meg a jogsértést. Az ítélet rendelkező része ennek ellenére általánosságban a személyiségi jog megsértését rögzítette." ${ }^{441}$ E szemléletet támogatja a Legfelsőbb Bíróság következő indokolása is: „a szépirodalmi alkotás tartalma, utalásai alapján felismerhető személy orvoslást kérhet, ha az ábrázolás személyhez füzödö jogait (hírnevét, becsületét, emberi méltóságát, magántitokhoz való jogát) sérti." ${ }^{442}$

A Kúria szerint a személyiségi jog megsértése esetén nem érvényesül a jogcímhez kötöttség. ${ }^{443}$ A Debreceni Ítélőtábla is hangsúlyozta, hogy a kereseti kérelemhez kötöttség csak a követelés alapjául szolgáló tényálláshoz kötöttséget jelenti, ezért az elsőfokú bíróságnak vizsgálnia kellett volna, hogy az alperes per tárgyává tett magatartása a névviselési jogon kívül sért-e más személyiségi jogot." ${ }^{444}$ A személyiségi jog alanyi jogi jellegéből következik az, hogy a történeti tényállás megállapítása tekintetében nem pusztán az egyes személyiségi jogi tényálláshoz kapcsolódó törvényi (jogi) tényállási elemek megvalósulását kell állítani, hanem mögöttesen a személyiség szabad érvényesítésének gátolását. ${ }^{445}$ Ez lényegében a

\footnotetext{
${ }^{440}$ BALÁS, 1941. 634.

${ }^{441}$ PÍT BDT 2017. 79. [15].

${ }^{442} \mathrm{BH} 1980.377$.

${ }^{443}$ BH 2014. 301. [12]. („Horthy Miklós és a zsidók”)

${ }^{444}$ DÍT BDT 2018. 87. [6].

${ }^{445}$ DÍT BDT 2018. 87.
} 
bizonyítás oldaláról bír relevanciával, és valószínüleg az anyagi pervezetéssel összefüggésben további fejlemények várhatóak a kérdésben.

A személyiségi joghoz kapcsolódó jogalkalmazásban a nevesített személyiségi jog és a generálklauzula közötti viszony tekintetében az álláspontok eltérőek, és azok explicit konkretizálására lenne szükség. Mint látható, a Kúria és a felsőbíróságok alapvetően az egységes alanyi jogi jelleg mellett foglalnak állást. Én ennek megfelelően a személyiségi jogi modell mellett foglalok állást, és az egyes nevesített személyiségi jogokat egy egységes alanyi jog részjogosultságának tekintem.

\section{A személyiségi jog igényváza}

1. Tényállás

A tárgyi jog a személyiség vonatkozásában teljesen általános, konkrétumot nem tartalmaz. A Ptk. csak annyit rögzít, hogy mindenkinek joga van személyisége szabad érvényesítéséhez, amelyben őt más nem gátolhatja. A személyiségi jog esetén nem egy tényálláselem a keretszabály, hanem az egész tényállás maga. Bizonyos tekintetben a jogalkotó a Ptk.-ban ezt konkretizálta, és meghatározott olyan tényállásokat, amelyek az alkalmazását segítik. Ezek a generálklauzula alkalmazási körébe eső önállótlan jogi normák, amelyek a személyiségi jog megsértése esetén az igény vizsgálata során elsőbbséget élveznek. A félig zárt generálklauzulát követő uralkodó álláspont ezeket nem a generálklauzula értelmezésének tekinti, hanem önállóan alkalmazandó normának.

Amennyiben ezek egyike sem valósul meg, úgy a bírónak egy további lépcsőfokot kell közbeiktatnia a szubszumcióban: az alanyi jog keretei között meg kell határoznia először azt a jogi tényekből álló rendelkezést, amely a személyiségi jog vonatkozásában releváns, és ezt alkalmazni a szubszumció során, mint a személyiségi jog generálklauzulájának egyik értelmét. Miután megfogalmazta ezt az absztrakt, de az alanyi joghoz képest konkrétabb tényállást, akkor kell összevetnie azt a történeti tényállással, s ehhez képest kell megállapítania, sérült-e a személyiségi jog a konkrét esetben. Ezt tette a Legfelsőbb Bíróság, amikor a személyiségi jog tartalmát a magánélet vonatkozásában egy eseti döntésében úgy határozta meg, hogy „,személyhez 
füződő jogot sért a magánéletbe való önkényes beavatkozás.” ${ }^{446}$ A bíróság itt nem a magánélethez való jog megsértéséről beszélt, hanem a személyhez füződő jog megsértéséröl. Ebben a tekintetben az önkényes beavatkozás tényállási elemét is konkretizálta, és ezáltal az esetnorma absztraktsági szintjét három fokra bontotta. Az a beavatkozás lesz önkényes, amely az érintett akaratával, szándékával kifejezetten ellentétes, és a beavatkozást a gondosan mérlegelt körülmények sem indokolják. 447

Itt, ahogy Szladits mondja, a jogszabály csak hézagos, és nem hiányos: „ezekben az esetekben a jogrendszerben bennrejlő, implikált szabályokról van szó, amelyeket a bírónak célszerüségi és igazságossági levezetés útján le kell fejtenie". ${ }^{448}$ Ennek során pedig a társadalmi szokásokból (a közmeggyőződésből), a magánjog alapelveiből kell kiindulnia (nem pedig egyes jogok sérelméből). Ez a módja annak, hogy a személyiségvédelem a korral lépést tudjon tartani, s mindig új szempontú védelmet tudjon beépíteni, illetve a régit a társadalmi elvárásokhoz alakítani, amely a személyiség jogának értő továbbfejlesztésén alapul.

\section{Jogellenesség}

Minden személyiségi jogot sértő magatartás jogellenes. Ez azt jelenti, hogy a személyiségi jog bármely megsértése indukálja a jogkövetkezmények alkalmazhatóságát. A tényállás lényegében magába foglalja automatikusan a jogellenességet is, az attól nem válik élesen külön. Hasonlóan a kártérítési igény vizsgálatához, a bizonyítási teher itt is tulajdonképpen fordított, és a másik félnek kell azt bizonyítania, hogy a személyiségi jogba történő beavatkozás nem volt jogellenes, így ez a tényállás megállapítása után külön lépcsőfokot képez ellenjog formájában. Az erre való felhatalmazást maga a generálklauzula tartalmazza, amikor kimondja, hogy törvény és mások jogainak korlátai között kell gyakorolni e jogosultságot. Ebben a vonatkozásban egyrészről a törvény külön nevesíti a hozzájárulást, másrészről a generálklauzuláris szabályozás miatt a tényállás teljesen üres, így az egyes jogok közötti érdek- és jogtárgymérlegelés az, amely a személyiségi jogba való beavatkozás jogellenességét kizárhatja. Fontos hangsúlyozni, hogy a mérlegelés nem a

\footnotetext{
${ }^{446}$ BH 2001.61.

447 U.o.

448 SZLADITS, 1941. 159.
} 
szükségesség-arányosság tesztje szerint jelenik meg, ${ }^{449}$ hanem az egyes jogtárgyak összemérése folytán. Ez a jogtárgy a generálklauzulából fakadóan lehet individuális, egyéni jogtárgy (más személyiségi joga) vagy lehet kollektív, általános jogtárgy (pl.: véleménynyilvánítás szabadsága). Így például a tüntetést biztosító rendőrök képmásának hozzájárulásuk nélkül, felismerhető módon való nyilvánosságra hozatala esetén a sajtószabadságnak a jelenkor eseményeiről, illetve a közügyekről való hiteles tájékoztatás alkotmányos jogának van primátusa a közszereplőnek nem minősülő rendőrök emberi méltóságából fakadó személyiségi jogával szemben. ${ }^{450}$

A tényállás nyitott jellege ugyanakkor ahhoz is vezet, hogy ez az érdekmérlegelés összemosódik a tényállással, így van ez különösen a közszereplés esetén, amely a személyiségi jog jogosultjának specifikációja okán zárja ki a jogellenességet. A „törvény” kitétel alatt érthető más jogszabály, illetve a Ptk. más normahelye is. Ilyen lehet a szülöi felügyeleti jog gyakorlása a gyermek nevének megválasztása során, ${ }^{451}$ illetve fiúgyermek vallási okból történő körülmetélése esetén a szülői felügyeleti jog. ${ }^{452}$ Hasonló, törvényi (alaptörvényi) érdeket képez a véleménynyilvánítás szabadsága, a müvészeti szabadság, a társadalom tájékoztatása az őt érdeklő eseményekröl. A tényállás és a jogkövetkezmény egybemosódása azért is jelentkezik, mert több ellenjog és ellenérdek is kapcsolódhat az adott tényálláshoz, amely a személyiségi jog jogosultja oldaláról szintén több körülménnyel ellensúlyozható, ez azonban azt feltételezi, hogy az eset körülményei ezekkel összemérésre kerüljenek.

A magánélet védelméről szóló törvény új szempontokat vezetett be az érdekmérlegelésbe. A közéleti szereplők tekintetében a személyiségi jogukba való behatások jogellenessége a magánszemélyekkel szemben sokkal kevesebb esetben állapítható meg, azon okból, mert ők e minőségüknél fogva a személyiségi jogukba való behatást nagyobb mértékben kötelesek türni. ${ }^{453}$ A közéleti szereplés értékelésének a tényállás vizsgálata után kell sorra kerülnie. Ehhez kapcsolódik a

\footnotetext{
${ }^{449}$ Ezt az álláspontot támogatta a Ptk. 2:44. §-ának közlönyállapot szerinti változata. Más esetben a Kúria is erre az álláspontra helyezkedett, amikor egy, az örökbefogadás megszüntetése tekintetében az örökbefogadott gyermek nevének továbbviselésének vizsgálata tekintetében a szükségességiarányossági tesztet idézte; BH 2012. 174. („Papp”).

${ }^{450}$ BH 2018. 248. („Rendvédelmi szakszervezetek tüntetése”).

${ }^{451}$ BH 2012. 174. (,Рapp“)

452 KÜPPER, HERBERT: A fiúk körülmetélése Németországban - egy „,bortányos “ itélet és annak orvoslára. JURA 2013. 2. szám 107.

${ }^{453}$ Ehhez 1. SÁRKÖZY SZABOLCS: Gondolatok a közéleti szereplők magánszférája fokozott védelmének szabályozásáról. Gazdaság és Jog 2018/10. 26.
} 
törvénynek az a szabálya, hogy a közéleti szereplő magán- és családi életét, valamint otthonát a magánszeméllyel (közéleti szereplőnek nem minősülő személlyel) azonos védelem illeti meg. ${ }^{454} \mathrm{Az}$ azonban már korábban, az is egyértelmü volt, hogy a közéleti szereplőt a magánélet védelme megilleti. ${ }^{455}$

3. A személyiségi jog megsértésének megállapítása során vizsgálandó jogi tények

A fent vizsgált körülmények figyelembevételével az 5. számú táblázat tartalmazza azokat körülményeket, jogi tényeket, amelyeket a bíróságnak a személyiségi jog megsértése esetén meglátásom szerint vizsgálnia kell.

\section{5. sz. táblázat}

Az általános személyiségi jog megsértésének vizsgálati igényváza

\begin{tabular}{|c|c|c|}
\hline & VIZSGÁLATI LÉPÉS & $\begin{array}{l}\text { MEGJELENÉS A TÁRGYI } \\
\text { JOGBAN }\end{array}$ \\
\hline 0. SPECIALITÁS & $\begin{array}{l}\text { Ha van olyan igény, amely a tényállás } \\
\text { specialitása folytán elsőbbséget élvez, } \\
\text { úgy azt kell korábban vizsgálni. Ha } \\
\text { annak feltételei nem teljesülnek, azután } \\
\text { vizsgálható a személyiségi jogi igény } \\
\text { megvalósulása. }\end{array}$ & $\begin{array}{l}\text { Ilyen lehet a jellegbitorlás, } \\
\text { védjegybitorlás, szerzői } \\
\text { jog bitorlása, tulajdoni } \\
\text { igények, családi jogi } \\
\text { igények, } 6: 519 . \S, 6: 579 . \S \text {, } \\
\text { utaló magatartás. }\end{array}$ \\
\hline \multirow[t]{3}{*}{ I. TÉNYÁLLÁS } & $\begin{array}{l}\text { 1. Az adott magatartás sérti a } \\
\text { törvényben felsorolt valamely } \\
\text { magatartást. VAGY }\end{array}$ & $\begin{array}{l}\text { pl.: jóhírnév [Ptk.2:42. § } \\
\text { (1) bek. és a Ptk. 2:45. § (1) } \\
\text { bek. együttes alkalmazása] }\end{array}$ \\
\hline & $\begin{array}{l}\text { 2. Az adott magatartás egyébként } \\
\text { sérti a személyiségi jogot (a } \\
\text { jogalkalmazó határozza meg a } \\
\text { zsinórmértéket). VAGY }\end{array}$ & $\begin{array}{l}\text { Ptk. 2:42. § (1) bek. } \\
\text { pl.: BH 2001. } 61 .\end{array}$ \\
\hline & $\begin{array}{l}\text { 3. A magatartás az emberi } \\
\text { méltóságot sérti, ekkor a II. } \\
\text { lépcső, a jogellenesség } \\
\text { vizsgálata kiesik. }\end{array}$ & \\
\hline II. JOGELLENESSÉG & $\begin{array}{l}\text { 1. A magatartás jogellenessége a } \\
\text { törvényben felsorolt kizáró } \\
\text { okok alapján nem zárható ki. } \\
\text { VAGY } \\
\text { 2. A magatartás jogellenessége } \\
\text { más jogszabályhely alapján } \\
\text { sem zárható ki. VAGY }\end{array}$ & $\begin{array}{lr}{[2: 42 . \S(1) \text { bek.] }} & \\
\text { A képmás } & \text { és } \\
\text { sajtószabadság } & \text { közötti } \\
\text { érdekmérlegelés } & \text { rendör } \\
\text { képmásának } & \\
\text { nyilvánosságra } & \text { hozatala } \\
\text { esetén. }{ }^{457} & \\
\end{array}$ \\
\hline
\end{tabular}

454 2018. évi LIII tv. 7. § (2) bek.

455 EJEB 2004. június 24., 59320/00 Caroline von Hannover v. Germany; MENYHÁRD ATTILA: $A$ magánélet védelme az Emberi Jogi Bíróság gyakorlatában. In: Görög Márta - Menyhárd Attila Koltay András (szerk.): A személyiség és védelme. ELTE ÁJK, Budapest, 2017. 56.

456 Összhangban a magánjogi emberi méltóság 3. §-ban meghatározott szerepével és helyével.

${ }^{457}$ BH 2018. 248. („Rendvédelmi szakszervezetek tüntetése”). 


\begin{tabular}{|c|c|c|}
\hline & $\begin{array}{l}\text { 3. A magatartás magánérdeket } \\
\text { vagy közérdeket sért. ÉS }\end{array}$ & \\
\hline & $\begin{array}{l}\text { 4. a másik személynek nincsen } \\
\text { erősebb magánérdeke, VAGY } \\
\text { 5. a személyiségi jogba való } \\
\text { behatás a közérdek által nem } \\
\text { igazolható. }\end{array}$ & \\
\hline III. FELRÓHATÓSÁG & $\begin{array}{l}\text { Csak akkor vizsgálandó, ha az adott } \\
\text { esetben alkalmazandó } \\
\text { jogkövetkezmény okán a felróhatóság } \\
\text { az igény megvalósulásának része. }\end{array}$ & 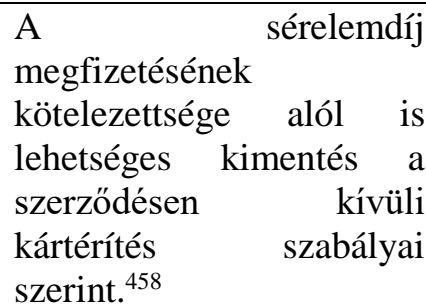 \\
\hline
\end{tabular}

(saját szerkesztés)

\section{Részösszegzés}

Az emberi méltóság és a személyiségi jogi generálklauzula közötti értelmezési ellentmondás tekintetében arra az álláspontra helyezkedtem, hogy a Ptk. 2:42. § (1) bekezdése az, ami legtágabb körben, általánosságban védi a személyes viszonyokat, és ez tekintendő alanyi jognak, jogalapnak. A 2:42. § (2) bek. 2. m. nem ad tartalmi meghatározást, s ennél fogva kevesebbet nyújt, ez a törvényböl elhagyható, hiszen ugyanezt a funkciót az elöbbi szakasz sokkal jobban el tudja látni. A kibontakozás és a méltóság viszonyában az emelendő ki, hogy a Ptk. 2:42. § (2) bek. 1.m. szerinti emberi méltóság egyfajta értelmező szabály, amely az ember személyiségi jogainak egyfajta mögöttes értékminősége, alapvető minimuma. Az emberi méltóság az ember személyiségi jogainak minimum mércéje, olyan érték, amellyel szemben mások jogainak és érdekeinek minden esetben meg kell hajolnia, amely esetén nincs érdekmérlegelés. Ha ezt elfogadjuk, úgy a Ptk. 2:44. §-ával összhangban értelmezhető a Ptk. 2:42. § (2) bek. 1. mondata is, amely az emberi méltóságot egy korlátozhatatlan jogként írja le.

A magánélethez való jog védelmi köre nem terjedhet ki arra, hogy minden eddig nem nevesített személyiségi jogsértést alávonjanak, hiszen akkor az általános személyiségi jog funkciójába lépne. Meglátásom szerint elsősorban olyan tényállások tartoznak a magánélethez való jog megsértése körébe, amelyek a személyiségi szférát átfogóan, több tényezőre kiterjedően érintik és sértik. A magánélethez való jog mint

${ }^{458} \mathrm{BH} 2018.141$. 
magánjog lényegében tehát azokat az adatokat, információkat fogja át, amelyek az általános élettapasztalat szerint a jogosult érdekkörébe tartoznak, és amelyeket magának megtarthat, rendelkezhet arról, hogy kivel ossza meg azokat. Abban az esetben, ha az adat, információ más személyiségi jog formájában jelenik meg (pl.: képmás formájában), úgy az elsőbbséget élvez többlettényállási elem hiányában. A magánélet védelméről szóló törvény ezt a többlettényállási elemet a nevesített személyiségi jogok „magánélettel kapcsolatban” való megsértéseként szabályozza, ${ }^{459}$ ez kellő lehatárolást biztosíthat.

A személyiségi jog egységes alanyi jog, amely a kibontakozásból kiindulva biztosítja a személy önmegvalósítását. Ez az önmegvalósítás a dologi, vagyoni viszonyokkal szembeállítva elsősorban a személyes, nem vagyoni viszonyokra koncentrál, azonban amennyiben az önmegvalósítás módja vagyoni érdekekkel kerül kapcsoltba, úgy ennek oltalmazása is lehetséges a Ptk. 2:42. § (1) bekezdéssel összefüggésben. A személyiségi jog egységes védelme melletti állásfoglalás azt is jelenti, hogy a vagyoni értékminőség elismerése nem az egyes, nevesített személyiségi jogok vonatkozásában, külön-külön alakítandó ki, hanem absztraktan. A magyar jogi hagyományok töretlen módon egy absztrakt magánjogi generálklauzula mellett foglalnak állást, ebből kifolyólag a vagyoni érdekek védelmére is absztrakt módon kell, hogy sor kerüljön, különben külön néven és képmáson álló alanyi jogok kerülnének megkonstruálásra, amely a magyar személyiségvédelmi rendszertől idegen.

${ }^{459}$ 2018. évi LIII. tv. 2. § (1) bek. 
„Milyen szerencse az emberiségre ez a Jézus, ez az isten, aki ember volt. Az Istenröl nem tudom, milyen, a Jézusról tudom. A Jézus ösmerösöm, és mindenkinek ösmeröse. Tudom, mit csinált, tudom, hogy gondolkozott, még az arcát is ösmerem."

Mikszáth Kálmán: Szent Péter esernyője

\section{4. § A SZEMÉLYISÉGI JOG IMMATERIÁLIS JELLEGE ÉS TÁRGYIASULÁSA}

\section{Bevezetés}

Mind a német jog joggyakorlata, mind a személyiségi jog magyar fejlödése egyértelműen igazolják azt, hogy a személyiségi jog vagyoni értékkel rendelkezik. Ha elfogadjuk azt, hogy az emberi méltóság mint alkotmányos alapjog csupán értelmező szerepet tölt be a személyiségvédelemben, és ezáltal az emberi méltóság magánjogi értékelése a személyiség legbelső magvára szükül, úgy még mindig választ kell adni arra, a személyiségi jog legszemélyesebb jellegétől valamely vonatkozásban el tud-e távolodni. A személyiségi jog ugyanis csak akkor lehet átruházható, örökölhető jogosultság, ha a legszemélyesebb jelleg nem vagy nem teljes mértékben érvényesül a személyiségi jog egészében. A kérdés tehát lényegében az, hogyan modellezhetö és írható le jogilag az egyes személyiségi jegyek, személyiségi részjogosultságok személyiségtől való elválása. Ha ez valamilyen módon leírható, mérhető, úgy azzal megteremtődik annak az alapja, hogy a személyiségi jogban rejlő vagyoni részjogosultságok törvényi szinten megjelenhessenek.

A fejezet először a magánjog tárgykörébe eső életviszonyok osztályozására tér ki, bemutatja az alanyi jogok osztályozását, az uralkodó modellt, amely szerint a személyiségi jogok abszolút személyi jogok, majd az immateriális jogok szerinti felosztást, amelyben a személyiségi jog személyi immateriális jogosultság. Ezután vizsgálja azt, hogy a materiális világon, a testi tárgyakon túl hogyan jelent meg a személyi szemlélet, az eszmei, immateriális jogtárgyak védelme. Az eszmei jogtárggyal való kapcsolatba jutás a megszemélyesülés, a tárgyi, materiális világgal való kapcsolatba jutást pedig a tárgyiasulás fogalmával írható le. A materiális és immateriális jogtárgyak nem csupán egymás mellett léteznek, hanem átjárás is van 
közöttük. A fenti osztályozás szempontjából a tárgyiasulás a vagyoni immaterális javak csoportjához vezet, míg a megszemélyesülés a személyi immateriális javak csoportjába utalja a jogtárgyat. Ezzel érhető el az, hogy a tárgyiasulás folytán a személyi immateriális jog vagyoni értékűvé válhat.

\section{Az alanyi jogok természetrajza}

1. Az abszolút személyi jogok

A magyar kodifikációban a személyiségi jogok kódexbe foglalása jogirodalmi előzmény nélkül jelent meg. Az eddig kizárólag a büntetőjog és közigazgatási jog területére tartozó jogtárgyak rendszertani helyét a kódexben meg kellett találni. A magyar kodifikáció ezt végül nem egy általános rész elhelyezésével oldotta meg, hanem svájci mintára külön részt szentelt a személyeknek, és itt helyezték el a személyiség védelmét. A személyiségi jogok rendszerbeli helye emellett dogmatikailag is teljesen hiányzott. A XIX. században a magánjogot mint pusztán vagyonjogot fogták fel. Unger József az alanyi jogokat dologi és személyi jogokra (dingliche bzw. persönliche Rechte) osztja. Unger szerint a személyi jogok közé a családi viszonyok és a kötelmek tartoznak. A genusfogalom nála az, hogy a dologi jogokkal ellentétben nem egy személy és egy dolog kapcsolatát írják le ezek, hanem pusztán személyek közötti viszonyok. Unger szerint a személyi jogok létrejöttével már adva van a másik fél, aki ezt a jogot megsértheti. ${ }^{460}$ Nála tulajdonképpen a személyi jogok a relatív jogokat jelölik.

Személyi a magyar kódextervezettel kapcsolatban kifejezetten kiemeli, hogy az „egyenesen a német elméleti irodalom hatása alatt áll. ${ }^{461 ، ~ F a z e k a s ~ O s z k a ́ r ~ a ~ m a g y a r ~}$ jogirodalom hiányát azzal magyarázza, hogy a magyar népszellem „könnyelműbb és felületesebb felfogást tanusít mások szellemi és erkölcsi javainak megbecsülésében." ${ }^{462}$ A magyar jogirodalomban elsősorban két jelentős álláspont rajzolódik ki a személyiségi jogok terén. Egyrészről azoknak a szerzőknek csoportja,

\footnotetext{
${ }^{460}$ UNGER, JOSEF: System des österreichischen Privatrechts Band I. Breitkopf und Härtel, Leipzig 1856. 545.

${ }^{461}$ SZEMÉLYI, 1915. 41.

462 FAZEKAS OSZKÁR: Az eszmei javak jogi oltalma a magyar Polgári Törvénykönyv javaslatában. Budapest, 1914. 21.
} 
akik a személyiségi jog magánjogi védelmét támogatták, ${ }^{463}$ egy kisebbségi álláspont a más jogágak, a büntető jog, szabálysértési jog, közigazgatási jog által nyújtott védelmet elégségesnek tartotta. ${ }^{464} \mathrm{E}$ második álláspont szerint a személyiség védelme esetén minden támadás személyiség elleni támadásként fogható fel, amely így a jog létének értelmét veszi el. A Zlinszky-Reiner szerzőpáros 1902-es tankönyvében a névjog, illetve a képmáshoz való jog is mint eszmei javak kerültek elismerésre. Maga Reiner is megjegyzi, hogy ezek a szerzői, illetve a szabadalmi, védjegyjogtól különböznek, de ahhoz hasonló, egy genusba tartozó jogok, mert mindegyik „csak a gondolatban levő eszmei valami". ${ }^{465}$ Ö azon az állásponton van ugyan, hogy ezek abszolút jogok, így ellenük negatórius (eltiltó jellegü) védelem vehető igénybe, ugyanakkor nem nevezi ezeket legszemélyesebb jogoknak, hanem vagyonjognak minősíti. ${ }^{466}$ Reiner János két évvel az 1900-as Ptk. tervezet megjelenése után még tagadja azt, hogy a személyiségi jogra igényt lehetne alapítani, és a korábbi dogmának megfelelően a személyiségnek a személy fogalmáról való elhatárolását nem ismeri el. ${ }^{467}$ Ez tulajdonképpen a személyiségi jog védelmének a tagadása.

Bozóky Alajos akként csoportosítja a személyjogokat, hogy vannak abszolút és relatív személyjogok. Az első a személyiségi jognak felel meg nála, míg a második a családi jogviszonyoknak. ${ }^{468}$ A személyiségi jogok tehát egyrészről abszolút szerkezetü jogviszonyok, másrészről pedig nem vagyoni, személyi viszonyok. A magánjog tényleges hatóköre a vagyoni jogokra és a családi viszonyokra szorítkozott, és Szladits Károly még 1933-ban is ebben látja a magánjog legfőbb felosztását, ${ }^{469}$ annak ellenére, hogy a kir. Kúria ekkor már számos személyiségi jogi tárgyú ítéletet hozott. A személyiségi jog ennél fogva nem vagyoni, hanem személyi jog, másrészről nem relatív, hanem abszolút jog. A személyiségi jog abszolút személyi jogi kvalifikációja

${ }^{463}$ ALMÁSI ANTAL: A személyiség védelme a tervezetben. Ügyészek Lapja 1902. 29. sz. 2.; FEKETE KÁrolY: A fényképen való jog. Jogtudományi Közlöny 1903. 48. sz. 410; LADÁNYI BÉLA: $A$ személyiség védelmének elmélete és gyakorlati megvalósulása a magánjogi tervezetekben. Magánjogbölcseleti tanulmány. Budapest, 1904.; LÁNYI MÁRTON: Pár szó a névhez való jogról. Jogtudományi Közlöny 1907. 12. sz. 97.; MESZLÉNY ARTUR: A személyiség védelme a polgári törvénykönyv tervezetében. Jogászegyleti Értekezés XXVI. kötet. 217.;

464 ZLINSZKY JÁNOS - REINER JÁNOS: Magyar magánjog mai érvényében. Franklin, Budapest, 1902. 152.

465 U.o. 538.

466 U.o.

467 U.o. 152.

${ }^{468}$ BOZÓKY, 1905. 455, 541.

469 „Az életviszonyoknak föképen két köre az, amelyben az ember túlnyomóan mint magánegyén áll szemben más magánegyénekkel: a magángazdasági és a családi élet. Ezek a magánjog fő tárgyai; a magánjog lényegében vagyonjog és családjog." SZLADITS, 1933. 4. 
ugyanakkor nem ad választ arra, hogyan képzelhető el, hogyan osztályozható rendszerben a vagyoni érdek. Csupán arra van lehetőség, hogy a személyiségi jog vagyoni vonatkozásait mint kizárólagos vagyoni jogokként kvalifikáljuk, arra nincs, hogy a személyiségi jog további léte is igazolásra kerüljön a vagyonjog mellett. Ennél fogva ez a hagyományos dogmatikai osztályozás nem visz minket előrébb. Célszerü visszatekinteni arra, hogyan alakult ki a személyiségi jogok ezirányú osztályozása, milyen lépések vezettek erre a XX. század elején, hogy megtalálhassuk azt a pontot, amelyen az osztályozás eltérhet, ennek dogmatikai alapjai pedig részben egybevágnak a szellemi alkotások fejlődésével.

\section{A személyi eszme teljes tagadása}

A római jog tisztán materiális jellegü jog volt, azaz elsősorban a külvilágban beállott változásokra, a fizikai dolgokra és a vagyonra koncentrált. Balás P. Elemér a szerzői jog jogalkatának vizsgálata során mutat rá arra, hogy a rómaiak a szellemi alkotás jelentőségét sem tárgyi, sem alanyi vonatkozásban nem ismerték. „Már pedig a szellemi alkotás jelentöségének tudatos elismerése conditio sine qua non-ja a szerzői jog védelmére irányuló jogalkotó intézkedéseknek." ${ }^{470}$ A rómaiak azonban sem a szerzői jogot, sem a személyiség védelmét nem ismerték el a mai formájában. A személyi sérelmek miatti igényeket csak a kártérítés oldaláról, az actio iniurianum aestimatoria nevü keresettel lehetett érvényesíteni.

A római jog ugyanakkor a szellemi alkotásokat, különösen az egyéni, eredeti jellegü műveket valamilyen módon jogilag értékelte. Ez az értékelés azonban megmaradt a dologi jog keretei között, és ezek dolog módjára kerültek kezelésre. Elster ezt úgy írja le, hogy nem az alkotás, hanem a leírt szöveg, a kézirat volt az, amely oltalmat nyert a római jogban, ,míg az abban megtestesült szellemi teljesítmény, a res incorporalis, ahogy mi ma azt nevezzük, mint forgalomképtelen, mint egyfajta res extra commercium került értékelésre, amelyet a római polgár elajándékozott vagy önkéntesen adott ellenszolgáltatás fejében [...], de nem mint materiális árut adott el' ${ }^{471}$

\footnotetext{
${ }^{470}$ BALÁs P. EleméR: Szerzői jog és dologi dinamizmus. In: Emlékkönyv Dr. Szladits Károly tanári múködésének 30. évfordulójára. Grill, Budapest, 1938. 7.

${ }^{471}$ ELSTER, ALEXANDER: Urheber- und Erfinder-, Warenzeichen- und Wettbewerbsrecht (Gewerblicher Rechtsschutz). Walter de Gruyter \& co., Berlin und Leipzig, 1928. 11.
} 
Ennek jogi relevanciája akkor volt, ha több dolog egyesült (accessio). A dologegyesülés nem más, mint több különálló személyek tulajdonában álló dolgok oly módon történő egyesülése, amely által egy dologgá válnak. ${ }^{472}$ Mai fogalmainkkal ez tulajdonképpen a szellemi alkotótevékenység eredményeként tárgyiasult alkotás, és az azt hordozó, azt rögzítő fizikai tárgyon fennálló jog közötti kollízió. Így ebben a vonatkozásban a szerzői mü nem mint alkotás, hanem mint tintával leírt betük, felvitt festék tehát mint dolog kerültek értékelésre. Egy arckép tekintetében nem az volt a lényeg, hogy az valakit ábrázolt, hanem az, hogy a deszkát, a vásznat festékanyaggal látták el, és ezáltal a festék ezáltal a deszkával egyesült. A római jog tehát két dologi jog kollíziójaként fogta fel az ehhez kapcsolódó jogvitákat. A személyi eszme csírája jelenik meg Iustinianusnál, hiszen ő már a festményt tekinti fődolognak, amelyhez mellékdologként járul az az anyag, amire a festményt felvitték. ${ }^{473}$

A XX. század elejéig a római jogra épülő kontinentális jogrendszerekben a magánjog kizárólag vagyonjogra szükült. Kohler korábban idézett megállapítása nem csak a német személyiségi jogi kodifikáció elmaradására világít rá, hanem annak okára is, miért maradt a BGB vagyonjogi alapú: „és mivel a rómaiak azon esetekben, amikor a személyiség joga megsérült, kizárólag vétkes cselekményböl eredö kötelességszegést láttak, úgy azt gondoltuk, itt nem kell mélyebbre ásnunk; és a további magyarázatát annak, miben áll itt a jogtalanság, félretettük, pontosan úgy, ahogyan azt a rómaiak is tették ${ }^{*}{ }^{474}$ A BGB általános részének szerkesztője, Gebhard nem találta olyan jognak a személyiségi jogot, amelyből bármilyen alanyi jog származhatna, és ez az oka annak, hogy a kódex a mai napig nem védi a személyiséget. ${ }^{475}$

\section{A személyi eszme megjelenése}

A dologi szemléletben bekövetkezett első nagy fordulatot a könyvnyomtatás feltalálása hozta. ${ }^{476}$ A személyi eszme fokozatos térhódítása több történelmi lépcsőfokot járt meg. Kezdetben a szerzők nem tüntették fel a nevüket, ezután jelenik

\footnotetext{
472 FÖLDI ANDRÁS - HAMZA GÁBOR: A római jog története és instituciói. Nemzedékek Tudása Tankönyvkiadó, Budapest, 2014. 1080. szj.

${ }^{473}$ Inst. 2.1.34.

${ }^{474}$ KoHLER, JoSEPH: Das Eigenbild im Recht. Berlin, J. Guttentag, 1903.

475 Staudinger/KANNOWSKI (2013) Vorbem Rn $§ 1$ Rn 22.

${ }^{476}$ BAlÁs P. ElEMÉR: Szerzői jog és dologi dinamizmus. In: Koltay András (szerk.): Balás P. Elemér Emlékkönyv. Wolters Kluwer, Budapest, 2018. 367. Ehhez újabban: JAKAB ÉVA: Szerzők, kiadók, kalózok. A szellemi alkotások védelmének kialakulása Európában. Akadémiai kiadó, Budapest, 2012. 13.
} 
meg az író neve, amely rámutat, hogy ő áll a munka mögött, ezzel indul meg a szerző individualizálódása. A kötetek többszörözésének lehetöségével az egyes könyvpéldányok elveszítik individuális különvalóságukat, újabb fordulat áll be, majd pedig a közönség anonimmá válik, elkülönül a szerző személyétől, éppen fordítva, mint amikor a szerző névtelen volt. ${ }^{477}$

A szellemi javak védelmének modern jogokban való megjelenése a XIX. században indult el, és a XX. század elején teljesedett ki. A leglényegesebb fordulópont ugyanis a polgári kor magánjogi felfogásában jelentkezett. Ugyan a személyi szemléletet már a természet- és az észjog is megalapozta, ezek tételes jogi kifejeződésre mint követelési jogok nem jutottak. A polgári átalakulás, hazánkban a kiegyezés és az Országbírói Értekezlet által függetlenségét visszanyert magánjog volt az, amely utat teremtett a gazdaság, a kereskedelem új formáinak. A kapitalista piacgazdaság jelenségei jogi szabályozást igényeltek. Így született meg német mintára a Kereskedelmi Törvény, a védőjegyek, a találmányok oltalma, és később a tisztességtelen verseny elleni törvény is. E törvények mind olyan új, a római jogban nem jelentkező formái voltak a magánjogi szabályozásnak, amely a hagyományos, materiális világfelfogásba kevésbé voltak beilleszthetőek. Az új jogtárgyak magánjogba való strukturálatlan betolulása ellen emelte fel a hangját Fazekas Oszkár is. „Egyik másik téren a változott életviszonyok minden országban szétfeszítették a régi római jog ócska kereteit; új intézményalakulatokat kellett teremteni mindenütt, de mindenütt csak alkalomszerü, mondhatnók: ötletszerü szabályozással érte be a dogmatika. Mélyebb jogbölcseleti megfontolás nélkül, az érdekeltség által formulázott óhajtások szerint jöttek létre a speciális törvények, amelyek a céget, üzleti hírnevet, a szerzői jogot, az árújelzéseket, a találmányokat stb. jogtárgyakká tették [...]”." ${ }^{478}$

Az új jogtárgyakkal kapcsolatos szabályozás elméleti megalapozást is igényelt. Jakab Éva ezzel összefüggésben a német jogtudósok dogmatikai munkásságát elemzi, és mutat rá, hogy a szellemi, eszmei javak oltalmának dogmatikai kidolgozását elsősorban Bluntschli, Dahn, Gareis, Gierke és Kohler munkáiban találhatjuk. ${ }^{479}$ A személyi szemlélet lényege tulajdonképpen, hogy a dolgon mint testi, materiális tárgyon túl a magánjognak más, a fizikai világú alapállapotában meg nem jelenő,

\footnotetext{
477 BALÁS, 1938. 16-17.

${ }^{478}$ FAZEKAS OSZKÁR: A szellemi tulajdon jogbölcseletéhez. In: Emlékkönyv Nagy Ferenc huszonöt éves egyetemi tanárságának megünneplésére. Atheneum, Budapest, 1906. 143.

479 JAKAB, 2012. 140.
} 
ideális jogtárgyakat is védelmeznie kell. „[A] testi tárgyakba is belebújt az új idők szelleme és azt a dualizmust, amelyet eddig az ember magának vindikált, hogy t.i. testböl és lélekből áll, most már a gazdasági javak váltják valóra: állván egy érzékelhetö testböl és valamely elvont szubsztanciából, amely a testi tárgyban - és kívüle is - létezik." ${ }^{480}$ Kohler a fizikai jogtárgyakon túl a szerzői jog elismerését azzal modellezi, és ahhoz köti, hogy ezzel a jognak jogon fennálló jogot kell oltalmaznia, amit álláspontja szerint a jelzálogjog tekintetében a jog már meg is tett. ${ }^{481}$ Balás ezzel szemben keresztény találmánynak tekinti az eszmei javak védelmét, amely a végtelenség eszméjét a személyeken túl a dolgokra is alkalmazza bizonyos tekintetben. ${ }^{482}$ A személyi eszme, a személyi szemlélet a modern jogtudomány sajátja. A személyi eszme lényegében ott tudott megjelenni, ahol a tulajdon és a személy elkezdett különválni, és ebből a különválásból megszülethetett az absztrakt jogképesség, amelyről később a személyiség fogalmát leválasztják. ${ }^{483}$ Ezzel kapcsolatban emeli ki Sólyom László, hogy kezdetben a személyiségi jogokat is a tulajdonjog mintájára, analógiájára, a személytől elválva, dologként fogták fel. ${ }^{484}$

Kohler a megoldást kezdetben egy szellemi tulajdon létrehozásában látta, s később alakította ki az immateriális jogok elméletét. ${ }^{485}$ Balás P. Elemér szerint a személyi szemlélet meglétéhez az szükséges, „hogy elismerjük, hogy a természet értelmében vett létezők világán kivül van más világ is. Az, aki mindent az érzéki észrevevés körébe von, aki csak azt tekinti létezőnek, amit érzékeinkkel észlelni tudunk, aki az érzéki észrevevésnek minden tárgyát csupán s kizárólag a természet körébe utalja, aki mást, mint a külső világra irányuló tapasztalatot nem ismer, az semmi esetre sem beszélhet alkotásról". ${ }^{486}$ A személyi szemlélethez kapcsolódik elsősorban a személyiségi jog, a szerzői jog, a szabadalmi jog. Balás elsősorban a szerzői jog vonatkozásában vizsgálja azt, mennyiben materiális, illetve mennyiben eszmei a védelem jellege. Ö kifejezetten arra vezeti vissza a szerzői jog jogági, jogterületi vitáját, hogy abban a dologi és a személyi szemlélet keveredik, és egyes szerzők inkább az egyik oldalt, mások a másik oldalt, az alkotást, a személyiségi jogi oldalt

\footnotetext{
${ }^{480}$ FAZEKAS, 1906. 145-146.

${ }^{481}$ KOHLER, Josef: Das Autorrecht. Verlag von Gustav Fischer, Jena, 1880. 68

482 BALÁs, 1941. 626-627.

${ }^{483}$ Ennek részletes történelmi bemutatására lásd SÓLYOM, 1985. 226. sköv.

${ }^{484}$ SóLYOM, 1985. 24-25.

485 JAKAB, 2012. 152.

486 BALÁS, 1938. 8.
} 
emelik ki. ${ }^{487}$ A személyi szemlélet lényegében azt jelenti, hogy a jogi értékelésbe bevonunk olyan jelenségeket, amelyeket a külső, fizikai világban nem találunk meg, mert a materiális világban nem léteznek. Ilyen egy személy becsülete, lelki-érzelmi világa, ilyen egy festmény, amely nem különböző színü festékek összességei egy vásznon, ahogy azt a dologi szemlélet alapján leírhatnánk, hanem egy olyan kép, amely valamely üzenetet, benyomást, látványt közvetít, amely miatt $a z$ ember, $a z$ észlelö számára több lesz, mint festék. Gierke ezeket a jogtárgyakat egy fogalom alá, az általános személyiségi jog fogalma alá rendeli, ${ }^{488}$ és ezen belül különbözteti meg azokat a jogokat, amelyek átruházhatóak, és amelyek nem. Gierkénél ennél fogva a személyiségi jogok átruházhatósága nem is a mai értelemben vett személyiségi jogra, hanem sokkal inkább a szerinte az általános személyiségi jogba tartozó szerzői és szabadalmi jogra vonatkozik. Ezt az álláspontot a magyar jogtudomány a szellemi alkotások személyiségi jogi elmélete néven ismeri. ${ }^{489}$ Gierke tanait osztotta a hazai jogban Bozóky Alajos, aki az ész szüleményei elnevezés alatt a személyiségi jogba sorolta a szerzői jogot és a találmányi jogot is. ${ }^{490}$ Kohler ezzel szemben az immateriális, testetlen, eszmei jelleget emeli a középpontba, és élesen különválasztja a személyiségi jogokat a szellemi alkotásoktól. Szerinte ,a szerzői jog egy immateriális jog, azaz egy, az emberen kívül álló, de nem testi, nem megfogható jogtárgyon fennálló jog. Az immateriális jogok tana napjainkban annyira elfogadottá vált, hogy további ajánlást vagy megindokolást nem igényel. Mellette már csak a személyiségi- vagy személyi jog tana érdemel csak értékelést, amely esetében a jogtárgy az emberen belül és nem kívül helyezkedik el, és az ember lényétöl alapvetöen elválaszthatatlan, csak véletlenszerüen és kivételesen leválasztható lehet."491

A személyi szemlélet tiszta megjelenésére Balás ,a modern magánjogban csak legutóbb szóhoz jutó személyiségi jogot”, illetve a jóhiszemüség és tisztesség elvét említi, ${ }^{492}$ a személyiségi jog testetlen jellegét két jelentős helyen emeli ki. Az egyik a személyiségi jog jogosultjának halála, amikor abból indul ki, hogy a személy, a

\footnotetext{
${ }^{487}$ U.o. 3.

488 GIERKE, 1895. 702, 708, 748, 848.

489 LONTAI ENDRE - FALUdi GÁBOR - GYERTYÁNFy PÉTER - VÉKÁS GuSZTÁV: Szerzői jog és iparjogvédelem. ELTE Eötvös, Budapest, 2017. 30.

${ }^{490}$ BOZÓKY, 1905. 464.

${ }^{491}$ KOHLER, JOSEF: Urheberrecht an Schriftwerken und Verlagsrecht. Stuttgart, Ferdinand Enke, 1906. 1.

${ }^{492}$ BALÁs P. ElEMÉR: Személyi és dologi szemlélet az anyagi büntetőjog és a perjog fejlődésében. In. Eckhart Ferenc - Degré Lajos (szerk.): Emlékkönyv Dr. (Viski) Illés József tanár müködésének negyvenedik évfordulójára. Stephaneum, Budapest, 1942. 15.
} 
jogalany ugyan meghal, s ezzel jogképessége megszünik, a személyisége, amely nem része a külső világnak, továbbra is fennmarad, s annak a hozzátartozók szerezhetnek érvényt. ${ }^{493}$ A másik ilyen körülmény a névhasználati jogosultság, illetve annak az átengedése, ezzel összefüggésben pedig a cégnév személyiségi jogi jellege, amellyel összefüggésben rámutat, hogy ez utóbbit a dologi dinamika jellemzi, ${ }^{494}$ míg a névhasználat átengedését, a név tárgyiasulását bizonyos tekintetben szintén dologi szemlélet jellemzi. ${ }^{495}$

A személyiségi jogok védelme lényegében a szerzői joggal és az iparjogvédelemmel, a szellemi alkotásokkal párhuzamosan alakult ki - szembeállítva a hagyományos jogtárgyakkal, a testi tárgy formájában jelentkező dolgokkal. A személyiségi jog tehát mindenképpen immateriális, testetlen jogtárgy, attól függetlenül, hogy abszolút személyi jogként kerül besorolásra. Az osztályozás alapja elsősorban azon nyugodott, hogy egyes eszmei javak esetén a vagyoni viszonyokkal való összefüggés, azok társadalmi, gazdasági, ipari hasznosíthatósága, funkciója okán valamilyen fokú forgalomképességet szereznek, míg más jogok, így a személyiségi jogok mint veleszületett jogok ilyennel nem rendelkezhetnek. A személyiségi jogok magyarországi fejlődésén ugyanakkor már látható volt, hogy a vagyoni érdekek védelme a joggyakorlatban megindult, azonban csak csökevényesen, esetenként jelentkezett, így a jogintézmény jogi értékelésébe rendszerszinten nem került be. A vagyoni érdekek dogmatikai rendszerbe foglalása Németországtól (az NSZK-tól) eltérően nálunk a szocializmus térhódításával nem tudott végbemenni, így a személyiségtől esetlegesen elváló személyiségi javak más irányú osztályozása sem indult meg.

\section{A nem vagyoni jelleg trónfosztása}

A személyiségi jog történeti kialakulása vonatkozásában a nem vagyoni jelleg nem kizárólagos, egy kisebbségi álláspont szerint a személyiségi jogok vagyoni viszonyokkal, vagyoni értékkel is rendelkezhetnek, és történeti fejlödésükben is

\footnotetext{
493 BALÁs, 1941. 632.

${ }^{494}$ A cégnévre vonatkozó alanyi jogi felfogások történeti fejlődésére 1. SCHULTZ MÁRTON: $A$ cégnév szellemi tulajdon jellege és viszonya a személyiségi joghoz. In: Görög Márta - Mezei Péter: A szellemi tulajdonvédelem és a szabadkereskedelem aktuális kérdései. Pólay Elemér Alapítvány, Szeged, 2018. 55.

495 BALÁs, 1941. 646, 648. 652, 655, 656.
} 
ezekkel szorosan összefüggenek. ${ }^{496}$ A vagyoni viszonyokra való kiterjesztés kísérlete több szerzőnél tetten érhető, ${ }^{497}$ amelynek kapcsán a dologi jogokkal való kapcsolat ${ }^{498}$ és a szellemi tulajdonjogi jelleg vizsgálata kiemelkedő. ${ }^{499}$ A dologi jogokkal való rokonítás ugyanakkor csak a személy testével, fizikai megjelenésével kapcsolatos személyiségi vonatkozások tekintetében értékelhető: ezek egyedül azok ugyanis, amelyek a dologi jogok mintájára testi tárgyként jelentkeznek. A személyiség más vonatkozásai, a szellemi tulajdonjogokhoz hasonlóan immateriális, eszmei jogtárgyak, amelyek „empiria felettiségükben” ${ }^{500}$ a dologi jogokkal való összehasonlítást ily módon nem támogatják. A Kohler-féle immateriális jogok elméletének legnagyobb hazai támogatója és egyben továbbfejlesztője Meszlény Artur volt, aki a személyiségi jog, a szerzői és iparjogvédelmi jogok közös tulajdonságának a testetlen, immateriális jelleget tekintette, különbözőségnek azt, hogy a személyiségi jog a személytől elválaszthatatlan, míg az utóbbiak attól vagy teljesen vagy részlegesen elválaszthatóak. ${ }^{501}$ Más fogalomhasználattal ezt az álláspontot képviseli Szladits Károly is. ${ }^{502}$ Az elválaszthatóság szempontjából a szellemi alkotásokhoz való viszony vizsgálata így sokkal észszerübbnek tünik, hiszen az immateriális, testetlen jelleg közös.

A személyiségi eszme megjelenésekor a személyi, eszmei viszonyokon túl teljesen elfogadott volt, hogy a személyiségi jogok vagyoni viszonyokkal is kapcsolatba kerülnek, vagyoni értékkel bírnak. ${ }^{503}$ A vagyoni érték általában megilletheti a személyiségi jogot. Almási Antal szerint „ez az érték majd erkölcsi, majd vagyoni jelentöségü. Valahányszor a megjelölési jog ily eredménnyel is jár, aminek gyakori példáit a szinészek, müvészek, írók nevének, az ismert cégek áruinak reklám használatánál és hasonlóknál észlelhetjük [...]." ${ }^{504}$ Különösen hangsúlyozza több

\footnotetext{
496 SÓlYOM , 1983. 21.; KeCSKÉS LÁSZló: Polgári jog. A személyek joga. Dialóg Campus, BudapestPécs, 2007. 413-414.

497 GÖRÖG MÁRTA: A kereskedelmi név védelme. In: Faludi Gábor - Lukácsi Péter (szerk.): A védjegytörvény kommentárja. HVG-ORAC, Budapest, 2014. [GöRÖG, 2014b] NAVRATYIL ZOLTÁN: Gondolatok névjogról, szólásszabadságról. MTA Bölcsésztudományi Kutatóközpont, Budapest, 2015. SCHULTZ, 2016. 685.

498 TATTAY SZILÁRD: Az emberi személy mint ,, önmaga tulajdonosa “: a dominium sui fogalmától a selfownership eszméjéig. In: Menyhárd Attila - Gárdos-Orosz Fruzsina (szerk.): Személy és személyiség a jogban. Wolters Kluwer, Budapest, 2016.; MENYHÁRD, 2016. 78.

${ }^{499}$ MENYHÁRD, 2016. 78.

${ }^{500}$ BALÁS, 1941. 625.

${ }^{501}$ MESZLÉNY, 1909. 187.

502 SZLADITS, 1933. 359-360.

${ }^{503}$ SÓLYOM, 1983. 21.

${ }^{504}$ ALMÁSI, 1927. 133. 134.
} 
helyen Sólyom László a személyiséggel, elsősorban a képmással és a névvel kapcsolatba kerülő kereskedelmi, üzleti célú felhasználást. ${ }^{505}$

Nem lehet felróni azonban a korabeli jogirodalomnak azt, hogy a személyiségi jog elismerésének zászlajára a természetjogot, az embert megillető ,„pusztán az észből kivilágló jogokat" ${ }^{\$ 06}$ mint az egyén jog felettiségét, matériától független vonatkozásait emelte ki elsősorban, és ezzel próbálta legitimálni újdonságát. Hazánkban a személyi szemlélet, eszme legkövetkezetesebb keresztülvivője Balás P. Elemér volt, aki a személyiségi jogokat a kizárólag az embert megillető nem vagyoni jogokként határozta meg, és ennek megfelelően alakította ki a személyiségi jogi dogmatikát is. ${ }^{507}$

A személyiségi jog azonban nem korlátozható személyi viszonyokra, hanem kifejezetten vagyoni érdek védelmét is szolgálja, illetve kialakulásában is erősen hatott rá a vagyoni jelleg. Ennek okán a személyiségi jog olyan immateriális jog, amely a személyhez kapcsolódik, a személytől nem válik el, és bizonyos irányú elválása esetén is megmarad a kapcsolata a személyiséggel (személyi immateriális jog), ugyanis , $a$ személyiség jogi védelmének szükségessége ugyan a külsö világ jelenségeivel elsösorban társadalmi jelenségekkel - kapcsolatban merül fel, de sohasem ezek a külsö világbeli jelenségek a személyiségi jogi oltalom tárgyai, hanem maga a személyiség a maga empiria-felettiségében." 508

A magyar polgári jogban a szocializmussal, a szovjet polgári jogban fellelhető vitákkal, illetve a polgári jog árucsereviszonyként való felfogásával összefüggésben merült fel a személy védelmét szolgáló javak védelmének kérdése a vagyoni viszonyokkal való szembeállításában, amely ezután a jogterület egészének minőségét és felfogását meghatározta. A személyiségi jogok létét lényegében a vagyoni viszonyok mellett kellett legitimálni, ${ }^{509}$ ezért kúszott az előtérbe a nem vagyoni jelleg kizárólagossága, és így satnyult el a testetlen, immateriális jelleg hangoztatása. A korábbi fejezetekben láthattuk, hogy a személyiségi jog kereskedelmi, áruviszonyokkal összefüggő felhasználása és ennek jogi értékelése már a királyi Kúria joggyakorlatában megjelent, és az ezirányú fejlődésnek szabott gátat a szocialista polgári jog. A szocialista polgári jog a polgári jogot ugyanis elsősorban vagyoni

505 SÓlYOM, 1985. 24-25.

506 Optk. 16. §.

${ }^{507}$ BALÁs, 1941. 625.

${ }^{508}$ U.o.

${ }^{509}$ Vö. EÖRSI GYULA: A szocialista polgári jog alapproblémái. Akadémiai kiadó, Budapest, 1965. 27; PETRIK FERENC: A törvényszerkesztö dilemmái. HVG-ORAC, Budapest, 2008. 176. 
jognak képzelte el, amelynek célja az árucsere-viszonyok szabályozása. A csökevényes, és nagyrészt a kapitalizmusban jellemző felhasználási módok helyett így értelemszerüen a személyiségi jogok mint minden embert osztályhelyzettől függetlenül megillető, nem vagyoni személyjogokként kerültek artikulálásra.

A legtöbb esetben problémamentesen alkalmazható a személyiségi jog személyi viszonyokra való redukálása, mert az abszolút szerkezetből eredő szankciók így is alkalmazhatóak, másrészről a vagyoni vonatkozások nem tisztán jelentkeznek, hanem a személyi, belső-érzületi elemekkel vegyülve. A szankció oldaláról a nem vagyoni kártérítés (illetve a sérelemdíj) jogintézménye is e jogok személyes, pénzben kifejezhető oldalára helyezi a hangsúlyt, célja azonban a nem vagyoni sérelmek kompenzációja volt. A nemvagyoni jelleg kiemelése a testetlen, személyhez kapcsolódó jelleg helyett ahhoz vezetett, hogy a joggyakorlat a személyiségi jogi viszonyok esetén csak azok nemvagyoni oldalát értékelte. A személyiségi jog tekintetében annak nem vagyoni jellege a kiindulópont, erre az eszmei érdekre épül rá, azt egészíti ki bizonyos funkciók, felhasználási módok tekintetében a vagyoni értékminöség, a vagyoni jelleg.

\section{Az immateriális javak felosztása}

Meszlény Artur a svájci jog tárgyalása során teljesen egyedi felosztást alkalmaz (ezt az osztályozást átveszi tőle Dezső Gyula is): ${ }^{510}$ nála az immateriális (testetlen, lényegében a dolgokkal szembeállított) javak jelentik a genusfogalmat azzal, hogy az eszmei javak (Immaterialgüterrechte) védelmét nem szükíti a testetlen vagyoni javakra. Ezzel tehát az eszmei világba tartozó jogtárgyakat osztályozza. Ez a vizsgálati szempontjából előnyös, hiszen a személyiségi jogoknak ez a tulajdonsága mutat rokonságot más jogokkal. Az eszmei javakon belül három alcsoportot különböztet meg: a személyi immateriális javakat, az önálló és önállótlan immateriális javakat.

A személyi immateriális javak csak a természetes személyeket, az embert illethetik meg. Ebbe a csoportba tartozik megítélése szerint az élet, a szabadság, a testi épség, az egészség, a becsület, a jóhírnév, a szemérem, a vallásos érzület, a családi állás, a képmás joga, a névjog, a testületi tagság joga. ${ }^{511}$ Ezek közül elsősorban a névjognál gondolkozik el Meszlény annak különbözőségén, amit arra vezet vissza az

${ }^{510}$ DEZSŐ, 1914. 300. sköv.

${ }^{511}$ MeSZLÉNY, 1909. 173. 
Optk. 16. §-át idézve, hogy a felsorolt jogok mindegyike vitathatatlanul megillet minden embert, addig a névjognál (emellett a családi állás és a testületi tagságot is ide sorolja) kérdésként jelentkezhet annak megállapítása, hogy az egy adott személyt megillet-e, személyi javai körébe tartozik-e. ${ }^{512}$

Az önálló vagyoni immateriális javak nem a vagyonhoz tapadnak, hanem attól el is válhatnak, de azért nem dolgok, mert nem testi tárgyak. Ilyenek a szerzői jogok, illetve a szabadalom. ${ }^{513} \mathrm{Az}$ önállótlan vagyoni immateriális javak azok, amelyek a vagyon jogi sorsát osztják. Meszlény ezt mint immateriális ködburkot jellemzi, ,amely a vagyon materiáját körülveszi, mint a levegö a földtekét". ${ }^{514}$ Ide sorolja a céget, a védjegyet, az üzleti titkot, a vagyoni becsületet, a házjogot, a levéltitkot. Az önállótlan vagyoni immateriális javak esetében a függőség, a korlátozottság, az önállótlanság a jogalanytól függ, ahhoz képest akcesszoriális.

\section{6. sz. táblázat}

Az immateriális javak Meszlény-féle felosztása

\begin{tabular}{|c|c|c|}
\hline \multicolumn{3}{|c|}{ IMMATERIÁLIS JAVAK } \\
\hline \multirow{2}{*}{ SZEMÉLYI } & \multicolumn{2}{|c|}{ VAGYONI } \\
\hline & ÖNÁLLÓTLAN & ÖNÁLLÓ \\
\hline $\begin{array}{ll}\text { - } & \text { élet } \\
\text { - } & \text { testi épség } \\
\text { - } & \text { egészség } \\
\text { - } & \text { szabadság } \\
\text { - } & \text { becsület } \\
\text { - } & \text { jóhírnév } \\
\text { - } & \text { szemérem } \\
\text { - } & \text { vallásos érzület } \\
\text { - } & \text { családi állás } \\
\text { - } & \text { képmás } \\
\text { - } & \text { névjog } \\
\text { - } & \text { testületi tagság }\end{array}$ & $\begin{array}{ll}\text { - } & \text { cég } \\
\text { - } & \text { védjegy } \\
\text { - } & \text { üzleti titok } \\
\text { - } & \text { vagyoni becsület } \\
\text { - } & \text { házjog } \\
\text { - } & \text { levéltitok }\end{array}$ & $\begin{array}{ll}\text { - } & \text { szerzői jog } \\
\text { - } & \text { szabadalom }\end{array}$ \\
\hline
\end{tabular}

(saját szerkesztés)

Ez az osztályozás a vizsgálat szempontjából azért előnyös, mert egyrészről megtartja a szellemi alkotásokat és a személyiségi jogokat összevonja azok testetlen, immateriális jellege alapján, másrészről pedig ezen belül csatornázza be az egyes jogokat, mennyiben jelentenek ezek a személyhez tapadó eszmei jogtárgyat (mint a

\footnotetext{
512 U.o. 187-188.

${ }^{513}$ U.o. 169-172.

514 U.o. 154.
} 
személyiségi jogok), vagy mennyiben kötődnek a velük kapcsolatban levő fizikai jogtárgyakkal (vagyoni immateriális javak). Míg Bozókynál és Gierkénél az eltérő tulajdonságokkal bíró személyiségi jogok és szellemi alkotások teljesen összemosódnak, pl. a keletkezés, átruházhatóság, forgalomképesség tekintetében, addig ez a felosztás ezt már rendszerben tudja kezelni. Balás élesen elhatárolja a két kategóriát, és tulajdonképpen egy szükebb személyiségi jogi felfogást képvisel, amely a versenyjogi, kereskedelmi jogi, védjegyjogi vonatkozásoktól mentes. Meszlény ezeket a kategóriákat élesen nem választja el azzal, hogy summa divisiójának az immateriális jelleget teszi, és ez teremt lehetőséget arra, hogy a személyi és dologi szemléletben bekövetkező változásokat figyelemmel kísérjük, gondolok itt elsősorban az arcképen fennálló szerzői jogra, a személynév cégnévként, védjegyként való használatára. Sokkal fontosabb azonban, hogy ez a felosztás tudja számunkra besorolni és megértetni, miért rendelkezhetnek a személyiségi jogok vagyoni értékkel. Bizonyos jogtárgyak tekintetében a jogi felfogás 1909 óta megváltozott, így a védjegyjog már nem kizárólagosan a vállalattal együtt ruházható át, hanem attól függetlenül is, a szerzői jog monizmusa okán önállótlan vagyoni jog, az üzleti titok megítélése szintén az utóbbi időben változott meg. ${ }^{515}$ A Meszlény-féle osztályozás megteremti annak a lehetőségét, hogy egyes személyiségi vonatkozásokat vagyoni értékkel ruházzuk fel, és megtartsuk a személyiséggel való kapcsolatukat, azaz önállótlan vagyoni immateriális jognak tituláljuk azokat. Ez a rendszerezés nem kőbe vésett, így a személyiségi jog egyes vonatkozásai más kategorizálásba is kerülhetnek. A szerzői jog is változáson esett át, míg korábban vagyoni jognak tekintették, napjainkra a személyi és vagyoni viszonyok monizmusa jellemzi, amelynek okán Meszlény rendszerezésében az önállótlan vagyoni immateriális jogok közé kellene sorolni. Ez a klasszifikáció tehát végső soron teret enged annak az elgondolásnak, hogy az egyes személyiségi jogok vagyoni értékminőségét értékeljük a polgári jogon belül úgy is, hogy abban eszmei és vagyoni érdekek keverednek, a létrejövő forgalomképes vagyoni értékü személyiségi javak személyiségi jogi jellege tehát nem szünik meg. A tárgyiasítható vagyoni értékű személyiségi jegyek feletti rendelkezésbe, illetve e jogok ún. kvázidologi hatályú átruházásába is úgy fog behatni a személyiségi jog, mint fődolog, amely e jogtárgyak önállótlan immateriális jogi jellegét, szerzői joghoz hasonló kettős karakterét indukálja.

515 2018. évi LIV. törvény 


\section{A személyi és dologi viszonyok vegyülése}

Az immateriális jogok tehát beférkőznek az anyagi világba, és erre nemcsak a szerzői jog, a feltalálói, szabadalmi jog képes, hanem a személyiségi jog is. Az ember teste esetében a tárgyiasulás pillanata hiányzik, hiszen az emberi test a materiális világban kezdeténél fogva adott. Vannak bizonyos esetkörök, amelyek esetén egy adott jogtárgyat egy személy érdekkörébe tartozónak tekintünk, jóllehet az előtte nem tartozott oda. Ennek legfontosabb példája a névjog, amely minden esetben megszemélyesül. A név a személyiségnek nem része, ugyanakkor olyannyira képes kapcsolatba kerülni a személyiséggel, hogy annak legbelső szférájáig is eljut. Ezt az Alkotmánybíróság is elismerte, és a néven való jogot az emberi méltóságból származtatja. ${ }^{516}$ Ehhez hasonlóan a személyi érdekszférába kerülhet a domain név önálló jogtárgyként, illetve a védjegy is. Hasonló ehhez az, amikor a jogosult a személyi érdekszférájában, társadalmi hatásában a jogtárgyat, a védendő jogi érdeket újólag hozza létre, így amikor az életképét gazdagítja (pl. esküvő, botrányok, büncselekmény elkövetése).

A személyi és dologi viszonyok a szerzői jogban, illetve a tágabb értelemben felfogott szellemi alkotások jogában vegyülnek. Ilyen vegyülés jön létre a személyiségi szférában, illetve a személyi szférából, ha egy személy alkotótevékenysége eredményeként müvet alkot meg, vagy személyiségi jegye tárgyiasítható, vagy ha az már tárgyiasult. A személyi és vagyoni viszonyok azonban nemcsak ezen abszolút személyi jogokon belül képesek vegyülésre, hanem a relatív személyi jogon belül is. Így már Grosschmid megemlíti a családi jogviszonyok kötelmi viszonyokkal való vegyülését.

„A családi jogviszonyok azonban, mint mondám, be-be hintvék kötelmekkel. Ennek ismét többféle a megjelenése. Néhutt a családi jogviszonyban a kötelem, mint annak egyik oldala, eleitől fogva benne van. [...] Másutt a családi kapcsolat egyszerüen csak fundamentuma az olyan jogviszonyoknak, a melyekben nincs is egyéb, mint kötelem [...] Ismét néhány családi kapcsolatnak nem is ád egyéb tartalmat a jog, mint kötelmit. [...] Végül

\footnotetext{
516 58/2001. (XII. 7.) AB hat.
} 
olykor a kötelem a családi jogviszonyból úgy keletkezik, hogy az, a mi eredetileg család-erkölcsi tartalmu kötelezettség, átszürődik, átridegül szolgáltatási kötelemmé. [...]

Hogy hol válnak szélylyel e behintett kötelmek a tisztán családjogi jellegü oldaltól, akár mint eredeti párvonalas alkatelemek, akár az említett átridegülés szempontjából, erre nem lehet általános feleletet adni. Végre is a megösmerés nem az elnevezés, hanem a jogi elbánás miatt lehet fontos. [...] Azonban erre apriorisztikus utmutato nincsen. Ez csak a posteriori ösmerszik meg, jelesül kerülve-próbálgatva, illik-e az illető joghelyzetre egyik vagy másik kötelmi jogi tétel." 517

Az egyes alanyi jogok nem kezelhetőek izoláltan, figyelembe kell venni, hogy a személyes viszonyok esetében is releváns lehet a vagyoni érdek, hogy a jogos érdek lehet gazdasági érdek is. A személyiség védelme a személyiségi jog (illetve a különös személyiségi jogok) ${ }^{518}$ megjelenése előtt mind hazánkban, mind a kontinentális országokban speciális jogvédelemben öltöttek testet, amelyek a napjainkbeli osztályozás szerint a szerzői jog és iparjogvédelem területére esnek. A korabeli jogirodalom ezeket a személyiséghez kapcsolódó jogoknak tekintette: ilyen volt a cégnév, a védjegyjog, illetve a szerzői jog. Ezekben az intézményekben az a közös, hogy mind a személyiség külső megnyilvánulását, lecsapódását oltalmazták, azaz a személyiség külső jegyeit (elsősorban a nevet és a képmást), és a joggyakorlat fejlödésén látható is volt, hogy a személyiség védelme ezekből indult ki. A személyiség jogi védelme kialakulásában a nem vagyoni (eszmei) kár elismerését ${ }^{519}$ megelőzően, illetve azzal párhuzamosan a gazdasági, kereskedelmi tevékenységgel kapcsolatban illette meg a személyt. Az ehhez kapcsolódó törvényalkotás a cégbitorlás, a védjegybitorlás és a jellegbitorlás által nyújtott védelmet először,

517 ZSÖGÖD BENÖ: Fejezetek kötelmi jogunk köréböl II. Atheneum, Budapest, 1900. 1303-1304.

${ }^{518}$ A különös személyiségi jogok önálló alanyi jogi jelleggel bírnak, amely igényhalmazatot implikálhat az általános személyiségi joggal. A nevesített személyiségi jogok ezzel szemben kizárólag törvényhalmazatot indukálnak azon okból, hogy az alanyi jog egy és ugyanaz. A hatályos magyar jog szempontjából különös személyiségi jog a szerző személyhez füződő jogai, minden más személyiségi jog nevesített személyiségi jog, a Ptk. 2:49. § (2) bek. lex perfecta, ezért itt vitatható. A második világháború előtt ilyen volt a személyiségi jog szokásjogi elismerése előtt a képmáshoz való jog, amelynek védelmét az 1921-es Szjt.-ben elhelyezett különös alanyi jogi tényállás biztostotta, illetve a Bv. által védeltt becsület.

519 Szegedi Királyi Ítélőtábla 1911. G 156. 
anélkül, hogy a személyiség általános védelme bármilyen törvényi vagy szokásjogi formát öltött volna.

A személyiség joga a tulajdonjoggal is vegyülhet, több igény is releváns lehet annál fogva, hogy a személyiség világa a fizikai világgal találkozik. Ennek példája, hogy a bíróság nem dologi jogcímen, hanem a személyiségi jog megsértése okán kötelezte az alperest egy SIM-kártya visszaadására abból az okból, hogy a felperes magántitokhoz való jogát megsértette. ${ }^{520}$

A személyiségi jegyek iparjogvédelmi jogintézményi formában történő értékelési lehetősége, illetve hogy ebben a formában a személyiségi jegyek átruházhatóak, túlélik a személyt, és rendelkezési jogot biztosítanak a halál után is, mutatnak rá arra, hogy a személyiségi jegyek tárgyiasítása a jogalkotó által külön jogintézmények keretében már több mint száz éve elismerést nyert. Ez azonban élesen elhatárolásra kerül a személyiség védelmétől, és kizárólag az iparjogvédelmi, szellemi tulajdonjogi oldal kerül kidomborításra. Már maga Bozóky Alajos is kiemeli ezt: „magában véve a dolognak ilyetén megjelölése nem egyéb, mint a névviselési jog gyakorlása; de a mi törvényünk nem ilyen szempontból [sic!], hanem a védjegyoltalom szempontjából fogja fel" ${ }^{521} \mathrm{Ez}$ az elv máig tovább hat, és nem kerül értékelésre a személyiségi jogi pillanat, hanem más, személytelen szóbeli vagy képi megjelölésekkel azonos módon kezelik ezeket. A dinamikus dologi szemlélet teljesen beárnyékolja a jogi értékelést, amely a személyiség hathatós védelmét célozná, és amely egy vagyoni személyiségi jog elismerésében tudna jelentkezni.

${ }^{520}$ FÍT BDT 2018. 125. (,SIM-kártya”)

${ }^{521}$ BOZÓKY, 1905. 480. 


\section{Tárgyiasulás}

\section{A tárgyiasulásról általában}

A személyiség egyes külső megnyilvánulásai, az egyes személyiségi jegyek a külvilág tárgyaival szemben a fizikai valósághoz képest virtuális, immateriális, eszmei, testetlen javak, amelyeket a jog azon oknál fogva oltalmaz, hogy az embernek ezeken is állhat fenn jogos érdeke. A személyiségi jogok ugyanakkor, hasonlóan a szellemi alkotásokhoz, kapcsolatba kerülhetnek testi tárgyakkal, és manifesztálódhatnak is azokban valamilyen módon. Egy vagyoni személyiségi jog elismeréséhez nélkülözhetetlen, hogy a személyiség mint negatívum a külvilágban meg tudjon jelenni, ezért a tárgyiasulásnak óriási szerepe van, ez a megjelenés azonban együtt jár azzal is, hogy a tárgyiasult személyiségi jegy személyiségtöl való távolsága nö.

A tárgyiasulás már Balásnál megjelenik. Ennek magánjogbölcseleti alapjaként fekteti le a dologi dinamika mellett az ún. személyi szemléletet mint a magánjog új látásmódját. A személyiségi jogok tekintetében azonban a tételes jog szintjén is megjeleníti ezt. Az eszmei világba tartozó személyiségi javak vagyoni viszonyokkal való vegyülését, a dologi dinamika alá kerüléseként értékeli (lényegében ez a tárgyiasulás). ${ }^{522}$ Így a cégnév célja, hogy az elszemélyesített dolgokra nézve töltsön be megjelölési funkciót. ${ }^{523}$ Ehhez hasonlóan a névnek valamely vállalattal való kapcsolatba jutása eldologiasítja azt, és az üzleti célú névhasználati engedély esetén a dologi szemlélet dominál a személyi szemlélettel szemben abból az okból, hogy a jogot szerző vállalat diszpozícióhoz jut a név felett. ${ }^{524} \mathrm{~A}$ tárgyiasulás ugyanakkor annak fokmérője, hogy a jogtárgy jogi értékelése a személyiségi jog vagy a versenyjog területére esik. Ezt a bírói gyakorlat is átvette a Ritz-döntéseiben. A királyi Kúria úgy fogalmaz, hogy „ez az elnevezés, a „Ritz” név ebben a vonatkozásban meghatározott személyre, vagy családnévre utaló jellegét nyilván elvesztette, a szállodák egymásközötti üzleti kapcsolatában mintegy nemzetközi üzletjelzöjévé vált és mint ilyen ez az elnevezés nem is jelent meghatározott személlyel vagy családdal való kapcsolatot., ${ }^{25}$

\footnotetext{
${ }^{522}$ BALÁs, 1941. 646, 648. 652, 655, 656.

${ }^{523}$ U.o. 646.

524 U.o. 1941.652.

${ }^{525}$ K. P. IV. 1753/1939. - Ritz II.
} 
A tárgyiasulást Törö Károly is több személyiségi jog tulajdonságának tekintette. Törő a fogalmat mint viszonylagos elválást használja, amely elválás sosem lehet teljes. ${ }^{526} \mathrm{Ez}$ a tárgyiasulás megvalósulhat képmás vagy hang felvételével, valamilyen eszközzel történő rögzítéssel, ugyanígy a modell „a személyisége külső megnyilvánulását hordozó képet nyújtja a müalkotáshoz". ${ }^{527}$ A titoknál is általában a jogi védelem tárgya nem maga a titok, hanem annak külső megnyilvánulása, ${ }^{528}$ amely mint üzleti titok kifejezetten vagyoni értékü. ${ }^{529}$ A know-how apportálásának feltételeként a joggyakorlat is annak valaminemü tárgyiasulását kívánja meg. ${ }^{530} \mathrm{~A}$ know-how tárgyiasulása nem más, mint az azt a külvilág felé megjelenítő dolog: leírás, útmutatás, belső szabályzat stb. ${ }^{531}$ Vannak olyan javak, amelyek nem tárgyiasulnak, hanem megszemélyesülnek, azaz a személyiség részévé válnak. Törő szerint mivel a név a személyiségnek nem része, ezért először személyesülnie kell, s azután lehetőség van arra is, hogy az bizonyos fokban elváljon, tárgyiasuljon például az ember halálával vagy kereskedelmi név átszállása, öröklése által. ${ }^{532}$ A természetes személy neve meghatározott névszerzési tényállásokkal szerezhető. ${ }^{533}$ A névvel való azonosulásnak, a megszemélyesülésének feltételeit a Kúria is vizsgálta egy kiskorú gyermek estén az örökbefogadás felbontása vonatkozásában. ${ }^{534}$ Törönél, illetve általában a szocialista polgári jogban a személyiségi jogoknak a szerzői joghoz hasonló tárgyiasulása, a külső világbeli érzékelhetősége közötti összefüggés meglátásom szerint nem a véletlen műve, hanem a szerzői (szabadalmi, védjegy) jog jogrendszerbeli helyéből adódott, hiszen a szocialista polgári jog ezeket a személyiségi jogokhoz hasonlatosan személyi jognak tekintette.

A személyiségi jegyek tárgyiasulása tehát nem jelent mást ez alapján, mint azt, hogy a személyiségi jogok mint testetlen javak valamely testi tárggyal kapcsolatba kerülnek. A tárgyiasulás jelenti tehát azt a folyamatot, hogy a jogtárgy a személyiségtöl bizonyos fokban elválik, kapcsolatba kerül a külsö, fizikai világgal, harmadik személyek számára érzékelhetővé válik, és új funkciót szerez a személyiség

\footnotetext{
526 TÖRÖ, 1979. 28-29.

527 U.o. 543.

${ }^{528}$ U.o. 431.

${ }^{529}$ U.o. 492.

${ }^{530}$ Legfelsőbb Bíróság GK. 52. sz.

${ }^{531}$ GÖRÖG MÁRTA: A know-how védelmének alapvetö kérdései. HVG-ORAC, Budapest, 2012. 69.

532 TÖRÖ, 1979. 288-289.

${ }^{533}$ SCHULTZ MÁRTON: A férj joga felesége nevén. Gondolatok a névhasználati engedély szabályaihoz. Családi Jog 2017/4. 14.

${ }^{534}$ BH 2012. 174.
} 
megjelölése mellett vagy helyett. Ez történhet közvetlenül, de közvetve is, ha a személyiségi jegy először valamely szellemi tulajdonjoggal lép kapcsoltba, és ezen keresztül tárgyiasul. Erre azonban nem minden személyiségi jog képes, így célszerü e jogokat lehatárolni.

\section{A személyiségi jogok osztályozása}

A személyiségi jogok többféle osztályozása ismert. A személyiségi jogok osztályozása nem rangsort jelent, hanem a jogok valamilyen logika szerinti csoportosítását. Ez alapján különbség tehető ember és jogi személy jogai közt (személyiségi jog és személyhez füződő jog között), ${ }^{535}$ általános személyiségi jog és különös személyiségi jog közt, a személyiség belső magjától való távolság szerint stb. A csoportosítás alapulhat a joggyakorlatban kialakított esetcsoportok alapján is.

A korábbi hazai jogirodalomban a személyiségi jogok osztályozása tekintetében a svájci mintához hasonlóan ${ }^{536}$ különböző elnevezésekkel megjelent a személyiség külső megjelöléseinek védelme. August Egger a nyilvánosság elötti identifikáció szempontjából beszél a megjelölési javakról, ide sorolja a névjavakat (Namensgüter), illetve a gazdasági személyiség megjelölési jogát, amely elsősorban a néven és jegyen való jogokra (Namen- und Zeichenrechte) vonatkozik. A megjelölések sajátja, hogy lehetnek egyéniek, illetve egy családhoz való tartozást is kifejezhetnek. ${ }^{537}$

A személyiség külső megjelölései azok, amelyek által az egyén, a személyiség a társadalomban, a külvilágban individuumként jelenik meg; olyan jegyek, amelyek minden embernél más formában öltenek testet. Ennek megjelölésére a korabeli irodalom többféle terminust használ: az individualitás megjelölései, ${ }^{538}$ individualizáló jellegü jogtárgyak, ${ }^{539}$ a személyiség külső megjelölései, ${ }^{540}$ néven és jegyen való jogok, ${ }^{541}$ megjelölési jogok ${ }^{542}$ (Bezeichnungsrechte), ${ }^{543}$ a személyiség másodlagos vonatkozásai. ${ }^{544}$ Menyhárd Attila a személyiségi jegyek, a személyiség eleve adott /

\footnotetext{
535 GÖRÖG MÁRTA: A jogi személy személyi értéke. Jogtudományi Közlöny 2011. 569. 570.

${ }^{536}$ EGGER, 1930. 246-248.

${ }^{537}$ U.o.

538 ZLINSZKY- REINER, 1902. 153.

${ }^{539}$ SCHUSTER RUDOLF: Collisiók kérdése a név, a cég, a védjegy és vállalat megjelölések jogköréböl. Polgári Jog 1925. 151.

540 SZLADITS, 1933. 361.

541 BOZÓKY, 1905. 464.

542 ALMÁSI, 1927. 133. 135.

543 ALMÁSI, 1922. 164.

${ }^{544}$ KolOSVÁRY BÁLINT: Megjegyzések a magánjogi codex-javaslathoz. Polgári Jog 1929. 305. 314.
} 
egyéb attribútumai és a személység megjelenési formái elnevezéseket használja. ${ }^{545}$ Tovább bonyolítja a helyzetet, hogy a német jogban a névjog az ún. megjelölések jogának (Kennzeichenrecht) vagy jegyen való jogoknak (Zeichenrecht) ${ }^{546}$ szubszidiárius alaptényállása, amely azonban kizárólag a szóbeli megjelölések szabályrendszerére szorítkozik, és a névjog ebben a tekintetben egy másik jogi osztályozásába is besorolható.

Még nyilvánvalóbbá válik azonban e megjelölési jogok és más személyiségi jogok közti megkülönböztetés az 1914-es javaslat indokolásából, amely szerint „a névhez való jogot tartalmának megjelölésével külön is mint védelemben részesülö személyiségi jogot emeli ki, minthogy könnyen [sic!] kétség támadhatna e jog tartalmára és arra nézve, vajjon a névre, amely csupán [sic!] a személyiség megjelölésére szolgál, kiterjed-e a személyiség védelmét megállapító szabály". ${ }^{547} \mathrm{Ez}$ lényegében azonos a Meszlény Artur által öt évvel korábban kifejtett állásponttal. ${ }^{548}$ Ezt az 1928-as Mtj. 108. § (2) bekezdése más jogok védelmére is kiterjeszti, amely szerint „a személyiségi jog megsértése az is”, ha valaki a nevet, a képmást vagy a levéltitkot sérti. Itt a felsorolás már kiegészül más külső személyiségi jegyekkel, és gondolhatnánk, hogy az ,az is” fordulat a generálklauzulát értelmezi. A fent bemutatott osztályozásra és személyiségi jogi felfogásra tekintettel inkább úgy tűnik, hogy olyan jogokra terjeszti ki az alanyi jog alkalmazását a javaslat, amelyekre egyébként nem lenne alkalmazandó. Az értelmező norma helyett a kiterjesztő jelleget támogatja Kolosváry magyarázata is, aki szerint ezek a személyiség másodlagos vonatkozásai. ${ }^{549}$ Ebből is az a sejtésem nyer megerősítést, hogy e jogok esetén nem egyértelmü, hogy az élet, testi épség, becsület, szabadság jogaival egy tekintet alá esnek-e, hanem inkább két külön esetcsoportként kerültek ezek felfogásra. Az azonban bizonyos, hogy ezek esetén a külvilágban való megjelenés, kapcsolatba jutás a személyiség e jegyeinek tárgyiasulásához vezet, ami tézisemet még inkább alátámasztani látszik.

\footnotetext{
${ }^{545}$ MENYHÁRD, 2016. 65-82.

${ }^{546}$ A jegyen való jog elnevezést Bozóky Alajos használja először, akinek az elmélete nagyban követi Otto von Gierke személyiségi jogi elméletét, aki e tárgykörre a Zeichenrechte elnevezést használja. ${ }^{547}$ Indokolás a Polgári Törvénykönyv törvényjavaslatához I. Grill, Budapest, 1914. 34-35.

${ }^{548}$ MESZLÉNY, 1909. 187.

${ }^{549}$ KOLOSVÁRY, 1927. 314.
} 
Az elhatárolás alapját a vagyoni értékủ személyiségi javak tekintetében az adja, hogy egyes személyiségi jogok a külvilágban meg tudnak jelenni. A jóhírnév, a becsület, az emberi méltóság, a szabadság joga az ember belső érzületének megsértésére koncentrál, és így ilyen formában nem értékelhetőek. A becsület és a jó hrnév a külső, fizikai világban mint tényállítás vagy mint véleménynyilvánítás jelennek meg, ezek azonban nem magukat a jogtárgyakat jelentik, hanem arra azokból csak következtetni lehet, így itt nem beszélhetünk tárgyiasulásról. Ehhez hasonló az élet, testi épség, egészség triásza, amelyek a ember „testi tárgyi" ${ }^{550}$ minőségéhez kapcsolódnak, ahhoz ahogyan az ember „a testiség képében áll elöttünk”. ${ }^{551}$ Ezek a részjogosultságok a személyiség fizikai világban lecsapódott vonatkozásai, amelyek nem lépnek ki az eszmei világból, nem tárgyiasulnak, mert már eleve a fizikai valóságban adottak. Ezek ugyan rendelkezhetnének vagyoni értékkel (ezt azonban a magyar jog nem ismeri el), ${ }^{552}$ azonban ennek a vagyoni értéknek más a jellege, mint a dolgozat által tárgyalt jelenségekéi. Ennek oka az, hogy az emberi test, annak szövetei, illetve a vér és az ehhez kapcsolahtó jelenségek a fizikai világ egy részét materiálisan kitöltik, abban egyszer adottak a dolgokhoz hasonlóan. A vagyoni értékü személyiségi jegyek azonban nem léteznek a fizikai világban, csupán érzékelhetőek abban, így azok megsértése nem is egyszeri tipikusan (pl.: egy személy képmását és nevét egy ruházati üzlet 10.000 pólóra rányomja).

A két világháború közötti gyakorlatban már tapasztalható a személyiség másodlagos vonatkozásainak, a külvilágban megjelenő személyi javaknak a személyiségi jogon belüli külön kezelése. A megjelölések és ismeretek immateriális jellegük ellenére alkalmasak arra, hogy kilépjenek "empiria felettiségükböl" 553 és tárgyiasuljanak. Erre a tárgyiasulásra általában e meghatározott személyiségi jegyek tipikus társadalmi felhasználási módjai adnak lehetőséget, amelyek nem feltétlenül jelentenek kereskedelmi, reklámcélú felhasználást, de a személyiségi jegyet kirántják a személyiség belsö szférájából, és az esetek jelentös hányadában a jogalany

\footnotetext{
${ }^{550} \mathrm{Az}$ emberi test testi tárgy, hiszen a fizikai valóságban egy meghatározható helyet elfoglal, birtokba azonban nem vehető.

${ }^{551}$ KOLOSVÁRY BÁLINT: A dologi jog általános tanai. In: Szladits Károly (szerk.): Magyar Magánjog V. Dologi jog. Grill, Budapest, 1942. 9.

552 1997. évi CLIV. tv. 170. § (3) bek.; 171. § (4) bek. c) pont; 206. § (3) bek.; 207. § (1) bek.; 209. § (2) bek.

${ }^{553}$ BALÁs, 1941. 625.
} 
gazdasági érdekkörébe tartozó felhasználási módról beszélünk. A felhasználási (tárgyiasulási) módok nem is homogének, azok egyes személyiségi jegy-csoporthoz tartoznak tipikusan, és nem is eredményeznek automatikusan vagyoni értéket, azonban előszobáját képezik egy absztrahálható vagyoni személyiségi jognak. Ennek alapján a tárgyiasítható személyiségi jegyek a következő csoportokba rendezhetőek:

\section{7. sz. táblázat}

A tárgyiasitható személyiségi jegyek osztályozása

\begin{tabular}{|c|c|}
\hline SZEMÉLYISÉG KÜLSŐ MEGJELÖLÉSE & ISMERET, INFORMÁCIÓ ${ }^{554}$ \\
\hline $\begin{array}{l}\text { - név } \\
\text { - képmás } \\
\text { - hang } \\
\text { - jelmondat } \\
\text { - } \text { a külső megjelenés más módja }\end{array}$ & $\begin{array}{l}\text { - } \text { személyiségkép, életkép } \\
\text { - } \text { magántitok } \\
\text { - } \text { adat } \\
\text { egyéb magánéleti vonatkozások }\end{array}$ \\
\hline
\end{tabular}

(saját szerkesztés)

\section{A személyiség külső megjelölése}

A személyiség külső megjelölései magukban foglalnak számtalan, a személyt azonosító elemet: a nevet, a céget, a védjegyet, a képmást, a címert stb. A megjelöléseken belül külön csoportot képeznek a szóbeli megjelölések: ilyen különösen a név, amely a megjelöléseken belül speciális helyet foglal el, mert igényhalmazatba kerülhet más szóbeli megjelölésekkel, különösen a cégnévvel, kereskedelmi névvel, védjeggyel, a domain névvel, más áru- és üzletjelzővel is. Ez a halmazati konstelláció a képnél mint külső jegynél is megvan, ott azonban lényegében a védjegyre szükül ez, mivel más esetben a jogi védelem tárgya a szóbeli megjelölés.

A név alatt nem a természetes és jogi személy hivatalos neve értendő, hanem a név fogalma alá tartozik minden névfunkcióval bíró megjelölés, amelyről egy személy felismerhető. A névbe beletartozik ezáltal az utónév (Uwe, Marlene), ${ }^{555}$ az aláírás. A

\footnotetext{
${ }^{554} \mathrm{~A}$ know-how és az üzleti titok vizsgálatától eltekintek, e jogok ugyanis sokkal személytelenebbek, e jogtárgyak tekintetében a jogtárgy a tárgyi, illetve alkotási világból lép be a személyi szférába, erre utal a legújabb jogalkotás megoldása is, amely külön törvényben szabályozza a jogintézményeket, és ,"̈zleti titokhoz füződő jogról” beszél. Lásd a 2018. évi LIV. törvényt az üzleti titok védelméröl. A jogalkotó ugyanakkor nem tekinti iparjogvédelmi intézménynek ezeket, erre enged következtetni a Ptk. 2:55. §-ának változása. A know-how jogalkatára 1. SzTOJÁN KRISZTINA: Kétarcú know-how: személyiségi jog vagyoni értékkel? Gazdaság és Jog 2018/3.17.

${ }^{555}$ NJW 1983, 1184 - Uwe; NJW 2000, 2195 - Marlene Dietrich. A védelem elvileg a magyar jogban is lehetséges: BH 2003. 149. („Nárcisz”).
} 
külső megjelenéshez tartozik továbbá a képmás, ${ }^{556}$ a jelmondat (catch-phrase), ${ }^{557}$ illetve a külső megjelenés más módjai, mint amilyen a hasonmás személy alkalmazása reklámban, ${ }^{558}$ viaszképmás kiállítása plasztikonban. ${ }^{559}$

A személyiség külső megjelölései, az azok feletti rendelkezés vagyoni értékkel bír, s ezt bizonyos vonatkozásaiban a joggyakorlat is elismeri, s így vagyoni értékkel bír a képmás felhasználói joga, ${ }^{560}$ illetve a fényképfelvétel elkészítése is vagyoni jog. ${ }^{561}$ A névjog tekintetében ilyen a kereskedelmi név. ${ }^{562}$ A személyiségi jegy sokszor nem önmagában, hanem a felhasználás módja által kerül kapcsolatba vagyoni viszonyokkal. A jogosult engedélyének hiánya és a felhasználásra irányuló megállapodás elmaradása okán meg nem fizetett ellenérték miatt a felhasználás jogellenessége vagyoni kárt keletkeztet. ${ }^{563}$ A névvel kapcsolatos diszpozíció, szóbeli megjelölésként való felhasználása szintén kizárólagos vagyoni jog lehet, ${ }^{564}$ amely a személyiségi joggal vegyül. ${ }^{565}$ A személyiségi jegy személyiségi jogi, szellemi tulajdonjogi jellege a nemzetközi magánjogi kapcsolószabályokat is meghatározzák, és így jogi minősítésük ebből a szempontból is kiemelkedő lehet. ${ }^{566}$ Hasonló módon a domainnevek tartalom nélküli fenntartása és az azokról ellenérték fejében történő lemondás (domain grabbing vagy cybersquatting) is az azokban rejlö vagyoni potenciált mutatja. ${ }^{567}$

\section{Ismereti személyiségi jegyek}

556 BDT 2009. 24. („Budapesti Öszi Fesztivál”); BDT 2015. 70. („Élesztőtabletta”).

${ }^{557}$ Ötletkénti védelem: BH 1999. 252. („Mindannyian mások vagyunk!”); jó hírnév sérelme: BH 2002. 261. („Jó estét, jó szurkolást!”). A német jogalkalmazási gyakorlatból jelmondat személyiségi jogi sérelemként való értelmezésére 1. OLG Hamburg, 08.05.1989 - 3 W 45/89; NJW 1990, 1995 Heinz Erhardt.

558 NJW 2006, 3409 - Der blaue Engel II.

${ }^{559}$ Kúria 1939. márc. 23. — P. I . 623/1939 („Viaszképmás”), Grill Dtár XXXII. 554., Jogi Hírlap Dtár IV. 77.

560 BDT 2015. 70. („Élesztőtabletta”).

${ }^{561}$ BDT 2009. 24. („Budapesti Öszi Fesztivál”).

562 TÖRÖ, 1979. 289.

${ }^{563}$ Elvárhatóság hiánya okán vagyoni kár meg nem állapítása: BDT 2015. 70. („Élesztőtabletta”).

${ }^{564}$ Személynév cégnévbe adása (apport): BH 1990. 476., Legf. Bír Pf. IV. 21087/1993. („Rácz”).

565 Személynév mint cégnév személyiségi jogi jellegét hangsúlyozza: Legf. Bír. Pf 21007/1992. („Láng”). A személyiségtől el nem válás tekintetében: BH 1990. 255. („RORÁRIUS”); domain név személyiségi jogi jellegére BDT 2011. 123. (,szeged.hu”).

566 Domainvitában védjegyjog mint iparjogvédelmi jog kapcsolószabályát alkalmazta a Szegedi Ítélőtábla azzal, hogy a megsértett jog a névjog (azaz egy személyiségi jog volt) ÍH 2014. 58. (,facebook.hu”).

${ }^{567}$ P1. BDT 2009. 22. (,jakab.hu”). 
A vagyoni értékü személyiségi érdekek tekintetében elsősorban a külső megjelölésekre helyeződik a hangsúly, mert ebben az esetben a tárgyiasulás nyilvánvalóbb, a kereskedelemben betöltött szerep szembeötlőbb, ide sorolhatóak azonban egyes, a személyhez köthető ismeretek is. Vannak olyan jogok, amelyek alapja valamely ismeret. Ezek tárgyiasulásuk, felhasználásuk által szintén a személyiséggel kapcsolatban állnak, azonban nem megjelölik, hanem jellemzik azt. Az ismereti személyiségi jegyek azok, amelyek nem a személy azonosítására irányulnak, hanem a személyiségét, a magánéletét információ formájában hordozzák, és amelyek alkalmasak arra, hogy másokkal írásban vagy más módon megosztásra kerüljenek.

Ilyen ismereti személyiségi jegy a személyiségkép (életkép, image), ${ }^{568}$ amely a személy külvilágban kiváltott hatásának összlenyomata. Az egy személyhez kapcsolható tettek, események leggyakoribb felhasználása a sajtóban való közlés, amely jelentősen növelheti az azt közlő médium bevételét, eladott példányszámát. Hasonló, ám a müvészeti élet szabadsága által védett, egy személy életútjának vagy annak egy részének írásban, ${ }^{569}$ színpadon ${ }^{570}$ vagy filmalkotásban ${ }^{571}$ való felhasználása. Az életkép egy személy sorsát, cselekvését, tetteit, szavai, külső életének lefolyását jelenti. ${ }^{572}$ Az életkép a külső megjelölésekkel annyiban rokon, hogy megsértésének előfeltételeként a megjelöléseknél ismeretes azonosságiösszetéveszthetőségi mércéből kell kiindulni. Az életkép szintén vagyoni értékkel bír, bár ez talán kevésbé szembetünő, mint a név, képmás esetén, ennek ellenére leggyakoribb személyiség-árubabocsájtási mód ma Magyarországon a híres személyek, a celebek élete eseményeinek, történéseinek ellenérték fejében való átengedése bulvárlapoknak. A bulvárlapok engedély beszerzése nélküli, a magánéletbe tartozó megnyilvánulások közzétételével éppen e hozzájárulási díjfizetési kötelezettséget kerülik meg, amellyel a személyiségi jog jogosultjának kárt okoznak. Hasonló lehet egy személy életének megfilmesítése esetén a horrorfilm müfajának

\footnotetext{
568 BEUTHIEN, NJW 2003. 1220.

569 BH 1980 377. („Kányák”); Németországban: NJW 2008, 39 - Esra; Ausztriában: SZ 31/86 (,Asphaltkönig”).

${ }^{570}$ NJW 1975. 1882. - Der Geist von Oberzell.

${ }^{571}$ Magyarországon: BDT 2015. 84. („Gyurcsány vezetőszíjon”); Németországban: ZUM 2008, 793 Kannibale von Rotenburg II.; Ausztriában: OGH Wien NJW 1956, 1942 („Die Schuld des Dr. H”). ${ }^{572}$ Doralt, Roswitha: Der Schutz des Lebensbildes. ÖJZ 1973, 645.
} 
választása, amellyel az ismertetésen túl kifejezett vagyoni előnyszerzés is kapcsolódik. ${ }^{573}$

Tág értelemben ezekhez az ismereti személyiségi jegyekhez sorolhatóak a magánélet más vonatkozásai is. Az ismerethez, információhoz kapcsolódik az adatok védelme és az azokkal való rendelkezés is, amelyhez szintén vagyoni érték társulhat, különösen a digitális világban, ${ }^{574}$ illetve az egységes digitális piac vonatkozásában. ${ }^{575}$ A személyes adatok ilyen besorolása mint a digitális hagyaték része is értelmezhető lehet. ${ }^{576}$ Külön érdekes a magántitok, amely a többi joggal ellentétben közkinccsé válik azáltal, hogy nyilvánosságra kerül, a titok lényege ugyanis a valamilyen mértékü titkosságában rejlik. A magánélethez való viszonyáról az mondható el, hogy a magántitok a magánéleti adatokhoz képest szűkebb; körébe olyan nem nyilvános, kevesek által ismert tény, adat vagy körülmény tartozik, melyek megörzéséhez az adott személynek méltányolható érdeke füződik. ${ }^{577}$ A magántitok a személyiségképhez, életképhez viszonyítva is speciális.

\section{A név különutassága a személyiségi jogok között}

A névnek mint jogi és társadalmi jelenségnek a sajátos jellegére mutat rá az, hogy valakinek a névjogává válhat egy megjelölés, amely korábban őt nem illette meg ezzel a jogosult tulajdonképpen a néven, egy megjelölésen új jogot szerez. Ez az élet, testi épség és más személyiségi jogokkal szemben tehát a személyiség részévé válik, és nem adott az ember születésétöl kezdve. A bírói gyakorlat is következetesen vizsgálja a név személyiséghez füződő kapcsolatát, megszemélyesülését az egyes családjogi kapcsolatok felbontása esetén. ${ }^{578}$ A név tehát abból a szempontból kilóg a klasszikus személyiségi jogok közül, hogy az a személyiségi jogban nem kezdettől fogva adott, azt mindenképpen kapcsolatba kell hozni a személlyel, és a

${ }^{573}$ ZUM 2008, 793 - Kannibale von Rotenburg II.

574 A magánélethez való jog és a személyes adatok védelmének kapcsolódására az EJEB joggyakorlatával összefüggésben: SzEGHALMI VERONIKA: A magánélet védelmének változó megitélése az Emberi Jogok Európai Bíróságának gyakorlatában. In: Koltay András - Török Bernát (szerk.): Sajtószabadság és médiajog a 21. század elején 4. Wolters Kluwer, Budapest, 2017. 270.

575 GELLÉN, 2017/4. 3. 4.

${ }^{576}$ Egy öngyilkosságot elkövetett lány facebook-beszélgetéseinek kiszolgáltatása a szülőknek: LG Berlin, Urt. v. 17.12.2015, Az. 20 O 172/15; ellentétes döntést hozott a Kammergericht a távkközlési titokra (a beszélgetésekben részt vevő személyek jogára) tekintettel: KG Berlin, Urt. v. 31.05. 2017, Az. 21 U 9/16; a kérdésben a Német Szövetségi Alkotmánybíróság még nem döntött.

${ }^{577}$ Fővárosi Ítélőtábla 1. Pf. 20. 780/2015/6/II.

${ }^{578}$ BH 2012. 174. („Рapp”). 
személyiségtől a kereskedelmi és gazdasági életben való bizonyos irányú felhasználásával el is válhat, illetve elválhat teljesen is, ha valamely családi jogi kapcsolat megszünik, felbontásra kerül. A név e természete a személyiségi jogok közül kiemelkedik, és érdekes táptalajt nyújt a vizsgálódás számára.

Az 1914-es javaslat indokolása, amely a Ptk. generálklauzulájának alapjául is szolgált, azt tartalmazza, hogy a névjog külön kiemelésére a tervezetben azért került sor, mert kétség támadhatna e jog tartalmára és arra nézve, vajon a névre, amely csupán a személyiség megjelölésére szolgál, kiterjed-e a személyiség védelmét megállapító szabály. ${ }^{579}$ Ugyanerre érez rá Kolosváry Bálint az 1928-as Mtj. vonatkozásában, ő a névjog, a képmás- és titokvédelem külön deklarálását mint a „,személyiség másodlagos vonatkozását” említi, de az emögött meghúzódó elv, amire Kolosváry rá kíván mutatni, tulajdonképpen ugyanaz. ${ }^{580}$ Meszlény Artur a svájci jog tárgyalása során kétségbe vonja a név személyiségi jogi jellegét, s a magyar szerzők közül ő tette ezt eddig leghatározottabban. Meszlény szerint a név mint egyedi megjelölés „osztja a vagyoni jogoknak azt a sajátosságát, hogy specializálható, konkretizálható s ehhez képest felmerülhet rá vonatkozóan a kérdés, vajon ez a név megilleti-e ezt a személyt ${ }^{581}$ ". Egy tanulmányomban korábban rámutattam arra, hogy az ember nem minden személyiségi joga ered az emberi méltóságból, hanem egyes jogai a személyéhez, jogalanyi létéhez füződnek, és ehhez soroltam a névjogot is. ${ }^{582}$

A névjog e lényeges tulajdonságánál, dogmatikájánál és joggyakorlatánál fogva tehát kitünően alkalmas arra, hogy a tárgyiasulás és a megszemélyesülés jogi jelenségei általa leírásra kerüljenek.

\section{Részösszegzés}

A magánjog által védett jelenségek, jogi tárgyak osztályozása szempontjából elmondható az, hogy kezdetben ez kizárólagosan a vagyonjogokra szükült, amelyek a fizikai valóság jelenségeit írták le, azt értékelték jogilag. A XIX. században jelentkezik, elsősorban a szerzői jog, szabadalmi jog és védjegyjog irányából a fizikai valóságtól független, eszmei érdekek védelme. Ezután jelenik meg az eszmei valóság

\footnotetext{
${ }^{579}$ Indokolás a Polgári Törvénykönyv Törvényjavaslatához I., Grill, 1914. 35.

${ }^{580}$ KOLOSVÁRY, 1929. 7. szám 314.

${ }^{581}$ MESZLÉNY, 1909. 187.

${ }^{582}$ SCHULTZ, 2016. 695.
} 
egy másik szférája, a személyiségi jogok védelme. A magánjog által védett jogtárgyak átfogó rendszerezését Meszlény Artur már 1909-ben megadja. Ebben az osztályozásban a személyiségi jog személyi immateriális jog, azaz olyan eszmei jószág, amely a jogalanytól nem elválasztható.

A személyiségi jog magánjogi elhelyezése szempontjából az uralkodó álláspont nem az eszmei javak közötti elhelyezésböl indul ki, hanem a vagyonjogokkal állítja szembe azt. Ennél fogva a személyiség jogi védelme mint nem vagyoni jog jelenik meg. Ez a rendszerezés egyértelmüen korlátot jelent abban a vonatkozásban, hogy egyes személyiségi jogi részjogosultságok forgalomképes vagyoni jogként jelenhessenek meg, annak ellenére, hogy az egyes személyiségi részjogosultságoknak már a személyiségi jog megjelenésekor vagyoni értéket tulajdonítottak. Célszerü a személyiségi jogot személyi, azaz nem vagyoni jognak tekinteni, amely eszmei, erkölcsi érdekeket véd. Az egyes személyiségi jegyek azonban felhasználhatóak anyagi haszonszerzés céljára is. Ez az eszmei érdekekhez képest további lépcsőt jelent, ugyanakkor a személyiségi jog alanyi joga alkalmas arra, hogy vagyoni érdekeket is védjen akkor, ha a jogosultnak erre szüksége van. Ezzel a személyiségi jegyek kilépnek a személyi immateriális jog köréből és önállótlan vagyoni immateriális joggá válnak. E másik eszmei érdekkörbe való átlépés mérésére szolgál a tárgyiasulás, illetve vagyoni érdekkörben történő tárgyiasult felhasználás. Ezzel a tárgyiasulás útján történő transzformációval tulajdonképpen megteremtődik annak a dogmatikai alapja, hogy egyes személyiségi jogok a személytől, a jogalanytól elváljanak, átruházható, örökölhető, forgalomképes javakká váljanak. Az önállótlan immateriális jelleg utal arra, hogy a tárgyiasult személyiségi jegyek személyiséggel való kapcsolata fennmarad akkor is, ha az adott jogosultág (személyiségi jegy) öröklés vagy átruházás útján máshoz kerül, hiszen a személyiségtől való elválás részleges, a személyiségi jegy továbbra is vonatkozik a személyiségre.

A tárgyiasítható személyiségi jegyek két nagy csoportra oszthatóak, az egyik a személyiség külső megjelölését szolgálja, mint a név, képmás, a másik a személyiséggel kapcsolatos tulajdonságokat információ formájában hordozza, mint amilyen az életkép, magántitok vagy a magánélethez való jog egyéb vonatkozásai. Ezek a személyiségi jogi vonatkozások azok, amelyek felhasználásuk által önállótlan vagyoni immateriális joggá válhatnak. A tárgyiasítható személyiségi jegyek közül a névjogot emeltem a vizsgálat középpontjába annak szóbeli megjelölési jellege révén, amely által a név a tárgyiasulás számtalan módjára képes lehet. 


\title{
5. § A NÉV TÁRGYIASULÁSÁNAK MÓDOZATAI
}

\author{
Bevezetés
}

A tárgyiasulás tekintetében a névjogra koncentrálva kerül bemutatásra az, hogyan és milyen formában képes a név, illetve más szóbeli megjelölés tárgyiasulni a személyiségvédelmen belül. ${ }^{583}$ Ezzel tulajdonképpen arra kívánok rámutatni, hogy maga a tárgyiasulás sem egységes jelenség, annak számtalan altípusa van. Mint látható lesz, a névjog nem is csupán a jogalany nevét, hanem más jogtárgyakat is véd: a kereskedelmi nevet és a domain nevet. Ezek, ha nem tartalmazzák a jogalany nevét mint a személyiségre utaló szóbeli megjelölést, úgy sokkal kevésbé függnek a személyiségtől. Az azokkal való rendelkezés, azok átruházása nem függ a személyiségi jog jogosultjának más irányú eszmei vagy más érdekétől. Ezzel szembeállíthatóak lesznek a személynevet tartalmazó tárgyiasulási módok, amelyek esetén az önállótlan immateriális jelleg korábban említett tulajdonsága kidomborodik. Jelen fejezetben tehát a név tárgyiasulásának módozatai, a kereskedelmi, reklámcélú felhasználási módjai kerülnek kibontásra amellett, hogy a névjog joggyakorlatban jelentkező szerepéből kirajzolódik az a számtalan jogtárgy és jogi érdek, amelyet ez a jog valóban véd.

\section{A név tárgyiasulása: a névhasználat}

A törvényi szabályozásban mind a névviselés, mind a névhasználat fogalom használata előfordul, így kérdéses lehet, melyik alatt mit értünk, illetve, hogy van-e a két fogalom között egyáltalán különbség. Néhány jelentősebb törvény fogalomhasználata sem következetes. A Ptk. a személyiségi jog megsértéseként a névviseléshez való jog

\footnotetext{
${ }^{583} \mathrm{~A}$ tárgyiaulás témakörét több irányból körüljártam, e tanulmányaim egy részét a fejezet megírásához szintén felhasználtam: SCHULTZ MÁrTON: A cégnév szellemi tulajdon jellege és viszonya a személyiségi joghoz. In: Görög Márta, Mezei Péter (szerk.): A szellemi tulajdonvédelem és a szabadkereskedelem aktuális kérdései. Szeged, Iurisperitus Bt., 2018.; GöRÖG MÁRTA - SCHULTZ MÁRTON: A név tárgyiasulása a kereskedelmi megjelölések vonatkozásában. Megjelenés alatt; SCHULTZ MÁRTON: Azonosnevüség és domain nevek. In Medias Res 2018/2. Illetve jogesetelemzésem is jelent meg a témában: SCHULTZ MÁRTON: A Debreceni Ítélötábla döntése a név jogosulatlan kereskedelmi felhasználása tárgyában. JeMa 2019/1.
} 
megsértését nevesíti, ${ }^{584}$ ugyanakkor a Ptk. 2:49. § (2) bekezdésben a név használatát említi a felvett név esetén. A Ptk. szerint a jogi személy a nevét szintén viseli. ${ }^{585} \mathrm{~A}$ házastársak névviseléséről rendelkező szakaszok azonban következetesen a névviselés szót alkalmazzák, ${ }^{586}$ hasonlóan az anyakönyvi törvényhez. ${ }^{587}$ Az egyes címek és rangok megszüntetéséröl rendelkező törvény használatot említ. ${ }^{588}$

A régi Ptk. 77. § (4) bekezdés 1. mondata is következetlen volt: a névviselési jog megsértésének a jogosulatlan használatot tekintette. A névbitorlás tényállásával kapcsolatban idézhetnénk Göttét, aki a századfordulón, a BGB hatálybalépésekor fejtette ki aggályait a név megsértéséről rendelkező 12. §-ról, illetve annak kodifikációs előzményeiről. „Először úgy kellett volna nevezni [a sértő magatartást]: Aki illetéktelenül visel (führt) nevet, később: visel vagy használ (führt oder gebraucht), aztán: felhasznál (sich bedient), és most úgy nevezik: használ (gebraucht)." 589

Megyeri-Pálffi Zoltán azon az állásponton van, hogy jelentésbeli különbség nincs a két szó között, szerinte a két fogalom egymást feltételezi, „ugyanis aki egy nevet használ, annak azt viselnie is kell, ellenkező esetben más természetes személy nevét használná, ami jogellenes magatartás". ${ }^{590}$ Balás P. Elemérnél a névhasználat a tágabb fogalom, amibe a névviselés is beletartozik. ${ }^{591}$ Götte már 1899-ben tartalmi megkülönböztetést ad: a név viselése alatt kizárólag csak azt érti, amely néven a névre jogosult személy fellép, míg használaton azt, ha valaki a nevet valamilyen irányban felhasználja (benutzt). ${ }^{592}$ Valószínűleg ezen elhatárolás alapján mutat rá a Reichsgericht a Graf Zeppelin ügyben, hogy a név nem átruházható, és a problémát onnan kell megközelíteni, hogy a névviselésre jogosult a neve használatát - amely a név viselésétől megkülönböztetendő - egy másik személynek szerződéssel átengedi, azaz lemond ezzel a személlyel szemben arról a jogáról, hogy számára a név használatát megtiltsa. ${ }^{593}$ Görög Márta sem azonos fogalomként kezeli a két fogalmat,

\footnotetext{
${ }^{584}$ Ptk. 2:43. § f) pont.

${ }^{585}$ Ptk. 3:6. § (1) bek.

${ }^{586}$ Ptk. 4:27-28. $\S \S$

587 2010. évi I. tv.

588 1947. évi IV. tc.

589 GÖTTE, 1899, 322.

${ }^{590}$ MEGYERI-PÁLFFI, 2013. 100.

${ }^{591}$ BALÁS, 1941. 655.

592 GÖTTE, 1899. 322.

${ }^{593}$ RGZ 74, 312.
} 
és elsősorban arra mutat rá, hogy a Ptk. csak a névviselést szabályozza, a névhasználatról nem rendelkezik. ${ }^{594}$

Az egyes személyiségi jogok, így a névviselési jog is akkor érdekes a jogkereső közönségnek, a jogot alkalmazóknak, ha e jogot megsértik. Ahhoz, hogy egy jog megsértéséről beszéljünk, tudni kell, mit értünk az adott jogosultság alatt, ehhez az szükséges, hogy a névjog jogosultja hatalmi körébe tartozó részjogosultságokat kibontsuk. A régi Ptk. még tartalmazott ez irányú általános szabályt, amikor deklarálta, hogy mindenkinek joga van a névviseléshez. Ez a szabály a személyiség generálklauzulájában virtuálisan most is benne van, már csak azért is, mert ezt a tételt a névviselési jog megsértése is feltételezi. Mi jelen fejezetben elsősorban a névhasználatra fókuszálunk, tekintettel arra, hogy a névviselés alatt társadalmi viszonyokban az adott néven való fellépést értjük, amely által a névviselés a személyiség eszmei, erkölcsi oldalát emeli ki. ${ }^{595} \mathrm{Az}$, hogy a név használata milyen jogosultságokban ölt testet, nem kívánom teljeskörüen körüljárni, csak a vizsgálat szempontjából releváns vonatkozásait. Ennek okán a továbbiakban az is nyitva maradhat, hogy felvett nevek esetén névviselésről vagy névhasználatról beszélünk-e. Balás a névhasználat átengedését elsősorban a kereskedelmi, üzleti élettel kapcsolatban látja relevánsnak, ${ }^{596} \mathrm{mi}$ azon az állásponton vagyunk, hogy nem a kereskedelmi tevékenység a meghatározó a névhasználatba tartozó jogosultságok meghatározásánál. Helyesebbnek tünik az, hogy a név megjelölési, azonosítási funkciója nem csak a jogosult személyére vonatkozik (ez a névviselés), hanem az egyediesítő és identifikációs funkció az adott személyt valamely fizikai vagy eszmei dologgal hozza kapcsolatba, mintegy hidat teremtve a személy és e „tárgy” között. ${ }^{597}$ A névhasználat jogába tartozó egyes tételes jogosultságok a névviselés jogából válnak ki természetes személy esetén. ${ }^{598}$ A jogi személyek vonatkozásában a jogi személyt jelölő név minden esetben kapcsolatba kerül az általa végzett tevékenységgel, amely okán őt csak a névhasználat joga illeti meg.

\footnotetext{
${ }^{594}$ GÖRÖG, 2014b. 591.

${ }^{595}$ A névviselés speciális alfajával a szerzői névvel, illetve annak általános magánjog alapján történtő bitrolásával a következő tanulmányomban foglalkoztam 1. SCHULTZ MÁRTON A névbitorlás egyes kérdései, különös tekintettel a szerzői név bitorlására. In: Doktori Mühelytanulmányok, Győr, 2017.

${ }^{596}$ BALÁs, 1941. 652.

${ }^{597}$ Amennyiben ez a kapcsolat hiányzik, a magatartás nem sérti a személyiségi jogot, ld. BH 2003. 149. („Nárcisz”).

598 Vö. különösen: BH 1997. 476. („Pick”), BH 1990. 255. („Rorárius”)
} 
A névviselés tehát elsősorban a személyiség eszmei oldalát védi, a névhasználat pedig valamilyen funkcióhoz kötött joggyakorlást jelent. A névviselési jogból keletkezhet a névhasználat, lényegében ez a név tekintetében a tárgyiasulás pillanata. A névhasználat arra a funkcióra redukálódik, amely jogtárggyal, dologgal, fogalommal a név kapcsolatba kerül, ugyanakkor ennél szélesebb körre, más funkciókra is kiterjedhet. Ilyen lehet az, ha valamely vállalat cégnevét védjegyként bejegyzik. Különösen sok irányból alkalmas erre a domainnév. A megjelölések tekintetében ugyanis leginkább a szóbeli megjelölések között van átjárás, mert ezeket védi a legtöbb jogintézmény, így beszélhetünk a védjegyjog megsértéséről cégnévben való szerepeltetéssel, ${ }^{599}$ a cégnév sérelméről domainnévben való használattal, ${ }^{600}$ a domainnév megsértéséről cégnévben való használattal, a családi név kereskedelmi névként, üzletjelzőként való használatáról ${ }^{601}$ stb. Ez az átjárás a domainnév tekintetében viszonylag jobban összpontosul, amelynek oka értelemszerüen abban rejlik, hogy valamennyi piaci szereplő, illetve magánszemély is meg akar jelenni az interneten annak érdekében, hogy magukról harmadik személyek és ügyfeleik számára könnyen hozzáférhetően nyújtsanak információt, szolgáltatást. Domainnevet így valamennyien a saját nevükkel szeretnék használni, amelyen öket ismerik. Az azonosnevüségnek és az ezzel kapcsolatos jogütközéseknek számtalan elképzelhető formája létezik.

A névhasználati jog ezzel szemben nem válhat sosem névviseléssé, egy funkció szerinti megjelölés nem válhat a jogalany általános megjelölésévé, magánjogi szempontból ezért nem értelmezhető a védjegyként bejegyzett nemesi cím, illetve a szintén védjegyként bejegyzett parabolikus doktori cím természetes személy viselt nevének részeként. ${ }^{602}$ Erre a személyiségi jog védelme, a névjog gyakorlása nem terjed ki, hiszen itt a rendeltetésszerü joggyakorlás az előbb említett funkcionalitás kijátszásában, figyelembe nem vételében rejlik.

\footnotetext{
${ }^{599}$ BH 1993. 92. (,DLH”).

${ }^{600}$ BDT 2008. 20. (,,rekviem.hu”).

${ }^{601}$ BH 1994. 21. („Rácz”)

${ }^{602}$ SCHUltZ, MARTIN: Mißbrauch von Titel. FORVM, VII. évfolyam, 2017. 177.
} 


\section{A cégnév}

1. Általános gondolatok

A személyiségi jogba tartozó jogosultságok, így a névjog szabályozása, müködési mechanizmusa vonatkozásában számos vagyoni elemet találhatunk, amelyek elsősorban külön, speciális jogintézmények vonatkozásában jelentkeznek, mint amilyen a védjegy mellett a cégnév is. Apáthy István már 1873-ban így fogalmaz: „,nem szenved kétséget, hogy bizonyos czégek ${ }^{603}$ elvitázhatlan értékkel bírhatnak, melynek felhasználásától, ha mások érdekei nem sértetnek, jogosan senki meg nem foszthatoo" ${ }^{604}$ A személyiségi jog által az ember és tágabb értelemben a jogalany személyi, nem vagyoni érdekei kerülnek védelmezésre, s a vagyoni érdekek e dogmatikai felfogásnál fogva háttérbe szorulnak. Noha a cégnév védelmét elsősorban a jogi személyekhez kapcsolják, az kapcsolatba kerülhet a természetes személyek névvédelmével is, különösen abban az esetben, ha az a cégnévben szerepel. A természetes személy nevének, illetve a cégnévnek a védelme eltérő dogmatikai karaktert mutat, amely a névviselés-névhasználat terminusok dogmatikai elhatárolásában is jelentkezik. A cégnév mint a jogi személyek megjelölésére szolgáló lajstromozást igénylő jog sok szempontból a szellemi tulajdonjogokhoz hasonló karakterrel rendelkezik, amely miatt a német uralkodó felfogás azt ennek módjára is kezeli. Azt vizsgálom, hol érhető tetten a cégnév szabályozásában a személyiségi jogi pillanat (vonatkozás), s ez mennyiben jelent korlátot a cégnévre vonatkozó jogosultság gyakorlása, a szabad kereskedelemben való megjelenés szempontjából.

2. A cégnév mint alanyi jog elhelyezése a magánjog rendszerében

A cégnév alanyi jogi jellegének meghatározása által közelebb kerülhetünk azon kérdés megválaszolásához, milyen mögöttes szabályok alkalmazandóak dogmatikailag a cégnévre. E mögöttes szabályrendszer ugyanis jelentősen meghatározza a cégnévvel való rendelkezés korlátait, amely magának a gazdasági életben, a kereskedelmi forgalomban való részvételnek bizonyos tekintetben a korlátját képezheti. E mögöttes szabályrendszer, alanyi jogi jelleg nemcsak államonként, hanem koronként is változik.

${ }^{603}$ A cég és a cégnév kifejezéseket egymás megfelelőjeként használom.

${ }^{604}$ APÁTHY ISTVÁN: A magyar kereskedelmi törvénykönyv tervezete. Franklin, Budapest, 1873. 38. 
Célszerü ezeket felvázolni a tételes szabályok ismertetése előtt, az osztályozás szempontjából ugyanis vezérfonalként szolgálnak.

A személyi eszme magánjogi térhódítása előtt a magyar jog ezt kifejezetten a kereskedelmi jog körében tárgyalta kizárólagosan. Ennek oka nyilvánvalóan a cégnév szabályainak rendszerbeli elhelyezésében rejlik, arról ugyanis a Kt. rendelkezett. A személyiségi jog magánjogi alanyi jogi jellegét tagadó álláspont ezt ezen túl az eszmei javak (mai fogalmainkkal élve a szellemi alkotások) körébe sorolta a képmáshoz való joggal egyetemben. ${ }^{605}$

A személyiségi jogok századeleji térhódítása eltérő dogmatikai felosztást implikált. Bozóky Alajos a polgári név mellett a kereskedő nevét (cég) a név egy fajtájának tekinti, ezzel szemben a jegyek csoportjába tartozónak a címert, a pecsétet, az áru- és védjegyeket, ${ }^{606} \mathrm{~s}$ kitér a névre mint jegyre, azaz a névre mint áru-, illetve üzletjelzőre. ${ }^{607}$ A személyiségi jogi rendszer szempontjából jelentős, hogy-Gierkéhez hasonlatosan ${ }^{608}$ - a névjogot, illetve a jegyen való jogokat a személyiségi jogok közé sorolja, azokat ott azonban részletesen nem fejti ki, hanem külön fejezetbe viszi át az erre vonatkozó joganyagot, amely valaminemü érdemi különállást feltételez, ennek okát azonban Bozóky nem adja meg. A cégnév ezzel jelenik meg elsőként a személyiségi jogi oltalom körében. Ennek azért van jelentősége, mert a magánjogi kodifikáció során a személyiségi jogi rendelkezések között elhelyezett névjogi igény kizárólag az ember, a természetes személy ez irányú jogát kívánta védelemben részesíteni. Meszlény különválasztja e két jogot. A céget az önállótlan vagyoni immateriális javak csoportjába tartozónak tekinti, amelyek a vagyonhoz elválaszthatatlanul kapcsolódnak. A névjogot a személyi immateriális javak közé sorolja, amelyek csak a természetes személyeket, az embert illethetik meg. ${ }^{609}$ Ezek közül elsősorban a névjognál gondolkozik el Meszlény annak eltérő jogi jellegén. Míg a személyi immateriális javak mindegyike vitathatatlanul megillet minden embert, addig a névjognál (emellett a családi állás és a testületi tagságot is ide sorolja) kérdésként jelentkezhet annak megállapítása, hogy az egy adott személyt megillet-e,

\footnotetext{
${ }^{605}$ ZLINSZKY - REINER, 1902. 552.

${ }^{606}$ Evonatkozásban lásd különösen HOMOKI-NAGY MÁRIA: A védjegy magyarországi történetéről. In: Görög Márta - Mezei Péter (szerk.): A szellemi tulajdonvédelem és a szabadkereskedelem aktuális kérdései. Iurisperitus, Szeged, 2018.

${ }^{607}$ BOZÓKY, 1905. 464.

${ }^{608}$ GIERKE, 1895. 717. sköv.

${ }^{609}$ MESZLÉNY, 1909. 173.
} 
személyi javai körébe tartozik-e. ${ }^{610}$ Meszlény e gondolatmenete - amelyet 1909-ben fogalmaz meg, s amely a magyar jogi dogmatikában egyedülálló -, mutat kísérteties hasonlóságot a német jogi terminológiában a BGH által 1999-ben elismert személyiség vagyoni vonatkozásainak elméletével. ${ }^{611}$

Kiemelkedő jelentősége annak van, hogy a cég rendszertani, dogmatikai elhelyezése a névhez gravitált. Ebben jelentett változást Balás $P$. Elemér elmélete, aki sokkal jobban teret engedett a személyi elméletnek, s a személyiségi jogokat sokkal inkább - a korábbi szerzőkkel ellentétben - egy tisztán legszemélyesebb jellegü jogként közelíti meg, s elhatárolja azokat az iparjogvédelmi, szerzői jogi jogosultságoktól. Ennek legélesebb tettenérése az, hogy a cég védelmét a név védelméről teljes leválasztotta azon az alapon, hogy az ember neve a cégtől eltérően nem a dologi dinamika alapján bírálandó el. ${ }^{612}$

A cégnévvel kapcsolatos alanyi jogi fejtegetések a szocializmus időszakában jelentően háttérbe szorultak, $s$ teljesen más irányt vettek. Mielőtt e fejlődést bemutatnánk, célszerü azonban a német jog ez irányú álláspontját bemutatni. Ennek oka egyrészről abban rejlik, hogy a magyar szabályozás dogmatikailag hasonló elhelyezést biztosított mind a cég, mind a név vonatkozásában, mint a német; másrészről pedig az, hogy a német jog fejlődése a második világháborúban nem szakadt meg, és a jogszabályi háttér azonossága, illetve a piacgazdasági viszonyok fenntartása engedték, hogy a cég alanyi jogi dogmatikai elhelyezése tovább finomodjék.

A német joggyakorlatban a céget kezdetben mint szellemi tulajdon (Immaterialgüterrecht) fogták fel. ${ }^{613}$ Ezt a felfogást később egy kifejezetten, tisztán személyiségi jogi jellegű osztályozás követte mind a joggyakorlat, ${ }^{614}$ mind a jogtudósi réteg, különösen Otto von Gierke ${ }^{615}$ vonatkozásában. Götting mutat rá, hogy az uralkodó felfogás a céghez való jogot vegyes jellegü jogosultságnak (Mischrecht) tekinti, amely személyiségi jogi és szellemi tulajdonjogi vonásokat is felmutat, illetve arra is, hogy a BGH joggyakorlata nem egységes a cégnév jogi jellege tekintetében. ${ }^{616}$

\footnotetext{
${ }^{610}$ MESZLÉNY, 1909. 187-188.

611 Megelözően dogmatikailag kidolgozta: GöTTING, HORST-PETER: Persönlichkeitsrechte als Vermögensrechte. Paul Siebeck, Tübingen, 1995. A jogalkalmazási gyakorlatban elismerte: BGHZ 143, 214. („Marlene Dietrich”).

612 BALÁS, 1941. 650.

${ }^{613}$ GÖTTING, 1995. 118.

${ }^{614}$ RGZ 58, 166, 169; RGZ 70, 226, 229; RGZ 158, 226, 230.

${ }^{615}$ GIERKE, 1895. 702. sköv.

${ }^{616}$ GÖTTING, 1995. 118-119.
} 
Götting szerint a cégnév szellemi tulajdonjogi (immaterialgüterrechtliche) besorolása teljes mértékben megvalósul, hiszen a jog minden korlátozás nélkül továbbruházható, illetve dologi (quasidinglichen) hatállyal örökölhető is. Ez igaz akkor is, ha a cég bizonyos személyi vonatkozásokat is felmutat, mert ezt a szellemi tulajdonjogok egyébként is türik. ${ }^{617}$ Ilyen adott esetben valamely személy nevének mint személyiségi jognak cégnévben való szerepeltetése, tárgyiasítása.

A polgári jogi kodifikációban, az 1959-es Ptk. elfogadása során az a nézet nyert teret, amely absztraktan, a jogi személyekre is kiterjesztette a személyiség - s ezzel a név - védelmét. ${ }^{618} \mathrm{Ez}$ az álláspont a továbbiakban is fennmaradt, ${ }^{619} \mathrm{~s}$ ezen a Ptk. $1977-$ es novelláris módosítása sem változtatott. Ugyanígy a személyiségi jogi szabályozásban helyezte el azt a jogirodalom is, amely fenntartotta a burzsoá 'cég' elnevezést. ${ }^{620} \mathrm{Ez}$ Bozóky korábban bemutatott kategorizálásával egyező, azonban Bozóky nem a jogképesség miatt helyezte el a cég(névre) vonatkozó szabályokat a személyiségi jogban, hanem mert ő a céget a név egy speciális, meghatározott életviszonyokra (kereskedelmi ügyletek) vonatkozó alfajának tekintette.

A Ptk. hasonlóan a személyiségi jogi szabályozásban találta meg a cégnév védelmének a helyét. A Ptk. azonban bizonyos vonatkozásokban eltér az 1959-es Ptk. szabályaitól. A kodifikáció során a természetes és a jogi személyekre vonatkozó rendelkezéseket külön könyvben szabályozza a törvény, és a személyiségi jog az „ember mint jogalany” elnevezést viselő Második Könyvben került elhelyezésre. A személyiségvédelmet terjeszti ki a jogi személyekre a Ptk. 3:1. § (3) bekezdése. Míg a 1959-es Ptk.-ban bizonyos személyiségi jogok jogalanyiságból folyó jellegét a közös szabályozás implikálta, ${ }^{621}$ addig a Ptk. ezen utaló szabálya a jogi személyek személyiségvédelmére olyan szabályok alkalmazását rendeli, amelyek eredetileg azaz jogalanyiságuknál fogva - nem lennének alkalmazandóak rájuk. Ezt az álláspontot erősíti meg, a rendszertani elhelyezésen túl a Ptk. 2:42. § (2) bekezdése, amely arról rendelkezik, hogy a személyiségi jogok az emberi méltóságból fakadnak. ${ }^{622} \mathrm{Ez}$ a tény az alkalmazandó szabályok tekintetében változást nem eredményez, a dogmatikát ugyanakkor más irányba tereli, amely az értékelés, a

\footnotetext{
617 Uo. 122.

618 1959. évi IV. tv. 77. § (3)-(4) bek.

619 TÖRÖ, 1979. 330.

620 U.o.

${ }^{621}$ Lásd pl. PETRIK, 1992. 18.

${ }^{622}$ A probléma vonatkozásában lásd SCHULTZ, 2016. 685.; KOLTAY, 2017. 602.
} 
szubszumció során is jelentőséggel bírhat. A Ptk. ezzel akként foglal állást, hogy a cégnév mint a gazdasági társaság neve a személyiségi jogra vonatkozó szabályok alapján bírálandó el mindaddig, míg a védelem nem csupán az embert illeti meg. Ezzel a cégnév szabályozására a Ptk. rá is borítja a személyiségi jog jellegadó tulajdonságait, a „legszemélyesebb” jelleget: a személytől való elválaszthatatlanságot, a jogi személy megszünésével való megszünést, az átruházhatatlanságot azzal, hogy az emberi méltóság védelme a jogi személynél teljesen hiányzik.

\section{A védelem közös alapja: a jogképesség}

Természetes személyek esetén a (polgári) név ${ }^{623}$ a személyiségtől független, azon kívül álló jelenség, amely azonban alkalmas arra, hogy a személyiséget szóban megjelölje, azt felidézze. Hasonló funkciója van a cégnévnek a gazdasági társaságok vonatkozásában. Mind a természetes személy polgári nevének, mind a cégnévnek az alanyi jogi jellege a jogképességhez kapcsolódik. ${ }^{624} \mathrm{~A}$ Ptk. álláspontja ettől eltér: a személyiségi jogokat, így közöttük a névviselési jogot is az emberi méltóságból fakadónak tekinti, s ezt a védelmet terjeszti ki a jogi személyekre. Valóban vannak olyan jogok, amelyek az ember „testi-lelki realitásánál” ${ }^{625}$ fogva csupán az embert illetik meg, azonban vannak olyan jogok, amelyek esetén az alanyi jog a jogképességre vezethető vissza. Ilyen jog a névjog is. Ezen azonosság ellenére azonban a névjog vonatkozásában természetes személy esetén az emberi méltóság, az általános személyiségi jog mint alapjog magánjogi kisugárzása okán más megítélés alá esik, ${ }^{626}$ mint a gazdasági társaságok nevei. Ez a különbözőség az embert megillető speciális értékminőség, a név mögött rejtőző személyiség, illetve a gazdasági társaság személyiség i joga (személyhez füződő joga) tekintetében érhető tetten.

A gazdasági társaságok mint jogi konstrukciók nélkülözik az emberi méltóság bármilyen irányú védelmét. Céljuk a vagyoni, gazdasági, profitorientált jellegben

${ }^{623}$ A polgári név terminus használata a cégnévtől s más nevektől való megkülönböztetésre irányul, $\mathrm{s}$ értjük alatta a természetes személyt törvény alapján megillető születési, illetve házassági nevet, azaz a 2010. év I. tv. 43. § (1) bekezdés szerinti nevet.

${ }^{624}$ PeTRIK FERENC: A névviselés. In: Petrik Ferenc (szerk.): A személyiség jogi védelme. KJK, Budapest, 1992. 70.

${ }^{625}$ GÖRÖG MÁRTA: A jogi személy személyi értéke. Jogtudományi Közlöny 2011. 569. 570.

${ }^{626}$ Így például a román polgári jog a mai napig sokkal nagyobb jelentőséget tulajdonít a név vonatkozásában a név megszerzésének és elvesztésének, s a név védelme (a szabályozás célja, a személyiségvédelem vonatkozásában) elsikkad. Magyar nyelven lásd VARGA ATTILA: Román polgári jog. Státus, Csíkszereda, 2008. 52-60. Korábban: FEKETE GYÖRGY: Polgári jog. Általános rész, személyek és dologi jogok. Tanügyi Sokszorosító, Kolozsvár, 1958. 203-206. 
rejlik, s ennél fogva a név mögött, a név által megjelölt jogi személyiségüket is alapvetően ez határozza meg. Éppen az emberi méltóság védelmének hiánya okán nem beszélhetünk náluk olyan személyiségképről (életképről), amely pusztán nem vagyoni érdekekhez lehetne köthető. Vannak természetesen nem haszonszerzési céllal létesített jogi személyek, alapítványok, egyesületek is, amelyek esetén ez a vagyoni elem nem mutatható ki ilyen formában. Ez nem jelenti azonban azt, hogy a természetes személyekhez hasonló, azok emberi méltóságán alapuló védelemben részesülnének. Esetükben a védelem alapját a jogképesség biztosítja anélkül, hogy az emberi méltóság, az emberi értékminőség bármilyen módon is kiterjedne rájuk.

\section{Az elsőbbség követelménye}

Az elsőbbség elve általános szinten az ütköző jogosultságok esetén alkalmazandó elv. Az időbeli elsőbbség az az elv, amely alapján az a személy tekintendő jogosultnak, akinek a joga hamarabb elismerésre került (elsősorban a dologi jogok rendezőelve). Valószínüleg ennél fogva mondja Balás, hogy a cég(név) a polgári névvel ellentétben a dologi dinamika alapján müködik. ${ }^{627}$ Az elsőbbség elve tipikusan az iparjogvédelem területén is általánosan érvényesül. A bizonyítás szempontjából lényeges, hogy az időbeli elsőbbség vizsgálatának lajstromozást igénylő jogok tekintetében van jelentősége (pl.: szabadalom, védjegyjog). Meglepő módon ez az elv a megjelölések jogában máshol is érvényesül a domain név - mint lajstromozható jogosultság esetén. ${ }^{628}$ Cégnév esetén ez az ún. név-, vagy cégkizárólagosság követelményében manifesztálódik, amelynél fogva a (cég)név használat joga azt illeti meg, aki a cégbejegyzési kérelmet elsőként nyújtotta be. ${ }^{629}$

Be nem jegyzett kereskedelmi név, üzletjelző esetén ${ }^{630}$ (illetve lényegileg hasonlóan a Ptk. 2:49. § szerinti felvett név esetén) a rendszeres használat bír kiemelkedő jelentőséggel a jogosultság megszerzése tekintetében, itt ugyanis nincs lajstromozás, amely a jog korábbiságát tanúsítani tudná. ${ }^{631}$

${ }^{627}$ Vö: BALÁs, 1941. 655.

${ }^{628}$ ÍH 2014. 58. (,facebook.hu“) „A domain név regisztrációja és használata a védjegyhez hasonló lajstromzást igénylő jog..."

${ }^{629}$ Ptk. 3:6. § (1) bek., Ctv. 6. § (1) bek.

${ }^{630}$ A svájci jog korábban lehetőséget biztosított üzletjelző, kereskedelmi név cégnyilvántartásba való bejegyzésére, éppen bizonyítási okoknál fogva. Lásd ehhez VON BÜREN, BRUNO: Ueber die Beschränkungen des Rechtes, den eignen Namen zu gebracuhen. Schweizerische Juristen-Zeitung (Revue Suisse de Jurisprudence) (44)1948 Heft 5. 65.

${ }^{631}$ A német védjegytörvény e tekintetben ismeri az ú.n. be nem jegyzett védjegyet, szó szerinti 
Ugyancsak nem érvényesül az elsőbbség követelménye a névviselés vonatkozásában, polgári név esetén, amely szintén lajstromozást (anyakönyvezést) igénylő jogosultság. Ennek oka az, hogy a névviselési jogosultság a személyiség belső magvához közelebb áll a névhasználatnál, s azt az emberi méltóság joga sokkal jobban áthatja. Ennek okán létezhetnek azonos nevü személyek (homonyma), s tulajdonképpen az emberi méltóság az oka annak, hogy saját neve viselésétől senki nem tiltható el. Polgári név esetén tehát nem számít az elsőbbség, olyannyira, hogy a fennálló jogszabályok még testvérek között sem tiltják az azonos családi és utónevet, kivéve ha egy napon születtek. ${ }^{632}$ Jóllehet a polgári név mint szóbeli megjelölés céljának is a kizárólagos viselés, az összetéveszthetőség elkerülése felelne meg. ${ }^{633} \mathrm{~A}$ természetes személyek névvédelme vonatkozásában ennél fogva a névhasználat jogellenessége tekintetében is az összetéveszthetőség a, így a cégnévként való használat esetén is a jogosult engedélye szükséges.

\section{A cégnév mint lajstromozást igénylő megjelölés}

A cégnév mint megjelölés meghatározására több modell alakult ki. A cégnév lehet egy szóbeli megjelölés, amelyen másnak joga nem áll fenn (ún. tárgyi cég) ${ }^{634}$. Az ilyen szóbeli megjelölések esetén, a védjegyekhez hasonlóan nem beszélhetünk szellemi alkotótevékenységről, ugyanakkor bizonyos szempontból ötletnek, elgondolásnak tekinthetőek ezek. Az ilyen szóbeli megjelölések cégnévkénti bejegyzése esetén mindig eredeti szerzésről beszélünk. A jogi személy társaságnak mindenki mástól függetlenül keletkezik joga a név viselésére. Ezt a modellt támasztja a hatályos Ctv. is a cégnév alapjául.

A cég nevében lehet szerepeltetni természetes személy nevét, más cég nevéből levezetett megjelölést, annak részét, védjegyet vagy be nem jegyzett kereskedelmi nevet is. Ezek közös jellemzője az, hogy valamely más, szóbeli megjelölés formáját öltött jogtárgy képezi a bejegyzés alapját. Attól függetlenül, hogy e jogosultság kit illet meg, ebben az esetben a cégnév megszerzése származékos, ugyanis egy korábbi jogból

fordításban használati védjegyet (Gebrauchsmarke), amely szintén ebben a forgalomban való részvételnek van alávetve. ( $\$ 4 \mathrm{Nr}$. 2 MarkenG)

632 2010. évi I. tv. 44. § (5) bek. „Az ugyanattól az anyától származó, ugyanazon a napon született gyermekek nem viselhetnek megegyező utónevet."

${ }^{633}$ Vö: RAFFAY, 1906. 206. 1. 1j.

${ }^{634}$ FEHÉRVÁRY, 1941. 39. 
eredeztethetjük a cégnevet (származékos jogalapítás). ${ }^{635}$ Amennyiben a cégnév a természetes személy, elsősorban a cégtulajdonos vagy valamely alapító nevét tartalmazza, úgy a névbeli cég elnevezés volt korábban elterjedve. ${ }^{636}$ Vegyes cégröl akkor beszélhetünk, ha valamely személy neve mellett más szóbeli megjelölés is szerepel (Fehérváry példája: Papp Imre Mủbutorgyár r.t.), ${ }^{637}$ a fantáziaszóból képzett cég esetén egy kitalált megjelölés a cégnév védelmének tárgya. A hatályos német jog hasonló terminológiával operál (Sachfirma, Personenfirma, Fantasiefirma). ${ }^{638}$

A hatályos szabályok a jogi személyek, a gazdasági társaságok esetén nem teszik kötelezővé a polgári név használatát, a Kt.-hez hasonló konstrukciót az egyéni vállalkozókra vonatkozó szabályok tartalmaznak, mert ezesetben is az egyéni vállalkozó a saját nevét köteles használni. ${ }^{639}$ Hasonló szabályozást követett a német kereskedelmi törvény (HGB) is, azonban mára lehetőség van arra, hogy a kereskedő polgári nevétől (az anyakönyv szerint őt megillető névtől) eltérő nevet válasszon cégének. ${ }^{640}$ Annak ellenére, hogy a társasági jogi rendelkezések nem teszik főszabállyá a polgári név bejegyzésének kötelezettségét, erre a jog továbbra is lehetőséget nyújt. Ha egy személy nevét kívánják a cégnévben szerepeltetni, akkor ahhoz a jogosult hozzájárulása szükséges, amelyet a bejegyzési kérelemhez mellékelni kell. ${ }^{641} \mathrm{E}$ mellékletben ölt testet a korábbi jogra való jogosultság igazolása. A hozzájárulás mint jognyilatkozat alapvetően egyoldalú, ugyanakkor megadható szerződéssel is anyagi ellenszolgáltatás fejében. A hozzájárulás a társaság alapítása során apport formájában is megvalósulhat. ${ }^{642}$ Ebből egyrészről, kérdésként jelentkezhet, mi ennek a hozzájárulásnak a terjedelme, s mennyiben jelent ez korlátot a cégnév használata szempontjából, mennyiben jelent ez differenciát a tárgyi és a vegyes cégekhez képest, másrészről következik az, hogy a névviselési jog jogosultját megilleti az a jog, hogy saját nevét cégnévként bejegyeztesse. A névviselési jog jogosultjának ez a joga elvezet bennünket a névjogi váromány kérdésköréhez.

\footnotetext{
${ }^{635}$ SZLADITS KÁROLY: A magánjogi tényállások. In: Szladits Károly (szerk.): Magyar Magánjog I. Grill, Budapest, 1941. 251.

${ }^{636}$ FEHÉRVÁRY, 1941. 39.

${ }^{637}$ U.o.

${ }^{638}$ Ehhez pl.: Baumbach/Hopt/HoPT, HGB, 35. Aufl. 2012 § 17 Rn 6

639 2009. évi CXV. tv. 16. § (4) bek.

${ }^{640}$ Hopt, KlaUs J. - MERKT, HANNO - Roth, MARKUS - BAUMBACH, AdOLF: Handelsgesetzbuch. 35. Aufl., Beck, München, 2012. § 19 Rn 8.

${ }^{641}$ Ctv. 2. sz. melléklet I. 3. a)

${ }^{642}$ BH 1990. 476.; BH 1994. 21. („Rácz”)
} 
Sem a hatályos cégjogi szabályok, sem a Ptk. névjogi rendelkezései nem tartalmazzák kifejezetten azt, hogy a névjog jogosultját megilleti a jog, hogy nevét cégnévként bejegyeztesse - ez a személyiségi jogi pillanat. Míg a védjegyjog esetén az erre vonatkozó lehetőség egy viszonylagos kizáró ok formájában ölt testet, ${ }^{643}$ addig a Ctv. ezt melléklet formájában követeli meg igazolni. ${ }^{644}$ A névjoggal mint személyiségi joggal alapvetően nem egyeztethetö össze az, hogy a névjog jogosultja bármilyen vonatkozásban is lemondjon. A személynév cégnévként való bejegyzésével ugyanakkor más jogtárggyá alakul, cégnévhez füződő személyiségi joggá válik, önálló életre kel, a személyiségi jogtól eltérő dinamika mozgatja.

A cégnév bejegyzésének, használatának a korlátja a névszabatosság, a névkizárólagosság és a névvalódiság elve. Ezek közül elsősorban a névkizárólagosság bír jelentőséggel, amely alapján a jogi személy nevének olyan mértékben kell különböznie a korábban nyilvántartásba vett más jogi személy nevétől, hogy azzal ne legyen összetéveszthető. A jog lehetőséget biztosít arra is, hogy a név bizonyos vonatkozásának átruházása még azelőtt megtörténjen, mielőtt az a cégnévi minőséget megszerezné - így a korábban említett apportként való bevitel. Ez azt implikálja, hogy a névviselési jog jogosultját nemcsak a saját név cégnévként való bejegyzése illeti meg, hanem az is, hogy a saját nevének a cégnévként való használatát másnak átengedje. Ez a szabály nem a névhasználati jog gyakorlása, hiszen a név itt még nem került kapcsolatba a céggel, a gazdasági társasággal, itt még csupán egy várományi helyzetről beszélünk. Ennek a várományi helyzetnek az alapja értelemszerüen maga a névviselési jogosultság, hiszen csak olyan személy adhat jogszerủen engedélyt a neve cégnévként való bejegyzésére, akit a névjog megillet. Annak, hogy a névjog jogosultja ezen irányban lemond a neve használatáról, és hozzájárul ahhoz, hogy azt más személy használja, „az engedélyes kifogáshoz jut, amelynek segítségével a jogszerü névviselőnek a névviselés abbahagyására irányuló keresetét megerőtlenítheti”. ${ }^{645}$ Ebben az esetben a személyiségi jogba való beavatkozás a jogosult hozzájárulása okán nem jogellenes. ${ }^{646}$

\footnotetext{
${ }^{643}$ 1997. évi XI. tv. 5. § (1) bek. a)

${ }^{644}$ Ctv. 2. sz. melléklet I. 3. a)

${ }^{645}$ BALÁs, 1941. 651.

${ }^{646}$ Ptk. 2:42. § (3) bek.
} 
A Ctv. lehetőséget biztosít arra, hogy a cég bejegyzésének megindítása előtt a bejelentő cégfoglalással éljen. ${ }^{647}$ A cégfoglalás tehát egy még létre nem jött alanyi jogot (a cégnévre való jogosultságot) megelőző védelmi helyzet. A cég bejegyzését, a lajstromozást megelőzően a tényállás még nem teljes, s így a cégnév alanyi jogosultságáról sem beszélhetünk. E várományi helyzetet védi a jogalkotó a Ctv.-ben elhelyezett névfoglalás intézményével, amely tulajdonképpen a fent megfogalmazott általánosabb várományi jogosultság bizonyos konkretizálásának tekinthető.

Névfoglalással élni azon esetekben a legcélszerűbb, ha fantáziaszót, kitalált megjelölést kívánunk a cégnévben szerepeltetni. Abban az esetben, ha alapító tag nevét, uralkodó vállalat nevét vagy más, korábbi elsőbbségü jogot, például védjegyet kívánunk bejegyeztetni, már van egy alapul fekvő jogosultság. Ez mégsem teszi ezekben az esetekben indokolatlanná és feleslegessé a névfoglalás jogintézményét, ugyanis azonos nevü személyeknek a név cégnévként való használat szempontjából azonosan jogosultak lehetnének, joguk konkurál, ütközik. Ugyancsak elöfordulhat védjegyek vonatkozásában, hogy ugyanaz a szóbeli megjelölés más-más áru-, illetve szolgáltatási osztály tekintetében védelmet élvez. A cégnév bejegyzése szempontjából a cégbejegyzési kérelem hamarabbi benyújtása tekintetében főszabály szerint egyenlő mértékben illeti meg őket a jog.

\section{A cégbitorlás névbitorlástól való megkülönböztetésének elvi indokai}

Az 1959-es Ptk. a személyiségi jogokat polgári jogi védelemben részesítette, kimondta e jogok alanyi jogi jellegét. A személyiségi jogok között került nevesítésre a névviseléshez való jog is. A törvény szakított a korábbi álláspontokkal, amelyek a személyiség védelme körében kizárólag a természetes személy nevét kívánták oltalmazni, tekintettel arra, hogy a Kt. 24. §-a a céggel szembeni jogosulatlan magatartások ellen kellö védelmet nyújtott. A Ptk. az absztrakciós szintet akként emelte meg, hogy közös védelmet nyújtott a természetes személyek és a jogi személyek, illetve a jogi személyiség nélküli személyegyesülések tekintetében. A bitorlási kereset közös nevezőre hozásával tulajdonképpen a Kt. szerinti cégbitorlási

${ }^{647}$ A joggyakorlatban: ÍH 2007. 85. 
kereset lex posteriorrá vált. Az, hogy mind a természetes személy nevének, mind a jogi személy nevének jogellenes használatát közös elvi alapokra lehetett helyezni, arra mutatott rá, hogy a név és az ember kapcsolata nem olyan szoros jellegü, amely az embernek e jogot kizárólag biztosítaná. A közös elvi alapokra helyezés, az, hogy ugyanazon tárgyi jog biztosít jogot a cégnév és a polgári név érvényesítésére, kevésbé alkalmas arra, hogy e két alanyi jog tekintetében megfelelö különbségtétel alapjául szolgáljon. Ennek akkor van a legnagyobb jelentősége, ha a korábban említett várományi helyzet megsértése miatt a cégnév védelme a természetes személy jogával bizonyos tekintetben összemosódik. Ugyanígy jelentős lehet, ha más megjelölés (különösen a be nem jegyzett kereskedelmi név, üzletjelző) sérelme áll fenn, amely vonatkozásában a tisztességtelen verseny szabályai is tekintetbe jönnek. De az is kiemelendő, hogy a cégnévként bejegyzett polgári névnek nyújtott védelem is elsősorban a cégnévnek szól, noha névbitorlási színezettel is bírhat. Mindenképpen célszerü lenne ezért konkretizálni a névjogi alanyi jogokat, illetve azok megsértésének eseteit.

\section{9. Állásfoglalás a cégnév tárgyiasulását illetően}

A cégnév alanyi jogi, dogmatikai rendszerben való elhelyezése tekintetében a személyiségi jogi, személyhez füződő jogi jelleg nem egyedülálló jelentőségű. A személyiségi jogi besorolás mellett a vagyoni értékü jogi jelleg, a szellemi tulajdonjogi jelleg tekinthető jelentősnek. A cégnév a természetes személy nevétől több vonatkozásban is eltér. Ez az eltérés ölt testet már magában a névviselés-névhasználat fogalmi elhatárolásában, amely segíti a személyiség belső magvától távolabb eső jogosultságok s így a cégnév könnyebb dogmatikai finomhangolását. A cégnév a polgári névtől eltérően a gazdasági társaság profitorientált tevékenységét támogatja, $\mathrm{s}$ megjelölési funkciója révén a társaság által kialakított, fejlődő goodwill értékéhez, azonosításához tesz hozzá.

A természetes személy polgári neve és a cégnév legjelentősebb elhatárolásaként jelentkezik az a körülmény, amely a cégnév kizárólagosságában ölt testet. Az elsőbbség, a névkizárólagosság az iparjogvédelmi jogokhoz hasonló monopolhelyzetet biztosít a gazdasági társaságnak, s általában a jogi személyeknek arra, hogy a cégnév, a jogi személy neve mint szóbeli megjelölés vonatkozásában a piaci szereplök s általában a jogalanyok csak az adott céget ismerjék fel a névről. 
Ennélfogva a cégnév tulajdonképpen sokkal hatékonyabban betölti funkcióját a természetes személy nevéhez képest, amely az azonosnevüség miatt további korrekcióra szorul.

\section{Domain név}

\section{A domainnév fogalma}

A domainnév (tartománynév) egy számítógép-azonosító számot (IP cím) helyettesítő, felhasználóbarát egyedi név az interneten, amely az adott gép (és rajta lévő honlap) hálózaton keresztüli azonosítását lehetővé teszi, megkülönböztetve az egyes számítógépeket egymástól. ${ }^{648}$

A Legfelsőbb Bíróság a domain nevet kezdetben úgy fogta fel, hogy a domainnév az internetes szolgáltatások körében névhasználatot jelent, amely az elektronikus szolgáltatások körében azonosítja a szolgáltatást nyújtó természetes vagy jogi személyt, mert annak nevét és elérhetőségét (címét) egyaránt meghatározza. ${ }^{649} \mathrm{~A}$ bíróság ezen álláspontját számos más döntésben átvette a bírói gyakorlat, ${ }^{650}$ ezzel a fogalommeghatározással azonban csupán a névhasználati oldalról közelíti ezt meg, magára a domainnév jellegére általánosan nem ad választ. Így ebből következően a domainnév használata csak és kizárólag akkor jelent névhasználatot, amennyiben természetes vagy jogi személy nevét vagy kereskedelemi nevét tartalmazza. ${ }^{651}$

A bírói gyakorlat ezután kezdte felfedezni azt, hogy a domainnév általánosan rendelkezhet valamiféle megkülönböztető funkcióval, a Fővárosi Ítélőtábla arra jutott, hogy a domainnév az internet világában egyfajta azonosításra és megkülönböztetésre szolgál, így az valamilyen névhez, leginkább kereskedelmi névhez állhat legközelebb. ${ }^{652}$ A domainnév tehát egy adott számítógép (tkp. IP cím), és a mögötte levő tartalom megjelölésére szolgál. Más megjelölések esetén a megjelölés tárgya is más, így védjegy esetén áruk és szolgáltatások, kereskedelmi név esetén áru, szolgáltatás, személy, üzlethelyiség stb. A domainnevek azonban alkalmasak arra,

\footnotetext{
${ }^{648}$ ÍH 2017. 11. („,muszakieredetvizsgaszeged.hu”); BDT 2017. 33. (,,antikvarium.hu”); Kúria Pfv. IV. $20.489 / 2011 / 3$

${ }^{649}$ Legfelsőbb Bíróság Pf. V. 22.818/2001.

${ }^{650}$ BDT 2008. 20 („,rekviem.hu”); BDT2008. 21. („hella.hu”).

651 ÍH 2017. 11. (,,muszakieredetvizsgaszeged.hu”).

652 ÍH 2011. 154 (,,biztositas.hu”).
} 
hogy minden más szóbeli megjelölésre vonatkoztatott jogtárgy tekintetében azok internetes platformon való megjelenését biztosítsák, vagy ettől függetlenül egy weboldalt azonosítsanak. Kiemelendö, hogy a domainnevek nem minden tekintetben bírnak vagyoni értékkel, céljuk nem minden esetben kapcsolódik a kereskedelemhez, árukhoz, szolgáltatásokhoz, és a rajta fennálló érdek részben eszmei. ${ }^{653}$

\section{A domainnév védelme más jogalapokon}

A joggyakorlat a megjelölésekkel kapcsolatos törvényi szabályozást lezártnak tekinti, így csak azon igények vonatkozásában vizsgálódik, amelyeknek pozitív jogi alapja van. Ez lényegében a védjegybitorlást, a jellegbitorlást és a névbitorlást jelenti, hiszen a gazdasági, társadalmi életben használt, kiforrott és megkülönböztető képességgel rendelkező megjelölések azok, amelyek jogi védelemben részesülnek. A domainnév ezekhez képest újabb jellegü, s külön törvényi szabályozásban nem is részesül az EU egyes tagállamaiban általában, ${ }^{654}$ szemben a .eu TLD-vel. ${ }^{65}$ A domainnévre vonatkozóan tehát elsősorban az összetéveszthetőség szempontjából a bitorlási igények specialitása a döntő azzal, hogy az eset körülményei szempontjából egyes igények kieshetnek, tekintettel arra is, a konkrét esetben milyen jogalapon lépnek fel az igény érvényesítése érdekében.

\section{Megkülönböztető toldat és megkülönböztető képesség hiánya}

Az elsőbbség követelményéből fakad az is, hogy az, aki később igényli a nevet, megkülönböztető toldatot kell, hogy a névhez csatoljon. Ez a megjelölések jogában alapvető rendező elv, amely sok tekintetben még a természetes személyek esetén is érvényesül [Ptk. 2:49. § (2) bek.]. A megkülönböztető toldat használata lényegében egy jogkövetkezmény, ennek lényegében az az oka, hogy egy megjelölés kizárólagossága okán más nem lehet jogosult, mert az összetéveszthetőséghez vezet, $\mathrm{s}$ a lényeget jelentő megkülönböztető képesség válik jelentéktelenné. A védjegyjogban az is alkalmas alapvetően az összetéveszthetőség kizárására, ha azonos szóvédjegyet

\footnotetext{
${ }^{653}$ A védjeggyel való összehasonlításra 1. AL-RAWASHDEDH, Waddah: Dispute Resolution Mechanisms and Trademark Cybersquatting. Szeged, disszertáció, 2017.

${ }^{654} \mathrm{PosCH}$ in Schwimann/Kodek, $\mathrm{ABGB}^{4} \mathrm{Ia} \S 43 \mathrm{Rz} 36$.

${ }^{655}$ A Bizottság 874/2004/EK rendelete (2004. április 28.) a.eu felső szintü domain bevezetésére és funkcióira vonatkozó általános szabályok, valamint a bejegyzésre irányadó elvek megállapításáról.
} 
más-más jogosultak használnak különböző áru- és szolgáltatási osztályok tekintetében. $\mathrm{Az}$ összetéveszthetőség, különösen a lényegi azonosság a megkülönböztető képességgel nem bíró domainnevek esetén is jogos érdeket sérthet, amely ugyanakkor csak a jóhiszemüség és tisztességre hivatkozva, a Ptk. 2:42. § (1) bekezdése alapján oldható meg meglátásom szerint. ${ }^{656}$

Mind a cégnévnek, védjegynek, üzletjelzőnek és más kereskedelmi névnek az a célja, hogy kizárólagos módon a jogosult érdekkörébe vonjon valamit. Ezt a kizárólagosságot pedig azzal éri el, hogy a megjelölés vagy bejegyzés útján vagy forgalomban történő részvétellel névfunkciót szerez magának. A névfunkció lényege ugyanis abban áll, hogy egyediesíti az adott megjelölést, egy személyre vonatkoztatja azt. Egy adott tevékenységi körre vonatkozó általános jelentésű szavak erre nem képesek. Ez hasonló azon ötlet védelméhez, amely a szerzői jogi védelem szintjét nem éri el. Mindkettő a közkincs részét képezi, ezek bárki által felhasználhatóak. Így nem beszélhetünk védelemről akkor, ha a megjelölés a szolgáltatás hétköznapi elnevezésére vonatkozik. ${ }^{657}$ A rekviem szó kapcsán kifejtette a bíróság, hogy a szó tágabb értelmű és tágabb körben használatos, ennek ellenére jogsértőnek tekintette abból az okból, hogy a perbeli domain megegyezik a felperes cégnevének vezérszavával. ${ }^{658} \mathrm{Nem}$ tekintette ilyennek ugyanakkor a bíróság azt, amikor a felperes „Jakab” családi neve megsértése miatt lépett fel abból az okból, hogy a szükebb körben megvalósuló beazonosíthatóságot is elegendőnek találta a személyiségi jogi igény érvényesítéseként. ${ }^{659}$

4. Sui generis domainbitorlás mint névbitorlás

A legtöbb jogvitában a megjelölések kollíziójának egyik oldalán egy domainnév, másik oldalán pedig egy másnemü megjelölés áll, mint amilyen a védjegy, bejegyzett cégnév, üzletjelző, természetes személy neve.

A névjog és a névbitorlás lényege abban rejlik, hogy az adott személy kizárólagos érdekkörébe tartozó jogokban ne következzen be zavar, azaz kerüljön kizárásra az összetéveszthetőség. A névjog ezzel összefüggésben hagyományosan a

\footnotetext{
${ }^{656}$ Ellentétes ÍH 2011. 154. (,biztositas.hu”)

657 ÍH 2017. 11. („muszakieredetvizsga.hu”); BDT 2017. 33. (,antikvarium.hu”); BDT 2012. 68. (,szallasinfo.info").

${ }^{658}$ BDT 2008.20. (,rekviem.hu”)

${ }^{659}$ BDT 2009. 22. (,jakab.hu”)
} 
jogalany nevét (természetes személy, jogi személy neve, de ideértve a polgári jogi társaság névvédelmét is), illetve a kereskedelmi nevet védi. A jogalany érdekkörébe tartozhatnak ugyanakkor más megjelölések is, ilyenek az épületnevek, amelyek külön kereskedelmi névi minőséggel nem rendelkeznek, ${ }^{660}$ illetve a címer. Hasonló a helyzete a telefonszámoknak, amelyek nem élveznek névjogi védelmet az összetéveszthetőség ellen. Téves telefonszám megadása kapcsolattartási módként Németországban az általános személyiségi jog sérelmét eredményezi, ${ }^{661}$ a hazai bírói gyakorlat pedig a jóhírnév, illetve a személyiségi jog sérelmeként értelmezi. ${ }^{662}$

A domainnév önálló alanyi jogként való elismeréséről akkor beszélhetünk, ha az védelemben részesül akkor is, ha nincs vagy nem kerül figyelembevételre a mögötte álló korábbi jog (prioritásos jog), amelyből a domainnevet adott esetben származtatják. $\mathrm{Az}$ esetek többségében ugyanakkor nem a domainnévre mint olyanra, hanem a mögötte levő korábbi megjelölésre helyezte a hangsúlyt a bíróság, és kísérelte meg vagy védjegybitorlásként, jellegbitorlásként vagy névbitorlásként értelmezni, hiszen ennek hiányában csak egy önálló domainbitorlás (általános megjelölésbitorlás) keretében lehetett volna ennek helyt adni, amely egy új jog analóg elismerését vonta volna maga után.

Vannak azonban olyan esetek, amikor a domainnév korábbi elsőbbsége okán egy későbbi megjelöléssel szemben a jogütközésben elsőbbséget élvez. Ez merült fel a 2009-es vedjegy.hu-ügyben, amikor a domainnév regisztrálását követően egy gazdasági társaság a (rövidített) cégnevét Védjegy Bt.-re változtatta meg. Mivel a vedjegy.hu jogosultja korábban szerzett jogot a domainnév használatára, így az ellen a cégnév jogosultja nem tiltakozhatott. ${ }^{663}$ Ebböl kitűnik, hogy a domainnéven egyfajta alanyi jog áll fenn, hiszen, ha ez nem így lenne, a későbbi cégnév mint speciális megjelölési jog egyfajta „erősebb jog” lehetne, ez azonban azt feltételezné, hogy a domainnév regisztrálásához egy korábbi vagy másfajta jog felmutatása mindenképpen szükséges. Az ügyben eljáró Szegedi Ítélőtábla elvi megállapításokat ezzel kapcsolatban nem tett, de a domainnév-cégnév közötti konkurrencia lehetőségét nem zárt ki.

${ }^{660}$ Magyarországon a jogirodalomban és a joggyakorlatban ez egyáltalán nem jelenik meg. Németországban a védelem elvi szinten nem kizárt, a konkrét ügyben ugyanakkor az épület elnevezése túl általános volt. WM 1976, 384 („Sternhaus”); Staudinger/HABERMANN (2013) § 12 Rn 104.

${ }^{661}$ LG Berlin NJW-RR1992, 1247. (,Launische Domina 342, Mannequin”)

${ }^{662}$ BDT 2006. 45. („Hívj éjjel-nappal”)

663 ÍH 2009. 111. (,vedjegy.hu”) 
A Fővárosi Ítélőtábla két évvel később 2011-ben már elvi éllel, jóllehet óvatosan fogalmazott, amikor kijelentette, hogy általában nem kizárt, hogy az internetes felhasználás körében névként funkcionáló domainnév sérelmére is megvalósuljon egy másik domainnévvel a névjog megsértése és részesüljön névjogi védelemben, de csak akkor, ha a hasonlóság vagy megtévesztő jelleg folytán a jogellenes névhasználat egy konkrét személlyel összefüggésbe hozható. A névjogi védelem sajátossága miatt a megkülönböztető képességnek van jelentősége. ${ }^{664}$

A Fővárosi Ítélőtábla ezzel tulajdonképpen a személyiségi jogi névvédelmen belül elismerte a domainnév önálló bitorlását. A bíróság itt már nem kísérli meg, mint korábban, hogy a jogalany neve oldaláról minősítse névhasználatnak a domainnévhasználatot, illetve, hogy egyfajta kereskedelmi névi minőséghez kösse azt. Mindaddig míg volt korábbi más jog, annak részjogosultságának tekintette a domainnévként való regisztrációt, illetve használatot. A védelem alapja az, hogy a teleologikus értelmezés szerint a névjog célja a megkülönböztető képességben és az összetéveszthetőség kizárásában áll. Minden olyan megjelölés, amely a személy érdekkörébe tartozik, amelyről őt ismerik fel, védelemben kell, hogy részesüljön. Ezt terjesztette ki a bíróság a konkrét ügyben a domainnevekre. A Szegedi Ítélőtábla egy 2017-es ügyben más állásponton volt, a domainnevet más jogtárgyak felöli értékelés oldaláról közelítette meg, elsősorban a kereskedelmi név és cégnév oldaláról. A bíróság szerint a domainnév huzamos ideig történő rendszeres használata alkalmas lehet az elektronikus szolgáltatások körében a szolgáltatást nyújtó személyek beazonosítására, de önmagában nem biztosít a jogi személy nevekénti védelmet. ${ }^{665}$ Megjegyezzük, hogy az adott ügyben a domainnév önálló jogi alapkénti elismerése után az igény megvalósulása ugyanúgy kizárható lett volna a megkülönböztető képesség hiányára történő hivatkozással, hasonlóan a jellegbitorlás adott esetben történő vizsgálatához.

A liechtensteini OGH sokkal egyértelmüen fogalmaz a német, svájci és osztrák egységes joggyakorlat ${ }^{666}$ és jogirodalmi álláspontok áttekintése után. A bíróság döntvény-jelleggel kijelentette, hogy az internetes domainnevek, amelyek nevet

${ }^{664}$ ÍH 2011. 154. („,biztositás.hu”)

${ }^{665}$ ÍH 2017.11. (,,muszakieredetvizsgaszeged.hu”)

${ }^{666}$ Különösen OGH 21. 12. 1999, 4 Ob 320/99h; ÖJZ 2000, 507; „Domain-Namen, die einen Namen enthalten oder namensmäßig anmuten, haben Kennzeichnungs- und Namensfunktion; sie fallen demnach unter den Schutz des \& 43 ABGB.” (,ortig.at”); OGH 18.1.2011, 17 Ob 16/10t schladming.com. 
tartalmaznak, vagy egyébként névszerüen hatnak, név- és megjelölési funkcióval rendelkeznek, és a PGR 43. cikkének védelme alá esnek. Ez a névjog (sic!) egy, a PGR 39. szakasza szerinti személyiségi jog. ${ }^{667} \mathrm{Ki}$ kell emelni ugyanakkor azt, hogy a liechtensteini jog a nevesített személyiségi jogok között a névjog mellett az általános megjelölési jogot is védelemben részesíti, ez Németországban hiányzik, így ott korábban egy általános névjogi klauzulát alakított ki a bíróság, ${ }^{668}$ amit 1995 óta egy általános vállalatjelző-bitorlás váltott fel a védjegytörvényben. ${ }^{669}$ Magyarországon ehhez hasonlóan az általános névjogi klauzula irányába tolódik el a jogalkalmazás ${ }^{670}$ akkor, amikor a polgári jogi társaság nevét, ${ }^{671}$ a kereskedelmi nevet, ideértve az üzletjelzőket, illetve újabban a domainneveket is idevonják a megkülönböztető képesség teleológiájánál fogva.

\section{A domainbitorlás létjogosultsága}

A személyiség védelmének olyan körre való kiterjesztése, amely esetén a jogtárgy nem közvetlenül a jogalanyra vonatkozik (azaz pl. kereskedelmi név, esetünkben domainnév) már azon problematikák közé tartozik, amelyekre az emberi méltóság magánjogi beszüremlése csak ráerősít. A személyiség védelmének alapja, hasonlatosan a svájci, s liechtensteini joghoz, a magyar jogban is a magánosok személyi érdekeinek védelme. Márpedig személyi érdeke lesz a magánosnak az, hogy egy közkincsnek nem tekinthető jogtárgyat az ő érdekkörébe tartozóként tekintsen a külvilág, s ha ebben zavar támad, az ellen magánjogi igénnyel léphessen fel. Ezen az állásponton van Bozóky Alajos is. „A dolognevek, melyeket a különféle testi és testetlen dolgoknak [...] adni szoktunk, tulajdonképpen csak a jogtárgyaknak egymástól való megkülönböztetésére szolgálnak és ez által több irányban jogi nyomatékot is nyerhetnek, csakhogy ebbéli jelentőségök nem tartozik a személyjog körébe, de valamely dolognév valamely személyi hatáskör bizonyos alkatelemének megjelölésére is szolgálhat és mint ilyen a személyiség igen becses javát képezheti, a

\footnotetext{
667 OGH (Li) 6 Cg 45/00-17 (,,eschen.li”).

668 Staudinger/HABERMANN (2013) § 12 Rn 4.

${ }^{669}$ Értve vállalatjelző alatt minden olyan egyediesítő megjelölést, amely a kereskedelmi, gazdasági életben használatos, azaz elsősorban a cégnevet, védjegyet, kereskedelmi nevet (üzletjelzőt, árujelzőt), mücímet.

${ }^{670}$ Eltérő: ÍH 2017. 51. (,régimódi”).

${ }^{671}$ BH 1979. 411. („B-vonósnégyes”); BH 1980. 467. („Dankó Pista nótaegyüttes”); BH 1987. 11. (,System").
} 
midőn az ilyen jegy alkotóját vagy jogutódját a személyiség jogánál fogva szintén törvényes oltalom kell hogy megillesse mindazok ellen, kik avval a jegygyel visszaélnek". ${ }^{672}$ A domainnéven fennálló érdek lehet eszmei, erkölcsi érdek, bizonyos esetekben azonban kifejezetten vagyoni érdek, amely esetben a Ptk. 2:51. § e) és a 2:53. § jogkövetkezményei is igényelhetőek.

Ebben a tekintetben a domainnév bitorlásának annyiban lehet jelentősége, amennyiben nem más jogintézmény keretében kerül jogosulatlanul felhasználásra a szóbeli megjelölés. Két domainnév kollíziójakor a jogtárgy alacsony megkülönböztető képessége esetén a jogsérelem kizárt, ha azonban a megkülönböztető képesség erős, a jogvédelem fennáll. Az osztrák legfelső bírói fórum is megkülönböztető képességet tulajdonít a domainneveknek (legalább is vizsgálja, rendelkeznek-e ilyennel), s a név mintájára nyújt védelmet annak ellenére, hogy konkrétan nem foglal állást, hogy az Optk. 43. §-a szerinti névvédelemben részesülnek-e. ${ }^{673}$ A kérdés már csak az, hogy a magyar bírói gyakorlat mikor fogja egyértelmủen kimondani azt, hogy a domainnév a személyiség által védett jogtárgy, s ezzel artikulálni azt, ami a cégnév és a kereskedelmi név személyiségi jogi oltalmában eddig is lappangott a névvédelmen belül: hogy a névjog magánjogi oltalma az adott személyhez rendelhető szóbeli megjelölésekre általános jelleggel kiterjed. Ezzel a névjog összetéveszthetőségi funkciójának joggyakorlatbeli, teleologikus alkalmazása valósulna meg ugyanis a domainnevek tekintetében.

\section{A név tárgyiasulása a domainnév vonatkozásában}

A domainnév mint szóbeli megjelölés mellett a domainnév mint természetes személy nevének használataként is megjelenhet. Ebben az esetben a hazai bírói gyakorlat a névbitorlás vizsgálatából indul ki, hiszen jogalany nevének használatáról van szó. A BGH természetes személy nevének domainnévként való delegálását, és ezzel a név használatát nem csupán a személyiségi jog részének tekinti, hanem a személyiségi jog vagyoni vonatkozásai részének is. ${ }^{674}$ Ez azt jelenti, hogy az erre vonatkozó jogosultság átruházható és örökölhető.

\footnotetext{
672 BOZÓKY, 1905. 481.

${ }^{673} \mathrm{SZ} 71 / 35$ - jusline I.

${ }^{674}$ NJW 2007, 684 - kinski-klaus.de.
} 
A domainnéven való jogosultság örökölhetőségét bizonyos tekintetben a magyar jog is elismeri, s ezzel a név tárgyiasulását értékeli a joggyakorlat. Verebics János mutat rá, hogy ,a delegálás törlését [...] a domain használó halála vagy jogutód nélküli megszünése esetében 60 nap türelmi idő követi, amely idő alatt a felszabadult domain névre vonatkozóan kizárólag a volt domain-használó, illetve [...] örököse vagy átruházó nyilatkozatának kedvezményezettje nyújthat be új igényt". ${ }^{675} \mathrm{Ez}$ a szabály ugyanis rendelkezési jogot biztosít a domain név jogutódjának a jogtárgy felett egy olyan esetben, amely a kegyeleti jog jogintézménye alá nem vonható.

\section{Védjegy}

1. A név mint korábbi jog

A védjegy tekintetében a személyi szemléletnek elsősorban akkor van jelentősége, ha a személy nevét védjegyként bejegyzik, bejegyezhetik, mert ebből a szempontból a név (a képmás, hangfelvétel, jelmondat) korábbi jognak minősül, amelynek anyagi jogi szabályai a személyiségi jog területére esnek.

Védjegyként főszabály szerint bármilyen ábrázolható megjelölés lajstromozható, amely alkalmas áruknak vagy szolgáltatásoknak más, hasonló áruktól vagy szolgáltatásoktól való megkülönböztetésére. A lajstromozás feltétele azonban az, hogy ne álljon fenn abszolút kizáró ok a védjeggyel szemben. Védjegyként tehát szabadon bejegyezhetők nevek is, a Vt. 5. § (1) bek. a) pontja mint relatív kizáró ok azonban a névviselési jog sérelmével járó lajstromozással szemben védelmet nyújt a jogosultnak. A névjog (természetes személy neve, cégnév) tehát korábbi jognak minősül, s így e felett csak az arra jogosult személy rendelkezhet.

Az említett kizárási ok csupán utal a jogsérelemre, de nem határozza meg annak megvalósulási módját, ezért erre a Ptk. személyiségvédelmi szabályai az irányadóak. A kizáró ok megvalósulásához a névbitorlás tényállásának a megvalósulását kell vizsgálni. Azt, hogy a Vt. a névbitorlást ilyen formában tartalmazza, arra lehet következtetni, hogy a névjog jogosultjának hatalmi körébe

${ }^{675}$ VEREBICS JÁNOS: A domain nevek használati jogának megszünése. Gazdaság és Jog 2011. 2. sz. 23, 26. 
tartozik az, hogy fellépjen azzal szemben, aki engedély nélkül lajstromoztat védjegyet a személyiségi jogot sértő módon. E szabály pozitív irányból való megközelítésével arra juthatunk, hogy a névjog jogosultját megilleti az a kizárólagos jogosultság, hogy a személyisége részét képezö nevet védjegyként bejegyeztesse. Ezzel ugyan a jog lehetőséget teremt arra, hogy a személy a nevét áruk, szolgáltatások megjelölésére használja, ugyanakkor védi is az egyént az ez irányú használatban. A személy nevének e funkcióbeli váltása, azon túl, hogy az már a védjegyjog jogintézményének keretei között kerül értékelésre a bejegyzés után, alkalmas arra, hogy e jogosultságot névhasználati jogosultságnak tekintsük. Ezt a felfogást képviseli Meszlény a tisztességtelen verseny vonatkozásában: „a név-, cég- és címerjogot ehhez képest elsősorban mint abszolút és konkretizált személyi jogot oltalmazza a § és ebből kifolyólag kereseti jogot ad mindenkinek, akit jogosulatlan használat ért”. ${ }^{676}$ Sőt, ő ezt a védjegyjogra is átvezeti, hiszen a személyiségi jogok oltalma először közvetetten, más jogtárgyak útján került csak oltalmazásra. Meszlény szerint „eddigi jogunk is védelmet nyujtott továbbá névnek, cégnek, címernek, üzletmegjelölésnek védjegy gyanánt való jogosulatlan használata ellen". ${ }^{677}$

Annak során, hogy megállapításra kerüljön a kizárási ok, ${ }^{678}$ a névbitorlás tényállásának megvalósulását kell vizsgálni. Névbitorlást követ el az, aki más nevét használja vagy máséhoz hasonló nevet használ. A jogviszony tárgyát képező névnek olyannak kell lennie, hogy az kapcsolatba hozható legyen konkrét személlyel, hiszen csak ekkor keletkezik relatív jogviszony. Nem ilyenek általában az utónevek, pl.: Nárcisz. ${ }^{679}$ A bitorlás megállapítása szempontjából nem pusztán a nevek hasonlósága a döntő, a törvény megfogalmazása túl tág, s okot ad a méltánytalanságra, erre mutat rá Törő is. ${ }^{680}$ Elsősorban az összetéveszthetőséget és az ebből következő érdeksérelmet kell vizsgálni. ${ }^{681}$

Azzal, hogy a név védjegyoltalomban részesülhet ily módon, a név védelméhez képest (a névviselési jog a személyiségvédelmen belül) különösebb védelmet szerez az oltalommal az azt igénylő, amely lehetővé teszi számára, hogy meghatározott megjelöléssel (a dolgozat szempontjából névvel) lássa el termékét, szolgáltatását. A

\footnotetext{
${ }^{676}$ MESZLÉNY ARTUR: A tisztességtelen versenyröl szóló (1923. évi V. törvénycikk) magyarázata. Atheneum, Budapest, 1923. 73. 677 U.o.

${ }^{678}$ Vt. 5. § (1) bek. a) pont.

679 BH 2003. 149. („Nárcisz”).

680 TÖRÖ, 1979.

${ }^{681}$ BH 2001. 161.
} 
védjegy funkciójánál fogva árujelző, szemben a névvel, amely egy jogalanynak a megjelölésére szolgál. Kérdéses is lenne, ha védjegyoltalom hiányában valaki saját nevével látja el termékeit és más, arra jogosulatlan személy is így tesz, az mennyiben lehetne a névjog megsértésének tekintendő, itt a védelem ugyanis nem a névnek, hanem a megjelölésnek szól. Míg a védjegy lajstromozásra kerül, addig a kereskedelmi név, elsősorban ha az mint árujelző jelenik meg, inkább a védjegyhez hasonlítható, nem pedig a természetes személy nevéhez. A kereskedelmi név esetén nincsen lajstromozás, amely magát a jog bizonyítását nehezíti meg. Tattay Levente mutat rá arra, hogy „amennyiben a kereskedelmi név értékes, annak védjegyként való levédése hatékonyan megoldja az oltalom kérdését." ${ }^{8} 2$ Ugyanígy kereskedelmi névröl beszélünk akkor is, ha a védjegy üzletjelzővé válik, hiszen a funkcióján ezzel a megjelölés túllép, és kiterjeszkedik másra, amit a jog a kereskedelmi név oltalmával részesít védelemben.

\section{A védjegyjogosult engedélye}

A védjegy szellemi tulajdonjog (személyiségi jegyet tartalmazó megjelölés esetén önállótlan vagyoni immateriális jog), s a védjegy bejegyzésével, lajstromozásával létrejövő védjegyoltalmi jogviszony abszolút szerkezetü. A védjegy használatára annak van kizárólagos joga, aki a védjegyoltalom alapján védjegyjogosultnak tekintendő. ${ }^{683} \mathrm{~A}$ név védjegyként való lajstromozásának lehetősége, mint már említettük, a személyiségi jogból fakadó jogosultság. Védjegyen fennálló jogosultság átruházható, illetve az azzal szembeni magatartások ellen a jogosult felléphet.

A védjegy önmagában elidegeníthető, szemben a névvel mint személyiségi joggal. Az elidegenítés licencia szerződéssel valósulhat meg. Az elidegenítéssel az a személy, aki a nevét védjegyoltalomban részesítette, elesik attól, hogy saját nevén mint védjegyen kizárólagos jogot gyakoroljon, s így attól is, hogy a nevét újólag, ismételten védjegyoltalomban részesítse, hiszen az így már más személy korábbi védjegyével azonos lenne. Az átruházásnak tulajdonképpen tehát az az eredménye, hogy a személy (a névviselési jog jogosultja) vagyoni érték ellenében kötelezi magát arra is, hogy a megjelölést nem jegyeztetheti be védjegyként, amely a vagyonában értékcsökkenésként jelentkezik, mert ebben az irányban nemtevésre kötelezi magát.

${ }^{682}$ TATTAY LEVENTE: A kereskedelmi nevek. Gazdaság és Jog 2011. 6. sz. 20.

${ }^{683}$ Vt. $12 . \S(1)$ bek. 
Ez kerül pénzben kompenzálásra szerződés útján. Ugyan a védjegy immateriális vagyoni jog, e minősége csak az oltalom megadásával, annak lajstromozásával keletkezik, a védjegyként való bejegyzés lehetősége mint váromány (függő jogi helyzet) ezzel szemben nem védjegy, így nem is szellemi tulajdoni jellegü, csak a névviselési jogosultságban rejlő cselekvési szabadság egyik megnyilvánulása, amely a védjegy más általi bejegyzése esetén a névjog eredeti jogosultja vonatkozásában már csak kisebb hatókörben tud érvényesülni.

Ezzel összefüggésben ismerte el a BGH az általános személyiségi jog vagyoni vonatkozásainak jogrendszerbeli létét. ${ }^{684}$ A BGH ugyanis abból indult ki, hogy a személyiségi jog jogosultját, illetve az ő jogutódját illeti meg az a jog, hogy a személyiségi jog részét képező névvel és képmással akként rendelkezzen, hogy azt vagy ö maga védjegyként bejegyezteti, vagy a más általi bejegyzéshez hozzájárul, illetve ezzel kapcsolatban merchandising szerződést kössön. Ezzel kerülhető el az, hogy az elhunyt személy személyiségi jegyeinek védjegyként való bejegyzése a jogosult halála után nem válik közkinccsé. Ez a jogosultság ugyanis a kegyeleti jog tárgyát nem képezi, hiszen nem az elhunyt méltó emlékezetét van hivatva szolgálni. Az egyetlen mód egyfajta rendelkezési jog biztosítása a személyiségi jog azon részjogosultságai felett, amelyek védjegyként bejegyezhetőek. Ilyen lehet ennek okán a hang, a jelmondat is. Az ebbe az irányba való eltolódást mutatja egyébként az is, hogy meghalt híres személy nevének védjegyként való lajstromozása a névviseléshez való jogot sérti, ${ }^{685}$ másrészről pedig, hogy a joggyakorlat az örökösök hozzájárulását követeli meg e legszemélyesebb jellegü jog irányú felhasználásához, ${ }^{686}$ amelyre ugyanakkor a Ptk. rendelkezései nem köteleznek implicite. Ebből az az absztrakt szabály rajzolható körül, hogy a névjog jogosultját megilleti a jog, hogy nevét védjegyként bejegyeztesse, vagy másnak erre engedélyt adjon, ha a jogosult már nem él, e jog örököseit illeti meg.

\footnotetext{
${ }^{684}$ NJW 2000, 2195 - Marlene Dietrich.

${ }^{685} \mathrm{BH}$ 1993. 548. („CHAGALL“).

${ }^{686}$ Pablo Picasso vonatkozásában 1. GÖDÖLLE IsTVÁN: Vt. 5. §. In: Faludi Gábor - Lukácsi Péter (szerk.): A védjegytörvény magyarázata. HVG-ORAC, Budapest, 2014. 164.
} 


\section{Kereskedelmi név}

1. A vállalatjelzők osztályozása a háború előtti magánjogban

Mielőtt a kereskedelmi név részletesebb vizsgálatának, személyiségi jogba való behatásának tanulmányozásába kezdenék, szükséges meghatározni azt, hogy mi tekintendő a megjelölések jogán belül kereskedelmi névnek, mi az, amit a jog e címszó alatt véd. A gazdasági, kereskedelmi szempontból releváns szóbeli megjelölések osztályozása eltérő a háború előtti magánjogban, illetve napjainkban. Először ezek kerülnek röviden felvázolásra. Ezek alapján meghatározzuk a kereskedelmi név fogalmát, s ebből kiindulva vizsgálom a név tárgyiasulását $\mathrm{s}$ a kereskedelmi név magánjogi védelmét.

A háború előtti magánjog a gazdasági szempontból releváns megjelöléseket vállalatjelző név alatt említi. Vállalatjelző lényegében mindaz, ami a kereskedőt ${ }^{687}$ és a vállalatát individualizálja, egyéniesíti. ${ }^{688}$ Nagy Ferenc 1913-ban még csak kereskedelmi jelzőkről, jelvényekről beszél a cég és a védjegy mellett. ${ }^{689}$ A vállalatjelzők közé sorolják (a) a céget, (b) a védjegyet, (c) az üzletjelzőket. Míg a cég és a védjegy fogalmi meghatározása törvényileg kötött, úgy az üzletjelző meghatározása negatív irányból történik. Az üzletjelző ez alapján az, ami sem cég, sem védjegy, ${ }^{690}$ azaz magában foglal minden, a vállalatot más vállalattól megkülönböztetni alkalmas megjelölést, s nem is csupán a szóbeli megjelölésekre, hanem a grafikailag ábrázolhatóakon túl a térbeliekre is kiterjed (pl.: kirakat). ${ }^{691}$ A kereskedelem szabadsága érdekében a törvény nem korlátozta, mely megjelölés lehet üzletjelző, csupán azt írja elő, hogy az általános jogelveknek (törvény, közrend, jóerkölcs, mások jogai, akár személyiségi joga) megfeleljen, s hogy alkalmas legyen arra, hogy a vállalatot minden más hasonló vállalattól megkülönböztesse. ${ }^{62}$ Az üzletjelző mint

\footnotetext{
${ }^{687}$ A cég minden esetben a vállalatjelzők közé sorolandó, az álláspontok abban térnek el, hogy az valójában a kereskedőt individualizálja-e vagy magát a vállalatot, a kereskedelmi üzletet. Az álláspontok bemutatására lásd SCHULTZ MÁRTON: A cégnév szellemi tulajdon jellege és viszonya a személyiségi joghoz. In: Görög Márta - Mezei Péter (szerk.): A szellemi tulajdonvédelem és a szabadkereskedelem aktuális kérdései. Pólay Elemér Alapítvány, Szeged, 2018. 61.

${ }^{688}$ FEHÉRVÁRY, 1941. 38.; KUNCZ ÖDÖN: A magyar kereskedelmi- és váltójog tankönyve. Grill, Budapest, 1938. 45.; KUNCZ ÖDÖN - BALÁS P. ELEMÉR: A tisztességtelen verseny. Politzer Zsigmond, Budapest, 1924. 42.

${ }^{689}$ NAGY, 1913. 138.

${ }^{690}$ KUNCZ, 1938. 45.

${ }^{691}$ KUNCZ - BALÁS P., 1924. 42.

${ }^{692}$ KUNCZ, 1938. 45.
} 
szóbeli megjelölés a cégtől és védjegytől abban különbözött elsősorban, hogy az nem lajstromba vétel útján keletkezik, hanem korábbi használat útján. Lehetőség van arra is, hogy a személyiség részét képező név a személyiségtől elváljon, s üzletjelzővé váljon. ${ }^{693} \mathrm{Az}$ üzletjelző tehát egy használati jog, amely esetén a puszta használat a jogszerzéshez nem elegendő, hanem a megjelölésnek alkalmasnak kell lennie a megkülönböztetésre is. ${ }^{694} \mathrm{Ez}$ lényegében abból az általános szabályból következik, amely a védjegyjogban is jelen van, t.i. hogy általános, individualizáló funkcióval nem bíró hétköznapi megjelöléseket az üzleti életben senki se sajátíthasson ki önkényesen. Az üzletjelző jogi védelméről a tisztességtelen versenyről szóló törvény 7 . §-a gondoskodott, mely szerint üzleti vállalata körében senki sem használhat oly nevet, céget, ismertetőjelet, rajzot, vagy az 5 . § rendelkezése alá nem eső oly címert, amely őt meg nem illeti. Ez a tilalom kiterjed arra is, aki üzlettelepét más által jogosan használt névvel, cégérrel, vagy egyéb jellemző megjelöléssel látja el.

Ebben a felosztásban a kereskedelmi név terminust ugyan nem található meg, azonban bemutatásra került egy olyan rendszert, amely a kereskedelmi megjelöléseket átfogó módon, a teljesség igényével osztályozza. A vállalatjelzők mint szóbeli megjelölések tulajdonképpen a gazdasági élet névjogát jelentik.

\section{A kereskedelmi név fogalmára vonatkozó álláspontok}

A vállalatjelző a kortárs jogirodalomban a vállalat individualizálására szolgál, amelytől különbözik az áru individualizálása, amelyre a védjegyek, illetve a földrajzi árujelzők alkalmasak. ${ }^{695}$

A kereskedelmi név fogalma a vállalat- és árujelzőkkel összefüggésben Világhy Miklósánál található meg 1968-ban. Világhy a kereskedelmi nevet a céggel teljes mértékben azonosítja, ugyanis úgy fogalmaz, hogy „kereskedelmi név, vagy cég alatt azt az elnevezést értjük, amely az áruforgalomban részes személynek mint ilyennek (a mi viszonyaink között valamely vállalatnak) a megjelölésére szolgál, amely alatt az áruforgalomban részes személy mint ilyen szerepel." ${ }^{696}$ A kereskedelmi névnek céggel való azonosítására valószínüleg a jogintézmény burzsoá jellegének

\footnotetext{
${ }^{693}$ Személyiségtől elvált: K. P. IV. 1753/1939. Nem vált el a személyiségtől a név: K. P. IV. 3967/1937. ${ }^{694}$ KUNCZ, 1938. 46.

${ }^{695}$ LONTAI ET AL, 2017. 360-361.

696 VILÁGHY, 1968. 595.
} 
megszünése és levetkőzése okán kerülhetett sor. Erre abból következtethetünk, hogy Világhy a marxi ideológiába ágyazva magyarázza meg a jogintézmény fenntartásának létét és értelmét: „A kereskedelmi név tehát jellegzetesen árutulajdonosi név, s mint ilyen - elvileg - elvonatkoztatást jelent a személy más viszonylatban használt (ún. polgári) nevétől, de bizonyos fokig a konkrét tevékenységtől is, amelyet az árutulajdonos akár az áruviszonyok körében is folytat (mert adott árutulajdonos mástól szerzett név alatt is kifejtheti ezt a tevékenységét, vagy különféle árutulajdonosi tevékenysége körében eltérő kereskedelmi neveket is használhat). Így érthető helyesen [sic!] régi Kereskedelmi Törvényünknek ma is érvényben levő $10 . \S$-a, amely szerint „a cég azon név, mely alatt a kereskedő üzletét folytatja, s melyet aláírásul használ.")" ${ }^{697}$ A cég tulajdonképpen eddig is a kereskedő kereskedelmi ügyletek kötésére használt neve volt, ezzel Világhy nem mondott tulajdonképpen újat, s így nem is helyes és helytelen értelmezésről van itt szó, hanem pusztán a fogalom szocialista polgári jogi áruviszonyaira való vetítéséről.

Lontai Endre a kereskedelmi néven a céget érti, azt a nevet, megjelölést, amely alatt a gazdasági társaság vagy személy gazdasági tevékenységét folytatja. ${ }^{698}$ Ezen az állásponton van Faludi Gábor is. ${ }^{69}$ A fogalom meghatározása ellenére eszerint az álláspont szerint a kereskedelmi név hatóköre kiterjed az áru, szolgáltatás más fantázianevére, vagy olyan nevére, melynek alapját más személy neve képezi, s amelynek védelmét a versenytörvény biztosítja. ${ }^{700}$ Ide sorolja továbbá a domainnév védelmét. $^{701}$

Törö Károly szerint a kereskedelmi név az a név, amelyet a gazdálkodó szerv rendszeres kereskedelmi vagy ipari tevékenysége körében használ, amely vagy cégbejegyzéssel (cégnév) vagy anélkül rendszeres használat útján jöhet létre. ${ }^{702}$ Görög Márta a kereskedelmi néven belül szintén különbséget tesz a cégnév és a be nem jegyzett kereskedelmi név között. ${ }^{703}$

Petrik Ferenc a kereskedelmi név fogalmát nem szükíti le a gazdasági tevékenységet folytató személy mint jogalany nevére, hanem beleérti a fogalomba az

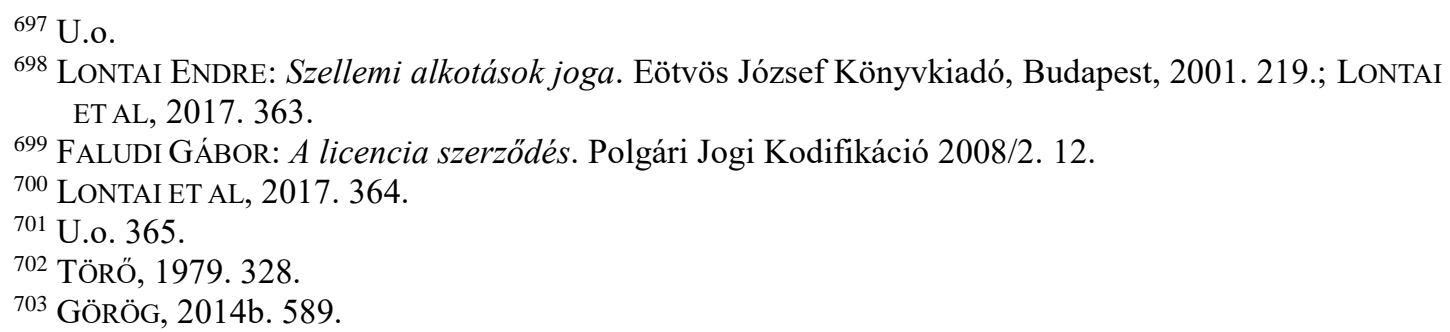


üzletjelzőket is, sőt, annak legáltalánosabb formájának minősíti azt. ${ }^{704}$ Tattay Levente a kereskedelmi nevek alatt minden olyan megjelölést ért, amelyet jogképes szervezetek abból a célból használnak, hogy tevékenységüket más hasonló területen vállalkozóktól megkülönböztessék. ${ }^{705}$ Verebics János a kereskedelmi név fogalmát hasonlóan tágan fogja fel. ${ }^{706}$ Tattay szerint a védjegy áruk és szolgáltatások megkülönböztetésére szolgál, míg a kereskedelmi név a vállalkozás megkülönböztetésére, ${ }^{707}$ ennek okán ő csak a cégnevet és az üzletjelzőket (alapítók, tulajdonosok nevei, a kereskedelmi vállalkozások feliratai, üzletnevek, vállalatnevek, étteremnevek, mozaikszavak) sorolja ide, illetve a domainneveket. ${ }^{708}$ Tattay lényegében nem ad választ arra, hogy ha a védjegyjog a kereskedelmi nevek oltalmán kívül áll, úgy a védjegyoltalom hogy lehet a kereskedelmi név védelmének része.

\section{A kereskedelmi név fogalma}

A kereskedelmi név és a cégnév fogalmi azonossága feleslegesnek tünik, hiszen egy jogintézményt elég egy néven nevezni. Ha a kereskedelmi nevet akként fogjuk fel, hogy az létrejöhet cégbejegyzéssel, illetve huzamos használattal is, úgy a cégbejegyzéssel létrejövő részjogosultságot a cégnév elnevezéssel illethetjük, azonban a cégbejegyzés nélküli, huzamos használattal létrejövő kereskedelemi név számára a be nem jegyzett kereskedelmi név elnevezés marad. A kereskedelmi név ekkénti felfogása ugyanakkor két eltérő jogosultságot egyesít, amelyeknek a keletkezési módjai is eltérnek. Ennél fogva mi a kereskedelmi név alatt minden olyan, a vállalattal, gazdasági élettel kapcsolatos megjelölést értünk, amely huzamos használattal keletkezik, és külön jogintézmény által (cégnév, védjegyjog, domainnév) nincsen védve. Ide tartoznak elsősorban a be nem jegyzett árujelzők, az üzletjelzők s a gazdasági társaságok azon nevei, amelyek nem minősülnek cégnévnek, azaz nincsenek lajstromoztatva. Nem tekintjük a kereskedelmi név részének a domainnevet, hiszen az nem minden esetben kapcsolható gazdasági tevékenységhez. ${ }^{709}$ A Szegedi Ítélőtábla szerint a domainnév kereskedelmi névvé válhat, és a domainnév használata

\footnotetext{
704 PETRIK, 1992a. 77.; PETRIK, 2001. 125.

705 TATTAY, 2011. 18.

706 VEREBICS JÁNOS: Kereskedelmi névoltalom és domain-regisztráció. Gazdaság és Jog 2007. 1. sz. 17, 17-18.

707 TATTAY, 2011. 20

${ }^{708}$ U.o. 18.

${ }^{709}$ BDT2009. 22. (,jakab.hu”); NJW 2007, 684 - kinski-klaus.de.
} 
névhasználatnak többek között akkor minősül, ha az kereskedelmi nevet tartalmaz. ${ }^{710}$ Ehhez a huzamos használaton túl megkülönböztető jellegre is szükség van. ${ }^{711}$ Azonban önmagában nem lesz kereskedelmi név, a domainnév delegálása nem feltétlen gazdasági, kereskedelmi célból történik.

A kereskedelmi név védelmének anyagi jogi alapjai tehát a versenyjogi szabályoktól függetlenül is, általános jelleggel a személyiségi jogon belülre pozicionálhatóak. A védelem a név mint szóbeli megjelölés analógiájára a megkülönböztető képesség fenntartására és az összetéveszthetőség kiküszöbölésére irányul. A kereskedelmi név keletkezésére vonatkozó szabályokat sem a Ptk., sem a Tptv. ugyan nem tartalmaz, a bírói gyakorlat azonban annak szempontjait kialakította. ${ }^{712}$ A kereskedelmi névhez való jog megszűnése tekintetében szintén nincs fogódzó, a bírói gyakorlat bizonyos esetekben a belenyugvással történő megszűnést elismeri. $^{713}$

\section{A név tárgyiasulása kereskedelmi név esetén}

Míg a cégnév és a védjegy esetén a jog nyilvántartásbavétellel keletkezett, addig a kereskedelmi név esetén egy másik jogi tény, a huzamos használat eredményezi a jogszerzést. Ebből fakadóan a korábbi jogok jogosultjainak engedélyét hatóság felé nem lehet bemutatni. A jogsértéssel szembeni fellépés intézményes keretei a jogszerzéssel összefüggésben hiányoznak. Míg védjegy esetén a relative kizáró okra történő hivatkozás a védjegy közzétételét követően megtörténhet, addig kereskedelmi névnél a használatról való tudomásszerés ténye után bármikor. A joggyakorlat ezt a forgalom biztonsága érdekében beszükíti. Erre a belenyugvás intézménye szolgál, amelynek időtartamát ugyanakkor a bírói gyakorlat absztrakt jelleggel nem határozta meg, azt csupán a konkrét esetre vonatkoztatva vizsgálta.

VI. A megjelölések személyiségi jogba való behatásának értékelése

\footnotetext{
${ }^{710}$ ÍH 2017. 11. (,muszakieredetvizsgaszeged.hu”).

${ }^{711}$ U.o.

${ }^{712}$ U.o.

${ }^{713}$ BH 1990. 255. („RORÁRIUS”); Legf. Bír. Pf. IV. $21007 / 1992$ („Láng”); BH 1993. 350. („Herz”); BH 1994. 21. („Rácz”); BH 1997. 467. („Pick”).
} 
A névjog alapvetően a jogalany nevét védi, emellett ugyanakkor jogalanynak nem minősülő polgári jogi társaságok, munkaközösségek ${ }^{714}$ és együttesek névvédelmét is áthatja. ${ }^{715}$ A cégnév mint a személyiségi jogon belül, a névtől tulajdonságaiban eltérő alanyi jog védelme szintén a névvédelem körébe sorolandó. A cégnév esetében a jogtárgynak a személyiség belső magvától való távolsága értelemszerüen a gazdasági társaságok mint jogi személyek másodlagos jogalanyi mivoltából fakad A cégnek ez a jellemzője eredményezi azt, hogy a névkizárólagosság meg tud valósulni. A cég ugyanakkor mégis személyes jogosultság, személyi jog, hiszen a jogalany megjelölésének elsődleges eszköze, attól alaptermészetében elválaszthatatlan, hiszen a jogalany nem maradhat név nélkül. A cég ugyanakkor vagyoni értékkel bír, részben átruházható, forgalomképes jogosultság. A cég e tulajdonsága emeli be az önállótlan vagyoni immateriális javak közé. Igaz ez akkor is, ha a cég természetes személy nevét tartalmazza. Ebben az esetben a névjog a cégjog szempontjából korábbi jog, amely a cég személyi jellegét erősíti ugyan, de mégsem billenti azt át a személyi immateriális javak körébe.

A kereskedelmi név szintén önálló védelemben részesül. A természetes személy nevének, illetve a cégnév védelmétöl abban különbözik, hogy a jogtárgy nem a jogalany neve, hanem egy, a jogosulthoz köthető gazdasági életben használt szóbeli megjelölés, amely huzamos használattal megkülönböztető képességet szerzett magának. A cégnév és a természetes személy neve kereskedelmi névvé válhat, ha a névhasználat funkcióbeli változása által a kereskedelmi név által védett esetkörökbe illeszkedik. A kereskedelmi név átruházható, örökölhető jogosultság, amely vagyoni értékkel bír és megsértése esetén a jogosult vagyoni érdekkörének sérelme mutatható ki elsődlegesen. A kereskedelmi néven való jog tehát önálló alanyi jog.

A védjegy a személyiségi jognak nem része. A védjegy személyiségi joggal való összefüggése a személyiségi jogban gyökerező, elsősorban a névhez és a képmáshoz kapcsolódó függő jogi helyzetből keletkezik. A személyiségi jog jogosultját ugyanis megilleti a jog, hogy (ábrázolható) személyiségi jegyét védjegyként bejegyeztesse. Míg a védjegy lajstromozására, bejelentésére sor nem kerül, addig a tényállás hiányos, így az ezzel kapcsolatos jogsértéseket a korábbi jog, a személyiségi jog tekintetében kell megítélni. A személy nevének, illetve képmásának áruk és szolgáltatások megjelölésére való használata jelentős vagyoni előnyt és

714 BH 1979. 411. („B-vonósnégyes”); BH 1980. 467. („Dankó Pista nótaegyüttes”).

715 BH 1987. 11. (,System”). 
kizárólagos jogot biztosít a jogosultjának. Ebböl fakadóan a személyiségi jog jogosultját illeti meg a kizárólagos rendelkezési jog, hogy személyiségi jogának e vonatkozásait védjegyként bejegyzetesse, vagy másnak erre engedélyt adjon. Ez a jog szintén a jogosult vagyoni érdekkörébe tartozik, s e függő jogi helyzetek megsértése a személyiségi jog megsértését vonja maga után. A védjegy lajstromoztatása után a jogtárgy kikerül a személyiségi jog védelmi köréből, és a személyiségi jog jogosultjának afelett nincsen ráhatása, a név ezzel tárgyiasul, és lényegében önálló vagyoni immateriális joggá válik. A védjegy által a név teljes mértékben tárgyiasul, áruk és szolgáltatások megjelölésére szolgál, s csak másodlagosan utal a személyiségi jog jogosultjára mint névjogosultra.

A domainnév több jogintézmény által védett szóbeli megjelölés, amelyet a joggyakorlat abból az irányból ragad meg, mely korábbi jog került domainnévként jogellenesen felhasználásra. vannak bizonyos esetek, amelyekben a domainnév önálló alanyi jogként funkcionál. Ebben a tekintetben a joggyakorlat most kezdi elismerni a domainnév önálló, a személységi jogba illeszkedő alanyi jogi jellegét. Ez a jog is egy önálló névjogi tényállást jelent. A domainnév szintén vagyoni értékkel bír és átruházható jogosultság, amely örökölhetőségét, a rendelkezési jog továbbélését a magyar joggyakorlat is elismeri. A domainnév mint szóbeli megjelölés önmagában tárgyiasult jogtárgy, a természetes személy neve domainnévben való felhasználásával tárgyiasítható, hiszen funkciójában a számítógépek, honlapok azonosítására szolgál.

Mindezek alapján helyesebb azt mondani, hogy a személyiségi jog a név vonatkozásában nem egy alanyi jogot véd, hanem több alanyi jogosultságot, melyek alaptermészetükben azonosak, funkciójuk a megkülönböztető képességükben rejlik, ugyanakkor mégis különböző dinamika alapján müködnek. A személyiségi jog védelmi körébe tartozik ennél fogva a néven való jog, a cégen való jog, a domainnéven való jog és a kereskedelmi néven való jog is. Az egyértelmü elhatárolást nehezitette részben, hogy e jogok egy része a tisztességtelen verseny által részesült elsösorban védelemben, s a személyiségi jogi védelem csupán szubszidiárius volt, másrészröl pedig az a körülmény, hogy ezen alanyi jogok szóbeli megjelölések, s így egymás tekintetében korábbi, prioritásos jogként funkcionáltak. Az előbb említett jogosultságok tehát a hagyományos értelemben felfogott névjogtól eltérő jogtárgyak, amelyek szabályai (keletkezés, védelem módja, megszűnés) részben eltérőek, célszerü lenne ennél fogva inkább névjogokról beszélni, semmint egy névjogról. 
E jogok közös jellemzője, hogy a személyiséggel való kapcsolatuk a hagyományos, szük értelemben vett névjoggal szemben nem annyira szoros. Itt inkább arról van szó, hogy e jogtárgyak a személy személyes viszonyai körébe sorolandóak, olyan jogtárgyak, amelyek felett az adott személy jogilag elismert hatalmi körrel bír. Ez a hatalmi kör egyrészt magában foglalja e megjelölési jogok feletti eszmei, esetlegesen erkölcsi védelmet (abbahagyás, eltiltás stb.), s ezen túl a vagyoni érdeket is. A fenti megjelölések ugyanis bizonyos esetekben jelentős vagyoni értéket képviselnek, s ezzel tulajdonképpen egyfajta gazdasági személyiségi jog részét képezik, hiszen legnagyobb részben a kereskedelmi forgalom szempontjából kerülnek ezek figyelembevételre a jogalkalmazási gyakorlatban. A vagyoni érdekkör megléte tulajdonképpen e megjelöléseket a dinamikus dologi szemlélet ernyője alá emeli, s ez alól kerülnek ki ezek részben akkor, ha a szóbeli megjelölés a szükebb értelemben vett névjogot, a jogalany nevét magában foglalja. A személyiséggel való kapcsolatba jutás lényegében a jogtárgy eredeti jogosultjának, a személyiségi jog jogosultjának tárgyiasulás utáni hozzájárulását követeli meg a jogtárggyal való bizonyos irányú rendelkezés esetén. Ez a hozzájárulás nem azon alapul, hogy a jogtárgy csupán kötelmi hatállyal került átruházásra, inkább egyfajta iura in re aliena jelleget ölt a tárgyiasult személyiségi jegy. A tárgyiasult személyiségi jegy ugyanis dologi hatállyal átruházható, a jogtárgy máshoz kerül, s az mégis a korábbi (eredeti) jogosult bizonyos irányú hatalma alatt áll.

Példaként hozható ezzel összefüggésben az a szabály, hogy a jogszerzőt a név használata nem jogosítja fel arra, hogy további, önálló jogi személyeknek a név viselését engedélyezze, még olyan formában sem, hogy társaságot alapítva nevét adja egy új társaságnak. ${ }^{716}$ Figyelemre méltó a Kt. azon szabálya, amely szerint aki valamely létező kereskedelmi üzletet szerződés vagy örökösödés útján szerez meg, azt a volt tulajdonos vagy jogutódainak beleegyezésével az addigi cég alatt az utódlást kifejező toldással vagy a nélkül folytathatja. ${ }^{717}$ Ezt a szabályt törvényi rendelkezés hiányában a bírói gyakorlat is elismeri, a Pécsi Ítélőtábla szerint ugyanis a társaság

716 Legf. Bír. Pf. IV. 21007/1992. („Láng”). Bizonyos esetben a névhasználati engedély adása kötelezettségként jelentkezik, így a külföldi vállalkozás magyarországi fióktelepének teljes és rövidített cégnevében a külföldi ,,anyacég” nevének szerepeltetése kötelező - ÍH 2006. 79. Ebben a tekintetben a személyiségi jog mint korábbi jog korlátként nem jelentkezik azon oknál fogva, hogy a törvény implicite elöírja a névhasználati engedély megadását. A jogalkotó nem tekinti kivételnek azt, ha nem rendelkezik róla kifejezett szabály alakjában, amikor valamely személy vagy tag neve szerepel a cégnévben, úgy a jogalkotó azt nem tekinti kivételnek.

${ }^{717}$ Kt. $12 . \S$ 
tagjaiban történt változás ellenére viselheti a volt tag nevét is tartalmazó cégnevet, ha ehhez a volt tag hozzájárul. ${ }^{718}$

VII. A név sui generis tárgyiasulása - a néven való vagyoni jog

A korábbi esetekben a név tárgyiasulása valamilyen más jogintézményi formát öltött, és úgy tárgyiasult, úgy szerzett magának vagyoni értéket. Ez egyes jogok tekintetében a személyiségi jogon belül történt, más jogok esetében azon kívül, iparjogvédelmi intézmény, a védjegyjog keretében. A név használata ugyanakkor más jogintézmény nélkül, önmagában is képes arra, hogy tárgyiasulása folytán vagyoni értéket szerezzen magának. Ez a vagyoni értékminőséget a név szóbeli megjelölési jellegéből fakadó számtalan felhasználási módja eredményezi, amelynek okán a név a kereskedelmi forgalom részévé válhat. A név ezzel sui generis tárgyiasul, nem lép át más szóbeli megjelölés intézményébe, hanem tisztán kerül át az általános személyiségi jogból a vagyoni személyiségi jogba. A név sui generis tárgyiasulásának legtipikusabb esetköre a név reklám célú felhasználása, bizonyos személyek termékekkel való kapcsolatba hozása nevük feltüntetésével.

Míg a korábbi tárgyiasulási módok esetén a név a más megjelölési jogok intézményes keretei között jelentkezett korábbi erősebb (prioritásos) jogként, addig a név sui generis tárgyiasulása esetében a vagyoni személyiségi jog tekintetében viselkedik így. Természetesen a névjog tulajdonságai ezen a területen is relevánsak: a névnek megkülönböztető képességgel kell bírnia, egyértelműen valamely személlyel összefüggésben kell jelentkeznie. Leginkább e második esetkör volt az, amelyet a bírói gyakorlat kitágított a név halál utáni felhasználásával összefüggésben. ${ }^{719}$ Ezzel érte el azt ugyanis a joggyakorlat, hogy elismerjen egy örökölhető, átruházható néven való vagyoni jogot. A név tárgyiasulása után a személyiséggel való kapcsolata továbbra is fennmarad, ebböl kifolyólag nem választhatóak el a vagyoni személyiségi jogon belül a vagyoni és eszmei érdekek. A névnek a személyiséggel való kapcsolata ugyanakkor kizárólag azon személy vonatkozásában áll fenn, akinek a neve tárgyiasult, függetlenül attól, hogy léteznek azonos nevü személyek, különösen hozzátartozók. A bírói gyakorlat ugyanakkor a hozzátartozói rendelkezési jogot a kegyeleti jog keretében

${ }^{718}$ PÍT ÍH 2007. 84.

${ }^{719}$ BH 1994. 21. (,Rácz”) 
értelmezte, s nem egy megörökölt vagyoni jog keretében, amelynek adott esetben végső soron az örökösök szerezhetnek érvényt. A halál után a személyiség különösen akkor él ugyanis tovább, ha annak egyes vonatkozásai tárgyiasulnak. Ezzel az elhalt személy személyiségi jogának jogosultja tekintetében jogutódlás következik, illetve következhet be. Kegyeleti joggá ez nem tud traszformálódni teljes mértékben a vagyoni összetevők egyértelmủen kimutatható jelenléte okán. A korábbi irodalom a név halállal való elválását egyértelmüen a kegyeleti jog keretében kezelte, ugyanakkor a kizárólag eszmei érdekkör ellenére a név vagyoni értékét kereskedelmi név formájában dologi hatállyal átengedhetőnek tartotta. Erre enged legalább is következtetni Törö Károly azon kijelentése, hogy „,van egyéb lehetőség is a név tárgyiasulására. A kereskedelmi névhez fontos vagyoni hatások kapcsolódnak, a kereskedelmi név kifejezetten vagyoni értékké válhat, a személytől elkülönülve vagyoni forgalom tárgya lehet. A kereskedelmi név örökösödés vagy üzletátruházás alapján az üzlettel együtt átszállhat az új tulajdonosra."720 A név erre nemcsak akkor képes, ha vállalatjelző, azaz elsősorban üzlet- vagy árujelző, hanem akkor is, ha csupán áruk kelendőségének fokozása érdekében kapcsolatba hozzák egy meghatározott termékkel, szolgáltatással. A név ekkor is tárgyiasul, azaz örökölhető és dologi hatállyal átruházható jogosultsággá válik.

A név reklámcélú felhasználásával összefüggésben a BGH már egészen korán nem a névjog, hanem az általános személyiségi jog megsértését látta megállapíthatónak mind a Caterina Valente, ${ }^{721}$ mind a Carrera ${ }^{722}$ döntésekben. Ennek a gyakorlatnak végső soron az lett az eredménye, hogy nem a BGB 12. §-ának jogfejlesztése útján ért el egy néven való vagyoni jogot, ahogy azt egyébként Klippel is javasolta, ${ }^{723}$ hanem az általános személyiségi jog vagyoni vonatkozásainak részeként. ${ }^{724}$ A név jogosulatlan kereskedelmi felhasználása (kommerzielle Verwertung, Vermarktung) az általános személyiségi jog vagyoni vonatkozásainak a megsértését jelenti. ${ }^{725}$ Ezzel a névjog, illetve a képmáshoz való jog tekintetében is a

\footnotetext{
720 TÖRÖ, 1979. 289.

${ }^{721}$ BGHZ 30, 7 - Caterina Valente.

722 BGHZ 81, 75 - Carrera.

723 „Soweit das Namensrecht dagegen das Interesse an der Beseitigung von Verwechlungsgefahr betrifft, ist es als Immaterialgüterrecht aufzufassen. Dieses Interesse entsteht erst dann, wenn der Name in einer Bezeichnung gebraucht wird, die - wie z.B. die Firma - nicht mehr nur den Namensträger kennzeichnet, sondern zusatzlich etwas anderes (z.B. Handelsgeschäft); insofern ist also eine Lösung des Namens von der Person und eine gewisse Verkehrsfähigkeit eingetreten. “ KLIPPEL, 1985. 520-522.

${ }^{724}$ NJW 2000, 2195 - Marlene Dietrich.

${ }^{725}$ Erman/KLASS, BGB, 15. Aufl., Anh § 12 Rn. 208.
} 
jogtárgy eszmei és vagyoni védelmét külön jogalapra helyezte végső soron. A BGH ezt annak ellenére tette, hogy a névjog tekintetében a reklámcéllal összefüggő, anyagi érdekek kiszolgálására szolgáló védelmét a BGB kodifikációja is elismerte, ${ }^{726}$ szemben az általános személyiségi jog jelenségével, s ebből következően annak bárminemü vagyoni jellegével. A név az általános személyiségi jog vagyoni alkotórészeként nemcsak abban az esetben sérül, ha reklámokkal összefüggésben a jogosultat hozzájárulása nélkül megnevezik, hanem akkor is, ha a hirdetés szatirikusélcelődő módon vitat meg egy olyan közéleti eseményt, amelyben a névjogosult is részt vett, akkor is, ha a megnevezéssel a névjgosult image-e, reklámértéke nem kerül kihasználásra, és nem kelti azt a látszatot sem, hogy a jogosult a reklámozott termékkel azonosul vagy ajánlja azt. ${ }^{727}$ A BGH első Marlene döntvényében nem csupán a személyiségi jegy jogosulatlan védjegyként való felhasználását, és használati engedély adását tekintette a vagyoni érdek megsértésének, hanem Marlene nevének reklámcélú felhasználását is. Marlene nevének a reklámban való megnevezésével a jogsértő Marlene Dietrich örökösének azon jogát sértette meg, hogy arról döntsön, hogy e saját neve reklámcélra egyáltalán felhasználható-e. Ez a jogosultság ugyanúgy az általános személyiségi jog vagyoni vonatkozásainak részét képezi a német jogban mindaddig, míg az a névviselő vagyoni érdekeinek védelmét szolgálja. ${ }^{728}$

Az újabb magyar bírói gyakorlat a név reklámcélú felhasználását nem a jóhírnév megsértésének, hanem az adott személyiségi jegy, a névjog megsértésének tekinti. A Debreceni Ítélőtábla 2018-as eseti döntésében arra az álláspontra helyezkedett, hogy más nevének kereskedelmi (reklám) célból történő használatára csak az érintett hozzájárulásával kerület sor, ennek hiányában a névviseléshez füződő személyiségi jog sérelme megállapítható. ${ }^{729}$

Nem minősül a név sui generis tárgyiasulásának az, ha a nevet úgy használják reklámcélra, hogy az valamely áru vagy szolgáltatás megjelölésére szolgál. Ebben az esetben a név kereskedelmi névvé válik, hiszen üzletjelzőként funkcionál. A név reklám célú kereskedelmi felhasználása abban az esetben lehet releváns mint a vagyoni

\footnotetext{
${ }^{726}$ Protokolle der Kommission für die Zweite Lesung, Bd. 6. 113. (A BGB második szövegét tárgyaló bizottsági jegyzőkönyvek).

${ }^{727}$ Erman/KLASS, BGB, 15. Aufl., Anh $§ 12$ Rn. 208.; BGH GRUR 2008, 1124, 1126 - Lucky Strike: Ernst August v Hannover; NJOZ 2008, 4549, 4553 - Lucky Strike: Dieter Bohlen; EGMR NJW 2016, 781 - Ernst August v Hannover/Deutschland II; EGMR ZUM-RD 2016, 561 - Dieter Bohlen/Deutschland.

${ }^{728}$ NJW 2000, 2195 - Marlene Dietrich.

${ }^{729}$ DÍT BDT 2018. 87. [fej] (,,kutatóintézet”).
} 
érdekkör megsértése, ha a személyiségi jog jogosultja tekintetében olyan látszat keletkezik, mintha az adott terméket, szolgáltatást maga ajánlaná, használná vagy azzal egyébként valamilyen módon azonosul, azt támogatja. Ez lényegében hagyományos értelemben véve nem esik a névbitorlás hatókörébe, hiszen nem az összetéveszthetőség ellen védi a jogosultat. Jelen esetben ugyanis egyértelmüen a névviselőről beszélhetünk, nem keletkezik olyan látszat, amely összetéveszthetőségre vezet. Sokkal inkább arról van szó, hogy a névviselőt akarta ellenére, beleegyezése nélkül hozzák kapcsolatba egy termékkel vagy szolgáltatással, jogosulatlanul nevezik meg. Ez a magatartás azonban ennek ellenére névbitorlásként kvalifikálható, hiszen a jogsértő jogosulatlanul más nevét használja. A vagyoni érdekkör jelen esetben abban áll, hogy a jogosult maga dönthessen, szerződhessen arról, hogy mely szolgáltatások, termékek tekintetében hogyan járul hozzá, milyen módon és milyen környezetben annak népszerüsítéséhez és kelendőségének fokozásához. A hozzájárulásnak kifejezettnek kell lennie, a név csak a meghatározott összefüggésben használható fel. A név alatt valamennyi névjogot érteni kell, így az anyakönyvi név mellett a felvett nevet is.

Ez a használat érinthet eszmei érdekeket, mint ahogy azt a Caterina Valenteügy esetében láthattuk, ${ }^{730}$ amikor a felperest protézis és müfogsorrögzítő reklámozásával összefüggésben említették meg, de a név reklámcélú felhasználása alapvetően a jogosult vagyoni érdekkörét sérti. Az eszmei és erkölcsi érdekek messzemenő megsértése esetén azonban Götting szerint a jogalap nélküli gazdagodás, a vagyoni kár megtérítésére vonatkozó igények és a nem vagyoni hátrány sérelemdíj útján való megtérítése nem kumulálható. ${ }^{731}$ Ezt az álláspontot foglalta el a Müncheni Táblabíróság is. A poszt mortem kegyeleti igény (Würdeanspruch) sajtó általi durva megsértése esetén az abbahagyásra irányuló igény mellett nem vagyoni kár megtérítésére vonatkozó igény is keletkezik, ugyanis a személyiségi jog vagyoni vonatkozásainak elismerésével a bíróságoknak a halál utáni eszmei érdekkör védelmének továbbfejlesztése is a feladata. ${ }^{732}$

A névjog ilyen irányú megsértése a név jogellenes, a jogosult akarata ellenére történő tárgyiasítása. A BGH a képmásvédelem során abból indul ki, hogy a név reklámcélú, jogosulatlan felhasználása esetén egy megfelelő mértékű licenciadíj-

\footnotetext{
${ }^{730}$ NJW 1959. 1269 - Caterina Valente.

${ }^{731}$ GÖTTING, 1995. 130.

732 GRUR-RR 2002, 341.
} 
fizetési (angemessene Lizenzengebühr) kötelezettség attól függ, hogy a sértett (a jogosult) objektív lehetősége és szubjektív készsége megvolt-e arra, hogy a nevét piacra vigye. ${ }^{733}$ A konkrét esetben a felperes kijelentette, hogy nevének reklám célú felhasználására egyáltalán nem gondolt, és ennél fogva nem követelhette a megfelelő mértékü licencia díjat. ${ }^{734}$

\section{Részösszegzés}

A névjog tárgyiasulása többféleképpen végbemehet. Ide sorolható egyrészről a más jogintézmény keretében történő tárgyiasulás. Ilyen a szellemi tulajdonjog körébe tartozó védjegyjog, és ilyen a személyiségi jogi védelmen belüli, más jogtárgy formájában történő tárgyiasulás. A személyiségi jogon belüli tárgyiasulásra példa a cégnév, a kereskedelmi név és a domainnév formájában történő tárgyiasulás, amelynek vizsgálata során különbséget kell tenni aközött, hogy a megjelölés alapja egy fantáziaszó vagy a személyiségi jog mint korábbi jog. A névjog tárgyiasulása, a képmáshoz való joghoz hasonlóan, másrészről sui generis módon is végbemehet. A névjog ily módon történő tárgyiasulásával jön létre a néven való vagyoni jog, amelybe a név reklámcélú felhasználása tartozik. A név termékek és szolgáltatások megjelölése tekintetében tulajdonképpen üzletjelzőként funkcionál, és ennél fogva elsősorban mint kereskedelmi név részesülhet védelemben. Ez az oka annak, hogy a név sui generis tárgyiasulásának az alkalmazási köre sokkal szükebb, mint a képmásé, amely esetén az üzletjelzőként való használat a szóbeli megjelölési jelleg hiányában nem értékelhető a kereskedelmi név megsértéseként.

A név cégnévként való tárgyiasulása által cégen való joggá válik. Amennyiben a cégnév fantáziaszó, úgy a személyiségi jog értelemszerüen a jog gyakorlása során nem jelent korlátot. Abban az esetben, ha a cégnév természetes személy nevét tartalmazza, úgy a céghasználat korlátja a névjog jogosultjának személyiségi joga. Ilyen korlát lehet az, ha a gazdasági társaság a cégnevet más jogi személy alapítása során fel kívánja használni annak nevéuil.

Ugyanígy tárgyiasul a név, ha az domainnévvé válik. Ebben az esetben szintén új, a névjog mint személyiségi jogtól független új alanyi jog jön létre, amely szintén

${ }^{733}$ GRUR 1959, 430, 433.

${ }^{734}$ U.o. 
abszolút, kizáró jelleget biztosít a jogosultnak. A domainnév nem a jogalany neve, nem cégnév, de nem is védjegy. A domainnév ugyanígy nem üzletjelző, nem kereskedelmi név automatikusan, noha szerezhet ilyen minőséget huzamos használattal, mint ahogy bejegyzéssel az adott megjelölés védjeggyé vagy cégnévvé is válhat. Ekkor azonban új jogosultság keletkezik. A domainnév tehát, mivel nem minden esetben rendelkezik kereskedelmi névi minőséggel, nem kizárólagosan a jogosult gazdasági, üzleti, kereskedelmi érdekét védi, ugyanúgy kiterjed az ettől független, nem vagyoni, erkölcsi jellegü sérelmek orvoslására és ennek keretében is kizáró jogot biztosít a jogosult számára.

A névjog alkalmazásának a személyiségvédelmen belüli előbb felleltározott dogmatikai rendszere ugyanakkor egy másik következtetésre is vezet. A személyiséghez kapcsolódó érdekek köre tág, nem pusztán az ember érzületére, nem vagyoni érdekeire terjed ki kizárólagosan, hiszen nem csak az emberrel szoros összefüggésben álló jogtárgyak védelmét látja el a magánjogi személyiségvédelem. Ebből is látszik egyrészről azon állításom helyessége, hogy az alkotmányos emberi méltóság joga csupán a személyiségvédelem egy részét fedi le, és hogy a személyiségi jog magánjogi alapja a 2:42. § szerinti kibontakozás joga. Másrészről a magyar személyiségi jog, a svájci és a liechtensteini joghoz hasonlatosan elsősorban az egyén személyes viszonyait védi. A személyes viszonyok körébe tartozik minden olyan, elsősorban eszmei érdek, jogtárgy, amely a közfelfogás által egy személy kizárólagos rendelkezési jogába utalt. E személyes viszonyoknak a vagyoni viszonyokkal való keveredése, de el nem enyészése érhető tetten a névjogok tárgyiasulásán. Itt rajzolódik ki leginkább az a feszültség is, amely e jogtárgyak forgalomképessége okán azok osztályozásában is jelentkezik. Az eszmei, immateriális javak summa divisiója alapján a személyiségi jog a forgalomképtelen, nem örökölhető immateriális jog, míg a társadalmi, ipari felhasználhatósága okán forgalomképes immateriális javak a szellemi alkotások területére esnek. A személyi és vagyoni viszonyoknak a tárgyiasulás általi keveredése, különösen az így létrejött új alanyi jogban a személyiségi jog további fellelhetősége jelentős klasszifikációs problémákat vet fel, különösen az individuum és a személy kiemelt fokú védelme okán.

A magánjogi személyiségi jogba betoluló jogtárgyak és érdekek védelme a német jognál jóval tágabb, azt is mondhatjuk: más jellegü. A német jogban látható volt, hogy az általános személyiségi jog magánjogi elismerése előtt a képmás és a név védelme kiterjeszthető lett volna a vagyoni érdekekre, azt maga a jogalkotó is 
előrevetítette már a kodifikáció során is. A nagy váltást az emberi méltóságból és a kibontakozáshoz való jogból eredeztetett általános személyiségi jog elismerése jelentette egyrészről. Ez ugyanis jelentős eszmei, nem vagyoni védelmi áramlatot adott a személyiségi jog joggyakorlatának alkotmányos jogalapja és szankciói által. Erre erösített rá a Markengesetz, a védjegytörvény 1995-ös módosítása, amely a kereskedelmi név védelmét a védjegybitorlással összekapcsolta egy általános vállalatjelző-bitorlást hozott létre. Ez kivette a talajt a BGB 12. §-a szerinti névjog kiterjesztő és analóg alkalmazása alól. Ez azt jelentette, hogy a BGB 12. §-ának alkalmazási köre a jelentős vagyoni érdeket magában foglaló vállalat- és árujelzők tekintetében nem volt alkalmazható, tárgyi hatálya a lényegesen erőteljesebb, fennmaradó eszmei érdekekre szűkült. Ezután a jogváltozás után ismerte el a jogalkalmazási gyakorlat a személyiségi jog vagyoni vonatkozásait, amelyek már szintén ebben a személyiségvédelmi keretrendszerben kerültek értelmezésre és alkalmazásra. Ennek okán sem a BGH a jog elismerésekor, sem a bírói gyakorlat nem tud hivatkozni arra, hogy a BGB 12. §-a szerinti névjog védelme tágabb kört fog át, a vagyoni érdekek sokkal szerteágazóbbak a személyiség védelmén belül.

A magyar jogban más a helyzet, ott az előbb említett megjelölések, névjogok a személyiségvédelemben jelen vannak. Hasonló helyzetben a svájci jog van, ez viszont a személyiségi jog vagyoni értékét nem ismeri. A jogtárgyak sokasága okán ugyanakkor megnő a tárgyiasulási módok száma, és ezzel a vagyoni érdekek, a vagyoni, kereskedelmi felhasználhatóság módjainak száma is. Ez azt is eredményezi, hogy a vagyoni és eszmei érdekek a személyiségvédelmen belül sokkal több területen ütköznek, és hogy egy esetleges vagyoni személyiségvédelmi rendszer kialakításának német útja nem alkalmazható, azt más módon kell biztosítani. Erre a tárgyiasulás alapú vagyoni személyiségvédelem eddig alkalmasnak bizonyult. 


\section{A VAGYONI SZEMÉLYISÉGI JOG}




\title{
6. § VAGYONI ÉRTÉKMINŐSÉG ÉS TÉTELES JOG
}

\author{
Bevezetés
}

A személyiségi jog magyar fejlődése alapján látható, hogy a személyiségi jogon belül a vagyoni érték akkor is megjelenik, ha az elsősorban eszmei érdeket véd. Látható volt az is, hogy a személyiségi jog jogalapját lehet úgy értelmezni, amely ezt nem zárja ki a tételes jogban sem. A személyiségi jegyek tárgyasíthatósága és tárgyiasulása egyértelmü bizonyítékként szolgált arra, hogy a személyiségi jog egyes vonatkozásaiban megszünik legszemélyesebb jognak lenni. Azt kell tehát vizsgálni, lehetséges-e a Ptk. szabályait akként értelmezni, hogy a személyiségi jog vagyoni értéke értékelésre kerüljön, vagy mindenképpen szükséges jogalkotói beavatkozás? Ezzel összefüggésben további kérdésként merül fel, hogy milyen következménnyel jár az, ha a Ptk. és a joggyakorlat a vagyoni érdekeket a személyi érdekekkel azonosan kezeli.

I. Elismeri-e a tételes magyar jog a személyiségi jog vagyoni értékét?

Jelen fejezet azt vizsgálja, a Ptk. tartalmazza-e, óvja-e a vagyoni érdekek védelmét, elismeri-e, el kell-e ismernie egyes személyiségi jegyek forgalomképességét. A kérdésnek viszonylag egyértelmünek kellene lennie, legújabb kutatásaim szerint mégsem az. Megtalálhatóak ugyanis annak morzsái, hogy a jogalkotó a német jognak a személyiségi jog eszmei érdekei melletti vagyoni érdekeket is védő koncepcióját részben átültette. Ez a morzsa pedig az, hogy a Ptk. a személyiségi jog önálló szankciójává emelte a jogsértéssel elért vagyoni előny átengedését [Ptk. 2:51. § e) pont], illetve hogy ezzel kapcsolatosan a személyiségi jog jogosultjának halála után az örökösei jogosultak lesznek az erre vonatkozó igény érvényesítésére [Ptk. 2:50. § (2) bek.]. Ez azt követeli meg, hogy a Ptk. elismerje azt, hogy a személyiségi jog megsértése vagyoni hátrány okozásával is történhet. Ezzel pedig a Ptk. vagyoni érdeket véd, hiszen a személyiségi jog jogosultjának okoz vagyoni hátrányt a jogsértő. A jogsértéssel elért vagyoni előny átengedésének Ptk.-ba való beépítésére azért került sor, mert „, a személyiségi jogok gyakorlása sok esetben vagyonjogi elönyök forrását is szolgálhatja, éppen ezért a jogsértéssel elöállt vagyoni viszonyok eltolódását vissza 
kell állítani."735 A vagyoni hátrány elismeréséből következik a személyiségi jog vagyoni értékének elismerése is. Külön érdekes az, hogy az etekintetben relevanciával bíró jogirodalomban nem található olyan utalás, hogy a jogalkotó a német bírói gyakorlatot és jogirodalmat vette figyelembe. Sem a Szakértői Javaslat, ${ }^{736}$ sem a 2009. évi Ptk. magyarázata, ${ }^{737}$ sem a Bizottsági Javaslat, ${ }^{738}$ sem a kommentárirodalom nem utal erre, ${ }^{739}$ a jogirodalom sem tér ki ezekre úgy mint koncepcionális újítás, ${ }^{740}$ azonban a szabályozás mégis erre épül. ${ }^{741}$ Erre Vékás Lajos 2009-es német nyelvü tanulmányának jogirodalmi hivatkozásai mellett Petrik Ferenc is utal, aki kiemeli, hogy

„a Szakértői Javaslat szerzői a jogsértéssel elért vagyoni elöny átengedésére az alaptalan gazdagodás szabályainak alkalmazását javasolták. Bevallottan a német $C$. W. Canaris nyomán [...]. Canaris abból indult ki, hogy az elöny elvonására a fájdalomdíj nem alkalmas, ezért fel kell használni a jogalap nélküli gazdagodás szabályait. Ezt a javaslatot a német jogtudomány nem fogadta egyöntetü helyesléssel. Nálunk ugyanakkor a Szakértői Javaslat a gondolatot magáévá tette: azokban az esetekben, amikor a sértett érdeksérelme a jogsértö részére vagyoni előnyt eredményezett, indokolt a gazdagodás elvonása éspedig a sértett javára."742

A vagyoni érdeket védő normahelyek a kifejezetten személyi jellegünek tekintett jogosultság vonatkozásában nem generáltak különösebb vitát a jogirodalomban, amely ezekre nem tekint koncepcionális újításképpen.

Ha a Ptk.-t szövegét az általános jogérzék alapján vizsgáljuk, úgy a vagyoni érdekekhez köthető szakaszhelyek közül több is releváns lehet. Nem tartozik ide a sérelemdíj, amely ugyan pénzfizetésre irányuló követelés, de nem vagyoni jellegü

\footnotetext{
735 VÉKÁs LAJOS: Über die Expertenvorlage eines neuen Zivilgesetzbuches für Ungarn. ZeuP 2009. 536, 551.

736 VÉKÁS LaJOS (szerk.): Szakértői javaslat az új Polgári Törvénykönyv tervezetéhez. Complex, Budapest 2008.

${ }^{737}$ GÁRDOS PÉTER (szerk.): Kézikönyv az új Polgári Törvénykönyvhöz. Törvényszöveg. Egységes szerkezetü indokolás. Megjegyzések. Complex, Budapest, 2009.

738 VÉKÁs LAJOS (szerk.): Az új Polgári Törvénykönyv Bizottsági javaslata magyarázatokkal. Complex, Budapest, 2012.

739 VÉKÁs LAJOS: A Polgári törvénykönyv magyarázatokkal. Complex, Budapest, 2013.

740 VÉKÁS LAJOS: Az új. Ptk. Szakértői Javaslatának elvi kérdései. Magyar Jog 2008. 65. 71.

741 VÉKÁS, 2009. 551.

742 PETRIK FERENC: Személyiségi jogok. In: Wellmann György (szerk): Polgári jog. Bevezető és záró rendelkezések. Az ember mint jogalany. öröklési jog. HVG-ORAC, Budapest, 2014. 201-202.
} 
sérelem, hanem az eszmei, erkölcsi sérelem orvoslására szolgál, így vagyoni érdeket jellegénél fogva nem véd. A vonatkozó szabályoknak az összefoglalását az alábbi táblázat tartalmazza.

\section{8. sz. táblázat}

A Ptk. vagyoni értékminöséget érintö szakaszhelyei

\begin{tabular}{|l|l|l|}
\hline & \multicolumn{1}{|c|}{ Szakaszhely } & \multicolumn{1}{c|}{ Elismeri? } \\
\hline alanyi jog / tényállás & $\begin{array}{l}2: 42 . \S(1) \text { bek. } \\
\text { (kibontakozás joga) }\end{array}$ & lehet \\
\cline { 2 - 3 } & $\begin{array}{l}2: 42 . \S(2) \text { bek. } \\
\text { (emberi méltóság) }\end{array}$ & nem (?) \\
\hline \multirow{2}{*}{ igény / jogkövetkezmény } & $\begin{array}{l}2: 51 . \S \text { e) pont } \\
\text { (kártérítés) }\end{array}$ & lehet \\
\cline { 2 - 3 } & $\begin{array}{l}\text { 2:50. § (2) bek. } \\
\text { (jogalap nélküli } \\
\text { gazdagodás) }\end{array}$ & igen \\
\cline { 2 - 3 } & $\begin{array}{l}\text { 2:53. § } \\
\text { (post-mortem jogalap } \\
\text { nélküli gazdagodás) }\end{array}$ & igen \\
\hline
\end{tabular}

(saját szerkesztés)

A jogszabály célja szerinti értelmezés tekintetében megkülönböztethetjük az objektív és a szubjektív teleologikus értelmezést. Az objektív teleologikus értelmezés alapján a személyiségvédelem célja nem csupán az erkölcsi, nem vagyoni érdekek védelme, hanem kellő jogvédelem biztosítása azon esetben, ha a személyiség sérelmével a jogsértő vagyoni előnyhöz jut vagy kárt okoz. Erre sem a tényállásból, sem a kártérítési utalószabályból nem következtethetünk, de a Ptk. 2:51. § e) pontjából igen, hiszen az egy vagyoni szankció alkalmazását irányozza elö. Az objektív cél ez alapján az, hogy a magánosok vagyoni viszonyaiban bekövetkezö értékcsökkenést helyre kell állítani, kompenzálni kell, ki kell egyenlíteni. Ez új cél a személyiségvédelemben. A jogalkotó szubjektív célja egyébként ezzel egybevág.

„A személyiségi jogok megsértése nem egyszer vagyoni javak forrása is lehet, és ezért a jogsértéssel kapcsolatban bekövetkezett vagyoni eltolódás kiküszöbölésére is szükség van. Külföldi joggyakorlatban már elöfordult példája ennek, ha az újság jogellenesen készített felvétel közzétételével növeli a példányszámot. Ilyen esetben indokolt a gazdagodás elvonása is, éspedig a sértett javára. Erre a legalkalmasabb magánjogi eszköz a jogalap nélküli gazdagodás. A jogalap nélküli gazdagodás szabályainak alkalmazásával a 
leginkább érdekelt, a sérelmet szenvedett személy válik az igényérvényesitésre jogosulttá, ezáltal biztosítva a szabályozás céljának [sic!] megvalósulását, nevezetesen, hogy a jogsértéssel elért vagyoni elönyt a jogsértö ne tarthassa meg."743

A jogalap nélküli gazdagodás alkalmazására külön rendelkezés nélkül is lehetőség lenne, ha a Ptk.-ra nem mint szabályok halmazára, hanem mint alanyi jogok és igények, illetve ezek értelmezését és alkalmazását segítő normák rendszerére tekintünk. A Ptk. a kondikció külön kiemelésével a vagyoni érdekek védelmére irányuló jogalkotói célt emeli ki, egyértelműsíti. Kérdés, végigvihető-e ez a cél a személyiségvédelem teljes szabályozásán.

II. Alkalmas-e az alanyi jog a vagyoni érdekek védelmére?

\section{1. Általában}

A fenti táblázat alapján a vagyoni érdekkör megléte és védelme elsősorban az alanyi jog, a jogalap tekintetében problémás, hiszen a jogalkotó a tényállás, az alanyi jog oldaláról a vagyoni érdeket nem értékelte. Az értékelés hiánya nem tudatos döntés eredménye, és arra vezethető vissza, hogy a vagyoni érdek szankció oldalán való elismerésén túl nem is gondoltak az alanyi joggal kapcsolatos aggályokra, illetve ebben a tekintetben a német bírói gyakorlat és jogirodalom eredményeit nem vették figyelembe. A kodifikáció lényegében figyelmen kívül hagyta azt, hogy a vagyonjogi szankciók alkalmazásához egyfajta (forgalomképes) vagyoni jogra van szükség, függetlenül attól, hogy e vagyoni jogot forgalomképesnek ismerjük el, és ezáltal örökölhetőnek, illetve átruházhatónak. Bydlinski szerint nem várható el a jogalkotótól az, hogy egy adott törvényhozási kérdésben egy rendszerszintü tervvel álljon elö. Bizonyos résztervek a reálisak a szabályozás céljai és alapértékei tekintetében. ${ }^{744}$ Ilyen részterv jelen esetben a jogalap nélküli gazdagodás megléte, illetve az a jogalkotói cél, hogy a személyiségi jog sérelmével létrejött vagyoneltolódást helyre kell állítani, a jogosult vagyoni érdekét védeni kell. Mivel a kódexben elhelyezett vagyonjogi

743 SZÉKELY - VÉKÁS, 2013. 70.

${ }^{744}$ BYDLINSKI, 2012. 82. 
szankciók mindenképpen olyan alanyi jogot igényelnek, amelyek esetén vagyoni érdekről beszélhetünk, így e szabályok részletes meghatározása a bírói gyakorlat feladata. A bírói gyakorlatnak a jogértelmezésből és a bírói jogfejlesztésből (analógia) kell ezt levezetnie, illetve a rendszertani értelmezésből adódóan a személyiségvédelmi rendelkezésekkel összhangba hoznia. Ez két vonatkozásban lehet releváns: az eszmei érdekeket védő, a személyiségvédelem egészére kiterjedő szabályok (különösen az emberi méltósághoz való jog alkalmazási körének) konkretizálása tekintetében, másrészről a meglévő szabályok felülvizsgálata és a nem tervezett törvényi hézagok analógia útján történő kitöltése által.

\section{A kibontakozás joga [Ptk. 2:42. § (1) bek.]}

A Ptk. 2:42. § (1) bekezdése szerint mindenkinek joga van arra, hogy a törvény és mások jogainak sérelme nélkül személyiségét szabadon érvényesítse, és abban őt senki se gátolja (kibontakozás joga). A törvény az alanyi jog keretében nem rendelkezik arról, hogy a személyiségi jog személyes jellegü jogosultság, nem mondja ki azt, hogy az nem átruházható, nem örökölhető, nem forgalomképes jog. A Ptk. 2:54. § (1) bekezdése, amely alapján a személyiségi jogokat csak személyesen lehet érvényesteni ennek mérésére nem alkalmas, ez csak a felperesi legitimácóra utal, és ez akkor is releváns lehet, ha valamely személyiségi jegy dologi hatályú átruházását elismernénk. Ekkor a jog jogosultja nem a személyiségi jog jogosultja, hanem egy jogszerző személy lenne, ekkor ez a személyes érvényesthetőség rá vonatkozna.

A legszemélyesebb jellegre, azaz arra, hogy a személyiségi jog kizárólag eszmei, erkölcsi érdekeket véd csak a jogirodalomból és a dogmatikából következtethetünk egyértelműen. ${ }^{745}$ Általánosan elfogadott, hogy a személyiségi jog elsősorban a személy erkölcsi, eszmei érdekeit, azaz személyi viszonyait védi. Ennek keretében a bírói jogértelmezés eltolodhat abba az irányba, hogy a Ptk. 2:42. § (1) bek. szerinti védelmet kiterjeszti a vagyoni érdekekre is. A személyi és vagyoni viszonyok közötti különbségtétel nincsen kőbe vésve, azok keveredhetnek is, a személyi alapú viszony teljes mértékben lehet vagyoni tartalmú is. ${ }^{746}$ Egyes személyiségi jegyeknek (névjog)

\footnotetext{
${ }^{745} \mathrm{Pl}$. „Fontos jellemzője a személyhez füződő jogoknak: a jog személyessége. [...] A személyesség egyben azt is jelenti, hogy ezek a jogok a jogosult személyességétől elválaszthatatlanok, más személyre csak meghatározott feltételek mellett szállhatnak át.” PETRIK, 2001. 28.

746 ZSÖGÖD, 1900. 1303-1304.
} 
már korábban is tulajdonítottak vagyoni értéket. ${ }^{747}$ Korábban egyébként az is vitás volt, hogy a személyiségi jog megsértése esetén elég-e a jogos érdek sérelmének bizonyítása. ${ }^{748}$ Praktikus szempontból, a jogalkalmazás tekintetében az a lényeges, hogy a Ptk. 2:42. $§(1)$ bekezdésébe beleérthető a bírósági jogértelmezés keretében a jogosult vagyoni érdeke, azt nem zárja ki semmi.

3. Az emberi méltóság [2:42. § (2) bek. 1.m.] és a vagyoni érdek

A Ptk. az emberi méltósághoz való jogot a magánjogi személyiségvédelem központi normájává emelte. Az emberi méltóság alanyi joggá emelésével ugyanakkor a személyiségi jegyek forgalomképessége kizárt, hiszen az emberi méltóság fogalmánál fogva tiltja, hogy az ember, a személyiség a jogban tárggyá váljon. Az általam képviselt értelmezés alapján az emberi méltóság egy belső szük mag a személyiségvédelmen belül, és a kibontakozás joga ernyő módjára magában foglalja e jogot, a magánélet szféráját, s minden más, e rendszerbe foglalt nevesített és nem nevesített személyiségi jogot is. Ennél fogva lehetőség nyílik arra, hogy az emberi méltóság és a vagyoni érdekek megférjenek egymás mellett.

4. Az eszmei és vagyoni érdekek védelméről való állásfoglalás

Ha a vagyoni érdekek védelme elvileg lehetséges, úgy kérdéses, hogyan védi azt a jogalkotó, mi a viszonya az eszmei érdekekhez. Ha a Ptk. normaszövegében kívánjuk elhelyezni a személyiségi jog vagyoni értékminőségére vonatkozó jogosultságokat, úgy a monista álláspont mellett kell mindenképpen állást foglalnunk, hiszen a tárgyi jog külön alanyi jogot a vagyoni értékü személyiségi jegyek tekintetében nem tartalmaz. Ha a jogalkotó külön, önálló alanyi jog keretében kívánta volna oltalmazni a vagyoni érdekeket, úgy azt megtehette volna. Ugyan a jogalkotói cél az volt, hogy a vagyoni érdekek is védelmezésre kerüljenek, azonban mégsem foglalt állást abban a kérdésben, hogy a német bírói gyakorlat mintájára a személyiségi jog eszmei és vagyoni vonatkozásokkal is bír-e, ettől függetlenül a törvény szövegéböl erre a következtetésre juthatunk. A monista védelem a német jogalkalmazásban egyértelmủen nem okoz problémát, hiszen ott a személyiségvédelem teljes rendszere

\footnotetext{
747 ALMÁSI, 1927. 133. 134.

${ }^{748}$ ALMÁSI, 1902. 29. sz. 2.
} 
a joggyakorlat által kimunkált. A magyar jogban azonban, ahol a személyiségvédelem törvényben szabályozott, problémás lehet a vagyonjogi jogkövetkezmények alkalmazhatósága. Ennek az az oka, hogy a személyiségi jog bármely (legyen az pusztán erkölcsi, ideális sérelem) megsértése az alanyi jogot olyan igényállapotba helyezi, amely esetén vagyonjogi szankciók kérhetőek a bíróságtól. Ez nyilvánvalóan téves, így ezek alkalmazási körét a bírónak kell leszükítenie. Ezt a Ptk. nem egyértelműsíti, az alkalmazás kört túl tágan vonja meg.

\section{Jogkövetkezmények}

A BGH a vagyoni értékeltolódás megtérítésének három módját ismeri. Ide sorolható a szerződésen kívül okozott károkért való felelősség, a jogalap nélküli gazdagodás, illetve a jogsértéssel elért előny kiadása a szerzői jog szabályai szerint. ${ }^{749}$ Ezek azok az általános magánjog, a szerzői, védjegy- és versenyjogban is alkalmazott vagyonjogi jogkövetkezmények, amelyek a vagyoni érdekekben bekövetkező zavar orvoslására szolgálhatnak.

Mivel a személyiségi jogon fennálló vagyoni érdek tekintetében is abszolút jogról beszélünk, így a jog kizáró (in rem) jellegéből eredő jogkövetkezmények (pl. abbahagyás, eltiltás), illetve a személyiségvédelem más jogkövetkezményei (pl. megállapítás) alkalmazhatóak. Erre a törvény lehetőséget is ad. Ennek megfordítása okoz problémát azáltal, hogy a Ptk. általánosan lehetőséget ad a kártérítés és a jogalap nélküli gazdagodás igénybevételére; tehát akkor is, ha csupán az eszmei, erkölcsi érdekek sérülnek. Ugyanebben az esetben a szubszumció során ezek alkalmazása kizárható, azonban célszerü lenne a jogalkotónak ezt lehatárolnia. Míg erre nem kerül sor, úgy a bírói gyakorlatnak a Ptk. 2:42. § (1) bekezdésének megsértése tekintetében a Ptk. 2:51. § e), 2:50. § (2) bek. és (ha nem következménykárról beszélünk) a 2:53. § alkalmazása során többletfeltételként vizsgálnia kell a vagyoni érdek sérelmét. Ez több módon, megfogalmazással valósulhat meg: jogellenes kereskedelmi felhasználás útján, termék kelendőségének fokozása által, a média szenzációhajhász tevékenysége okán, a tárgyiasult felhasználás jellegéhez kapcsolódóan stb. A személyiségi jog sérelmének vizsgálata során tehát e jogkövetkezmények tekintetében a Ptk. 2:42. § (1)

\footnotetext{
${ }^{749}$ Staudinger/HAGER, § 823 Rn. C 290.
} 
bekezdésének alkalmazhatóságát teleologikusan redukálni kell, erre alkalmas a személyiségi jog sérelme körében a vagyoni érdekkör sérelmének vizsgálata.

\section{A vagyoni értékminőség el nem ismerésének problémája}

\section{1. Általában}

A vagyoni érdekbe tartozó személyiségi jogi részjogosultságok alapvetően forgalomképes javakká válhatnak. Azaz átruházhatóak, használatukra engedély adható, örökölhetőek. Ha a bírói gyakorlat ezt a vagyoni érdekkört nem értékeli, és az eszmei vonatkozásokkal azonosan kezeli, úgy „félreszubszumál”. Az eszmei érdekek nem örökölhetőek, a halállal megszünnek és nem választhatóak el a személytől. Számos probléma keletkezik azonban abból, ha a vagyoni érdekkörbe tartozó részjogosultságokat is e szabályok alá vonjuk. A probléma abból adódik, hogy az ide sorolható jogok a személytől elválnak, tárgyiasulnak, és ezzel a jogosult halála után is felhasználhatóak, megsérthetőek, és a jogsértő oldalán a jogellenesen felhasznált, tárgyiasított személyiségi jegy általi kelendőség fokozása számszerüsíthető pénzügyi előnnyé válik. A jogsértő vagyona kimutathatóan gyarapodik. A bírói gyakorlat ettől függetlenül az eszmei érdekek védelme alapján próbálta kezelni ezeket, ennél fogva születtek olyan érdekes döntések, amelyek a hozzátartozók kegyeleti jogtól független, saját személyiségi jogukon alapuló perlését lehetővé tették. ${ }^{750}$ Ebben a tekintetben a jogalkalmazónak teleologikusan redukálnia kell a jogszabály (az eszmei érdekek) védelmi körét. Teleologikus redukcióról akkor beszélünk, ha a törvény szövege több esetkört is átfog, mint amit a törvény célja megkövetel. Ebben az esetben a törvény célja által át nem fogott esetkörök esetén, a törvény szó szerinti értelmezése lehetőségének ellenére, az adott norma nem alkalmazható. ${ }^{751}$ A probléma ezzel kapcsolatban az, hogy mind az eszmei, mind a vagyoni érdekek ugyanazon törvényhely keretében [Ptk. 2:42. § (1) bek.] részesülnek védelemben, így ez kizárólag jogalkotói beavatkozás hiányában a bírói jog szintjén értékelhető.

\footnotetext{
${ }^{750}$ K. 2571/1936. („,herceg Esterházy Miklós”); BH 1994. 21. („Rácz”); Legfelsőbb Bíróság Pf. IV. 21007/1992. („Láng”).

${ }^{751}$ WANK, Rolf: Die Auslegung von Gestzen. Carl Heymanns Verlag, Köln, 2005. 126.
} 
A jogalkotó nem határozta meg azt, mikor keletkezik e vagyoni értékminőség. A jog tartalma körében nem határozta meg a rendelkezési jog terjedelmét, azaz, hogy mikor használható fel szabadon a személyiségi jegy, mikor kell hozzájárulás, mennyiben ruházható át egy személyiségi jegy (dologi hatályú jogszerzés), illetve mennyiben adhat használati engedélyt a személyiségi jog jogosultja a személyiségi jegy felett (kötelmi hatályú jogszerzés). Nem határozta meg a jogalkotó azt sem, hogy meddig terjed a védelem (a jog megszünése), hogyan rendelkezhetnek az örökösök a személyiségi jog felett. Természetesen ezek a kérdések az eszmei érdekek védelme tekintetében is csak részben tisztázottak, és nagyrészt az esettől függően a bírói érdekés jogtárgymérlegelés körébe utaltak, a két érdek hasonlósága okán azonban kiemelt szerephez jutnak.

\section{Megváltozott társadalmi viszonyok}

A képmáshoz való jog törvényi elismerésekor, 1907-ben a német jogalkotó tisztában volt azzal, hogy e jog kereskedelmileg hasznosítható, s mégsem állított semmilyen gátat annak útjába, hogy az ilyen célú felhasználást kizárja, amely egyértelmüen szemben állt a képmáshoz való jog nemvagyoni természetének hangoztatásával. Götting abból indul ki, hogy a képmáshoz való jog társadalmi felfogása az idő folyamán jelentősen megváltozott. „Időközben a gazdasági, technológiai és társadalmi változások, különösen a virtuális tömegmédia fejlödése és az általa kiváltott kép-zuhatag itt is az erkölcsi alapok alapvető változásához vezetett. ${ }^{752}$ Hírességek képmásának reklámcélú felhasználása elsősorban inkább vagyoni, mint eszmei sérelemhez vezet, amelyet Götting a Zeppelin- és a Tull Harder-döntéseken ${ }^{753}$ keresztül mutat be. Míg a Graf Zeppelin-ügyben a felperes erkölcsileg volt károsult képmása védjegyként való lajstromozása által, addig a Tull Harder-ügyben a Reichsgericht nem látott jogértést abban, hogy egy abszolút kortörténeti szereplő képmását reklámcélra használják fel. ${ }^{754}$ A Blauer Engel II.-döntésben a Szövetségi Alkotmánybíróság egy teljesen más nézőpontból támasztotta alá ugyanezt a meglátást: „ma már, másként mint 1956-ban, amikor a tényállást megállapitó bíróság a BGHZ 20, 345 számú döntésben szakértöt rendelt ki, nem szükséges elsö körben szakértői

\footnotetext{
752 Götting, 1995. 46-47.

${ }^{753}$ RGZ 125, 80 - Tull Harder.

754 Lásd GÖTTING, 1995. 45 sköv.
} 
bizonyítás elrendelése annak megállapitásához, hogy a hírességek képmásának kereskedelmi célú felhasználása reklámokban igen gyakori jelenség”. ${ }^{755}$ A kutatóintézet-döntésben a Debreceni Ítélőtábla is kiemelte, hogy a reklámtevékenységhez manapság már nem társul automatikusan negatív társadalmi megítélés. ${ }^{756}$

A társadalmi viszonyok tekintetében kiemelkedő az, hogy a szocialista polgári jogban a személyiségi jog megsértésének az esetei éppen azokkal az esetkörökkel csökkentek, amelyek a személyiségi jogok vagyoni viszonyokkal való összefüggésével kapcsolatosak. Ezek az esetkörök a piacgazdaság 1990-es újraindulásával, mind a médiajog, mind a reklámozási szokások, mind a gazdasági társaságok piaci érdekei okán tulajdonképpen nem újonnan jelentek meg, hanem visszatértek, lényegében abban a formában, ahogy az az 1945 előtti joggyakorlatban is jelentkeztek. Ehhez képest csak az internet és a televízió jelenléte jelent újabb jogsértési módokat. A gazdasági, jogi, társadalmi viszonyokban jelentkező törés miatt a magyar jogban nem tudott annyira organikusan alakulni a személyiségi jogok vagyoni viszonyokkal összefüggő másodlagos felhasználásra vonatkozó jogi álláspont, azonban a joggyakorlat jó irányban halad a vagyoni vonatkozások minél teljesebb körü értékelése és jogvédelme tekintetében.

A kereskedelmi felhasználás nemcsak valóság, hanem érdek is. Érdeke elsősorban a vállalatoknak és a sajtónak a profit növelése, ha a személyiségi jog jogosultjának a jog nem biztosít védelmet személyisége kereskedelmi irányú felhasználásával szemben, úgy jogait csorbítva jutnak mások vagyonilag is mérhető elönyhöz. ${ }^{757} \mathrm{Ez}$ az állítás akkor is igaz, ha ezzel a személyiséget bizonyos vonatkozásban jogi szempontból „el kell dologiasítani”, ha a kellő jogvédelem, a személyiség hathatós védelme ezáltal tud csak megvalósulni. ${ }^{758} \mathrm{Ez}$ az eldologiasítás alapvetően az örökölhető, átruházható személyiségi jogi vonatkozások elismerését jelenti.

\footnotetext{
${ }^{755}$ NJW 2006, 3409 - Blauer Engel II.

756 BDT 2018. 87. (,kutatóintézet”)

${ }^{757}$ MENYHÁRD, 2016. 78.; a német jogelméletben ennek megalapozására, amelyet a német legfelső bírói fórum is felhasznált a személyiségi jog vagyoni vonatkozásainak elismerésére: GÖTTING, HORSTPETER: Persönlichkeitsrechte als Vermögensrechte. Paul Siebeck, Tübingen, 1995.

${ }^{758}$ NJW 2000, 2195 - Marlene Dietrich.
} 
3. A személyiségi jegyek jogellenes kereskedelmi felhasználása mint hamis látszat

A személyiségi jegyek jogosulatlan felhasználása esetén a joggyakorlat abból indul ki, hogy ezzel a személyiségi jog a jóhírnév vonatkozásában sérül. A szalaghirdetésügyben a Legfelsőbb Bíróság a következőképpen indokolt: „a felperesek nem vállalkoztak a perbeli reklámszövegben szereplö vállalkozás termékeinek a reklámozására, ezért a személyiségüket sértö, hamis látszatot keltö, sajtóhelyreigazításra alapot adó volt az a sajtóközlemény, amely a képi és szöveges anyag sajátos módon való csoportositásával a felperesek személyét összefüggésbe hozta a reklámszövegben szereplö vállalkozás termékeinek reklámozásával." ${ }^{759}$ Ezt a bírói gyakorlatot a Legfelsőbb Bíróság 2002-ben megerősítette, és szintén a hozzájárulás hiánya következtében létrejövő hamis látszatra helyezte a hangsúlyt:

„A felperest mint ismert sportriportert ugyanis a sportközvetítések alkalmával köztudottan reá jellemzö köszönést felhasználva, gazdasági reklámtevékenységgel hozták összefüggésbe, olyan látszatot keltve, mintha a felperes a reklámfilmnek valamilyen résztvevöje lenne, mintha a felperes közremüködne a rádiótelefon-készülékek reklámozásában. Helyesen állapította meg a jogerős itélet, hogy ezt a hamis látszatot keltő összefügést a felperes által használt köszönési forma alkalmazásával és azzal teremtették meg az alperesek, hogy a reklámfilmet a felperes riporteri közremüködése mellett közvetített sportversenyek közben sugározták. Amint arra a Legfelsőbb Bíróság a jogerös itéletben is megjelölt eseti döntésében (BH. 1998/509. sz. ${ }^{760}$ már rámutatott, a személyhez füzödö jogok megsértését, ezen belül a jó hírnév megsértését jelenti, ha valakit hozzájárulása nélkül úgy tüntetnek fel, hogy általában vagy egy adott áruval, illetve szolgáltatással kapcsolatban konkrétan reklámtevékenységet végez. Ezt a hamis látszatot keltö kapcsolatot többféle módon meg lehet teremteni. Az említett eseti döntésben a reklámtevékenység végzésének hamis látszatát a közismert személyek képmásának felhasználásával érték el. A kapcsolatot megteremtheti az érintett személy hangfelvételének, nevének felhasználása is, de megteremtheti egy olyan, az adott személlyel közvetlenül kapcsolatba hozható egyéb körülmény is, egy olyan jellegzetesség, mint a perbeli esetben a felperes által használt és a felperesre jellemzö, a sportközvetitéseknél

\footnotetext{
${ }^{759}$ BH 1995. 509. (,„szalaghirdetés”).

${ }^{760}$ Az ítélet rosszul hivatkozza le a döntést, helyesen a BH 1995. 509. sz. döntés.
} 
alkalmazott egyedi köszönési mód, amelyről a közvélemény a felperes személyére következtet."761

A bíróság tehát nem az egyes személyiségi jegyeken fennálló rendelkezési jogból indult ki, amelynek keretében a személyiségi jog jogosultja egyes személyiségi jegyek felhasználását más számára engedélyezheti, hanem ezen túllépve abból, hogy a felek közötti szerződés hiánya hamis látszatot kelt harmadik személyek számára. Ezt az álláspontot képviseli Görög Márta is. ${ }^{762}$

Az utóbbi időben megjelent egy másik álláspont is. A Debreceni Ítélőtábla szerint a jóhírnév megsértése [..] azért nem valósul meg, mert a reklámtevékenységhez ma már nem társul automatikusan negatív társadalmi megítélés. ${ }^{763}$ Ezzel a jogalkalmazás részben elismeri azt, hogy a személyiségi jogok kereskedelmi felhasználásával az egyes személyiségi jogi jogosultságok felett más személy rendelkezik, mégsem erről az oldalról értékeli ezt, hanem a hamis látszat, a jóhírnév sérelme irányából. Hasonló állásponton van Navratyil is, aki szerint valamely személy személyiségjegyének kereskedelmi célú felhasználásakor „,nem feltétlenül kell a jóhírnév vagy a becsület csorbításáról beszélni, sokkal inkább arról van szó, hogy gazdasági érdekeik sérülnek, ha személyiségük, nevük jogosulatlanul jelenik meg a sajtóban egy üzleti hirdetés kapcsán, hiszen erre az érintett személyek adhatnának engedélyt, amiért - általában - díjazásban is részesülnek. [...] Ez alapján megállapítható lenne a névjog sérelme a név, képmás vagy egyéb személyiségjegy jogosulatlan kereskedelmi célú felhasználása esetében is". ${ }^{764}$ Meglátásom szerint a bíróság azért indult ki a jóhírnév megsértéséből, s azért ebből az irányból értékelte a cselekményt, mert a név, képmás, hangfelvétel, jelmondat megsértésének kimondásával nyíltan szembekerült volna azzal, hogy a személyiségi jogról bizonyos tekintetben le lehet mondani, azt más személy ellenérték fejében felhasználhatja. Ez azonban szembemenne a személyiségi jog legszemélyesebb jellegével, illetve annak nem vagyoni karakterével is. Az újabb joggyakorlat ugyanakkor - úgy tünik - kezdi ezt a jóhírnév sérelme helyett az egyes személyiségjegyek oldaláról megközelíteni, s azok tekintetében állapítja meg a jogellenességet a kereskedelmi felhasználáshoz való

\footnotetext{
${ }^{761}$ BH 2002. 261. (,Jó estét, jó szurkolást!”)

${ }^{762}$ GÖRÖG MÁRTA: Gondolatok a merchandising jelentéstartamához, egyes típusaihoz. Iparjogvédelmi és Szerzői Jogi Szemle. 2011/3. 23-24.

${ }^{763}$ BDT 2018. 87. [19] (,kutatóintézet”)

${ }^{764}$ NAVRATYIL, 2016. 230.
} 
hozzájárulás hiányára alapozva. ${ }^{765}$ Ezzel a jogértelmezéssel a bírói gyakorlat közelebb került, közelebb kerülhet a személyiségi jogok vagyoni vonatkozásainak, esetlegesen egy vagyoni személyiségi jog elismeréséhez is.

4. A családi név kereskedelmi felhasználása

Hasonló jogértelmezési problémákhoz vezet a családi név kereskedelmi felhasználása, különösen az engedélyt adó családtag halála utáni igényérvényesítés tekintetében. A családi név specialitása abban rejlik, hogy több személy is rendelkezik efelett mint személyiségi jog felett. Ez elsősorban a családtagokat jelenti, másrészröl azonban azokat a személyeket is, akik tőlük függetlenül azonos családi nevet viselnek. Ezt a névjog vonatkozásában úgy oldja fel a joggyakorlat, hogy a családi névre egyfajta kollektív jogként tekint, amelynek megsértése esetén a családtagok saját jogon személyiségük megsértésének címén felléphetnek. ${ }^{766}$ Erre kiváló példa a Láng-ügy: „ebböl eredöen - mivel a család többi tagja sem tiltakozott a névhasználat ellen - az évtizedes használat tudomásulvételét Láng Gusztáv László leszármazói részéröl olyan ráutaló magatartással megadott hozzájárulásnak kell tekinteni, amely a Ptk. 75. § (3) bekezdése alapján a jogsértés megállapíthatóságát kizárja." 767 A bíróság sokkal egyszerüebben lezárhatta volna a jogi értékelést azzal, hogy a perbeli esetben a név felhasználása nem volt kegyeletsértő, hiszen az elhunyt személy méltó emlékezését nem sértette. Ezzel szemben a Legfelsőbb Bíróság belement az értékelésbe, és sokkal később, a belenyugvás vonatkozásában látta az igény megvalósulásának kizártságát. Legtovább azonban az herceg Eszterházy-ügyben a kir. Kúria ment, amikor kiemelte, hogy a névhez való jog sohasem enyészik el, a nevet a család bármely tagja bármikor visszakövetelheti, s így mégha az Eszterházy család tagjai is tudtak volna a név használatáról, erre irányuló külön akaratkijelentés nélkül a használathoz való hozzájárulásra, avagy arra, hogy a felperes a családi névnek az alperes általi használatába örök időkre beleegyezett, okszerü következtetést levonni nem lehet. ${ }^{768}$

Ez a megoldás azonban logikailag nem ad választ arra, hogy azonos név esetén miért csak a családtagok élhetnek ezzel, illetve nem magyarázza meg azt sem, hogy a

\footnotetext{
765 BDT 2018. 87. (,kutatóintézet”).

766 BH 1994. 21. („Rácz”); Legfelsőbb Bíróság Pf. IV. 21007/1992. („Láng”); eltérő álláspont: BH 1993. 350. („Herz”); a korábbi joggyakorlatból: Grill Dtár XXX.684. („herceg E.M.”).

${ }^{767}$ Legfelsőbb Bíróság Pf. IV. 21007/1992. („Láng”)

768 Grill Dtár XXX. 684. (,herceg E.M.”)
} 
személyiségi jog jogosultjával összefüggésbe hozott név használatával összefüggésben, különösen ha ahhoz egy tőle származtatott engedély kapcsolódik, más személy (hozzátartozó) saját jogán miért léphet fel. A jogtárgy tartalmi azonossága ugyanis erre nem adhat lehetőséget, hiszen kötelmet csak a hozzájárulást adó, a személyiségi joga felett rendelkező személy tekintetében lehet vizsgálni.

A név problémája más tekintetben is felmerült, így mikor a személyiségi jog jogosultja egy leszármazójának leánykori neve alapján engedte a perlést a bíróság. Ahelyett, hogy a bíróság azt vizsgálta volna, hogy az alperes a személyiségi jog jogosultjának lánya által megörökölt, a név hasznosítására irányuló kizárólagos vagyoni jogát sérti-e, meglehetősen nyakatekert érveléssel a jogosult lányának önálló perlési joga mellett foglalt állást. A Legfelsőbb Bíróság szerint ,a Ptk.-nak az a rendelkezése pedig, amely szerint a személyhez füzödö jogokat csak személyesen lehet érvényesíteni [...] nem jelenti azt, hogy az a házasságban élö nö, aki a házastársa nevét használja, ezáltal el van zárva attól, hogy a lánykori (családi nevének) jogosulatlan használójával szemben [...] fellépjen." 769 A Rácz-ügyben ugyanis a bíróság kifejezetten a felperes édesapjának személyiségi jogával hozza összefüggésbe a cukrászda elnevezését, s így a kötelem ebben a tekintetben alakult ki.

5. Személyiségi jegyek jogosult halála utáni felhasználása

Az eszmei érdekek mintájára történő értékelés szintén nem alkalmas a személyiségi jegyek halál utáni felhasználása tekintetében, legyen ez a felhasználás reklámcélú, történjen üzletjelzőként vagy árujelzőként (védjegyként) való használat formájában. Az eszmei javak ugyanis a halál után addig részesülnek védelemben, míg a kegyelet megkívánja. A nem kegyeletsértő felhasználás nem is jogsértő a bírói gyakorlat szerint. A vagyoni érdekek tekintetében a jogosult életében kizárólagos hasznosítási jog és az ahhoz kapcsolódó vagyoni előnyök szünnek meg a halállal. Ezek az előnyök alapvetően nem ideális, erkölcsi érdekeket védenek, hanem kizárólagos gazdasági monopóliumot biztosítanak, amely külön törvényi rendelkezés hiányában megszűnik, és az bárki által felhasználható. Ez ugyanígy visszásságokat eredményezhet a védjegyjogban is, ahol más személyiségi jogának sérelme a kegyeleti jog sérelmén túl nem mutatható ki, így tulajdonképpen a leggyorsabb bejelentő lesz a szerencsés

${ }^{769}$ BH 1994. 21. („Rácz”) 
jogosult, hogy az elhalt személyiségi jegyeinek meghatározott áru- és szolgáltatási osztályok tekintetében védjegyként használja.

\section{A személyiségi jog vagyoni értékminőségének nevezéktana}

A személyiségi jogok vagyoni értékminősége a személyiségi jog teljes rendszerét érintő jelenség. Az egyes jogrendszerek eltérő módon értékelik a személyiség védelmét a személyi és vagyoni viszonyok vonatkozásokban. Van olyan megközelítés, amely a személyiség fogalmából, a magánélet, privacy fogalmából indul ki, ide sorolható továbbá a szellemi tulajdonjog mintájára megvalósuló védelem, illetve a tisztességtelen verseny (jellegbitorlás) keretében való értékelés. ${ }^{770}$ Egyes jogrendszerek külön alanyi jog, egy image, egy vagyoni értékü személyiségi jog útján látják azt oltalmazni. ${ }^{771}$

A hangsúly ezzel kapcsolatban arra helyeződik, hogyan írható le a kontinentális jog rendszerében az, hogy egyes személyiségi jegyek örökölhetőek, átruházhatóak és a személytől elválnak, tárgyiasulnak. Ennek megragadásához a magánjog általános rendelkezéseihez kell visszanyúlnunk, hiszen a személyt megillető jogosultságokat a magánjog alanyi jog (facultas agendi) formájában tartalmazza. Az alanyi jogok védelmének több modellje alakult ki, ${ }^{772}$ az alábbiakban továbbra is a jogi érdekek alapján vizsgálódok. Ennek megfelelően az a lényeges, hogy a tárgyi jog elismerje, hogy a személyiségi jog részét képező egyes jogosultságok felett a jogosultnak vagyoni érdeke áll fenn. Ez a vagyoni érdek azt jelenti, hogy a vagyonjogok mintájára működik a jogosultság, azaz forgalomképes lehet és ezáltal jogutódlás tárgyát képezheti.

A személyiségi jogot védő vagyoni érdekek gyüjtőfogalmaként használom a vagyoni értékminőség elnevezést. Ezt a vagyoni értékminőséget a különböző jogrendszerek és az egyes jogirodalmi álláspontok eltérő elnevezéssel illetik. Egyes szerzők a személyiségi jogon belüli vagyoni jogosultságok megjelölésére a gazdasági

\footnotetext{
770 Beverly-Smith, Huw - Ohly, Ansgar - LuCAs-Schloetter, Agnés: Privacy, Property, Personality. Cambridge University Press, New York, 2005. 4-11.

${ }^{771} \mathrm{Az}$ amerikai jog tekintetében 1. CORBETT, VAL: A képmáshoz füződő jog és az elvi megalapozás nehézségei. In Medias Res 2014/2.; CORBETT, VAL: The right of publicity and the search for principle. In: Koltay András (szerk.): Media Freedom and regulation in the new Media World. Wolters Kluwer, Budapest, 2014; a német jog vonatkozásában 1. BEUTHIEN, VOLKER: Was ist vermögenswert, die Persönlichkeit oder ihr Image? NJW 2003. 1220.

772 Ehhez lásd LÁBADY TAMÁS: A magánjog általános tana. Szent István Társulat, Budapest, 2013. 189.
} 
személyiségi jog (das wirtschaftliche Persönlichkeitsrecht) ${ }^{773}$ elnevezést használják. Legelőször a két világháború közötti időben, August Egger svájci jogtudós alkalmazta a személyiségi jog versenyjoggal is összefüggő, elsősorban szubszidiárius megsértési eseteire. ${ }^{774}$ Ezt a fogalmat javasolta alkalmazni Götting is disszertációjában, 1995-ben a név, képmás és a személyiség más megnyilvánulásainak örökölhető és átruházható vonatkozásaira. ${ }^{775} \mathrm{~A}$ BGH ettől függetlenül kezdte el használni az általános személyiségi jog vagyoni vonatkozásai kifejezést, ${ }^{776}$ amelyet aztán Götting is átvett. ${ }^{777}$ Ez az elnevezés azonban csak akkor fenntartható, ha a személyiség eszmei és vagyoni érdekei kizárólag egy alanyi jog keretében kerülnek értékelésre.

A right of publicity-ból kiindulva funkcionális fordítással arculathoz való jogként, arculathoz füződő személyiségi jogként adható ez vissza, szó szerinti fordításban pedig a publicitáshoz való jogként. Sajnálatos módon Corbett Val tanulmányának magyar fordítása a képmáshoz való jogként fordítja le ezt, amely nyilvánvalóan hibás. ${ }^{778} \mathrm{Az}$ arculathoz való jog elnevezés előnye az, függetlenül attól, hogy azt a right of publicity-vel összefüggésben vagy egy kontinentális vagyoni értékminőséggel összefüggésben használjuk, hogy közérthető, gördülékeny megfogalmazás, s a jogkereső közönség számára is nagyjábóli képet ad a jog tartalmáról. A német jogirodalomban Beuthien az, aki a személyiségi jog dualizmusa mentén a vagyoni jogokat a személyiségkép jogának (Persönlichkeitsbild), image-nek nevezi. ${ }^{779}$

Asztalos László 'nem árujellegü személyiségi javakról' beszél, nála valószínüleg az árujellegű személyiségi javak a szellemi alkotásokat takarják, azonban ez a terminus igen találó, és sokkal gyakorlatiasabb, mint az alapvetően dogmatikus vagyoni személyiségi jog. ${ }^{780}$ Meglátásom szerint nem tompítja ennek találóságát az sem, hogy az „árujellegü” szó meglehetősen erőteljes szocialista polgári jogi hatást tükröz, ugyanis terminológiailag teljesen kifejezi a jogintézmény lényegét és hétköznapibb, közérthetőbb kifejezés a vagyoni személyiségi jognál.

\footnotetext{
773 GÖTTING, 1995. 134.

${ }^{774}$ EGGER, 1930. 246-248.

775 GÖTTING, 1995. 134.

776 NJW 2000, 2195 - Marlene Dietrich.

777 GÖTTING, 2001. 585.

${ }^{778}$ CORBETT, VAL: A képmáshoz füződö jog és az elvi megalapozás nehézségei. In Medias Res 2014/2.; CORBETT, VAL: The right of publicity and the search for principle. In: Koltay András (szerk.): Media Freedom and regulation in the new Media World. Wolters Kluwer, Budapest, 2014.

779 BEUTHIEN, 2003. 1221.

${ }^{780}$ AsZTAlos LÁSZLÓ: A polgári jogi szankció. KJK, Budapest, 1966. 292.
} 
A román terminológiában használják a személyiségi jogokra a nemvagyoni személyjogok (drepturilor personale nepatrimonial) kifejezést, ${ }^{781}$ ennek megfordításával kapható a vagyoni személyiségi jog kifejezést. A német jogterületen Christoph Luther is a nemvagyoni személyiségi jogok kifejezést használja. ${ }^{782}$ Én nem e szempont okán kívánom ezt az elnevezést használni, hanem azért, mert egyértelmüen utal arra a jogi problémára, amely a dolgozat egészének a tárgyát képezi; arra, hogy ezen alanyi jogosultság vagyoni értékü, vagyoni jogi minőséget mutat fel. Ennek alapján leginkább a vagyoni személyiség, illetve a vagyoni személyiségi jog fogalmával írhatóak le az ide tartozó személyiségi jogi részjogosultságok. Dogmatikai szempontból ez tünik a legjobb választásnak.

\section{Miért nem adaptálható a német megoldás?}

A német joggyakorlat és az uralkodó jogirodalmi álláspont is a monista elvet támogatja. Bydlinski szerint az objektív-teleologikus értelmezés keretében a jogösszehasonlító értelmezésnek is tér engedhető. ${ }^{783}$ Mivel a Ptk. kodifikációja és előmunkálatai során a német jog szolgált például, ez különösen adott. Van egy lényeges különbség azonban a két jogrendszer müködése tekintetében. A német és a magyar jog eltérő müködési mechanizmus, más jogfogalom alapján müködik. A német jogban a BGB a pandekta vagyonjogi alapokon nyugszik, így nem csupán abban tér el a Ptk.-tól, hogy nem tartalmaz külön személyekről szóló könyvet, hanem a személyiség fogalmát sem ismeri, a személyiség védelmét nem tartalmazza. Ott ennek következtében a személyiség általános védelme a bírói gyakorlatban alakult ki, és szabadjogi jogelvek alapján került legitimálásra. Ez a szabadjogi jelleg, az általános személyiségi jog korábban említett proklamálása, lehetővé teszi azt, hogy a jog (egyes részletszabályainak) kontúrjai meglehetősen homályosak legyenek, és azok is maradjanak, azt a bírói gyakorlat alakítsa. Ennek oka az analogikus jogfejlesztésben is rejlik, s ennek kiküszöbölésére csupán a jogalkotó, az eddig elmaradt személyiségi jogi kodifikáció útján adhatna kielégítő választ.

\footnotetext{
${ }^{781}$ FeKeTE GYÖRGY: Polgári jog. Tanügyi sokszorosító, Kolozsvár, 1958.

${ }^{782}$ LUTHER, CHRISTOPH: Postmortaler Schutz nichtvermögenswerter Persönlichkeitsrechte. V \& R unipress, Göttingen, 2009.

783 BYDLINSKI, 2012. 57.
} 
A Ptk. rendszere ettől eltérő, a Ptk.-ban szövegszinten megjelenik az alanyi jog, a személyiség általános klauzulája. A szabadjogi elveken nyugvó törvénykezés távol áll a magyar jogalkalmazási gyakorlatot jellemző, a pozitivizmus és az érdekkutatóteleologikus jogfelfogást transzformáló megoldási lehetőségektől. A pozitivista ilyenkor egyből jogalkotói beavatkozás után kiált. A jogalkotói beavatkozás szükségessége azonban nem ennyire egyértelmü. A probléma az, hogy a személyiség általános joga mint önálló alanyi jog nem hasonulhat meg. Ha azt mondjuk, hogy a Ptk. 2:42. § (1) bek. alanyi joga egyszerre átruházható és átruházhatatlan, egyszerre örökölhető és nem örökölhető, úgy a különböző részjogosultságok nem kerülnek elválasztásra. Ez hasonló dogmatikai visszásságokhoz vezetne, mint amit a kereskedelmi név tágabb felfogása eredményez. Az alanyi jog keletkezésére, tartalmára és megszünésére vonatkozó szabályoknak viszonylag világosnak kell lenniük, vagy legalább is mindenképpen egyértelmüen el kell tudni határolni azt más alanyi jogi helyzetektől. Jogalkotói beavatkozás hiányában a jogalkalmazás értelmezheti úgy a Ptk. 2:42. § (1) bekezdését, hogy az két alanyi jogot is biztosít, hiszen a személyiségi jog vagyoni értékminősége is ehhez a tényálláshoz kapcsolódik. Ezt a megoldást én szükséghelyzetnek tekintem arra az esetre, ha a bíró „hiányt érez”. Egy másik, kielégítőbb megoldás az lenne, ha a jogalkotó beavatkozna, és külön, speciális alanyi jogként szabályozná a vagyoni vonatkozásokat. Ezt az indukálja, hogy a Ptk. a pusztán eszmei és erkölcsi érdekek megsértésének jogkövetkezményei közé sorolja a vagyoni jogkövetkezmények igényelhetőségét, amellyel az egyes érdekeket, így az alanyi jog alkalmazási körét nem határolja el, erre pedig a jogkövetkezmények alkalmazása körében mindenképpen szükség van. A másik körülmény, amely miatt a jogalkotói beavatkozás szükséges, hogy a Ptk. jogkövetkezményi rendszere a vagyoni érdekek védelme tekintetében nem következetes, így az csak törvénysértő analógiával lehetne továbbfejleszteni, ami a jogbiztonság követelményével ellentétes.

Ebből kifolyólag végső soron a személyiségi jog szabályrendszerének törvényi kodifikációjából eredően szükséges a vagyoni értékminőséggel rendelkező diszpozíciók leválasztása az eszmei érdekeket védő személyiségi jogról. A korábbiakban a névjog esetében számos részjogosultságot, diszpozíciót, sőt, alanyi jogot is azonosítottunk, amelyek a jogosult vagyoni érdekét is védik tárgyiasult formájukban. A személyiség vagyoni értékminőségét védő szabályt ugyanakkor úgy kell kialakítani, hogy az rugalmas és absztrakt legyen, hogy a joggyakorlat azt finomíthassa, tágíthassa, szükíthesse. Az, hogy ez egy kizárólagos vagyoni jog 
formájában történjen-e, vagy ezen újonnan megkonstruálandó alanyi jog eszmei érdekeket is véd-e, alapvetően a jogalkotón múlik, a végeredményen nem igazán változtat.

\section{Részösszegzés}

A személyiségi jog vagyoni értékét a jogalkotó elismerte ugyan azzal, hogy lehetővé tette a jogsértéssel elért vagyoni előny átengedését. Ez az elismerés egy hézagos rendszerben történt, a vagyoni érdeket a jogalkotó kizárólag a szankciók oldaláról értékelte. A jogalkotó célja egyértelmüen az volt, hogy a személyiségi jogon fennálló vagyoni érdekek védelemben részesüljenek. A részleges elismerés azonban több problémát eredményezett, hiszen a jogalkotó az alanyi jog oldalán a vagyoni érdeket nem értékelte, nem rendelkezett az emberi méltóság és a vagyoni érdekek viszonyáról, nem rendelkezett a vagyoni jogok jogutódlásáról és átruházásáról, azok védelmi idejéről. E szabályozási hézagok és hiányosságok ellenére a vagyoni érdek, a személyiségen fennálló vagyoni jog léte a jogszabály szintjén megjelenik, így azt a jogalkalmazónak is rendszerszinten értékelnie kell, nem moshatja össze az eszmei érdekek védelmével.

A jogalkalmazónak teleologikusan redukálnia kell az eszmei jogok védelmét, amelyben nehézséget jelent, hogy azok a vagyoni jogokkal egy alanyi jogon belül helyezkednek el, és a törvény explicite nem is említi azokat. A vagyoni érdekbe tartozó személyiségi jogi részjogosultságok alapvetően forgalomképes javak. Azaz átruházhatóak, használatukra engedély adható, örökölhetőek. Ha a bírói gyakorlat ezt a vagyoni érdekkört nem értékeli, és azokat az eszmei vonatkozásokkal azonosan kezeli, úgy „félreszubszumál”. Az eszmei érdekek nem örökölhetőek, a halállal megszünnek, és nem választhatóak el a személytől. Számos probléma keletkezik azonban abból, ha a vagyoni érdekkörbe tartozó részjogosultságokat is e szabályok alá vonjuk. A probléma ezzel kapcsolatban az, hogy mind az eszmei, mind a vagyoni érdekek ugyanazon törvényhely keretében [Ptk. 2:42. § (1) bek.] részesülnek védelemben, így ez kizárólag jogalkotói beavatkozás hiányában a bírói jog szintjén értékelhető.

A vagyoni érdek nem csupán a törvény szintjén, hanem a jogalkotó akarata, a törvény célja keretében is megjelenik, noha igen rejtetten. A bírói esetjog a 
személyiséghez kapcsolódó materiális érdekeket ugyanakkor számos vonatkozásában értékeli, kezeli, kártérítés alapján licencia díj fizetését látja megengedhetőnek. Ez azonban nem a vagyoni érdek rendszerszintü elismerésén nyugszik és nem is a jogalkotó szándékán, hanem kizárólag az észszerüség és igazságosság mentén, önállóan, függetlenül munkálódik.

Lényegében a magánjog-bölcseleti probléma alapját az képezi tehát, hogy a bírói esetjog és a jogirodalom ugyanabba az irányba halad, mint amerre a Ptk., ezt az irányt sem az egyik, sem a másik nem ismeri fel kétséget kizáróan, s mégis egy eredmény, cél felé közelednek. A Ptk. rendszerezése azonban a vagyoni érdekek védelme tekintetében tökéletlen, és statikája okán a bíróságok feladata az, hogy a szöveg és a cél szerinti értelmezést segítségül hívják, és szintetizálják azokat a jogirodalmi eredményekkel, ennek során foglaljanak állást és vizsgálják a jog tartalmát, keletkezését és megszűnését. Foglaljanak állást a kegyeleti jog és a post mortem vagyoni jogok viszonyát illetően, határozzák meg a védelmi időt, vizsgálják a jog átszállásának dologi hatályú lehetőségeit stb. Ennek a módszere alapvetően a jogfejlesztő értelmezés: az analógia alkalmazása, a jog általános elveinek felhasználása és a teleologikus redukció. Talán túl nagy elvárás ez azonban a bíróságoktól, hiszen egyrészről a jogterületnek nincsen kellő irodalma, és teljesen új területként tünik fel, másrészről a Ptk. nem is következetes a vagyoni érdek elismerését illetően. A jog értelmezése tekintetében azonban a vagyoni érdek észrevétele és értékelése követelmény, így a bíró a jogalkotói beavatkozásra nem várhat, neki kell megtalálni az igazságos megoldást, de az eszmei érdekekre vonatkozó szabályokat nem alkalmazhatja a más jelleget felmutató forgalomképes, tárgyiasult személyiségi jegyekre. Számos részletkérdés megválaszolása elsősorban a jogalkotó feladata lenne, így elsősorban az alanyi jog keletkezése, tartalma és megszünése tekintetében ki kell alakítania az ahhoz kapcsolódó dogmatikai rendszert. Hogy ez milyen módon lenne ideális, azt a következő fejezetben mutatom be. 


\title{
7. § A VAGYONI SZEMÉLYISÉGI JOG KÖRÜLHATÁROLÁSA
}

\author{
Bevezetés
}

A személyiségvédelem modern piacgazdasági viszonyokban nem értelmezhető csak eszmei értékként, érdekként, ugyanis az áruk kelendősége fokozásának, a gazdasági versenynek, a kereskedelemnek olyan új mechanizmusai jelentek meg, amelyek személyiségi jogi jogsértésként értelmezhetőek, és a személyiségi jog jogosultjának vagyoni hátrányt jelenthetnek. Erre azért van lehetőség, mert az egyes személyiségi jegyek a személyiségi szférából részben kilépnek, kapcsolatba kerülnek más immateriális jogtárggyal vagy dolgokkal, tárgyiasulnak. Ennek alapján ha a vagyoni érdekkörben felhasznált tárgyiasult személyiségi jegyeket egy jól lehatárolt halmazba sorolhatjuk, azaz ha a személyiségi jog vagyoni értékminőségéhez kapcsolódó jogi tényeket meg tudjuk határozni, úgy meg tudjuk fogalmazni az alanyi jogot, és ehhez kapcsolódóan az alanyi jog megsértését is. A Ptk. nem tartalmazza a személyiségi jog vagyoni érdekkörü eseteinek konkretizálását, az alanyi jogot. A tényállást ebben a tekintetben nem írja körül, sem a cselekvési lehetőség, sem a jog megsértése oldaláról. Ez a fejezet ebből kifolyólag a személyiségi jog vagyoni értékminőségét kihasználó új jogsértési módok elleni védelem jegyében az alanyi jogot vizsgálja, és az alanyi jog megsértéséhez kapcsolódó bitorlási tényállást. Dogmatikus szempontokból építkezve először a vagyoni értékminőség megszerzésével kapcsolatos jogi tényeket enumerálom, illetve a jog elvesztésének eseteit.

\section{A vagyoni személyiségi jog előfeltételei}

A vagyoni érdek megjelenése vagy más jogintézményi védelemhez kapcsolódó függő jogi helyzethez kapcsolódik (védjegy, domain név, kereskedelmi név, cégnév), vagy más tényállás által le nem fedett esetekhez (ún. sui generis tárgyiasulás). E második esetkör leggyakoribb megvalósulását képezi a reklámcélú felhasználás, a merchandise termékeken való használat, áruk, szolgáltatások kelendőségének fokozása, illetve a sajtóval összefüggő felhasználás. A vagyoni vonatkozás, a személyiség kereskedelmi célú felhasználásához több tényező együttes fennállása esetén van lehetőség. E feltételek azok, amelyek esetén az általános személyiségi jogból kiváló vagyoni 
személyiség mint önállótlan vagyoni immateriális jog létét elismerjük. Előfeltételként szükséges, hogy a személyiségnek legyen olyan része, amely a személyiség belső magjától távolabb fekszik, és ennél fogva bizonyos tekintetben leválasztható. Ezek a fent bemutatott személyiségi jegyek, amelyek elválasztása a tárgyiasulásban nyilvánul meg. Szükséges ezen túl valamilyen fokú ismertség, amely vagyoni értéket kölcsönöz ennek azáltal, hogy a piacon keresletet és nagyobb vásárlási hajlandóságot generál. Szükséges ezen túl, hogy külső, harmadik személyek, a forgalmi viszonyok a személyiségi jegy e tárgyiasult formáját meghatározott személyhez kössék, és hogy az általános felfogás rendelkezési jogot, jogi érdeket tulajdonítson e személynek a személyiségi jegy felett. A létrejövő, kialakuló vagyoni személyiségi jog nem egy, az általános személyiségtől függetleníthető jog, hanem annak egy új értékminősége lesz azáltal, hogy tárgyiasulása okán képes lesz a kereskedelmi forgalomban valamilyen módon részt venni.

\section{Tárgyiasulás}

A tárgyiasulást mint feltételt részletesen vizsgáltam, és megállapítottam, hogy tárgyiasulni csak azok a személyiségi vonatkozások tudnak, amelyek a személytől bizonyos mértékben elválaszthatóak, a személyiség szférájából kilépnek, és a fizikai világ tárgyaival kapcsolatba tudnak lépni. Ilyenek a személyiség külső megjelölései, illetve bizonyos ismeretek és információk, amelyek így a vagyoni személyiség részét képezhetik. Ez alapján a tárgyiasulás azt jelenti, hogy a személyiségi jegy elválik a személyiség belső magvától, kapcsolatba kerül a fizikai világgal oly módon, hogy harmadik személyek számára a személyiségi jegy érzékelhetővé válik, és ezáltal új funkciót is szerez a személyiség megjelölésén túl.

A vagyoni személyiségi jog elhelyezésének alapjaként tehát a személyiségtől való elválást a tárgyiasulás fogalmával mérhetjük, amely így kiindulópont a tényállás meghatározása során. A tárgyiasulás számtalan formában végbemehet, a személyi szféra kapcsolatba kerülhet a szellemi alkotásokkal, ahogy azt a védjegyjog és a kereskedelmi név példáján is láttuk, kapcsolatba kerülhet a fizikai valósággal a név, képmás, hangfelvétel sui generis tárgyiasulása útján, és kapcsolatba kerülhet a virtuális valósággal is, ahogy az a domainnév példáján látható volt.

A tárgyiasulás a publicitás és az értékestés (vagyoni érdekkörben történő felhasználás) triásza szempontjából jogelméleti, dogmatikai fogalomnak tűnhet, 
amelynek a pozitv jogban nem igazán lehet helye. A személyiségi jog vagyoni értékének megalapozására mind az ismertségi fok, mind az értékesítés alkalmas lehetne. Ha a vagyoni értékminőség dogmatikai és elvi alapjait keressük, akkor azonban a tárgyiasulás az a gondolati lépés a kontinentális jogban, amely a közvetettsége okán hiányzott. Ez csak a tipikus életviszonyok absztrahálásából nyerhető köztes lépésként. E dogmatikai karakter ellenére mégis két szempontból fontos a tárgyiasulás: a vagyoni értékminőség tekintetében ez tesz különbséget az emberi test, szövetek és a vér forgalomképessége között, és azok között a személyiségi jogok között, amelyek tértől, időtől függetlenül megsérthetőek, amelyekre a szellemi tulajdonjogokhoz hasonlatosan az ubikvitás jellemző (a jogsértés a jogtárgyak eltérő jellege miatt más, szövetek esetében pl. a licencia analógia nem értelmezhető). A másik körülmény, ahol értékelhető a tárgyiasulás az a jogsértés és az átruházás. Itt a teljes vagy részleges tárgyiasulással (tehát a személyiségtől való kapcsolat mértékével) magyarázható a személyiségi jog jogosultjának esetleges utólagos beleegyezése a személyiségi jegy további felhasználására.

\section{Ismertség avagy publicitás}

A személyiségi jog vagyoni értéke akkor általában nyilvánvalóbb, ha az érintett személy korábban széles körben ismert volt. publicitással bírt. A személyiség ismertté válása szempontjából a külső szemlélőnek, a forgalomnak van jelentősége. Ismertté válik egy személy, ha közszereplővé válik, közéleti szereplése okán a társadalom érdeklődését, szimpátiáját vagy éppen ellenszenvét kiváltja. A személyiségének külső jegyei által a személy felismerhető lesz - kiválik a névtelenség tömegéből, és egyéniséggé válik. A publicitás alapú, azt feltételként megkövetelő vagyoni személyiségvédelem ellen legelőször az hozható, hogy ez a személyiségi javak „érdem szerinti elosztásához vezetne". ${ }^{784}$ Függetlenül attól, hogy a közéleti szereplőkkel azonosan húzzuk-e meg ezt a határt, bizonyos személyeket ebből a körböl kirekesztetnénk. Az pedig teljesen életszerütlennek tünik, hogy egy lány, akinek a fényképét az Opera az engedélye nélkül reklámpklakátain felhasználja, ne követelhesse azt a díjazást, ami neki járt volna, ha az engedélyt megadja. A

${ }^{784}$ SZÉKELY LÁSZLÓ: A személyiségi jogok ,érdem szerinti elosztásáról”. Jogtudományi Közlöny, 1985. $277,279$. 
magánszemélyek vagyoni személyiségvédelme úgy tünik nemzetközi tendencia, amelyet a tárgyiasulás hozhat közös nevezöre az ismert személyekkel.

A személy ismertsége (celebrity) a mérvadó volt az amerikai jogban a right of publicity szempontjából, amely ez alapján különítette el a személyiség védelmének vagyoni és személyi vonatkozásait, azzal azonban nem tud mit kezdeni, ha ismeretlen személy személyiségi jegyeit használják fel kereskedelmi célra jogellenesen, s ezt már a privacy oldaláról közelíti meg. ${ }^{785}$ Ez azért helytelen kiindulása alap egy vagyoni személyiségi jog meghatározása szempontjából, mert az ismeretlen, hírességnek nem minősülő személyek személyiségi jegyeinek jogosulatlan kereskedelmi használatát nem tudja ebben a rendszerben kellően, logikusan elhelyezni. Ezt felismerték egyes amerikai tagállamok is, és a right of pubclity tagállami törvényi szabályozása ennél sokkal absztraktabb. Prosser klasszifikációjában a személyiség jogellenes értékesítése elleni védelem, a publicity (a tanulmányban appropriation, szabadon fordítva értékesítés) a right to privacy egy ,aljoga”. ${ }^{786}$ A joggyakorlat ezt azonban külön tortként kezte el kezelni, így a common law védelem szintén a right of publicity elsősorban nem magánszemélyeket véd, míg a tagállami törvényi védelem absztrakciója okán a hírességek mellett öket is átfogja a szintén right to publicity nevü törvényi jog. Az újabb joggyakorlatban csak elvétve található olyan döntés, amelyben a bíróságok nem ítélik meg magánszemélyek számára a publicitás megsértését. ${ }^{787}$ Ezt a mozgást, amely a magánélet-kitárulkozás dichotómiájának felbomlásaként fogható fel a jogirodalom is támogatni látszik. ${ }^{788}$

A BGH a Marlene-döntésben, megemlíti, hogy a név, képmás, a hang akkor bír jelentős vagyoni értékkel általában, ha az ahhoz kapcsolódó személy széles körben ismert, társadalmi megbecsülésnek örvend, és iylen ismertség lehet az, amely a kelendőséget ténylegesen növelheti. ${ }^{789} \mathrm{Az}$ azonban, hogy ez nem feltétele a személyiség vagyoni vonatkozásainak meglétéhez, és ezzel kapcsolatosan ennek örökölhetőségéhez, az ítélet fejrészéből egyértelműen kitűnik. Az ismertség mint feltétel sejlett fel a Herrenreiter-doktrínában is, amely szerint a gazdagodás visszatérítésének megállapítására csak akkor van lehetőség, ha a jogosult személyiségi

\footnotetext{
${ }^{785}$ WARBY - MOREHAM - CHRISTIE, 2011. [2.34-2.41.]; Pavesich v. New England Life Insurance Co 50 SE 68 (1905).

786 Prosser, William L.: Privacy. California Law Review 1960, 383, 389, 401.

${ }^{787}$ Sarver v. Chartier, 813 F.3d 891 (9th Cir. 2016).

788 DREYMANN, NOA: John Doe's Right of Publicity. Berkeley Technology Law Journal 2018. 673.

${ }^{789}$ NJW 2000, 2195 - Marlene Dietrich.
} 
jegyét egyébként értékesíteni kívánta volna. ${ }^{790} \mathrm{Ez}$ szintén a személy publicitására vezetett vissza, és az újabb gyakorlat nem is tartja ezt a Joschka Fischer-döntés óta, ${ }^{791}$ így a jogsértés megállapíthatósága ebben a tekintetben is eltávolodott az ismertségi foktól. Az osztrák OGH, ugyan a Marlene-döntésre hivatkozással ismerte el saját nemzeti jogában a személyiségi jog vagyoni értékü összetevőit, azonban mégis egy pénzben kifejezhető ismertségi fokból (geldwerter Bekanntheitsgrad) indul ki. ${ }^{792} \mathrm{Ez}$ pedig inkább egy, a publicitás felé hajló, azt feltételező védelmet indukál.

Hasonló megállapításra jut más irányból Beverly-Smith, Ohly és LucasSchloetter, akik a méltósági (dignitary) és a gazdasági (economical) érdekek védelmére egy általános privacy jogot vagy egy személyiségbitorlási tortot javasolnak. ${ }^{793} \mathrm{Az}$ angol jogban a személyiségi jegyek értékesítését megvizsgálva is azt láthatjuk, hogy a publicitás és a magánélet (privacy) nem játszik szerepet, hiszen a privacyt el nem ismervén az angol jog a breach of confidence nevü torthoz fordul, ${ }^{794}$ amely szempontjából a publicitás, az élet nyilvánossága nem feltétel.

A publicitás, a pénzben kifejezhetö ismertségi fok ezért csak rendszerinti és nem szükségképpeni feltétele a vagyoni értékminöség kimutatásának. A tipikus életviszonyok körében általában előfordul, de nem általános jellegadó sajátossága a vagyoni értékminőségnek. Az ismertség sokkal inkább a vagyoni személyiség kialakulásának egyik, rendes módja. Az ismertség megszerzése után a személyiségi jegy vagyoni előny szerzése céljából történő felhasználása hozzájárulás hiányában jogosulatlan. Az ismertté válással ugyanakkor a személyiségi jogtól még nem válik el a személyiségi jegy, csak megnöveli annak az esélyét, hogy azt jogosulatlanul tárgyiasítsák, ennél fogva a vagyoni személyiségi jog körülhatárolása szempontjából nem is releváns. Az ismertségnek elsősorban a személyiségi jegy jogellenes felhasználása során jut szerep a vagyoni hátrány mértékének meghatározásakor, vagy akkor, ha a jogosult dologi vagy kötelmi hatállyal szerződésben a személyiségi jegyet vagy annak használati jogát átruházza, és az átruházás ellenértékét meg kell határozni. Ez tehát a jogkövetkezmény alkalmazása és nem a tényállási elemek szempontjából

\footnotetext{
${ }^{790}$ BGHZ 26, 349 - Herrenreiter.

${ }^{791}$ NJW 2007, 689 - Lafontaine.

${ }^{792}$ SZ 2010/70 - Maria Treben.

793 BEVERLEY-SMITH - OHLY - LUCAS-SCHLOETTER, 2005. 62.

${ }^{794}$ Szeghalmi Veronika: The definition of the Right to Privacy in the United States of America and Europe. In: Szabó Marcel - Varga Réka - Láncos Petra Lea (szerk.): Hungarian Yearbook of International Law and European Law. Eleven, Budapest, 2015. 397, 401; Campbell v MGN Ltd (HL) [2004] UKHL 22; Gulati v. MGN Ltd [2015] EWHC 1482 (Ch).
} 
releváns. Ez ugyanakkor nem jelenti azt, hogy a személy ismertésének hiányában automatikus a védelem. A BGH nem ítélt meg licencdíjat egy meghalt lány szüleinek, amiért az egyik leghíresebb német bulvárlap halált okozó balesetet követően amelyben a másik fél egy eurovízióban részt vevő énekes volt - a lány életét bemutatta, képpel illusztrálta, ${ }^{795}$ és ebben közrejátszott, hogy a lány előtte nem volt ismert.

\section{Tárgyiasított használat}

Nemcsak a személy ismertté válásával, egy ,image” kialakításával érhető el a vagyoni érdekkör kialakulása, hanem a személyiségi jegy minden előzmény nélküli tárgyiasításával is. Ilyen az, ha egy nem ismert személy személyiségi jegyét tárgyiasítják, és a forgalomban való részvétellel szerez magának ismertséget, vagyoni értéket. Példa lehet az az Egyesült Államokbeli döntés, amikor egy hölgy képmását engedély nélkül tüntették fel lisztet reklámozó plakátokon reklámján. ${ }^{796}$ A jogosulatlan tárgyiasítás ebben az esetben is jogsértő, ugyanis az általános személyiségi jog mint függő jogi helyzet a tárgyiasítással teljessé válik, és ugyanúgy vagyoni személyiségi jog részévé válik, amely megalapozza a vagyoni szankciók alkalmazását. A vagyoni értékminőség szempontjából csak a jogellenes tárgyiasításnak van jelentősége, annak nem, hogy az adott személy ismert volt-e vagy nem.

A tárgyiasult használatot a magyar jog is ismeri más helyütt: a lajstromozást nem igénylő megjelölések esetén a széles körü használattal válik védetté a megjelölés. Ez mind a megjelölések, mind a személyiségi jegyek esetén funkcióváltozással jár, amely a részleges elszemélytelenedés eredménye. Ilyen lehet a természetes személy neve vonatkozásában többek között a cégnévként, a védjegyként való bejegyzés, domainnévként való bejelentés, kereskedelmi névként való huzamos használat, illetve önmagában, elsősorban termékekkel való kapcsolatba hozás, reklámozás. Ezek egyike sem követeli meg, hogy a személyiségi jog a név tekintetében bármilyen, szükebb vagy tágabb körü ismertséggel bírjon a kereskedelmi forgalomban vagy a társadalmi életben.

Szükséges azonban ehhez, hogy a személyiségi jegy felhasználásra kerüljön, nem elég a felhasználás lehetősége. Addig, amíg a személyiségi jegy tárgyiasult

\footnotetext{
795 NJW 2012, 1728 - Unfallopfer.

${ }^{796}$ Roberson v. Rochester Folding Box Co. 32 Misc. 344 (N.Y. Misc. 1900)
} 
formában nem kerül felhasználásra, az általános személyiségi jog részét képezi, hiszen az mint eszmei jogtárgy nem lép ki a személyiség védelmi köréböl. A személyiségi jegy e tárgyiasítható jellege folytán ugyanakkor egyfajta várományi, függő jogi helyzetet eredményez, amely a tárgyiasult felhasználással válik teljessé. Ez lesz az a pillanat, amikor a jogtárgy kilép a személyiségi jog köréből, és átkerül a vagyoni személyiségi jog körébe és vagyoni immateriális joggá válik, amely átruházható, örökölhető és (legalábbis részben, korlátozottan) forgalomképes.

A személyiségi jog széleskörben való ismertsége, illetve a tárgyiasított használat közötti különbségtétel csupán a vagyoni személyiségi jog különböző módozatú létrejötte szempontjából releváns, a jog megsértése szempontjából a jogsértőnek a személyiségi jegyet tárgyiasult formában fel kell használnia, ha erre nem kerül sor, a tényállás hiányos.

\section{Jogi érdek a személyiségi jegy felett}

Mivel a személyiségi jegy tárgyiasul, a személyiségi jogtól bizonyos fokban elválik, így az sem egyértelmü, hogy afelett valakinek jogi hatalma, jogi érdeke áll-e fenn továbbra is, azaz van-e abszolút jellegü, kizáró alanyi joga a személyiségi jegy felett a jogosultnak. Egy jogtárgynak valamely személy érdekkörébe való tartozása szempontjából negatív irányban az a döntő, hogy az adott jogtárgy nem vált közkinccsé. A közkinccsé válás szempontjából az vizsgálandó, hogy az alkotás nem vált bárki számára hozzáférhetővé, azt nem lehet szabadon felhasználni. ${ }^{797} \mathrm{~A}$ személyiségi jegyek kereskedelmi felhasználása során a közkinccsé válás tekintetében általában nem a titokban tartásnak van jelentősége (kivétel pl. a magántitok), hanem az a jelentős, hogy a személyiség és a tárgyiasult személyiségi jegy elválása mennyiben valósult meg. Az elválás zsinórmértéke elsősorban az lesz, hogy harmadik személyek mennyiben tekintik úgy, hogy a személyiségi jog jogosultjának rendelkezési joga, jogilag védett érdeke (azaz alanyi joga) áll-e fenn az adott személyiségi jegyen. A közkinccsé válás tulajdonképpen annak negatív megfogalmazása, hogy a jogosult érdekköréből a jogtárgy kiesik. Ezt megfordítva tehát az nem vált közkinccsé, amely valamely személy érdekkörébe tartozik, azaz külső szemlélők a jogtárgy felett a jogosultnak (kizárólagos) rendelkezési jogot

797 U.o. 
tulajdonítanak. A közkinccsé válásnak számtalan módja képzelhető el, legtipikusabb ilyen az, ha a személy halála után hosszabb idő eltelik; ${ }^{798}$ ugyanígy ha egy megjelölés fajtanévvé válik, mint a Ritz név. ${ }^{799}$ A közkinccsé válás dologi jogok tekintetében nem értelmezhető, hiszen a testi tárgyak a fizikai valóságban tulajdonságuknál fogva adottak, azok birtokba vehetőek, a felettük fennálló tulajdonjog időmúlással önmagában nem szünik meg. Más a helyzet a szellemi alkotások tekintetében, ahol a jogalkotó mérlegeli azt, hogy az egyes alkotások, szellemi tulajdonjogok időben meddig illetik meg a jogosultat. A jog lehetőséget biztosíthat arra, hogy a védelem időben meghosszabbítható legyen, és arra is, hogy a védelem meghatározott idő leteltével megszünjön, és az alkotás közkinccsé váljon. Ebben a tekintetben a személyiségi jegyek feletti jogi érdekek értékelése a szellemi alkotásokhoz hasonló módon alakítandó, hiszen a személyiségi jegyek feletti rendelkezés tekintetében is ugyanaz az érdekütközés vizsgálandó: kizárólagos kereskedelmi hasznosítás biztosítása egy személynek, vagy bárki által szabadon felhasználható, az innovációt és a szabad kereskedelmet támogató jogi érdekek védelme közötti kollízió.

A halállal a név, képmás védjegyként való bejegyzéséhez az örökösök hozzájárulása szükséges, egyébként a lajstromozás a személyiségi jogot sérti. ${ }^{800}$ Ebből arra következtethetünk, hogy e személyiségi jegyek a halállal nem is válnak közkinccsé. Ebben az esetben az örökösöknek valaminemű rendelkezési joga kell, hogy maradjon e tárgyiasítható jegyek felett. Hasonló módon nem válik közkinccsé egy megjelölés akkor, ha egy másik személynek rendelkezési joga keletkezik a személyiségi jegyen akár szerződéssel, akár huzamos használattal. Nem válik közkinccsé a személyiség külső megjelölése akkor, ha nyilvánosságra hozzák, mert lényege éppen abban rejlik, hogy az adott személyt idézi fel külső szemlélők számára. $^{801}$

A rendelkezési jog pozitív irányból tekintve azt jelenti, hogy az adott külső megjelölés vagy ismeret felett a jogosultnak tekintett személynek áll fenn jogi érdeke. A tárgyiasítást nem türő személyiségi jogok esetében nem merül fel kérdésként az, hogy az adott jog megilleti-e a jogosultat. Senki sem vonja kétségbe, hogy valakit megillethet-e az élethez, jóhírnévhez való jog. A rendelkezési jogot először Meszlény

\footnotetext{
${ }^{798}$ A német jogalkalmazási gyakorlatból 1. NJW 2001, 615 - Johann Sebastian Bach, GRUR 1998, 1021 - Mona Lisa. 
Artur említi a névjoggal összefüggésben: „,[a névjog] osztja a vagyoni jogoknak azt a sajátosságát, hogy specializálható, konkretizálható s ehhez képest felmerülhet rá vonatkozóan a kérdés, vajon ez a név megilleti-e ezt a személyt". ${ }^{802}$ A névjog tekintetében valóban kérdéses, hogy családtagok a rokonuk által tárgyiasított személyiségi jog megsértése esetén saját jogon felléphetnek-e. Ugyanígy felmerül, hogy azonos nevü személyek felléphetnek-e bizonyos tekintetben névbitorlás esetén. Ez azonban nemcsak a névjog vonatkozásában releváns. A képmáshoz való jog megsértése körében is vitás lehet, hogy valóban a jogosultat ábrázolja-e a jogsértő ábrázolás, az ő képmáshoz való joga sérül-e. Ennek legkifejezőbb példája a Blauer Engel-döntés. Az ügy egyik jogi problémáját az képezte, hogy Marlene Dietrich saját képmáshoz való jogának megsértéseként értelmezhető-e az, ha hasonmás személy alkalmazásával imitálják Marlene Dietrichet, abban a jellegzetes ülő pozícióban, amely a Der blaue Engel c. film egyik leghíresebb jelenete. ${ }^{803}$ A személyt megillető rendelkezési jog, jogosultság ugyanakkor az életkép jogával összefüggésben is felmerülhet, ha egy személy leírása, lényeges tulajdonságai megegyeznek egy ténylegesen létező (és általában bírósághoz forduló) személyével. Ebben a tekintetben a bírói gyakorlat afelé hajlik, hogy nem állapítja meg a jogsérelmet csak az egyértelmü, minden kétséget kizáró azonosíthatóság esetén, ${ }^{804}$ jóllehet ellenpélda is fellelhető. ${ }^{805}$

Az egyes személyiségi jegyek, a vagyoni személyiségi jog egyes személyiségi jegyeinek dologi hatályú átruházása esetén a külső szemlélők számára a személyiségi jeggyel való rendelkezés a személyiségi jog jogosultját illeti. E személyiségi jegyek más általi felhasználása körében ugyanakkor harmadik személyek abból indulnak ki, hogy a személyiségi jog jogosultjának rendelkezése útján annak felhasználását másnak engedélyezheti. Ebben a tekintetben a joggyakorlat is figyelembe vette, hogy ez nem a jóhírnév megsértése, nem hamis látszat keletkezik ebben a tekintetben, hanem a személyiségi jegy jogosulatlan (kereskedelmi) használata által keletkezik zavar a jog hovatartozása tekintetében. ${ }^{806}$

5. Vagyoni érdekkörben történő felhasználás

\footnotetext{
${ }^{802}$ MESZLÉNY, 1909. 187.

${ }^{803}$ NJW 2000, 2301.

${ }^{804}$ RGZ 91, 350 - Weberlied; NJW 2004. 605 - Derrick; BH 1980. 344. („Kányák“).

${ }^{805}$ SZ 31/86 - Asphaltkönig.

${ }^{806}$ BDT 2018. 87. (,kutatóintézet”)
} 
A tárgyiasult személyiségi jegyek szempontjából a felhasználás módja azért kiemelkedő, mert ez az a tényállási elem ugyanis, amelynek megléte a vagyoni jellegü jogkövetkezmények alkalmazását indukálja. A személyiségi jegyek tárgyiasult formájukban felhasználhatóak nemvagyoni, ideális módon is. Ilyen lehet egy elhunyt személy nevének alapítvány névadójaként való használata, fénykép készítése, önéletrajzi regény írása stb. Az értékelésben ez a „haszonszerzési célzat” általában elsikkad, vagy azért, mert kizárólag a jog megsértését mint erkölcsi, morális jogsérelemet minősítik, vagy a leggyakoribb eset, hogy a személyi és vagyoni vonatkozások vegyülnek, és a személyi oldal dogmatikai monopóliuma miatt erre fókuszál a bíróság. Az ilyen tényállásra is a személyiségi jogok rendes jogkövetkezményei kerülnek alkalmazásra, az esetleges vagyoni értékeltolódás nem kerül értékelésre. ${ }^{807} \mathrm{~A}$ felhasználásnak, a személyiségi joggal való rendelkezés módjának így egyrészt a felek diszpozitív szerződéses rendelkezései vonatkozásában, másrészt a jogsértés feltételeinek megállapítása szempontjából van jelentősége, nem pedig a tárgyiasítható személyiségi jegyek feltételei szempontjából. A tárgyiasult személyiségi jegyek nemvagyoni felhasználása ugyanis az általános személyiségi jog szabályaival kell, hogy egy tekintet alá essen, lévén az annak csupán konkretizálása, bizonyos irányú betagozódása. Ez azt is jelenti, hogy a tárgyiasult személyiségi jegyek csak akkor válnak a vagyoni személyiség részévé, ha a felhasználás a jogosult vagyoni érdekkörébe esik - a tényállás ennek hiányában nem teljes. A vagyongyarapítást szolgáló felhasználás tehát nem más, mint a tárgyiasult személyiségi jegyben rejlő vagyoni érték kiaknázása. Ez lényegében a korábban vizsgált alanyi jog megléte szempontjából kvalifikált érdeket kíván meg, a jogi tárgy feletti vagyoni érdeket. A korábbi magyar bírói gyakorlat nem a személyiségi jegy, hanem a jóhírnév megsértését állapította meg akkor, ha valakit a hozzájárulása nélkül úgy tüntetnek fel, mint aki egy adott áruval kapcsolatban reklámtevékenységet végez. ${ }^{808}$

A személyiségi joghoz kapcsolódó vagyoni érdekkörü esetcsoportok osztályozása tekintetében a magyar jogirodalom hiányos, mert elsősorban az egyes személyiségi jegyek vagyoni értékminőségét vizsgálja. Menyhárd említi meg, hogy a személyiségi

\footnotetext{
${ }^{807}$ Különösen: BDT 2015. 70. („Élesztőtabletta”).

${ }^{808}$ BH 1995. 509 („,szalaghirdetés”); BH 2002. 261. („Jó estét, jó szurkolást!”); homályosabban fogalmaz a kir. Kúria egy döntésében a közizlésre hivatkozva C. I. 3618/1930. (,hirdertőoszlop”).
} 
jegyek tipikus kereskedelmi felhasználására Michael Madow hármas csoportosítást alkalmaz, ${ }^{809}$ amelyeket a fenti megállapításokra tekintettel példákkal láttam el:

1. A társadalom kíváncsiságával kapcsolatosan (ismeretjegyek, de keveredhet külső megjelöléssel is). Ide tartozik elhunyt hírességek holttestéről készült fényképek sajtótermékben való nyilvánosságra hozatala; bünözőkkel kapcsolatos ismertség kiaknázása horrorfilm, viaszfigura formájában; hírességek magánéletének bemutatása szenzációhajhász módon.

2. Termékek kereskedelmi forgalomba hozatala, amelyek valamely személyiségjeggyel vannak ellátva (tipikusan külső megjelölések). Elsősorban merchandise termékek.

3. Áruk, szolgáltatások vonatkozásában reklámszemélyként felhasználás, hirdetések, promóciók vagy más kapcsolatba hozatal (tipikusan külső megjelölések). Ide sorolhatóak azok a magatartások, mikor egy híresség az adott terméket használja a reklámban, a terméket ajánlja vagy egyébként a reklámban másmilyen módon fel van tüntetve és a termékkel kapcsolatba van hozva.

Madow csoportorsítása alapvetően a right of publicityhez kapcsolódik, és nem fedi le teljes mértékben azokat az esetköröket, amelyek a személyiségi jog vagyoni érdekkörébe tartoznak, és jogellenes tárgyiasítás útján megsérthetőek. A névjog korábban tárgyalt tárgyiasulási módozatai csak részben helyezhetőek el ebben a rendszerben, ennek az az oka, hogy az amerikai jog alapvetően a publicitásból indul ki, ahhoz köti a jogsértést. A tárgyiasulás alapú vagyoni személyiségvédelmi rendszerben ugyanakkor a vagyoni érdek megsértésének további, a civiljogi dogmatikába beágyazódó esetei is azonosíthatóak, ezek a média és reklámjog mellett az iparjogvédelem területén jelentkeznek. Én ezért a következő osztályozást, esetcsoportokat javaslom elkülöníteni:

1. A személyekkel kapcsolatos ismeretek kereskedelmi felhasználása tágabb kört fog át, mint pusztán a társadalom kíváncsiságával kapcsolatos felhasználás. Ide sorolható elsősorban a médiajog körében a bulvársajtó által az életkép, a személy élete fontosabb eseményeinek bemutatása. Ehhez képest speciálisabb a magánélethez való jog elemeinek, a magántitkoknak a bemutatása. Ezeknek az ismereti személyiségi

${ }^{809}$ MADOW, MiCHAEL: Private Ownership of Public Image: Popular Culture and Publicity Rights. California Law Review, 1993/1. sz. 125-140. 129.; MENYHÁRD, 2016. 76. 
jegyeknek a megsértése gyakran együtt jár a személyiség külső megjelöléseinek a megsértésével. A kapcsolat nem szükségképpeni, hanem rendszerinti, és az ismereti jegyek illusztrálásával függ össze. A személyiséggel kapcsolatos ismeretek kereskedelmi célú felhasználása valósul meg akkor, ha a média valamely személlyel kapcsolatos eseményről számol be, amennyiben regény vagy más mủ formájában mutatják be egy személy életútját szenzációhajhász módon. Ide sorolható az is, ha egy közismert személy viaszképmását állítják ki.

2. Termékekkel és szolgáltatásokkal való kapcsolatba hozás az az esetkör, amely a személyiség külső megjelölései tekintetében sui generis tárgyiasul. A kapcsolatba hozás mint a termék kelendőségének fokozása értelmezendő. Ebben az esetben a terméket, szolgáltatást a személyiség külső megjelölései körébe tartozó személyiségi jegy nem megjelöli, hanem azt a kelendőségének fokozása érdekében, reklámtevékenység során használják fel. A képmás megsértése tekintetében ez sokkal jellemzőbb, hiszen a 3. pont alá tartozó esetek nagy része szóbeli megjelölést kíván meg, amely miatt a képmás megsértése objektíve kizárt. Az áru kelendőségének a fokozása elérhető azáltal, hogy az adott személy a terméket használja, ajánlja, szimpatizál vele, de akár úgy is, hogy a személy ismertsége okán a termék, szolgáltatás azt tartalmazza pl. játékfigura formájában, rágóban elhelyezett gyűjtőkártyaként stb.

3. Speciális jogintézményi formában történő felhasználás. Az üzlet-, illetve árujelzőként való felhasználás körébe elsősorban a személy nevének, képmásának üzlet, áru, termék, szolgáltatás megjelölésére való használata értendő. Ebben az esetben a személyiségi jegy úgy tárgyiasul, hogy magára az üzletre vagy árura vonatkozik, így a személyiség külső megjelölésének megkülönböztető képessége az áru- és vállalatjelzőre vonatkozik. Ide sorolandó a cégnévként való használatot, hiszen a cégnév tulajdonképpen bejegyzett üzletjelző. Ide sorolandó a kereskedelmi név mint üzletjelző, amely esetén a jellegbitorlásra irányuló igény speciális. Nem üzlet- vagy árujelző, de ide tartozik a domainnév védelme is, mint a személyiségi jogon belüli speciális, külön alanyi jog formájában történő tárgyiasulás. Ide sorolható továbbá a védjegyként való felhasználás is. Ebben a tekintetben a vagyoni személyiségi jog részét a védjegyjogi lajstromozáshoz kapcsolódó függő jogi helyzet képezi. Ennek az alapja az előbb felsorolt esetekhez hasonlóan ugyanis a vagyoni személyiségi jogban gyökerező rendelkezési jog védelme. 


\section{Jogellenesség és felróhatóság}

Természetesen lehet szó arról is, hogy köz- vagy magánérdek a személyiségi jegy felhasználását korlátozza. Ilyen lehet a közszereplői minőség, a véleménynyilvánítás és a müvészet szabadsága, ilyen lehet a társadalom információs érdeke, más hasonló kifogások és ellenjogok, amelyeknél fogva a személyiségi jog megsértésének jogellenessége kizárt. A jogsértés vizsgálata során az általános személyiségi joghoz hasonlóan az érdekmérlegelésnek van óriási szerepe. Hiába állapítható meg sokszor a vagyoni személyiségi jog megsértése, mégis a közfelfogás szerint sokszor más érdeke erősebb. Az érdekmérlegelés az általános személyiségi jogtól annyiban tér el, hogy a vagyoni érdek a személyi pillanat mellé betolul, s így az nem szükül az eszmei érdekre. Jóllehet a jogsértés, a jogellenes tárgyiasítás a legtöbb esetben tényállásszerü, azonban az érdekmérlegelés a jogellenességet a legtöbb esetben kizárja. Sok esetben a német bírói gyakorlat azonban az érdekmérlegelésre hivatkozással próbálja a személyiség túlárazását elkerülni. ${ }^{810} \mathrm{~A}$ jogellenesség tekintetében nehéz általános megállapításokat tenni, mások jogai és a közérdek behatolhat a felhasználás élc jellege miatt a véleménynyilvánítás, illetve a müvészeti élet szabadsága okán, de akár más személyek vallásos érzülete által is. A jogellenesség, illetve annak kizárása tehát mindig a konkrét esetben vizsgálandó, és az az általános közfelfogás alapján ítélendő meg. A jogsértő felelőssége minden esetben vizsgálandó a jogsértés megállapításához, ez azonban nem a vagyoni személyiség tényálláselemeiből, hanem az alkalmazandó jogkövetkezményekből adódik.

\section{A vagyoni személyiségi jog igényváza}

A Ptk. nem ad arra vonatkozóan fogódzót, hogy mikor sérül meg a személyiségi jog jogosultjának vagyoni érdekköre, így nem határolja el a normaszöveg a személyiségi joggal kapcsolatos eszmei és vagyoni érdekek védelmét. A vagyoni személyiségi jog tényálláselemeinek meghatározása során több körülmény került megvizsgálásra, annak érdekében, hogy a vagyoni érdekkör, illetve annak megsértése más személyiségi jogi sérelmekről lehatárolható legyen. Összegezve az mondható el, hogy a vagyoni személyiségi jog akkor sérül, ha a jogsértö azt vagyoni érdekkörében jogellenesen

${ }^{810}$ Először és explicite kimondja: GRUR-RR 2002, 341. 
tárgyiasítja. A tényállás ilyen absztrakt megfogalmazása magában foglalja a fent említett három tipikus jogsértő magatartást. A vagyoni személyiségi jog mint alanyi jog hatóköre azonban a megsértés eseteinél sokkal tágabb, hiszen az alanyi jog védelme, szabályozása nem csupán annak megsértését jelenti. Az alanyi jog magában foglalja a személyiségi joggal való vagyoni rendelkezés minden esetkörét, így az alanyi jog pozitív irányú meghatározása is indokolt.

A személyiségi jegyek tárgyiasulása a forgalomképes vagyoni személyiségi jog elismerésének előfeltétele, hiszen a jog átruházhatósága és örökölhetősége esetén ezzel mérhető a személyiségi jogtól való elválás. A személyiség ismertté válása a vagyoni személyiségi jog, illetve annak megsértése vonatkozásában tulajdonképpen nem releváns. A személyiségi jegyen fennálló rendelkezési jog, jogi érdek külön kiemelését sem kell törvényi szinten megtenni, az dogmatikai kategória marad, hiszen a tényállás szempontjából a vagyoni érdekkörben való felhasználás, tárgyiasítás lesz a releváns. A vagyoni érdekkör megkövetelése speciális érdek, így magában foglalja az alanyi jog, jogi érdek létét mint előfeltételt. Ebből kifolyólag a vagyoni személyiségi jog alapján a jogosultat megilleti a jog, hogy személyiségi jegyeit kereskedelmi úton felhasználja, átruházza, azok használatára engedélyt adjon, a halála utáni felhasználás jogosultját megnevezze. Ez alapján egy törvénybe iktatandó tényállás akképpen hangozhat, hogy „aki személyiségi jegye jogellenes kereskedelmi felhasználása által vagyoni érdekkörében sérelmet szenved", az bírói jogvédelmet vehet igénybe. A vagyoni személyiségi jog megsértése tekintetében a következő körülményeket kell tehát vizsgálni:

\section{9. sz. táblázat}

A vagyoni személyiségi jog bitorlásának vizsgálati szempontjai

\begin{tabular}{|l|l|}
\hline 0. SPECIÁLIS IGÉNY & $\begin{array}{l}\text { Ilyen lehet többek között a védjegyjog, szerzői jog, } \\
\text { jellegbitorlás, dologi jogok. }\end{array}$ \\
\hline \multirow{2}{*}{ 1. TÉNYÁLLÁS } & $\begin{array}{l}\text { 1. a személyiségi jegy tárgyiasítható ÉS } \\
\text { 2. vagyoni érdekkörben felhasználják (értékesítik) } \\
\text { vagy erre engedélyt adnak (elsősorban kereskedelmi, } \\
\text { reklám-, üzleti, haszonszerzési céllal) }\end{array}$ \\
\hline 2. JOGELLENESSÉG & $\begin{array}{l}\text { 1. Szerződés vagy más jogcím (pl. öröklés) hiánya, } \\
\text { 2. Jogtárgy- és érdekmérlegelés }\end{array}$ \\
\hline (3. FELRÓHATóSÁG) & $\begin{array}{l}\text { Ha a jogkövetkezmény szempontjából szükséges a } \\
\text { vizsgálata, lényegében a 2:53. § és a 6:519. § együttes } \\
\text { alkalmazása, esetleg a 6:142. §. }\end{array}$ \\
\hline
\end{tabular}

(saját szerkesztés) 
A vagyoni személyiségi jog az általános személyiségi joghoz képest speciális. Ennél fogva, ha a konkrét esetben a szubszumció során a történeti tényállás egyes elemei nem kerülnek értékelésre, úgy az általános személyiségi jog sérelme továbbra is vizsgálandó. Hasonló ehhez az, ha ugyanazon tényállás vonatkozásában az általános személyiségi jog eltérő jogkövetkezményre vezet, amelyek közül a sérelemdíj emelkedik ki gyakorlati jelentőségénél fogva.

\section{A vagyoni személyiség jogi jellegének egyes kérdései}

\section{Származékos jogszerzés}

Egy jog származékos szerzése alatt azt érjük, ha a jogszerző tényállásban valamely más jog szerepel a tényállás elemeként. Ezen belül származékos jogalapításról, más néven a jog átruházásáról akkor beszélhetünk, ha a régi jog megmarad, és eltérő tartalmú új jog keletkezik. ${ }^{811}$ A vagyoni személyiség a személyiségi joghoz képest ilyen speciális, származékos jogalapítással keletkező jogosultság. Míg az általános személyiségi jog az embert jogképességétől, születésétől kezdve megilleti, addig a vagyoni személyiség kialakul, fejlődik, és az egyén önmegvalósításának különös vonatkozását képezi. A származékos úton szerzett vagyoni személyiségi jog vonatkozásában - ha azt átruházták - korlátként is jelentkezhet a személyiségi jog mint régi jog, ${ }^{812}$ hiszen a személyiségtől való elválás sosem lehet teljes, és a személyiségröl való joglemondást nem lehet kiterjesztően értelmezni.

A vagyoni személyiségi jog tehát a személyiségi jogból jön létre tárgyiasulással és vagyoni érdekkörben történő felhasználással, míg a felhasználás nem történik meg sem a jogosult, sem bitorló, sem harmadik kötelmi vagy dologi jogosult részről, úgy függő jogi helyzet áll fenn. Ezekben az esetekben a tényállás nem teljes, a vagyoni érdekkörü felhasználás hiányzik, így a mozgástér az általános személyiségi jogon belül marad.

2. Viszonya a generálklauzulához

811 SZLADITS, 1941. 250-251.

${ }^{812}$ Legfelsőbb Bíróság Pf. IV. 21007/1992. („Láng”). 
A vagyoni személyiségi jog feltételeinek megvalósulásával új alanyi jog keletkezik. Ennek az alanyi jognak, jóllehet az általános személyiségi joghoz hasonló jogtárgyat véd, tulajdonságai lényegesen eltérőek. A vagyoni személyiségi jog részjogosultságai ugyanis átruházhatóak, örökölhetőek, tárgyiasíthatóak, és legfontosabb jellemzőként vagyoni értékkel bírnak. Ez a vagyoni érték és a személyiséggel fennálló kapcsolata a német dogmatikában is uralkodó felfogású monista elvet látszik támogatni, szintén hasonlóan a szerzői jog szabályozásához.

A vagyoni személyiség eltérő alanyi jogi jellegénél fogva igényhalmazatot implikál, és specialitása folytán az általános személyiségi joghoz képest elsőbbséget élvez. A német bírói gyakorlat ebből a szempontból nem tesz különbséget, hanem egy jogként kezeli a két alanyi jogot, és az eset körülményeire bízza annak eldöntését, vagyoni részekkel bír-e az adott személyiségi jog. Ott e homályos megoldás nemcsak a magánjog, hanem az alkotmányjog szintjén is jelentkezik, ugyanis mindig a konkrét esettől függ, hogy alkotmányos védelemben részesül-e a személyiségi jog, vagy pusztán a bírói jogfejlesztés által létrehozott vagyoni vonatkozásokról beszélünk, amelyek ilyen védelem alatt nem állnak. A német jog e megoldása az elmaradt személyiségi jogi kodifikációra vezethető vissza, illetve a judikatúra „személyiségi jogi aktivizmusára”, amely a személyi szemléletet kodifikáció hiányában is végig akarja vinni.

A vagyoni személyiségi jog, szemben Beuthien álláspontjával nem egy külön leválasztott vagyoni jog, „személyiségkép”, azon oknál fogva, hogy a személyiség külvilágban megjelenő, tárgyiasítható személyiségi jegyei nem tekinthetőek a személyiségi jogról teljes mértékben leválaszthatónak. Sokkal inkább összefonódik ez a személyiséggel, enélkül ugyanis egy korlátlan rendelkezési jog kerülne konstruálásra, amely a személyiségi jog jogosultjának uralmi köréből teljesen kikerülne. A vagyoni személyiség ugyanakkor nem azonosítható Götting álláspontjával sem, aki az általános személyiségi jogot tekinti olyan jognak, amelyben a vagyoni és személyi viszonyok keverednek. Álláspontom szerint az általános személyiségi jogból kell kiindulni, amelyből a fent vázolt feltételek megvalósulásával létrejöhet egy vagyoni értékminőséggel, felhasználhatósággal bíró különös személyiségi réteg, a vagyoni személyiségi jog. A vagyoni személyiség vagyoni és nem vagyoni elemeket is tartalmaz, és létrejöttével az általános személyiségi jog mint nem vagyoni jogosultság továbbra is fennáll, a kettő azonban egymástól különbözik, $s$ a vagyoni személyiség átruházása és öröklése által a jogosultja is elválhat az általános 
személyiségi jog jogosultjától. A vagyoni személyiségi jog ennél fogva egy speciális tényállást képezhet a személyiség védelmén belül. Ezzel megőrizhető a személyiségi jog monizmusa, amelyet a tipikus életviszonyok rugalmas jogi értékelése megkövetel, másrészről a vagyonjogi karakter eltérő jellege is leválasztható az eszmei érdekekről, mint amilyen a személyiségi jegyek feletti rendelkezési jog örökölhetősége.

A személyiségi jog tárgyiasulásával létrejövő vagyoni személyiségi jog, mint az eszmei és vagyoni érdekeket ötvöző különös alanyi jog ugyanakkor dogmatikai kategória. A személyiségi jegyek tárgyiasulásuk folytán ugyan elválnak a személyiségtől, és egyfajta „idegen dologbeli jogként” funkcionálnak. A személyiségi jog jogosultjának joga nem vész el teljesen, bizonyos esetekben korlátját képezi a dologi hatállyal megszerzett személyiségi jegyek, a vagyoni személyiségi jogi jogosultságok gyakorlásának. Az, hogy ez dogmatikailag így van, nem jelenti azt, hogy ez a törvényszöveg szintjén is ekképpen írható le. Noha azokban az esetekben, amikor a személyiségi jog tárgyiasulása folytán csupán eszmei, erkölcsi érdekek állapíthatóak meg, úgy a személyiségi jog alá tartozik a tényállás. Abban az esetben, ha a tárgyiasulás folytán vagyoni és eszmei érdekek keverednek, úgy a vagyoni személyiségi jogba tartozik a jogosultság. Ez a megoldás azonban a személyiségi jog igen terjedelmes területét indokolatlanul más jogalap körében helyezi el. Ennek okán a jog szövegrétegének kialakítása során a személyiségi jog dualizmusa jobban támogatható. Ez azt jelenti, hogy a személyiségi jog [Ptk. 2:42. § (1) bek.] azokat az eszmei és erkölcsi érdekben bekövetkező sérelmeket is lefedi, amelyek a vagyoni érdekkörben történő jogellenes tárgyiasítás során keletkeznek. Ez dogmatikailag a vagyoni személyiségi jog sérelmét indukálja. A dualista elmélet alapján azonban, ha a törvény egy kizárólag vagyonjogi vagyoni személyiségi jogot ismerne el, úgy a jogeset megoldása során két alanyi jog sérülne. Az eszmei sérelmek tekintetében a személyiségi jog, a vagyoni sérelmek tekintetében a vagyoni személyiségi jog. Ezzel a megoldással is teljeskörüen biztosított a személyiség védelme. A hangsúly ebben a tekintetben azon van, hogy a kereseti kérelemben mind a személyiségi jog jogkövetkezményeit, mind a vagyonjogi jogkövetkezményeket igényelni kell. Az egyes jogkövetkezmények vizsgálata tekintetében mindenképpen külön kell vizsgálni azok alkalmazhatóságát, ugyanakkor a későbbi jogalkalmazási gyakorlatban nem vezet olyan eredményre, hogy a személyiségi jog helyett tipikus jogsérelmek egy másik igény alá esnek. Ezzel a megoldással lényegében hathatósabban és egyértelműebben reagálna a jogalkotó arra, hogy a jogalkalmazás ne csupán az eszmei 
érdekek védelmére helyezze a hangsúlyt, és arra is, hogy a két jogot ne keverje össze, azokat kezelje külön. Ezáltal elérhető lenne az, hogy a vagyoni sérelmet biztosan ne értékeljék nem vagyoni jogkövetkezmények (különösen a sérelemdíj) keretében, illetve, hogy a vagyoni jogokkal összefüggő eszmei sérelmek, amelyek az eddigi joggyakorlatban igen terjedelmes részét képezték a személyiségi jog megsértésének, nem kerülnek más jogalap alá, így ebben a tekintetben nem üresedik ki a személyiségi jogi generálklauzula. A dogmatikailag helyes osztályozás azonban ezt eredményezné, nem lehet ezért minden tárgyiasulással összefüggő jogsérelmet a vagyoni személyiségi jog önálló alanyi joga alá vonni, csupán a vagyoni jogokat.

3. Az önállótlan vagyoni immateriális jogi kategorizálás

A vagyoni vonatkozások, a bírói gyakorlat által rendelkezési jognak ${ }^{813}$ nevezett jogosultság felveti azt a kérdést, vajon nem vált-e a személyiség egy szférája egyfajta szellemi tulajdonjoggá. A kérdés a német jogirodalmat addig foglalkoztatta, míg a BGH el nem ismerte a vagyoni vonatkozásokat, utána a kérdés, hasonlóan e személyiségi jegyek dologi hatályú átruházásához, elült.

Ehhez annak a vizsgálata szükséges, fennállnak-e a szellemi tulajdonjogként való kezelés feltételei. Götting szerint mindaddig, amíg a nevet vállalat- vagy árujelzőként használják fel, úgy e tárgyiasulással összefüggésben a kérdés arra irányul, hogy a név a személytől elvált-e, és tárgyiasult-e oly módon, hogy az egy teljesen forgalomképes és átruházható eszmei joggá (Immaterialgüterrecht) önállósult. ${ }^{814} \mathrm{~A}$ képmáshoz való jog tekintetében sokkal részletesebben kibontja ezt, és a forgalomképességen és átruházáson kívül konkrét szempontokat határoz meg: ,a vagyonjogi igények elismerésének szükséges előfeltétele sokkal inkább az, hogy a jog már annak megsértése előtt kommercializálódjon vagy kommercializálhatóvá váljon, ez azt jelenti, hogy a jogosultat megilleti a lehetőség, hogy a képmását piacra vigye (vermarkten). Vagyonjogi minőség a képmáshoz való jogot akkor illeti, ha piaci értékkel bír, amely a BGH szerint abban nyilvánul meg, hogy a leképezett személy vagy maga, vagy legalábbis hasonló helyzetben levő személyek által a képmása gazdasági értékesítését rendszerint díjazás ellenében engedi." ${ }^{815}$ Klippel abból indul

\footnotetext{
${ }^{813}$ BDT 2015. 70. („Élesztőtabletta”).

${ }^{814}$ GÖTting, 1995. 108.

${ }^{815}$ U.o. 51.
} 
ki, hogy az eszmei javak körébe sorolandó egy jogtárgy akkor, ha a gazdasági érdek a jogtárgy értékesítésében és forgalomképességében túlnyomó szerepet tölt be. ${ }^{816} \mathrm{~A}$ névjoggal is összefüggésben ő ebből azt hangsúlyozza in concreto, hogy adott esetben milyen fokban, milyen mértékben tárgyiasult a jogtárgy, mert csak az eszmei javak esetén válnak el az eszmei érdekek a személyiségtől, és csak ezek esetén beszélhetünk gazdasági önállósulásról. ${ }^{817}$ Én egyrészről a személytől való elválásban (tárgyiasulásban), illetve az ehhez járuló vagyoni érdekkörben (felhasználási módban) látom a kérdés megválaszolását. Ez azonban megindokolható a magyar jogban korábban hézagmentes oltalomnak nevezett szubszidiárius klauzulának való alávonással is. ${ }^{818}$

A jogirodalom általában nem tartalmaz minden szellemi tulajdonjogra általánosan alkalmazható feltételrendszert, nem sorolja fel, mely feltételek teljesülése esetén tekinthető valami szellemi alkotásnak. Ahhoz, hogy a logikai müveletet, a szillogizmust el lehessen végezni, és az állaáspont igazolható legyen, valamely feltételt, feltételeket vizsgálni kell. Ezzel összefüggésben a magyar jogban korábban ismert hézagmentes oltalom generálklauzulája is vizsgálható. A szellemi tulajdonjogi jelleg másképpen is megindokolható, deklarálható, azonban ezt tartottam legkonkrétabb mércének, amely feltétele a társadalmi felhasználhatóság tekintetében vizsgált tárgyiasulás a személyiségi jogi jogirodalomban is megjelenik mind Balás $P$. Elemérnél, mind Törő Károlynál, amely ennek legitimációját erősíti. A hézagmentes oltalomnak nem tulajdonítható normatív hatás, s annak hasznossága-hasztalansága tekintetében sem foglalok állást, csupán érvként használom fel, hogy a vagyoni személyiségi jog szellemi alkotási, immateriális vagyonjogi karakterét alá lehessen támasztani a szellemi alkotások feltételrendszerének irányából.

A védelem feltétele a hézagmentes oltalom szempontjából, hogy a megjelölés 1) társadalmilag széles körben felhasználható legyen és 2) ne váljon közkinccsé. ${ }^{819} \mathrm{~A}$ társadalmi felhasználhatóság akkor állapítható meg, ha az eredmény a) tárgyiasulhat, illetve b) amely hasznosítható, utánozható, alkalmazható. ${ }^{820}$ A tárgyiasíthatóság

\footnotetext{
816 KLIPPEL, 1985. 497.

${ }^{817}$ U.o. 521.

${ }^{818}$ A hézagmentes oltalom a Ptk. hatálybalépésével szünt meg. Ehhez 1. GRAD-GYENGE ANIKÓ: Búcsú a szellemi alkotások jogától? - A szerzői jog és az iparjogvédelmi oltalmi formák polgári jogi védelme a magyar magánjogban. (http://ptk2013.hu/szakcikkek/grad-gyenge-aniko-bucsu-aszellemi-alkotasok-jogatol-a-szerzoi-jog-es-az-iparjogvedelmi-oltalmi-formak-polgari-jogivedelme-a-magyar-maganjogban/1776).

${ }^{819}$ Analóg módon a 1977. évi IV. tv. 86. § (3) bekezdését alkalmazva.

${ }^{820}$ TÖRÖ, 1978. 982. 991.
} 
szempontjából a személyiségi jogok két csoportra oszthatóak: a személlyel, a személyiséggel elválaszthatatlanul összefonódott vonatkozások, illetve azok a külső megjelölések és ismeretek, amelyek bizonyos mértékben elválnak. Ezen utóbbiakat mi tárgyiasítható személyiségi jegyeknek neveztük, amelyek esetén a személyiségtől való távolodás mérhető, és a személyiségi jogok ekkénti igénybevétele társadalmunkban jelenlevő jelenség. A tárgyiasításnak ekkénti meghatározása egyrészt ahhoz vezet, hogy kizárásra kerülnek azok a személyiségi jogok, amelyek esetén nem beszélhetünk „dologiasodásról”, másrészt ahhoz, hogy dogmatikailag csak azok a jegyek kerüljenek be a vagyoni személyiségbe, amelyek esetén a kommercializálódás a gyakorlatban valóban megjelenik. A társadalmi felhasználhatóság másik feltétele a hasznosíthatóság, alkalmazhatóság és utánozhatóság. A vagyoni személyiségi jog meghatározása tekintetében a tárgyiasított felhasználást nem általánosságban véve, hanem kizárólag a vagyoni érdekkörbe eső, esetcsoportok szerint meghatározott felhasználást a jelentős, ekkor beszélhetünk oylan értékestésről, amely nem eszmei érdekeket érint. A vagyoni érdekkör, a „haszonszerzési célzat” mint a felhasználás esszenciája ugyanis alkalmas arra, hogy a pusztán nemvagyoni, ideális érdekek körében történő tárgyiasult használatot kizárja, anélkül azonban, hogy a vagyoni személyiségen belüli vagyoni-személyi viszonyok esetében is ugyanezt tenné.

A vagyoni személyiségi jog tekintetében további elemként jelentkezett a személyiség ismertté válása, illetve annak tárgyiasult használatba vétele. E két feltétel valamelyikével kerül sor ugyanis arra, hogy a személyiség, illetve a személyiségi jegy vagyoni értékkel bírjon. Ez azonban nem további tényállási elem, hanem sokkal inkább az előbb említett felhasználáshoz kapcsolódóan a vagyoni értékminőség mérésére szolgál. A tárgyiasult személyiségi jegy vagyoni érdekkörben való felhasználása ugyanis mindenképpen vagyoni értéket mutat fel, annak értéke mintegy a helyettesíthetetlen dolgok analógiájára az eset összes körülménye alapján dönthető el. $^{821}$

A közkincs negatív feltétel, és elsősorban a tárgyiasuláshoz kapcsolódik. A közkincs a „dologiasodás zsinórmértéke”. A közkinccsé válás szempontjából ugyanis az vizsgálandó, hogy a személyiségi jegyet nem lehet szabadon felhasználni. ${ }^{822}$ Azokban az esetekben ugyanis, ha a személyiségi jegy elveszíti személyes jellegét, és

\footnotetext{
${ }^{821}$ A kép mint személyiségi jegy vagyoni értéke során a Szegedi Ítélőtábla által figyelembevett szempontok: BDT 2015. 70. (,Élesztőtabletta”).

${ }^{822}$ TÖRÖ, 1978. 991.
} 
a közfelfogás nem tulajdonít a jogosultnak rendelkezési jogot a személyiségi jegy felett, úgy az közkinccsé válik.

A szellemi tulajdonjogokhoz hasonló tulajdonsága e személyiségi jegyeknek az, hogy a tárgyiasítás, a felhasználás nincsen helyhez és időhöz kötve, azt bárki megsértheti, attól függetlenül, hogy az elkövetővel személyes kapcsolatba került-e (ún. ubikvitás). Az iparjogvédelmi jogokkal összefüggésben Götting az ubikvitást a következőképpen jellemzi: „utánzással [az iparjogvédelmi jogokat] fel- és kihasználhatják az országhatáron kívül is. A szellemi javak mindenhol jelenlevőek, ha nyilvánosságra hozzák, ismertetik őket vagy azok egyébként hozzáférhetőek; ninsenek egy meghatározott helyhez vagy országhoz kötve (ún. ubikvitás)" ${ }^{823}$ Ez az időtől és helytől független tárgyiasítás, jogsértés egybevág azzal a személyiségi jogon belül tapasztalható jelenséggel, miszerint a jogsértő és jogosult közötti távolság nő. Ez ugyan a tárgyiasítható személyiségi jegyek esetében általában adott, vagyoni értéktől függetlenül, az azonban látható, hogy a személyiségi jegyek ilyetén felhasználásának dinamikája az áruk kelendőségének fokozása szempontjából (pl.: egy híresség nevének 10.000 db pólóra nyomása; újság címlapján megjelenés 60.000 példányban, naptáron való felhasználás stb.) a védjegyjog, illetve a vállalat- és árujelzőjog analógiájára múködik. Ez különösen azért érdekes, mert a német jog csak a szerzői jog analógiáját emlegeti, céljában azonban a védjegyjoghoz áll közelebb akkor is, ha ez az összehasonlítás viszonylag durva.

Ezek alapján a hézagmentes oltalom által támasztott feltételek maradéktalanul megvalósulnak. A tárgyiasult személyiségi jegyek társadalmilag széles körben felhasználhatóak és nem válnak közkinccsé, amelynek okán a tárgyiasult személyiségi jegyek szellemi alkotásnak, s így átruházható és örökölhető jogosultságnak, tekintendőek. A polgári jogi kodifikáció során azonban a hézagmentes oltalom szabályától a jogalkotó eltekintett, ${ }^{824} \mathrm{~s}$ a szellemi alkotások numerus claususa okán a jogalkotói beavatkozás ebben a tekintetben szükséges lehet. Az analógia feltételei fennállnak, illetve egy esetleges hézagmentes oltalmi klauzula esetén a teleologikus redukció feltételei állnának fenn.

A személyiségi jogi-szellemi tulajdonjogi klasszifikáció a magánjog szempontjából elsősorban elméleti kategória marad, akkor is, ha a jog a személyiségi

\footnotetext{
823 GÖTTING, HoRST-PETER: Gewerblicher Rechtsschutz. C.H. Beck, München, 2014. § 3 Rn 1.

${ }^{824}$ FALUDI GÁBOR: Szerzői jog és iparjogvédelem. In: Vékás Lajos (szerk.): Szakértői Javaslat az új Polgári Törvénykönyv tervezetéhez. Complex, Budapest, 2008. 383.
} 
jog vagyoni értékminőségét, forgalomképességét elismeri. Elsősorban abból a szempontból lehet jelentősége ennek, hogy e tárgyiasult jogtárgyak megsértését melyik bíróság, illetve milyen tanács tárgyalja, illetve, hogy melyik az a nemzetközi kapcsolószabály, amelyet ezek esetében alkalmazni kell.

\section{A vagyoni személyiségi jogok átruházhatósága}

A tárgyiasulás általi elválással elméletileg megnyílik a lehetősége annak, hogy az egyes személyiségi jegyek átruházhatóak legyenek. Az átruházás alapvetően dologi (tényleges átruházás) vagy kötelmi hatályú (használati engedély adása) lehet. ${ }^{825}$ Dologi hatályú átruházás esetén a jogtárgy feletti rendelkezési jog a jogszerzőt illeti, aki abszolút jogot szerez a vagyoni személyiségi jogon. Ez a jog őt tehát a személyiségi jog jogosultjával szemben is megilleti. Ez elég szélsőségesen hangzik, ugyanakkor ez a helyzet például a személyiségi jegyek védjegyként való bejegyzése esetén is (csak ez nem ebböl az irányból kerül értékelésre, hanem védjegyjogi szemüvegen keresztül). A kötelmi hatályú átruházás, a használati engedély adása esetében a jogosult és a személyiségi jog jogosultja között kötelmi viszony keletkezik. Ennek a természete jogügyleti jellegü, ez ezért követelési jogot alapoz meg. A két átruházás közötti különbségtételt nehezíti a rendelkező ügylet (dologi jogügylet) hiánya, hiszen a jogtárgy fizikai átadása nem értelmezhető immateriális jellege okán. A Ptk. 2:42. § (3) bekezdés jellegében más, hiszen az egy egyoldalú jogügylet, ${ }^{826}$ az ingyenessége vitatható.

A BGH a képmáshoz való jog átruházhatóságát még a személyiségi jog vagyoni vonatkozásainak elismerése előtt vizsgálta, és megállaptotta, hogy a képmáshoz való jog mint az általános személyiségi jog megnyilvánulása jogalkatánál fogva alkalmatlan az átruházásra. ${ }^{827}$ Ezt az álláspontot osztotta később az Hamburgi Tábla is, kiemelve, hogy nem a képmáshoz való jog átruházásáról, hanem a képmáshoz kapcsolódó vagyoni használati jogok átengedéséről (azaz kötelmi hatályú jogosultság szerzéséről) van szó azzal, hogy a képmáshoz való jog magva feletti rendelkezési jog továbbra is az abszolút jog jogosultjánál marad. ${ }^{828}$

\footnotetext{
${ }^{825}$ Ehhez lásd még általánosságban: TöKEY BALÁZs: A szerződések hatásai harmadik személyekre. Habilitáció, ELTE, 2019. 7.

${ }^{826}$ SZÉKELY, 1985. 282.

${ }^{827}$ GRUR 1987, 128 - NENA.

${ }^{828}$ OLG Hamburg, Urteil vom 11.6.1998 - 3 U 284/97 - Vermarktung einer Musikgruppe.
} 
Az osztrák bírói gyakorlat sokkal rugalmasabb volt már a személyiségi jog vagyoni vonatkozásainak német, illetve osztrák elismerése előtt. Az OGH a Radetzky Weingut-ügyben a következő megállapítást tette: a névjog legszemélyesebb jellege okán a névhasználat engedélyezése nem tekinthető a névjog átruházásának, hanem csak az abbahagyási igény érvényestéséről való lemondásnak. Egy ilyen engedélyezési szerződés azonban nem csak a szerződő felek között, hanem „dologi hatállyal” harmadik személyekre is hatással van. A szerződés ennél fogva az engedélyező örököseit is köti, egy ilyen vagyonjogi jogokat és kötelezettségeket tartalmazó szerződés alapvetően örökölhető. ${ }^{829}$ A vagyoni értékkel bíró személyiségi javak kötelmi hatályú átruházását a németen és az osztrákon kívül több európai jog elismeri, így a francia, ${ }^{830}$ a lengyel, ${ }^{831}$ a svájci ${ }^{832}$ jog is, anélkül, hogy ezekben a jogrendszerekben a személyiségi jog vagyoni értéke ténylegesen értékelésre kerülne. A magyar jog hasonló helyzetben van, így ez általános jelenségnek tünik.

A német jogirodalom az átruházhatóság tekintetében abból indul ki, hogy a személyiségi jognak van-e vagyoni értéke. ${ }^{833}$ Ehhez köti azt a kérdést is, hogy a személyiségi jog jogosultjának beleegyezésére szükség van-e bizonyos irányú felhasználás esetén (pl.: valaki hozzájárul, hogy nevét egy cég használja péktermékek megjelölésére, de a cég később bővíti kínálatát és húsipari termékeket is ellátna a névvel). Mint látható volt a más jogtárgy formájában tárgyiasult név védjegyjogi felhasználása esetében ilyen utólagos beleegyezés nem létezik, míg a cégnévként való használat esetén felmerülhet. Frederik Bungart arra mutat rá, hogy a személyiségi javak „elválásával” azok átruházhatóvá válnak a szellemi tulajdonjogokhoz hasonlatosan. ${ }^{834}$ Forkel 1988-ban szintén a személyiségi javak „eldologiasításáról” beszélt. Ő a személyiségi jogot anyajognak tekinti, míg az eldologiasított javakat részjogoknak, amelyek korlátok között átruházhatóak. Ezáltal a jogszerző dologi

${ }^{829}$ MR 2000, 368 - Radetzky; SZ 2010/70 - Maria Treben.

${ }^{830}$ TREBES, ANJA: § 59. Frankreich. In: Götting, Horst-Peter - Schertz, Christian - Seitz, Walter (szerk.): Handbuch des Persönlichkeitsrechts. C.H. Beck, München, 2019. Rn 51-

831 TARGOSZ, TOMASZ: $\$$ 62. Polen. In: Götting, Horst-Peter - Schertz, Christian - Seitz, Walter (szerk.): Handbuch des Persönlichkeitsrechts. C.H. Beck, München, 2019. Rn 16.

832 Bohne, MichaEL: $\S$ 63. Schweiz. In: Götting, Horst-Peter - Schertz, Christian - Seitz, Walter (szerk.): Handbuch des Persönlichkeitsrechts. C.H. Beck, München, 2019. Rn 13, 15.

${ }^{833} \mathrm{Ez}$ már csak azért is ellentmondásos, mert sokszor a vagyoni érték megállapítását köti az átruházhatóság meglétéhez. Emiatt a circulus vitosus miatt van szükség a vagyoni értékminőség megállapításának más feltételekhez kötésének mint amiylen az ismertség (publicitás) vagy a tárgyiasulás.

${ }^{834}$ BUNGART, FREDERIK: Dingliche Lizenzen an Persönlichkeitsrechten. Nomos, Baden-Baden, 2003. 129. 
hatállyal jogot szerezhet egy részjogon, az anyajog azonban annak későbbi korlátja lehet. ${ }^{835}$ Forkel koncepciója a német jogirodalomban nem kapott nagyobb visszhangot, azonban nagyon hasonló a tárgyiasulás alapú személyiségvédelemhez, ő Unselddel együtt a szerzői jogi vagyoni jogok átruházásának szabályait látja analógan alkalmazandónak. ${ }^{836}$ Célszerü a tárgyiasulással összefüggésben is megvizsgálni az átruházás mértékét, ezzel összefüggésben a személyiségi jog jogosultjának jogait az átruházás után. Sokszor ugyanis nagyon vegyes az a kép, mikor léphet közbe a személyiségi jegy átruházása után a személyiségi jog jogosultja, illetve az ő örököse. Ennek az oka abban rejlik, hogy a legtöbb esetben a tényleges, teljes tárgyiasulás az átruházás után megy végbe, a személyiségi jog új funkciója ekkor lesz teljes. Éppen ebből fakadóan a személyiségi jog jogosultjának elállási, tiltási jogai is az átruházást követő jogi tényekhez kapcsolódnak, így azok terjedelme nem dönthető el elöre, absztraktan.

Meglátásom szerint az ilyen utólagos beleegyezés, jóváhagyás eldöntését a bírói gyakorlatra kell bízni, amely az eset körülményei alapján dönthet. Ezt a tárgyiasulás alapú személyiségvédelemben a tárgyiasulás foka határozhatja meg. Ha a személyiségi jegy csupán részben tárgyiasult, azaz ha az funkciójában a személyre továbbra is utal, úgy bizonyos esetekben megkövetelhető a felhasználáshoz a személyiségi jog jogosultjának hozzájárulása (pl.: ha az előző példában a névjog jogosultja vegetáriánus és tiltakozik, hogy nevét húsipari termékeken tüntessék fel). Ha a személyiségi jegy teljes mértékben tárgyiasult, elvált attól a funkciójától, hogy személynév legyen, úgy nem szükséges hozzájárulás (pl.: Dr. Oetker kifejezés esetén senki sem Dr. August Oetker gyógyszerészre gondol, aki a sütőport feltalálta). A személyiségi jog jogosultjának utólagos beleegyezése sok esetben azért nem egyértelmű, mert a tárgyiasult személyiségi jegyek a használat útján keletkező vállalatés árujelzőkhöz hasonlítanak: a forgalom, illetve harmadik személyek szempontjából ki kell alakulnia annak a képzetnek, hogy a személyiségi jegy nem a személyre, hanem a tárgyiasult funkciójára vonatkozik. Ez pedig nem egy pillanat, hanem huzamos, tartós használat eredménye akkor is, ha a személyiségi jegy nem vállalat- vagy árujelzőként tárgyiasul. Ennél fogva azt mondhatjuk, hogy nincs szükség a

\footnotetext{
${ }^{835}$ FORKEL, HANS: Lizenzen an Persönlichkeitsrechten durch gebundene Rechtsübertragung. GRUR $1988,491,495$.

${ }^{836}$ FORKEL, 1988. 497. UNSELD, FLORIAN: Die Übertragbarkeit von Persönlichkeitsrechten. GRUR 2011,985
} 
személyiségi jog jogosultjának hozzájárulására az olyan felhasználáshoz, amelyben a felek nem állapodtak meg, ha a személyiségi jegy teljes mértékben tárgyiasult.

A másik fontos kérdés ezzel összefüggésben, hogy egy ilyen átruházó szerződés mikor szüntethető meg felmondással. Erre az OGH szerint fontos okból kerülhet sor. ${ }^{837}$ Ilyen fontos ok az előbbi példában az, ha a névadó személy vegetáriánus és nevét húsipari termékeken tüntetnék fel. Ez a gyakorlati élet szempontjából is fontos, hiszen a gyakorlatban előforduló, a személyiségi jegyek értékestését célzó (szponzoring, influencer stb.) szerződések esetén iránymutatást adhat a felmondásra. Másrészt releváns lehet az adatkezelés és a személyiségi jogok felhasználásnak kollíziója esetében is.

Abban az esetben, ha elismerjük, hogy a személyiségi jog kereskedelmi felhasználása tekintetében a jogosultat egy vagyonjog illeti meg, úgy az örökösök lesznek azok, akik ezt a rendelkezési jogot a hagyaték részeként megszerzik. Ennek azért kell így lennie, mert a személyiségi jegyek mint a személyiség megnyilvánulásai már nem jelentenek negatívumot a külvilággal szemben, hanem a halál után is fennmaradnak - mint ahogyan az eszmei világ részeként a személyiség is fennmarad a halál után ${ }^{838}$-, ennél fogva rendelkezni lehet velük. Ennek a rendelkezési jognak a szabályai, jogosultjai, időbeli és tárgyi terjedelmének meghatározása nem lelhető fel a Ptk.-ban, és arra a jogalkotó a személyiségi jog halállal való megszünése okán nem is gondolt. A tárgyiasult személyiségi jegyek helytől és időtől függetlenül megsérthetőek akár a halál után is, pontosan annál az oknál fogva, hogy a személyiségtől bizonyos fokban önállósodtak.

Ha elfogadjuk azt, hogy a személyiségi jegyek teljesen vagy bizonyos (pl. védjegyjoghoz kapcsolódó függő jogi helyzetek) vonatkozásában örökölhetőek, úgy az örökösöket kell, hogy illesse a rendelkezési jog a vagyoni személyiségi jog kereskedelmileg felhasználására, értékesítésére, átruhzására és használati engedély adására. A Ptk. erről semmit nem mond, nem biztosítja az örökösök e jogát, sőt, abból indul ki, hogy a halál utáni kereskedelmi felhasználás nem jogsértő, abból vagyonjogi szankciók nem származnak. Vannak azonban olyan szabályok a jogrendszerben, amelyek egy ilyen rendelkezési jog meglétére utalnak. Ilyen szabály az, hogy a domain név jogosultjának halála után új igényt ugyanarra a domainnévre a jogosult örökösei,

${ }^{837}$ MR 2000, 368 - Radetzky.

${ }^{838}$ BALÁS, 1941. 632. 
illetve az átruházó nyilatkozat kedvezményezettje nyújthat csak be. ${ }^{839}$ Ilyen szabály az is, hogy az örökösök hozzájárulása szükséges a név védjegyként való bejegyzéséhez. ${ }^{840}$ A hozzájáruló nyilatkozat jogalkalmazó szervek általi megkövetelésének (pl.: más személy személyiségi joga mint relatív kizáró ok a védjegyjogban) ugyanis valamilyen jogalapon kell nyugodnia, amely a kegyeleti jog keretében, annak jellegénél fogva, nem értelmezhető. A hozzájáruló nyilatkozat örökösökhöz való kötése azonban már egy olyan rendelkezési jogot jelenthet, amely logikusan rendezi a problémát. Ennek jogalapja tehát nem is helyezhető el a kegyeleti jog keretében, és meglátásom szerint a vagyoni személyiségi jog lehet az, amely egy halál után fennmaradó rendelkezési jogot jelenthet. Lényegében már Bozóky Alajos is amellett áll ki, hogy a védelem nem szünhet meg a halállal: „valamely dolognév valamely személyi hatáskör bizonyos alkatelemének megjelölésére is szolgálhat és mint ilyen a személyiség igen becses javát képezheti, amidőn az ilyen jegy alkotóját vagy jogutódját [sic!] a személyiségi jogánál fogva [sic!] szintén törvényes oltalom kell hogy illesse azok ellen, akik avval a jegygyel visszaélnek. "841

A Ptk. nem rendelkezik arról a helyzetről sem, hogy a személyiségi jog kereskedelmi felhasználására vonatkozó jogosultságot harmadik személyek dologi hatállyal megszerezhetik. Az ily módon megszerzett jogosultság nem lesz a hagyaték része, lévén az öröklés megnyílásakor nem része az örökhagyó vagyonának. A dologi hatállyal jogot szerzett személyeknek a személyiségi jog jogosultjának halála utáni igényérvényesítése ezzel a Ptk.-ban nem biztosított, arra nincs lehetőség.

A Ptk. ennél fogva a vagyoni értékminőséggel való rendelkezést mint jogosultságot nem ismeri a személyiségi jog jogosultjának halála után. Ez nem lenne probléma, hiszen a vagyoni érdekek védelme a halállal meg is szünhetne, a Ptk. azonban ellentmondásba kerül önmagával, és a vagyoni érdekek védelmét a kegyeleti jogsértéssel összefüggésben bizonyos tekintetben engedi. Ezzel a törvény a vagyoni érdekek halál utáni védelmét nem szabályozza kielégítően, hiszen önellentmondásba kerül.

\footnotetext{
839 VEREBICS, 2011. 26.

${ }^{840}$ BH 1993. 548. („CHAGALL”); Pablo Picasso vonatkozásában 1. GöDÖLLE, 2014. 164.; A német jogalkalmazási gyakorlatból a szabad felhasználásra 1. NJW 2001, 615 - Johann Sebastian Bach, GRUR 1998, 1021 - Mona Lisa.

${ }^{841}$ BOZÓKY, 1905. 481.
} 
5. A vagyoni érdekek halál utáni védelme

A vagyoni érdekek védelmét el kell határolni az eszmei érdekek védelmétől. A német jog a személyiségi jog védelmének monizmusa mentén a két érdeket együttesen oltalmazza. Ettől függetlenül azonban a személyiség halál utáni védelme és az igényérvényesítés tekintetében külön szabályokat tartalmaz: más a jogosultak köre, más a védelmi idö, más jogkövetkezmények alkalmazhatóak. A jogalkalmazási gyakorlat a poszt mortem eszmei vonatkozásaitól függetlenül kezeli a vagyoni vonatkozásokat. A Ptk. ettől eltérően a kegyeleti jog sérelme körében ad lehetőséget az örökösöknek a jogsértéssel elért vagyoni előny átengedésére. Ezzel a kegyeleti jog alkalmazási körébe tereli a vagyoni érdekek védelmét, ez azonban hibás, hiszen a kegyeleti jog funkciójánál fogva kizárólag az eszmei, erkölcsi érdekek védelmét szolgálja.

A kegyeleti jog tényállása [Ptk. 2:50. §] a meghalt ember emlékét védi, s így az az eszmei, ideális jellegü sérelmek ellen nyújt védelmet. A Kúria a kegyeleti jogot, az elhalt emlékének megsértését nem az elhunyt személy személyiségi jogának tekinti, hanem a hozzátartozók joga sérelmének. ${ }^{842}$ A bírói gyakorlatban a kegyeleti jog a holttesttel való rendelkezés által jelenik meg, másrészt nevesített személyiségi jogok sérelme mentén. ${ }^{843} \mathrm{E}$ tényállások tulajdonképpen egy speciális generálklauzulát képeznek a személyiségi jogon belül, amelynek többlettényállási elemét az elhunyt személy emlékének a megsértése képezi. A személyiségi jegyeknek a jogosult halála utáni felhasználása, az azokkal való rendelkezés a kegyeleti jogot általában nem is sérti. ${ }^{844}$ Elhibázott is lenne a kegyeleti jogot ilyen irányban tágítani, hiszen a jogintézmény létének célja más jellegü, a kegyeleti jog ugyanakkor az egyetlen fogalmi keret, amelyet a pozitív jog a személyiségi jog halál utáni érdekérvényesítése tekintetében elismer.

A vagyoni érdekek halál utáni védelmét egy vagyoni személyiségi jog tudná ellátni. A vagyoni személyiségi jogot az örökösök szerzik meg a halál után, illetve ettől független vagyoni személyiségi joggal rendelkezik az a személy, aki dologi hatállyal jogot szerzett valamely személyiségi jegy felett. A személyiségi jog jogosultjától annak életében megszerzett in rem jog jogosultja jogának folytonossága tekintetében

\footnotetext{
${ }^{842}$ BH 1980. 377. („Kányák”).

${ }^{843}$ TÖRÖ KÁROLY: A személyhez füzödő jogok érvényesitésének rendje. In: Petrik Ferenc (szerk): A személyiség jogi védelme. KJK, Budapest, 1992. 211-222.; GÖRÖG 2008. 22-52.

${ }^{844}$ MENYHÁRD, 2016. 79; SZEGHALMI, 2017. 233.
} 
nem jelent megszakítást az öröklés megnyílása, hiszen a jogszerzés az öröklés megnyílása előtt, attól függetlenül keletkezett.

A Ptk. ebben a tekintetben tehát nem viszi keresztül a dologi szemléletet, és a személyi érdekek mentén akarja megoldani a vagyoni érdekek védelmét, amely dogmatikailag hibás. Ez alapján az mondható el, hogy a Ptk. a vagyoni értékminőség halál utáni érvényesítése körében a vagyoni értékminőséget nem ismeri el ellentmondás-mentesen.

A Ptk. a védelmi idő tekintetében abból indul ki, hogy az elhalt személy személyiségi jegyei szabadon felhasználhatóak mindaddig, amíg a felhasználás a kegyeleti jogot nem sérti. Külön szabályt a kártérítési jog tekintetében nem tartalmaz, csak a jogsértéssel elért vagyoni előny tekintetében szabályozza ezt, jóllehet a kártérítési igény is öröklődő vagyoni igény. Ezzel a Ptk. a kegyeleti jog (az erkölcsi érdekek) egyidejü sérelméhez kötia személyiségi jegyek halál utáni kereskedelmi felhasználását. Ez a megoldás azért hibás, mert az eszmei, erkölcsi érdekek sérelméhez köti a vagyonjogi igények megvalósulását. Függetlenül attól, hogy a személyiségi jog vagyoni értékminőségét a monizmus vagy a dualizmus alapján ítéljük meg, a vagyonjogi igények megvalósulása független az eszmei érdekek sérelmétől. Ennél fogva a vagyoni érdekek védelme, a német megoldáshoz hasonlatosan, eltérhet a kegyeleti jog védelmétől. A Ptk. azonban a vagyoni érdekeket nem is védi önmagában, azok a halállal megszünnek, és csak a kegyeleti jog sérelmének a keretében ismeri el azokat. Szeghalmi is azt állapítja meg, hogy az elhunyt személy személyiségi jogának kereskedelmi célú felhasználása a kegyeleti jog keretei között közkinccsé válik, azaz bárki szabadon felhasználhatja azokat. ${ }^{845} \mathrm{~A}$ vagyoni érdekek ilyen módon történő értékelése dogmatikailag hibás akkor, ha a kegyeleti jogot fenntartjuk az eszmei, erkölcsi érdekek védelmére. Ez persze nem érinti azt, hogy a két érdek védelmi ideje azonos is lehet. Azt azonban látni kell, hogy a Ptk. 2:50. § (2) bekezdésből nem derül ki, az örökösök meddig érvényesthetnek igényt. Másrészt az eszmei és vagyoni érdekek ilyen vegyülése pont azért lenne elkerülendő, mert a halál utáni kereskedelmi felhasználás ritkán jár az eszmei érdekek megsértésével. Ennek megköbetelése a tényállásban az igény alkalmazásának körét nagy mértékben szükíti le.

${ }^{845}$ SZEGHALMI, 2017. 233. 
Az eszmei (és vagyoni) jogok védelme a KUG 22. §-a szerinti képmáshoz való jog tekintetében 10 év. Az általános személyiségi jog vagyoni vonatkozásainak elismerésekor a Marlene és a Blauer Engel-döntésekben a védelmi idő kérdése fel sem merült (Marlene halála nem volt olyan távoli), ezt ismerte fel az OLG München polgári tanácsa is, és tett javaslatot egy 20 éves védelmi időre. Kifejezetten kiemelte az ítélet, hogy a KUG 22. §-a szerinti védelem analóg alkalmazása nem kizárólagos, és nem is támogatták azt. ${ }^{846}$ Végül a BGH tett pontot az ügy végére 2007-ben, amikor kimondta, hogy a KUG 22. § analóg módon alkalmazandó a post mortem személyiségi jog vagyoni vonatkozásai védelme tekintetében. ${ }^{847}$ A BGH 10 éves védelmi ideje a vagyoni vonatkozások tekintetében az eszmei érdekek védelmére is kiterjesztendő lenne Luther szerint azért, hogy határozott legyen az igényérvényesítés időbeli terjedelme. ${ }^{848}$ Egy másik álláspont szerint a védelmi időt a jogosult halálát követő hetven évben kellene megállapítani, tehát a szerzői joghoz hasonló módon. ${ }^{849}$ Görög Márta szintén 70 éves időre tesz javaslatot a szerzői jog analógiájára. ${ }^{850}$

Az amerikai jogban a right to publicity védelmi ideje tagállamonként eltérö. Az ehhez kapcsolódó jogi álláspontokra kitér mind Stump Krisztina, ${ }^{851}$ mind Szeghalmi Veronika. ${ }^{852}$ Az eltérő védelmi idők összefoglalását az alábbi táblázat tartalmazza:

\footnotetext{
${ }^{846}$ GRUR-RR 2002, 341 - Nacktbilder.

${ }^{847}$ NJW 2007, 684 - kinski-klaus.de.

${ }^{848}$ LUTHER, 2009. 172.

${ }^{849}$ GÖTTING, 2001. 586. Schricker/Gerstenberg/Götting, UrheberR, 2. Auflage, 1999, § 60/ §22 KUG, Rn 24.

${ }^{850}$ GÖRÖG, 2008. 84.

${ }^{851}$ STUMP, 2014. 612.

852 SZEGHALMI, 2017. 230.
} 
10. sz. táblázat

A post mortem right to publicity védelmi ideje az USA egyes tagállamaiban

\begin{tabular}{|c|l|}
\hline VÉDELMI IDÖ & \multicolumn{1}{|c|}{ TAGÁLLAM } \\
\hline nincs & New York, ${ }^{853}$ Wisconsin ${ }^{854}$ \\
\hline 10 év & Tennesse ${ }^{855}$ \\
\hline 20 év & Virginia \\
\hline 40 év & Florida ${ }^{856}$ \\
\hline & $\begin{array}{l}\text { Kentucky, Nevada, }{ }^{857} \text { Texas, New Jersey, } \\
\text { California }{ }^{858} \\
\text { Az 50 éves védelmi időt támogatja } \\
\text { szövetségi szinten Buchanan, }{ }^{859} \text { hozzá } \\
\text { hasonlóan Goodman is az 50 éves védelmi } \\
\text { idöt látja ideálisnak a kaliforniai jog } \\
\text { mintájára. }{ }^{860}\end{array}$ \\
\hline & Washington \\
\hline 75 év & Indiana ${ }^{861}$ Oklahoma \\
\hline 100 év & \\
\hline &
\end{tabular}

(Saját szerkesztés)

A vagyoni személyiségi jog védelme egyrészről egy konkrét időintervallumhoz köthető, de a bíró mérlegelési körébe is utalható. Abban az esetben, ha bírói mérlegelésbe utaljuk a védelmi idő hosszának megállapítását, úgy abból kell kiindulni, hogy a védelem addig illeti meg a jogosultakat (örökösöket), ameddig a külső szemlélő, a kereskedelmi forgalom a személyiségi jegy felett rendelkezési jogot tulajdonít az adott személyeknek. Luther a poszt-mortem személyiségi jog eszmei vonatkozásai tekintetében is egy konkrét időintervallum meghatározását javasolja. 863 Ez megszívlelendő lehet a vagyoni személyiségi jog tekintetében, hiszen egy vagyoni jogról beszélünk. A védelmi idő határozatlanságának az lesz az eredménye, hogy visszafogja a médiát, a sajtót és a vállalatokat a személyiségi jegyek felhasználása tekintetében. Ennek okán lép fel Beuthien is a személyiségi jog vagyoni

\footnotetext{
${ }^{853}$ N.Y. CIv. RIGHTS LAW $\S \S 50,51$

${ }^{854}$ MCCARTHY, ThOMAS: The Rights of Publicity and Privacy. Thomson West, 2011. § 9:19.; VICK, KEVIN L. -JASSY, JEAN-PAul: Why a Federal Right of Publicity Statute Is Necessary. Communications Lawyer, Volume 28, Number 2, August 2011. 18.

${ }^{855}$ GÖTTING, 1995. 242.

${ }^{856}$ FLA. STAT. $\S 540.08(\mathrm{c})(4)(1997)$

${ }^{857}$ NEv. REV. STAT. ANN. $§ 597.790$.

${ }^{858}$ CAL. CIVIL CODE $\S 990$

${ }^{859}$ BuChanan, CATHERINe Louise: A Comparative Analysis of Name and Likeness. Golden Gate University Law Review 1988 Volume 18. Issue 23. 70.

${ }^{860}$ GoOdMAN, ERIC J.: A National Identity Crisis: The Need for a Federal Right of Publicity Statute. DePaul J. Art, Tech. \& Intell. Prop. L. 1999. Vol. 9. 227.

${ }^{861}$ IND. CODE ANN. § 32-13-1-8.

${ }^{862}$ OKLA. STAT. tit. $12, \S 1448(\mathrm{G})(1983)$

${ }^{863}$ LUTHER, 2009. 172.
} 
vonatkozásainak ködös kontúrjaival szemben. ${ }^{864} \mathrm{~A}$ törvény által meg nem határozott védelmi idő azonban elindíthat egy hasonló folyamatot a média részéről, mint amit a „rendőrképmás” tekintetében a rendőri szakszervezetek tüntetése-ügy ${ }^{865}$ jelentett, s így a magánszereplők szándékosan kényszerítik a bíróságokat a jog által nem szabályozott kérdésben való egyértelmủ állásfoglalásra. Amennyiben a jogalkotó a védelem idejét szabályozni szeretné, úgy azt kell eldöntenie, meddig terjedjen a kizárólagos jog, és mikor kezdődjön a szabad felhasználás. Egy arany középutat keresve a jogosult halálát követő 20 év lehet ideális, amely után a személyiségi jegyek vagyoni érdekkörü felhasználása közkinccsé válhat. Ennek meghatározása nemcsak a szükebb értelemben vett személyiségi jog szempontjából lenne jelentős, hanem abból a szempontból is, meddig szükséges elhunyt híres személyek nevének és képmásának védjegykénti bejegyzéséhez az örökösök (hozzátartozók) hozzájárulása, hiszen ennek a kérdésnek a megválaszolása is ezen az anyagi jogi szabályon nyugodna.

6. A vagyoni személyiségi jog más módon történő megszünése

A vagyoni személyiségi jogra való jogosultság megszünhet még elévüléssel is. Ez az alanyi jog igényállapotára szorítkozik, mivel abszolút jogról beszélünk egyébként, így az nem évül el, védelme addig biztosított, amíg a jogalkotó az oltalmazni rendeli (ez a védelmi idő). A vagyoni személyiségi jog bitorlása esetén az elévülési idő az általános szabályok szerint alakul, és független az eszmei javakra vonatkozó elévülési szabályoktól, lévén más alanyi jogról van szó. Így az eszmei érdekektől, az általános személyiségi jogból származó igényektől függetlenül ${ }^{866}$ a vagyoni személyiségi jog elévülése annak vagyonjogi jellegéből következik.

Az elévülés mellett releváns lehet még a belenyugvás, amely már korábban is megjelent a személyiségi jog joggyakorlatában jogszüntető okként. Belenyugvásról akkor beszélünk, ha a személyiségi jog jogosultja öt éven át megszakítás nélkül eltürte személyiségi jegyének kereskedelmi, reklámcélú használatát, noha tudomása volt erről a használatról. Ennek az lesz a következménye, hogy a továbbiakban nem léphet fel e más személy általi használattal szemben. Ennek relatív hatálya van, csupán a személyiségi jogon kívüli személyre vonatkozik a belenyugvás. A harmadik személyek általi használat tekintetében az alanyi jog ugyanúgy igényállapotba kerül.

864 BEUTHIEN, 2003. 1220.

${ }^{865}$ BH 2018. 248. [32] („Rendvédelmi szakszervezetek tüntetése”)

${ }^{866}$ Ehhez lásd CSEHI ZOLTÁN: Elévülés a személyiségi jogok rendszerében, az új Ptk.-ra tekintettel. In Medias Res 2016/1. 
A belenyugvás személyiségi jogba való beszüremlése a rendszerváltozással összefüggő névjogi jogsértések vonatkozásában érhető leginkább tetten. ${ }^{867}$ Ebben a tekintetben a Legfelsőbb Bíróság valószínűleg nem a nemzetközi trendekben fellelhető új, alanyi jogot megszüntető körülményeket értékelte, hanem elsősorban a vagyoni értéket felmutató védjegyjog analógiájára alkalmazta ezt a megszünési módot az egyébként vagyoni érdekkört is felmutató személyiségi jogi esetekben.

7. Az alapjogi védelem jellege

A vagyoni személyiségi jog eszmei oldala az alkotmányjog szempontjából mint az emberi méltóság és az ahhoz kapcsolódó alkotmányos általános személyiségi jog keretében kerül figyelembevételre. A vagyoni személyiségi jog vagyoni vonatkozásai azonban ezen a körön kívül esnek, ennek megsértése, elvonása, törvényi korlátozása, mint amilyet a Ptk. 2:50. § (2) bekezdése jelent, az alkotmányos tulajdon fogalmával hozható kapcsolatba. Götting szerint a gazdasági személyiségi jog nyitott törvényi tényállása kifejezésre juttatja azt, hogy a név és a képmás mellett más személyiséget megjelölő jegyek is vagyonjogi tartalommal rendelkezhetnek, amelyek esetén a tulajdonhoz való alkotmányos alapjog védelme szintén igény bevehető. ${ }^{868}$ A BVerfG a Blauer Engel II. döntésében nem foglalkozott a kérdéskörrel. ${ }^{869}$ Később, egy másik döntésében azonban a Grundgesetz 14. cikke alapján a vagyoni összetevők alapjogi védelmét megállapította. ${ }^{870} \mathrm{~A}$ német jogirodalom ebben a tekintetben is a szerzői jog monizmusának analógiáját látja. ${ }^{871}$ Egy ügyben az EJEB egy személyiségi jogi (névjogi) igényérvényesítéssel kapcsolatos domainvitában a tulajdonhoz való jog sérelmét állapította meg. ${ }^{872}$ Szellemi tulajdonjog alapjogi védelme szintén a tulajdon alkotmányos védelméhez kapcsolódik. ${ }^{873}$ Figyelembe véve azt is, hogy a vagyoni személyiségi jog önállótlan vagyoni immaterális jogkénti besorolása szintén egyfajta szellemi tulajdonjogot hoz létre, célszerü a vagyoni személyiségi jog védelmét is a

\footnotetext{
${ }^{867}$ BH 1990. 255. („RORÁRIUS”); Legf. Bír. Pf. IV. 21007/1992 („Láng”); BH 1993. 350. („Herz”); BH 1994. 21. („Rácz”); BH 1997. 467. (,Pick”).

${ }^{868}$ GÖTTING, 1995. 139.

${ }^{869}$ NJW 2006, 3409 - Der blaue Engel II.

${ }^{870}$ ZUM 2009, 479.

871 SCHERTZ, CHRISTIAN - REICH, HELGE: Vermögensrechtliche Ansprüche bei unzulässiger publizistischer Verwendung von Bildnissen aus der Privatsphäre. In: Götting, Horst-Peter - LauberRönsberg, Anne (szerk.): Aktuelle Entwicklungen im Persönlichkeitsrecht. Nomos, Baden-Baden, 2010. 39.

${ }^{872}$ EJEB 25379/04; 21688/05; 21722/05; 21770/05 - Paeffgen GmbH v Germany.

${ }^{873} 1338 / \mathrm{B} / 1992$. AB hat.
} 
tulajdonjog védelmi körébe vonni. Nemzetközi kapcsolószabály tekintetében már szintén láttunk példát arra a hazai joggyakorlatban, hogy az iparjogvédelmi jogokra vonatkozó utalónormát alkalmazta a bíróság a személyiségi jog kapcsolószabálya helyett, annak ellenére, hogy (vagyoni vonatkozású) személyiségi jogi jogsérelemről volt szó. ${ }^{874}$

A Szövetségi Alkotmánybíróság azt állapította meg, hogy a személyiségi jogok vagyoni vonatkozásainak magánjogi elismerése nem ellentétes az alkotmányjogi szabályokkal, de nem vonta azt az alapjogi általános személyiségi jog körébe. ${ }^{875} \mathrm{~A}$ spanyol alkotmánybíróság a képmáshoz füződő vagyoni jogot nem tekinti az alapjog alkalmazási körébe tartozónak azon okból, mert az alapjog csupán az eszmei érdekeket védi, amelyek az emberi méltósággal vannak kapcsolatban. ${ }^{876}$

\section{Részösszegzés}

A korábbiakban részletesen vizsgált tárgyiasulás mint a személyiségi jog eszmei szférájának a fizikai vagy más eszmei világokkal való kapcsolatba jutásának leírására szolgáló jogi tény, ebben a formájában önállóan nem alkalmas a személyiségi jog vagyoni minőségének egyedüli mérésére. A személyiségi jogi részjogosultságok tárgyiasulásuk által nem kerülnek ki minden esetben az eszmei, erkölcsi érdekkörből, így ez inkább csak a vagyoni értékminőség vizsgálatának előfeltételeként értelmezhető. A tárgyiasulás által ugyanakkor a személyiségi jogok, a személyiségi jegyek a személyiségtől részlegesen elválnak, és ez a részleges elválás az, amely a forgalomképes, és ezáltal örökölhető, dologi hatállyal átruházható személyiségi jogi vonatkozások létjogosultságát mind dogmatikailag, mind pozitív jogilag meg tudja alapozni.

Az egyes tárgyiasítható személyiségi jogi jogosultságok tekintetében, a személyiségi jogtól való elválásuk lehetőségének eredményeképpen az vizsgálandó, hogy a jogosultnak van-e afelett jogi érdeke, azaz megilleti-e a jogtárgyra vonatkozó

\footnotetext{
874 ÍH 2014.58. („facebook.hu”); SCHULTZ MÁRTON: Azonosnevüség és domainnevek. In Medias Res 2018/2. 360-361.

${ }^{875}$ NJW 2006, 3409 - Blauer Engel II.

876 TREBES, ANJA: $\S$ 68. Spanien. In: Götting, Horst-Peter - Schertz, Christian - Seitz, Walter (szerk.): Handbuch des Persönlichkeitsrechts. CH Beck, München, 2008. 1167. [44]; STC 81/2001 (26.03.2001) - Emilio Aragón.
} 
alanyi jog. Ez mind a személyiség külső megjelölésének eszközei, mind az ismereti személyiségi jegyek vonatkozásában releváns. Míg a személyiségi jog vonatkozásában, annak elválaszthatatlansága okán, egyértelmü a jogosult érdeke, addig e jogok tekintetében ez nem egyértelmüen megállapítható. Azt kell vizsgálni, hogy a jogosultnak van-e joga rendelkezni a személyiségi jegy felett, illetve, hogy a jogellenes tárgyiasítás az ő érdekkörét, jogi érdekét sérti-e.

A vagyoni értékminőség elismerése szempontjából a jogosult személyének széles körü ismertsége, esetleges közszereplöi minősége csekély szerepet játszik. Ennek oka az, hogy a személyiségi jog tárgyiasulása és vagyoni értékminősége akkor is kimutatható, ha publicitás, ismertség korábban az adott személyiséggel kapcsolatban fel nem merült. A jogellenes tárgyiasítással a személyiségi jog ennek hiányában is vagyoni értékkel bír. Ez különösen jelentős a más jogintézmények formájában történő tárgyiasítás tekintetében (védjegy, kereskedelemi név, cégnév, domainnév), de ugyanígy fellelhető a név, képmás sui generis tárgyiasítása tekintetében is. Ennél fogva a személyiség ismertségének, egy esetlegesen kialakult arculatnak (a vagyoni személyiségi jognak mint függő jogi helyzetnek) ebből kizárólag a jogkövetkezmények vonatkozásában van jelentősége, az az elmaradt díjazás, illetve a jogsértéssel elért vagyoni előny bírói megállapítása során az érték meghatározása tekintetében vehető figyelembe.

A vagyoni értékminőség megállapítására akkor kerülhet sor, ha a személyiségi jegyet vagyoni érdekkörben használják fel, tárgyiasítják. Ebben a tekintetben a jogosult rendelkezési joga elöfeltétel, a vagyoni érdekkörben történő felhasználás kvalifikált jogi érdeket feltételez. Ez a jogi érdek vagyoni érdek, ezzel válik a személyiségi jegyen fennálló jog vagyoni joggá. A vagyoni érdekkörben történő felhasználás alapvetően a személyiségi jegyek tárgyiasulásuk és tárgyiasításuk által a kereskedelmi fogalomban, az áruforgalomban való részvételükhez köthető. Ennél fogva a jogosult vagyoni érdekkörébe tartozik a személyiségi jegy felhasználása reklámcélra, termékekkel, szolgáltatásokkal való kapcsolatba hozása, üzletjelzőként való használata, hírértékének kihasználása.

Egy vagyoni személyiségi jog elismeréséhez az szükséges tehát, hogy a személyiségi jog egyes vonatkozásainak tárgyiasulását elismerjük, és e tárgyiasulás nem teljes, az eredeti jogosulttal való kapcsolata fennmarad. Ennek oka, hogy a személyiségi jegy tárgyiasulása után továbbra is vonatkozik e személyre is, amelynél fogva ennek továbbra is állhat fenn jogos érdeke ezen. 
A vagyoni személyiségi jog körülhatárolásával és elismerésével számos kérdés megválaszolatlan marad. A vagyoni személyiségi jog a személyiségi jogból jön létre annak kvalifikált felhasználásával, többlettényálláselemek megvalósulásával. A vagyoni személyiségi jog megszerzése ennél fogva származékos jogszerzés. A jogszerzésnek ez a származékos jellege az, amely a személyiségi jogtól való részleges elválás értékelése. A tárgyiasulással ugyanis a személyiségi jegy a személyiségi jogtól elválik, ez az elválás ugyanakkor részleges, amely megteremti annak a lehetőségét, hogy a személyiségi jog jogosultja fellépjen akkor, ha a személyiségi jegyét jogellenesen használják fel. A vagyoni személyiségi joghoz képest a(z általános) személyiségi jog alkalmazása szubszidiárius, mert az általánosabb, kevésbé konkretizált. A vagyoni személyiségi jog kielégíti azokat a feltételeket, amelyek a szellemi alkotási, önállótlan vagyoni immateriális jogi kvalifikációhoz szükségesek. Ez rámutat arra is, hogy a személyiségi jegyek, a tárgyiasítható személyiségi jogi szféra a személyiség legbelső magjától távolabb kerül, ezáltal átruházható, örökölhető jogosultságként funkcionálhat.

A tételes magyar jog nem ismeri el a személyiségen fennálló vagyoni érdekek örökölhetőségét. A német jog példáján láttuk, hogy ez a bírói gyakorlatban 10 év, az USA tagállamaiban pedig igen eltérő védelmi idők kerültek meghatározásra 10 évtől 100 évig. Álláspontom szerint egy 20 éves védelmi idő lenne idális, azonban elsősorban a jogalkotónak kellene mérlegelnie abban a kérdésben, hogy az örökösök számára biztosít monopóliumot a személyiségi jegyek vagyoni felhasználása felett, vagy ennek kisebb teret biztosítva rövid idő után bárki számára lehetővé teszi a kereskedelmi reklám célú üzleti felhasználást is. 
„A kir. itélötábla már más hasonló perekböl tudja, hogy hasonló egyszerü fényképek leközlésének átengedéséért a hírlapok a fényképészeknek 3-5 pengö körüli összeget szoktak fizetni."

Budapesti Kir. Ítélőtábla 1932. IX. 19. P. XIV. 2755.

\section{8. § A VAGYONI ÉRDEK MEGSÉRTÉSE ESETÉN ALKALMAZANDÓ JOGKÖVETKEZMÉNYEK}

\section{Bevezetés}

A korábbiakban már megvizsgáltam a jogirodalom által a személyiségi jog vagyoni értékminőségére vonatkozó német szabályanyagát, illetve a BGH-nak a vagyoni értékminőséggel összefüggő fontosabb döntéseit. Ezen túl a magyar jog vonatkozásában arra a következtetésre jutottam, hogy az egyes személyiségi jegyek jogosulatlan tárgyiasításával a vagyoni személyiségi jog jogosultja vagyoni érdekkörében sérelmet szenved. Az általános személyiségi jog jogkövetkezményein túl a kártérítés és a vagyoni előny átengedése alkalmas a magánosok vagyonában beállott értékeltolódások kiegyenlítésére. Ezzel összefüggésben a vagyoni jogkövetkezmények mint a személyiségi jog megsértésének elöfeltételeit vizsgálom. Ezt követően a német jog megoldásait, majd a magyar polgári jog előbb említett két szankcióját. Jelen fejezet vizsgálata végső soron arra irányul, mennyiben ismeri el a magyar hatályos jog a jogkövetkezmények által a személyiségi jogok vagyoni értékét, illetve mennyiben alkalmas a kielégítö jogvédelemre a Ptk. rendszere.

I. Az általános személyiségi jog megsértéséből eredő jogkövetkezmények

1. Az alanyi jog elismerésével járó jogkövetkezmények

A személyiségi jog alanyi jogként való elismerésének értelme az volt, hogy a magánosok e jog megsértése esetén bírói jogvédelmet igényelhettek, azaz a jogsértővel szemben valamiféle követelési joguk támadt. Ez a követelési jog elsősorban az abszolút jogi jellegből eredő szankciókra koncentrált. A kizárólagos jelleg, a kizáró 
(abszolút) jog ugyanis egyfajta uralmi jogot (Herrschaftsrecht) biztosít az alanyi jog jogosultjának, attól függetlenül, hogy ezt érdekként vagy jogi hatalomként fogjuk fel. Ennek megfelelően lehetőség van a személyiségi jog megsértése esetén a jogsértés megállapítására (actio quasi confessoria), ezen túl a dologi jog mintájára a jogsértés abbahagyására és az eltiltásra (actio negatoria). ${ }^{877} \mathrm{Az}$ abbahagyásra irányuló per célja az in rem jellegből fakadóan az, hogy a jogsértő a jogellenes cselekményt hagyja abba, az eltiltásra irányuló per pedig akkor eredményes, ha további jogsértéstől lehet tartani, ezért a bíróság a jogsértőt a további jogsértéstől tiltsa el. ${ }^{878}$ Ezen túl sajátos jogkövetkezményként jelentkezett és alakult ki az eszmei, erkölcsi kár megtérítése, mint „a személyi jog kártérítése”, ez azonban már létező jogalapon, a kártérítési jog körében értékelte a személyiség sérelmét. Az előbb említett követelési jogok, a magyar jogintézményi fejlődés során elsőként a névjog vonatkozásában jelentek meg önálló jogalapon.

A személyiségi jog tárgyiasulását, a tárgyi valósággal való kapcsolatba lépését értékeli az a jogkövetkezmény, amely alapján a jogosult kérheti, hogy a jogsértő valamely dolog jogsértő jellegét szüntesse meg, vagy ha ez nem lehetséges, úgy a jogsértő dolgot semmisítse meg. Ezzel kapcsolatban a FÍT kiemelte, hogy a fényképfelvétel negatívjának jogszerü megszerzése esetén nem kérhető a negatív kiadása, ha annak megszerzése jogszerü volt. A bíróság szerint csak a jogsértést megvalósító tárgyiasult dolog kiadását, megsemmisítését lehet kérni, amely a konkrét ügyben a plakátokat és a reklámanyagot jelenti. ${ }^{879}$ Ezzel összefüggésben kiemelte, hogy a fényképfelvételnek az elkészítése, negatívra történő rögzítése jogszerü volt, és az így keletkezett negatív képmás a képet készítő fényképész tulajdonából nem került ki, így afelett a jogsértőnek nem is volt rendelkezési joga. ${ }^{880}$

A személyiségi jogok megsértése esetén azonban nem minden esetben egy szankció alkalmazása járul hozzá a felek érdekhelyzetének helyreállításához. Ennél fogva a tényállás szintjén generálklauzulát tartalmazó személyiségi jog esetében több jogkövetkezmény együttes alkalmazásat is lehetséges. A személyiségi jog védelme ennél fogva komplex jellegü. ${ }^{881}$ „Ugyanazon személyiségi jog megsértése is többféle

\footnotetext{
${ }^{877}$ Ennek megfelelően alakította ki a német jogalkotó a BGB 12. §-a szerinti névjogot is.

${ }^{878}$ A jogellenes névhasználat miatt keresettel csak akkor lehet fellépni, ha a jogellenes névhasználat szándékosnak mutatkozik, vagy annak megismétlésétől lehet tartani. (K. P. IV. 48/1928.)

${ }^{879}$ FÍT BDT 2009. 24. („Budapesti Öszi Fesztivál”)

${ }^{880}$ U.o. Hasonló BGH 1979, 425 - Paul Dahlke.

${ }^{881}$ AszTALOS, 1966. 279.
} 
módon történhet. Ennek megfelelöen - a sértő magatartásának felróhatósága hiányában is - egymás mellett is, többféle, egymást kiegészítő, komplex szankció alkalmazható. Az alkalmazható objektív szankciók azonban nemcsak a jogsértés minősége szerint adnak lehetőséget a szankciók halmozására, hanem a személyiségében megsértett alany igénye szerint is." ${ }^{882}$ A személyiségi jogok tekintetében alkalmazandó megállapítási kereset kumulatívan is előterjeszthető negatoria actio mellett is, mert ezt a jogosult nem a jogai megóvása érdekében veszi igénybe. ${ }^{883}$

\section{A nem vagyoni kár megtérítése}

A kártérítési joggal összefüggésben kezdte kialakítani a joggyakorlat a nem vagyoni károk értékelését a személyiséggel összefüggő sérelmek tekintetében. Kezdetben kifejezetten vagyoni kárnak tulajdonítva az elszenvedett eszmei, erkölcsi sérelmet. ${ }^{884}$ Ezt követően már önállóan, a vagyoni kár mellett állapította azt meg a bíróság, jóllehet a vagyoni kár meglétét az igény megvalósulásának előfeltételeként támasztotta. Ezután indult el önálló útjára a nem vagyoni (eszmei) kártérítés mint kompenzációs kártérítés a személyiségi jogi sérelmek orvoslása tekintetében. ${ }^{885} \mathrm{~A}$ nem vagyoni kár jogintézményének 1953-ban történő megszünését követően ${ }^{886}$ azt az 1977-es Ptk. novella élesztette újra. ${ }^{887}$

A nem vagyoni kár megtérítése, jóllehet a kártérítési jogon belül helyezkedik el mind a régi magánjogban, mind a későbbi írott jogban, nem a vagyoni kár megtérítésére irányult, így ténylegesen nem a vagyonban bekövetkezett értékeltolódásokat hivatott kompenzálni. Ennek megfelelően a Ptk. már sérelemről és

882 U.o. 293.

${ }^{883}$ PETRIK, 1992. 232.

${ }^{884}$ „Bírói gyakorlatunk azonban a legújabb időkig, mint már említettük a kártérítési kötelezettséget az erkölcsi károk megtérítésére nem terjesztette ki. [...] Felperes leányos szüzessége alperesek cselekménye által érintve lett, ezáltal bizonyos mérvben jövőjére is kiható erkölcsi kárt is szenvedett. Bár a nőnek a szüzesség nem feltétlen kelléke, a mindennapi tapasztalat bizonyítja, hogy a szüzességét vesztett leány a megvetés bizonyos nemének ki van téve, és férjhezmenetele, amely a nőnek természetszerü hivatása, meg van nehezítve" DEZsö, 1917. 336.

885 „Bírói gyakorlaton alapuló szabály szerint a testi sérülést szenvedő fél a sértés okozójától, ha testi sértésböl anyagi kára nem is származott, amennyiben az eset körülményei szerint méltányosnak jelentkezik, erkölcsi kár megtérítéséül vagyoni elégtételt követelhet.” C. 977/1914.

${ }^{886}$ Legfelsőbb Bíróság III. sz. Polgári Elvi Döntése (1953).

${ }^{887}$ 1977. évi IV. tv. 354. § „A károkozó köteles megtéríteni a károsult nem vagyoni kárát, ha a károkozás a károsultnak társadalmi életben való részvételét, vagy egyébként életét tartósan vagy súlyosan megnehezíti, illetőleg a jogi személynek gazdasági forgalomban való részvételét hátrányosan befolyásolja". 
nem nem vagyoni kárról beszél, ${ }^{888}$ és ekként értékeli a személyiséget ért erkölcsi, eszmei jellegü sérelmeket. Az eszmei érdekek sérelme ennek ellenére kialakulásában szoros összefüggést mutat a kártérítéssel. Ez a német jogon is meglátszódik, ahol a bírói gyakorlat a vétkes felelösség generálklauzulájára, ${ }^{889}$ a BGB 823. § (1) bekezdésére támaszkodva alakította ki a személyiségi jogok megsértése esetén igénybe vehető nem vagyoni érdekek kompenzációját (billige Entschädigung in Geld). ${ }^{890}$

A Legfelsőbb Bíróság 1953-ban a személyiség vagyonban kifejezett értékének tilalmára alapította a nem vagyoni kártérítés megszüntetésének legitimációját. Ezt a helytelen álláspontot képviseli Asztalos is, mert szerinte „a személyiségi jogok megsértésénél a személyiség védelmére szolgáló kártérítési szankció [...] abban különbözik a burzsoá szemlélettől, hogy a nem vagyoni javak áruraváltását, és ennek következtében kártérítésben részesítését nem teszi lehetővé". ${ }^{891}$ A személyiségi jog vagyoni értékének kifejezésére a nem vagyoni kár, illetve sérelem nem alkalmas, hiszen az kompenzációs célt szolgál. Erre a vagyoni kárból, a vagyoni hátrányból lehet következtetni, és ez a személyiségi jogok két világháború között is jelentkező vagyoni felhasználásával függ össze.

\section{A vagyoni kár és a személyiségi jog kapcsolata}

A vagyoni kár kártérítés keretében való megtérítése az eszmei érdekeket védő személyiségi jogvédelemtől idegen. Ennek az oka az, hogy a kártérítési igényhez szükséges vagyoni értékcsökkenésröl nem beszélhetünk, hiszen az csak a vagyonba

\footnotetext{
${ }^{888}$ E fogalmi megkülönböztetést támogatja Almási Antal is 1907-ben. „Megjegyzendö, hogy az optk. a maga naiv egyszerüségében itt alighanem jobb kifejezésekkel élt, mint a magánjogi T., mely az elégtételt nem vagyoni kárnak minősiti, holott a kár nyilvánvalóan vagyonjogi fogalom és a fájdalomdíj vagy elégtételi összeg jóformán tilos cselekmény kiegyenlítő és sujtó következményeinek határterületét képezi, mert a fájdalomdíj létesítésével a törvény elismeri, hogy a személyjogi tilos cselekménynyel az áldozatul esett sértetten többé-kevésbé helyrehozhatatlan értékcsorbulás történt hogy ezért a sértöt az okozott vagyoni kár megtérítésén felül még külön magánjogi büntetéssel is kell sujtani." ALMÁsI ANTAL: Tilos cselekmény a magánjogban. Grill, Budapest, 1907. 247-248.

${ }^{889}$ A BGB más szakaszhelyei alapján is lehetőség volt a nem vagyoni sérelmek orvoslására. Így a BGB 253. §-a alapján sérelemdíj (Schmerzensgeld) volt követelhető abban az esetben, ha a törvényben felsorolt jogokat megsértették. Ehhez hasonlóan a BGB 826. §-a alapján a jóerkölcsbe ütközö károkozásra hivatkozva a személyiségi jogi sérelmek orvoslásra kerülhettek.

${ }^{890}$ Ehhez lásd GÖRÖG MÁRTA: A fájdalomdij mértékét befolyásoló körülmények összehasonlitó elemzése a német joggyakorlat elốtérbe helyezésével. Jogelméleti Szemle 2001. 4. sz.; GöRÖG MÁRTA: Az általános személyiségi jog megsértésének fájdalomdíjjal való orvoslása. Jogelméleti Szemle 2002. 4. sz.

${ }^{891}$ AsZTALOS, 1966. 294.
} 
tartozó dolgok és javak tekintetében merülhet fel. Az eszmei érdekeket védő (általános) személyiségi jog nem ilyen, a személyiségi jogon ugyanis az uralkodó kánon szerint vagyoni érdek nem áll, nem állhat fenn. Asztalos is azon az állásponton van, hogy „a személyiség nem vagyoni jellegénél fogva a személyiséget ért vagyoni kár megtéríttetése - a megfelelő feltételek fennállása mellett - nem közvetlenül a személyiség konkrét sérelmének reparálására szolgál, hanem a személyiséget ért sérelem másodlagos és vagyoni következményeinek reparálására. A polgári jogi módszerü szankcionálás a személyiség épségének megsértése esetén is csak az ennek következtében beálló vagyoni károk reparálására szolgál". ${ }^{892}$ Törő szerint is a kártérítésre elsősorban ,akkor van lehetőség, ha a személyiségi sérelem közvetetten vagyoni kárt okozott, illetve vagyoni eszközökkel csökkenthető vagy kiküszöbölhetö". ${ }^{893}$ A személyiségi jogon fennálló eszmei érdekek ugyanis csak a következménykárokat engedik meg, így például a gyógyítás, kezelés költségét. Ugyan Törő a hírnévrontást és a titoksértést példának hozza a közvetlen vagyoni kárra, ${ }^{894}$ ez azonban már dogmatikailag a személyiségi jog vagyoni értékminőségének elismerését jelenti, jelentené.

4. A vagyoni jogkövetkezmények alkalmazhatóságának előfeltétele

A vagyoni jogkövetkezmények alkalmazásának előfeltétele tehát az, hogy a jogtárgyon vagyoni érdek álljon fenn. Ilyen vagyoni érdek a vagyoni jogokon áll fenn. Ilyen vagyoni jog elsősorban a tulajdonjog, más dologi jogok. Ilyen vagyoni jog a vagyoni személyiségi jog azzal, hogy e jogon belül a vagyoni érdekek az eszmei érdekekkel keveredve jelennek meg.

A vagyoni érdekkör megsértése azzal írtható le, hogy a jogellenes tárgyiasítással a jogsértő a személyiségi jegyet jogosulatlanul használja fel, és ezzel a jogosult vagyoni érdekkörét sérti, amely a jogsértő oldalán jogosulatlan vagyoni előnyt is eredményez. Ebből kifolyólag bármely személyiségi jegy vagyoni érdekkörben történő jogosulatlan felhasználása a vagyoni személyiségi jog sérelmét eredményezi. Médiajogi szempontból azonban szinte kizárólagosan az ismereti személyiségi jegyek sérelme az, amely releváns lehet. Ide sorolható a magánélet, a magántitok védelme,

\footnotetext{
892 AsZTALOS, 1966. 295.

${ }^{893}$ TÖRŐ KÁROLY: A személyiség jogi védelmének polgári jogi eszközei. In: Petrik Ferenc (szerk.): A 894 U.o. személyiség jogi védelme. KJK, Budapest, 1992. 184.
} 
különösen az életkép jogának megsértése. A médiajog szempontjából a személyiség külső megjelölésére szolgáló személyiségi jegyek mellékesen, az ismereti személyiségi jegyekhez kapcsolódva jelennek meg, és elsősorban - bár nem kizárólagosan - akkor válnak relevánssá, ha a jogosulatlan tárgyiasítás tekintetében a magánéleti vonatkozások többletelemként jelentkeznek a tényállás tekintetében.

Fontos körülmény az, hogy a jogalkalmazóknak, illetve a bírói jogvédelmet igénybe vevőknek tisztában kell lenniük azzal, hogy a személyiségi jog jogellenes tárgyiasításával történő megsértése esetén az esetek legnagyobb többségében a felhasználás a vagyoni érdekkörben történik, a jogsértő a jogosult személyiségi jegyét kereskedelmi, reklámozási célból használja fel. Ezekben az esetekben a jogosultnak tehát nem a hagyományos, objektív jellegü szankciók azok, amelyek kizárólagosan rendelkezésére állnak, hanem emellett a vagyoni előny jogosulatlan átengedése is kérhető, illetve kártérítés mint szubjektív szankció. Ez a szemléletmódbeli váltás a joggyakorlat részéről szükséges ahhoz, hogy a vagyoni értékeltolódások valóban kiküszöbölhetőek legyenek. Ez a folyamat nagyon hasonló a személyiségi jog elismerésekor jelentkező bírói gyakorlathoz, amelyben a bíróság a személyiségi jogok megsértése esetén az abszolút jellegből fakadó jogkövetkezmények alkalmazását megállapíthatónak látta. Míg ott maga az alanyi jog léte volt vitás, ${ }^{895}$ úgy most az alanyi jog minősége az, amely az alkalmazandó és kérhető jogkövetkezmények tekintetében növeli a jog megsértése esetén az anyagi „kénytetőség” körét.

\section{A vagyoni szankciók funkciója és szükségessége}

A vagyoni szankciók alkalmazásának szükségessége alapvetően nem jogi indokokkal adható meg, hanem gazdaságiakkal. A korábbi ítéleteknek, az ítélkezési gyakorlatnak és a jog értékrendjének a jogsértőkkel szemben kitüntetett szerepe van abban, hogy a piaci szereplök hogyan viselkednek. Ez lényegében az önkéntes jogkövetés és a jogsértés tekintetében azt jelenti, hogy a piaci szereplők, a médiavállalatok és gazdasági társaságok nem a jogos-jogtalan értékduál szerint mérlegelik

895 „Az egyén szabadsága, testi épsége, egészsége a közkeletű terminologia szerint nem annak jogosultságai ugyan, hanem csak előfeltételei a jogosultságok keletkezésének. Részünkről ezzel szemben minden jogilag védett érdekben egyúttal alanyi értelemben vett jogosultság elemeit véljük felismerni. A fogalomról különben vitatkozhatni, mit ehelyütt azért tartunk feleslegesnek, mert hiszen akár jogosultság is a szabadság, testi épség, becsület, akár pedig csak egyszerüen jogilag védett érdek, kötelességek ezekből mindenképen fakadnak, és a kötelességek tudatos megsértése mindenképen tilos cselekvés is leszen.” ALMÁsı, 1907. 156. 
cselekedeteiket, hanem a rentábilis-nem rentábilis értékduálja alapján. ${ }^{896}$ Menyhárd ezt úgy fogalmazza meg, hogy „,a profitorientált szervezetek számára a piaci müködési elvek mellett annak eldöntése, hogy a károkozó magatartást folytatják, vagy - vállalva a kisebb haszon lehetőségét - tartózkodnak a károkozó magatartástól, üzleti döntés" ${ }^{897}$ A gazdasági haszon és a jogkövető magatartás ugyanakkor csak egymást metsző halmazok, így előfordulhat, hogy az, ami rentábilis, sokszor jogsértő is. A személyiség minél teljesebb körü és hatékonyabb védelme azzal érhető el, ha a jogsértés által bekövetkező hátrány meghaladja a jogsértéssel szerezhető előnyöket. 898 Ezzel lényegében közelíthető a rentábilis és a jogszerü magatartás a piaci szereplők oldalán, és végső soron célja a személyiség védelme mellett a magánosok vagyoneltolódásának korrigálása is. Ahogy Sólyom László fogalmaz: „amilyen a veszély, olyannak kell lennie a védekezésnek" ${ }^{899}$

Müller szerint a kártérítési követelések érték-kiegyenlítő funkciója mellett azok megelőző, preventív funkciója is felértékelődik a sajtó és a média tájékoztatási igénye okán. ${ }^{900}$ A kártérítési igények tekintetében az eredeti állapot helyreállítása is releváns lehetne, azonban a gyakorlat azt mutatja, hogy a pénzbeli megtérítés áll az előtérben. ${ }^{901}$ Ennek az oka elsősorban az, hogy a pénzbeli kártérítés általános trendjével szemben más megoldások nem kellően csábítóak. ${ }^{902}$

Az európai jogrendszerek esetében hasonló az irány: egyrészről fiktív licenca díj, „a hozzájárulás ellenértéke”, elmaradt haszon és más hasonló elnevezésekkel licencia-analógia alapú védelem létezik (pl.: Franciaország, 903 Svájc, 904 Lengyelország ${ }^{905}$ ), másrészről pedig a jogsértéssel elért előny elvonására van lehetőség (pl.: Spanyolország ${ }^{906}$ ).

\footnotetext{
${ }^{896}$ Ehhez 1. POKOL BÉLA: Politikaelmélet. Társadalomtudományi Trilógia III. Századvég, Budapest, 2006. 16. sköv.

${ }^{897}$ MENYHÁRD, 2014. 208.

${ }^{898}$ MENYHÁRD, 2014. 207.

${ }^{899}$ SÓLYOM, 1985. 318.

900 MÜLLER, GERDA: $\S$ 50. Der Anspruch auf materiellen Schadensersatz. In: Götting, Horst-Peter Schertz, Christian - Seitz, Walter (szerk.): Handbuch des Persönlichkeitsrechts. C.H.Beck, München, 2008. Rn 2.

901 U.o. Rn. 29.

902 U.o. Rn. 30.

903 TREBES, 2019. § 59. Rn 77.

904 BOHNE, 2019. Rn 51.

905 TARGOSZ, 2019. Rn 57.

906 TREBES, ANJA: $\$ 64$ Spanien. In: Götting, Horst-Peter - Schertz, Christian - Seitz, Walter (szerk.): Handbuch des Persönlichkeitsrechts. C.H.Beck, München, 2019. Rn. 57.
} 
A vagyoni tartalom elismerése nem kizárólag a generálklauzula konkretizálását jelenti, hanem olyan jogkövetkezmények alkalmazásának a lehetőségét, amelyek a vagyoni, kereskedelmi érdek megléte nélkül nem lennének alkalmazhatóak. A személyiségi jogok a rendelkezés, átruházás, használati engedély adása és hasznosítás tekintetében pénzben kifejezhető értékkel bírnak, ez a vagyoni elem ahhoz vezet, hogy a hitelező és az adós között egy vagyoni értékeltoldódás következik be. Ha ez a vagyoneltolódás jogellenes, illetve nem szándékolt volt, úgy a kötelmi jog jogkövetkezményei megilletik a jogosultat, amely alapján meghatározott pénzösszeg fizetését követelheti. A német jogban, annak ellenére, hogy a személyiség védelmét a BGB szintjén nem tartalmazza, az absztrakt törvényszerkesztésnek köszönhetően a törvényben szabályozott jogalapok (Anspruchsgrundlage) specialitásuktól függően itt is igénybe vehetőek. $^{907}$

A poszt mortem személyiségi jog eszmei vonatkozásainak megsértése esetén csak abbahagyásra, eltiltásra, visszavonásra, helyreigazításra, illetve az eszmei kár megtérítésére lehet perelni. ${ }^{908}$ Az általános személyiségi jog eszmei vonatkozásainak megsértése kizárólag az abszolút jog tiszteletben tartásából erdő igények származnak, kártérítés azonban nem. ${ }^{909}$ Abban az esetben, ha a gazdasági tevékenységgel összefüggésben kereskedelmi célra használják a személyiségi jegyeket, úgy továbbra is kérhető a jogsértés abbahagyása, azzal azonban, hogy a jogosult döntése szerint halmazatban kártérítést is követelhet. Tehát ha kizárólag anyagi, kereskedelmi érdekek vezérlik a jogsértőt, a jogsértéstől való eltiltás ugyanúgy kérhető. ${ }^{910}$

A nem szándékolt vagyoneltolódások kiegyenlítésére egy úgynevezett háromfokú kárelszámolási rendszert alakított ki a német joggyakorlat (dreifache Schadensberechnung), 911 amely megmutatja, hogy milyen igények és jogkövetkezmények azok, amelyek a jogosultat megilletik. A vagyoni kár

907 A német didaktikában és részben a jogalkalmazási gyakorlatban is az igények vizsgálatának sorrendje a következő: 1. szerződéses igények (elsődleges követelés: teljesítés; másodlagos követelések: kártérítés, elállás stb.); 2. szerződésszerü igények (culpa in contrahendo, megbízás nélküli ügyvitel); 3. dologi, személyiségi jogi igények (tulajdoni per, tulajdonos-birtokos-viszony); 4. felelősség magánjogi tiltott cselekményből, BGB 823. §.; 5. jogalap nélküli gazdagodás, BGB 812. §. A vizsgálat szempontjából a 4. és 5. pont jön tekintetbe.

${ }^{908}$ FROMMEYER, 2002, 13, 18.

${ }^{909}$ NJW 2006, 605.

910 ZUM 2008, 793 - Kannibale von Rotenburg II.

911 Petersen, 2010. 273. DiEDERICHSEN, 2008. 1. 
elszámolásának három útja, amelyet a jogosult kérhet:

- konkrét tényleges vagyoni kár likvidációja (BGB 823. §),

- egy, az eset körülményeihez mért licencia díj követelése (BGB 812. §),

- a jogsértéssel elért előny kiadása a szerzői jog szabályai alapján. ${ }^{912}$

912 Staudinger/HAGER, § 823 Rn. C 290. 


\section{Kártérítés}

1. Kártérítés a BGB 823. §-a alapján

A BGB 823. § (1) bekezdéséhez szükséges az, hogy egy abszolút jogot sértsen meg a jogsértő, ez az abszolút jog jelen esetben az általános személyiségi jog vagyoni vonatkozásait jelenti, amely a törvényben az „egyéb jog” tényállási elem részeként értelmezendő. A kártérítési igénynek a személyiségi jog akkor lesz jogtárgya, ha vagyoni kár keletkezik. ${ }^{913}$ Ennek tulajdonképpen az az előfeltétele, hogy elismerésre kerüljön a személyiségi jog vagyoni értéke. Az igény megvalósulásához vizsgálni kell, hogy a cselekmény jogellenes és vétkes volt-e. A magánjogi vétkesség szempontjából az objektív gondatlanságfogalom az irányadó, amely akkor valósul meg, ha a jogsértés a kereskedelmi gyakorlat (Verkehr) szerint irányadó gondosság elmulasztásával valósul meg. ${ }^{914}$ A kártérítési igény és az alaptalan gazdagodás közötti leglényegesebb különbség ebböl a szempontból az, hogy az elöbbi a jogsértő szubjektív tudatát is vizsgálja, addig az utóbbi objektív, külső körülményekre, a külvilágban bekövetkező változásra és vagyongyarapodásra koncentrál kizárólagosan.

A vagyoni kár értékelésére a bírói gyakorlatban először nem az általános személyiségi jog elismerésével együttesen került sor, hanem korábban, a különös személyiségi jogokkal összefüggésben. A BGH már az 1956-os Paul Dahlkedöntésében világossá tette azt, hogy a személyiségi jogok megsértése vagyoni kiegyenlítő igényeket indukálhat, ez azonban nem volt hozzákapcsolva egyértelmüen a személyiségi jogok vagyoni értékminőségéhez. A konkrét esetben ez egyrészről az elmaradt licencia díj fizetésére vonatkozott, amelyet mind a jogalap nélküli gazdagodás, mind a deliktuális felelősség alapján lehetségesnek tartott a bíróság. ${ }^{915} \mathrm{~A}$ kártérítés akkor jelent meg egyértelmüen, amikor a bíróság az egyes személyiségi jegyek felett nem csupán hasznosítási jogot ismert el, hanem hogy e jogok örökölhetőek is. ${ }^{916} \mathrm{~A}$ kártérítési igénnyel szemben lép fel Beuthien abból az okból, hogy a BGB 252. §-a szerinti elmaradt haszon minden esetben fellelhetö, ez ugyanis azt feltételezné, hogy a jogosult minden esetben pénz ellenében értékesíti a

\footnotetext{
913 MÜLLER, 2008. Rn. 4.

914 MÜLLER, 2008. Rn 7.; BGHZ 113, 297, 303.; NJW 2003, 2311.

915 NJW 1956, 1554 - Paul Dahlke; NJW 2000, 2195 - Marlene Dietrich.

916 NJW 1999, 2195 - Marlene Dietrich.
} 
személyiségét, ez azonban nem így van. ${ }^{917}$

2. Kártérítés és a magyar jog

\section{a. Tapadó kár és következménykár}

A törvény a személyiségi jog megsértése esetére lehetővé teszi a kártérítés alkalmazását, ${ }^{918}$ ugyanakkor annak szabályai és alkalmazhatósága, illetve jogpolitikai célja tekintetében az indokolás részletes információt nem tartalmaz, a kártérítési jog általános szabályára utal csupán. ${ }^{919}$ Lábady Tamás a vagyoni értékcsökkenés szempontjából kiemeli, hogy a kártérítés során a vagyoni értékcsökkenés alatt a nem dologi, azaz a jogban bekövetkezett károkat is érteni kell. ${ }^{920}$ A vagyonban beállott értékcsökkenés szempontjából, mivel egy immateriális jogról van szó, elsősorban a jog térbeli és időbeli körülményektől független felhasználása által beállott értékbeli megfogyatkozása az, ami releváns. Ennek az értékcsökkenésnek az az alapja, hogy a jogosult a felhasználásra nem adott engedélyt. Menyhárd szerint a kártérítési jog keretében történő licencia-analógia alapú kárszámítás felveti azt a problémát, hogy a személyiségi jog alapvetően forgalomképes javakat feltételez. ${ }^{921}$ Azonban, ha a Ptk. lehetővé teszi a kártérítést és a jogsértéssel elért előny átengedését, akkor azzal a vagyoni jelleget is elismeri. Ha ugyanis ez nem így lenne, és a személyiségi jog nem vagyoni jog lenne kizárólagosan, úgy e jogkövetkezmények alkalmazására elvi, objektív okokból nem is lenne lehetőség, természetesen ide nem értve a következménykárokat, mint amilyen pl. a gyógyítási, kezelési költségek. Más oldalról azonban ilyen a jogalkotó objektív szándéka is, hiszen éppen a német megoldás mintájára helyezte el ezeket a jogkövetkezményeket. A probléma ebben a tekintetben csak az, hogy a Ptk. a forgalomképes személyiségi jogokról egy szót sem ejt. Az előbbi érv azonban rámutat arra, hogy egyes személyiségi javak forgalomképessége a Ptk. szerint is valóság, azt a törvény logikai ellentmondás-mentessége megköveteli. A

917 BEUTHIEN - SCHMÖLZ,1999. 4.

918 2009. évi CCX. tv. 2:92. §

919 GÁRDOS, 2009. 162.

${ }^{920}$ LÁBADY TAMÁs: Felelősség a szerződésen kívül okozott károkért. In: Vékás Lajos (szerk.): Szakértői Javaslat az új Polgári Törvénykönyv tervezetéhez. Complex, Budapest, 2008. 1123.

${ }^{921}$ MENYHÁRD, 2014. 222. 
forgalomképes személyiségi jogok törvényi hiányolása ilyen értelemben pozitivista értelmezést feltételez.

\section{b. Bírói gyakorlat}

A Ptk. előtti bírói gyakorlat egyébként meglepő módon mindezen dogmatikai fejtegetések ellenére bevonta a licencanalógia alapú kárszámítást a jogi értékelésbe. A probléma ebben a tekintetben meglátásom szerint inkább az, hogy a törvény nem szól a forgalomképes személyiségi javak milyenségéről, jogalkatáról, s ezzel tátongó hézagot hagy maga után, amelyet a jogi hasonszerüség (analogia juris et de jure) elve alapján egy vagyoni személyiségi jog mint önálló alanyi jog elismerése vagy szabályozása oldhat fel kielégítően. A korábbi bírói gyakorlat s valószínüleg az ez utáni is e problémák megválaszolása nélkül alkalmazza a kártérítést, jóllehet a jogalap tekintetében ez komoly aggályokat vet fel. A bíróság ezzel ugyanis nem ad választ arra, hogy az alkalmazott jogszabályhely, amely elméletileg nem vagyoni jogosultság, hogyan engedi meg az elmaradt szerződés ellenértékének kárként való értelmezését, ha forgalomképes vagyoni jog nem is sérült.

A kártérítési jog vonatkozó bírói gyakorlata kizárólag a régi Ptk.-hoz kapcsolódó bírósági döntésekből ismerhető meg, új ügy még nem lelhető fel. Fontos körülmény, hogy a régi Ptk. 339. §-a, az általános kártérítési klauzula ötvözte, egy normában tartalmazta a vagyoni és a nem vagyoni kár megtérítését. Sajnálatos módon, azon túl, hogy a vagyoni kárhoz kapcsolódó ügyek száma igen csekély, a joggyakorlat szenved attól, hogy a történeti tényállás szempontjából releváns nem vagyoni elemeket, sérelmeket kihangsúlyozza, és a személyt ért hátrányt kizárólag a nem vagyoni kártérítés szabályai alapján bírálja el. Ez ahhoz is vezet, hogy igen kevés az olyan bírói döntés, amely ténylegesen a személyiséget ért vagyoni (tapadó) károk tekintetében érdemi megállapításokat tesz. Ez a tendencia látható Lengyelországban is. Targosz mutat rá, hogy „sajnos sokszor arról van szó, hogy a pénzbeli elégtétel jogintézményét használják, ami dogmatikailag teljesen elhibázott lépés."922

Ettől az állásponttól a Ptk. már eltér, s koncepcionálisan külön, az eszmei, erkölcsi érdekek sérelmét sérelem és nem nem vagyoni kár formájában tartalmazza. Ezzel a változtatással lényegesen tisztább terepet hagy a bírói gyakorlatban a vagyoni

922 TARGOSZ, 2019. Rn. 57. 
hátrányok és a nem vagyoni sérelmek egymástól való elkülönítésének. A BGB ettől eltérően, mint fent látható volt, ennek a hatásától most is szenved, hiszen mind a deliktuális felelősség, mind a méltányos pénzbeli kártalanítás a BGB 823. § (1) bekezdésén nyugszik. A sérelemdíj önálló és különálló jogintézménnyé tételével remélhetőleg változás áll majd be. A Ptk. szabályait alkalmazó újabb bírói gyakorlat is kizárólag a tényállás oldaláról tekinti a névjog sérelmének a jogosulatlan kereskedelmi felhasználást, ${ }^{923}$ fontos azonban, hogy e mellett hatalmas szerep jut a tényállásnak, hiszen a felek közötti érdekek kiegyenlítése szempontjából a tényállás oldalán jelentkező elismert vagyoni értékbe való jogellenes behatások ezzel tudnak értékelésre kerülni.

\section{c. Vagyoni kár}

A vagyoni kár tekintetében az vizsgálandó, hogy a jogosult vagyona valamilyen módon csökkent-e. A károkozás az abszolút (vagyoni) jog megsértéséhez kapcsolódik, ilyen jog a vagyoni személyiségi jog, amelynek jogellenes tárgyiasítása alkalmas arra, hogy a jogosult vagyoni érdekkörét sértse. A kár tehát abban áll, hogy a jogosult a személyiségi jegye tárgyiasításához, és a kereskedelmi irányú felhasználásához nem járult hozzá. A kár elemei közül így az elmaradt vagyoni előnyre (lucrum cessans) helyeződik a hangsúly. A joggyakorlat körében kiemelkedő a Fővárosi Ítélőtábla aktfotó-döntése, amely az elmaradt licencia-díj megtérítését a kártérítés szabályainak alkalmazásával látta megtérítendőnek. A FÍT szerint „téves az alperes azon hivatkozása, miszerint a felperesnek kára, sérelme az alperesi magatartással összefüggésben nem jelentkezett, mert a fényképfelvételt kifejezetten nyilvános közlés céljából készítették. A felperes ugyanis a szerződéses szabadság elvének megfelelően szabadon dönthetett arról, hogy kivel, milyen feltételek mellett állapodik meg a képmásának a nyilvánosságra hozataláról. A felperes és az alperes között a kép közlésével kapcsolatosan semmilyen megállapodás nem jött létre". ${ }^{924}$ Hasonló álláspontra helyezkedett a Szegedi Ítélőtábla is az élesztőtabletta-ügyben: „tényként kezelendő, hogy az alperes jogellenes magatartást tanúsított azáltal, hogy a felperes képmását hozzájárulása nélkül felhasználta. Az ezzel okozati összefüggésben előállott hátrány bekövetkezte is nyilvánvaló, hiszen a képmás felhasználásáért a felperes

923 BDT 2018. 87. („kutatóintézet”)

924 BDT 2007. 171. (,aktfotó”) 
díjazásban nem részesült, holott, mint fotómodell képmása jogszerü felhasználásáért díjazásra igényt tarthatott volna". ${ }^{925}$ A jogirodalom más állásponton van, és a licenciaanalógia alapú értékcsökkenést a jogalap nélküli gazdagodás szabályai alapján látja megtéríthetőnek. Menyhárd szerint „kézenfekvő lehet abból kiindulni, hogy a gazdagodás értéke legyen az az összeg, amelyet a sérelmet szenvedett fél akkor kapott volna, ha szerződéssel megállapodik a gazdagodóval (sérelmet okozó féllel) annak a hozzájárulás hiányában jogsértő magatartásába (licencia-analógia)". ${ }^{926}$ Hasonló álláspontot foglal el Görög Márta. ${ }^{927}$ Mivel a vagyoni személyiségi jog fogalmát sem a jogirodalom, sem a bírói gyakorlat nem ismeri, így ebből kifolyólag az egyes személyiségi jogok jogellenes felhasználásából indul ki a bíróság. ${ }^{928}$ A védjegyjog alapján fizetendő licencia díj fizetése tekintetében a FÍT összemossa azt a jogsértéssel elért előnnyel, és az elért gazdagodás visszatérítése címén mindkettőt megítéli. ${ }^{929}$ Amennyiben a kártérítési igényből kizárjuk az elmaradt licencia díj fizetését, úgy kérdéses, hogy mi az, ami valójában kárként jelentkezhet.

A bírói gyakorlat szerint a személyiségi jegyek jogosulatlan kereskedelmi felhasználásával megvalósított tárgyiasításával előállt hátrányt bizonyítani nem kell, az nyilvánvaló abból az okból, hogy a jogosult díjazásban nem részesült, holott mint fotómodell képmása jogszerü felhasználásáért díjazásra igényt tarthatott volna. ${ }^{930} \mathrm{~A}$ bírói gyakorlat szerint a megrendelésre készült fényképek tekintetében a Szerzői Jogi Szakértő Testület szakvéleményének a beszerzése nem szükséges, azok felhasználása, illetve a hozzájárulás megadása az általános magánjog, a Ptk. alapján bírálandóak el. ${ }^{931}$

Az aktfotó-ügyben az elsőfokú bíróság a vagyoni kár megtérítésére irányuló igényt azon az alapon utasította el, hogy a felperes a vagyoni kár meglétét nem bizonyította. A felperes utalt arra, hogy a fényképfelvételének napilap címlapján történő jogellenes felhasználásával alperes megsértette személyiségi jogát. Ezt az alperes sem vitatta, sőt arra érdemben válaszolt, és a felperes által meghatározott

\footnotetext{
925 BDT 2015. 70. (,élesztőtabletta”)

926 MENYHÁRD, 2014. 221.

927 GÖRÖG MÁRTA: A nem vagyoni kártérités összege. In: Tanulmányok Dr. Besenyei Lajos egyetemi tanár 70. születésnapjára. SZTE, Szeged, 2007. 203.; GÖRÖG MÁRTA: A fájdalomdij mértékét befolyásoló körülmények összehasonlitó elemzése a német joggyakorlat elötérbe helyezésével. Jogelméleti Szemle 2001/4.

${ }^{928}$ Képmáshoz való jog tekintetében 1. BH 1995. 509.; BDT 2007. 171. („aktfotó”); BDT 2009. 24. („Budapesti Ôszi Fesztivál”); BDT 2015. 70. (,élesztőtabletta”), névviselési jogra 1. BDT 2018. 87. (,kutatóintézet”), jelmondatra 1. BH 2002. 261. („Jó estét! Jó szurkolást!”)

929 BDT 2008. 207. („Eredeti Pick Szalámi”)

${ }^{930}$ BDT 2015. 70. (,élesztőtabletta”)

931 BDT 2009. 24. („Budapesti Öszi Fesztivál”)
} 
összeget túlzott mértékűnek tartotta. ${ }^{932}$ A Budapesti Öszi Fesztivál-ügyben a felperes a fesztivál logójaként való felhasználásáért, a reklámanyagokban, internetes honlapon és plakátkiállításon való felhasználásáért 5.000.000. Ft. vagyoni kár megtérítését kérte. ${ }^{933} \mathrm{Az}$ élesztőtabletta-ügyben a felperes képmásának színes, ábrás védjegy formájában, élesztőtabletta csomagoláson, annak dobozán való feltüntetése tekintetében azt állította, hogy képmása felhasználását 3.000.000 Ft ellenérték fejében engedte volna meg. ${ }^{934} \mathrm{Az}$ elsőfokú bíróság a kártérítés éves összegét 700.000 Ft-ban állapította meg, így az érintett 6 év 3 hónapos időszak tekintetében $4.375 .000 \mathrm{Ft}$ kártérítés fizetésére kötelezte alperest, az ügyben eljáró ítélőtábla felróhatóság hiánya miatt az igény megvalósulását kizárta. ${ }^{935} \mathrm{Az}$ aktfotó-ügyben az alperes, aki napilapja címoldalán a jogosultról készült aktfotót engedély nélkül közölte azt hangsúlyozta, hogy a felperesről készített képfelvételek piaci ára 50.000-100.000 Ft között mozog, és a felperes által kért 350.000. Ft-os összeg túl magas. ${ }^{936} \mathrm{Az}$ elsőfokú bíróság egyébként csak a nem vagyoni kár megtérítését állapította meg 350.000 Ft értékben, az ugyanekkora értékü vagyoni kárigényt elutasította.

\section{d. Elvárhatóság}

A fényképek akár üzletszerü, akár nem üzletszerü közzététele időszaki lapokban a jogosult hozzájáruló nyilatkozatának megléte esetén jogszerü. Már a korábbi joggyakorlat is megkövetelte a kellő gondosság körében azt, hogy a fényképet közlő médium, sajtószerv a fénykép közlésének jogszerűsége tekintetében a hozzájárulást szerezze be. ${ }^{937} \mathrm{Az}$ elvárhatóság vizsgálatát a jogellenesség vizsgálata után kell elvégezni. A bírói gyakorlat szerint megfelel az elvárható magatartásnak az, ha az alperes a képet fényképarchívumból vásárolta, és e körülmény miatt nem várható el tőle az, hogy a fényképfelvételekre vonatkozó rendelkezési jogosultságot ellenőrizze, különösen, ha erre vonatkozóan a fotógyüjtemény tulajdonosa szerződéses nyilatkozatot is tesz. ${ }^{938}$ A Szegedi Ítélőtábla más álláspontra helyezkedett. Lényeges

\footnotetext{
932 BDT 2007. 171. (,aktfotó”)

933 BDT 2009. 24. („Budapesti Öszi Fesztivál”)

934 BDT 2015. 70. (,élesztőtabletta”)

935 BDT 2015. 70. („élesztőtabletta”), lehetséges: BDT 2018. 87. („kutatóintézet”)

936 BDT 2007. 171. (,aktfotó”)

937 Grill Dtár XXXI. 494. („vaselin”); Grill Dtár XXXII. 560. („,lemetszett lábak”); Grill Dtár XXXIII. 538. (,spiccelés”); Grill Dtár XXXIV. 423. (,ez a biztos tipp”).

938 BDT 2009. 24. („Budapesti Öszi Fesztivál”)
} 
különbség volt a tényállás szempontjából azonban az, hogy az adott ügyben nem a képmás sui generis jogellenes tárgyiasításáról volt szó, hanem a képmás felhasználására korábban védjegy formájában jogosultságot szereztek, s ezzel kapcsolatban került a képmás jogosulatlanul tárgyiasításra, és ez sértette a képmáshoz való jogot. A bíróság szerint a védjegy bejegyzésre került a védjegylajstromba, így az alperes alappal bízhatott a védjegy jogszerüségében, abban, hogy az más személyiségi jogát nem sérti. Ilyen körülmények között a termék gyártását, illetve forgalmazását megelőzően nem volt elvárható annak a felderítése, hogy kit ábrázol a grafika, nem kellett nyomoznia a fotó készítője után, és azt sem kellett feltételeznie, hogy a védjegy jogosulatlanul került lajstromozásra. ${ }^{939}$ Az ügyben eljárt elsőfokú bíróság szerint az alperes a kellő körültekintést elmulasztotta, amikor nem győződött meg arról, hogy a fényképfelvétel jogosultja a felhasználáshoz engedélyt adott-e, nem kutatta fel ennek érdekében a lehetséges szerződéseket, illetőleg a fénykép készítőjét. ${ }^{940}$

\section{Jogalap nélküli gazdagodás}

\section{Alaptalan gazdagodás a BGB 812. § alapján}

A jogalap nélküli gazdagodás megtérítésére irányuló igényt a BGB 812. § (1) bek. 1 . mondata tartalmazza. A személyiségi jog megsértése esetén az alaptalan gazdagodás tartozatlan fizetés (Nichtleistungskondiktion) címén követelhető vissza. Az alaptalan gazdagodás célja az egyik fél oldalán keletkező jogosulatlan vagyoni elönyök eltüntetése. ${ }^{941}$ Seitz szerint a következő tényálláselemeket kell vizsgálni az igény megvalósulása tekintetében:

1. A kötelezett „megszerzett-e valamit”?

2. Ez nem egy más általi teljesítés által következett be.

3. A szerzés a valószínű jogosult „rovására” történt.

4. A szerzés nélkülözi a jogalapot. ${ }^{942}$

\footnotetext{
939 BDT 2015. 70. (,élesztőtabletta”)

940 U.o.

${ }^{941}$ SeITZ, WALTER: $\S$ 52. Der Anspruch auf Herasugabe des Erlangten. In: Götting, Horst-Peter Schertz, Christian - Seitz, Walter (szerk.): Handbuch des Persönlichkeitsrechts. C.H.Beck, München, 2008. Rn 2. ${ }^{942}$ U.o. Rn 10.
} 
A jogalap nélküli gazdagodás szabályainak alkalmazását már az általános személyiségi jog vagyoni vonatkozásainak elismerése előtt megengedhetőnek tartották a képmás és a név megsértésével összefüggésben. A bírói gyakorlat e jogok tekintetében párhuzamot vont az immateriális jogokkal (Immaterialgüterrechte), és a jogosulatlan kereskedelmi hasznosításra a szerzői és szabadalmi jog megsértésére vonatkozó analóg szabályokat alkalmazta. ${ }^{943}$ Petersen a személyiségi jog első, jogalap nélküli gazdagodáshoz köthető döntésének a Bismarck-döntést tekinti. ${ }^{944}$ Ebben a döntésben a Reichsgericht a condictio ab iustam causam ${ }^{945}$ alapján rendelte el a dolog (a jogsértő fényképfelvételek negatívjainak) kiadását. ${ }^{946}$ Maga Petersen is felhívja a figyelmet ugyanakkor arra, hogy ez az ügy a hatályos jogi megoldásoktól eltérően közelíti meg a jogalap nélküli gazdagodást. ${ }^{947}$

A képmáshoz való különös személyiségi jog tekintetében a BGH az általános személyiségi jog elismerése után 4 évvel az elmaradt licencia-díj megfizetésére kötelezte a jogsértőt. ${ }^{948}$ A bíróság a szerzői jogban fellelhető joggyakorlatra támaszkodva ismerte el az erre való jogot, és terjesztette ki a KUG 22. sköv. §§ szerinti képmáshoz való jog megsértésének esetére. A BGH szerint azzal, hogy az alperes társaság a felperes képmását, annak előzetes beleegyezése nélkül, kereskedelmi úton felhasználta, az e hozzájárulás esetén fizetendő díjazást spórolta meg. A felperesi beleegyezés honorálásának elmaradását a képmáshoz való joga alapján követelhette volna. Az alsófokú bíróság az ügyben szakértőt rendelt ki annak meghatározására, hogy mekkora az a díjazás, amely jelen ügyben fizetendő lenne, és a ZPO alapján lehetséges saját hatáskörben történő mérlegelés lehetőségét ${ }^{949}$ ki is zárta. A bíróság felhívta a figyelmet arra, hogy az alaptalan gazdagodásból származó igénynek nem az a célja, hogy a károsult vagyonában beálló vagyoncsökkenést ellensúlyozza ki, hanem hogy a gazdagodó vagyonában beálló alaptalan vagyonnövekedést vonja el.

943 MÜLLER, 2008. Rn 35.

944 PETERSEN, 2010. 120.

945 Szladits a condictio ob turpem vel injustam causam cím alatt tárgyalja. SzLADITS KÁROLY: A magyar magánjog vázlata II. Grill, Budapest, 1935. 275.

946 RGZ 45, 170.

947 PETERSEN, 2010. 120.

948 NJW 1956, 1554 - Paul Dahlke.

${ }^{949}$ ZPO 287. § (1) bek. Ist unter den Parteien streitig, ob ein Schaden entstanden sei und wie hoch sich der Schaden oder ein zu ersetzendes Interesse belaufe, so entscheidet hierüber das Gericht unter Würdigung aller Umstände nach freier Überzeugung. 
A BGH ezt követően a BGB 812. § alkalmazását a BGB 12. §-ra is kiterjesztette, így lehetővé vált, hogy a névjog mint különös személyiségi jog jogosulatlan reklámcélú felhasználása esetén is kérhető legyen. Olyan idegen név jogosulatlan reklámcélú használata esetén, amelyen a jogosult maga is részt vesz az üzleti életben, a gazdagodással elért vagyon átengedése kérhető akkor is, ha a jogosulatlan névhasználat nem áll összefüggésben a jogosult megítélésének csökkenésével. ${ }^{950} \mathrm{Az}$ alaptalan gazdagodás tekintetében a gazdagodó vagyonában bekövetkező, jogalapot nélkülöző vagyongyarapodás a lényeges, amely a jogosult irányába egy, az engedély megadásával járó szokásos díjazás formájában térítendő meg. 951

Az ún. Unfallopfer-ügyben a felperesek egy közlekedési balesetben elhalt lányuk örökösei voltak, akik az alperesi sajtóvállalat ellen kérték licencia díj fizetésének megállapítását, eszmei kártérítést, illetve a bírósági eljárást megelőző ügyvédi költségek megtérítését, mert az alperes által kiadott Bild nevü újságban, a Bild am Sonntag folyóiratban és elektronikus formában is lányuk fényképének többszöri közlésével megsértették jogaikat. A bíróság a licenciadíj-fizetésre irányuló igényt nem látta megalapozottnak, mert a felperesek elhunyt lánya személyiségének vagyoni vonatkozásai nem tették lehetővé a lány személyiségének kereskedelmi felhasználhatóságát. Az elhalt nő ugyanis a nyilvánosság számára nem volt ismert, a fényképe sem a halála előtt, sem azután nem rendelkezett olyan gazdasági értékkel, amely a verseny szempontjából jelentős. ${ }^{952}$

2. A jogalap nélküli gazdagodás vs. jogsértéssel elért előny átengedése

A Ptk. 2:51. § e) pontja szerint a jogsértés ténye alapján követelheti a jogosult a jogsértéssel elért vagyoni előny átengedését a jogalap nélküli gazdagodás szabályai alapján. A német jog példáján látható volt, hogy a jogsértéssel elért vagyoni előny átengedése és a jogalap nélküli gazdagodás két külön szankció. A Ptk. alapján arra kell jutnunk, hogy a helyes értelmezés a jogalap nélküli gazdagodás szabályainak az alkalmazása, hiszen a Ptk. 2:51. § e) pont csupán utaló norma, amely a Ptk. 6:579. §-

\footnotetext{
${ }^{950}$ NJW 1981, 2402 - Carrera.

951 SEITZ, 2008. Rn 36.

952 NJW 2012, 1728 - Unfallopfer.
} 
ra utal. Erre következtethetünk a Ptk. indokolásából is. ${ }^{953}$ Ezt a megoldást támogatja a rendszertani értelmezés is. A magánjogban két „szomszédos” jogintézmény esetén találjuk meg szankcióként a gazdagodás átengedését: a védjegyjogban és a szerzői jogban. A FÍT védjegybitorlás esetén a vagyoni előny átengedése tekintetében kizárta a Ptk. jogalap nélküli gazdagodására vonatkozó szabályainak alkalmazását abból az okból, mert ez az igény a szerzői joghoz hasonló jogintézményhez áll közel. ${ }^{954} \mathrm{~A}$ bíróság szerint a gazdagodás visszatérítésének a feltétele szempontjából az az irányadó, hogy a bitorló magatartás megállapításra kerüljön, és a jogtalan használattal összefüggésben álljon a bitorló vagyonában kimutatható vagyoni előny. Ezzel összefüggésben az igény vizsgálata során kiindulási alapot képez az alperesnél a jogsértéssel összefüggésben elért teljes bevétel összege, a ténylegesen igazolt költség levonása után, illetve a licencia díj, amit, ha jogszerüen, engedéllyel használta volna a védjegyet, fizetnie kellett volna, és e nem fizetés folytán mint haszon jelentkezik a bitorlónál. ${ }^{955}$ A szerzői jogban a vétlen jogsértéssel elért gazdagodás visszatérítése szempontjából a vagyoni igény tekintetében az elmaradt jogdíjból kell kiindulni, ha a gazdagodás ezt meghaladja, úgy a különbözet is kérhetö. ${ }^{956} \mathrm{~A}$ jogirodalom szintén kizárja a Ptk. jogalap nélküli gazdagodásra vonatkozó szabályainak alkalmazását. ${ }^{957}$ A rendszertani értelmezés alapján a kérhető szankció a jogalap nélküli gazdagodás és nem a jogsértéssel elért vagyoni előny átengedése.

A jogalap nélküli gazdagodásból fakadó igények a magyar jogrendszerben is szubszidiárius jelleggel jelentkeznek, alkalmazásuk meglehetősen visszaszorított. Menyhárd szerint a jogalap nélküli gazdagodás jogintézményének a szemléletében a II. világháború után következett be jelentős változás, amikor a jogintézményt leegyszerüsítően kezelték, és erősen korlátozottan alkalmazták. ${ }^{958}$

A jogalap nélküli gazdagodás szubszidiárius alkalmazását tehát egyrészről az a körülmény indokolja, hogy minden más igény speciális hozzá képest. A jogalap

953 SZÉKELY- VÉKÁS, 2013. 70

954 BDT 2008. 207. (,Eredeti Pick Szalámi”)

955 U.o.

956 FALUdi GÁBOR - KABAI ESZTER - TARR PÉTER: XIII. fejezet. A szerzői jog megsértésének jogkövetkezményei. In: Gyertyánfy Péter (szerk.): Nagykommentár a szerzői jogi törvényhez. Wolters Kluwer, Budapest, 2014. 581.

957 U.o.

${ }^{958}$ MENYHÁRD ATTILA: A magánélethez való jog a szólás- és médiaszabadság tükrében. In: Csehi Zoltán - Koltay András - Navratyil Zoltán (szerk.): A személyiség és a média a polgári és a büntetőjogban. Complex, Budapest, 2014. 219. 
nélküli gazdagodás a polgári jogon és a magánjogon belüli vagyoni viszonyok helyreállításának ultima rációja. Másrészről a tulajdonátruházás jogcímes jellege okán a dologi és kötelmi igény tulajdonképpen összeolvad jogügyleti szinten, harmadrészröl a szerződés érvénytelensége tekintetében külön gazdagodási igényt helyezett el a jogalkotó. Megjegyzendő, hogy a bírói jogi gondolkodás és jogalkalmazás minőségének emelése tekintetében ez elkerülhető lett volna. Ha a jogalkotó ugyanis e külön önálló szabályt kihagyja, úgy a jogalkalmazásnak kell a problémát megoldania, és a tartozatlan fizetést a Ptk. 6:579. §-ban meglelnie és alkalmaznia.

A Ptk. lehetővé teszi a jogsértéssel elért vagyoni előny átengedését, ${ }^{959}$ amelynek feltétele más személy személyiségi értékeinek jogosulatlan felhasználása, bitorlása és az ebből eredő jogosulatlan vagyoni előny megléte a jogosult rovására. ${ }^{960} \mathrm{Az}$ indokolás szerint a vagyoni előny átengedésének lehetővé tételével elérhető az, hogy a jogsértő személy azt ne tarthassa meg. ${ }^{961}$ A törvény indokolása sokkal kisebb hangsúlyt helyez magára a jog jogosultjára, akinek érdeke áll fenn a személyiségi jogának vagyoni felhasználása és rendelkezése tekintetében. A valóság ezzel szemben az, hogy ő az a személy, akinek érdekében, a személyiségi jog megsértése okán lehetősége van a jogkövetkezmények igénybevételére. Lényegében annak a személynek az érdekei nem kerülnek részletesebben kibontásra, akinek érdekét e jogkövetkezmény elsősorban védi. A Ptk ugyanis nem abból indul ki, hogy a személyiségi jogon fennálló vagyoni érdekkör eddig jogilag nem volt elismerve, hanem abból a pozitivista megközelítésből, hogy a személyiségi jogok esetén szemben a szerzői és a szabadalmi joggal - erre törvényi szinten nem volt lehetőség. Nem kerül ezzel az indokolással feloldásra az, hogy a jogalap nélküli gazdagodás jogalapja az absztraktan szerkesztett régi Ptk.-ban erre miért ne adott volna lehetőséget. ${ }^{962}$ A német jog ugyanis ezt a megoldást alkalmazza, ${ }^{963}$ és ehhez a magyar

\footnotetext{
959 2009. évi CCX. tv. 2:89. § e) pont.

960 GÁRDOS, 2009. 160.

961 U.o.

962 GÁRDOS, 2009. 160.

${ }^{963}$ Leginkább ebben a tekintetben tünik ki a német és a magyar magánjogi gondolkodás közötti különbség. A német jog ugyanis a BGB-re úgy tekint mint jogalapok (Anspruchsgrundlage) egymásra épülő rendszerére, amely szempontjából, ha speciálisabb igény nem valósul meg, úgy a jogalap nélküli gazdagodás (BGB 812. sköv §§) minden esetben felhívható. A magyar jogi gondolkodás ezzel szemben nem tekinti automatizmusnak a magánjogi igények egymás utáni, specialitáson alapuló vizsgálatát, ez látható a kártérítési szabály elhelyezéséből is a személyiségvédelmen belül. A magyar magánjogi gondolkodásban ugyanis külön szabályt kell biztosítani a személyiségi jogok esetén a kártérítési igény felhívhatóságára, annak ellenére, hogy a
} 
jogban sem lenne szükség az ún. mozgó rendszer (bewegliches System) alapú jogalkalmazásra sem.

Sokkal érdekesebb ebből a szempontból az a szabály, hogy a jogsértéssel elért vagyoni előny átengedését bármely örökös kérheti. Több örökös egymás közötti viszonyában az elvont vagyoni előnyt úgy kell megosztani, mintha a meghalt személy hagyatékából részesednének. A törvény ugyan a kegyeleti jog szabályai között helyezi el az erre vonatkozó szabályokat, azonban mégis úgy tünik, mintha a vagyoni jogok tekintetében dogmatikailag túllépett volna azon a dogmán, hogy a jogosult halálával a személyiség megszünik. Petrik Ferenc emeli ki, hogy a személyiség halállal való megszünése jogilag egyre kevésbé tartható, bár ennek vizsgálata nála az eszmei és erkölcsi érdekekre szükül. ${ }^{964}$ A személyiségi jog vagyoni vonatkozásainak kegyeleti jog köréből való kiemelése azzal magyarázható, hogy a személyiségi jogon belüli tárgyiasulással az egyes jogtárgyak a halállal megszűnő személyiségi jogtól elválnak, s egyfajta vagyoni jogként lesznek jogutódlás tárgyai. Lényegében ezt az álláspontot követi a törvény más indokkal, de helytelenül rendszertanilag a kegyeleti jog keretei között helyezi el azt. A kegyeleti jog ugyanis erkölcsi kategória, ${ }^{965} \mathrm{~s}$ mind történetiségében, mind a jelenlegi bírói gyakorlatban a meghalt személy méltó emlékezetét kívánja oltalmazni, azaz a kegyelet jogi tárgya eszmei, erkölcsi érdekeket véd.

Amennyiben a személyiségi jog vagyoni vonatkozásait a személyi vonatkozásokkal elválaszthatatlan egységként kezeljük, úgy mindkét megoldás logikailag lehetséges: a személyi érdekek megléte miatt a kegyeleti jogosultak joga, a vagyoni érdekek miatt az örökösök joga. Éppen a személyiségi jog monizmusa okán a vagyoni érdekek nem választhatóak le, nem önállósíthatóak teljesen, s emiatt ez az egységes jog is megbomlik. A személyi jogon fennálló vagyoni jogok tekintetében az örökösök, míg az erkölcsi érdekek tekintetében a kegyeleti jogosultak lesznek jogosultak.

A Ptk. nem emeli ki, de tulajdonképpen az örökösök saját jogon lépnek fel a személyiségi jog érvényesítése során, ugyanis a jogosult halálával a hagyaték részeként a személyiségi jog vagyoni jogai is az örökösökre szállnak. A törvény ennek

törvény rendelkezik egy külön absztrakt, általános kártérítési jogi klauzulával, amely ennek hiányában is felhívható lenne. Sőt! A személyiségi jogon belül elhelyezett szabály csak egy e szabályt felhívó utaló szabály: önállótlan jogi norma, így tényleges funkciója nincs is.

964 PETRIK FERENC: A törvényszerkesztö dilemmái. HVG-ORAC, Budapest, 2008. 227-228.

965 GÖRÖG, 2008. 19. 
ellenére arról nem tartalmaz szabályt, hogy a halál után az örökösök ezekkel a személyiségi jogokkal mennyiben rendelkezhetnek, s ezt a vagyoni előnyt ők mennyiben hasznosíthatják. Ezzel a Ptk. csupán a jog feletti érdek érvényesíthetőségéről rendelkezik (negatív oldal), a jogosultnak a jog feletti hatalmáról, annak terjedelméről nem (pozitív oldal).

A 2009-es Ptk. szerint a jogsértéssel elért vagyoni előny közérdekű célra történő átengedését az ügyész is indítványozhatta, ha a kegyeleti jogot sértő magatartás közérdekbe ütközik. ${ }^{966}$ A Ptk. ezt a rendelkezést már nem tartalmazza, valószínűsíthetően abból az okból, hogy az ügyész perbelépését a magánjogi viszonyokba lecsökkentse, az ügyész keresetindítási joga ugyanis az 1977-es Ptk. novella maradványa. ${ }^{967}$

A szerzett vagyoni előny átruházását mint szankciót a jogalap nélküli gazdagodás szabályai szerint kell elbírálni, az azonban bizonytalan, hogy a német rendszer szerint ez egy licanciadíjfizetés-szerü vagy a jogsértéssel szerzett elönyhöz hasonló jogkövetkezmény. A német jogban ugyanis az eset körülményeihez mért licenciadíj-fizetés az, amely a jogalap nélküli gazdagodás szabályai szerint történik. Ezt támogatja a jogintézmény korábbi értelmezése is, így ez tünik a helyes álláspontnak.

3. Jogalap nélküli gazdagodás a jogosult halála után [Ptk. 2:50. § (2) bek.]

A Ptk. nem rendelkezik általában a vagyoni jogok megszünéséről, illetve védelmi idejéröl. A német bírói gyakorlatban a védelem a jogosult halála utáni 10 évig terjed. ${ }^{968}$ A Ptk. nem szabályozza azt, hogy az örökösök a halott személyiségi jegyeit felhasználhatják-e, rendelkezhetnek-e vele, szerződést köthetnek-e valakivel azok használatára. Emiatt helyesnek tünik az az álláspont, hogy a vagyoni jogok védelme általában véve megszűnik a jogosult halálával, és a kegyeleti jogot nem sértő használat közkincs tárgyát képezi. ${ }^{969}$ A megsértés tekintetében kizárólag a jogalap nélküli gazdagodás vonatkozásában tartalmaz szabályt a Ptk., a kártérítés tekintetében nem. Mivel ez is vagyonjogi igény, így dogmatikailag a jogérvényesítés itt is lehetséges,

\footnotetext{
966 2009. évi CCX. tv. 2:87. § (3) bek.

967 1977. évi IV. tv. 85. § (3) bek.

${ }^{968}$ BGHZ 169, 193 - kinski-klaus.de; Ettől eltérően az OLG München polgári tanácsa: GRUR-RR 2002, 341 - Nacktbilder; a védelmi időre vonatkozó álláspontokat részletesen körüljárom SCHULTZ, Márton: Vermögenswerte Bestandteile des Persönlichkeitsrechts. Masterarbeit, Potsdam, 2018. ${ }^{969}$ MENYHÁRD, 2016. 81.; SZEGHALMI, 2017. 233.
} 
analógia alkalmazása nélkül is, ehhez persze a bírói gyakorlatnak el kell ismernie azt, hogy a forgalomképes, tárgyiasult személyiségi jegyek a halállal nem válnak ipso jure közkincs tárgyává, hanem a jogutódok rendelkezési joggal bírnak azok felett meghatározott ideig.

A Ptk. 2:50. § (2) bekezdés alapján bármelyik örökös kérheti a kegyeleti jogsértéssel elért vagyoni előny átengedését. Ez részben kivétel a közkinccsé válás alól, azonban nehezen értelmezhető ez a szabály. Ez valószínüleg azért van így, mert a vagyoni érdek védelmét előirányzó kodifikáció során nem kerültek feltárásra a vagyoni értékű személyiségi javak szabályozására vonatkozó vitás kérdések. Helyes a Ptk. álláspontja atekintetben, hogy az igény jogosultja nem a kegyeleti jog esetén releváns hozzátartozókat, hanem az örökösöket jelöli meg. Ezzel a törvény a jogsértéssel elért vagyoni előny átengedésére való jogot olyan vagyoni jogként ismeri el, amely öröklődik.

Problémás ugyanakkor az, hogy a Ptk. a személyi szemléletet a dinamikus dologi szemlélet alá eső vagyoni jogokkal keveri. A személyi szemlélet azzal férkőzik be a szabályozásba, hogy a Ptk. a jogsértés megállapításának feltételéül szabja a kegyeleti jog sérelmét. Ennek tényálláselemként való szerepeltetése indokolatlanul szükíti le az igény megvalósulásának a körét, azt a vagyoni érdek post mortem megsértése esetére nem teszi lehetővé (és ezzel lényegében a Ptk. egy új, beazonosíthatatlan jogkövetkezményt hoz létre). Az igény megvalósulása szempontjából ugyanis a jogosulatlan kereskedelmi használat és ehhez kapcsolódóan a vagyoni hátrány okozása az, ami releváns. A Ptk. egyedül azt az esetet tartalmazza tehát, ha a vagyoni érdekek mellett az eszmei érdekek is egyidejüleg sérülnek. Az lenne az ideális, ha a kegyeleti jogosultak, a hozzátartozók a kegyeleti jog megsértése címén léphetnek fel az eszmei, erkölcsi érdekek védelme érdekében, az örökösök pedig a vagyoni érdekek védelme érdekében ettől függetlenül. A személyi és vagyoni viszonyok post mortem védelmének keveredése ugyanakkor a vagyoni érdek halál utáni védelmét nem zárja ki, csupán leszükíti az érvényesülését. A bírói gyakorlat feladata annak eldöntése, mennyiben egyezik ez a jogi közmeggyőződéssel.

Nagyobb problémát képez az, hogy az egyes személyiségi jegyeken dologi hatállyal, élők között, szerződéses úton jogot szerzett személyek tekintetében - akik még a jogosult életében in rem jogot szereztek az adott személyiségi jegy meghatározott irányú tárgyiasítására és használatára - ez a szabály a perlés lehetőségét kizárja. Ezzel a Ptk. azt a koncepcionálisan helytelen megoldást valósítja meg, hogy 
az élök között kizárólagos jogot szerzett szerződő fél jogosultsága a hagyaték megnyílásával a jogsértéssel szerzett vagyoni előny tekintetében kötelmivé változik a Ptk. 2:50. § (2) bekezdés miatt. Ez azt eredményezi, hogy a jogosultak, elsősorban a médiaszereplők és a vállalatok, a személyiségi jog jogosultjának halála utáni jogsértések tekintetében saját jogon nem érvényesíthetnek igényt, és a jogosultságuk egyfajta használati engedéllyé (kötelmi jogosultsággá) degradálódik. Az igényérvényesítés lehetősége egyedül az örökösök diszpozíciójába kerül.

\section{Jogkövetkezmények egymás mellett alkalmazhatósága}

\section{Az igénykumuláció Németországban}

$\mathrm{Az}$ alkalmazandó jogkövetkezmény értelemszerüen mindig a megvalósult tényálláshoz kapcsolódik. Abban az esetben, ha az általános személyiségi jog, illetve a poszt-mortem személyiségi jog eszmei vonatkozásokban sérül, úgy az alkalmazandó jogkövetkezmény az alanyi jog kizáró jellegéből eredő abbahagyásra, eltiltásra irányulhat elsősorban, illetve a magánjog elégtételi funkcióját védő méltányos pénzbeli kártalanításra (billige Entschädigung in Geld), azaz nem vagyoni kártérítésre. Abban az esetben, ha e két jog vagyoni vonatkozásai sérülnek, úgy nyitva áll a lehetőség a háromfokú kárelszámolásra. Ha mindkét vonatkozásban sérül az általános személyiségi jog, illetve a poszt-mortem személyiségi jog, úgy minden vonatkozás tekintetében külön vizsgálni kell az alkalmazandó jogkövetkezményeket. Fontos körülmény, hogy a Kölni Táblabíróság legújabb gyakorlatában egyértelmüen leszögezte, hogy az általános személyiségi jog poszt-mortem megsértésének esetében igényelhető méltányos pénzbeli kártalanítás nem öröklődő igény, annak érvényesítésére az elhunyt házastársa saját jogon nem jogosult, ha a jogosult a perindítás után halt is meg. ${ }^{970}$ A nem vagyoni kártérítésre irányuló igény a BGH állandó joggyakorlata szerint sem öröklődik, ${ }^{971}$ ezt az álláspontot foglalta el a Kölni Táblabíróság is: ${ }^{972}$

\footnotetext{
${ }_{970}$ OLG Köln 29.05.2018 - Az. 15 U 65/17.; OLG Köln, 29.05.2018 - I-15 U 64/17 - Kohl-Protokolle. ${ }^{971}$ BGH v. 29.04.2014 - VI ZR 246/12, GRUR 2014, 702.

972 OLG Köln, 29.05.2018 - I-15 U 64/17 - Kohl-Protokolle.
} 
Az e kérdéshez kapcsolódó felsöbírói gyakorlat jogszerüsége azon alapszik, hogy a méltányos pénzbeli kártalanítási igény a fájdalomdíjra vonatkozó igényekkel szemben (BGB 253. §; és a korábban hatályban levö BGB 847. §) egyértelmüen a kiemelkedö elégtételi eszmén nyugszik, amely a jogsértéssel közvetlenül érintett személy halálával rendszerint veszít jelentöségéböl, és az e jogintézmény tekintetében elötérben levö, a GG 1. cikk (1) bek. és a 2. cikk (1) bekezdésben gyökerezö elégtételi funkció gyakorlatilag nem valósulhat meg. Egy, még a jogosult életében keletkezett pénzbeli kártalanítási igény a jogosult halála utáni fennállására vonatkozó jogi indokok, legalább is általános jelleggel, e nézöpontból nem fellelhetöek. Az ún. prevenciós célt ${ }^{973}-$ tehát a jövőbeli jogsértések pénzbeli kártalanítás különleges szankciója általi megakadályozását, amely e jogintézmény (további) céljaként elismert egyedül nem hordozhat a pénzfizetésre irányuló igény, ha az elégtételi funkció a jogosult halála miatt elmarad.

Más a helyzet a BGH joggyakorlata szerint a fájdalomdíj iránti igény öröklödése, vagy az általános személyiségi jog „,vagyoni alkotóelemeinek” megsértése esetén irányadó vagyoni kár megtérítésére irányuló igények tekintetében. ${ }^{974}$ Ezek a jogintézmények nem összehasonlíthatóak a pénzbeli kártalanítás jogintézményével, amely (kizárólag) a személyiségi jog eszmei alkotóelemeinek védelmére szolgáló különleges jogvédelmi eszköz.

Az előző fejezetben már rámutattam arra, hogy a magyar joggyakorlat alapvetően kizárólag az eszmei érdekekre korlátozza az értékelést, s így az alanyi jogon fennálló érdek tekintetében kizárólag az eszmei, erkölcsi érdekekre szúkíti ezt. A magyar bírói gyakorlatban tehát az eszmei és vagyoni érdekek keveredése esetén az eszmei oldalra billen a mérleg nyelve a jogi értékelés tekintetében. Ennek az az oka, hogy a vagyoni értékminőséget általános jelleggel, uralkodó álláspontként a jogirodalom nem képviseli, illetve, hogy a joggyakorlat irányából is csak formálódik ennek a jogi észrevétele. Más a helyzet Németországban, hiszen ott a bírói gyakorlat élö joggá emelte a vagyoni értékminőséget. Ebből kifolyólag a szubszumcióban bekövetkező jogalkalmazási diszfunkciók elsősorban afelé tendálnak, hogy a bíróság vagy az eszmei, vagy a vagyoni oldal sérelmét emeli ki attól függően, hogy melyiknek a

${ }^{973}$ AfP 2017, 228.

${ }^{974}$ NJW 2006, 605. 
sérelme az, amely az általános élettapasztalat szerint a történeti tényállásban kiemelkedőbb. Ennek oka az lehet, hogy az igények együttes megvalósulása maga után vonná azt is, hogy több jogkövetkezmény együttes alkalmazásával a jogosult több jogcímen jutna pénzbeli előnyhöz. Ez nem lenne gond, de ha belegondolunk abba, hogy a nem vagyoni kára mellett kártérítést, illetve a gazdagodás visszatérítését is megítélik, úgy könnyen elindulhat egy olyan jogalkalmazási tendencia, amely a személyiség „túlárazásához” vezetne. Másrészről nyomós érv az is, hogy a személyiségi jegyek kommercializálódásának elismerésével nem szorítható ki az eszmei érdekek élők közötti és poszt-mortem védelme sem.

A tényállás szempontjából túlnyomó eszmei érdeket képezett a Müncheni Táblabíróság szerint Marlene Dietrich aktképének újságban való nyilvános közlése is. ${ }^{975}$ A bíróság szerint Marlene Dietrich meztelen fényképének magazinban történő nyilvánosságra hozatala pusztán a poszt-mortem személyiségi jog eszmei vonatkozásait érinti, amely eszmei kártérítésre adhat alapot a BGB 823. §-a alapján. Nem jön létre tehát kártérítési igény Marlene Dietrich személyiségének vagyoni vonatkozásainak megsértése miatt. ${ }^{976}$ Megjegyzendő, hogy az eszmei kártérítés és a vagyoni kártérítés között nem áll fenn igényhalmazat, amely a kártérítést objektíve kizárná, éppen ellenkezőleg, a két igény párhuzamosan, egymás mellett is kérhető, mert teljesen eltérő érdekeket szolgálnak, s egymást semmilyen tekintetben nem fedik át. Sokkal inkább arról van szó azonban, hogy a bíróság attól félt, hogy a kártérítésben és az eszmei kártérítésben való együttes marasztalással a személyiségi jog kommercializációjában egy eltúlzott védelem alakul majd ki.

Korlátként jelentkezhet továbbá az igényérvényesítés szempontjából az is, hogy az általános személyiségi jog eszmei vonatkozásainak értékelése során kifejlesztett érdek- és jogtárgy-mérlegelés a vagyoni érdekek tekintetében is megjelenik. ${ }^{977}$ A BGH egy ügyben akként döntött, hogy a kortörténeti szereplönek minősülő híres személyeknek általában türniük kell, hogy a képmásukat harmadik személyek reklámcélokra felhasználják. ${ }^{978} \mathrm{Ez}$ azonban egyes esetekben, mint amilyen az adott ügy is volt, alá van vetve a jogtárgy-mérlegelésnek, amely ahhoz vezethet, hogy idegen képmás hirdetésben történő reklámozási célú felhasználása, amely egy

\footnotetext{
975 GRUR-RR 2002, 341 - Nacktfoto.

976 BEUTHIEN, 2003. 1222.

977 BGHZ 13, 334 - Leserbrief.

${ }^{978}$ NJW 2007, 689 - Lafontaine.
} 
aktuális társadalmi eseményt szatirikus formában mutat be, a jogosult által eltürendő. ${ }^{979} \mathrm{Ez}$ a fiktív licencia díj fizetésére irányuló igényt ki is zárja. Más szóval az általános személyiségi jog vagyoni vonatkozásainak megsértése nem vezet automatikusan a vagyoni szankciók alkalmazásához, hanem annak megítélése az eszmei érdekekhez hasonlóan érdekmérlegelés kérdése.

2. A vagyoni szankciók halmazatai a magyar jogban

A vagyoni szankciók tekintetében azok jönnek számításba, amelyek vagyoni eszközökkel kívánják ellensúlyozni a személyiségi jogba való behatásokat. Ide sorolható a sérelemdíj, a nem vagyoni sérelem megtérítése mellett a kártérítés és a vagyoni előny átengedése. A sérelemdíj a személyiségi jogon fennálló eszmei, erkölcsi érdekek megsértésének ellentételezésére szolgál. A vagyoni érdekkörbe való jogellenes behatások kompenzálására pedig a kártérítés és a jogsértéssel elért vagyoni előny átengedése. Az igényhalmazatok tekintetében azt kell vizsgálnunk, hogy mely szankciók kérhetőek egymás mellett, illetve melyek zárják ki egymást. A lényeg ebböl a szempontból az, hogy több jogalapra hivatkozással nem kérhető ugyanaz a jogkövetkezmény. Így nem kérhető egyszerre (kumulatívan) a dolog visszaadása tulajdoni és birtokper alapján. Nem követelhető a kár megtérítése egyszerre ugyanazon kár tekintetében a kontraktuális és deliktuális felelősség alapján. Ez persze nem zárja ki azt, hogy más-más károk tekintetében a két igény együttesen igényelhető legyen, ezt a Ptk. 6:145. § szerinti non cumul-szabály sem zárja ki. A kérdés tehát az, hogy a személyiségi jog esetén alkalmazható vagyoni szankciók kérhetőek-e egymás mellett.

A sérelemdíj a nem vagyoni sérelmek orvoslását célozza, s ezzel mind a kártérítés, mind az alaptalan gazdagodás mellett kérhető. Ennek az oka az, hogy a sérelemdíj tényállásából eredően az általános személyiségi jog sérelme esetén igényelhető, ideértve a személyiségi jegyek azon tárgyiasítását is, amelyhez vagyoni érdek nem füződik. A sérelemdíj akkor is kérhető, ha a vagyoni személyiségi jog sérelme nem csak vagyoni hátrány okozásával történik, hanem egyidejűleg eszmei, erkölcsi érdekek sérelmét is okozza. Ilyen például az, ha valakiről 40 évvel ezelőtti képet kereskedelmi célra használnak fel, ${ }^{980}$ valamint ha hazai napilap címoldalán

\footnotetext{
979 NJW 2007, 689 - Lafontaine.

980 BDT 2009. 24. („Budapesti Öszi Fesztivál”)
} 
közszereplőről aktképet közölnek le hozzájárulása nélkül. ${ }^{981}$ A sérelemdíjra való igény megállapítása és mértékének meghatározása során azonban el kell kerülni azt, hogy abba a jogsértéssel előny mértéke vagy az elmaradt licenciadj beszámításra kerüljön. ${ }^{982}$ A joggyakorlat sokszor a nemvagyoni kártérítés jogintézményét látta alkalmasnak arra, hogy annak mértéke tekintetében valami módon a vagyoni károkat, a vagyoni értékeltolódást is értékelje. Erre enged következtetni elsősorban az aktfotóügy ${ }^{983}$ és a Budapesti Öszi Fesztivál-ügy is, ${ }^{984} \mathrm{~s}$ ez párhuzamokat mutat a német joggyakorlatban a 2002-es, Marlene aktképének leközlésével kapcsolatos üggyel is. ${ }^{985}$

A kártérítés és az alaptalan gazdagodás elhatárolása elsősorban a vagyoneltolódás specialitásában jelentkezik. A kártérítés ebből a szempontból az alaptalan gazdagodást megelőzi, hiszen ebben az esetben a vagyoneltolódás vagyoni kár formájában jelentkezik. A kártérítési igény tehát speciális, s ez a specialitás a tényállás szintjén a felróhatóság tekintetében is jelentkezik. Az alaptalan gazdagodás objektív jellegü. Az igény vizsgálata szempontjából ugyanazon vagyoneltolódás tekintetében az alaptalan gazdagodás akkor igényelhető, és vizsgálható, ha a Ptk. 6:519. § tényálláselemei nem valósultak meg. Ezen felül az alaptalan gazdagodás akkor kérhető a kártérítés mellett, ha eltérő vagyoneltolódásokat kell értékelni. Így a kártérítés az elmaradt haszon tekintetében arra irányul, hogy a károkozó térítse meg a jogosultnak azt a kárát, amelyet a személyiségi jegyének felhasználása és tárgyiasítása tekintetében kötendő szerződés elmaradása okozott. Ez a kár lényegében a felhasználáshoz való hozzájárulásának értéke a licencia-analógia alapján. A jogalap nélküli gazdagodás szabályainak alkalmazásával az a kár kérhető, amelyhez a jogsértő azzal jutott, hogy a személyiségi jegyet jogellenesen tárgyiasította. Ez lényegében többletelem, amelyet az elmaradt díjazás megtérítése nem fed le. A kártérítési jog csupán a szerződés hiányát kívánja orvosolni, és olyan állapotot teremteni, mintha a szerződés megkötésre került volna, amely által a jogosult személyiségi jegyének bizonyos irányú tárgyiasításáról lemondott, és ezzel a lemondással a felhasználás tkp. utólag jogszerüvé vált, az ebből eredő többletbevételek már a károkozót illetik. Az alaptalan gazdagodás azonban abból indul ki, hogy a kötelezett többletbevételei is jogellenesek voltak, amelyek azonban a kártérítési jogon belül nem értékelhetőek,

\footnotetext{
981 BDT 2007. 171. (,aktfotó”)

982 MENYHÁRD, 2014. 221.

983 BDT 2007. 171. (,aktfotó”)

984 BDT 2009. 24. („Budapesti Öszi Fesztivál”)

985 GRUR-RR 2002, 341 - Nacktfoto.
} 
hiszen az a licencanalógia alkalmazásának mondana ellent. Amennyiben a kereseti kérelem a történeti tényállásban fellelhető e két körülményt együttesen érinti, úgy nincs akadálya mindkét igény együttes alkalmazásának. Menyhárd is abból indul ki, hogy ,a jogalap nélküli gazdagodás a gazdagodó által elért vagyoni előnyt, a kártérítési felelősség pedig az elszenvedett vagyoni veszteséget méri”, ${ }^{986}$ és szerinte a jogalap nélküli gazdagodás egyfajta kártérítési minimumot jelenthetne ebből a szempontból. ${ }^{987}$ Menyhárd is amellett érvel, hogy a két igény egymás mellett alkalmazható. ${ }^{988}$ Az más kérdés, hogy mennyiben alkalmazható a jogalap nélküli gazdagodás az után, ha a kártérítés keretében a fiktív licencia díj fizetésére kötelezte a jogsértőt a bíróság, hiszen ezzel a jogellenes cselekményt kvázi jogszerüvé változtatja az elmaradt díjazás megtérítésével. Ha ezt teszi, úgy már nincs felesleges vagyontöbblet, a jogsértés miatti többletbevételek kiadása alól kiveszi a talajt. Így három lehetőség kínálkozik: fiktív licencia díj fizetés mellett a bíróság további vagyoni hátrányt nem állapíthat meg, a kár mértékét úgy határozza meg, hogy a többletbevételeket is figyelembe veszi, és egyfajta preventív funkciót alkalmaz a kártérítésen belül, vagy a licencia díj felett jogalap nélküli gazdagodást is alkalmaz arra tekintettel, hogy a személyiségi jegy tárgyiasítása jogellenes volt, így a hozzájárulás ellenértékén felül, amely egy szerződéses konstrukcióban működne, a jogellenes felhasználás okán ítéli meg az elért többletelőny átengedését, szintén preventív funkcióval.

\section{Részösszegzés}

A személyiségi jog vagyoni értékminőségének megjelenése a jogkövetkezmények körében a vagyonjogi szankciók alkalmazásának lehetővé tételével valósulhat, valósult meg. Ilyen vagyonjogi szankció a kár megtérítése és a gazdagodás visszatérítése, vagyoni jogkövetkezmény ugyan, de nem tartozik ide az eszmei érdekek kompenzálása okán a sérelemdíj, illetve a nem vagyoni sérelem bármilyen formájú megtérítése. A Ptk. szövegszinten lehetővé teszi a kártérítés és a jogsértéssel elért vagyoni előny átengedését a személyiségi jogok megsértése esetére. Amennyiben a személyiségi jogok között külön szabályt ezekre vonatkozóan nem tartalmazna a törvény, úgy a kódex absztrakt jellegéből adódóan a Ptk. 6:519. § és a 6:579. § szerinti

\footnotetext{
986 MENYHÁRD, 2014. 219.

987 U.o.

${ }^{988}$ U.o. 223.
} 
igények ekkor is megvalósulhatnak. A vagyonjogi szankciók alkalmazása a pozitív értelmezés alapján mindenképpen lehetséges. Problémát képez ugyanakkor, hogy a személyiségi jog általában eszmei érdekeket oltalmaz, amelyek esetén a vagyonjogi igények objektíve nem merülhetnek fel. A Ptk. nem határolja le a személyiségi jog megsértéséről azokat az eseteket, amikor ezek a jogkövetkezmények igénybe vehetőek, és ezzel összemossa a személyiségi jog eszmei és vagyoni érdekeinek védelmét.

A kártérítés alkalmazása tekintetében az az uralkodó jogirodalmi álláspont, hogy a személyiségi jogok megsértése esetén a károk körében csupán a következménykárok megtérítésére van lehetőség. Ennek oka, hogy a személyiségi jogok alapvetően mint nem vagyoni jogosultságok jelennek meg a Ptk. rendszerében. A tapadókárok ${ }^{989}$ elismerésének feltétele az lenne, hogy elismerjük, hogy a személyiségi jog megsértésével vagyoni kár keletkezik, amely vagyoni kár elsősorban a személyiségi jog kereskedelmi felhasználásához köthető licencia díj megfizetésének elmaradásában áll. A Ptk. kodifikációja során nem merült fel olyan álláspont, amely a kártérítési jog ilyen irányú alkalmazását is előirányozta volna. Ez azt jelenti, hogy a kártérítési jog vonatkozásában a vagyoni értékminőségét a Ptk. nem értékelte - jóllehet nem is zárta ki. A jogalkalmazási gyakorlat korábban több döntésében hajlott az elmaradt hozzájárulás esetén fizetendő díjazás mint kár megállapítására, így ezzel a törvény előtt jár. A probléma elsősorban abban jelentkezik, hogy a kereseti kérelemben a vagyoni kár megtérítését egyáltalán nem kérik a személyiségi jog jogosulatlan kereskedelmi felhasználása esetén.

A jogalap nélküli gazdagodás az objektív teleologikus értelmezés szerint egyértelműen a személyiségi jogon fennálló vagyoni érdekkör megsértésének szankcionálására szolgál. A Ptk. ezt élők között következetesen végigviszi. A személyiségi jog jogosultjának halála után az örökösöknek biztosít jogot arra, hogy $a$ kegyeleti jogsértéssel elért vagyoni előnyt a jogsértő számukra térítse meg. Helyes a Ptk. álláspontja abban a vonatkozásban, hogy az igényérvényesítésre jogosultak körét az örökösökben határozza meg, hiszen az igény vagyonjogi igény, így türi a jogutódlást. A jogsértő cselekmény vonatkozásában a törvény az eszmei és vagyoni érdekek védelmét mossa össze azzal, hogy a kegyeleti jogsértést az igény megvalósulásának feltételéül támasztja. A kegyeleti jogsértés mindig kizárólagosan az

989 Tekintettel arra, hogy fiktv licencia díjról van szó, tehát egy olyan díjról, amit a jogsértőnek fizetnie kellett volna, ha a felek között szerződés jött volna létre. 
eszmei érdekek halál utáni védelmére szolgál, így a vagyoni jogkövetkezmény értékelésében nem játszhatna szerepet. Másik hibája ennek a szabálynak az, hogy a személyiségi jogi részjogosultságok dologi hatályú átruházása esetén a személyiségi jog jogosultjának halála után a jogszerző nem érvényesítheti ezzel kapcsolatos igényét. Az igény elvesztése által a dologi hatállyal megszerzett jog tulajdonképpen kötelmi igénnyé válik. Helyesebb lett volna ezért az erről rendelkező Ptk. 2:50. § (2) bekezdést a törvényből kihagyni a vagyoni előny átengedése esetén, lévén kötelmi, vagyonjogi jogintézmény, így dogmatikailag az örökösök szerzik azt meg a hagyaték részeként.

A Ptk. által alkalmazott jogkövetkezményi rendszer ebből eredően nem következetes. A vagyoni értékminőséget, a vagyoni szankciók alkalmazását kizárólag a jogsértéssel elért vagyoni előny esetén, a személyiségi jog jogosultjának életében biztosítja. Dogmatikailag helytelenül építi ezt be az öröklés általi jogutódlás tekintetében azáltal, hogy a kegyeleti jog keretében helyezi el az erre irányuló igényt. A kártérítést ugyan a törvényszöveg lehetővé teszi, a kodifikáció azonban nem foglalkozott a személyiségi jog megsértéséből eredő vagyoni károk megtérítésével, és nem határolta le azt az eszmei érdekek esetén is alkalmazandó következménykárokról.

Az alanyi jogok biztosítása a tárgyi jogban önálló jogi normával történik. Az önálló jogi norma tényállásból és jogkövetkezményből áll. A Ptk. rendszere együtt védi a vagyoni és személyi viszonyokat, nem különíti el az azok esetén alkalmazandó jogkövetkezményeket. Ha a személyiségi jogon fennálló egységes alanyi jogon belül megkülönböztetjük az eszmei és vagyoni érdekeket, úgy védhető a Ptk. rendszere, hiszen ezzel lehatárolható a vagyoni szankciók alkalmazási köre. Ezzel a törvényt nem kell módosítani. Mivel egy írott kódexről beszélünk, ezért meglátásom szerint helyesebb az, ha a törvény meghatározza azokat az esetköröket, amikor ezek a jogkövetkezmények alkalmazandóak. Ezzel a jogalkotó maga értékelné, mikor sérül a vagyoni érdekkör, és mikor alkalmazható a kártérítés, illetve a jogsértéssel elért vagyoni előny átengedése. Én ezt a vagyoni személyiségi jog elismerésében látom a tényállási oldalon, amelyhez ez a két jogkövetkezmény hozzákapcsolandó. Ezzel jönne létre egy önálló alanyi jog, amely a személyiségi joghoz képest speciális. Ez a vagyoni személyiségi jogi szféra nem szükül kizárólag a vagyoni érdekkörre, annak megsértése esetén a személyiségi jog további szankciói is alkalmazhatóak. A joggyakorlat ugyanis azt mutatja, hogy az esetek többségében a jogosult eszmei érdekköre is sérül a vagyoni mellett. Annak sem lenne egyébként akadálya, hogy a két érdek sérülése esetén az eszmei személyiségi jog és a vagyoni személyiségi jog 
megsértését külön-külön állapítsa meg a bíróság, és ezek jogkövetkezményét külön alkalmazza (a személyiségi jog dualizmusa). Így az sem okozna zavart a jogalkalmazásban, ha a jogalkotó az eszmei érdekeket védő személyiségi jog mellett egy kizárólagosan vagyoni érdeket védő vagyoni jogot hozna létre.

A kártérítési jog külön, a vagyoni személyiségi jog szankciójaként való elhelyezése körében konkretizálásra szorul, hiszen az a következménykárok tekintetében az eszmei érdekek sérelme esetén is alkalmazható. Ebben a tekintetben a jogalkotónak elsősorban a lucrum cessans körében kellene értékelnie az elmaradt licencia díj megtérítését, amely által egyértelművé válna, hogy a személyiségi jog vagyoni érdekkörének sérelme vagyoni kárt indukál. Illetve célszerü lenne ebben a tekintetben a jogalap nélküli gazdagodás analógiájára, a bírói gyakorlatot segítendő, az igény öröklődését kimondani, ám ezzel azt is meg kellene válaszolni, hogy a halál után mennyi ideig tart a jog védelmi ideje. 


\section{ÖSSZEGZÉS}

\section{A. Történeti fejlödés}

Mind a magyar, mind a német jogfejlődés vizsgálata alapján látható az, hogy a személyiségi jogok magánjogi védelmének életre hívásában jelentős szerepet játszottak a vagyoni érdekek. A német jogban a jogalkotó a személyiség általános jogától eltekintett, ugyanakkor külön-külön alanyi jogok formájában biztosította a név és a képmás védelmét. Ez a két személyiségi jog az, amely az eszmei érdekek védelme mellett jelentős vagyoni érdeket is oltalmaz, annál fogva, hogy felhasználásuk kapcsolatba kerülhet az ipar jogi védelmével, a gazdasági versennyel és a sajtó gazdasági érdekeivel is. E két jog volt az is, amely az általános személyiségi jog önálló jogalapon való elismerése után, saját jogalapjaikon hozzákapcsolódtak a BGB 812. §ának, a jogalap nélküli gazdagodás jogkövetkezményeihez, megalapozva ezzel a személyiségi jogok vagyoni értékének általános elismerését a német jogban.

Magyar viszonylatban a történeti fejlődés vizsgálata ennél sokkal összetettebb volt, hiszen míg a német jogban a személyiségi jogok vagyoni értékminőségének fejlődése tekintetében számos kutatási eredmény rendelkezésre állt, addig a magyar jogban sem ez, sem a tételes jog meghatározása nem képezte részletes kutatás tárgyát a nem vagyoni kártérítést leszámítva. Ennél fogva elsőként a jog tételes szabályainak felderítése volt a feladat, amelyből tartalmában ki is bontakozott a személyiségi jogok vagyoni viszonyokkal való kapcsolata, összefüggése. Mivel a személyiségi jogok védelme elsősorban a XX. század elejének a terméke, ezért korábban e jogok magánjogi védelméről nem beszélhettünk. Ekkor indult meg, vált valóságossá és gyürüzött be a társadalom, a gazdaság, a technika mindazon változása, amely újfajta jogsértéseket eredményezett. Ezt felismerve már az 1900-as Máptk. is tartalmazott önálló személyiségvédelmi tényállásokat, ezután pedig mind az 1914-es Tervezet, mind az Mtj. kiállt az általános jellegü védelem mellett. Mivel a jog forrását elsősorban a törvényi jog és a szokásjog képezte, így törvény híján a bíróságok gyakorlatát kellett részletesen vizsgálni.

Elsőként a névjog tört utat magának a szokásjogi elismerés felé. Ez az elismerés azonban nem általános volt, hanem más jogalapok kiterjesztő és analóg alkalmazásán nyugodott. Ezek a jogalapok alapvetően két csoportra oszthatóak. Az első nagy csoportot a kizárólag erkölcsi, eszmei sérelmek jogi oltalma jelentette. Így 
nőttek ki a névjog egyes területei, tényállásai a Ht. 94. §-a szerinti bitorlási perből, amely alapján a férj a bontóper során s később azután is, eltilthatta a vétkes feleséget házassági neve további viselésétől. Hasonló volt a szerzői névjog alá nem tartozó, de viszonylagosan a szerzői joghoz kapcsolódó névjogi viták általános magánjog alapján történő megoldása. Ezzel került elismerésre a névbitorlás egy másik ága, a szerzői névbitorlás, amely esetén a szerző-mű kapcsolat hiányzik, és ezáltal a szerzői jog szabályainak alkalmazása kizárt. A második nagy kategóriát a vagyoni, gazdasági érdekek jelentették. A természetes személy nevének cégnévben történő szerepeltetése a Kt. cégbitorlási keresetét kinőtte, és ugyan jogalapjában a bírói gyakorlat azt továbbra is megőrizte, itt másfajta jogsérelemről volt szó már az akkori jogirodalom szerint is. Hasonló volt a név reklámcélú felhasználása, a név üzletjelzőként, kereskedelmi névként való megjelenése és az azzal kapcsolatos jogviták. A vagyoni érdekek több oldalról tolultak be a személyiség kialakuló védelmébe: a kereskedelmi jog felöl, a tisztességtelen verseny oldaláról, az iparjogvédelem felől.

A vagyoni érdekek második nagy bástyája a képmáshoz való jog bírói elismerése később ment végbe, noha elismerése után igen jelentős joggyakorlat halmozódott fel. A képmáshoz való jog a névjogi tényállásokhoz hasonlóan szintén más jogalapon, a szerzői jog szabályainak kiterjesztő értelmezése által nyert elismerést. A jogsértő magatartások ugyanakkor alapjaiban sokkal jobban összefonódtak a vagyoni érdekekkel, hiszen azok elsősorban a sajtó, a média szenzációhajhász, példányszámnövelő tevékenysége körében jelentek meg. A képmáshoz való jog bizonyos esetei ennek ellenére kifejezetten erkölcsi, eszmei érdeket védtek abból fakadóan, hogy egy-egy képmás közlése, nyilvánossá tétele, plakáton való megjelenítése a leképzett személy tekintélyét, társadalmi állását és megbecsülését jelentősen rombolta. Voltak azonban olyan esetek, amelyek kifejezetten vagyoni haszonszerzési célzatúak, amelyeknél a jogsértő vagyonának gyarapodása az elszenvedett csekélyebb jellegü eszmei sérelemnél sokkal kirívóbb. Az első esetkörhöz kapcsolódóan a királyi bíróságok elsősorban a nem vagyoni kár megtérítését javallották a szerzői jog szabályai szerint, míg a második esetkörben arra is volt példa, hogy a vagyoni kár megtérítését rendelték el ugyancsak e törvény alapján. Volt olyan ítélet is, amely a képmás felhasználásának elmaradása esetén fizetendő ellenértéket határozta meg, ráadásul a korábbi joggyakorlat figyelembevételével.

Ugyan a '30-as, '40-es években a személyiségi jog már általános védelemben részesült, és a hozott ítéletek már az Mtj.-n alapultak, ez a védelem elsősorban eszmei 
jellegü volt. Az eszmei jelleg ellenére egyre jobban teret törtek maguknak a vagyoni érdekek, amelyeket a jogi értékelés során nem lehetett kizárni. Ennek a vagyoni vonulatnak, amely sok esetben jelentősen keveredik az erkölcsi érdekekkel, a fejlődése, kikristályosodása dogmatikailag félbeszakadt a szocialista polgári jog térhódításával. Ennek oka abban rejlett, hogy a kapitalista, piacgazdasági viszonyok, illetve a tervgazdasági, közjogiasított polgári jog egymástól eltérő szabályozása okán a személyiséget is eltérö területeken tudták, látták oltalmazni. E területek egy része olyan, amely esetében kevéssé lényeges a gazdasági berendezkedés, és ennek okán mindkét jogrendszer védi a személyiséget az ilyen behatások ellen. Ilyen a kegyeleti jog, a feleség névviseléstől való eltiltása, a jóhírnév. Másrészük viszont kifejezetten olyanok, amelyek léte erősen a piacgazdasági viszonyok által determinált, ide sorolható a cégnév bitorlása, a név és képmás reklámtevékenységgel összefüggő felhasználása és a sajtó szenzációéhsége is. Mint látható a személyiségvédelem vagyoni viszonyokkal összefüggő területei e második csoportba esnek, és ennél fogva ezek a rendszerváltozásig nem tudtak továbbfejlődni. Ez azonban egy másik problémát is indukált: a nem vagyoni jelleg még eröteljesebb megjelenését. Erre rátett az is, hogy más szocialista országoktól eltérően, a Legfelsőbb Bíróság a nem vagyoni kártérítést megszüntette, és annak újbóli élő joggá tétele szintén erre a kizárólagos nem vagyoni jellegre erősített rá. Ezt vitte tovább a rendszerváltozás után a magyar jogtudomány, amikor az alkotmányos általános személyiségi jogot a személyiségi jog általános szabályával kezdte azonosítani.

\section{B. A vagyoni értékminőség dogmatikai előfeltételei}

Mivel a személyiségi jogokhoz kapcsolódó vagyoni érdekek védelmének dogmatikai és elvi alapjai nem tudtak kialakulni, így elsősorban azt kellett vizsgálni, hogyan helyezhetők el ezek a jogok, jogi érdekek a magánjog és az alanyi jogok rendszerében. Mielött ezek vizsgálatához nekikezdhettem volna, volt egy másik, igen sarkalatos probléma, amely az új Ptk.-val szüremlett be tételes jogi szinten a magánjogi személyiségvédelembe. Ez pedig az előbb említett alkotmányos általános személyiségi jog magánjogi jogalappá emelkedése volt.

A német jogfejlődésen az volt látható, hogy a jogalkotói beavatkozás hiányában a bírói gyakorlat a Grundgesetzre és az alkotmánybírósági gyakorlatra 
alapítottan kényszerült elismerni az általános személyiségi jogot. A BGH átvette a BVerfG-nek azt az álláspontját, hogy az általános személyiségi jog az emberi méltósághoz való jog és az általános cselekvési szabadság (kibontakozás joga) alapjogainak együttes alkalmazása megalapozza egy alkotmányjogi alapjog, az általános személyiségi jog létét. Ennek magánjogi behatására tekintettel ismerte el analógiával, a jog általános elveinek figyelembevételével a magánjogi személyiségi jogot. Ez a koncepció alkalmas volt például arra, hogy a méltósághoz való jog figyelembevétele nélkül, a kibontakozás jogára alapítottan a jogi személyeket is megillesse a személyiségvédelem. De alkalmas volt arra is, hogy ne legyen korlátja a személyiségi jog vagyoni vonatkozásai elismerésének.

A magyar jogban az általános személyiségi jog kizárólagosan emberi méltósághoz való jogként való értelmezése számos problémát eredményezhet, amelyek közül a vagyoni értékminőség kizárása kerül a középpontba. A vagyoni érték azért kerül szembe az emberi méltósághoz való joggal, mert ennek értelmében a személyiségi jog semmilyen körülmény között nem lehet forgalomképes, átruházható, örökölhető. Fel kellett tehát oldani e két jog közötti kollíziót a jogértelmezés eszközével. Ez alapján a Ptk. 2:42. § (2) bekezdése úgy értelmezendő, mint ami a Ptk. 2:42. § (1) bekezdésének generálklauzuláját magyarázza, s rámutat az emberi méltósággal való összefüggésre, anélkül azonban, hogy e normára önállóan hivatkozni lehetne. Ezzel a magyarázattal van összhangban a (2) bekezdés is, ami figyelmeztet, hogy a személyiségi jogokat a polgári jog szűrőjén keresztül kell megközelíteni. Ezzel elkerülhető a generálklauzula megduplázása, választ adható a Ptk. 2:42. § (1) bekezdésének funkciójára, s az emberi méltóság is kielégítően elhelyezhető ebben a rendszerben. E kibontakozás-alapú személyiségvédelmi rendszerben az emberi méltóság nem csupán a magánjogi személyiségi jog mögöttes, alkotmányjogi alapját képezi, hanem egyfajta emberi minimumot is jelent. Az Alaptörvény II. cikk (1) bekezdése szerint az emberi méltóság sérthetetlen, amely sérthetetlenség hagyományosan korlátozhatatlanságot jelent. Ebben a rendszerben tehát az emberi méltóság egy belső szük mag a személyiségvédelmen belül, és a kibontakozás joga ernyő módjára magában foglalja ezt a jogot, a magánélet szféráját és minden más, e rendszerbe foglalt nevesített és nem nevesített személyiségi jogot is. A legfontosabb ugyanakkor az, hogy az emberi méltóság ilyen értelmezésével nyitva áll a lehetősége annak, hogy a személyiséggel kapcsolatos vagyoni érdekeket elismerhessükanélkül, hogy a kódexet tulajdonképpen módosítani kellene, legalább is ebben a tekintetben. 
Az alanyi jogok klasszikus osztályozása szerint a személyiségi jog abszolút személyi jog. Abszolút jog azért, mert a személyiségi jog jogosultját a jog gyakorlása mindenki mással szemben megilleti, mindenki más köteles tartózkodni a jogosult hatalmi körének zavarásától. A személyiségi jog tehát kizáró jog. Másrészről személyi jog, azaz nem vagyoni jog. A személyiségi jog a jogalany alapvető személyes viszonyait védi a háborítatlanság ellen. Ennél fogva a jog tartalma alapvetően nem vagyoni jellegü, hasonlóan a családi joghoz mint relatív személyi joghoz. Az alanyi jogok ilyen formájú osztályozása azonban nem alkalmas a vagyoni érdék értékelésére. Ennél fogva elsősorban azt vizsgáltam, milyen jogokat szabályoz a magánjog, hogyan írja le a külső világot. A római jog és a pandektizmus is elsősorban a fizikai világ, a külső, tapintható világ tárgyaihoz kapcsolódóan rendelt szabályokat. Ez az ún. fizikai világ, fizikai valóság, amelynek terepe a dolgok feletti jogi uralom szabályanyaga, a vagyoni jog. E mellé szüremlett be a XIX. században az ún. személyi eszme, a fizikai világban, materiális formában fel nem lelhető immateriális jogokkal. Ez elsőször a szerzői jog és az ipari jogok védelme által jelent meg a magánjogban, és ezt követte a személyiségi javak kizáró jogi oltalmának elismerése. Az immateriális jogok osztályozása tekintetében Meszlény és Dezsö felfogását vettem alapul, amely e jogok forgalomképessége és személyhez való tapadása szempontjából osztályozza ezeket a jogokat. Ennél fogva a személyiségi jog alaptermészetében mindenképpen személyi immateriális jog, azaz forgalomképtelen, a személytől elválaszthatatlan jog. Lehetőség nyílik ugyanakkor arra is, hogy a személyiségen fennálló egyes, forgalomképes jogi érdeket ebbe a rendszerbe mint önállótlan vagyoni immateriális jogot besoroljuk. A vagyoni értékü személyiségi jog olyan részben forgalomképes jog, amely bizonyos tekintetben forgalomképes, ugyanakkor a személyiséggel (a korábbi jogosultsággal) való kapcsolata továbbra is fennmaradt az eszmei érdekek tekintetében.

A személyiségi jog egyes részjogosultságainak ilyen átvándorlását, transzformálódását a tárgyiasulás fogalmával írtam le. A tárgyiasulás jelenik meg a szellemi alkotások tekintetében is akkor, amikor az alkotótevékenység eredményeként megszülető, védendő gondolatot az alkotó a külső világban megjeleníti. A tárgyiasulás az egyes személyiségi jogokkal kapcsolatban is megjelent korábban az irodalomban. Az eszmei, immateriális valóságból a tárgyi valóságba átszüremlő, és ezáltal a személyiség belső magjától eltávolodó részjogosultságok tárgyiasulnak, míg a személyiség részévé váló jogi érdekek, jogtárgyak megszemélyesülnek. 
A tárgyiasulás a személyiségi jogba tartozó jogosultságok csak egy részének privilégiuma. Vannak olyan jogok, amelyek nem távolodnak el a személyiségtől, eszmei, erkölcsi érdekeket védenek kizárólagosan (pl.: jóhírnév, becsület), és vannak olyan jogok is, amelyek elve az ember fizikai valóságban való létezése miatt adottak (pl.: testi épség, szabadság). E jogok vagy azért nem tudnak kilépni az eszmei valóságból, mert az fogalmilag kizárt, vagy mert már eleve a fizikai valóságban létező jelenségre reagálnak. Vannak azonban olyan jogok, amelyek tárgyiasulni képesek, ezek a személyiségi jegyek. A személyiségi jegyek két nagy csoportra oszthatóak, amely felosztás elsősorban a jogsértési magatartások közötti differenciálás szempontjából jelentős. Az első csoportba a személyiség külső megnyilvánulásai tartoznak (pl.: név, képmás, jelmondat), a másik csoportba pedig az ismereti személyiségi jegyek (pl.: életkép, magánélet, magántitok). E személyiségi jegyek azok, amelyek tárgyiasulásuk által vagyoni értéket szerezhetnek maguknak, és önállótlan vagyoni immateriális joggá válhatnak. Mivel a név számtalan formában, több jogtárgy keretében is tárgyiasítható, ezért célszerü volt e tárgyiasulási módozatokat is vizsgálni, ez ugyan jelentős eltérés a német jogtól, másrészről a személyiségi jog vagyoni értékminőségének lehetőségét az angolszász felfogástól eltérően más irányban is megnyitja.

A névjog tárgyiasulása többféleképpen végbemehet. Ide sorolható egyrészről a más jogintézmény keretében történő tárgyiasulás. Ilyen a szellemi alkotások körébe tartozó védjegyjog, és ilyen a személyiségi jogi védelmen belüli, más jogtárgy formájában történő tárgyiasulás. A személyiségi jogon belüli tárgyiasulásra példa a cégnév, a kereskedelmi név és a domainnév formájában történő tárgyiasulás, amelynek vizsgálata során különbséget kell tenni aközött, hogy a megjelölés alapja egy fantáziaszó vagy a személyiségi jog mint korábbi jog. A névjog tárgyiasulása, a képmáshoz való joghoz hasonlóan, másrészről sui generis módon is végbemehet. A névjog ily módon történő tárgyiasulásával jön létre a néven való vagyoni jog, amelybe a név reklámcélú felhasználása tartozik. A név termékek és szolgáltatások megjelölése tekintetében tulajdonképpen üzletjelzőként funkcionál, és ennél fogva elsősorban mint kereskedelmi név részesülhet védelemben. Ez az oka annak, hogy a név sui generis tárgyiasulásának az alkalmazási köre sokkal szükebb, mint a képmásé, amely esetén az üzletjelzőként való használat a szóbeli megjelölési jelleg hiányában nem értékelhető a kereskedelmi név megsértéseként. 
A név cégnévként való tárgyiasulása által cégen való joggá válik. Amennyiben a cégnév fantáziaszó, úgy a személyiségi jog értelemszerủen a jog gyakorlása során nem jelent korlátot. Abban az esetben, ha a cégnév természetes személy nevét tartalmazza, úgy a céghasználat korlátja a névjog jogosultjának személyiségi joga. Ilyen korlát lehet az, ha a gazdasági társaság a cégnevet más jogi személy alapítása során fel kívánja használni annak nevéül.

Ugyanígy tárgyiasul a név, ha az domainnévvé válik. Ebben az esetben szintén új, a névjog mint személyiségi jogtól független új alanyi jog jön létre, amely szintén abszolút, kizáró jelleget biztosít a jogosultnak. A domainnév nem a jogalany neve, nem cégnév, de nem is védjegy. A domainnév ugyanígy nem üzletjelző, nem kereskedelmi név automatikusan, noha szerezhet ilyen minőséget huzamos használattal, mint ahogy bejegyzéssel az adott megjelölés védjeggyé vagy cégnévvé is válhat. Ekkor azonban új jogosultság keletkezik. A domainnév védelme tehát, mivel nem minden esetben rendelkezik kereskedelmi névi minőséggel, nem kizárólagosan a jogosult gazdasági, üzleti, kereskedelmi érdekét védi, ugyanúgy kiterjed az ettől független, nem vagyoni, erkölcsi jellegü sérelmek orvoslására, és ennek keretében is kizáró jogot biztosít a jogosult számára.

A névjog alkalmazásának a személyiségvédelmen belüli, előbb felleltározott dogmatikai rendszere ugyanakkor egy másik következtetésre is vezet. A személyiséghez kapcsolódó érdekek köre tág, nem pusztán az ember érzületére, nem vagyoni érdekeire terjed ki kizárólagosan, hiszen nem csak az emberrel szoros összefüggésben álló jogtárgyak védelmét látja el a magánjogi személyiségvédelem. Ebből is látszik egyrészről azon állításom helyessége, hogy az alkotmányos emberi méltóság joga csupán a személyiségvédelem egy részét fedi le, és hogy a személyiségi jog magánjogi alapja a 2:42. § szerinti kibontakozás joga. Másrészről a magyar személyiségi jog, a svájcihoz és a liechtensteini joghoz hasonlatosan elsősorban az egyén személyes viszonyait védi. A személyes viszonyok körébe tartozik minden olyan, elsősorban eszmei érdek, jogtárgy, amely a közfelfogás által egy személy kizárólagos rendelkezési jogába utalt. E személyes viszonyoknak a vagyoni viszonyokkal való keveredése, de el nem enyészése érhető tetten a névjogok tárgyiasulásán. Itt rajzolódik ki leginkább az a feszültség is, amely e jogtárgyak forgalomképessége okán azok osztályozásában is jelentkezik. Az eszmei, immateriális javak summa divisiója alapján személyiségi jog a forgalomképtelen, nem örökölhető immateriális jog, míg a társadalmi, ipari felhasználhatósága okán forgalomképes 
immateriális javak a szellemi alkotások területére esnek. A személyi és vagyoni viszonyoknak a tárgyiasulás általi keveredése, különösen az így létrejött új alanyi jogban a személyiségi jog további fellelhetősége jelentős klasszifikációs problémákat vet fel, különösen az individuum és a személy kiemelt fokú védelme okán.

A személyiségi jogon belülre pozicionálható jogtárgyak és érdekek köre a németnél jóval tágabb, azt is mondhatjuk: más jellegü. A német jogban látható volt, hogy az általános személyiségi jog magánjogi elismerése előtt a képmás és a név védelme kiterjeszthető lett volna a vagyoni érdekekre, azt maga a jogalkotó is előrevetítette már a kodifikáció során is. A nagy váltást az emberi méltóságból és a kibontakozáshoz való jogból eredeztetett általános személyiségi jog elismerése jelentette egyrészről. Ez ugyanis jelentős eszmei, nem vagyoni védelmi áramlatot adott a személyiségi jog joggyakorlatának alkotmányos jogalapja és szankciói által. Erre erősített rá a Markengesetz, a védjegytörvény 1995-ös módosítása, amely a kereskedelmi név védelmét a védjegybitorlással összekapcsolván egy általános vállalatjelző-bitorlás beiktatását jelentette. Ez kivette a talajt a BGB 12. §-a szerinti névjog kiterjesztő és analóg alkalmazása alól, és a BGB 12. §-ának alkalmazási köre a jelentős vagyoni érdeket magában foglaló vállalat- és árujelzők tekintetében többé nem volt alkalmazható, tárgyi hatálya a lényegesen erőteljesebb, fennmaradó eszmei érdekekre szükült. Ezután a jogváltozás után kerültek elismerésre a személyiségi jog vagyoni vonatkozásai, amelyek már szintén ebben a személyiségvédelmi keretrendszerben kerültek értelmezésre és alkalmazásra. Ennek okán sem a jog elismerésekor a BGH, sem a bírói gyakorlat nem tud hivatkozni arra, hogy a BGB 12 . §-a szerinti névjog védelme tágabb kört fog át, a vagyoni érdekek sokkal szerteágazóbbak a személyiség védelmén belül.

A magyar jogban más a helyzet, ott az előbb említett megjelölések, névjogok a személyiségvédelemben jelen vannak. Hasonló helyzetben a svájci jog van, ez viszont a személyiségi jog vagyoni értékét nem ismeri. A jogtárgyak sokasága okán ugyanakkor megnő a tárgyiasulási módok száma, és ezzel a vagyoni érdekek, a vagyoni, kereskedelmi felhasználhatóság módjainak száma is. Ez azt is eredményezi, hogy a vagyoni és eszmei érdekek a személyiségvédelmen belül sokkal több területen ütköznek, és hogy egy esetleges vagyoni személyiségvédelmi rendszer kialakításának német útja nem alkalmazható, azt más módon kell biztosítani. Erre a tárgyiasulás alapú vagyoni személyiségvédelem eddig alkalmasnak bizonyult. 


\section{A vagyoni személyiségi jog}

A Polgári Törvénykönyv jogkövetkezményei egyértelmüen utalnak a vagyoni érdekek észrevételére. Ezt megerősíti mind a jogszabály objektív célja, mind a jogalkotói szándék, a szubjektív cél is. A jogkövetkezmények ellenére a tényállási oldalon ugyanakkor óriási a hiátus, a jogalkotó nem rendelkezett a vagyoni érdekek védelméről. Nem mondta meg, mi számít vagyoni érdekkörü felhasználásnak, mikor enyészik el a jog, és hallgat a bírói gyakorlatban egyre gyakrabban jelentkező szerződéses konstrukciókról is. Ennek oka az volt, hogy a kodifikációhoz kapcsolódó jogirodalomban nem jelentkeztek azok a kérdések, amely az alapul vett német jogban vitás kérdésnek minősültek, nem került figyelembe vételre, hogyan valósítja meg a gyakorlati életben a német jogalkalmazás a vagyoni érdekek védelmét.

A bírói gyakorlat ugyan sok szempontból a kodifikáció előtt jár, és fiktív licencia díj fizetésére kötelezi a jogsértőt kártérítés keretében, azonban sok tekintetben az eszmei érdekek védelmére vonatkozó szabályok alapján bírálja el a vagyoni érdekkörben felhasznált tárgyiasítható személyiségi jegyeket. Ez viszont alapvetően helytelen álláspont, amely a nem megfelelö törvényszerkesztésen nyugszik. Ennek okán a vagyoni érdekek védelme tényállási szinten mindenképpen elkülönítendő az eszmei, erkölcsi érdekek védelmétől, amely egyrészről a bírói gyakorlatban teleologikus redukció, a törvényszöveg szintjén egy, a szerző személyhez füződő jogaihoz hasonló személyiségi szféra, a vagyoni személyiségi jog elhelyezésével lehetne feloldható. Végső soron ebben a tekintetben megállapítható, hogy a Ptk. a vagyoni érdekeket részben védi, a nem szabályozott kérdéseket pedig a jogszabály céljának egyértelműsége okán a bírói gyakorlatnak kell feloldania. Ez azonban inkább szükségmegoldásnak tűnik, és inkább a jogalkotónak kellene beavatkoznia a szabályozás egyértelműsége, biztonsága és a piac megfelelő müködésének biztosítása végett.

Ez a jogalkotói beavatkozás meglátásom szerint egy vagyoni személyiségi jog formájában képzelhető el. Számtalan modell van a vagyoni és személyi viszonyok személyiségi jogon belüli viszonyára. A vagyoni érdekek a személyi érdekektől nem választhatóak le, ez ugyanakkor nem jelenti azt, hogy a pozitív jogi szabályozásban ezek ne válhatnának külön. Ennek több oka van, amelyek közül a legfontosabb az, hogy a két érdek védelme eltérő jellegü alanyi jogi jogosultságokat keletkeztet, így a 
jogalkalmazásban is eltérően kezelendőek ezek. Ennek elvi alapjaként azt adtam meg, hogy az egyes személyiségi jegyek tárgyiasulásuk útján alkalmasak arra, hogy a vagyoni forgalomban részt vegyenek. Ez a tárgyiasulás a személyiségi jog egy részének egy speciális értékminőségét képezi, amely a jog átalakulásához is vezet.

Mivel két alanyi jogi helyzetről van szó, a hozzájuk kapcsolódó jogkövetkezmények tekintetében is differenciálni kell. Míg a sérelemdíj kifejezetten csak eszmei és erkölcsi sérelmek orvoslására szolgál, addig a kártérítés mint az elmaradt díjazás megtérítése, illetve a jogalap nélküli gazdagodás vagyonjogi igények, csak vagyoni érdekek körében alkalmazhatóak. Ennél fogva a jogalkalmazást megkönnyítendő az alapvetően eszmei érdekeket védő személyiségi jogról le kell választani a vagyoni érdekek védelmét, akkor is, ha a tárgyiasulás által a személyiségi jogon belül a két érdek együttesen, összefonódva jelentkezik egy életviszonyon belül is.

A vagyoni személyiségi jog két lépcsőben válik ki az általános személyiségi jogból. Az egyik lépcsőfok a személyiségi jog korábban említett tárgyiasulása a személyiségi jegyek tekintetében, a másik lépcsőfok pedig a felhasználás vagyoni érdekkörébe eső jellegében, a kereskedelmi, üzleti felhasználásban rejlik. A tárgyiasulás alapú vagyoni személyiségvédelemben a publicitásnak nincsen központi szerepe a jogsértés megállapításában, annak elsősorban a vagyoni hátrány mértékének számításánál, az alkalmazandó jogkövetkezmény körében jut tér. A kontinentális, illetve a magyar jogrendszer sajátosságai okán a vagyoni érdekkör megsértéséhez több olyan esetkör, várományi helyzet is kapcsolódik, amely során a publicitás egyáltalán nem jelentkezik, másrészről a right of publicity tortjának megsértése esetén az amerikai bírói gyakorlat szintén nem igazán tud mit kezdeni a magánszemélyek, a nem híres személyek személyiségi jegyeinek kereskedelmi felhasználásával.

A tárgyiasult vagyoni személyiségi jegyek önálló alanyi jog keretében megvalósuló védelme további kérdéseket is felvetett. A kapcsolódó német jogirodalom a vagyoni érdekkörü felhasználáshoz kapcsolódó, forgalomképes személyiségi javakat egyértelmüen szellemi tulajdonjogként, eszmei javakként kvalifikálja, és ennek a magyar jogban sincsen akadálya. Sőt, a személyi és vagyoni viszonyok vegyülésének a módja, a jogtárgy feletti rendelkezési jog monopóliumának időmúláshoz kötött konstrukciója (védelmi idő), a jogsértés időtől és tértől független megsértésének lehetősége mind párhuzamot képez a szellemi tulajdonjogokkal. 
A vagyoni személyiségi jogba tartozó jogosultságok védelmi idejéről nem rendelkezik a törvény, így az egyrészről a halállal megszünik, másrészről, a kegyeleti jog egyidejű sérelmével, a jogutódok rendelkezési körébe utalt. Meglátásom szerint célszerü lenne egy 20 éves védelmi időt bevezetni, ezzel feloldásra kerülne az az értelmezési ellentmondás, hogy a Ptk. a jogalap nélküli gazdagodás esetén részben engedi a jogutódlást, a kártérítési igény esetén viszont nem szól arról.

A vagyoni érdekek alapjogi védelmét a szellemi alkotásokhoz hasonlóan célszerü lenne a tulajdonhoz való alkotmányos jog védelme körébe vonni. Ezt indukálja a német és a spanyol megoldás is, illetve részben az EJEB jogértelmezése is, másrészről szellemi tulajdonjogok mintájára kezeli a vagyoni érdekeket védő jogokat a nemzetközi magánjog tekintetében a bírói gyakorlat is a védjegyjog mintájára.

A jogkövetkezmények tekintetében a sérelemdíj a vagyoni érdekek védelme körében nem bír relevanciával, hiszen az az elszenvedett nem vagyoni sérelem kompenzálására szolgál. A vagyoni hátrány megtérítésére két megoldás kínálkozik: a kártérítés és a jogalap nélküli gazdagodás. A kártérítés tekintetében a magyar joggyakorlat a némettől függetlenül szintén az elmaradt hasznosítási díj, fiktív licencia díj megtérítésére mint elmaradt haszonra helyezi a hangsúlyt (licencia-analógia). A jogalap nélküli gazdagodás során a jogsértéssel elért vagyoni előny átengedését írja elő a Ptk., amely által két eltérő jogkövetkezményt vegyít. Mind a rendszertani, mind a teleologikus értelmezés azonban arra vezet, hogy a két jogkövetkezmény közül a jogalap nélküli gazdagodás szabályai az alkalmazandóak. Ez a kártérítéstől lényegileg a szubjektív elem, a felróhatóság hiányában különbözik. Másik eltérés az, hogy a jogalap nélküli gazdagodás körében nem pusztán az elmaradt díjazás, hanem minden, a jogsértéssel összefüggő vagyoni előny kiadását, megtérítését kérheti a jogosult. A jogalap nélküli gazdagodás tekintetében a jogutódlást a jogalkotó egyértelműen rögzítette, annak megvalósulási körét azonban a kegyeleti jog egyidejü sérelmére korlátozta.

A jogkövetkezmények tekintetében egyrészről célszerü lenne a kártérítés tekintetében a vagyoni érdekek sérelme esetén az elmaradt haszon körébe, értelmező szabályként elhelyezni az elmaradt hasznosítási díjat, másrészről azt, hogy ez is öröklődő vagyoni igény, amely esetén jogutódnak szintén az örökösök számítanak, ez jelenleg csupán a rendszertani értelmezés alapján állapítható meg. A jogalap nélküli gazdagodás körében célszerű lenne a post-mortem jogalap nélküli gazdagodást a kegyeleti jogtól függetleníteni, az ugyanis dogmatikailag helytelen megoldáshoz 
vezet, és indokolatlanul szükíti le a vagyoni érdekek védelmének halál utáni körét. Emellett célszerü lenne, ahogy az a tényállás tárgyalása során felmerült, e két jog sérelmét az eszmei vonatkozásoktól függetleníteni egy olyan alanyi jogi tényállás által, amely kizárólag a vagyoni érdekek védelmére szolgál, valamint a kártérítés és a sérelemdíj közötti értékelési feszültség feloldásához is nagymértékben hozzájárulhatna. 


\section{Forrásjegyzék}

A felhasznált irodalom egyes tételeinél található kapcsos zárójelbe helyezett rövidítés az adott müben javasolt saját rövidítés, amely a (német) jogtudományban általánosan elterjedt és használt hivatkozási mód. A dolgozat lábjegyzeteiben e müvek tekintetében kizárólag e rövidített hivatkozási módokat használom, azok visszafejtését pedig a többi hivatkozásnak megfelelően itt adom meg. (Ehhez 1. MÖLLERS, THOMAS M.J.: Juristische Arbeitstechnik und wissenschaftliches Arbeiten. Vahlen, München, 2016. § 6. Rn 44.)

\section{Felhasznált jogirodalom}

AlfÖLDY DEZSÖ: A magyar szerzöi jog. Különös tekintettel a m. kir. Kúria gyakorlatára. Grill, Budapest, 1936.

ALMÁSI ANTAL: A személyiség védelme a tervezetben. Ügyvédek Lapja 1902. 29. sz.

2.

ALMÁSI ANTAL: Tilos cselekmény a magánjogban. Grill, Budapest, 1907.

[Almási Antal] Almási, Anton: Ungarisches Privatrecht. Band I., Walter de Gruyter \& Co. Leipzig, 1922.

ALMÁSI ANTAL: A személyiségi jog elhatárolása és tartalma. Jogtudományi Közlöny 1927. 133.

AlMÁsi ANTAL: Házassági jog. In: Szladits Károly (szerk.): Magyar Magánjog II. Családi Jog. Grill, Budapest, 1940.

AL-RAWASHDEDH, Waddah: Dispute Resolution Mechanisms and Trademark Cybersquatting. Szeged, disszertáció, 2017.

APÁTHY ISTVÁN: A magyar kereskedelmi törvénykönyv tervezete. Franklin, Budapest, 1873.

AsZTAlos LÁSZló: A polgári jogi szankció. KJK, Budapest, 1966.

BALÁs P. ElemÉR: Szerzői jog és dologi dinamizmus. In: Emlékkönyv Dr. Szladits Károly tanári müködésének 30. évfordulójára. Grill, Budapest, 1938.

BALÁs P. ElemÉR: Személyiségi jog. In: Szladits Károly (szerk.): Magyar Magánjog I., Grill, Budapest, 1941. 
BAlÁs P. ElEMÉR: Személyi és dologi szemlélet az anyagi büntetöjog és a perjog fejlödésében. In. Eckhart Ferenc - Degré Lajos (szerk.): Emlékkönyv Dr. (Viski) Illés József tanár müködésének negyvenedik évfordulójára. Stephaneum, Budapest, 1942.

BALÁs P. ElEMÉR: Szerzői jog és dologi dinamizmus. In: Koltay András (szerk.): Balás P. Elemér Emlékkönyv. Wolters Kluwer, Budapest, 2018. 367.

BARZÓ TÍMEA: A személyiségi jogok. In: Bíró György (szerk.): Általános Tanok és Személyek Joga. Novotni, Miskolc, 2014.

BARzó TímeA: Személyiségvédelem. In: Barzó Tímea - Papp Tekla (szerk.): Civilisztika I. Dialóg Campus, Budapest, 2018.

B.S. [Beck Salamon]: A személyiségi jog magánjogi oltalma. Polgári Jog 1927. 238.

BEREND BÉLA: A nyilvánossághoz való jog. In: Emlékkönyv Meszlény Artur születésének 60. évfordulójára. Politzer Zsigmond, Budapest, 1936.

Beuter, Claudia: Die Kommerzialisierung des Persönlichkeitsrechts. Dissertation, Konstanz, 2004.

BEUTHIEN, VOLKER: Was ist vermögenswert, die Persönlichkeit oder ihr Image? NJW 2003. 1220.

BEUTHIEN VOLKER - SCHMÖLZ, ANTON S.: Persönlichkeitsschutz durch Persönlichkeitsgüterrechte. Erlösherausgabe statt nur billige Entschädigung in Geld, CH Beck, München, 1999.

Beverly-Smith - OHLy - LuCAS-Schlotter: Privacy, Property and Personality, Cambridge University Press, 2005.

BoDA GyUlA: A jogi hírlap döntvénytára. A Jogi Hírlap Kiadása, Budapest, 1930.

Boda GyUla - Meszlény ARTUR: Magánjog: 1930. IX. 1.-1933. IX. 1. Jogi Hírlap kiadása, Budapest, 1933.

Boda Gyula - Vincenti GuszTÁv: Magánjog: 1933. IX. 1.-1936. IX. 1. Jogi Hírlap kiadása. Budapest, 1936.

Bohne, Michael: $\S$ 63. Schweiz. In: Götting, Horst-Peter - Schertz, Christian - Seitz, Walter (szerk.): Handbuch des Persönlichkeitsrechts. C.H. Beck, München, 2019. Rn 13, 15.

BozÓKY Alajos: A személyjogokról. In: Fodor Ármin (szerk.): Magyar Magánjog I. Singer és Wolfner, Budapest, 1905.

Brox, Hans - Walker, Wolf-Dietrich: Allgemeiner Teil des BGB. 40., neu bearbeitete Auflage, Vahlen, München, 2016. 
BrüCKner, Christian: Das Personenrecht des ZGB. Zweiter Teil. Der Schutz der Persönlichkeit. Basel, 2000.

Buchanan, CATHERINE Louise: A Comparative Analysis of Name and Likeness. Golden Gate University Law Review 1988 Volume 18. Issue 23. 70.

VON BÜREN, BRUNO: Ueber die Beschränkungen des Rechtes, den eignen Namen zu gebracuhen. Schweizerische Juristen-Zeitung (Revue Suisse de Jurisprudence) (44)1948 Heft 5. S. 65.

Bydlinski, Peter: Grundzüge der juristischen Methodenlehre. Facultas wuv, Wien, 2012.

COHN, GEORG: Neue Rechtsgüter. Liebmann, Berlin, 1902.

CORBETT, VAL: A képmáshoz füződő jog és az elvi megalapozás nehézségei. In Medias Res 2014/2.

CORBETT, VAL: The right of publicity and the search for principle, In: Koltay, András (szerk): Media Freedom and Regulation in the new Media World, Budapest, Wolters Kluwer, 2014.

CSEHI ZOLTÁN: Elévülés a személyiségi jogok rendszerében, az új Ptk.-ra tekintettel. In Medias Res 2016/1.

Dezső Gyula: Az objectiv kártérítés tana. Grill, Budapest, 1917.

DORALT, Roswitha: Der Schutz des Lebensbildes. ÖJZ 1973, 645.

Dreymann, NoA: John Doe's Right of Publicity. Berkeley Technology Law Journal 2018.

Egger, August: Einleitung. Das Personen. Zürich, Schultheß \& Co, 1930.

ELSTER, ALEXANDER: Urheber- und Erfinder-, Warenzeichen- und Wettbewerbsrecht (Gewerblicher Rechtsschutz). Walter de Gruyter \& co., Berlin und Leipzig, 1928.

ENSTHALER, JÜRGEN: Gewerblicher Rechtsschutz und Urheberrecht. Springer, Berlin, 2003.

EÖRSI GyULA: A szocialista polgári jog alapproblémái. Akadémiai kiadó, Budapest, 1965.

FALUdi GÁBOR: A licencia szerződés. Polgári Jogi Kodifikáció 2008/2. 12.

FALUDI GÁBOR: Szerzői jog és iparjogvédelem. In: Vékás Lajos (szerk.): Szakértői Javaslat az új Polgári Törvénykönyv tervezetéhez. Complex, Budapest, 2008.

FAludi GÁBor - KABAi ESZTER - TARR PÉTER: XIII. fejezet. A szerzői jog megsértésének jogkövetkezményei. In: GYERTYÁNFY Péter (szerk.): Nagykommentár a szerzői jogi törvényhez. Wolters Kluwer, Budapest, 2014. 
FAZEKAS OSZKÁR: A szellemi tulajdon jogbölcseletéhez. In: Emlékkönyv Nagy Ferenc huszonöt éves egyetemi tanárságának megünneplésére. Atheneum, Budapest, 1906.

FAZEKAS OSZKÁR: Az eszmei javak jogi oltalma a magyar Polgári Törvénykönyv javaslatában. Franklin, Budapest, 1914.

FEHÉRVÁRY JENŐ: Magyar kereskedelmi jog rendszere. Grill, Budapest, 1941.

FeKeTE GyÖRgY: Polgári Jog (Általános rész, személyek és dologi jogok). Tanügyi sokszorosító, Kolozsvár, 1958.

FEKETE KÁROLY: A fényképen való jog. Jogtudományi Közlöny 1903. 48. sz. 410.

[FEZER $§ 15$ MarkenG Rn 29.] FEZER, KARL-HeInZ: Markenrecht. Kommentar zum Markengesetz, zur Pariser Verbandübereinkunft und zum madrider Markenabkommen. Dokumentation des nationalen, europäischen und internationalen kennzeichenrechts. C.H. Beck, München, 2009.

FÖlDI ANDRÁS - HAMZA GÁBOR: A római jog története és instituciói. Nemzedékek Tudása Tankönyvkiadó, Budapest, 2014.

FRIEDRICH, KATRIN: Internationaler Persönlichkeitsrechtsschutz bei unerlaubter Vermarktung. München, CH Beck, 2003.

FRITZSCHE, JörG: Fälle zum BGB Allgemeiner Teil. CH Beck, München, 5. Auflage, 2014.

FrommeYer, Ingo: Persönlichkeitsschutz nach dem Tode und Schadensersatz BGHZ 143, 214 ff. (,Marlene Dietrich”) und BGH, NJW 2000, 2201 f. (,,Der blaue Engel“). JuS 2002, 13.

FÜRST LÁsZLÓ: A magánjog szerkezete. Grill, Budapest, 1934.

GÁRDOS PÉTER (szerk.): Kézikönyv az új Polgári Törvénykönyvhöz, Complex, Budapest, 2009.

GELLÉN KLÁRA: Az egységes digitális piaci stratégia törekvései az áruk távértékesitése és a digitális tartalomszolgáltatások körében. Gazdaság és Jog 2017/4. 3 .

GELLÉN KLÁRA: Balás P. Elemér a sajtóhelyreigazítási jog tárgyáról. In: Koltay András (szerk.): Balás P. Elemér emlékkönyv. Wolters Kluwer, Budapest, 2018.

GiERKe, OtTo von: Deutsches Privatrecht Band I. Leipzig, Verlag Duncker \& Humblot, 1895.

GoldBerger JózSEF: Közszereplés és személyiségi jog. Polgári Jog 1931. 134. 
GoOdman, ERIC J.: A National Identity Crisis: The Need for a Federal Right of Publicity Statute. DePaul J. Art, Tech. \& Intell. Prop. L. 1999. Vol. 9. 227.

GöDÖLle IstVÁN: Vt. 5. §. In: Faludi Gábor - Lukácsi Péter (szerk.): A védjegytörvény magyarázata. HVG-ORAC, Budapest, 2014.

GÖRÖG MÁRTA: A fájdalomdíj mértékét befolyásoló körülmények összehasonlító elemzése a német joggyakorlat elötérbe helyezésével. Jogelméleti Szemle 2001. 4. sz.

GÖRÖG MÁRTA: Az általános személyiségi jog megsértésének fájdalomdíjjal való orvoslása. Jogelméleti Szemle 2002. 4. sz.

GÖRÖG MÁRTA: A nem vagyoni kártérités kiterjesztése az általános személyiségi jog megsértésének eseteire. Acta Universitatis Szegediensis. Acta Juridica et Politica, Tomus LXVI. Fasc. 7. Szeged, 2004.

GÖRÖG MÁRTA: A nem vagyoni kártérítés összege. In: Tanulmányok Dr. Besenyei Lajos egyetemi tanár 70. születésnapjára. SZTE, Szeged, 2007. 203.

GÖRÖG MÁRTA: A kegyeleti jog és nem vagyoni kártérítés. Pólay Elemér Alapítvány, Szeged, 2008.

GÖRÖG MÁRTA: A személyhez füzödö jogok védelmét deklaráló generálklauzula. In: Csöndes Mónika - Nemessány Zoltán (szerk.): Merre tart a magyar civilisztikai jogalkotás a XXI. század elején? Kódex, Pécs, 2010.

GÖRÖG MÁRTA: A jogi személy személyi értéke. Jogtudományi Közlöny 2011. 569.

GÖRÖG MÁRTA: Gondolatok a merchandising jelentéstartamához, egyes típusaihoz. Iparjogvédelmi és Szerzői Jogi Szemle. 2011/3.

GÖRÖG MÁRTA: A know-how védelmének alapvetö kérdései. HVG-ORAC, Budapest, 2012.

[GÖRÖG, 2014a] GÖRÖG MÁRTA: A személyiség védelme a becsület és a jóhírnév vonatkozásában, in: CSEHI ZOLTÁN - KOLTAY ANDRÁS - NAVRATYIL ZOLTÁN (szerk.): A személyiség és a média a polgári és a büntetőjogban, Complex, Budapest, 2014.

[GÖRÖG, 2014b] GÖRÖG MÁRTA: A kereskedelmi név védelme. In: Faludi GáborLukácsi Péter (szerk.): A védjegytörvény magyarázata, HVG-ORAC, Budapest, 2014.

GÖRÖG MÁRTA: A magánélethez való jog mint a személyiségi jog újabb, magánjogi kóxben nevesített vonatkozása. In: Balogh Elemér (szerk.): Számadás az Alaptörvényről. Magyar Közlöny- és Lapkiadó Budapest, 2016. 
GÖRÖG MÁRTA: Néhány gondolat a Ptk. személyiségi jogi katalógusához. In: Görög Márta - Hegedűs Andrea (szerk.): Lege duce, comite familia. Ünnepi tanulmányok Tóthné Fábián Eszter tiszteletére jogászi pályafutásának 60. évfordulójára. Pólay Elemér Alapítvány, Szeged, 2017.

GÖRÖG MÁRTA-SCHULTZ MÁRTON: A név tárgyiasulása a kereskedelmi megjelölések vonatkozásában.

GÖTTE: Einiges über das Namensrecht des bürgerlichen Gesetzbuches. Archiv für bürgerliches Recht Bd. 15 1899, 322.

GÖtting, Horst-Peter: Persönlichkeitsrechte als Vermögensrechte. Paul Siebeck, Tübingen, 1995.

GÖtTING, HORST-Peter: Die Vererblichkeit der vermögenswerten Bestandteile des Persönlichkeitsrechts - ein Meilenstein in der Rechtsprechung des BGH, NJW 2001, 585 .

[GötтING in: Götting/Schertz/Seitz, Handbuch des Persönlichkeitsrechts, § 1] GÖTting, HORST-PETER: $§ 1$. Inhalt, Zweck und Rechtsnatur des Persönlichkeitsrechts. In: Götting, Horst-Peter - Schertz, Christian - Seitz, Walter (szerk.): Handbuch des Persönlichkeitsrechts. C.H.Beck, München, 2008.

[GötTING in Götting/Schertz/Seitz (Hrsg.): Handbuch des Persönlichkeitsrechts, CH Beck, 2008. § 11] GÖTTING, HoRST-PETER: § 11. Die Unterscheidung zwischen allgemeinem Persönlichkeitsrecht und besonderen Persönlichkeitsrechten. In: Götting, Horst-Peter - Schertz, Christian - Seitz, Walter (szerk.): Handbuch des Persönlichkeitsrechts. C.H.Beck, München, 2008.

[GötTING in: Götting/Schertz/Seitz, Handbuch des Persönlichkeitsrechts, § 10] GÖTTING, HORST-PETER: $§$ 10. Ideeller und komerzieller Persönlichkeitsschutz. In: Götting, Horst-Peter - Schertz, Christian - Seitz, Walter (szerk.): Handbuch des Persönlichkeitsrechts. C.H.Beck, München, 2008.

GÖtTING, Horst-Peter: Gewerblicher Rechtsschutz. C.H. Beck, München, 2014.

GRÁD ANDRÁS - WELLER MÓNIKA: A strasbourgi emberi jogi bíráskodás kézikönyve. HVG-ORAC, Budapest, 2011.

GRAD-GYEnge ANIKó: Búcsú a szellemi alkotások jogától? - A szerzői jog és az iparjogvédelmi oltalmi formák polgári jogi védelme a magyar magánjogban. 
[Grunsky/Jacoby ZivilProzR Rn.] GRUNSKY, WOLFGANG - JACOBY, FlORIAN: Zivilprozessrecht. Vahlen, München. 2014.

[Staudinger/HABERMANN (2013) § 12] HABERMANN, NORBERT: $\$ 12$ Namensrecht. In: Roth, Herbert (szerk.): J. von Staudingers Kommentar zum Bürgerlichen Gesetzbuch mit Einführungsgesetz und Nebengesetzen. Sellier - de Gruyter, Berlin, 2013.

[Staudinger/Hager $§ 823]$ Hager, JohanNes: $\S 823$ A-D. In: Mansel, Heinz-Peter (szerk.): J. von Staudingers Kommentar zum Bürgerlichen Gesetzbuch. Sellier de Gruyter, Berlin, 2017.

HARKAI ISTVÁN: A képmáshoz való jog és pénzben kifejezhető értéke a számitógépi programalkotásokban. In: Báró-Farkas Margit Chiara, Kemény Zsanett (szerk.): A pénzügyi világ kihívásai a 21. században. Pro Talentis Universitatis Alapítvány, Szeged, 2018.

HAMBACH, HEINRICH: Das bürgerliche Gesetzbuch aus Sicht der angloamerikanischen Literatur unter besonderer Beachtung des Richterleitbildes und des allgemeinen Persönlichkeitsrechts, Dissertation, Hamburg, 2004.

HARTL, MiCHAEL: Persönlichkeitsrechte als verkehrsfähige Güter. Dissertation, Konstanz, 2004.

HeitmanN, LuTZ: Der Schutz der materiellen Interessen an der eigenen Persönlichkeitssphäre durch subjektiv-private Rechte - zugleich ein Beitrag zur Abgrenzung des allgemeinen Persönlichkeitsrecht, Diss. Hamburg, 1963.

HOKKES ZOLTÁN: A festő müvészi személyiségének oltalma. Jogtudományi Közlöny 1916. 334 .

HoMoki-Nagy MÁRIA: A védjegy magyarországi történetéröl. In: Görög Márta, Mezei Péter (szerk.): A szellemi tulajdonvédelem és a szabadkereskedelem aktuális kérdései. Iurisperitus, Szeged, 2018.

HONSELL, HeINRICH: Einleitung zum Bürgerlichen Gesetzbuch. In: Roth, Herbert (szerk.): J. von Staudingers Kommentar zum Bürgerlichen Gesetzbuch mit Einführungsgesetz und Nebengesetzen. Sellier - de Gruyter, Berlin, 2013.

Hopt, Klaus J. - Merkt, Hanno - Roth, Markus - BaUmbach, Adolf: Handelsgesetzbuch. 35. Aufl., Beck, München, 2012.

Hubmann, HeinRich: Das Persönlichkeitsrecht, Böhlau Verlag, Münster / Köln, 1953. 
JAKAB ÉVA: Szerzők, kiadók, kalózok. A szellemi alkotások védelmének kialakulása Európában. Akadémiai kiadó, Budapest, 2012.

JANCSÓ GYÖRGY: Házassági jog. In: Fodor Ármin: Magyar Magánjog IV. Családjog. Singer és Wolfner, Budapest, 1899.

JOHNSON, ERIC E.: Disentangling the right of publicity. Northwestern University Law Review Vol 111. No. 4.

[KANNOWSKI/Staudinger Vorbem zu § 1] KANNOWSKI, BERND: Vorbemerkungen zu $\S$

1. In: Roth, Herbert (szerk.): J. von Staudingers Kommentar zum Bürgerlichen Gesetzbuch mit Einführungsgesetz und Nebengesetzen. Sellier - de Gruyter, Berlin, 2013.

KANT, IMMANUEL: Az erkölcsök metafizikája. Gondolat, Budapest, 1991.

KeCsKés LÁszló: Polgári Jog. Személyek Joga. Dialóg-Campus, Budapest-Pécs, 2005.

KeCsKés LÁszló: Polgári jog. A személyek joga. Dialóg Campus, Budapest-Pécs, 2007.

[Erman/Klass, BGB, 14. Aufl., Anh $§ 12$ Rn.] Klass, NADine: Anhang zu $§ 12$. Das Allgemeine Persönlichkeitsrecht. In: Westermann, Harm Peter, Grunewald, Barbara, Maier-Reimer, Georg (szerk.): Erman. Bürgerliches Gesetzbuch. Dr.

Otto Schmidt Verlag, Köln, 2011.

KLIPPEL, DiETHELM: Der zivilrechtliche Schutz des Namens eine historische und dogmatische Untersuchung. Ferdinand Schöningh, Paderborn, 1985.

KOHLER, JoseF: Das Autorrecht. Verlag von Gustav Fischer, Jena, 1880.

KoHLer, JosePh: Das Eigenbild im Recht, Berlin, J. Guttentag, 1903.

KOHLER, JOSEF: Urheberrecht an Schriftwerken und Verlagsrecht. Stuttgart, Ferdinand Enke, 1906.

KoKoly Zsolt: A képmáshoz való jog Balás P. Elemér és kortársai szemléletében. In:

Koltay András (szerk.): Balás P. Elemér emlékkönyv. Wolters Kluwer, Budapest, 2018.

Kolosváry BÁlint: Az arckép és a jog. Széphalom Könyvtár, Szeged, 1927.

Kolosváry BÁLInT: Megjegyzések a magánjogi codex-javaslathoz. Polgári Jog 1929. 305.

Kolosváry BÁlint: A dologi jog általános tanai. In: Szladits Károly (szerk.): Magyar Magánjog V. Dologi jog. Grill, Budapest, 1942.

KOLOSVÁRY BÁLINT: Magánjog. Vezérfonal a magyar magánjogból tartott egyetemi 
elöadásokhoz. Studium, Budapest, 1944.

KolTAY ANDRÁS: A szólásszabadság alapvonalai. Századvég, Budapest, 2009.

KOLTAY ANDRÁs: Az „általános személyiségi jog“ nyomában - kisérlet a méltóság, becsület, jó hírnév fogalmi elhatárolására. Magyar Jog 2017. 602.

KOLTAY ANDRÁs: Az ,általános személyiségi jog “ azonositása felé. In: Koltay András

- Török Bernát (szerk.): Sajtószabadság és médiajog a 21. század elején 4.

Wolters Kluwer, Budapest, 2017. 295.

KOLTAY ANDRÁs: Mit üzen Balás P. Elemér a 21. század médiaszabályozásának? In:

Koltay András (szerk.): Balás P. Elemér emlékkönyv. Wolters Kluwer, Budapest, 2018.

KunCz ÖDÖN - BALÁs P. ElEMÉR: A tisztességtelen verseny. Politzer Zsigmond, Budapest, 1924.

KUNCZ ÖDÖN: A magyar kereskedelmi- és váltójog tankönyve. Grill, Budapest, 1938. 45

KÜPPER, HERBERT: A fiúk körülmetélése Németországban-egy „,bortányos “itélet és annak orvoslása. JURA 2013. 2. szám 107.

LÁBADY TAMÁs: Felelösség a szerződésen kívül okozott károkért. In: Vékás Lajos (szerk.): Szakértői Javaslat az új Polgári Törvénykönyv tervezetéhez. Complex, Budapest, 2008.

LÁBADY TAMÁS: A magánjog általános tana. Szent István Társulat, Budapest, 2013.

LADÁNYi BÉLA: A személyiség védelme. Jogállam 1904. 372.

LADÁNYI BÉLA: A személyiség védelmének elmélete és gyakorlati megvalósulása a magánjogi tervezetekben. Magánjogbölcseleti tanulmány. Budapest, 1904.

LÁNYI MÁRTON: Pár szó a névhez való jogról. Jogtudományi Közlöny 1907. 12. sz. 97.

LEGEZA DÉNES: A kiadói szerzödés története. A reformkortól 1952-ig. Pólay Elemér Alapítvány, Szeged, 2018.

LEKOVICS BARNABÁS - KESERÜ BARNA ARNOLD: Általános rész. In: Lenkovics Barnabás - Keserü Barna Arnold - Köhidi Ákos (szerk.): Polgári jogi alapok. ELTE Eötvös, Budapest, 2018.

LETTL, TOBIAS: Urheberrecht. CH Beck, München, 2. Auflage, 2013.

LONTAI ENDRE: Szellemi alkotások joga. Eötvös József Könyvkiadó, Budapest, 2001.

LONTAI ENDRE - FALUDI GÁBOR - GYERTYÁNFY PÉTER - VÉKÁS GUSZTÁV: Szerzői jog és iparjogvédelem. ELTE Eötvös, Budapest, 2017. 
LUTHER, CHRISTOPH: Postmortaler Schutz nichtvermögenswerter Persönlichkeitsrechte. V \& R unipress, Göttingen, 2009.

Madow, Michael: Private Ownership of Public Image: Popular Culture and Publicity Rights. California Law Review 1993/1. sz. 125-140.

McCarthy, Thomas: The Rights of Publicity and Privacy. Thomson West, 2011.

Medicus, Dieter - Petersen, Jens: Bürgerliches Recht. Eine nach Anspruchsgrundlagen geordnete Darstellung zur Examensvorbereitung. 23. Auflage, Vahlen, München, 2011.

MEgYeRI-PÁlfFi Zoltán: Név és Jog. Gondolat, Budapest, 2013.

MENYHÁRD ATTILA: A magánélethez való jog elméleti alapjai. In Medias Res 2014/2. 384-406.

MENYHÁRD ATTILA: A magánélethez való jog a szólás- és médiaszabadság tükrében. In: Csehi Zoltán - Koltay András - Navratyil Zoltán (szerk.): A személyiség és a média a polgári és a büntetőjogban. Complex, Budapest, 2014.

MenYhÁRD AtTILA: Forgalomképes személyiség? In: Menyhárd Attila - GárdosOrosz Fruzsina (szerk.): Személy és személyiség a jogban. Wolters Kluwer, Budapest, 2016.

MENYHÁRD ATTILA: A magánélet védelme az Emberi Jogi Bíróság gyakorlatában. In: Görög Márta - Menyhárd Attila - Koltay András (szerk.): A személyiség és védelme. ELTE Eötvös, Budapest, 2017.

MESZLÉNY ARTUR: A személyiség védelme a polgári törvénykönyv tervezetében. Jogászegyleti értekezések. XXVI kötet. 1903.

MESZLÉNY ARTUR: A svájci polgári törvénykönyvröl. Atheneum, Budapest, 1909.

MESZlÉNY ARTUR: A tisztességtelen versenyröl szóló (1923. évi V. törvénycikk) magyarázata. Atheneum, Budapest, 1923.

MeSZlÉny ARTuR: Magánjog I. Személyi és Családi Jog. Grill, Budapest, 1931.

[MÜLLER in: Götting/Schertz/Seitz, Handbuch des Persönlichkeitsrechts, § 50] MüLLER, GERDA: § 50. Der Anspruch auf materiellen Schadensersatz. In: Götting, Horst-Peter - Schertz, Christian - Seitz, Walter (szerk.): Handbuch des Persönlichkeitsrechts. C.H.Beck, München, 2008.

NAgy FerenC: A magyar kereskedelmi jog kézikönyve. Atheneum, Budapest, 1913.

NAVRATYIL ZOLTÁN: Gondolatok névjogról, szólásszabadságról. MTA Bölcsésztudományi Kutatóközpont, Budapest, 2015. 
NAVRATYIL ZOLTÁN: Az emberi méltóság magánjogi szerepe és a véleménynyilvánítás szabadsága. In: Koltay András - Török Bernát (szerk.): Sajtószabadság és médiajog a 21. század elején 3. Wolters Kluwer, Budapest, 2016.

NóTÁRI TAMÁs: Megjegyzések a kép védelméhez a magyar szerzői jog történetében. Acta Universitatis Sapientiae, Legal Studies, 6, 2 (2017) 323.

OpOKu, K.: Delictual Liability in Germany. International and Comparative Law Quarterly 21, 1972.269.

Petersen, Jens: Namensrecht und Domain-Namen. JURA 2007, 175.

Petersen, Jens: Postmortaler Persönlichkeitsschutz. JURA 2008, 271.

Petersen, Jens: Medienrecht. CH Beck, München, 2010.

PETRIK FERENC: A törvényszerkesztő dilemmái 2. Polgári Jog 1978. 150.

Petrik Ferenc: A személyiségi jogok vázlata. In: Petrik Ferenc (szerk.): A személyiség jogi védelme. KJK 1992.

PETRIK FERENC: A névviselés. In: Petrik Ferenc (szerk.): A személyiség jogi védelme. KJK, Budapest, 1992

PETRIK FEREnC: A személyiség jogi védelme. A sajtó-helyreigazítás. HVG-ORAC, Budapest, 2001.

PETRIK FERENC: A törvényszerkesztő dilemmái. HVG-ORAC, Budapest, 2008.

Petrik Ferenc: Személyiségi jogok. In: Wellmann György (szerk): Polgári jog. Bevezető és záró rendelkezések. Az ember mint jogalany. öröklési jog. HVGORAC, Budapest, 2014.

PoKol BÉLA: The Concept of Law. The multi- layered legal system. Rejtjel Kiadó, Budapest, 2001.

POKOL BÉlA: Politikaelmélet. Társadalomtudományi Trilógia III. Századvég, Budapest, 2006.

POKOL BÉLA: Alkotmánybíráskodás. Szociológiai, politológiai és jogelméleti megközelítésekben. Kairosz Kiadó, Budapest, 2014.

PÓLAY ELEMÉR: Die römischrechtlichen Wurzeln des zivilrechtlichen Schutzes der Persönlichkeit. Acta Universitatis Szegediensis: Acta Juridica et Politica, (37) 1-22. (1987) 257-280.

RAFFAY FEREnCZ: Magyar Magánjog I. Sziklai Henrik kiadása, Eperjes, 1906.

REINER JÁnOS: Jogi Dolgozatok. Pfeiffer Ferdinánd, Budapest, 1898.

SÁRKÖZY SZABOLCS: Gondolatok a közéleti szereplök magánszférája fokozott védelmének szabályozásáról. Gazdaság és Jog 2018/10. 26. 
SCHERTZ, Christian - REICH, HELge: Vermögensrechtliche Ansprüche bei unzulässiger publizistischer Verwendung von Bildnissen aus der Privatsphäre. In: Götting, Horst-Peter - Lauber-Rönsberg, Anne (szerk.): Aktuelle Entwicklungen im Persönlichkeitsrecht. Nomos, Baden-Baden, 2010.

SCHULTZ MÁRTON: Gondolatok a személyiségi jogok generálklauzulájáról és az emberi méltóságról. Magyar Jog 2016. 685.

SCHULTZ MáRton: A férj joga felesége nevén. Gondolatok a névhasználati engedély szabályaihoz. Családi Jog 2017. 4. sz. 14.

SCHULTZ MÁRTON: Valós alakok megjelenitése szerzői müvekben: névoltalom, életképoltalom vagy a magánszféra oltalma? Jogösszehasonlitás a magánszféra védelmének elméleti és gyakorlati kérdéseiről. In: Görög Márta Menyhárd Attila - Koltay András (szerk.) A személyiség és védelme: Az Alaptörvény VI. cikkelyének érvényesülése a magyar jogrendszeren belül. ELTE Eötvös, Budapest, 2017.

SCHUltz MÁRTON: A névbitorlás egyes kérdései, különös tekintettel a szerzői név bitorlására. In: Doktori Mühelytanulmányok. Györ, 2017.

SCHUlTZ, MARTIN: Mißbrauch von Titel. FORVM Szeged, VII. évfolyam, 2017.

SCHULTZ MÁRTON: Az általános személyiségi jog vagyoni szankcióktól független elismerése, tekintettel a kir. Kúria névjogi joggyakorlatára. Megjelenés alatt.

SCHULTZ MÁRTON: Személyi és vagyoni érdekek különválása a névjog elismerésének hajnalán. Megjelenés alatt.

SCHULTZ, MÁRTON: Vermögenswerte Bestandteile des Persönlichkeitsrechts. Masterarbeit, Potsdam, 2018.

Schultz MÁRton: Azonosnevüség és domain nevek. In Medias Res 2018/2.

SCHULTZ MÁRTON: A szocializmussal összefüggö névjogi jogsértések és az ipari tulajdon kapcsolata. Gondolat, Budapest, 2019.

SCHULTz MÁRTON: A Debreceni Ítélötábla döntése a név jogosulatlan kereskedelmi felhasználása tárgyában. JeMa 2019/1.

SCHULZE WESSEL, LAMBERT: Die Vermarktung Verstorbener. Persönlichkeitsrechtliche Abwehr- und Ersatzansprüche. Arno Spitz, Berlin, 2001.

SCHUSTER RUDOLF: Collisiók kérdése a név, a cég, a védjegy és vállalat megjelölések jogköréből. Polgári Jog 1925. 151. 
SCHUSTER RUDOLF: Bírói gyakorlat a tiltott utánzás és mintaoltalom kérdéseiben tekintettel a Tvt.-re. Polgári Jog 1938. 183.

SCHWEERS, CHRISTIAN: Die vermögenswerten und ideellen Bestandteile des Persönlichkeitsrechts nach dem Tod des Trägers. Dissertation, Köln, 2006.

SeItz, Walter: § 52. Der Anspruch auf Herasugabe des Erlangten. In: Götting, Horst-Peter - Schertz, Christian - Seitz, Walter (szerk.): Handbuch des Persönlichkeitsrechts. C.H.Beck, München, 2008.

SeEmann, Bruno: Prominenz als Eigentum. Parallele Rechtsentwicklungen einer Vermarktung der Persönlichkeit im amerikanischen, deutschen und schweizerischen Persönlichkeitsschutz. Nomos, Baden-Baden, 1996.

Solove, Daniel J.: Conceptualizing Privacy. California Law Review 2002. 1087.

SólyOM LÁSZLó: A személyiségi jogok elmélete. Közgazdasági és Jogi Könyvkiadó, Budapest, 1983.

STAUDINGER, ANSGAR - SCHMIDT, RÜDIGER: Marlene Dietrich und der (postmortale) Schutz vermögenswerter Persönlichkeitsrechte. Jura 2001, 241.

STUMP KRISZTINA: A személyhez füzödö jogok vagyoni vonatkozásai - új fejlemények. Jogi Tanulmányok, 2014.

SULYOK MÁRTON: Magánszféravédelem a tisztességes eljárásban - Az alapjogsértő bizonyítás összehasonlító alkotmányjogi vizsgálata. Disszertáció, Szeged, 2017.

Szeghalmi Veronika: The definition of the Right to Privacy in the United States of America and Europe. In: Szabó Marcel - Varga Réka - Láncos Petra Lea (szerk.): Hungarian Yearbook of International Law and European Law. Eleven, Budapest, 2015.

SzEGHALmi VeroniKa: A személyiség „értéke“ és annak post-mortem továbbélése. FORVM Szeged, Szeged, 2017.

SZEGHALMI VeRONIKA: A magánélet védelmének változó megítélése az Emberi Jogok Európai Bíróságának gyakorlatában. In: Koltay András - Török Bernát (szerk.): Sajtószabadság és médiajog a 21. század elején 4. Wolters Kluwer, Budapest, 2017.

SZÉKELY LÁSZLÓ: A személyiségi jogok „érdem szerinti elosztásáról”. Jogtudományi Közlöny, 1985. 
SzÉKELY LÁSZLó: Harmadik Rész. Személyhez füzödő jogok. In: Vékás Lajos (szerk.):

Szakértői Javaslat az új Polgári Törvénykönyv tervezetéhez. Complex, Budapest, 2008.

SzÉKELY LÁSZLÓ - VÉKÁs LAJOS: Személyiségi jogok. In: Vékás Lajos (szerk.): A Polgári Törvénykönyv magyarázatokkal. Complex, Budapest, 2013.

SzÉKELY LÁszló: Személyiségi Jogok. In: Vékás Lajos - Gárdos Péter (szerk.):

Kommentár a Polgári Törvénykönyvhöz, Wolters Kluwer, Budapest, 2014.

SZEMÉlyi KÁlmán: A névjog. Franklin, Budapest, 1915.

Ifj. SzIGETi LÁsZló: Magánjogi csábitás. Polgári Jog 1926. 289.

Ifj. SzigeTI LÁszló: Csábítás. Polgári Jog 1928. 47.

SzLADITS KÁROLY: A magyar magánjog vázlata I. Grill, Budapest, 1933.

SzLADITS KÁROLY: A magyar magánjog vázlata II. Grill, Budapest, 1935.

SZladiTS KÁROLY: A magánjogi tényállások. In: Szladits Károly (szerk.): Magyar Magánjog I. Grill, Budapest, 1941.

SZTOJÁN KRISZTINA: Bismarcktól Tiger Woodsig: a személyiség kereskedelmi értéke. (https://arsboni.hu/bismarcktol-tiger-woodsig-szemelyiseg-kereskedelmierteke/)

SzTOJÁN KRISZTINA: Kétarcú know-how: személyiségi jog vagyoni értékkel? Gazdaság és Jog 2018/3. 17.

TAKÓ SÁNDOR: Az emberi képmás filmalkotási és filmterjesztési célú felhasználásának személyiségi jogi vonatkozásai. In: Görög Márta - Menyhárd Attila - Koltay András (szerk.): A személyiség és védelme. ELTE Eötvös, Budapest, 2017.

Targosz, Tomasz: $\S$ 66. Polen. In: Götting, Horst-Peter - Schertz, Christian - Seitz, Walter (szerk.): Handbuch des Persönlichkeitsrechts. C.H.Beck, München, 2008.

TARgosz, Tomasz: $\S$ 62. Polen. In: Götting, Horst-Peter - Schertz, Christian - Seitz, Walter (szerk.): Handbuch des Persönlichkeitsrechts. C.H. Beck, München, 2019. Rn 16.

TAtTAy LeVEnTE: A kereskedelmi nevek. Gazdaság és Jog 2011. 6. sz. 18.

TATTAY SZILÁRD: Az emberi személy mint „önmaga tulajdonosa“: a dominium sui fogalmától a self-ownership eszméjéig. In: Menyhárd Attila - Gárdos-Orosz Fruzsina (szerk.): Személy és személyiség a jogban. Wolters Kluwer, Budapest, 2016. 
TÖrö KÁROly: A személyiség és a szellemi alkások védelme a módosított Polgári Törvénykönyvben. Magyar Jog 1978, 982.

TÖRÖ KÁROLY: Személyiségvédelem a polgári jogban. KJK, Budapest, 1979.

TÖRÖ KÁROLY: A személyiség jogi védelmének polgári jogi eszközei. In: Petrik Ferenc (szerk.): A személyiség jogi védelme. KJK, Budapest, 1992.

TÖRö KÁROLY: A személyhez füzödö jogok érvényesitésének rendje. In: Petrik Ferenc (szerk): A személyiség jogi védelme. KJK, Budapest, 1992.

TÖKEY BALÁZS: Az élethez és az emberi méltósághoz való jog mint személyiségi jog. In: In: Grad-Gyenge, Anikó - Kabai, Eszter - Menyhárd, Attila (szerk.): Liber Amicorum - Studia G. Faludi Dedicata. ELTE Eötvös, Budapest, 2018.

TŐKEY BALÁZs: A szerződések hatásai harmadik személyekre. Habilitáció, ELTE, 2019.

Trebes, AnJa: $\S$ 68. Spanien. In: Götting, Horst-Peter - Schertz, Christian - Seitz, Walter (szerk.): Handbuch des Persönlichkeitsrechts. CH Beck, München, 2008.

TrebeS, Anja: $\$ 64$ Spanien. In: Götting, Horst-Peter - Schertz, Christian - Seitz, Walter (szerk.): Handbuch des Persönlichkeitsrechts. C.H.Beck, München, 2019.

TREBES, ANJA: § 59. Frankreich. In: Götting, Horst-Peter - Schertz, Christian - Seitz, Walter (szerk.): Handbuch des Persönlichkeitsrechts. C.H. Beck, München, 2019. Rn 51.

UngÁR MARGIT - Tóth GYÖRGY - HAJNAL HENRIK: Csábítás jegyszegés és jog. Pécsi Egyetemi Könyvtár, Pécs, 1939

UNGER, JOSEF: System des österreichischen Privatrechts Band I. Breitkopf und Härtel, Leipzig 1856.

UnSELD, FlORIAN: Die Übertragbarkeit von Persönlichkeitsrechten. GRUR 2011.

VALlaseK Magdolna: A sajtószabadság eszméje és jogi fogalma Balás P. Elemér és kortársai sajtójogi írásaiban. In: Koltay András (szerk.): Balás P. Elemér emlékkönyv. Wolters Kluwer, Budapest, 2018.

VARGA ATTILA: Román polgári jog. Státus, Csíkszereda, 2008.

VEREBICS JÁNOS: Kereskedelmi névoltalom és domain-regisztráció. Gazdaság és Jog 2007. 1. sz. 17.

VEREBICs JÁNOS: A domain nevek használati jogának megszünése. Gazdaság és Jog 2011. 2. sz. 23. 
VÉKÁS LAJOS (szerk.): Szakértői javaslat az új Polgári Törvénykönyv tervezetéhez. Complex, Budapest 2008.

VÉKÁs Lajos: Az új. Ptk. Szakértői Javaslatának elvi kérdései. Magyar Jog 2008. 65.

VÉKÁS LAJOS: Über die Expertenvorlage eines neuen Zivilgesetzbuches für Ungarn. ZeuP 2009, 536.

VÉKÁS LAJOS: Történeti visszapillantás a magyar magánjog kodifikációjára. Jogtudományi Közlöny 2011. 261.

VÉKÁS LAJOS (szerk.): Az új Polgári Törvénykönyv Bizottsági javaslata magyarázatokkal. Complex, Budapest, 2012.

VÉKÁS LAJOS: Bírálat és jobbitó észrevételek az új Ptk. Törvényjavaslatához (a zárószavazás elött). Magyar Jog 2013, 1.

VÉKÁs LAJOS: A Polgári törvénykönyv magyarázatokkal. Complex, Budapest, 2013.

Vick, Kevin L. - Jassy, Jean-Paul: Why a Federal Right of Publicity Statute Is

Necessary. Communications Lawyer, Volume 28, Number 2, August 2011.

VILÁGHY Miklós - EÖRsi GyUla: Magyar Polgári Jog I. Tankönyvkiadó, Budapest, 1965. 163.; hasonló állásponton a román jog tekintetében Fekete, 1958.

Világhy MikLós: A kereskedelmi név (cég) problémája. Polgári Jog 1968. 595.

W AGNER LiLla: Az elvált nö nevéröl. Polgári Jog 1926. 232.

WANK, Rolf: Die Auslegung von Gestzen. Carl Heymanns Verlag, Köln, 2005.

WArby, MARK - Moreham, NiCOle-Christie, IAIN (szerk): The Law of Privacy and the Media. Oxford University Press, Second Edition.

Warren, SAmuel - Brandeis, Luise: The Right to Privacy. Harvard Law Review (1890) 4, 193.

WELTNER ANDOR: Érvényesithetö-e a sajtótörvény alapján a kártérítési igény polgári úton, megelőző bünvádi eljárás nélkül? Polgári Jog 1935. 246.

ZLINSZKY JÁNOS - REINER JÁNOS: Magyar magánjog mai érvényében. Franklin, Budapest, 1902.

ZsÖGÖD BENÖ [GROSSCHMID BÉNI]: Fejezetek kötelmi jogunk köréböl II. Atheneum, Budapest, 1900.

Felhasznált jogszabályok

874/2004. EK rendelet.

BGB - Bürgerliches Gesetzbuch (1900) 
CAL. CIVIL CODE

D - Digeszta

FLA. STAT.

GG - Grundgesetz (1949)

IND. CODE ANN.

KUG - Kunsturhebergesetz (1907)

MarkenG

NEv. REV. STAT. ANN.

N.Y. CIv. RIGHTS LAW

OKLA. STAT.

PGR - Personen- und Gesellschaftsrecht

ZGB - Zivilgesetzbuch (Svájc)

1875. évi XXXVII. törvénycikk - kereskedelmi törvény, Kt.

1876. évi XIII. tc. - cselédtörvény

1884:XVI. tc - a szerzői jogról

1914. évi XIV. törvénycikk - Sajtótörvény, St.

1921. évi LIV. törvénycikk - a szerzői jogról

1948. évi XXV. törvénycikk az egyes ipari vállalatok állami tulajdonba vételéről. 1959. évi IV. törvény a Polgári Törvénykönyvröl

1997. évi XI. törvény

1997. évi CLIV. törvény az egészségügyről

2006. évi V. törvény

2009. évi CXV. törvény

2009. évi CXX. törvény a Polgári Törvénykönyvről

2010. évi I. törvény

2013. évi V. törvény a Polgári Törvénykönyvről

2018. évi LIV. törvény az üzleti titok védelméről

Felhasznált jogesetek

8/1990. (IV. 23.) AB hat.

1338/B/1992. AB hat. 
58/2001. (XII. 7.) AB hat.

998/B/2009. Ab. hat.

AfP 2017, 228.

BDT 2006. 45. („Hívj éjjel-nappal”)

BDT 2007. 171. (,,aktfotó”)

BDT 2008. 20. (,rekviem.hu”)

BDT 2008. 207. („Eredeti Pick Szalámi”)

BDT 2009. 22. (,jakab.hu”)

BDT 2009. 24. („Budapesti Öszi Fesztivál”)

BDT 2011. 123. (,szeged.hu”)

BDT 2012. 68. (,szallasinfo.info”)

BDT 2015. 70. (,élesztőtabletta”)

BDT 2015. 84. („Gyurcsány vezetőszíjon”)

BDT2017. 33. (,antikvarium.hu”)

BDT 2017. 79.

BDT 2018. 87. („kutatóintézet”)

BDT 2018. 125. (,SIM-kártya”)

BGE 104 II 225 E. 5 b 234.

BGE 129 I 302 E. 1.2.1306.

BGH 14.10.1986 VI ZR 10/86 „NENA”

BGH v. 29.04.2014 - VI ZR 246/12

BGHZ 8, 318.

BGHZ 13, 334 - Leserbrief.

BGHZ 26, 349 - Herrenreiter.

BGHZ 50, 133 - Mephisto.

BGHZ 113, 297, 303.

BGHZ 169, 193 - kinksi-klaus.de.

BH 1979. 411. („B-vonósnégyes”)

BH 1980. 377. („Kányák”)

BH 1980. 467. („Dankó Pista nótaegyüttes”)

BH 1982. 507.

BH 1985. 57.

BH 1987. 11. (,System”)

BH 1990. 255. („RORÁRIUS”) 
BH 1990. 476.

BH 1993. 92. („DLH”)

BH 1993. 350. („Herz”)

BH 1993. 548. („CHAGALL”)

BH 1994. 21. (,Rácz”).

BH 1995. 509. (,szalaghirdetés”).

BH 1997. 467. („Pick”)

BH 1999. 252. („Mindannyian mások vagyunk!”)

BH 2001. 61.

BH 2001. 161.

BH 2002. 261. („Jó estét, jó szurkolást!”)

BH 2003. 149. („Nárcisz”).

BH 2012. 174. („Рapp”)

BH 2014. 301 („Horthy Miklós és a zsidók”)

BH 2016. 240.

BH 2018. 141.

BH 2018. 248. („Rendvédelmi szakszervezetek tüntetése”)

Budapesti Kir. Ítélőtábla 1932. IX. 19. P. XIV. 2755.

Budapesti Kir. Törvényszék 1938. V. 5. - 9. P. 33.875/1938.

BVerfGE 30, 173 - Mephisto.

BVerfGE 49, 286.

C. $753 / 1878$.

C. $1328 / 1892$.

C. $4662 / 1900$.

C. 5336/1900.

C. 1902/2516.

C. 1906/3916.

C. 310/1908.

C. 676/1908.

C. $3555 / 1908$.

C. P. 2650/1909.

C. P. 38/1910.

C. $1140 / 1912$.

C. $977 / 1914$. 
C. $4811 / 1914$.

C. $3880 / 1915$.

C. $1435 / 1918$.

C. $6417 / 1924$.

C. $8668 / 1928$.

C. $4771 / 1929$.

C. $764 / 1929$.

C. $1056 / 1929$.

C. III. 6755/1929.

C. III. 7720/1929.

C. III. 8074/1929.

C. III. 831/1931.

C. III. 3304/1931.

C. III. 3884/1931.

C. III. 910/1932.

C. I. $1302 / 1935$.

C. I. $1401 / 1943$.

C. I. $1573 / 1943$.

Campbell v MGN Ltd (HL) [2004] UKHL 22.

DJZ 1906, 543 - Biedermann

EJEB 2004. június 24., 59320/00 Caroline von Hannover v. Germany.

EJEB 25379/04; 21688/05; 21722/05; 21770/05 - Paeffgen GmbH v Germany.

Fővárosi Ítélőtábla 1. Pf. 20. 780/2015/6/II.

Grill Dtár XXXI. 494. (,vaselin”)

GRUR 1998, 1021 - Mona Lisa.

GRUR-RR 2002, 341 - Nacktbilder

GRUR 2008, 1124, 1126 - Lucky Strike

GRUR 2014, 702.

Gulati v. MGN Ltd [2015] EWHC 1482 (Ch).

Győri Ítélőtábla Pf. I. 20.081/2015/3/I.

Haelan Laboratories Inc. v. Topps Chewing Gum Inc. 202 F 2d 866 (2nd Cir 1953) ÍH 2007. 84.

ÍH 2007. 85.

ÍH 2009. 111. (,,vedjegy.hu”) 
ÍH 2011. 154. (,,biztositás.hu”)

ÍH 2014. 58. („facebook.hu”).

ÍH 2017. 11. (,,muszakieredetvizsgaszeged.hu”)

ÍH 2017. 51. („,régimódi”)

K. IV. 8069/1927.

K. P. IV. 48/1928.

K. P. I. 3647/1928. (,olajügynök”)

K.P. I. 5201/1928.

K. IV. 2376/1930.

K. P. I. 3618/1930. (,hirdetőoszlop”)

K. P. I. 8640/1930. („Chanel nyolc”). Grill Dtár XXVII. 457.

K. IV. 1802/1931.

K. P. I. 348/1932.

K. P. I. 5332/1932. (,,igazolványkép”)

K. III. 301/1934. Jogi Hírlap 1934. 607.

K. I. 2193/1934. („Huszár Imre”)

K. P. IV. 2146/1936. - K. 1936. VI. 30. Grill Dtár XXX. 685.

K. 2571/1936. (,herceg E.M.”)

K. I. $1983 / 1937$.

K. IV. 3967/1937.

K. IV. 3968/1937.

Kúria 1938. máj. 3. — P. IV. 1284/1938.; Grill Dtár XXXI. 939.

K. 1758/1938. („Csángó”)

K. P I. 3463/1938. = Grill Dtár XXXII. 560. („lemetszett lábak”)

K. P. I. 4102/1938. (,meztelenül Dunaparton”)

K. P. I. 623/1939. (,viaszképmás”).

K. 1753/1939. (,Ritz”)

K. P. I. 5152/1939. Grill Dtár XXXIII. 537.

K. P. I. 5820/1939. = Grill Dtár XXXIII. 538. (,spiccelés”)

K. P. III. 1068/1940. - Kúria 1940. június 6.

K. III. 1938/1940. Jogi Hírlap 1940.630.

K. III. 2680/1940. Jogi Hírlap 1941. 34.

K. P. I. 4614/1940. Grill Dtár XXXIV. 420.

K. P. I. 860/1941. = Grill Dtár XXXIV. 423. („ez a biztos tipp”) 
K. P. I. 2110/1941. Grill Dtár XXXV. 457.

KG Berlin, Urt. v. 31.05. 2017, Az. 21 U 9/16

Legf. Bír. Pf. IV. $21007 / 1992$ („Láng”)

Legf. Bír. Pf. IV. 21.274/1992.

Legf. Bír. Pfv. IV. 20.895/1994.

Legfelsőbb Bíróság Pfv. (III. 22.) 084/1996.

LG Berlin NJW-RR 1992, 1247. („Launische Domina 342, Mannequin”)

LG Berlin, Urt. v. 17.12.2015, Az. 20 O 172/15.

MR 2000, 368 - Radetzky.

Nagyváradi Kir. Törvényszék 1913. évi P. 37.870. sz. döntés

NJOZ 2008, 4549, 4553 - Lucky Strike

NJW 1956, 1554 - Paul Dahlke

NJW 1956, 1942 („Die Schuld des Dr. H”)

NJW 1959. 1269 - Caterina Valente

NJW 1975. 1882. - Der Geist von Oberzell

NJW 1981, 2402 - Carrera

NJW 1983, 1184 - Uwe

NJW 1990, 1986 - Emil Nolde.

NJW 1990, 1995 - Heinz Erhardt

NJW 2000, 2195 - Marlene Dietrich.

NJW 2000, 2201 - Der Blaue Engel.

NJW 2000, 2301.

NJW 2001, 615 - Johann Sebastian Bach.

NJW 2003, 2311.

NJW 2004, 605 - Derrick.

NJW 2006, 3409 - Blauer Engel II.

NJW 2007, 648.

NJW 2007, 689 - Lafontaine.

NJW 2008, 39 - Esra.

NJW 2010, 3501, 3502 - Gen-Milch.

NJW 2012, 1728 - Unfallopfer.

NJW 2016, 781 - Ernst August v Hannover/Deutschland II

OGH 21. 12. 1999, 4 Ob 320/99h

OGH 18.1.2011, 17 Ob 16/10t - schladming.com. 
OGH (Li) 6 Cg 45/00-17 (,,eschen.li”).

OLG Hamburg, 08.05.1989 - 3 W 45/89.

OLG Hamburg, Urteil vom 11.6.1998 - 3 U 284/97 - Vermarktung einer Musikgruppe.

OLG Köln 29.05.2018 - Az. 15 U 65/17.

OLG Köln, 29.05.2018 - I-15 U 64/17 - Kohl-Protokolle.

ÖJZ 2000, 507.

Pavesich v. New England Life Insurance Co 50 SE 68 (1905)

RGZ 58, 166.

RGZ 70, 226.

RGZ 71, 413, 414 - Der Tor und der Tod / Rundfunk

RGZ 74, 308 - Graf Zeppelin

RGZ 86, 308, 310.

RGZ 91, 350 - Weberlied

RGZ 92, 401, 403. - Nietzsche Briefe

RGZ 125, 80 - Tull Harder

RGZ 158, 226.

Roberson v. Rochester Folding Box Co. 32 Misc. 344 (N.Y. Misc. 1900)

Sarver v. Chartier, 813 F.3d 891 (9th Cir. 2016).

STC 81/2001 (26.03.2001) - Emilio Aragón.

SZ 31/86 („Asphaltkönig“)

SZ 71/35 - jusline I.

SZ 2010/70 - Maria Treben.

Szegedi Királyi Ítélőtábla 1911. G 156.

WM 1976, 384 (,Sternhaus”)

ZUM 2008, 793 - Kannibale von Rotenburg II.

ZUM 2009, 479.

ZUM-RD 2016, 561 - Dieter Bohlen/Deutschland

X v Iceland Application 6825/74, (1976) 5 DR 86, 87.

Zacchini v. Scripps-Howard Broadcasting Co. 433 US 562 (1977). 


\section{Egyéb források}

A Magyar Általános Polgári Törvénykönyv tervezete, 1900

1914-es Magánjogi törvényjavaslat

Magánjogi Törvényjavaslat, 1928

Protokolle der Kommission für die Zweite Lesung, Bd. 6.

Indokolás a magyar általános Polgári Törvénykönyv tervezetéhez. Első kötet: Bevezetés, Személyjog, Családjog. Budapest, Grill, 1901.

Indokolás a Polgári Törvénykönyv Törvényjavaslatához I., Grill, 1914.

Indokolás Magyarország Magánjogi Törvénykönyvének Törvényjavaslatához I, 1932. Indokolás Magyarország Magánjogi Törvénykönyvének a m. kir. Igazságügyi Minisztérium által 1928 márc. 1-én az Országgyülés elé terjesztett törvényjavaslatához. M. Kir. Igazságügyi Minisztérium, Budapest, 1929.

Az Igazságügyminisztérium iratanyaga az 1959-es Polgári Törvénykönyv elökészitésével és hatályba léptetésével kapcsolatban, I. kötet. Magyar Közlöny Lapés Könyvkiadó Kft., Budapest, 2017.

Kúria 316. EH.

Legfelsőbb Bíróság III. sz. Polgári Elvi Döntése (1953).

Legfelsőbb Bíróság GK. 52. sz. 